FACULDADE DE ARQUITETURA E URBANISMO DA UNIVERSIDADE DE SÃO PAULO

História e Fundamentos da Arquitetura e do Urbanismo

BEATRIZ FERNANDEZ VAZ OLIVEIRA

\title{
O THEATRO MUNICIPAL DE SÃO PAULO: IMPLICAÇÕES TEÓRICAS DAS INTERVENÇÕES DAS DÉCADAS DE 1950, 1980 E 2010
}


EXEMPLAR REVISADO E ALTERADO EM RELAÇÃO À VERSÃO ORIGINAL, SOB RESPONSABILIDADE DO AUTOR E ANUÊNCIA DA ORIENTADORA.

A VERSÃO ORIGINAL, EM FORMATO DIGITAL, FICARÁ ARQUIVADA NA BIBLIOTECA DA FACULDADE.

SÃO PAULO, 28 DE MAIO DE 2021.

\section{O THEATRO MUNICIPAL DE SÃO PAULO: IMPLICAÇÕES TEÓRICAS DAS INTERVENÇÕES DAS DÉCADAS DE 1950, 1980 E 2010}

Dissertação a ser apresentada para obtenção do título de mestre em História e Fundamentos da Arquitetura e do Urbanismo da Faculdade de Arquitetura e Urbanismo da Universidade de São Paulo. 


\section{AUTORIZO A REPRODUÇÃO E DIVULGAÇÃO TOTAL OU PARCIAL DESTE TRABALHO, POR QUALQUER MEIO CONVENCIONAL OU ELETRÔNICO, PARA FINS DE ESTUDO E PESQUISA, DESDE QUE CITADA A FONTE.}

bfernandezvaz@gmail.com

Faculdade de Arquitetura e Urbanismo da Universidade de São Paulo

\section{Fernandez Vaz Oliveira, Beatriz}

Theatro Municipal de São Paulo: implicações teóricas das intervenções das décadas de 1950, 1980 e 2010 / Beatriz Fernandez Vaz Oliveira; orientador Maria Lucia Bressan Pinheiro. - São Paulo, 2021.

$292 \mathrm{p}$.

Dissertação (Mestrado) - Faculdade de Arquitetura e Urbanismo da Universidade de são Paulo. Área de concentração: História e Fundamentos da Arquitetura e do Urbanismo.

1. Theatro Municipal de São Paulo. 2. Restauração. 3. Teoria. 4. Preservação. I. Bressan Pinheiro, Maria Lucia, orient. II. Título.

Elaborada eletronicamente através do formulário disponivel em: http://www.fau.usp.br/fichacatalografica/ 


\section{RESUMO}

O Theatro Municipal de São Paulo é um edifício que carrega grande carga simbólica na construção da identidade cultural e memória paulistana. Inaugurado em 1911 e tombado como patrimônio histórico pelas instâncias municipal (CONPRESP, 1991), estadual (CONDEPHAAT, 1981) e federal (IPHAN, 2014), o Theatro passou por três grandes intervenções arquitetônicas no período compreendido entre sua inauguração e seu centenário. Essas intervenções, no entanto, nunca foram analisadas de maneira clara e sistemática. O objetivo dessa pesquisa é, portanto, a identificação, periodização e contextualização de tais intervenções por meio da análise retrospectiva dos projetos e memoriais descritivos das intervenções de restauro das décadas de 1950, 1980 e 2010 em relação ao original de 1903. Pretende-se analisar se as transformações do pensamento ligadas ao campo disciplinar do restauro no decorrer do século $X X$ veem-se refletidas nas posturas adotadas em cada intervenção, que serão analisadas sob o prisma das teorias vigentes em conservação e restauração de monumentos históricos. Verificar-se-á, também, se existe correlação entre posturas adotadas pelos órgãos de preservação do patrimônio brasileiros quanto a essas mesmas intervenções e as posições paradigmáticas dessas instituições (a nível municipal, estadual e federal).

Palavras-chave: patrimônio cultural, restauro arquitetônico, memória, representação, teoria da restauração, monumento histórico, Theatro Municipal de São Paulo, órgãos de preservação do patrimônio. 


\section{ABSTRACT}

The Theatro Municipal de São Paulo is a building that carries a great symbolic role in the construction of São Paulo's cultural identity and memory. Inaugurated in 1911 and declared a historic heritage by the municipal (CONPRESP, 1991), state (CONDEPHAAT, 1981) and federal agencies (IPHAN, 2014), the Theater underwent three major architectural interventions in the period between its inauguration and its centenary. These interventions, however, have never been analyzed in a clear and systematic way. The objective of this research is, therefore, the identification, periodization and contextualization of such interventions through the retrospective analysis of the descriptive memorials of the restoration interventions of the 1950s, 1980s and 2010 in relation to the original project of 1903 and the graphic representations referring to each intervention period. It is intended to analyze whether the transformations of theoretical thinking linked to the disciplinary field of restoration during the twentieth century are reflected in the positions adopted in each intervention, which will be analyzed from the perspective of the theories in force in the conservation and restoration of historical monuments. It will also be checked whether there is a correlation between positions adopted by Brazilian heritage preservation bodies regarding these same interventions and the paradigmatic positions of these institutions (at the municipal, state and federal levels).

KEY-WORDS: Cultural heritage, architectural restoration, memory, representation, restoration theory, historical monument, São Paulo Municipal Theater, heritage preservation bodies. 
Aos meus pais 


\section{AGRADECIMENTOS}

À Professora Maria Lucia Bressan Pinheiro, pela orientação e disposição para acompanhar a pesquisa desde sua concepção

À arquiteta Lilian Jaha, do Departamento do Patrimônio Histórico, pelo acolhimento e incentivo desde meu primeiro estágio na Fundação Theatro Municipal de São Paulo

Ao Narciso Leme, coordenador de manutenção da Fundação Theatro Municipal de São Paulo, pela atenção e disponibilidade para acompanhar a pesquisa em acervo

Às Professoras Fernanda Fernandes e Beatriz Kühl, por me acolherem e orientarem como estagiária PAE em sua disciplina de graduação

Ao colega Gustavo Sampaio, pelos convites de ministrar aulas sobre minha pesquisa

Ao Cristiano Trindade, pelo auxílio e paciência no Acervo Iconográfico da Biblioteca da FAU USP

Aos colegas de graduação, Isabela e Gustavo, por me acompanharem desde o início desta trajetória

Aos colegas de pós-graduação, Renan, Renata, Eduardo e Cyro, pela companhia nas orientações e estágios docentes

Aos meus amigos de longa data, Luciana, Amanda, Adriana e Victor, por me acompanharem desde que me lembro

Ao meu companheiro, Lucca Bacal, pelo apoio e pela continua reiteração de que eu estava no caminho certo

Ao meu pai e minha mãe, respectivamente arquiteto e professora, que fizeram nascer em mim o desejo de ser ambas as coisas 
O fio diacrônico é a urdidura, e o sincrônico é a trama do tecido da história cultural. O historiador é o tecelão (...) (SCHORSKE, 1988). 


\section{LISTA DE FIGURAS}

FIGURA 1: Tabela de organização e distribuição dos conteúdos por capítulo.

FIGURA 2: Teatro São José, localizado no Largo São Gonçalo, em 1876.

FIGURA 3: Antigo Teatro São José durante incêndio em 1898.

FIGURA 4: Aquarela de Carlos Ekman, que ilustra seu projeto para um teatro municipal, localizado no terreno do antigo Teatro São José.

FIGURA 5: Implantação do projeto de teatro de Giacomo Leoni, entre as ruas Formosa, Barão de Itapetininga e São João.

FIGURA 6: Mapa de 1877, onde se vê o terreno no qual seria implantado o Theatro Municipal ainda ocupado pela Oficina G Sidow e Cia, que teve sua propriedade desapropriada pelo Estado e cedida à Municipalidade em 1903.

FIGURA 7: Comparação entre o Champs Élysés e Av. Central.

FIGURA 8: Theatro municipal do Rio de Janeiro em 1910.

FIGURA 9: Theatro Amazonas em Manaus.

FIGURA 10: Theatro da Paz em Belém.

FIGURA 11: Antigo Viaduto do Chá, projetado por Jules Martin e construído em 1892.

FIGURA 12: Detalhe da "Planta Geral da Cidade de São Paulo", levantada por Alexandre Cococi e Luiz F. Costa, de 1905.

FIGURA 13: Projecto de Melhoramentos da zona limitada pelas ruas Libero Badaró, São João, Formosa, Largo do Riachuelo e Ladeira Dr. Falcão e assinado por Ribeiro da Silva e Eugênio Guilhem.

FIGURA 14: Plano de avenidas de Alexandre de Albuquerque.

FIGURA 15: Planta da proposta de Samuel das Neves para a região central da cidade de São Paulo.

FIGURA 16: Perspectiva apresentada por Victor da Silva Freire em 1911.

FIGURA 17: Proposta de alargamento da Avenida Tiradentes elaborada pelo Plano Machado-Caiuby em 1911.

FIGURA 18: Planta do Plano Bouvard para as modificações no centro de São Paulo, com ênfase na região do Anhangabaú.

FIGURA 19: Planta da proposta de Bouvard para a Esplanada do Theatro.

FIGURA 20: Vista da Esplanada do Theatro em 1923.

FIGURA 21: Ramos de Azevedo, Domizano e Cláudio Rossi em fotografia publicada na edição especial da revista Ilustração Paulista de 1911. 
FIGURA 22: Fachadas do projeto de Waegeneer, publicado na revista belga L'emulation em 1877.

FIGURA 23: Fotografia externa do Theatro publicada na Monografia de Inauguração em 1911.

FIGURA 24: Desenho do projeto original do escritório de Ramos de Azevedo para a fachada lateral do Theatro Municipal.

FIGURA 25: Desenho do projeto original do escritório de Ramos de Azevedo para a fachada principal do Theatro Municipal.

FIGURA 26: Vista da esplanada do Theatrp em 1909, com destaque para a chaminé destacada por Severo (esq.) e detalhe da chaminé hoje inexistente (dir.).

FIGURA 27: Fachada Principal do Teatro em 2015.

FIGURA 28: Grupo escultórico "Drama" (à esquerda) e grupo escultórico "Música" (à direita), 2015.

FIGURA 29: Grupo escultórico que representa o amor (à esquerda) e grupo escultórico que representa o lirismo (à direita), 2015.

FIGURA 30: Atlantis da fachada principal, esculpidos por Joo Pellicciotti do Liceu de Artes e Oficios, 2015.

FIGURA 31: Ampliação de fotografia da fachada principal, com destaque para vitrais do Salão Nobre, 2015.

FIGURA 32: Fotografia da fachada lateral em 2013.

FIGURA 33: Detalhe da ornamentação do ático da fachada posterior, com coroamento por máscara e lira, 2015.

FIGURA 34: Corte do projeto original do Theatro, feito pelo escritório de Ramos de Azevedo.

FIGURA 35: Planta do primeiro andar, projeto original do escritório técnico de Ramos de Azevedo.

FIGURA 36: Mapa de assentos original da Sala de Espetáculos.

FIGURA 37: Fotografia do vestíbulo em 1911.

FIGURA 38: Fotografia das cariátides que ladeiam o portal de ingresso à primeira ordem, 2015.

FIGURA 39: Fotografia do mosaico veneziano representando o "Ouro do Reno" (à esquerda) e do mosaico veneziano representando a "Cavalgada das Valquírias" (à direita), 2015. 
FIGURA 40: Fotografia do restaurante à época de sua inauguração em 1911.

FIGURA 41: Fotografia interna da sala de espetáculos.

FIGURA 42: Foto do frontão do palco e abóbada com medalhão de Carlos Gomes na década de 1920.

FIGURA 43: Planta do segundo andar, projeto original do escritório técnico de Ramos de Azevedo.

FIGURA 44: Planta do terceiro andar, projeto original do escritório técnico de Ramos de Azevedo.

FIGURA 45: Fotografia do aspecto original do Salão Nobre.

FIGURA 46: Pinturas decorativas do forro do Salão Nobre, 2017.

FIGURA 47: Planta do quarto andar, projeto original do escritório técnico de Ramos de Azevedo.

FIGURA 48: Fotografia do camarote do proscênio em 1911.

FIGURA 49: Planta do quinto andar, projeto original do escritório técnico de Ramos de Azevedo.

FIGURA 50: Aspecto externo da Casa do Butantã em 1954, antes do início da obra de restauro.

FIGURA 51: Aspecto interno da Casa do Butantã em 1954, antes do início da obra de restauro. Nota-se a ausência de madeiramento central.

FIGURA 52: Detalhe de aspecto externo da Casa do Butantã em 1954, antes do início da obra de restauro.

FIGURA 53: Respaldo das paredes concêntricas antes da concreção.

FIGURA 54: Respaldo das paredes concêntricas depois da concreção.

FIGURA 55: Construção da base de concreto como solução para o problema de erosão por água da chuva.

FIGURA 56: Preenchimento de lacunas nas fachadas por argamassa cimentícia. FIGURA 57: Esquema do processo de restauro, que culmina no revestimento das fachadas por argamassa e pintura à base de cal.

FIGURA 58: Planta do primeiro pavimento da área de camarins, correspondente à portaria, cabines telefônicas, ambulatório, relógio de ponto, rouparia de serviço e vestíbulo para professores da orquestra.

FIGURA 59: Planta do segundo pavimento da área de camarins, que abrigava seis camarins individuais, incluído o do Maestro, com instalações sanitárias próprias. 
FIGURA 60: Planta do terceiro pavimento da área de camarins, que abrigava sete camarins individuais, incluídos o do Maestro substituto e do Maestro regente, com instalações sanitárias próprias; além de dois salões de provas.

FIGURA 61: Planta do quarto pavimento da área de camarins, que abrigava dois camarins coletivos, com instalações sanitárias próprias; além de duas salas laterais para os corpos estáveis.

FIGURA 62: Planta do quinto pavimento da área de camarins, que abrigava um camarim coletivo, que serviria como depósito de móveis e cenários, com instalações sanitárias próprias; além de dois camarins individuais nas laterais, que serviriam como salas para joalheria e "perrucchiére".

FIGURA 63: Planta do sexto pavimento da área de camarins, que abrigava duas salas para bailarinos, com instalações sanitárias próprias; além de duas salas laterais para banda e coro.

FIGURA 64: Planta do sétimo pavimento da área de camarins, que abrigava uma grande sala para o coral, com instalações sanitárias próprias; além de duas salas laterais para sapateiro e alfaiate.

FIGURA 65: Corte longitudinal do novo corpo de camarins.

FIGURA 66: Elevação posterior do TMSP.

FIGURA 67: Fotografia sem data dos camarotes do proscênio, antes de sua retirada.

FIGURA 68: Demolição dos camarotes do proscênio.

FIGURA 69: Detalhe da demolição dos camarotes do proscênio.

FIGURA 70: Detalhe da demolição dos camarotes do proscênio.

FIGURA 71: Viga treliça de aço, construída para sustentação da cúpula.

FIGURA 72: Estrutura do ciclorama.

FIGURA 73: Detalhe da estrutura do ciclorama.

FIGURA 74: Fosso da orquestra com sistema de elevação.

FIGURA 75: Sistema de elevação do palco cênico.

FIGURA 76: Sistema de elevação do palco cênico.

FIGURA 77: quadro de manobras e efeitos na cabine do palco.

FIGURA 78: Manipuladores na cabine do palco.

FIGURA 79: Escavações para rebaixamento do lençol freático.

FIGURA 80: Rebaixamento do lençol freático por meio de bombeamento a vácuo. 
FIGURA 81: Escoramentos com estacas de ferro e tabuas de peroba para proteção das escavações.

FIGURA 82: Escoramentos com estacas de ferro e tabuas de peroba para proteção das escavações.

FIGURA 83: Desenhos esquemáticos da proposta de construção de mezanino sob a cúpula.

FIGURA 84: Pintura do forro e paredes do Saguão principal.

FIGURA 85: Estrutura montada para pintura do forro sobre a escadaria principal.

FIGURA 86: (à esq.) Desenho da proposta de remodelação da escadaria principal, que pressupõe a supressão das duas colunas de granito cinza do saguão, elaborada por Tito Pistoresi (à dir) Desenho da escadaria principal da Ópera de Paris.

FIGURA 87: Fotografia da escadaria principal da Ópera de Paris, de Charles Garnier.

FIGURA 88: Fotografia da escadaria principal do Theatro Municipal, de acordo com projeto original.

FIGURA 89: Desenho da proposta de fechamento das varandas laterais, por meio de caixilhos de ferro batido.

FIGURA 90: Estrutura da escada da galeria.

FIGURA 91: Escada da galeria em construção.

FIGURA 92: Plantas esquemáticas da proposta de bilheteria aceita pela CRTM.

FIGURA 93: Planta do projeto executivo da bilheteria (primeiro pavimento).

FIGURA 94: Planta do projeto executivo da bilheteria (quinto pavimento).

FIGURA 95: Armação da antiga estrutura da segunda ordem e galeria, em processo de demolição.

FIGURA 96: Estrutura dos setores antes da demolição.

FIGURA 97: Demolição da estrutura dos setores.

FIGURA 98: Construção da nova laje das frisas.

FIGURA 99: Pilares e armação da nova estrutura perimetral de concreto.

FIGURA 100: Colocação dos parapeitos superiores em gesso.

FIGURA 101: Aspecto final dos parapeitos decorados com folhas de ouro.

FIGURA 102: Parapeito metálico desmontado.

FIGURA 103: Montagem dos parapeitos metálicos inferiores, já remodelados. 
FIGURA 104: Cortes transversais do projeto executivo de remodelação das ordens da sala de espetáculos.

FIGURA 105: Corte longitudinal do projeto executivo de remodelação das ordens da sala de espetáculos.

FIGURA 106: Corte transversal do projeto executivo de remodelação das ordens da sala de espetáculos.

FIGURA 107: Cortes transversais do projeto executivo de remodelação das ordens da sala de espetáculos.

FIGURA 108: Corte transversal do projeto executivo de remodelação das ordens da sala de espetáculos.

FIGURA 109: Planta do projeto executivo de remodelação da plateia.

FIIGURA 110: Planta do projeto executivo de remodelação da primeira ordem.

FIGURA 111: Planta do projeto executivo de remodelação do foyer.

FIGURA 112: Planta do projeto executivo de remodelação da segunda ordem.

FIGURA 113: Planta do projeto executivo de remodelação da galeria.

FIGURA 114: Fotografia interna do aspecto original da sala de espetáculos.

FIGURA 115: Fotografia interna da sala de espetáculos com os andaimes, durante a obra da década de 1950.

FIGURA 116: Fotografia interna da sala de espetáculos com os andaimes, durante a obra da década de 1950.

FIGURA 117: Planta original do primeiro andar (1903-1911)

FIGURA 118: Planta do primeiro andar do projeto de 1952-1955

FIGURA 119: Elevação dos parapeitos das novas ordens da sala de espetáculos.

FIGURA 120: Comparação entre o mobiliário original e o mobiliário novo.

FIGURA 121: Comparação entre o mobiliário original e o mobiliário novo.

FIGURA 122: Encarte de página inteira sobre final da obra de intervenção do Theatro Municipal de São Paulo no qual misturam-se os termos restauração e reforma para designar o mesmo processo.

FIGURA 123: Exterior dos galpões que compunham o matadouro da Vila Mariana em 1900.

FIGURA 124: Vista aérea do conjunto do Matadouro da Vila Mariana após a sua desativação.

FIGURA 125: Fachada do conjunto antes da restauração na década de 1980. 
FIGURA 126: Detalhe da elevação do projeto de restauro das fachadas elaborado pelos arquitetos do DPH.

FIGURA 127: Elevação do projeto de restauro das fachadas elaborado pelos arquitetos do DPH

FIGURA 128: Manchete do jornal da Folha de S. Paulo, do dia 8 de fevereiro de 1985, anuncia importância de intervenção urgente no Theatro Municipal de São Paulo, após laudo do IPT.

FIGURA 129: Manchete de jornal que lamenta a ausência do Theatro Municipal em funcionamento.

FIGURA 130: Manchete de jornal que lamentam demonstra preocupação com a duração das obras.

FIGURA 131: Manchete de jornal que denota preocupação com o fechamento do Theatro.

FIGURA 132: Manchete de jornal que demonstra preocupação com fechamento do Theatro e seu impacto na cultura artística da cidade.

FIGURA 133: Artigo de jornal cuja manchete expressa preocupação financeira com relação às obras de restauro do Theatro Municipal.

FIGURA 134: Artigo de jornal cuja manchete expressa preocupação financeira com relação às obras de restauro do Theatro Municipal.

FIGURA 135: Esquema das etapas cronológicas da intervenção sofrida pelo edifício do Theatro durante a década de 1980.

FIGURA 136: Fotografia de superfície de pintura fissurada.

FIGURA 137: Fotografia de superfícies de pintura destacada.

FIGURA 138: Tabela dos estados superficiais dos componentes metálicos do exterior do edifício.

FIGURA 139: Tabela das análises químicas dos produtos de corrosão dos componentes metálicos do exterior do edifício.

FIGURA 140: Tabela de classificação do estado da matéria e respectivas recomendações.

FIGURA 141: Fotografia do teste de limpeza do arenito com detergente.

FIGURA 142: Fotografia do teste de limpeza do arenito com água oxigenada.

FIGURA 143: Fotografia do teste de limpeza do arenito, granito e argamassa com jato de água quente sob pressão. 
FIGURA 144: Fotografia do teste de limpeza do arenito, granito e argamassa com jato de água quente sob pressão.

FIGURA 145: Corte longitudinal do edifício do TMSP, dividida em quatro setores. FIGURA 146: Planta do subsolo do edifício do TMSP, dividido em quatro setores. FIGURA 147: Planta do primeiro pavimento do edifício do TMSP, dividido em quatro setores.

FIGURA 148: Planta do segundo pavimento do edifício do TMSP, dividido em quatro setores.

FIGURA 149: Planta do terceiro pavimento do edifício do TMSP, dividido em quatro setores.

FIGURA 150: Planta do quarto pavimento do edifício do TMSP, dividido em quatro setores.

FIGURA 151: Planta do quinto pavimento do edifício do TMSP, dividido em quatro setores.

FIGURA 152: Planta do sexto pavimento do edifício do TMSP, dividido em quatro setores.

FIGURA 153: Planta do sétimo pavimento do edifício do TMSP, dividido em quatro setores.

FIGURA 154: Planta do oitavo pavimento do edifício do TMSP, dividido em quatro setores.

FIGURA 155: Planta do nono pavimento do edifício do TMSP, dividido em quatro setores.

FIGURA 156: Planta do décimo pavimento do edifício do TMSP, dividido em quatro setores.

FIGURA 157: Planta da cobertura do edifício do TMSP, dividido em quatro setores.

FIGURA 158: Ficha para registro de vistoria.

FIGURA 159: Remoção do tanque de óleo do subsolo.

FIGURA 160: Remoção do tanque de óleo do subsolo.

FIGURA 161: Retirada de tubulação inservível.

FIGURA 162: Retirada de tubulação inservível.

FIGURA 163: Pistões hidráulicos do mecanismo de elevação do palco e infiltrações. 
FIGURA 164: Pistões hidráulicos do mecanismo de elevação do palco e infiltrações.

FIGURA 165: Interiores do setor de camarins durante a reforma.

FIGURA 166: Interiores do setor de camarins durante a reforma.

FIGURA 167: Corredor do setor de camarins durante a reforma.

FIGURA 168: Corredor do setor de camarins depois da reforma.

FIGURA 169: Estrutura metálica de reforço construída Fotografia da estrutura da cobertura da cúpula na cobertura do Salão Nobre.

FIGURA 170: Fotografia da estrutura da cobertura da cúpula.

FIGURA 171: Fotografia do interior do restaurante.

FIGURA 172: Exemplo de ficha de análise diagnóstica do estado de conservação dos vitrais.

FIGURA 173: Exemplo de ficha de análise diagnóstica do estado de conservação dos vitrais.

FIGURA 174: Diagrama de peças de ligação dos vitrais do Salão Nobre.

FIGURA 175: Planta do primeiro andar do projeto executivo de 1980, com destaque para bilheteria.

FIGURA 176: Desenho da proposta de intervenção para bilheteria.

FIGURA 177: Fotografia do projeto da bilheteria implementado.

FIGURA 178: Planta do primeiro andar do projeto executivo de 1980, com destaque para restaurante.

FIGURA 179: Planta do subsolo do projeto executivo de 1980.

FIGURA 180: Intervenção no subsolo.

FIGURA 181: Projeto para o subsolo.

FIGURA 182: Resultado da implantação do Salão dos Arcos.

FIGURA 183: Detalhe das poltronas da Sala de Espetáculos depois da mudança cromática.

FIGURA 184: Resultado geral da troca de cor do interior da Sala de Espetáculos para o verde.

FIGURA 185: Desenho da proposta de intervenção para a bilheteria.

FIGURA 186: Abertura da Avenida Central.

FIGURA 187: Fotografia de 1912 da fachada principal do Theatro Municipal do Rio de Janeiro. 
FIGURA 188: Fotografia do plano de alvenaria autoportante construído durante a intervenção da década de 1930.

FIGURA 189: Planta da cobertura do TMRJ.

FIGURA 190: Fotografia da cúpula da rotunda antes da intervenção (à esq.), fotografia da cúpula da rotunda após a intervenção (à dir.).

FIGURA 191: Diferença entre o cobre patinado artificialmente e naturalmente. FIGURA 192: Aquarela que sugere douramento dos elementos decorativos da cobertura.

FIGURA 193: Douramento novo dos elementos decorativos da cobertura.

FIGURA 194: Ficha técnica da obra de restauro.

FIGURA 195: localização do restaurante na planta do primeiro andar.

FIGURA 196: ampliação da planta do restaurante, dividida em dois ambientes.

FIGURA 197: Área do forro que apresenta reboco novo.

FIGURA 198: Área do forro que apresenta perda pictórica e no douramento.

FIGURA 199: Área antes da remoção de pintura posterior (esq.) e depois do procedimento (dir.).

FIGURA 200: Estado do forro antes da intervenção.

FIGURA 201: Forro proposto.

FIGURA 202: Barra decorativa imitando mosaico.

FIGURA 203: Pintura com frisos e elementos florais.

FIGURA 204: Barra decorativa com área grande de perda pictórica.

FIGURA 205: Pintura decorativa com grande área de perda pictórica.

FIGURA 206: Reintegração das lacunas na barra imitativa de mosaico.

FIGURA 207: Esquema de algumas das formas antropomórficas identificadas pelo estudo.

FIURA 208: Proposta de reconstituição da barra decorativa de uma das paredes. FIGURA 209: Identificação e testes de tonalidade para pintura lisa das paredes FIGURA 210: Teste de reintegração de pintura decorativa.

FIGURA 211: Colunas geminadas entre os dois ambientes do restaurante.

FIGURA 212: Teto da arcada sobre as colunas, que também apresenta resquícios de repintura e lacunas de douramento.

FIGURA 213: Localização das salas de apoio do palco na planta do primeiro pavimento.

FIGURA 214: Ampliação das plantas das salas de apoio do palco. 
FIGURA 215: Faixa decorativa com motivos florais.

FIGURA 216: Resquícios de faixa superior geométrica.

FIGURA 217: Recortes cobertos com massa e pintura lisa, realizados para embutir instalações elétricas.

FIGURA 218: Perda da camada pictórica da faixa superior geométrica.

FIGURA 219: Reconstituição dos motivos geométricos realizados com auxílio digital.

FIGURA 220: Uso das salas como apoio dos ajudantes do maestro (esq.) e guarda de instrumentos (dir.).

FIGURA 221: Localização da antiga Sala de Imprensa na planta do subsolo.

FIGURA 222: Ampliação da planta da Sala de Imprensa.

FIGURA 223: Interior da antiga Sala de Imprensa antes da intervenção.

FIGURA 224: Imagem das paredes da Sala antes da intervenção, nas quais se percebe a divisão tripartida de sua pintura decorativa.

FIGURA 225: Antes e depois da reintegração de pequenas lacunas.

FIGURA 226: Antes e depois da reintegração dos elementos florais com douramento.

FIGURA 227: Localização do Salão nobre na planta do terceiro andar.

FIGURA 228: Ampliação da planta do Salão Nobre.

FIGURA 229: Trincas no forro do Salão Nobre, antes da intervenção.

FIGURA 230: Descolamento da pintura em forma de bolha (esq.) e descolamento da pintura artística (dir.).

FIGURA 231: Lacuna na policromia (esq.) e retoque ligeiramente alterado (dir.).

FIGURA 232: Descolamentos nas áreas das portas do Salão Nobre, antes da intervenção.

FIGURA 233: Teste de fixação de descolamento (esq.). e obturação com massa acrílica (dir.).

FIGURA 234: Aplicação de bolo armênio (esq.) e aspecto posterior à reintegração (dir.).

FIGURA 235: Aspecto dos tapetes murais antes da intervenção.

FIGURA 236: Aspecto do piso da plateia após a restauração.

FIGURA 237: Aspecto geral da Sala de Espetáculos vermelha.

FIGURA 238: Aspecto das cortinas do palco.

FIGURA 239: Tapete desenhado pelos Irmãos Campana para o Salão Nobre. 
FIGURA 240: Artigo publicado na Folha de S. Paulo que tematiza o projeto de mobiliários dos Irmãos Campana para o restaurante do Theatro Municipal.

FIGURA 241: Identificação dos vitrais na fachada principal.

FIGURA 242: Fotografia retirada da edição de 23 de outubro de 2010 do jornal A Folha de São Paulo, que anunciam o início da instalação dos vitrais já restaurados no TMSP.

FIGURA 243: Fotografia retirada da edição de 23 de outubro de 2010 do jornal A Folha de São Paulo, que anunciam o início da instalação dos vitrais já restaurados no TMSP.

FIGURA 244: Elevação da fachada sul. Em vermelho, esquadrias do Salão Nobre; em amarelo, ósculos sob a cúpula; em azul, portas externas das salas Branca e Rosa; em verde, esquadrias da fachada posterior.

FIGURA 245: Elevação da fachada norte. Em vermelho, esquadrias do Salão Nobre; em amarelo, ósculos sob a cúpula; em azul, portas externas das salas Branca e Rosa; em verde, esquadrias da fachada posterior.

FIGURA 246: Elevação da fachada leste. Em vermelho, esquadrias do Salão Nobre; em amarelo, ósculos sob a cúpula; em verde, esquadrias das fachadas laterais.

FIGURA 247: Elevação da fachada oeste. Em vermelho, esquadrias do Salão Nobre; em amarelo, ósculos sob a cúpula; em verde, esquadrias das fachadas laterais.

FIGURA 248: Planta de cobertura do TMSP, na qual se destacam as estruturas de madeira (vermelho), metal (azul) e mistas (amarelo).

FIGURA 249: Fotografia aérea da cobertura, na qual se notam os diferentes tons de pátina sobre as telhas de cobre, com predomínio do verde.

FIGURA 250: Processo de remoção das amostras de argamassa, efetuada com broca-corpo.

FIGURA 251: Inspeção da aderência da argamassa, realizada com martelo de borracha.

FIGURA 252: Deterioração da cornija e seus respectivos elementos decorativos.

FIGURA 253: Desprendimento do plasticôte da cornija.

FIGURA 254: Áreas de desprendimento do plasticôte.

FIGURA 255: Arenito que sofreu perda de prótese (esq.) e reintegrações inadequadas (dir.). 
FIGURA 256: Esfoliação do arenito (esq.) e presença de biofilme (dir.).

FIGURA 257: Chapas de arenito desprendidas (esq.) e arenito com desprendimento (dir.).

FIGURA 258: Vegetação nas juntas do arenito (esq.) e pintura sobre cantaria (dir.).

FIGURA 259: lluminação externa do Theatro Municipal antes de 2011.

FIGURA 260: Destaque para visibilidade excessiva dos aparelhos de iluminação, fixação em cantaria, corrosão de elementos metálicos e péssimo estado de conservação dos refletores de piso.

FIGURA 261: lluminação externa do TMRJ (2004) e simulação do projeto de iluminação do TMSP. 


\section{LISTA DE ANEXOS}

ANEXO 1: Cronograma da obra de construção do TMSP

ANEXO 2: Ficha técnica da obra de construção do TMSP

ANEXO 3: Desenhos técnicos do projeto de 1952-1955

ANEXO 4: Desenhos técnicos do projeto de 1988-1991

ANEXO 5: Ficha técnica da intervenção de 1981-1991

ANEXO 6: Desenhos técnicos do projeto de 2006-2011 


\section{LISTA DE ABREVIAÇÕES}

TMSP - Theatro Municipal de São Paulo

TMRJ - Theatro Municipal do Rio de Janeiro

FTMSP - Fundação Theatro Municipal de São Paulo

DPH - Departamento do Patrimônio Histórico

Condephaat - Conselho de Defesa do Patrimônio Histórico, Arqueológico, Artístico e Turístico do Estado de São Paulo

Conpresp - Conselho Municipal de Preservação do Patrimônio Histórico de São Paulo

Iphan - Instituto do Patrimônio Histórico e Artístico Nacional

AHM-SP - Arquivo Histórico Municipal de São Paulo 


\section{Sumário}

INTRODUÇÃO

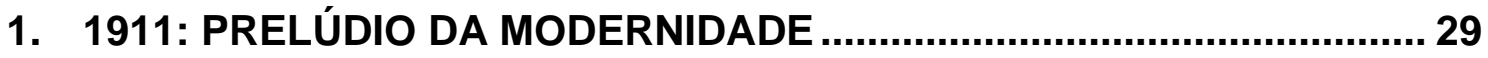

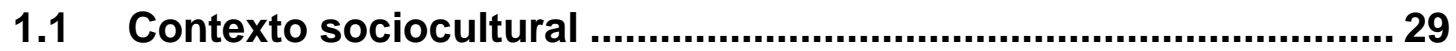

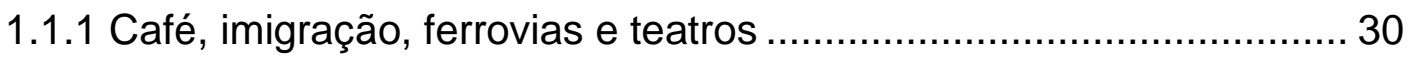

1.1.2 Antecedentes jurídicos e negociações............................................ 32

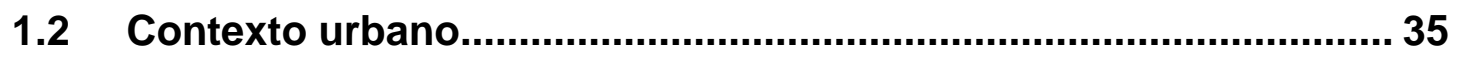

1.2.1 A recém-criada república e sua roupagem europeia ..................... 36

1.2.2 São Paulo e seus dois centros ................................................... 40

1.2.3 Parque do Anhangabaú e a Esplanada do Theatro .......................... 41

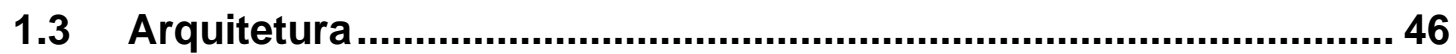

1.3.1 Polêmica da autoria e o ecletismo .............................................. 48

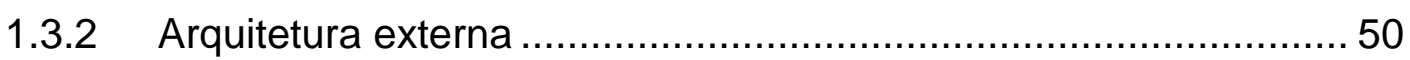

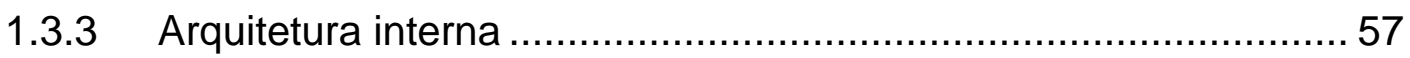

2. A DÉCADA DE 1950: SEGUNDA MODERNIDADE ................................ 71

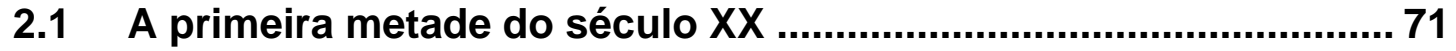

2.1.1 Contexto internacional: o Restauro Filológico e a Carta de Atenas 72

2.1.2 Contexto nacional: o Sphan e as restaurações em estilo .................. 78

2.2 A intervenção (1952-1955): IV Centenário da Cidade de São Paulo 86

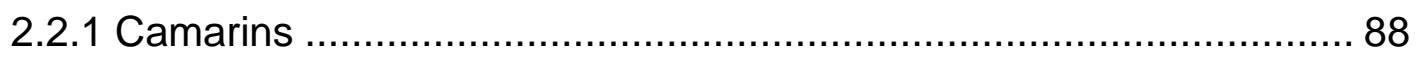

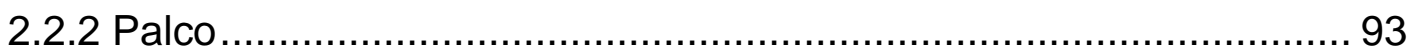

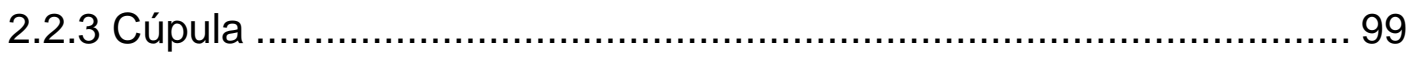

2.2.4 Saguão e Escadaria Principal.................................................. 100

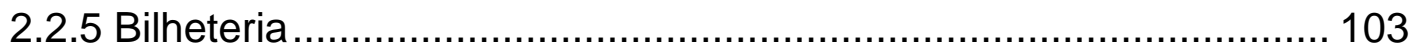

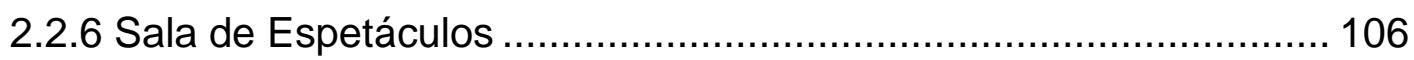

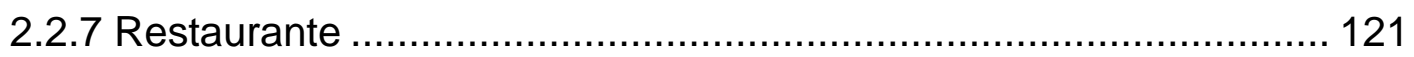

2.3 Balanço Crítico da Intervenção: Nova Cidade, Novos Monumentos

3. A DÉCADA DE 1980: RECONHECIMENTO …........................................ 126

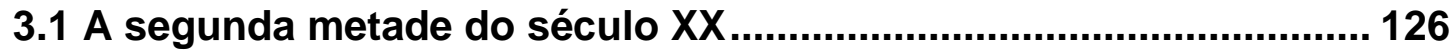

3.1.1 Contexto Internacional: Restauro Crítico, Cesare Brandi e Carta de Veneza. 
3.1.2 Contexto Nacional: Condephaat e alargamentos conceituais. 132

3.2 A intervenção (1982-1991): Tombamento ........................................ 139

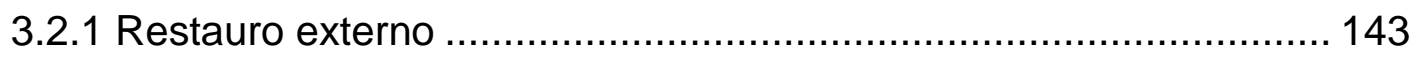

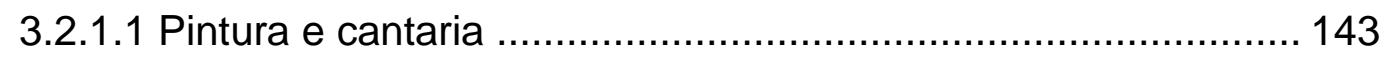

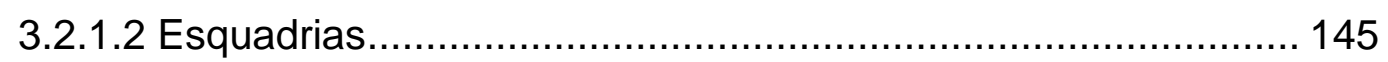

3.2.1.3 Estatuária metálica .......................................................... 145

3.2.1.4 A Questão do Arenito …………………........................... 150

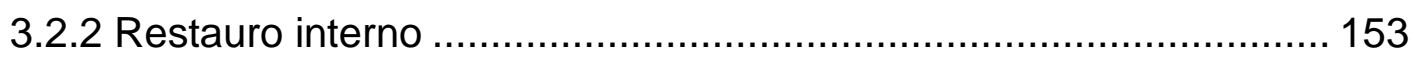

3.2.2.1 Estruturas, Instalações e Equipamentos ............................... 160

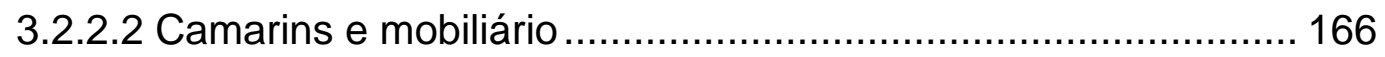

3.2.2.3 Salão Nobre e Insetos Xilófagos ........................................... 168

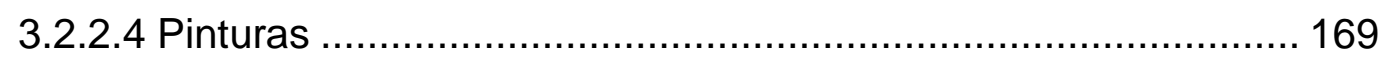

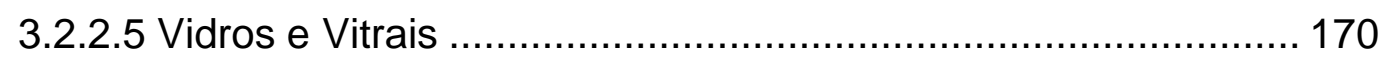

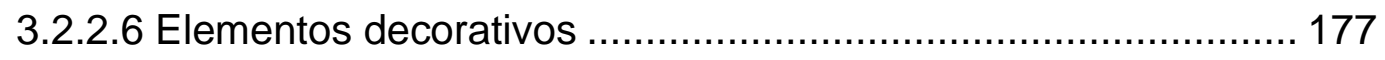

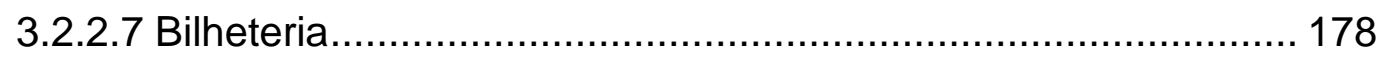

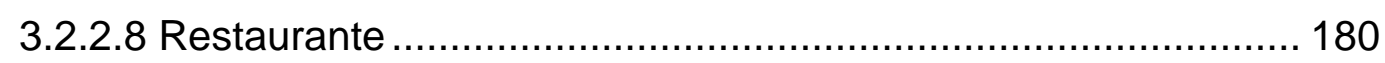

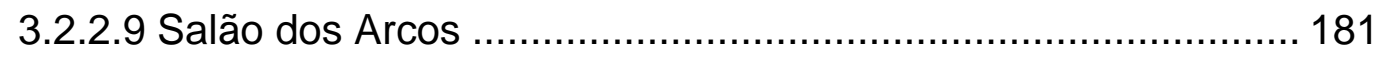

3.2.2.10 Sala de Espetáculos .......................................................... 183

3.3 Balanço Crítico da Intervenção: Consonâncias e Dissonâncias .... 184

4. A DÉCADA DE 2010: CONTEMPORANEIDADE .................................193

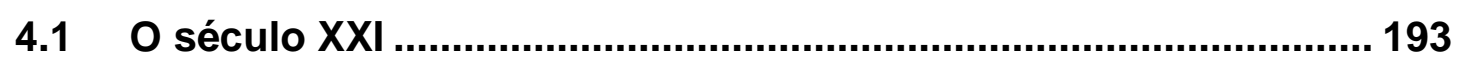

4.1.1 Contexto internacional: Revisões e atualizações de Cesare Brandi, do Restauro Crítico e da Carta de Veneza ................................................. 193

4.1.2 Contexto nacional: a Hipermanutenção e o Restauro do Theatro Municipal do Rio de Janeiro............................................................ 197

4.2 A intervenção (2006-2011): Centenário TMSP ................................. 207

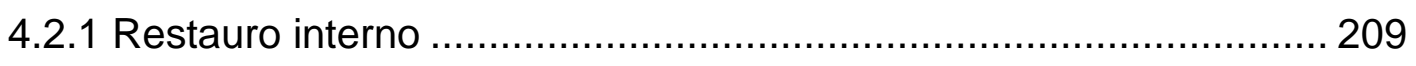

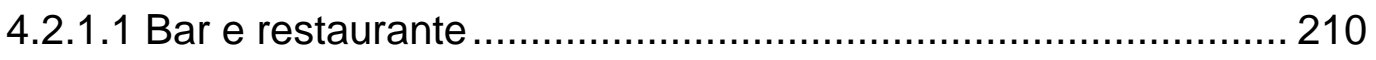

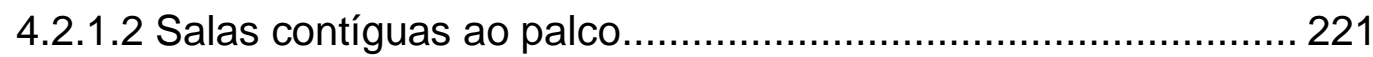

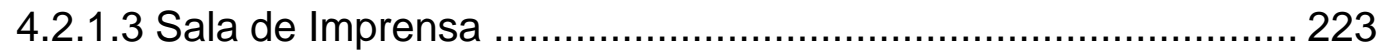

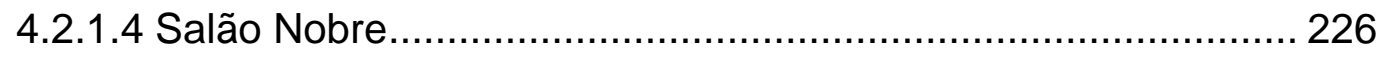

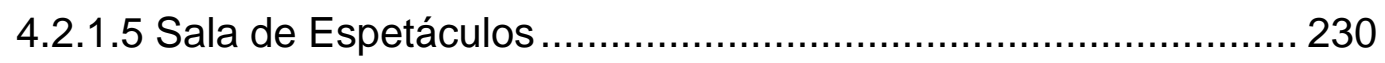

4.2.1.6 Mobiliário Irmãos Campana................................................... 231 


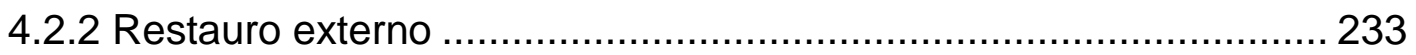

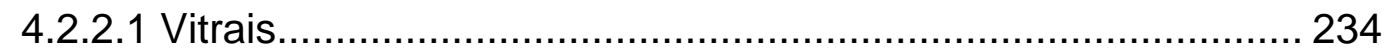

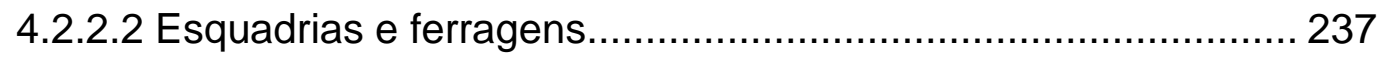

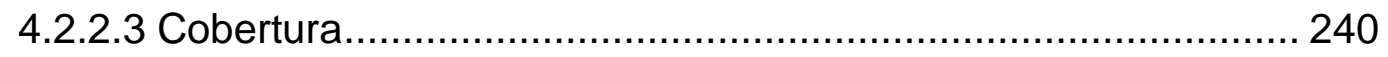

4.2.2.4 Argamassa e pintura............................................................ 243

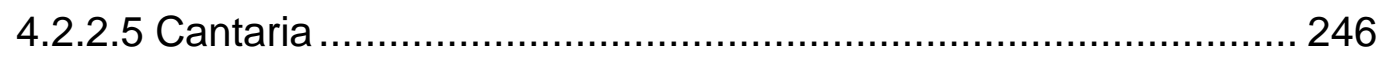

4.2.2.6 Elementos decorativos em metal......................................... 249

4.2.2.7 Projeto Luminotécnico das fachadas .................................... 250

4.3 Balanço crítico da intervenção: confusões teóricas ........................ 252

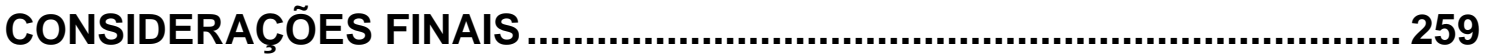

BIBLIOGRAFIA

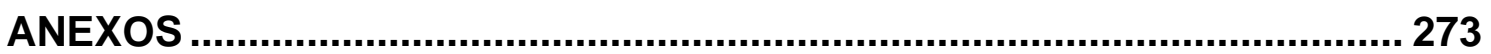

ANEXO 1: Cronograma da obra de construção do TMSP ...................... 273

ANEXO 2: Ficha técnica da obra de construção do TMSP ..................... 274

ANEXO 3: Desenhos técnicos do projeto de 1952-1955........................ 278

ANEXO 4:Desenhos técnicos do projeto de 1988-1991 …...................... 282

ANEXO 5: Ficha técnica da intervenção de 1981 - 1991 ........................ 284

ANEXO 6: Desenhos técnicos do projeto de 2006-2011 ........................ 287 


\section{INTRODUÇÃO}

O Theatro Municipal de São Pauloº, construído entre 1903 e 1911, passou por três grandes intervenções arquitetônicas, da sua inauguração ao seu centenário. A primeira delas ocorreu por ocasião do IV Centenário da cidade de São Paulo, durante a década de 1950; a segunda, logo após seu tombamento como patrimônio arquitetônico pela esfera estadual (Condephaat) na década de 1980 e a última, concluída em 2011, no ano de seu centenário.

Apesar de sua relevância como monumento paulista, reconhecido e tombado pelas instâncias municipal (Conpresp, 1991), estadual (Condephaat, 1981) e federal (Iphan, 2014), o edifício do Theatro nunca teve tais intervenções analisadas dentro do campo epistemológico da teoria da restauração ou mesmo da prática dos órgãos de preservação do patrimônio. Dito isso, a presente pesquisa tem por objetivos identificar tais intervenções, periodizá-las e contextualizá-las do ponto de vista teórico e prático, dentro dos respectivos contextos nacionais e internacionais.

A falta de informação clara, acessível e concisa a respeito das intervenções realizadas no edifício do Theatro Municipal ao longo de sua história, bem como a dos princípios teóricos de restauro que as nortearam, coloca em risco a leitura do objeto, que gera uma interpretação superficial de um processo que se deu pela sobreposição temporal de várias interferências. Lembrando as palavras de Michel de Certeau:

Os lugares são histórias fragmentárias e isoladas em si, dos passados roubados à legibilidade por outro, tempos empilhados que podem se desdobrar, mas que estão ali antes como histórias à espera e permanecem no estado de quebra-cabeças, enigmas, enfim simbolizações conquistadas na dor e no prazer do corpo (CERTEAU, 1994).

\footnotetext{
${ }^{1}$ Ao longo da presente dissertação, foi adotada a grafia desatualizada da palavra Theatro para referir-se especificamente ao edifício do Municipal, uma vez que seu nome ficou institucionalizado pelo decreto de regulamentação da Fundação Theatro Municipal de São Paulo em 2011 (decreto n. 53.225 de 19 de junho de 2011). Foge do escopo da pesquisa problematizar seu uso como recurso gerador de uma aura de ancianidade ou nobreza ao objeto.
} 
O problema a ser encarado pela pesquisa é, nos termos cunhados por Certeau, o desdobramento desses períodos cronológicos empilhados sob a forma de intervenções de restauro no edifício, cujo entendimento aprofundado é ponto de partida da resolução do enigma de legibilidade do objeto. A disponibilização de material sistematizado, sintético e gráfico sobre as etapas da materialização do edifício do Theatro de São Paulo e suas implicações do ponto de vista da teoria da restauração opera como ferramenta de interpretação da obra como um todo, a partir da leitura de suas sobreposições.

O recorte temporal abrangido pela pesquisa é marcado por quatro etapas cronológicas, correspondentes a cada um dos quatro capítulos da dissertação. Dessa forma, foi possível realizar uma análise ao mesmo tempo sincrônica e diacrônica das intervenções em questão, levando-se em consideração as aproximações e distanciamentos dos princípios que regiam as restaurações em cada período (Figura 1).

\begin{tabular}{|c|c|c|c|c|c|}
\hline CAPÍTULO & $\begin{array}{l}\text { 1. } 1910 \text { - Prelúdio } \\
\text { da Modernidade }\end{array}$ & \multicolumn{2}{|c|}{ 2. 1950 - Segunda Modernidade } & 3. 1980 - Reconhecimento & 4. 2010 - Contemporaneidade \\
\hline \multirow{2}{*}{$\begin{array}{c}\text { DATA/ } \\
\text { OCASIÃO }\end{array}$} & $1903-1911$ & \multicolumn{2}{|r|}{$1952-1955$} & 1982-1991 & 2006-2011 \\
\hline & Construção & \multicolumn{2}{|r|}{ 1. Intervenção } & 2. Intervenção & 3. Intervenção \\
\hline \multirow{3}{*}{ CONTEXTO } & Sociocultural & \multicolumn{2}{|c|}{ IV Centenário SP } & Tombamento Condephaat & Centenário TMSP \\
\hline & Urbano & $\begin{array}{c}\text { CONTEXTO } \\
\text { INTERNACIONAL }\end{array}$ & $\begin{array}{l}\text { Restauro Filológico e Carta } \\
\text { de Atenas }\end{array}$ & $\begin{array}{l}\text { Restauro Crítico e Carta de } \\
\text { Veneza }\end{array}$ & Revisões Restauro Crítico \\
\hline & Arquiteônico & $\begin{array}{l}\text { CONTEXTO } \\
\text { NACIONAL }\end{array}$ & $\begin{array}{l}\text { Restauro Casa Bandeirista } \\
\text { Butantã }\end{array}$ & $\begin{array}{l}\text { Restauro Cinemateca } \\
\text { Brasileira }\end{array}$ & $\begin{array}{l}\text { Restauro Theatro Municipal do } \\
\text { Rio de Janeiro }\end{array}$ \\
\hline
\end{tabular}

Figura 1: Tabela de organização e distribuição dos conteúdos por capítulo.

Fonte: Elaborado pela autora.

Cada etapa foi analisada em três eixos temáticos sobrepostos: o do referencial teórico interno ao campo disciplinar do restauro, a nível internacional; o das práticas de restauração coetâneas, a nível nacional e 0 das próprias intervenções que incidiram diretamente sobre o Theatro, a nível local. Tal postura vai ao encontro da corrente de pensamento historiográfico relativista encabeçada por Jacques Revel que:

(...) vê no princípio da variação de escala um recurso de excepcional fecundidade, porque possibilita que se construam objetos complexos e portanto que se leve em consideração a estrutura folheada do social. Ela afirma ao mesmo tempo que nenhuma escala tem privilégio sobre outra, já que é o seu cotejo que traz o maio benefício analítico (REVEL, 1996, p. 14). 
Sendo assim, o primeiro capítulo trata do momento inicial da concepção do edifício, na virada do século XIX para o XX, tendo em vista os contextos sociocultural, urbano e arquitetônico que a permearam. O segundo capítulo tematiza a primeira grande intervenção, ocorrida durante a década de 1950, tomando como base analítica os postulados teóricos do Restauro Filológico e da Carta de Atenas, além das práticas coetâneas do Iphan na restauração da Casa Bandeirista do Butantã.

O terceiro capítulo analisa a restauração da década de 1980, a partir das bases do Restauro Crítico e da Carta de Veneza, e do cotejamento com a restauração da Cinemateca Brasileira, realizada na mesma época e pelos mesmos agentes. O quarto capítulo versa sobre a última intervenção, concluída em 2011, sob a ótica das revisões do Restauro Crítico e do caso da restauração do Theatro Municipal do Rio de Janeiro, realizado coetaneamente.

Os materiais utilizados na pesquisa são de origem ora documental ora bibliográfica - e, na maioria das vezes ambas -, variando de acordo com a natureza do problema em questão. Para análise dos projetos, foram consultados os acervos iconográficos da biblioteca da Faculdade de Arquitetura e Urbanismo da Universidade de São Paulo (FAUUSP), do Arquivo Municipal Washington Luis (AMWL), da Fundação Theatro Municipal de São Paulo (FTMSP) e do Departamento de Patrimônio Histórico (DPH). Para análise de sua conjuntura teórico-prática, foi usado material bibliográfico-documental na forma de teses, dissertações, artigos, livros, jornais e revistas. 


\section{1911: PRELÚDIO DA MODERNIDADE}

O presente capítulo apresenta um panorama dos contextos sociocultural, urbano e arquitetônico que permearam a construção e inauguração do Theatro Municipal de São Paulo. Seu nome faz referência ao período de transição entre o século XIX e o XX na capital paulista, conforme Hugo Segawa (SEGAWA, 2014).

Para tal, foram utilizadas fontes documentais e bibliográficas, que ajudaram a reconstruir o contexto do qual emergiu o Municipal. Foi dada especial atenção às primeiras, sobretudo no que diz respeito ao seu aspecto arquitetônico - como se verá a seguir -, para que a análise diacrônica das intervenções estudadas em sequência não fosse prejudicada por anacronismos e interpretações inadequadas.

\subsection{Contexto sociocultural}

A São Paulo da virada do século vinha se transformando em uma metrópole. Aliadas às transformações promovidas pelo ciclo do café, o aumento da imigração e a implantação, estavam aquelas relativas ao cenário cultural, muito ligado à implementação de teatros e casas de ópera. De acordo com Gomes Cardim, foi daí que surgiu a necessidade da construção do Municipal:

\footnotetext{
Os nossos theatros, <S. José>, <Apollo> (agora <Sant'Anna>), e $<$ Polyethama>, entregues aos interesses da especulação industrial e comercial, se nos proporcionavam, de vez em quando, amostras modelares de bôa arte, mais seguiam como é natural, a corrente que se abastardava o gosto, com estações de breguice alegre em coplas de opereta e estimulações picantes de revistas e farças grosseiras (...) Urgia uma casa de espetaculos onde se impulsionasse o gosto artístico, estimulando-o e desenvolvendo-o: creando actores para que se manifestassem os autores, e uns e outros para que se educasse 0 publico, começando por habitual-o á frequencia do theatro sério, do theatro-arte (CARDIM, 1911, p.2) ${ }^{2}$.
} 2 CARDIM, Gomes. In: Ilustração Paulista, edição Especial, ano I, n. 35, São Paulo, 11/09/1911,
s/p. Acervo Biblioteca IEB, p. 2 . 
A seguir, o contexto sociocultural envolvendo o café, a imigração, as ferrovias e teatros, bem como as negociações levadas à cabo para a construção do próprio Municipal, será recuperado à luz de fotografias, desenhos e documentos da época, com especial atenção à publicação da edição especial de inauguração do Theatro Municipal da revista Ilustração Paulista (CARDIM, 1911). Sua análise será amparada pela bibliografia correspondente (AMARAL, 1979; AMADO, 2016; COSTA, 2017).

\subsubsection{Café, imigração, ferrovias e teatros}

O cenário paulista da virada do século XIX costuma ser explicado pelo trinômio café - ferrovia - imigração. Do ponto de vista cultural, essas circunstâncias culminaram em um processo de cosmopolitização das elites, sobretudo no que diz respeito à experiência urbana na capital. O desejo de se aproximar ao modelo europeu de vida cultural tornou imprescindível a existência de uma casa de ópera capaz de receber as grandes companhias do velho continente (AMARAL, 1979).

Nesse cenário, a capital paulistana dispunha de algumas casas de espetáculo, como o Teatro Minerva (1873), o Polietama (1892) e o São José (1864) (Figura 2). Nenhum deles, no entanto, oferecia a infraestrutura adequada para o novo programa de uso e aspirações europeizantes que vinha se fazendo necessário. Além disso, por serem todos eles instituições de iniciativa privada, não atendiam ao caráter oficial considerado fundamental para exprimir o "progresso e civilização"3 (AMADO, 2016).

\footnotetext{
${ }^{3}$ Em 1885, circulavam projetos de lei para construção de uma "Grande Ópera Paulista", nos quais se destacava seu papel fundamental para o "progresso e civilização" da capital (AMADO, 2016).
} 


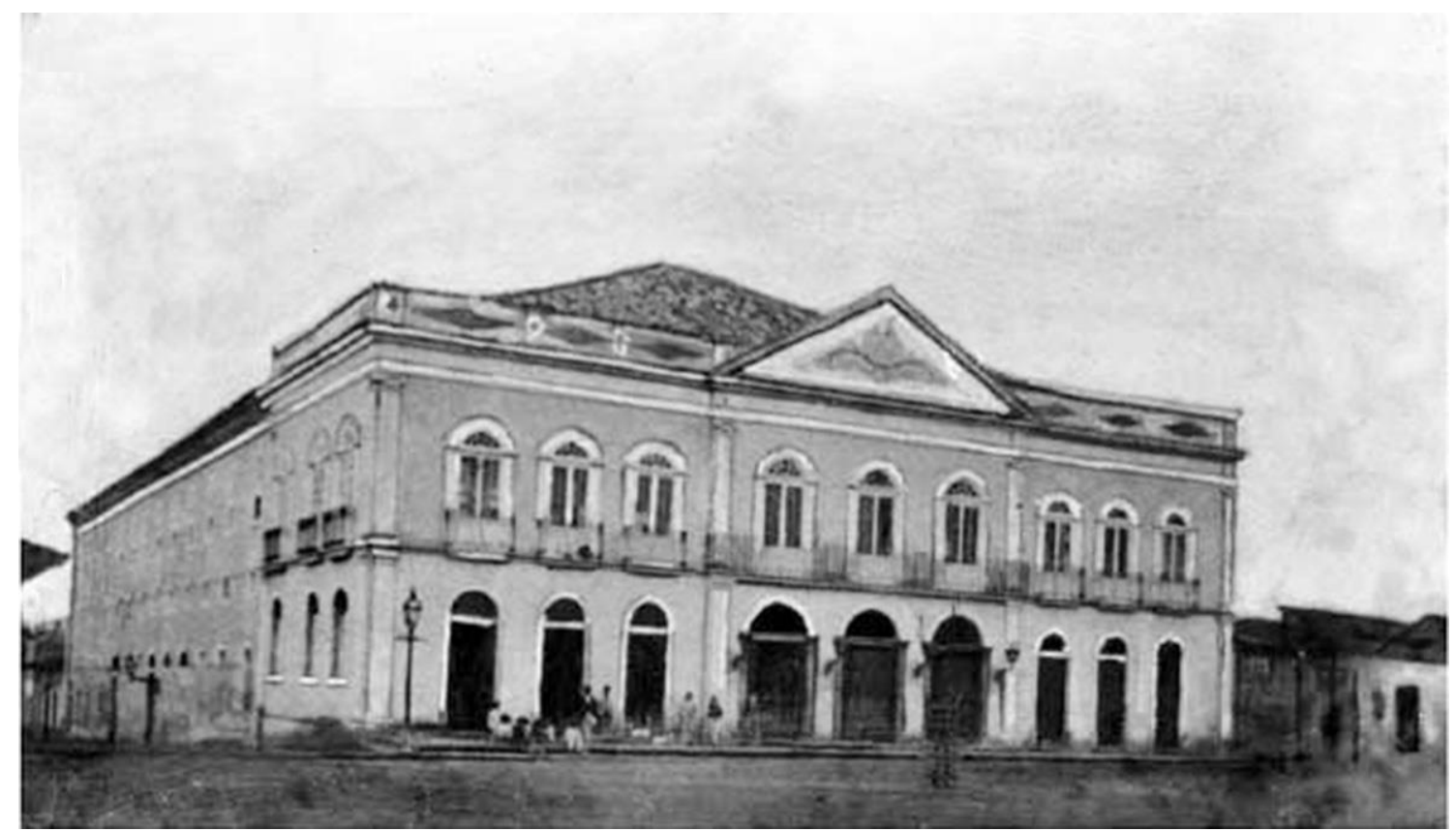

Figura 2: Teatro São José, localizado no Largo São Gonçalo, em 1876.

Fonte: https://saopaulopassado.wordpress.com

A historiografia tende a destacar o episódio do incêndio do Teatro São José, em 1898, como principal motivo da construção de um novo Teatro Municipal (Figura 3). No entanto, as iniciativas para sua concepção já circulavam em projetos de lei desde 1895. De fato, o incêndio funcionou mais no sentido de catalisar a mobilização para construção do Municipal do que de fundar esse anseio, já premente na sociedade (AMADO, 2016). 


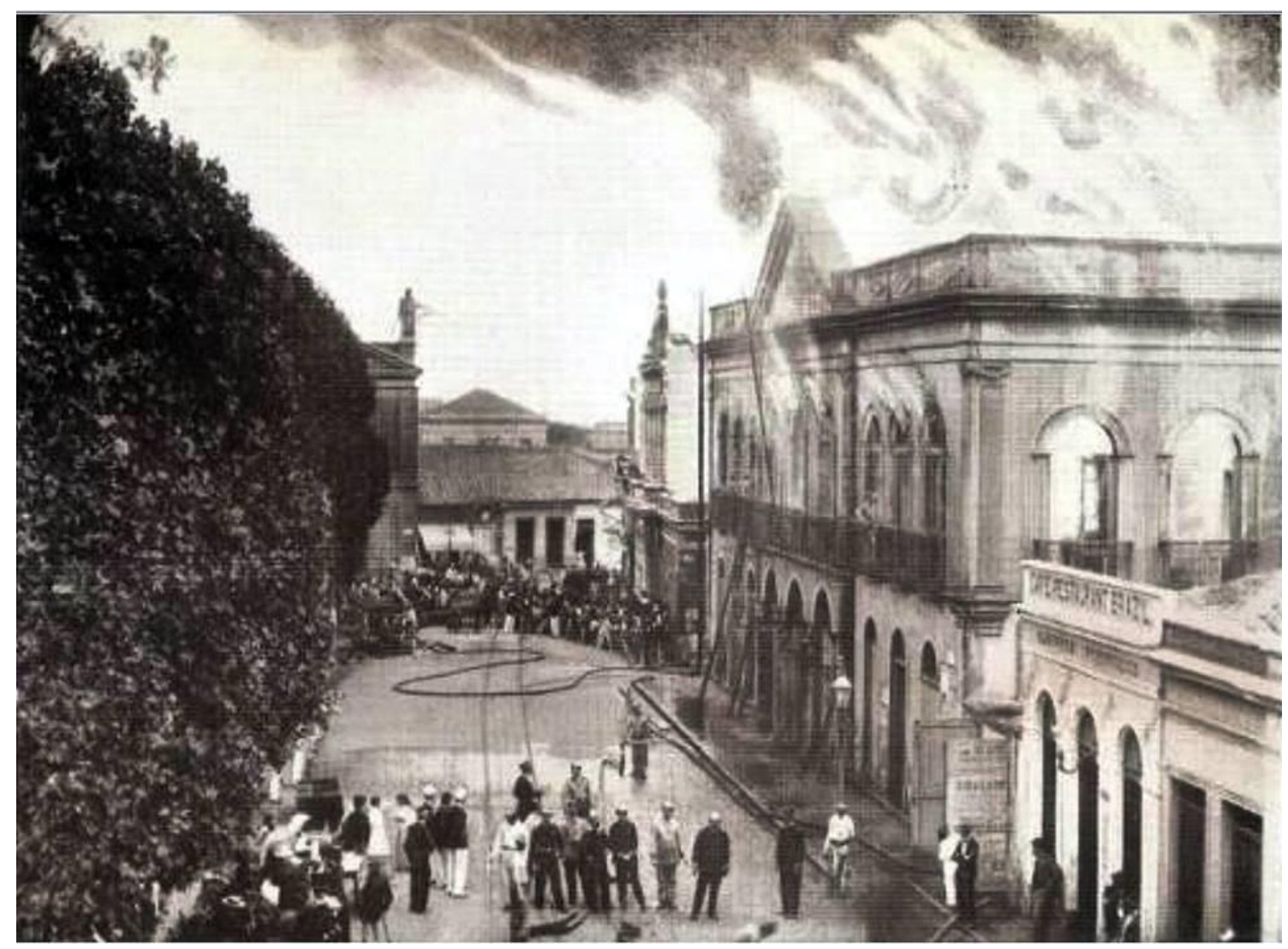

Figura 3: Antigo Teatro São José durante incêndio em 1898.

Fonte: https://sampahistorica.wordpress.com/2013/07/16/teatro-sao-jose/

\subsubsection{Antecedentes jurídicos e negociações}

Em 1895, o edil Carlos Garcia apresenta um projeto à Câmara Municipal que isenta de impostos aquele que construísse o novo teatro, que acaba sendo convertido na Lei n. 159 de 2 de maio de 1895. Depois de quase um ano sem receber proposta alguma, é votada a Lei n. 200 de 20 de fevereiro de 1896, elaborada pelos vereadores José Roberto e Pedro Gomes Cardim, a partir da qual se autoriza a abertura de concorrência pública para construção do teatro (CARDIM, 1911).

Nesse contexto, o construtor gozaria de vinte anos de isenção de impostos e do direito à livre escolha para desapropriação do terreno onde seria implantado o teatro. Foram submetidas duas propostas nos anos de 1897 e 1898, respectivamente pelos engenheiros João dos Reis de Souza Dantas e João Felício, com participação de Felipe Santoro, para construção da casa de espetáculos na Praça da República, mas ambas foram negadas por exigirem maiores regalias (AMADO, 2016). 
Motivada por esse entrave, foi promulgada a lei n. 336 de 24 de janeiro de 1898, que ampliava o período de isenção de impostos para o prazo de cinquenta anos. Apesar disso, nenhum dos engenheiros que haviam submetido propostas se apresentaram novamente a essa concorrência. Dos nove projetos recebidos, dois foram aprovados, sendo um deles de autoria de José Aranha e Arthur Cortines Laxe, para construção na Praça da República; e o outro de Carlos Ekman, para o terreno onde estivera localizado o incendiado São José ${ }^{4}$ (AMARAL, 1979) (Figura 4).

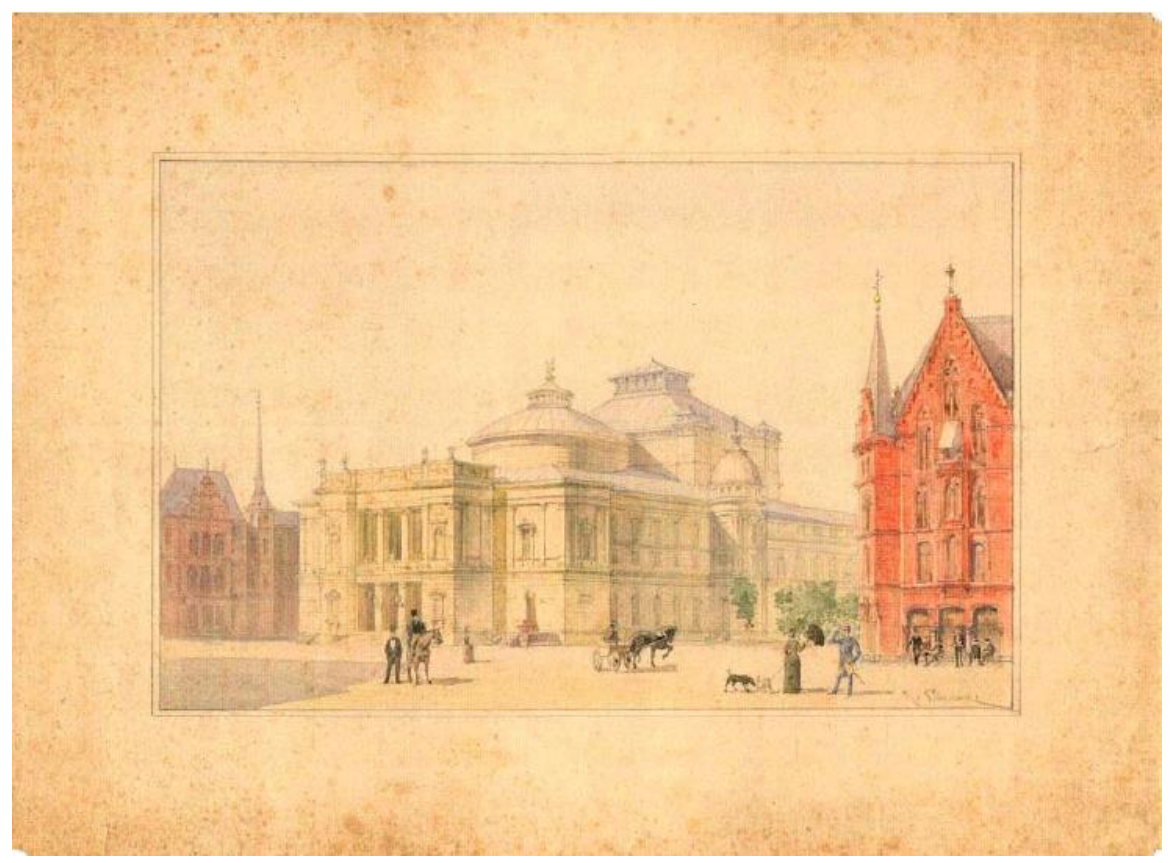

Figura 4: Aquarela de Carlos Ekman, que ilustra seu projeto para um teatro municipal, localizado no terreno do antigo Teatro São José. Chama a atenção o entorno de feições góticas que claramente não corresponde à realidade do local à época. Fonte: AMADO, 2016, p. 244.

Nenhuma dessas propostas é levada a cabo, devido à falta de capital para sua execução. No mesmo ano, o arquiteto Giacomo Leoni, que havia participado da concorrência com uma proposta para a Praça da República, celebra um acordo com a municipalidade para a construção de seu projeto em uma nova implantação, dessa vez entre as ruas Formosa, Barão de Itapetininga e São João (Figura 5). Esse acordo culmina na promulgação da Lei n. 583 de 8 de outubro

\footnotetext{
${ }^{4}$ Para análise individual de cada uma das nove propostas, ver: AMADO, Marina Rodrigues. Teatros em São Paulo (1890-1911): cultura, arquitetura e cidade a partir de fontes primárias. 2016. 313 f. Dissertação (Mestrado) - Curso de Arquitetura e Urbanismo, Universidade de São Paulo, São Paulo, 2016.
} 
de 1898, que incluia a desapropriação do terreno em questão, o mesmo onde hoje está de fato localizado o Theatro Municipal (AMARAL, 1979).

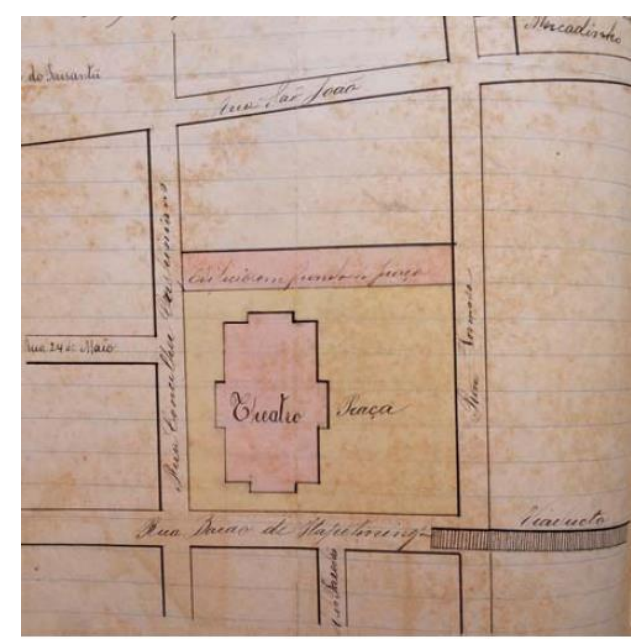

Figura 5: Implantação do projeto de teatro de Giacomo Leoni, entre as ruas Formosa, Barão de Itapetininga e São João.

Fonte: AMADO, 2016, p. 229.

Conta-se que a proposta de Leoni não foi levada adiante, uma vez que ele haveria falecido na viagem que fez a Europa para captação de recursos financeiros para a obra (AMARAL, 1979; AMADO, 2016). No entanto, documentos provam que ele continuava ativo profissionalmente em 1902, o que sugere que o mais plausível seja que seu projeto tenha sido abandonado não pela sua morte, mas pela aquisição de tal incumbência por parte do Estado (COSTA, 2017).

De fato, em 14 de agosto de 1900, o senador Frederico Abranches apresenta um projeto de lei que propõe que o custo da obra de construção do teatro seja integralmente público. Essa proposta é aprovada e convertida na lei n. 750 de 13 de novembro de 1900 pelo secretário Candido Rodrigues, que encarrega o arquiteto Ramos de Azevedo de apresentar um projeto de teatro dentro dos parâmetros por ela estabelecidos (CARDIM, 1911).

A recessão que marcou a transição para a República, impulsionada pela crise mundial que incidira diretamente sobre a produção de café, fez com que o projeto apresentado por Ramos ficasse esquecido na Secretaria do Interior (CARDIM, 1911). De fato, a proposta de Abranches havia encontrado oposição no cenário público, sobretudo nas figuras dos senadores Jorge Miranda e Ezequiel Ramos. 
O primeiro discordava do uso de verba pública para a construção de um equipamento cultural e o segundo alegava que o teatro desvirtuaria os bons costumes da população (COSTA, 2017). É com esses opositores que Gomes Cardim dialoga em seu artigo para a edição de aniversário da revista Plateia, de julho de 1901, ao defender a importância da construção do Theatro, mesmo em meio à crise, para a "prosperidade moral" da população (CARDIM, 1901).

Apesar dos esforços de Cardim, é apenas dois anos mais tarde que o prefeito Antonio Prado autoriza o acordo entre Estado e Municipalidade para a cessão do terreno onde seria construído o Theatro, na forma da lei n. 627 de 7 de fevereiro de 1903 (Figura 6). Em 26 de agosto do mesmo ano, é promulgada a lei n. 643, que autoriza a construção do Municipal e é dado início à obra (AMADO, 2016). A seguir, a edificação será analisada dos pontos de vista urbano e arquitetônico.

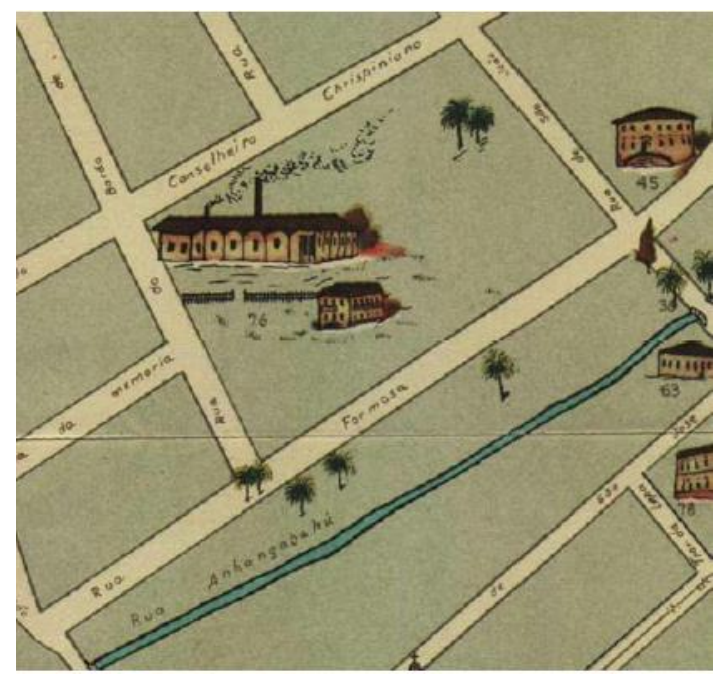

Figura 6: Mapa de 1877, onde se vê o terreno no qual seria implantado o Theatro Municipal ainda ocupado pela Oficina G Sidow e Cia, que teve sua propriedade desapropriada pelo Estado e cedida à Municipalidade em 1903. Fonte: AMADO, 2016.

\subsection{Contexto urbano}

A transição para o período de república foi marcada por um processo de europeização das capitais brasileiras que, em São Paulo, se manifestou através da expansão dos limites de ocupação do centro histórico da cidade. Com a construção do Theatro Municipal, inaugurou-se a era da monumentalidade 
arquitetônica para além do Vale do Anhangabaú, como destacou Severo em artigo publicado na edição especial da revista Ilustração Paulista de 1911:

\footnotetext{
Em torno (do Theatro) tudo se amesquinha; e como vassalos curvados sobre os primeiros degraus de um throno régio, os outros edifícios se prostram reverentes, tal como uma corte muda, humilde e submissa (...) N'esta impressão, que se vae generalizando, está o efeito da acção moral e civilizadora do Monumento (SEVERO, 1911, p. 27$)^{5}$.
}

A seguir, o contexto urbano envolvendo a criação da república, a europeização das grandes cidades brasileiras e a expansão do centro de São Paulo, bem como as propostas e projetos para a região do Anhangabaú - circundante ao Theatro -, será recuperado à luz de fotografias, desenhos e documentos da época, com especial atenção à publicação da edição especial de inauguração do Theatro Municipal da revista Ilustração Paulista (CARDIM; SEVERO, 1911). Sua análise será amparada pela bibliografia correspondente (FABRIS, 1987; BRENNA, 1987; PATETTA, 1987; COSTA, 2017; SIMÕES JÚNIOR, 2004; TOLEDO, 1989; CAMPOS, 2016; D’ELBOUX, 2015).

\subsubsection{A recém-criada república e sua roupagem europeia}

A virada do século XIX também introduziu importantes transformações urbanas no cenário paulista. Na Europa, as grandes reformas de cidades como Paris, Viena e Barcelona, que foram realizadas ao longo do século, serviram de referência para o que se daria em território nacional algumas décadas mais tarde (FABRIS, 1987) ${ }^{6}$.

No Brasil, o Rio de Janeiro se transformava na capital da recém-criada república com a remodelação da Avenida Central pelo prefeito Pereira Passos (Figura 7). A reforma, nos moldes da Paris de Haussmann, pressupunha a implantação de

\footnotetext{
5 SEVERO, Ricardo. In: Ilustração Paulista, edição Especial, ano I, n. 35, São Paulo, 11/09/1911, s/p. Acervo Biblioteca IEB, p. 27.

${ }^{6} \mathrm{O}$ urbanismo europeu da virada do século enfrentou o desafio de adequar a morfologia das cidades às novas escalas resultantes do crescimento populacional e da implantação de ferrovias. $\mathrm{O}$ isolamento de monumentos através de eixos perspectivados, o estabelecimento de hierarquia entre as estruturas urbanas e a implantação de parques e jardins foram alguns dos traços comuns entre as diversas remodelações pelas quais passaram algumas das grandes cidades europeias do período. O plano Cerdá, implementado a partir de 1858 em Barcelona e o plano Haussmann, de 1953 em Paris, são alguns desses exemplos (PATETTA, 1987).
} 
um largo boulevard arborizado, ladeado por edifícios de feições ecléticas dispostos em eixo monumental (BRENNA, 1987). Algumas cidades do norte também passaram por grandes transformações, fruto da era de ouro da economia extrativista dos seringais durante o Ciclo da Borracha.

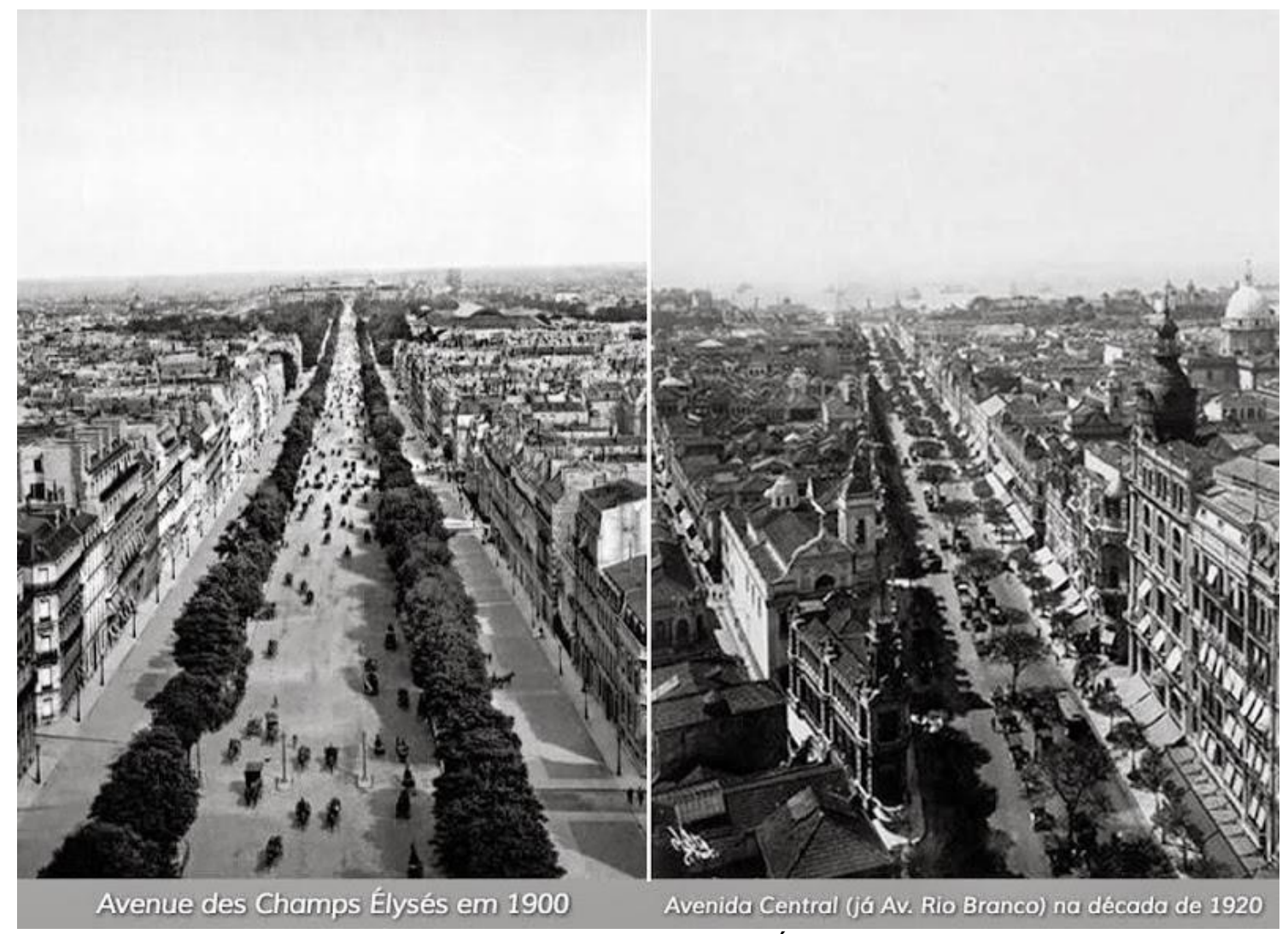

Figura 7: Comparação entre o Champs Élysés e Av. Central. Fonte: espacomorgenlicht.com.br

Em todos esses casos, a construção de teatros municipais foi peça central para as reformas urbanas, tenham sido elas seus produtos ou disparadores. $O$ Theatro Municipal do Rio de Janeiro (1905-1909) (Figura 8), construído na própria Avenida Central, encabeçou o processo de reurbanização da região. $O$ Theatro Amazonas em Manaus (1882-1896) (Figura 9) e o Theatro da Paz em Belém (1869-1878) (Figura 10) são também exemplos dessa relação imbricada entre o apogeu econômico de uma região e a mudança de aspecto das tipologias urbanas (COSTA, 2017). 


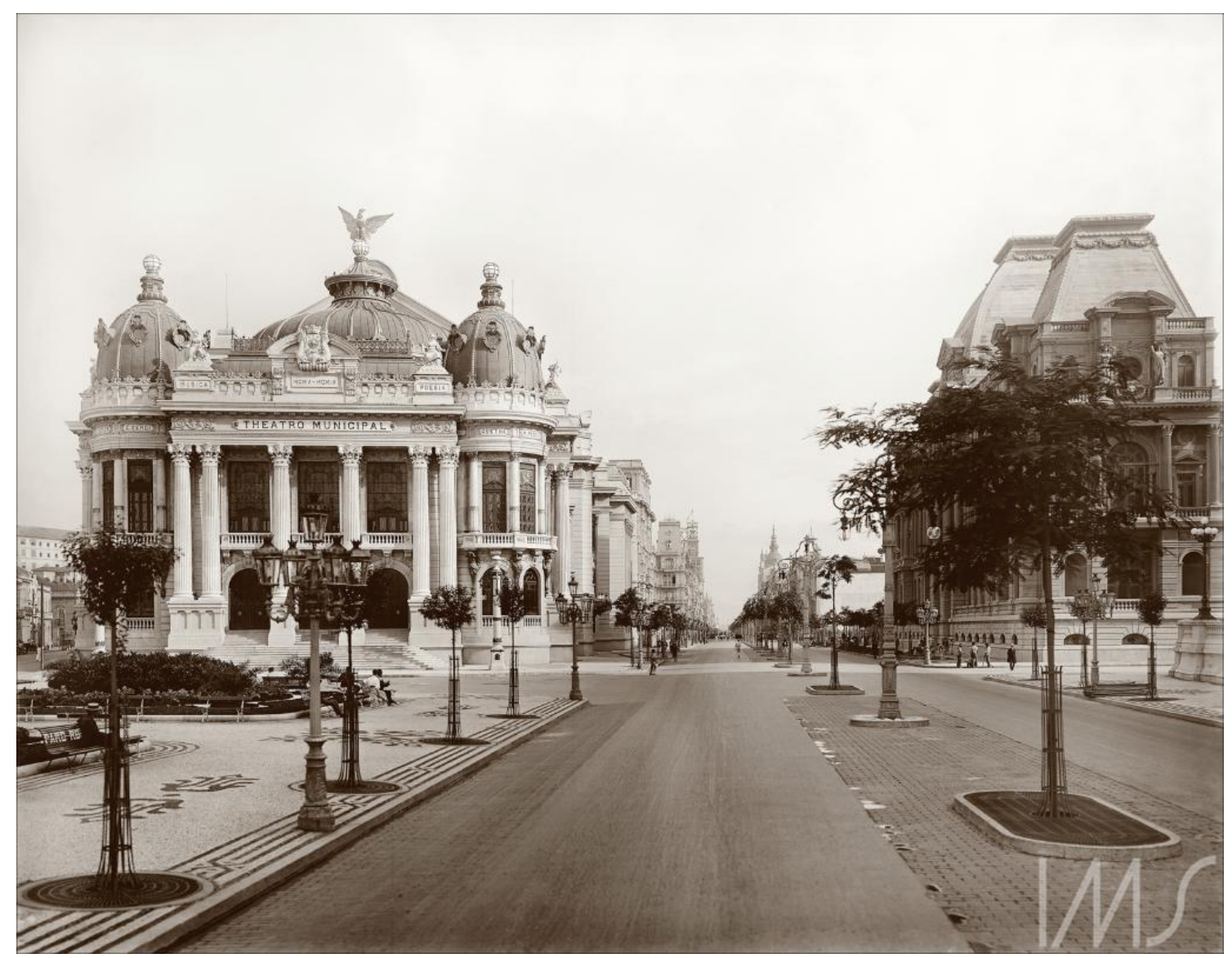

Figura 8: Theatro municipal do Rio de Janeiro em 1910.

Fonte: Acervo IMS - Coleção Marc Ferrez. Disponível em: http://brasilianafotografica.bn.br/?p=9445 


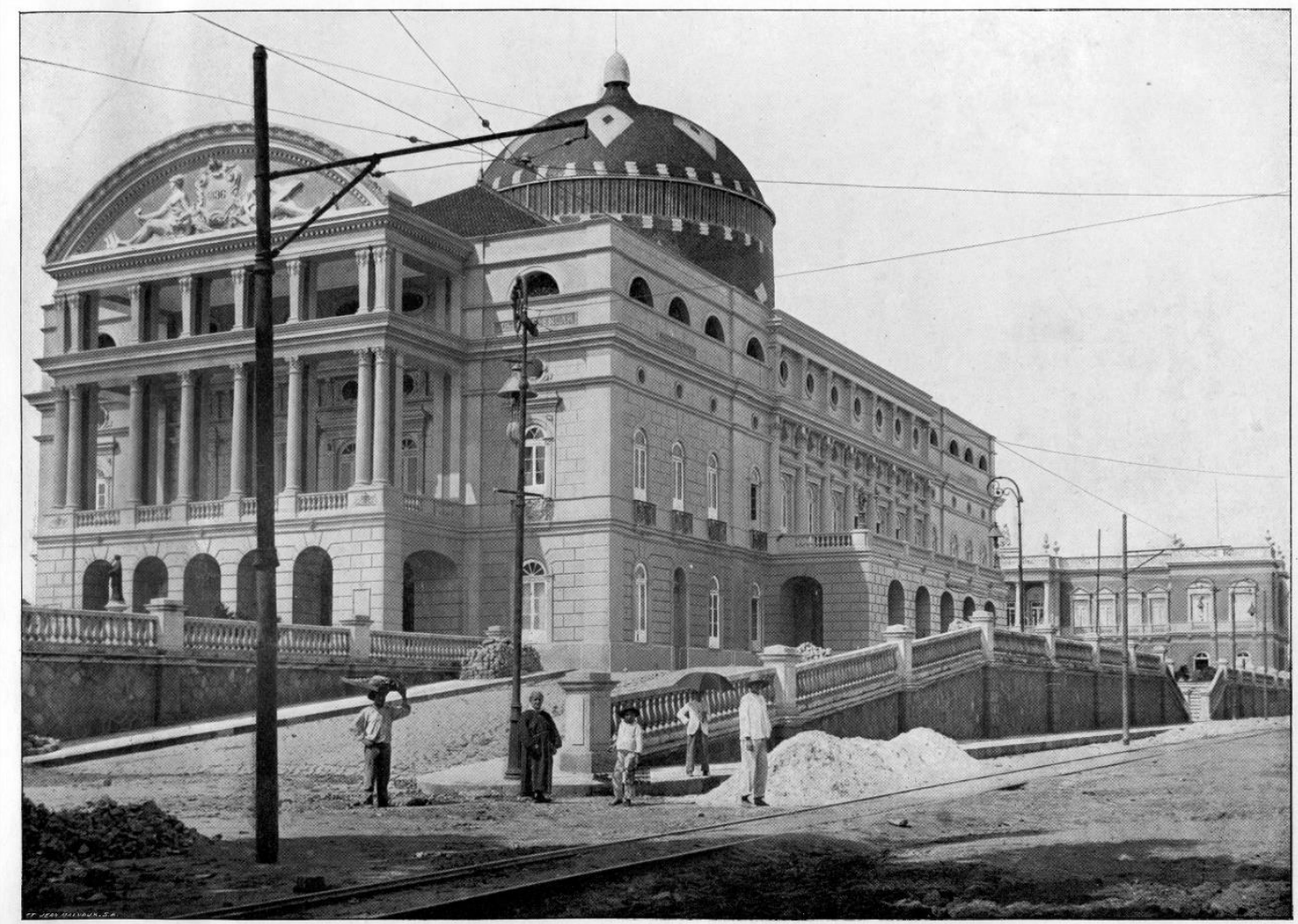

Theatro Amazonas

Figura 9: Theatro Amazonas em Manaus.

Fonte: https://idd.org.br/wordpress/wp-content/uploads/2016/04/Teatro-Amazonas.Album-do-Amazonas-1901-1902.-p.-08.jpg

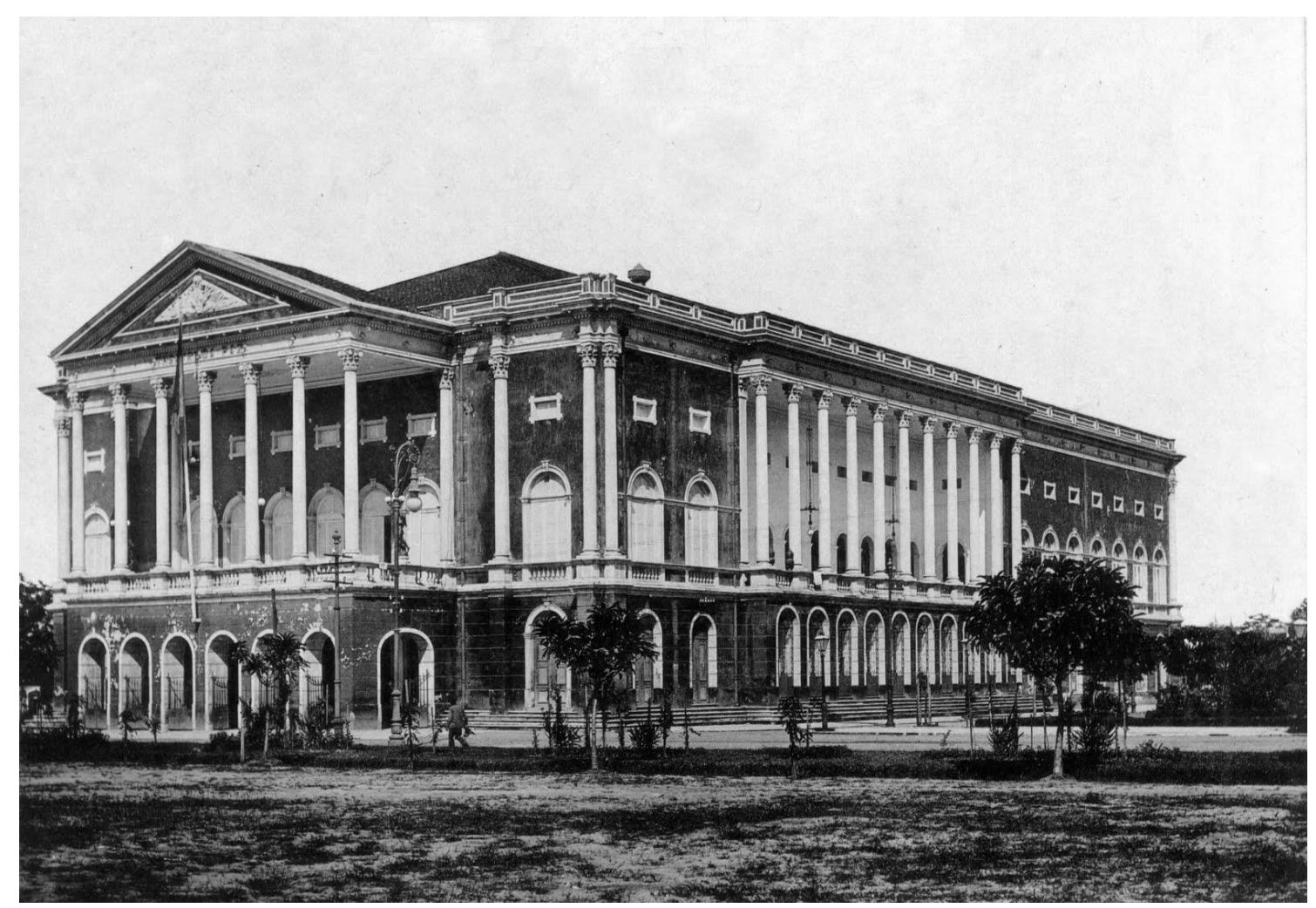

Figura 10: Theatro da Paz em Belém.

Fonte: https://miamimmastore.files.wordpress.com/2014/08/3cb9a-teatrodapaz.jpg 


\subsubsection{São Paulo e seus dois centros}

Em São Paulo, essa nova fase foi profundamente marcada pela transposição do território que continha o Triângulo Histórico para o chamado Centro Novo, por meio do recém criado Viaduto do Chá. Concebido em 1877 pelo francês Jules Martin para vencer a barreira imposta aos avanços da cidade pelo Vale do Anhangabaú, o viaduto foi inaugurado em 1892. (Figura 11).

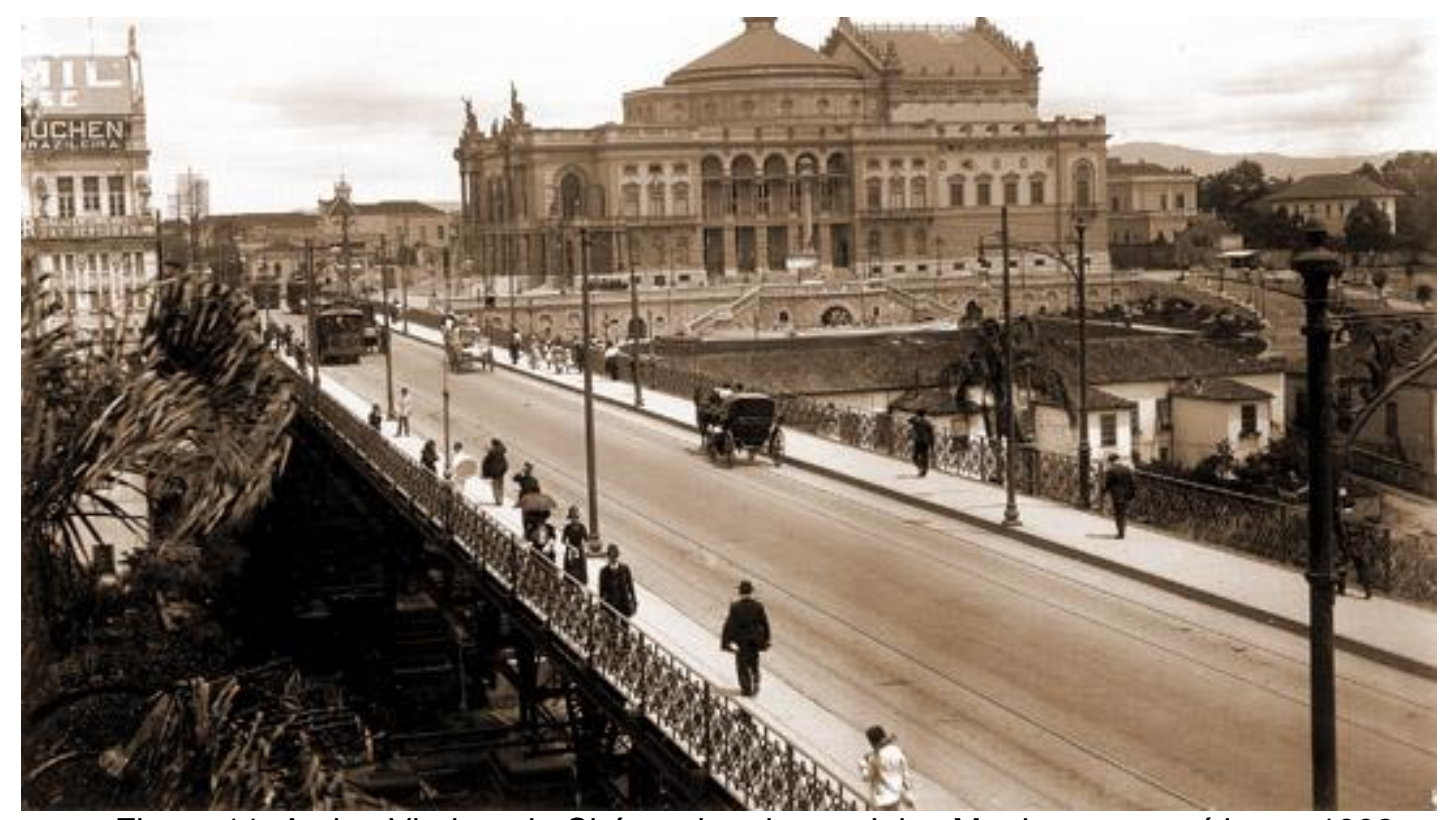

Figura 11: Antigo Viaduto do Chá, projetado por Jules Martin e construído em 1892. Fonte:https://www.prefeitura.sp.gov.br/cidade/upload/viaduto_do_cha_1250275863.jpg

Para o pesquisador José Geraldo Jr., esse interesse em conectar os dois centros se explica pela crescente atenção do mercado imobiliário dedicada aos bairros da zona oeste da capital, como Higienópolis e Campos Elíseos ${ }^{7}$. Na perspectiva do professor Benedito Lima de Toledo essa justificativa adquire caráter mais morfológico, pelo fato do antigo Triângulo não possuir espaços de características monumentais, adequados para a implantação de novos edifícios públicos da escala do Theatro Municipal, por exemplo. Pelo contrário, a maioria dos lotes reproduzia feições coloniais de estreita largura e extenso comprimento, incompatíveis com esse tipo de uso moderno ${ }^{8}$ (Figura 12).

\footnotetext{
${ }^{7}$ SIMÕES JÚNIOR, José Geraldo. Anhangabaú: história e urbanismo. São Paulo: Editora Senac; Imprensa Oficial do Estado de São Paulo, 2004.

8 TOLEDO, Benedito Lima de. Anhangabahú. São Paulo: Fiesp, 1989.
} 


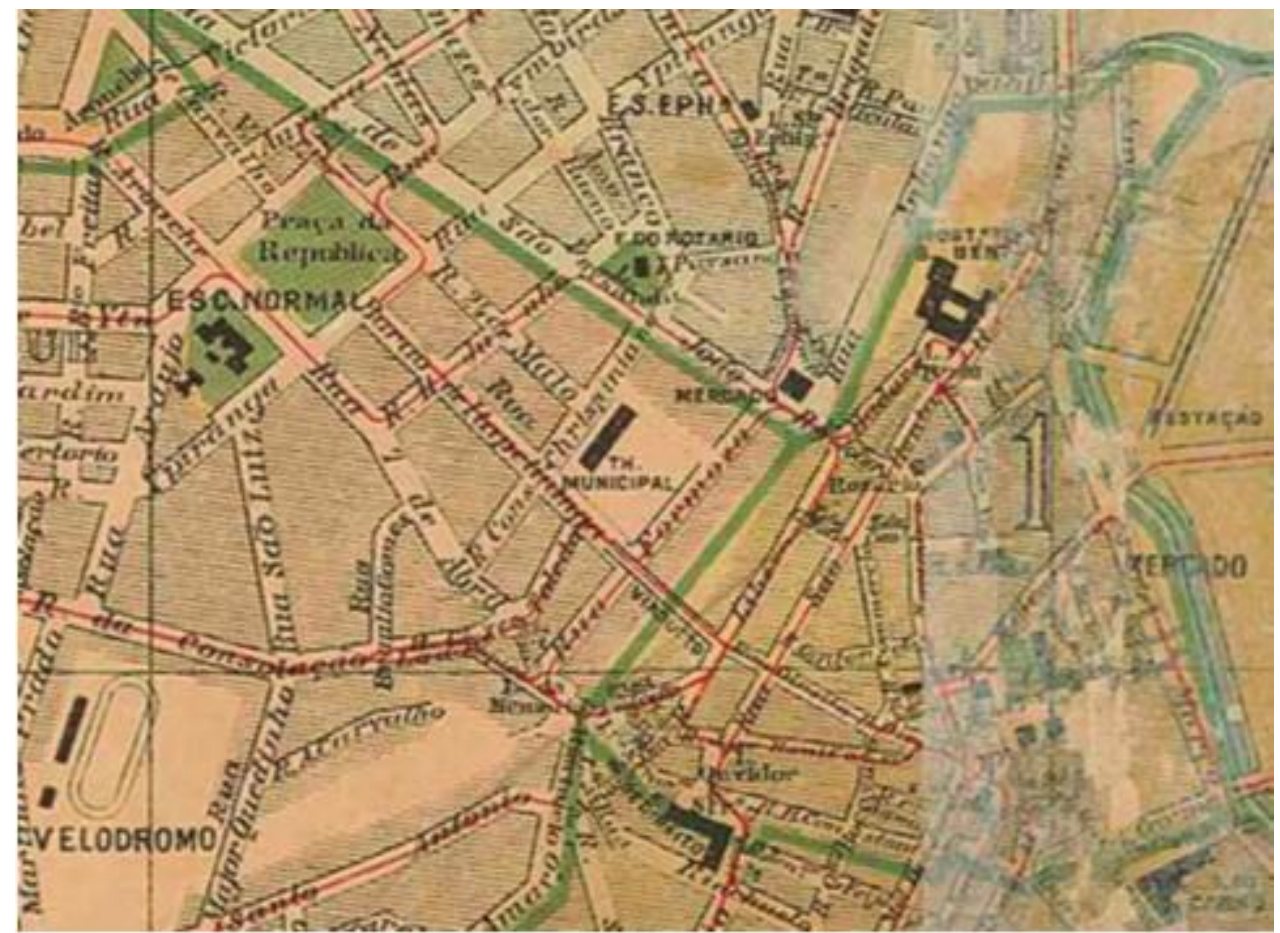

Figura 12: Detalhe da "Planta Geral da Cidade de São Paulo", levantada por Alexandre Cococi e Luiz F. Costa, de 1905.

Fonte: AMADO, 2016.

De fato, a implantação do edifício do Theatro operou como um catalisador importante das transformações urbanas da região, ao contrário do que acontecera no Rio de Janeiro, onde a construção do Theatro culminou a abertura da Avenida Central, sendo seu ápice e apogeu (COSTA, 2017).

\subsubsection{Parque do Anhangabaú e a Esplanada do Theatro}

A construção do Theatro paulista criou a demanda de um remanejamento urbanístico de seu entorno, caracterizado até então pelos "quintais descuidados do velho e modesto casario das imediações e o fundo do Vale (do Anhangabaú), descrito como uma horta de agrião à sombra do Viaduto do Chá"’. Não era só nos costumes que a elite paulista desejava emular a cosmopolitização europeia em detrimento de seu passado colonial, mas nas feições urbanas da cidade que funcionaria como seu cenário.

\footnotetext{
${ }^{9}$ CAMPOS, Eudes. São Paulo em reconstrução: A formação de uma cenografia urbana para o centro paulistano entre 1899 e 1926. Arquivo Histórico de São Paulo, São Paulo, 2016. Disponível em: http://www.arquipaulistana.com, p. 110.
} 
Com a publicação do livreto Melhoramentos de São Paulo pelo vereador Silva Telles em 1907, o debate sobre a modernização da cidade de São Paulo, existente desde o final do século XIX, se acirrou. Nesse documento, Telles tece observações sobre o crescimento e a industrialização da capital paulista, bem como considerações e propostas para determinadas regiões, dentre elas a do Vale do Anhangabaú (D’ELBOUX, 2015).

No mesmo ano, é apresentado o primeiro plano da Diretoria de Obras para o local, intitulado Projecto de Melhoramentos da zona limitada pelas ruas Libero Badaró, São João, Formosa, Largo do Riachuelo e Ladeira Dr. Falcão e assinado por Ribeiro da Silva e Eugênio Guilhem (Figura 13). Essa proposta é ampliada por Alexandre de Albuquerque alguns anos mais tarde, entre 1910 e 1911, e passa a conter um plano de grandes avenidas (Figura 14).

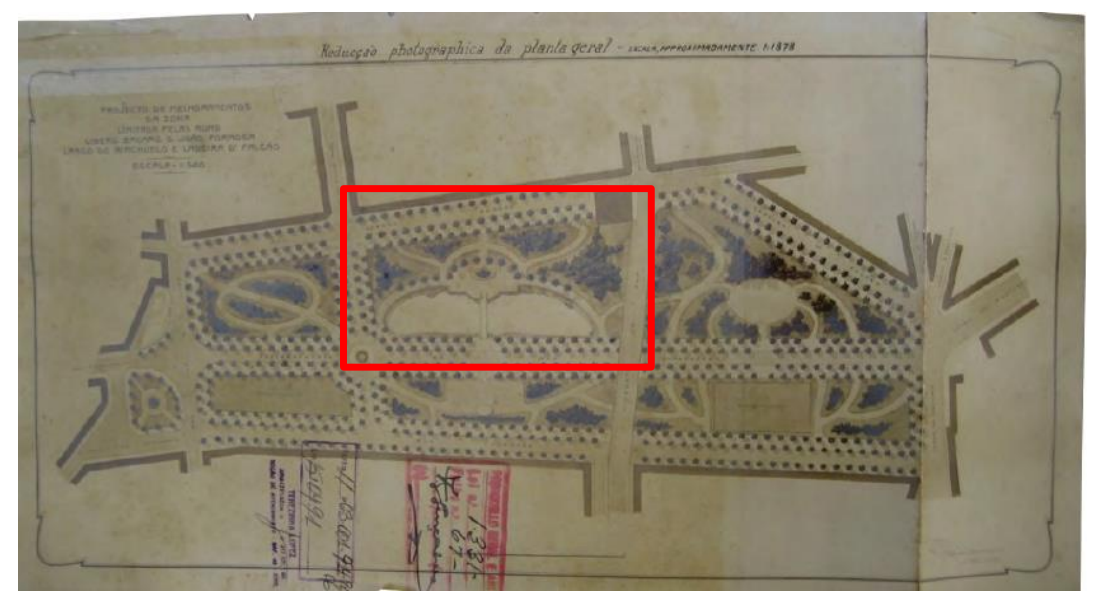

Figura 13: Projecto de Melhoramentos da zona limitada pelas ruas Libero Badaró, São João, Formosa, Largo do Riachuelo e Ladeira Dr. Falcão e assinado por Ribeiro da Silva e Eugênio Guilhem. Nota-se que, apesar de não figurar na implantação, a existência do Theatro incidiu de alguma forma na concepção da proposta, uma vez que nela já se configura seu jardim lateral (destacado em vermelho), hoje conhecido como Praça Ramos de Azevedo. Fonte: Acervo do AHM, In: D’ELBOUX, 2015, p. 280. 


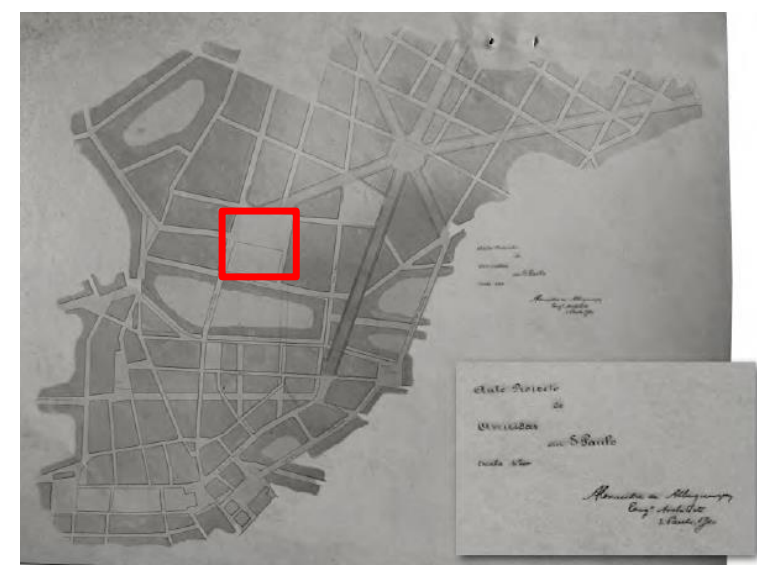

Figura 14: Plano de avenidas de Alexandre de Albuquerque. Consta na implantação do Plano a presença do volume ocupado pelo Theatro Municipal (destacado em vermelho).

Fonte: Acervo AHM, In: D’ELBOUX, 2015, p. 321.

Nesse mesmo biênio, são apresentadas mais quatro propostas. A primeira delas, submetida por Samuel das Neves, atendia os interesses privados de Eduardo Prates, o maior proprietário de glebas da região (Figura 15). A segunda foi fruto de uma associação entre Eugênio Guilhem e Victor da Silva Freire, diretor de obras municipais e o maior defensor da implantação de um parque público no Anhangabaú (Figura 16). Já a terceira, conhecida como Plano Machado-Caiuby, previa a construção de um enorme eixo viário a partir do prolongamento da Avenida Tiradentes em direção ao bairro de Santana e à Avenida Paulista, cortando o Vale do Anhangabaú (Figura 17).

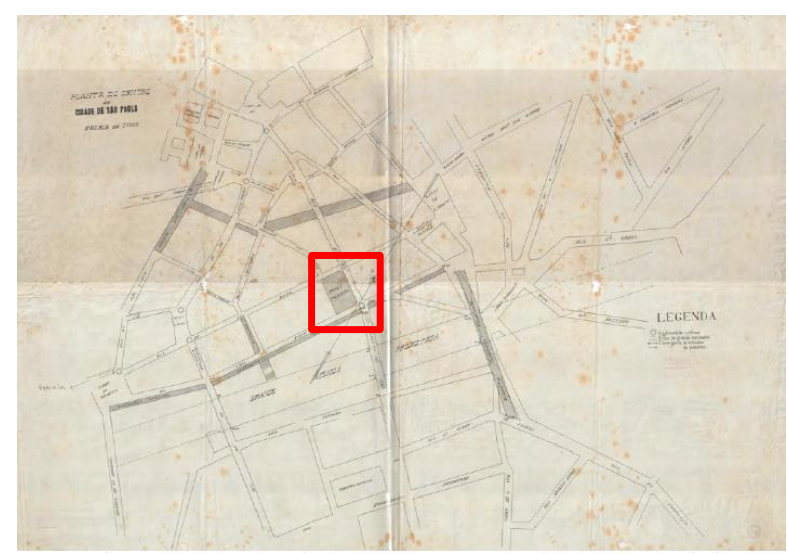

Figura 15: Planta da proposta de Samuel das Neves para a região central da cidade de São Paulo. O desenho oferece destaque à implantação do Theatro Municipal, pintado de preto junto às principais avenidas circundantes (destacado em vermelho).

Fonte: Acervo da Biblioteca FAUUSP, in: D’ELBOUX, 2015, p.349. 


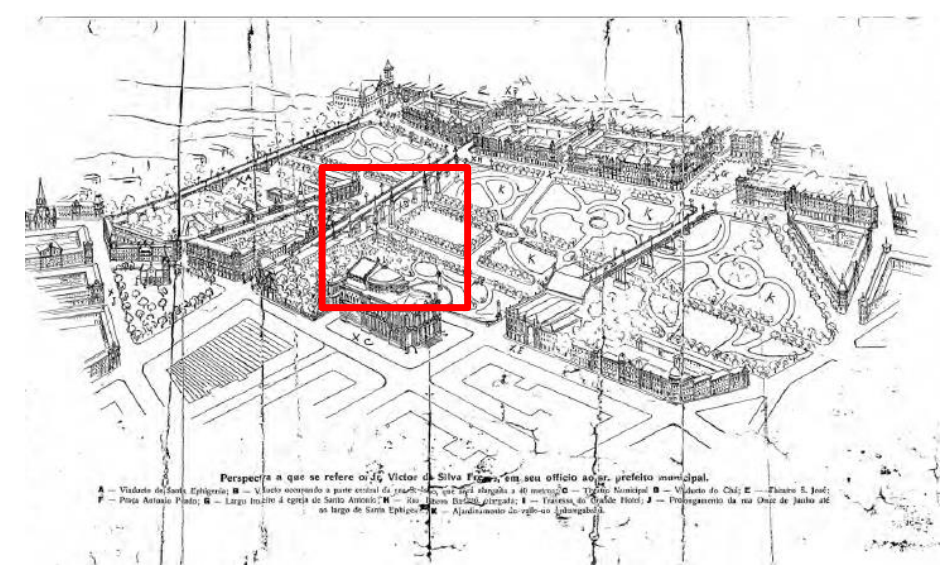

Figura 16: Perspectiva apresentada por Victor da Silva Freire em 1911. Aqui, o edifício do Theatro aparece concluído, em perspectiva externa (destacado em vermelho).

Fonte: Acervo do Arquivo da Câmara Municipal de São Paulo, In: D’ELBOUX, 2015, p. 385.

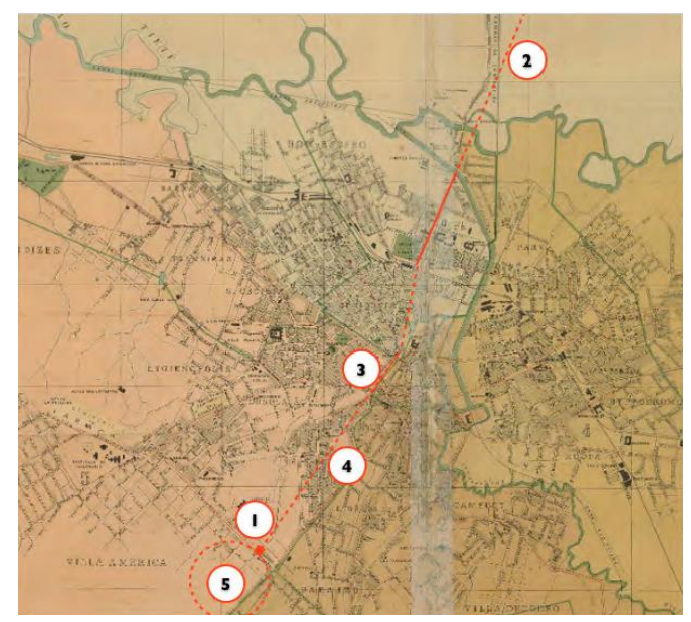

Figura 17: Proposta de alargamento da Avenida Tiradentes elaborada pelo Plano MachadoCaiuby em 1911.

Fonte: Esquema elaborado por Roseli D’Elboux sobre base do Acervo PMSP (D’ELBOUX, 2015, p. 394).

A quarta e última proposta, que acabou por ser implementada, é de autoria do urbanista francês Joseph-Antoine Bouvard. A historiografia tende a destacar dois fatores decisivos na contratação de Bouvard para execução dos melhoramentos, sendo eles a proximidade, devido à sua estadia na capital argentina, e a nacionalidade, que difundiria o modelo urbanístico parisiense, tão visado na virada do século.

Ainda de acordo com a pesquisadora, a atuação de Bouvard em São Paulo se deu nos âmbitos privado e pública. Na primeira instância, assessorou a escolha e negociação de territórios particulares que, juntos, equivaliam a um terço da área urbanizada da cidade na época. Na segunda, elaborou um plano de 
mudanças abrangente, que envolvia o Parque do Carmo, o Trianon, o Anhangabaú, o Centro Cívico e a localização da nova catedral, assim como a abertura de avenidas e a melhoria da circulação (D’ELBOUX, 2015).

Apesar da importância e ineditismo de sua proposta residir justamente nas soluções em sistema para as áreas verdes, partindo da organização de vias aliada à noção de embelezamento urbano nos moldes da Paris de Haussmann, para efeitos da presente análise, será dado enfoque à sua resolução conciliadora para a região do atual Vale do Anhangabaú, conhecida à época como Parque do Anhangabaú (Figura 18).

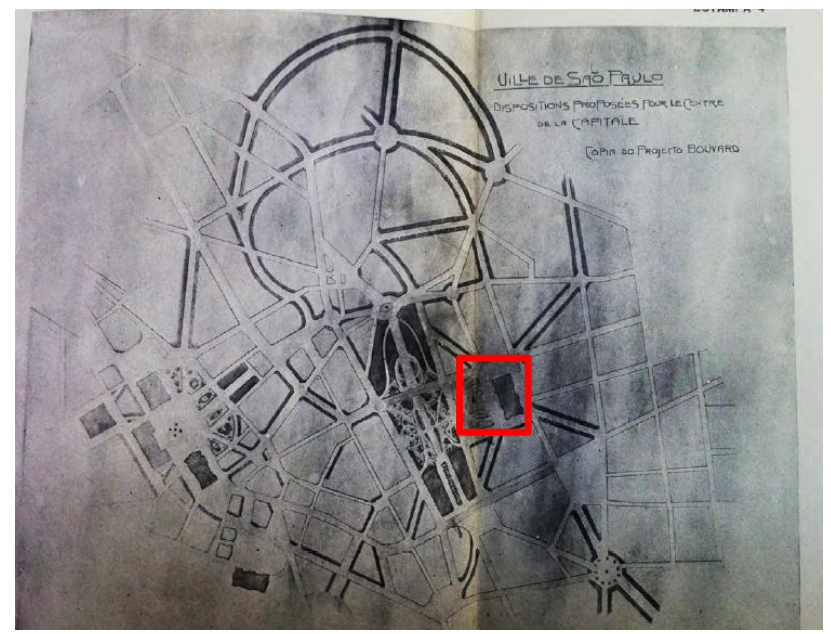

Figura 18: Planta do Plano Bouvard para as modificações no centro de São Paulo, com ênfase na região do Anhangabaú. Theatro Municipal e sua respectiva esplanada figuram na implantação (destacado em vermelho).

Fonte: Acervo da Biblioteca do AHM, In: D’ELBOUX, 2015, p. 456.

As obras da região tiveram início em 1915 e foram finalizadas apenas em 1918. Compunha o paisagismo do Parque a então chamada Esplanada do Theatro, hoje conhecida como Praça Ramos de Azevedo. A esplanada, localizada em frente à fachada da lateral leste do edifício, é constituída por um arco formado por dois caminhos que, em sua perspectiva, destacam a imponência do monumento (Figura 19). Essa suntuosidade era reforçada pelas palmeirasimperiais que ladeavam o arco, cuja tangente com a Rua Formosa fora coroada com a colocação de um piso em mosaico português com um grande símbolo da jovem república (Figura 20). 


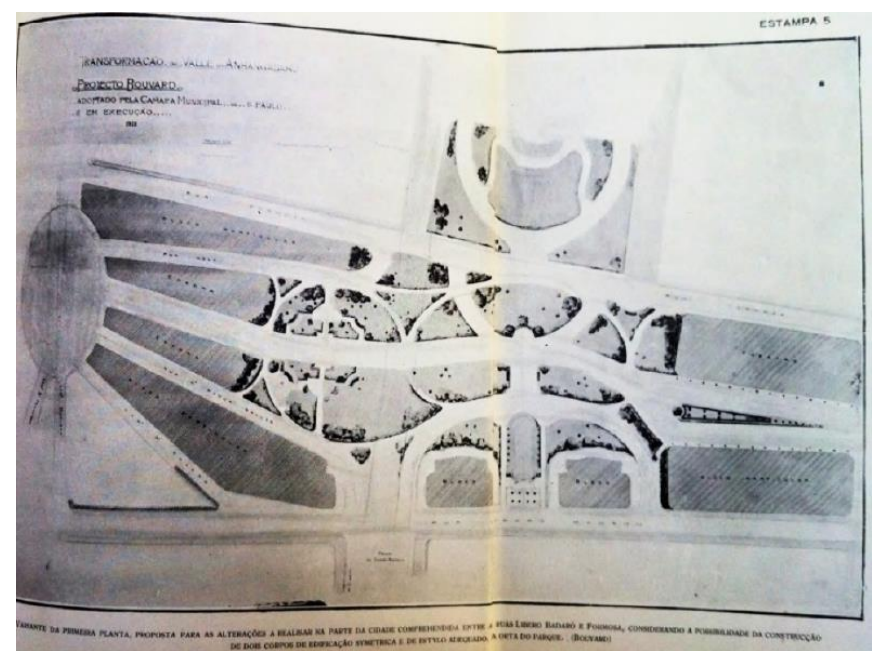

Figura 19: Planta da proposta de Bouvard para a Esplanada do Theatro.

Fonte: Acervo da Biblioteca do AHM, In: D’ELBOUX, 2015, p. 459.

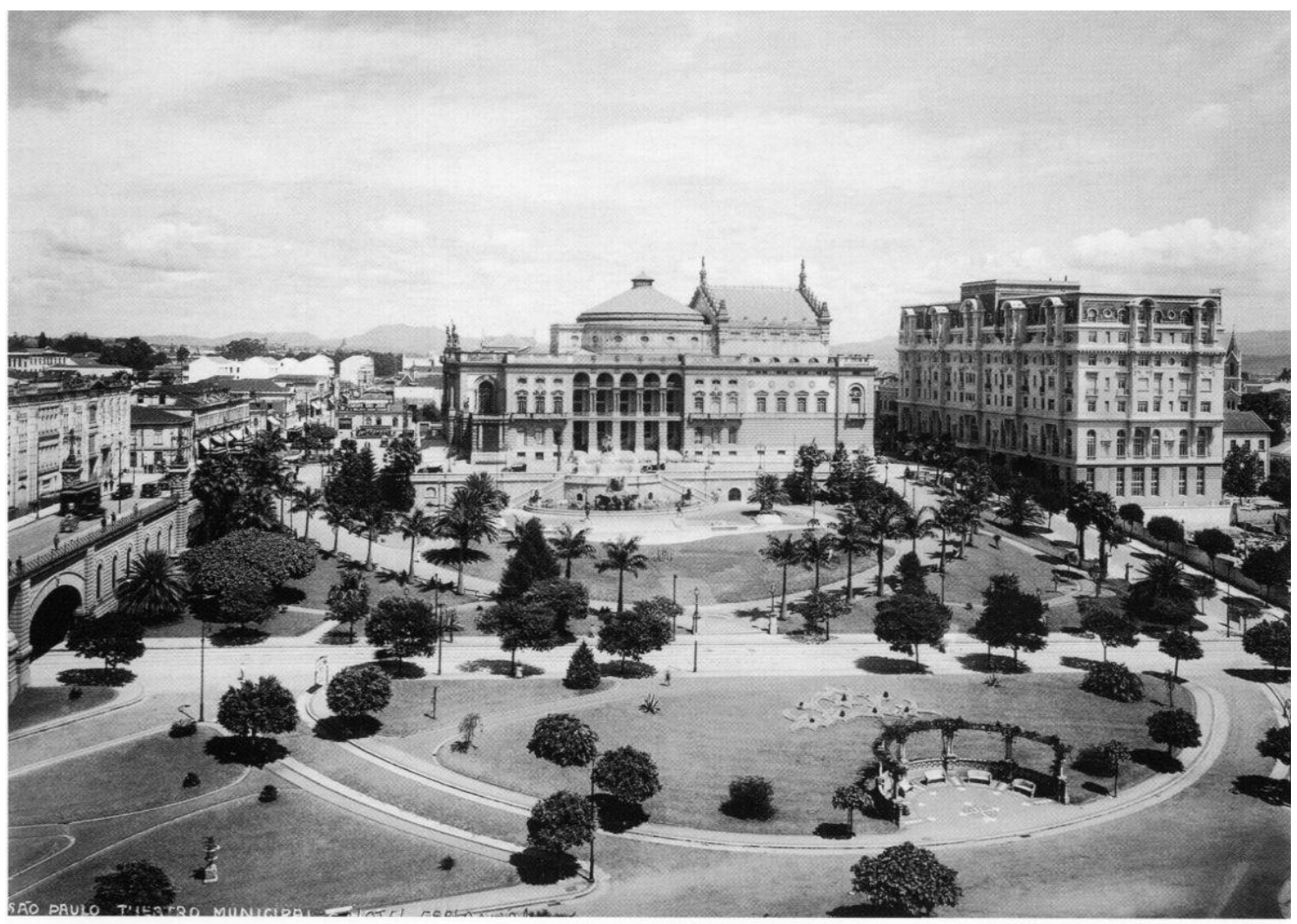

Esplanada do Municipal (c. 1923), tendo, à esq., o teatro São José, que daria lugar ao prédio da Light

Figura 20: Vista da Esplanada do Theatro em 1923.

Fonte: https://i.pinimg.com/originals/29/ef/1a/29ef1a071db698396cd7ded9c40c4f8f.jpg

\subsection{Arquitetura}

O edifício do Theatro Municipal de São Pauo é tido como um dos principais expoentes da arquitetura eclética paulista. A variedade de referências e o emprego de novos materiais como elementos constituintes de sua autenticidade é reivindicado por Ricardo Severo, na ocasião de sua inauguração: 
A architectura exterior do edifício é composta no estylo renascimento barroco, ao qual os artistas italianos chamam SEICENTO. É o estylo clássico, com os typos e modulos da renascença greco-romana, mais variada, porém, na apropriação e ornamentação d’esses typos e com maior liberdade imaginativa no emprego da linha curva, nos motivos e detalhes ornamentaes (SEVERO, 1911, p. 13) ${ }^{10}$.

O emprego de novos materiaes decorativos como os marmores, os mosaicos, os estuques lúcidos, o gesso, a pintura, prestou-se a que a architectura interior do edificio colhesse efeitos novos e tomasse um caracter diverso, se bem que se conserve nos moldes do estylo adoptado para o exterior. A ornamentação é mais caprichosa, o relevo dos ornatos é menor; mais delicados são estes, e levianos, mas são mais variados e baroccos. Não obstante, o architecto ainda se manteve com uma sobriedade que agrada (SEVERO, 1911, p. 19) ${ }^{11}$.

A seguir, a arquitetura do Theatro Municipal, desde a polêmica de sua autoria a questões tipológicas referentes ao modelo europeu, será estudada a partir de documentos da época, com especial atenção aos negativos de vidro dos desenhos do projeto original do escritório de Ramos de Azevedo (Consultados no Acervo Iconográfico da Biblioteca da FAUUSP) e às descrições elaboradas por Ricardo Severo em sua Monographia de Inauguração (SEVERO, 1911). Sua análise será amparada pela bibliografia correspondente (AMADO, 2016; CARVALHO, 2000; LEMOS, 1993 e COSTA, 2017).

Cabe destacar que o caráter extensamente descritivo conferido ao texto se deve à recuperação do discurso de Severo na Monographia, que foi priorizado em detrimento de leituras posteriores, com a intenção de evitar possíveis anacronismos de interpretações do objeto que sucederam as intervenções estudadas a seguir. A divisão entre arquitetura interna e externa também foi importada da lógica descritiva de Severo e será preservada, quando possível, para análise do edifício ao longo do trabalho.

10 SEVERO, R. Monographia do Theatro Municipal de São Paulo. São Paulo: Pocai e Weiss, 1911, p. 11.

11 Monographia do Theatro Municipal de São Paulo. São Paulo: Pocai e Weiss, 1911, p. 19. 


\subsubsection{Polêmica da autoria e o ecletismo}

A autoria do Theatro Municipal de São Paulo é comumente atribuída de forma integral à figura de Ramos de Azevedo. Entretanto, o debate historiográfico acerca do assunto vem demonstrando que as relações autorais do projeto são mais complexas do que parecem.

De fato, o engenheiro-arquiteto já havia adquirido fama como "empreiteiro oficial' das grandes obras públicas paulistas, além de ter reconhecida sua importância para o desenvolvimento de instituições como a Escola Politécnica e o Liceu de Artes e Ofícios, porém quando se trata da autoria do Theatro, há outras duas figuras incontornáveis a serem exploradas. São eles Domiziano e Cláudio Rossi, ambos imigrantes italianos atuantes no cenário nacional desde as últimas décadas do século XIX (Figura 21).

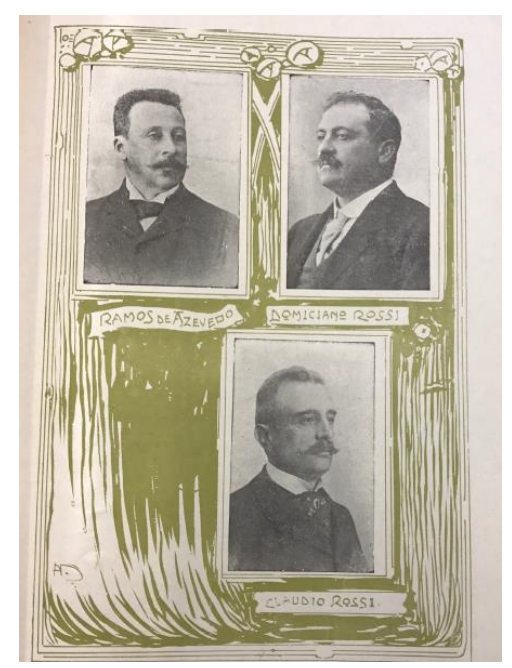

Figura 21: Ramos de Azevedo, Domizano e Cláudio Rossi em fotografia publicada na edição especial da revista Ilustração Paulista de 1911. Fonte: Acervo da Biblioteca do IEB.

O arquiteto genovês Domiziano Rossi (1865 - 1920) mudou-se para São Paulo em 1894 e começou a lecionar tanto no Liceu de Artes e Ofícios como na Escola politécnica, onde estabelece parceria com Ramos e passa a integrar a equipe de seu escritório técnico. Já Cláudio Rossi (1850 - 1935), que apesar do nome não tinha relação familiar com Domiziano, chegou ao Brasil em 1871 como cenógrafo da Companhia Ferrari e era amigo da família do prefeito Antonio Prado (AMADO, 2016). 
Para Carlos Lemos, os três arquitetos encarregaram-se do projeto e dos orçamentos, sem que saibamos em que regime de trabalho (LEMOS, 1993). Já para Cristina Wolff de Carvalho, a autoria do projeto do edifício é de Ramos de Azevedo, fundamentando sua tese na influência que seus estudos na Bélgica possam ter exercido sobre ele (CARVALHO, 2000).

Em sua estadia na Bélgica, entre 1875 e 1878, Ramos frequentou o curso de arquitetura e urbanismo da Universidade Real de Gante e a Academia de Belas Artes, de modo que sua formação se deu dentro da tradição europeia da École de Beaux Arts. Além disso, a Academia Real de Belas Artes de Gantes promovia um concurso entre seus alunos, conhecido como Grand Prix. A hipótese de Carvalho é a de que o arquiteto paulista teria entrado em contato com os projetos ganhadores desse concurso, entre eles, o teatro projetado por Waegeneer (Figura 22), cuja semelhança com o Municipal de São Paulo é inegável. O projeto foi publicado no único periódico especializado em arquitetura que circulava na Bélgica à época no ano de 1877, que coincide com seu período formativo no estrangeiro.

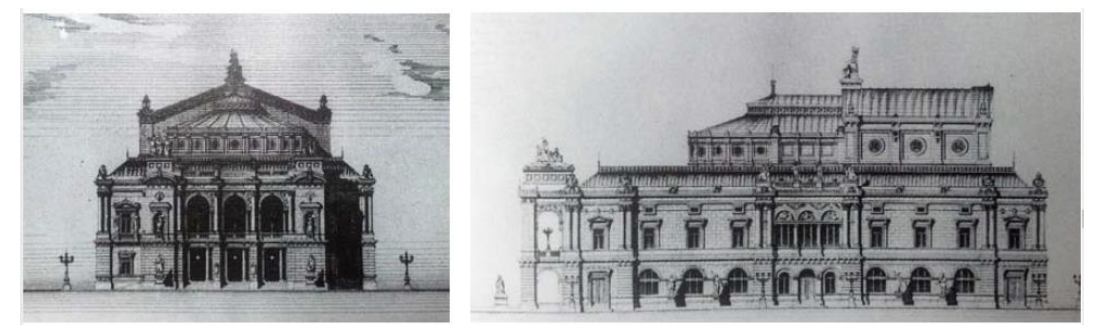

Figura 22: Fachadas do projeto de Waegeneer, publicado na revista belga L'emulation em 1877.

Fonte: AMADO, 2016, p. 252.

Uma terceira hipótese, de Marina Amado, parece contemplar melhor o entrave. Para a pesquisadora, Ramos teria concebido e elaborado o anteprojeto e, tanto Domiziano como Cláudio teriam colaborado com ele no detalhamento e no desenvolvimento das obras (AMADO, 2016).

Quanto à sua expressão arquitetônica, parece não haver dúvidas. Descrito por Ricardo Severo na Monografia de inauguração como "renascimento barroco", o edifício é tido como um dos expoentes do ecletismo brasileiro (Figura 23). 


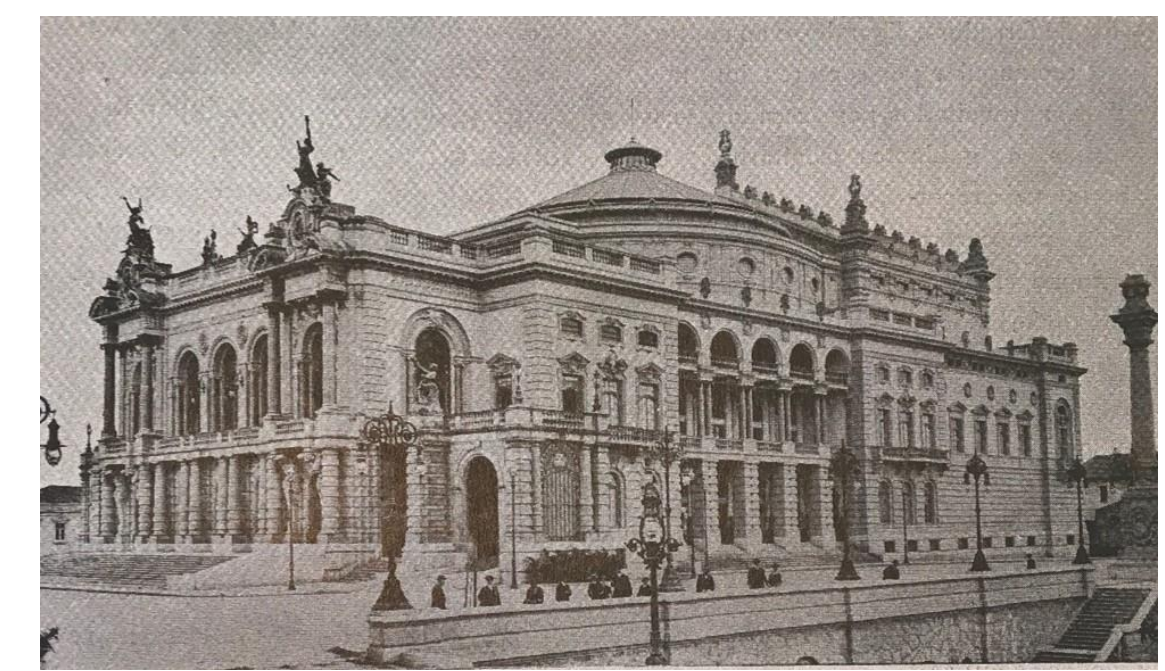

Figura 23: Fotografia externa do Theatro publicada na Monografia de Inauguração em 1911. Fonte: Acervo do AHM.

O ecletismo, entendido como a cultura arquitetônica de uma classe burguesa, que priorizava o conforto e o progresso (PATETTA, 1987), usando-se do léxico historicista somado às mais recentes inovações construtivas ou "a linguagem eufórica da liberdade calcada na nova tecnologia" (LEMOS, 1987, p. 68), de fato parece contemplar o caráter da construção. Para melhor compreensão das peculiaridades estilísticas do edifício, serão expostos a seguir os seus aspectos arquitetônicos exteriores e interiores.

\subsubsection{Arquitetura externa}

As fachadas do Theatro Municipal, sobretudo as laterais, explicitam claramente a divisão tripartida entre os volumes correspondentes a cada função do programa. No corpo frontal, correspondente à fachada principal, encontram-se $o$ saguão e o Salão Nobre; o corpo central, coberto pela cúpula em estrutura metálica, corresponde à Sala de Espetáculos; e o corpo posterior, coberto por telhado de duas águas, ao palco (Figura 24). 


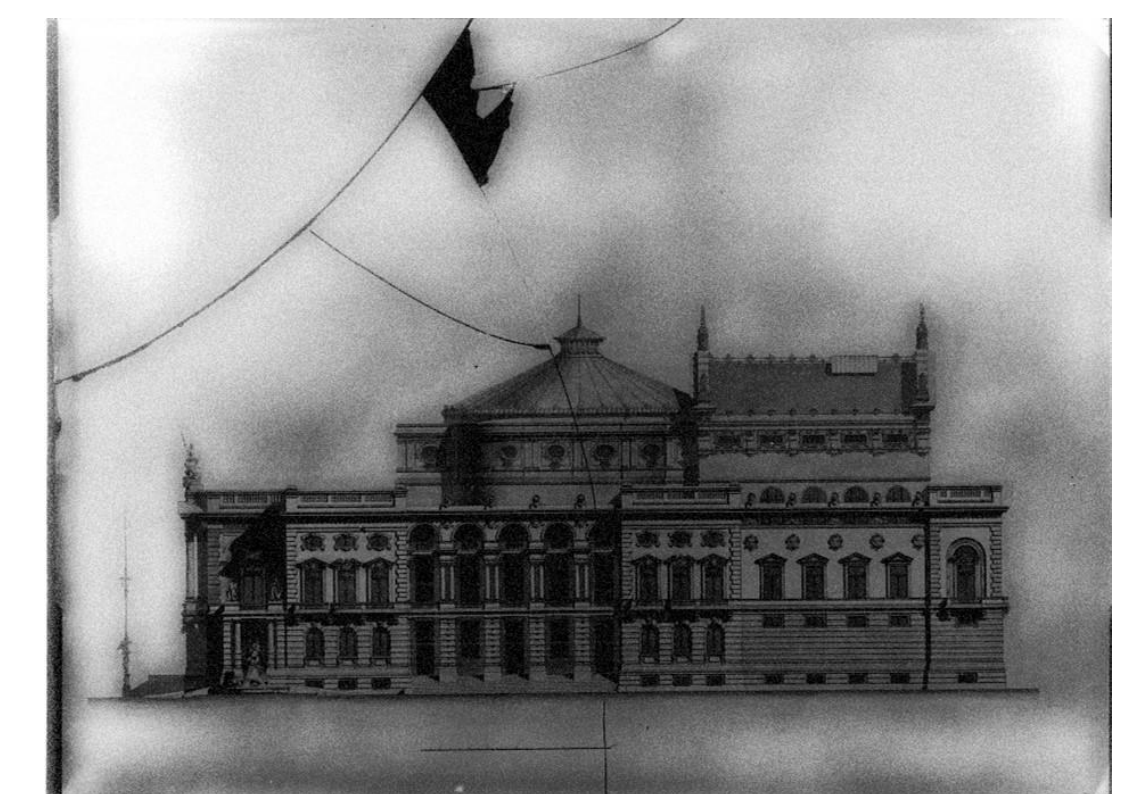

Figura 24: Desenho do projeto original do escritório de Ramos de Azevedo para a fachada lateral do Theatro Municipal.

Fonte: Acervo de fontes iconográficas da biblioteca da FAUUSP

A fachada principal, voltada para a Rua Barão de Itapetininga, também informa sobre a setorização interna dos ambientes. Assim como longitudinalmente o edifício se divide em três corpos, também o faz verticalmente. O embasamento, correspondente ao térreo e ao primeiro andar, é delimitado pela rusticação dos elementos em granito das fachadas laterais e posterior, assim como pela arcada em arenito, que serve à entrada da fachada frontal. A parcela central equivale ao andar nobre; e por fim, o topo, ao coroamento (Figura 25). 


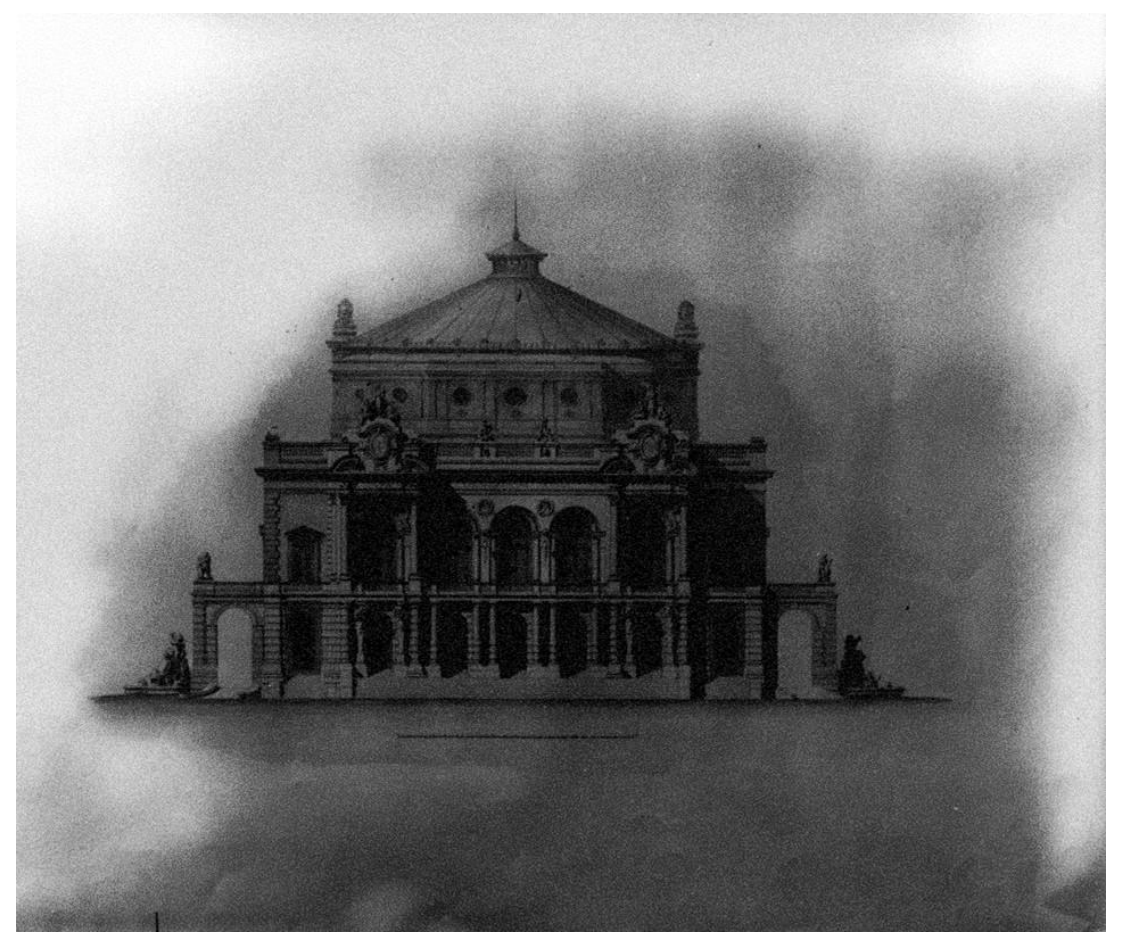

Figura 25: Desenho do projeto original do escritório de Ramos de Azevedo para a fachada principal do Theatro Municipal.

Fonte: Acervo de fontes iconográficas da biblioteca da FAUUSP

Em todas as vistas predominam as linhas retas horizontais, nas quais a originalidade reside na mistura entre a rigidez dos módulos clássicos e a liberdade decorativa barroca, traduzida por Severo na Monographia de Inauguração do Theatro pela importância dada à alternância entre frontões em voluta combinados aos clássicos frontões triangulares. Ainda de acordo com Severo, seu aspecto barroco "recurvo e caprichoso" se dá pela aplicação em madeira, ferro e cobre nas janelas, portas e gradis, bem como pelos elementos decorativos da cúpula e do ático e, sobretudo, pelos grupos escultóricos (SEVERO, 1911).

Para o engenheiro português, a síntese da "composição poética" do projeto foi materializada na chaminé, implantada ao lado do edifício, na atual Praça Ramos de Azevedo, onde hoje se encontra a estátua de Carlos Gomes. Na forma de uma coluna, o elemento era composto por fuste de forma clássica, com capitel e pedestal de linhas curvas e decoração barroca (Figura 26). 

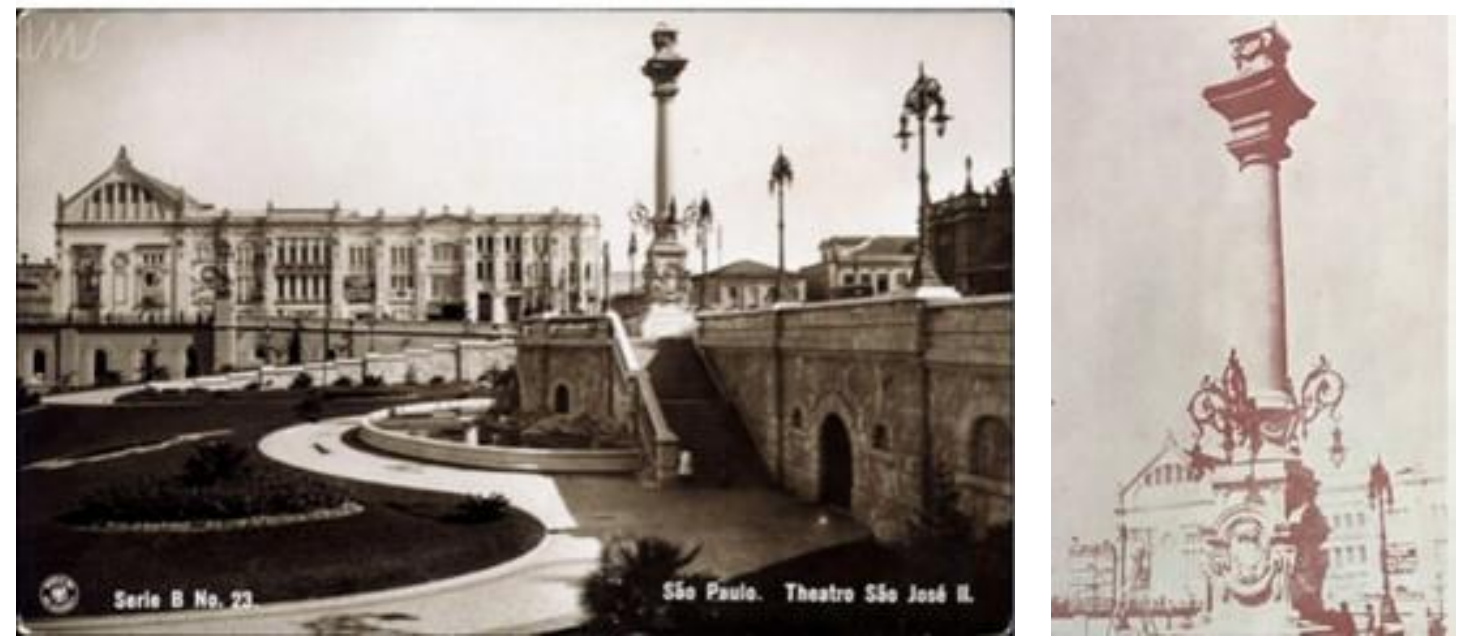

Figura 26: Vista da esplanada do Theatro em 1909, com destaque para a chaminé destacada por Severo (esq.) e detalhe da chaminé hoje inexistente (dir.).

Fonte: Guilherme Gaensly. Acervo IMS (esq.); A Ilustração Paulista, 1911. Acervo da Biblioteca do IEB (dir.)

Alguns dos elementos escultóricos obtém destaque na fachada principal, mais ornamentada e de materiais mais nobres (Figura 27). Os grupos escultóricos em bronze intitulados Drama e Música, que repousam sobre medalhões alegóricos no ático, representam as vocações do teatro (Figura 28). Na mesma fachada, outras duas alegorias em bronze, repousadas sobre os balaústres da varanda do Salão Nobre, representam o amor e a inspiração (Figura 29).

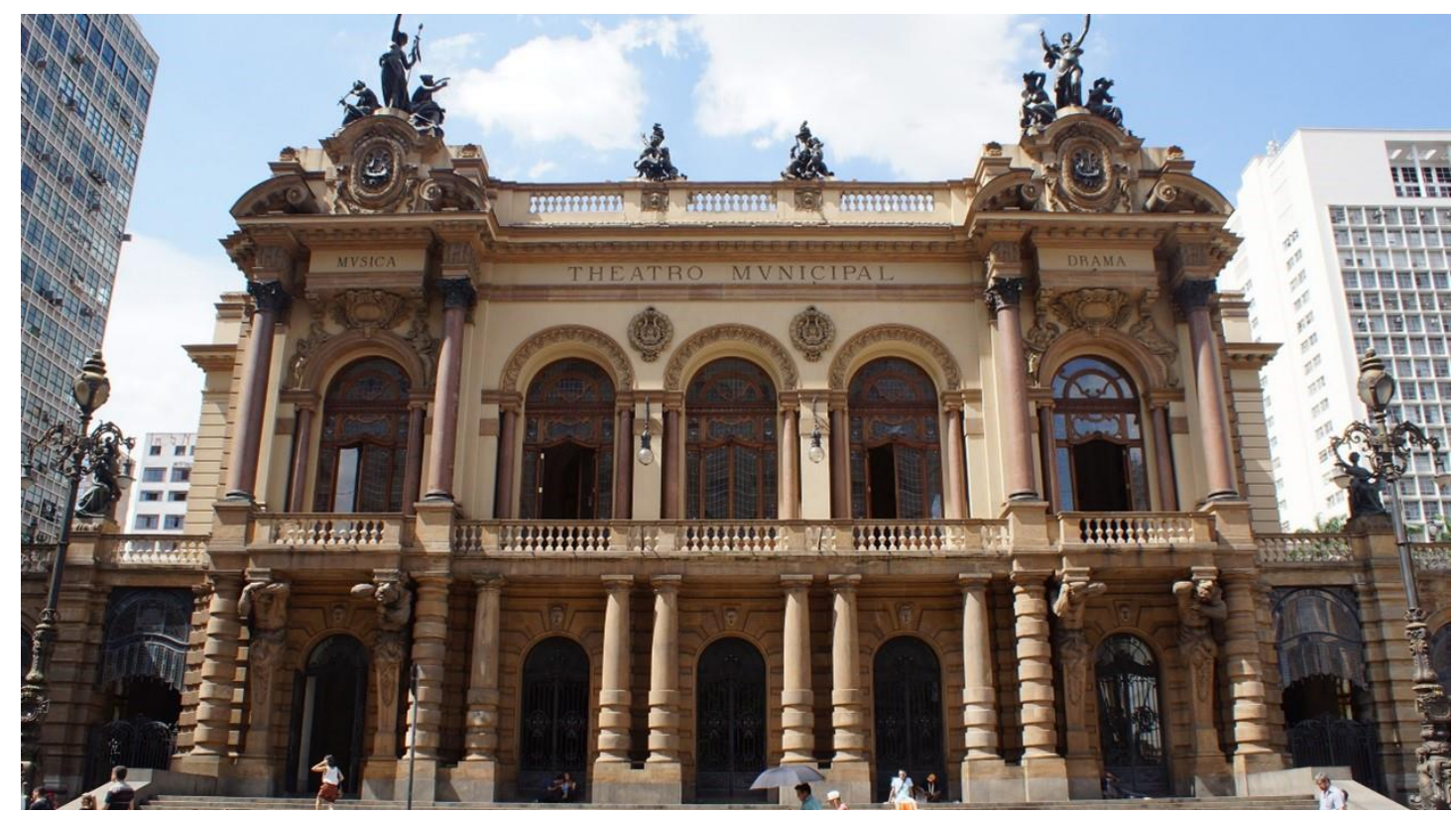

Figura 27: Fachada Principal do Teatro em 2015.

Fonte: Fotografia de Percival Tirapeli e tratamento de imagem por Letícia Mayumi Ozono (https://acervodigital.unesp.br/bitstream/unesp/252433/1/sp_tm_01.JPG) 

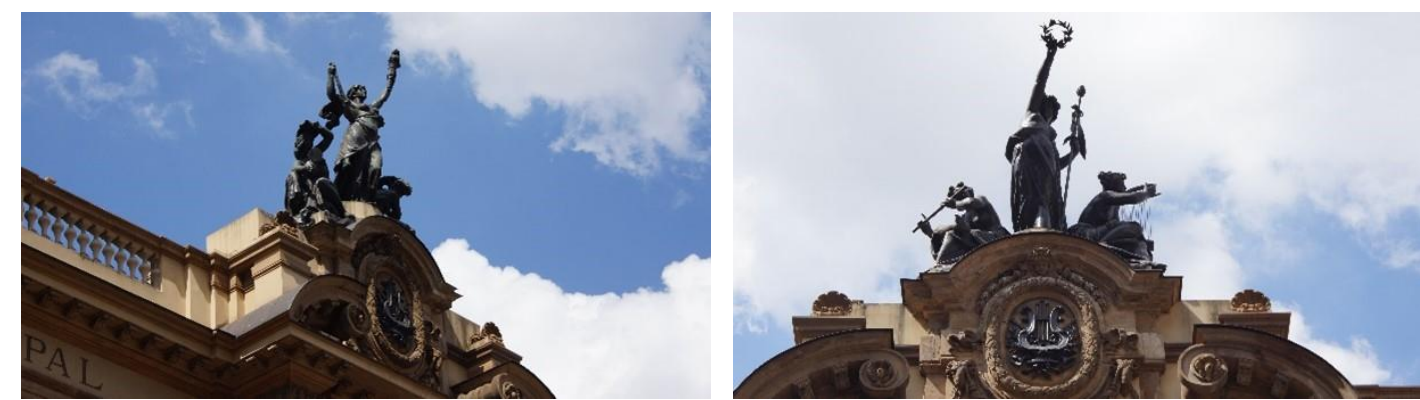

Figura 28: Grupo escultórico "Drama" (à esquerda) e grupo escultórico "Música" (à direita), 2015.

Fonte: Fotografias de Percival Tirapeli e tratamento de imagem por Letícia Mayumi Ozono.

(https://acervodigital.unesp.br/bitstream/unesp/252433/5/sp tm 03.JPG)

(https://acervodigital.unesp.br/bitstream/unesp/252433/6/sp tm 04.JPG)
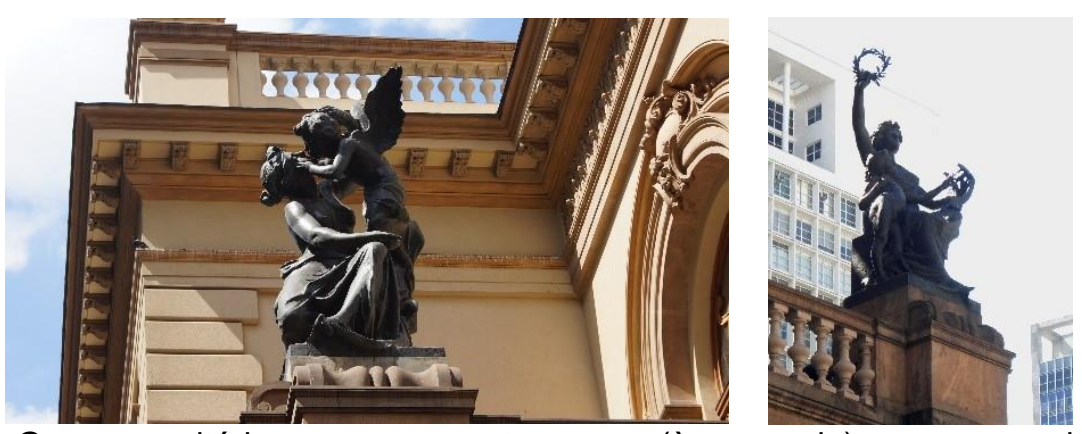

Figura 29: Grupo escultórico que representa o amor (à esquerda) e grupo escultórico que representa o lirismo (à direita), 2015.

Fonte: Fotografias de Percival Tirapeli e tratamento de imagem por Letícia Mayumi Ozono (https://acervodigital.unesp.br/bitstream/unesp/252433/5/sp tm 05.JPG)

(https://acervodigital.unesp.br/bitstream/unesp/252433/6/sp tm 06.JPG)

Os balcões centrais são suportados por duas colunas antropomórficas em forma de atlantes, esculpidos em arenito por Jo Pellicciotti, do Liceu de Artes e Ofícios (Figura 30). Para o historiador da arte Richard Costa, a relação entre os atlantes e os grupos escultóricos em bronze é reveladora do contraste entre a ênfase tectônica do embasamento e a delicadeza do coroamento (COSTA, 2017). 


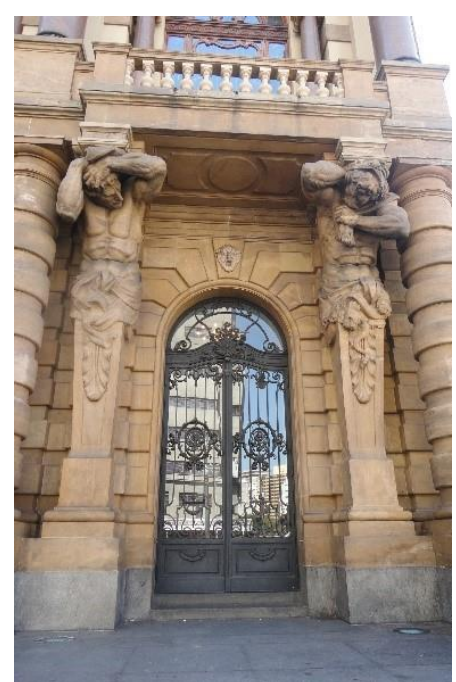

Figura 30: Atlantis da fachada principal, esculpidos por Joo Pellicciotti do Liceu de Artes e Oficios, 2015.

Fonte: Fotografia de Percival Tirapeli e tratamento de imagem por Letícia Mayumi Ozono (https://acervodigital.unesp.br/bitstream/unesp/252433/9/sp tm 09.JPG)

Outro elemento de destaque da fachada principal são os vitrais, que ora aparecem na caixilharia metálica do exterior do Saguão, ora nas portas de madeira varanda do Salão Nobre (Figura 31). Os panos de vidro colorido foram em parte produzidos pelo Liceu e em parte pelo ateliê V. Saile de Stuttgart (SEVERO, 1911).

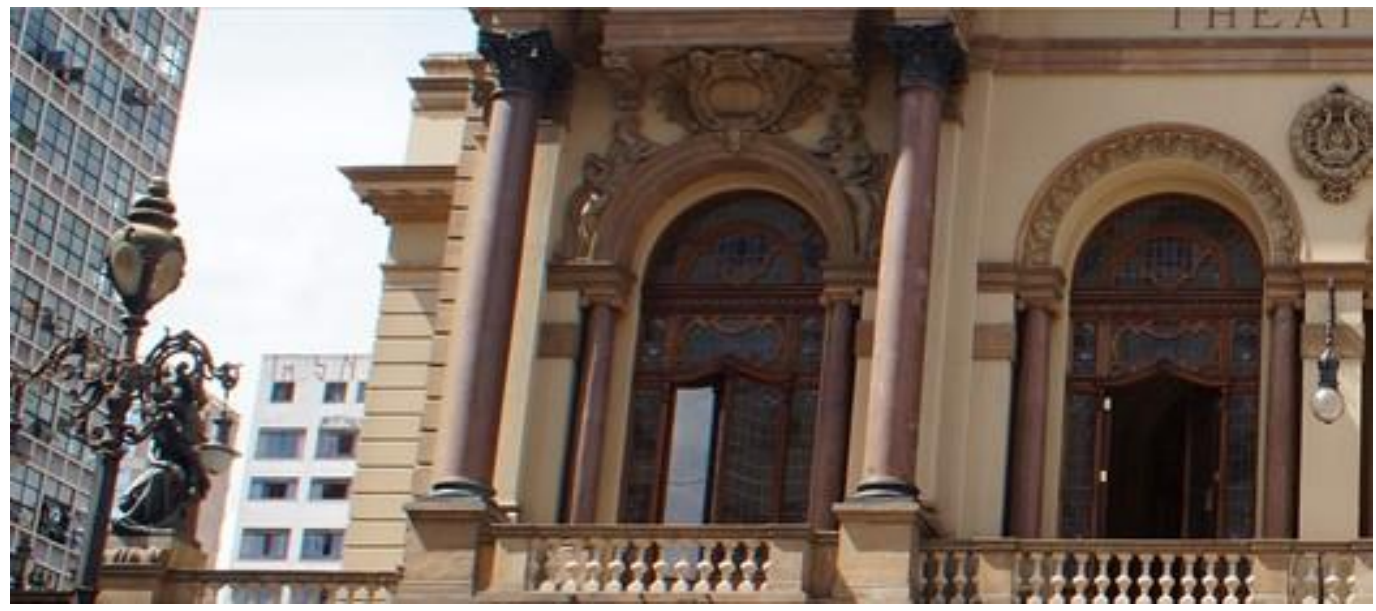

Figura 31: Ampliação de fotografia da fachada principal, com destaque para vitrais do Salão Nobre, 2015.

Fonte: Fotografia de Percival Tirapeli e tratamento de imagem por Letícia Mayumi Ozono (https://acervodigital.unesp.br/bitstream/unesp/252433/1/sp_tm_01.JPG)

As fachadas laterais, de ornamentação mais discreta, têm seu embasamento revestido em granito cinza, sobre o qual se erguem as paredes e pilares em alvenaria, correspondentes ao primeiro andar. Sobre os pilares do corpo central, uma balaustrada que sustenta colunata de sienito polido com capitéis de bronze 
e o último andar, sob arcaria, protegido por guarda-corpo de ferro com aplicações douradas (Figura 32).

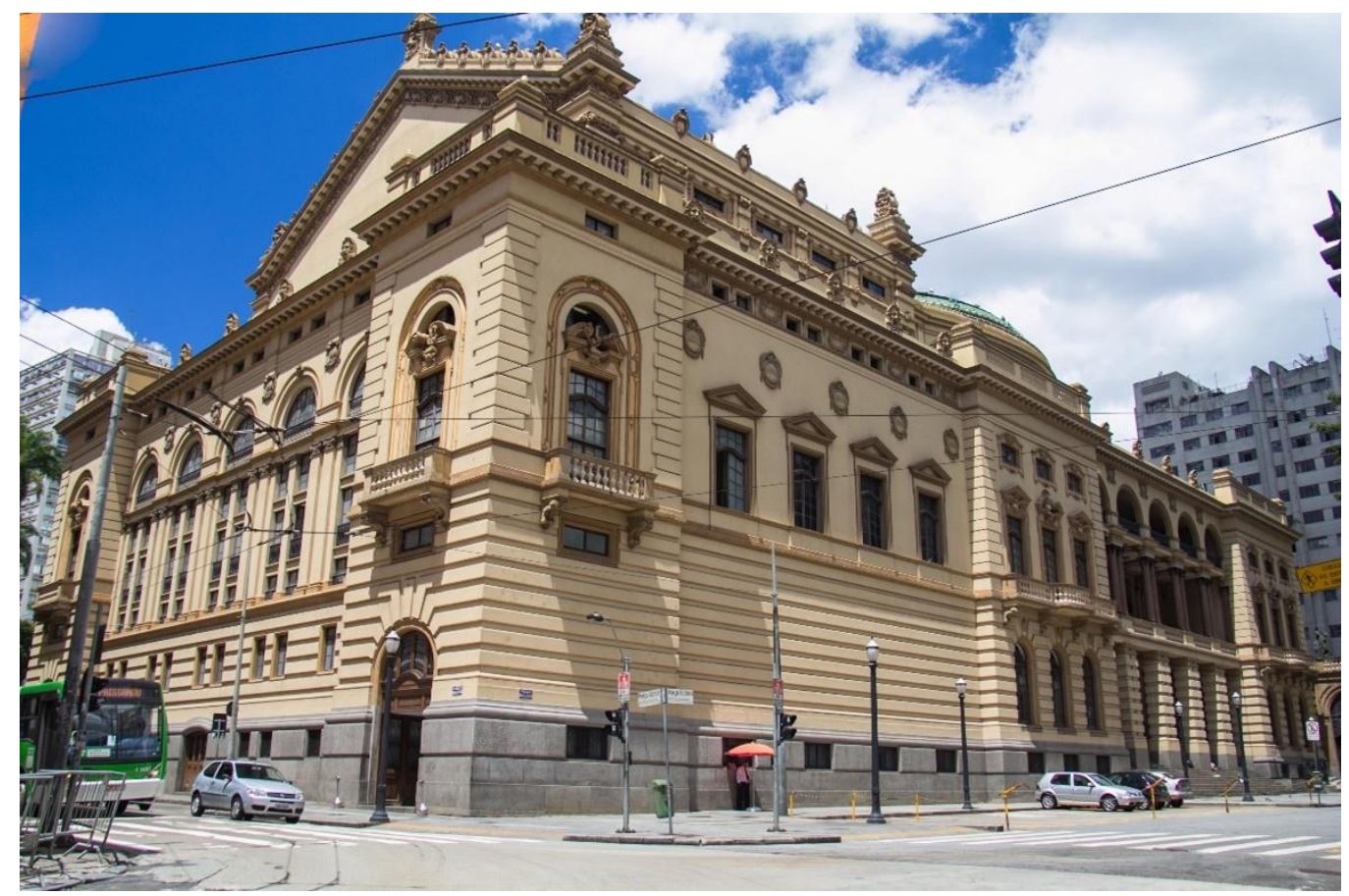

Figura 32: Fotografia da fachada lateral em 2013.

Fonte: Luiz Coelho, 2013

A cobertura que suporta a cúpula sobre a Sala de Espetáculos é vasada por olhos-de-boi ovais e a cúpula em si recebe uma cornija enfeitada por aplicações de cobre dourado e lanternim. O corpo posterior, relativo ao palco, é de composição mais simples. Foi decorado com medalhões inscritos com nomes de grandes personalidades da música ${ }^{12}$.

A fachada posterior, ainda menos ornamentada, segue a divisão horizontal tripartida verificada nas demais elevações. Verticalmente, é dividida em dois corpos laterais que se destacam levemente do central. O ático da cobertura de duas águas sobre o palco foi decorado com cartuchas e mascarões, cujos vértices culminam em uma grande máscara sobre a qual se eleva uma lira (Figura 33).

12 São eles Gomes, Verdi, Bizet, Bellini, Rossini, Mozart, Gounod, Beethoven, Weber e Wagner (SEVERO, 1911). 


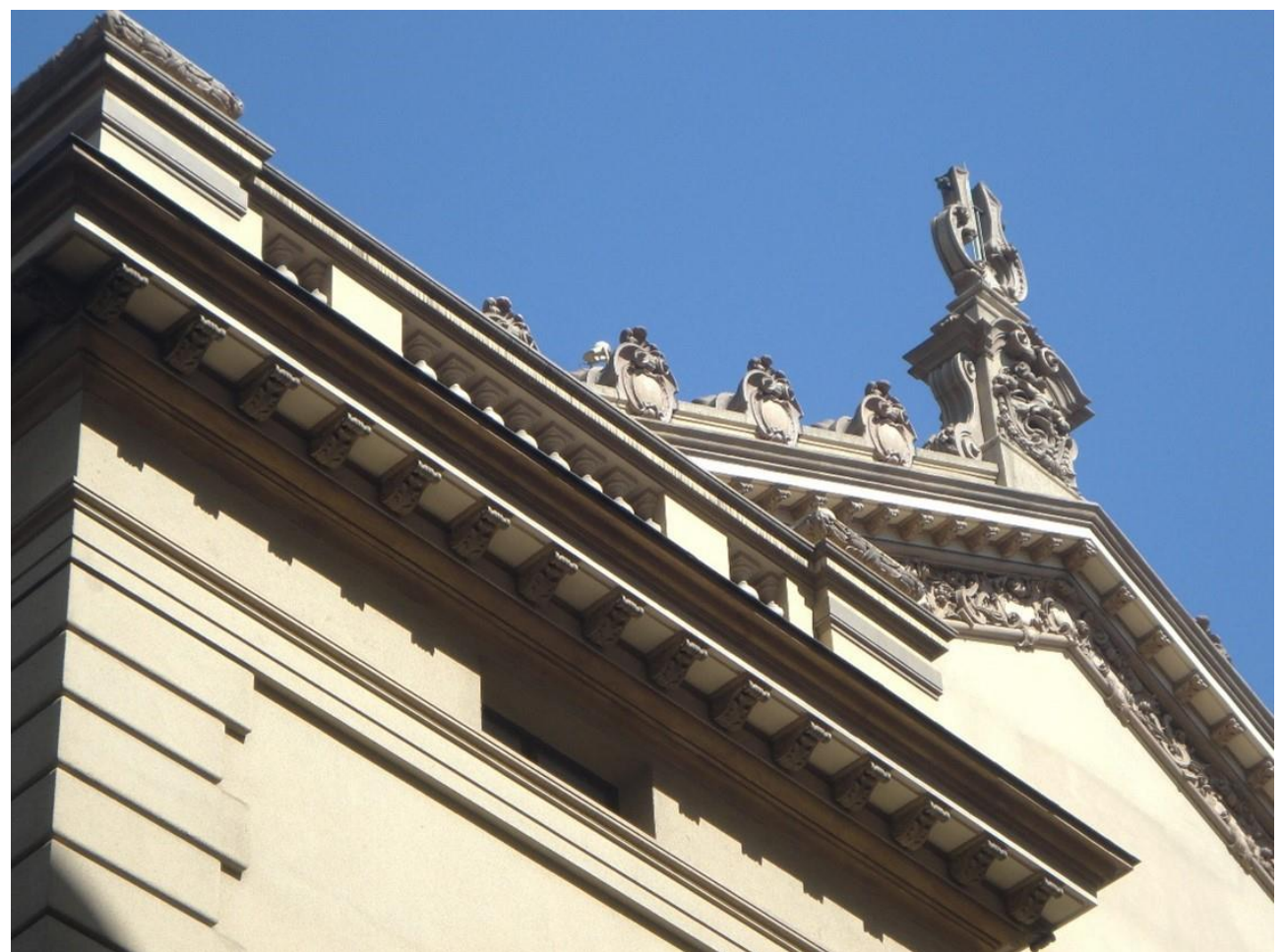

Figura 33: Detalhe da ornamentação do ático da fachada posterior, com coroamento por máscara e lira, 2015.

Fonte: Fotografias de Percival Tirapeli e tratamento de imagem por Letícia Mayumi Ozono (https://acervodigital.unesp.br/bitstream/unesp/252433/7/sp tm 07.JPG)

\subsubsection{Arquitetura interna}

Internamente, o edifício do Theatro se divide em sete pavimentos: subterrâneo, cinco pavimentos correspondentes aos planos e galerias da Sala de Espetáculos e um pavimento sob a cúpula. No setor posterior de apoio ao palco são quatro andares constituídos por camarins individuais e coletivos (Figura 34). 


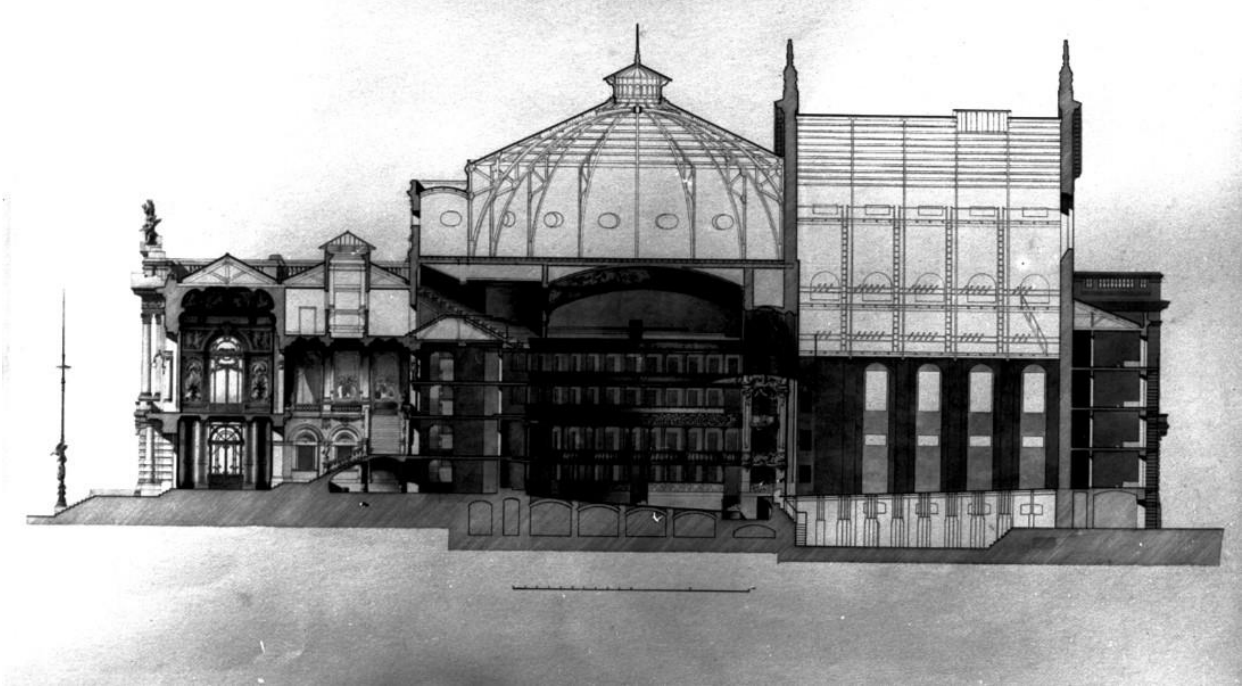

Figura 34: Corte do projeto original do Theatro, feito pelo escritório de Ramos de Azevedo. Fonte: Acervo de fontes iconográficas da biblioteca da FAUUSP.

O subsolo funcionava como um pavimento técnico que abrigava galerias, câmaras e maquinismos de ventilação; caldeiras de aquecimento, aparelhos refrigerantes e bombas; assim como a própria caixa do palco, com seus maquinismos de cena e depósitos. O primeiro andar ${ }^{13}$ (Figura 35), alocado doze degraus à cima do nível da rua, abrigava o vestíbulo principal com a escadaria nobre, dois vestíbulos laterais, bilheteria, salas administrativas, bar e restaurante; assim como o palco, o primeiro pavimento de camarins, a plateia e as frisas, que juntas totalizavam seiscentos e trinta e quatro lugares (Figura 36).

\footnotetext{
${ }^{13} \mathrm{Na}$ Monographia de Inauguração, Severo refere-se a esse pavimento como "rez-do-chão", sendo o pavimento seguinte nomeado "Terceiro pavimento". Para efeito de unificação da nomenclatura da presente pesquisa, esse pavimento será referenciado como "Primeiro andar", e os subsequentes como "Segundo andar", "Terceiro andar" e assim por diante, adotando a terminologia aplicada atualmente pela Fundação Theatro Municipal de São Paulo.
} 


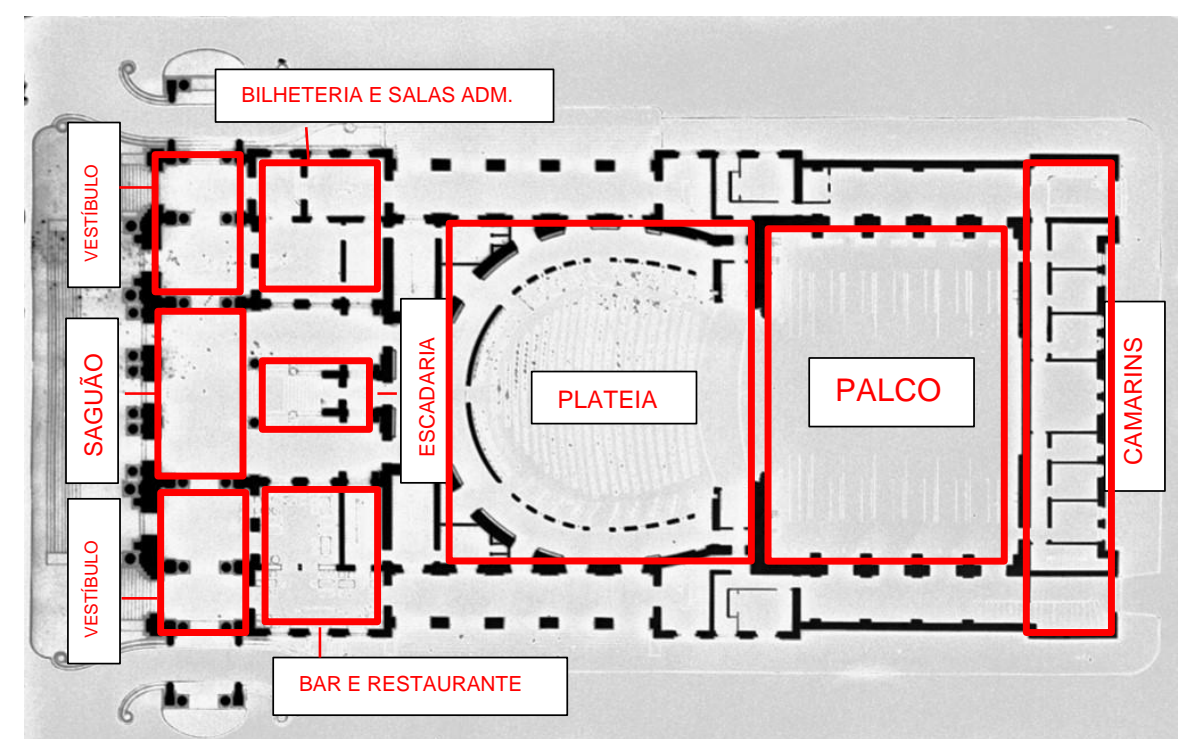

Figura 35: Planta do primeiro andar, projeto original do escritório técnico de Ramos de Azevedo.

Fonte: Acervo de fontes iconográficas da biblioteca da FAU-USP.

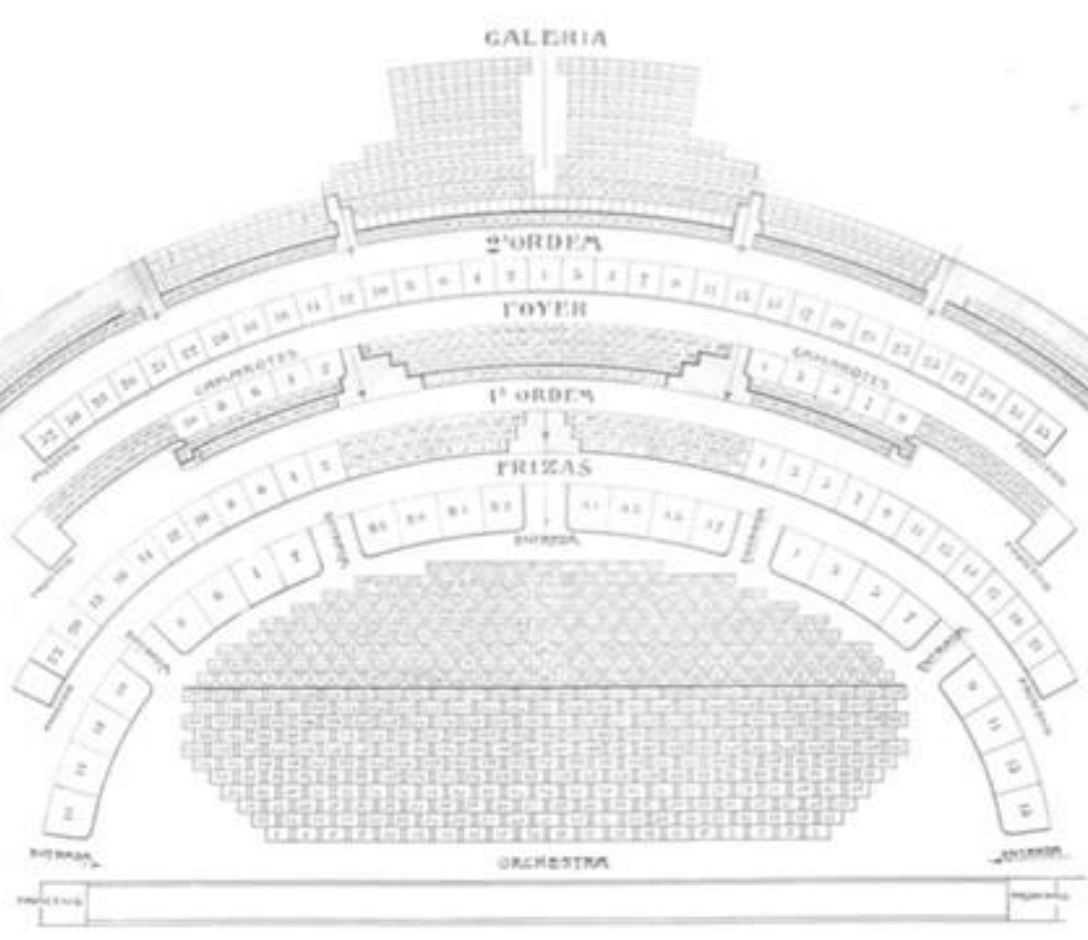

Figura 36: Mapa de assentos original da Sala de Espetáculos. Fonte: Acervo de fontes iconográficas da biblioteca da FAU-USP.

Os materiais que compunham o vestíbulo e a escadaria principal eram de origem nobre, como mármores e mosaicos, e as paredes, pintadas na técnica da scaiola (Figura 37). A decoração "conserva os moldes do estilo adotado no exterior", porém, sua "ornamentação é mais caprichosa, o relevo dos ornatos é menor; mais delicados são estes, e levianos, mas são mais variados e barrocos" (SEVERO, 1911, p. 19). 


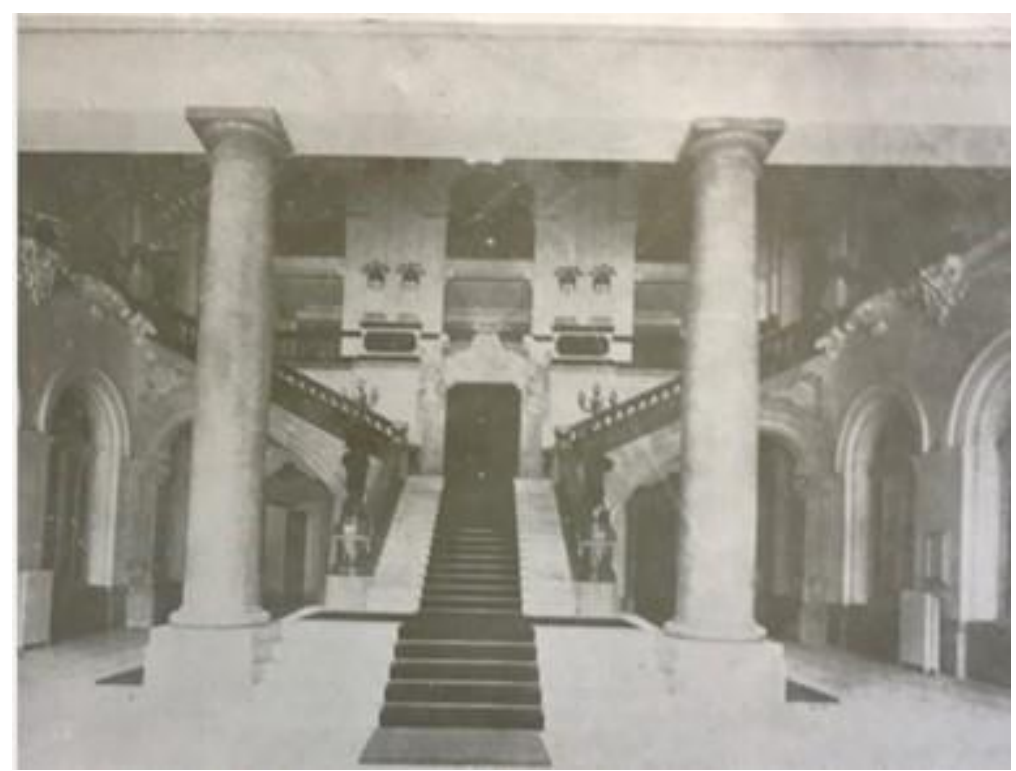

Figura 37: Fotografia do vestíbulo em 1911. Fonte: Ilustração Paulista, 1911.

A escadaria principal era ladeada por duas colunas de granito cinza do Lageado, no estilo clássico toscano, cujas dimensões ultrapassavam os seis metros de altura e quase um metro de diâmetro. A caixa da escada, com vinte metros de altura, era iluminada superiormente por caixilhos envidraçados e luminárias de cristal. Os degraus foram construídos em mármore branco e a balaustrada, em mármore amarelo italiano (SEVERO, 1911).

O primeiro lance de escada dava acesso ao portal de ingresso ao segundo andar da Sala de Espetáculos, feito em mármore branco com veios cinzentos com uma cariátide em cada lateral (Figura 38). A parede que divide a escadaria do terceiro andar é decorada por uma porta central de bronze dourado e dois painéis de mosaico veneziano. Um deles representa a cena do Ouro do Reno e o outro, a Cavalgada das Valquírias, ambas óperas de Wagner. ${ }^{14}$ (Figura 39).

\footnotetext{
${ }^{14}$ O Ouro do Reno e A Cavalgada das Valquírias são óperas do compositor alemão Wagner, que compõem, junto à Siegfried e Crepúsculo dos Deuses, a tetralogia musical intitulada O Anel do Nibelungo, composta entre 1848 e 1874 (FILIPE, Pedro José Leal. O Anel do Nibelungo: Reinterpretação pictórica da tetralogia de Wagner. 2011. 1 v. Dissertação (Mestrado) - Curso de Comunicação, Cultura e Arte, Estudos da Imagem, Universidade do Algarve, Algarve, 2011).
} 


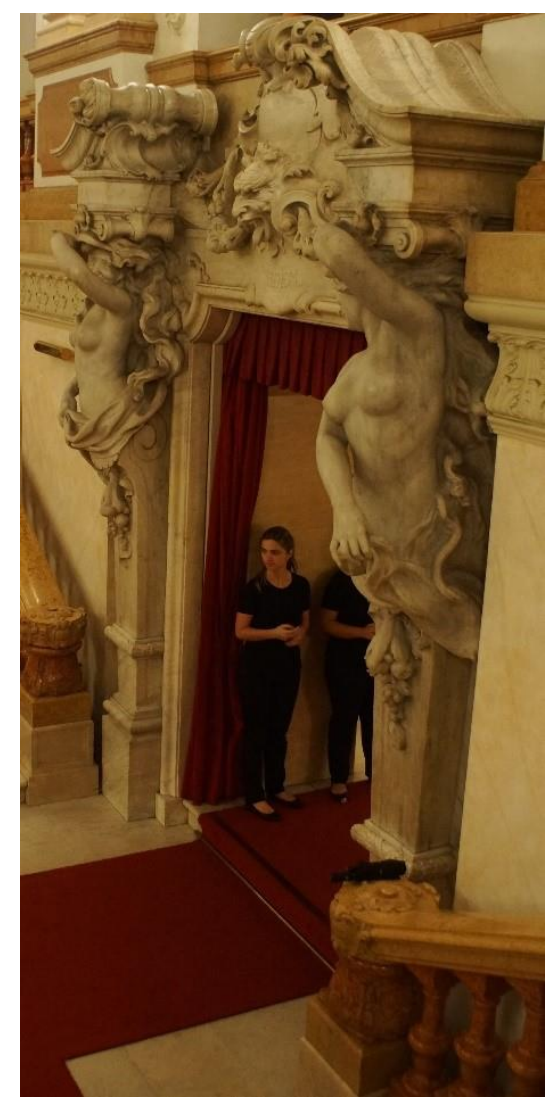

Figura 38: Fotografia das cariátides que ladeiam o portal de ingresso à primeira ordem, 2015. Fonte: Fotografias de Percival Tirapeli e tratamento de imagem por Letícia Mayumi Ozono (https://acervodigital.unesp.br/bitstream/unesp/252433/29/sp tm 29.JPG)

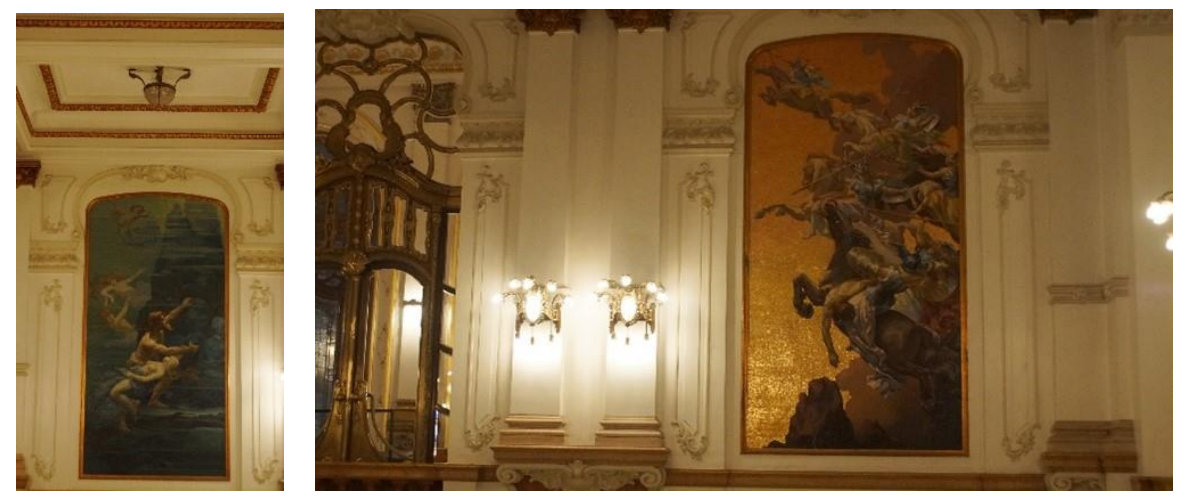

Figura 39: Fotografia do mosaico veneziano representando o "Ouro do Reno" (à esquerda) e do mosaico veneziano representando a "Cavalgada das Valquírias" (à direita), 2015.

Fonte: Fotografias de Percival Tirapeli e tratamento de imagem por Letícia Mayumi Ozono (https://acervodigital.unesp.br/bitstream/unesp/252433/27/sp tm 27.JPG) (https://acervodigital.unesp.br/bitstream/unesp/252433/25/sp tm 25.JPG)

O ambiente do restaurante era marcado pela riqueza de suas pinturas decorativas e pelo chão de ladrilhos hidráulicos norte-americanos, importados pela United States Encaustic Tile Co. de Nova Iorque (Figura 40). O teto era formado por molduras douradas que delimitavam o espaço dos forros e as portas eram fechadas por vitrais da Casa Conrado (COSTA, 2017). 


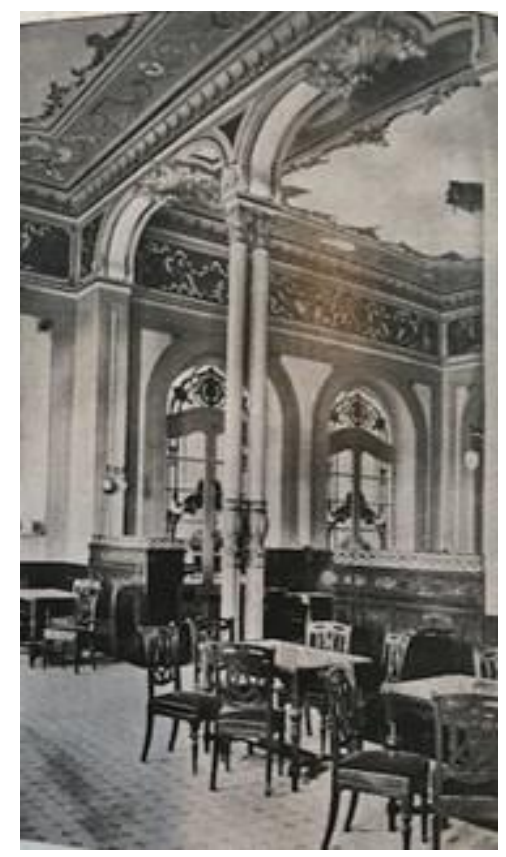

Figura 40: Fotografia do restaurante à época de sua inauguração em 1911. Chama a atenção o fato de esse ser o único registro iconográfico do ambiente original, que seria profundamente alterado na intervenção da década de 1950.

Fonte: SEVERO, 1911.

Assim como o restaurante, o ambiente da Sala de Espetáculos seria profundamente alterado durante a intervenção da década de 1950. Seu formato original em ferradura e seus balcões em balanço, apoiados em parte por finas colunas douradas, promoviam problemas de visibilidade e acústica os quais a intervenção visou corrigir ${ }^{15}$ (Figura 41). A coloração geral do ambiente, outro foco de atenção das intervenções posteriores ${ }^{16}$, é descrita na Monographia de Inauguração como sendo branca e dourada, com elementos decorativos cuja temática aludia à arte dramática, canto, dança e poesia (SEVERO, 1911).

${ }^{15}$ Ver Capítulo 2 - Segunda Modernidade.

16 Ver Capítulo 3- Reconhecimento e Capítulo 4 - Contemporaneidade. 


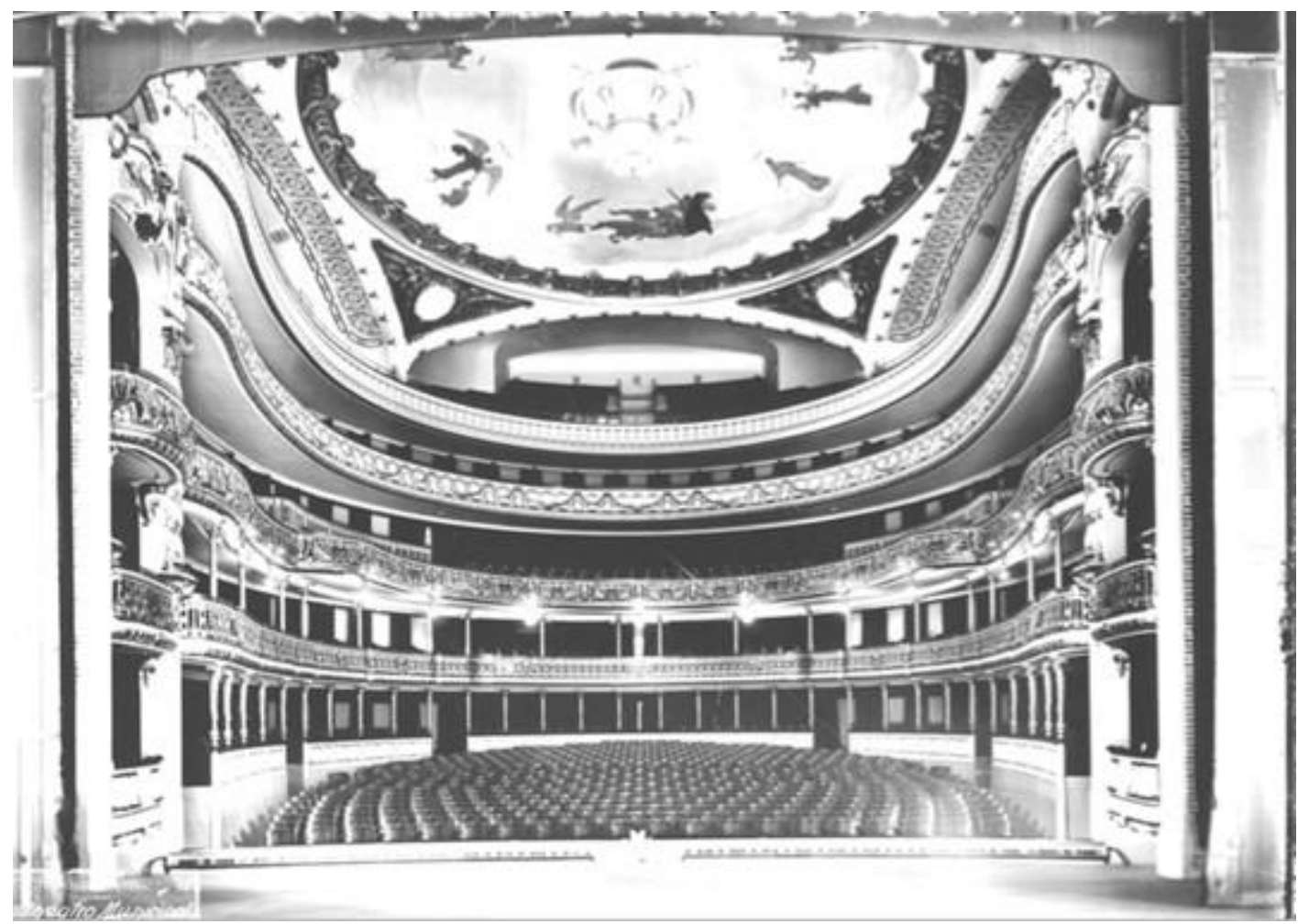

Figura 41: Fotografia interna da sala de espetáculos.

Fonte: Acervo de fontes iconográficas da biblioteca da FAU-USP.

O quadro de abertura de cena abrigava um medalhão de Carlos Gomes na posição central. O frontão do palco, por sua vez, era formado por friso de autoria do escultor Alfredo Sassi ${ }^{17}$, representando o nascimento de Vênus, com uma multidão de ninfas, Oceanides e Naiades (Figura 42). A orquestra era disposta em um nível inferior à plateia, sobre um estrado móvel nos moldes do dispositivo wagneriano $^{18}$.

\footnotetext{
${ }^{17}$ Alfredo Sassi foi um artífice italiano que integrou o grupo de artistas de mesma nacionalidade responsáveis pelas obras integradas as Theatro, entre eles Lorenzo Massa e Sebastiano Sparapani (ENCONTRO ESTADUAL DE HISTÓRIA - ANPUH-SP, 21., 2012, Campinas. O imigrante italiano e o patrimônio cultural paulistano no pós Segunda Guerra Mundial. Campinas, 2012, 12 p.)

${ }^{18}$ A disposição da orquestra abaixo do nível da plateia fora idealizada pelo compositor alemão Wagner (1812-1883), sendo assim "a ópera de Wagner já se utilizava de um jogo cênico que contrapunha sons acusmáticos (i.e., sem causa ou fonte visualmente determináveis) se sua orquestra à visualidade teatral dos cantores". (CAPELLER, Ivan. Introdução à arqueologia da escuta - Do Som e da voz como objetos de enunciação. Ciberlegenda: Revista Eletrônica do Programa de Pós-graduação em Comunicação, Rio de Janeiro, v. 2, n. 24, p. 7-15, jan. 2011. Disponível em: http://www.ciberlegenda.uff.br/index.php/revista/article/viewFile/446/271\#page=7. Acesso em: 15 fev. 2019).
} 


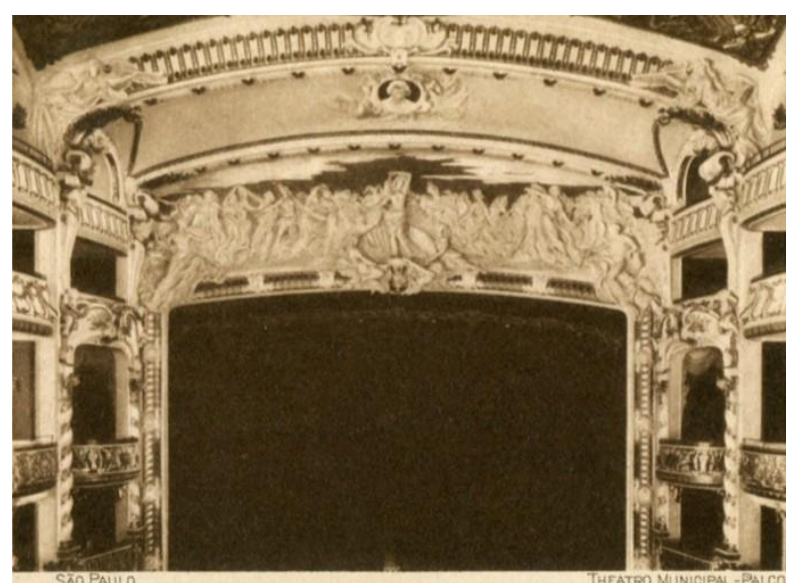

Figura 42: Foto do frontão do palco e abobada com medalhão de Carlos Gomes na década de 1920.

Fonte: http://www.caravelas.com.pt/teatro sao paulo palco.jpg

A ventilação era feita artificialmente por meio de uma corrente contínua de ar depurado ${ }^{19}$, que entrava pelos arcos da cúpula e pelos frisos recortados sobre os balcões da última ordem. $O$ ar interior era lançado para for a pelo lado oposto ao de sua entrada no edifício.

O segundo andar (Figura 43) abrigava aquilo que se chamava, dentro da sala de espetáculos, de "primeira ordem". Continha dois camarotes de boca de cena, vinte e dois camarotes com varandim e balcão central com três fileiras de poltronas, totalizando cento e oitenta e oito espectadores (SEVERO, 1911).

${ }^{19} \mathrm{O}$ ar era forçado a atravessar um filtro especial, que decantava a poeira e, em seguida, $\mathrm{O}$ resfriava ou aquecia (SEVERO, 1911). 


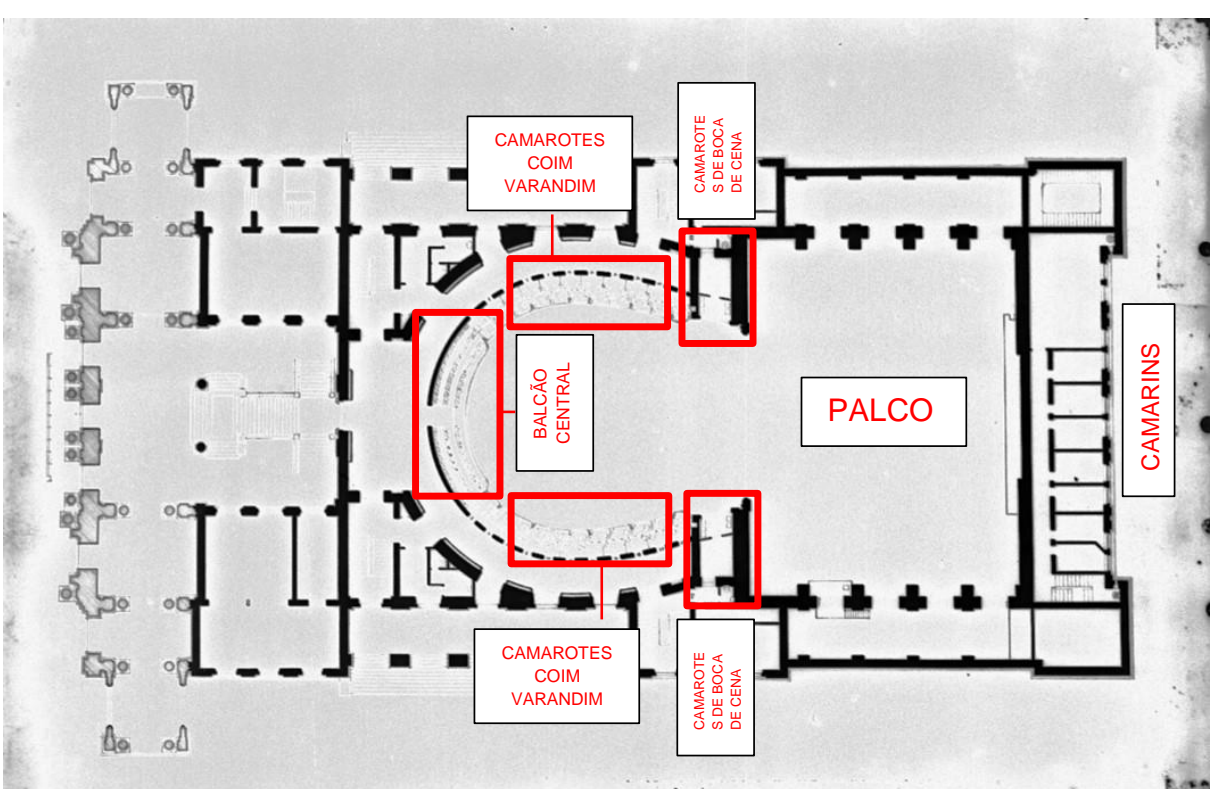

Figura 43: Planta do segundo andar, projeto original do escritório técnico de Ramos de Azevedo.

Fonte: Acervo de fontes iconográficas da biblioteca da FAU-USP.

O terceiro (Figura 44) andar abriga o Grande Salão de Festas ou Foyer, ambiente suntuoso ligado às antecâmaras por três portas em arco de bronze dourado com lâminas de cristal (Figura 45). As paredes são recortadas em arcaria com colunatas de pilastras, cujos capitéis e bases também são de cobre dourado. As bases das pilastras são de mármores variados, do Ituparanga aos importados da Itália, entre as quais ficam alojados espelhos com aplicações metálicas e pontos de iluminação. O piso é em parquet de marchetaria de pau-marfim e peroba rosa e o mobiliário, composto por sofás e cortinas, fora executado pelo Liceu de Artes e Ofícios.

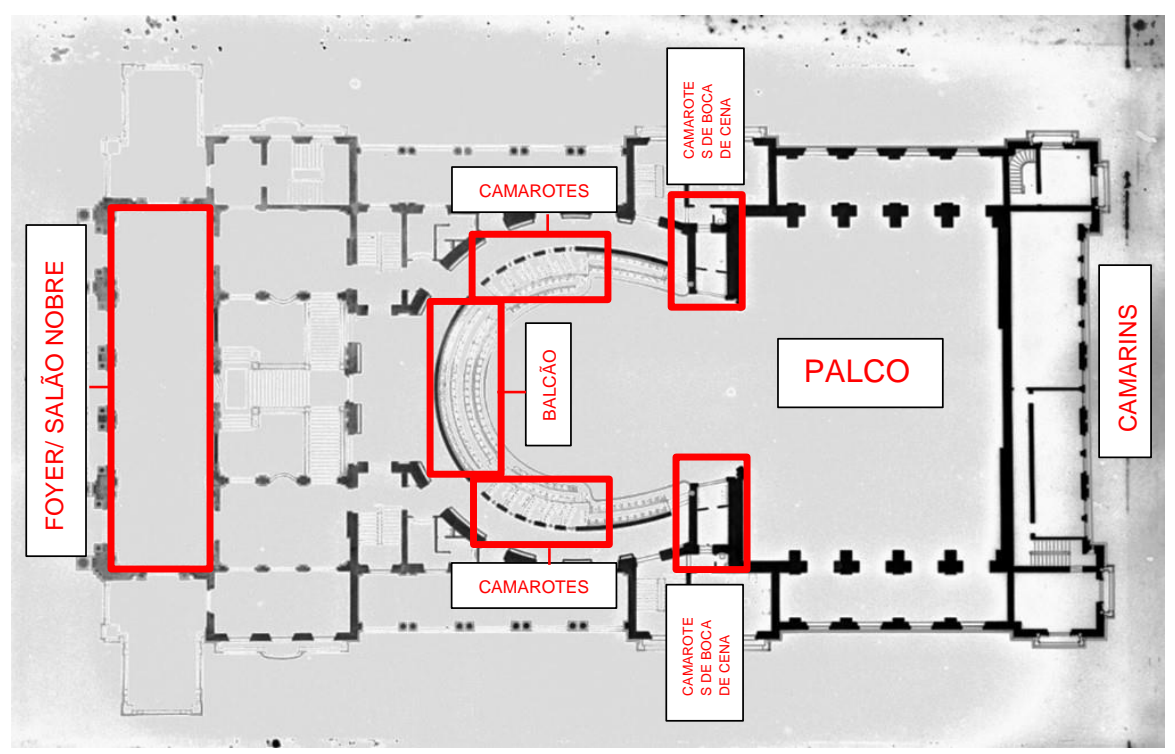

Figura 44: Planta do terceiro andar, projeto original do escritório técnico de Ramos de Azevedo. Fonte: Acervo de fontes iconográficas da biblioteca da FAU-USP. 


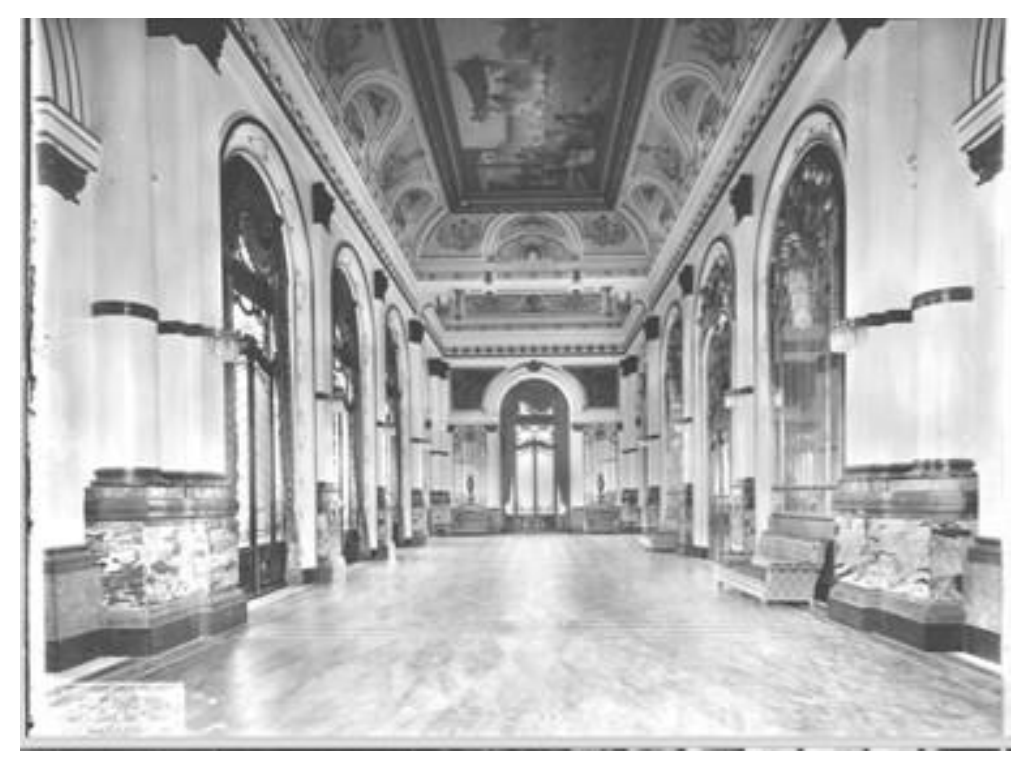

Figura 45: Fotografia do aspecto original do Salão Nobre.

Fonte: Acervo de fontes iconográficas da biblioteca da FAU-USP.

O destaque da sala, no entanto, são as pinturas decorativas do forro, de autoria de Oscar Pereira da Silva ${ }^{20}$, com o auxílio de Pusello Moseli, Pangela Giuseppe e Sebastião Sparapani, feitas diretamente sobre o estuque de gesso com a técnica fresco secco ${ }^{21}$ (Figura 46). A figura central reproduz uma cena do teatro romano, enquanto as laterais representam apoteoses à música e à dança (COSTA, 2017).

\footnotetext{
${ }^{20}$ Artista fluminense nascido em São Fidelis no ano de 1867 e migrado para São Paulo no final do século. Frequentou a Academia Imperial de Belas Artes a partir de 1882 e teve importante papel do desempenho da chamada pintura histórica, em especial por seu quadro "A Fundação de São Paulo" (MONTEIRO, Michelli Cristine Scapol. Fundação de São Paulo, de Oscar Pereira da Silva: trajetórias de uma imagem urbana. 2012. 177 f. Dissertação (Mestrado) - Curso de Arquitetura e Urbanismo, História e Fundamentos da Arquitetura e do Urbanismo, Universidade de São Paulo, São Paulo, 2012).

${ }^{21}$ Ao contrário do afresco, onde a pintura é aplicada sobre base úmida em tinta óleo (COSTA, 2017).
} 


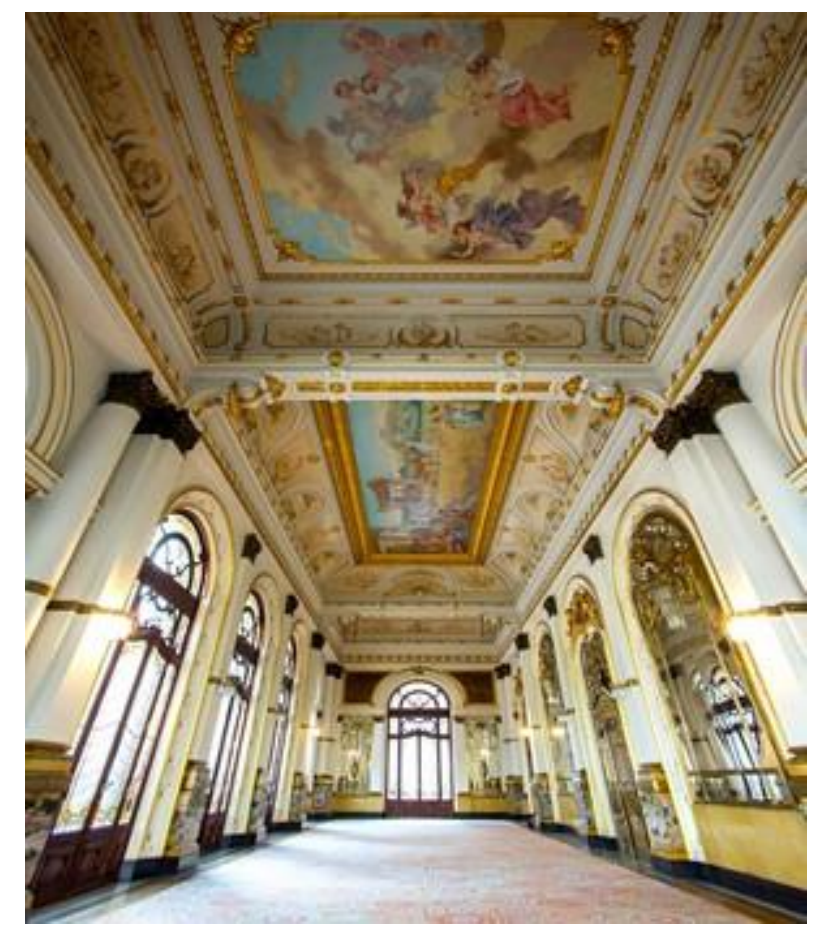

Fotografia 46: Pinturas decorativas do forro do Salão Nobre, 2017.

Fonte: Fotografia de Francisco Pereira de Figueiredo.

Além das pinturas do forro, o ambiente conta com os esquemas figurativos das cantoneiras retangulares sobre os espelhos, com tapeçarias do ateliê de Erulo Eroli de Roma 22 . O uso de tapeçarias como elemento decorativo em teatros europeus do século XIX é bastante comum, mas no Municipal de São Paulo, adquirem feições rococó ao retratarem uma paisagem campestre bucólica (COSTA, 2017).

No que tange ao interior da Sala de Espetáculos, o pavimento do foyer era dotado de dois camarotes de boca de cena, destinados ao prefeito e ao governador, além de balcão com duas fileiras laterais e quatro centrais, e dois setores de cinco camarotes cada, totalizando duzentos e trinta e quatro assentos que configuravam a chamada segunda ordem (Figura 44).

O quarto andar (Figura 47), ou terceira ordem, continha dois camarotes de boca de cena (Figura 48) acrescidos de trinta e um camarotes simples, totalizando cento e sessenta e cinco lugares. O quinto andar (Figura 49) também compunha a chamada terceira ordem, contando com dois camarotes de palco, um balcão de centro, quatro balcões laterais e uma galeria central com dez filas de cadeiras,

22 Pintor e recelão da Úmbira, tratou em suas obras de assuntos militares e religiosos (COSTA, 2017). 
que totalizava, quinhentos e cinquenta e quatro espectadores mais trinta lugares não numerados (SEVERO, 1911).

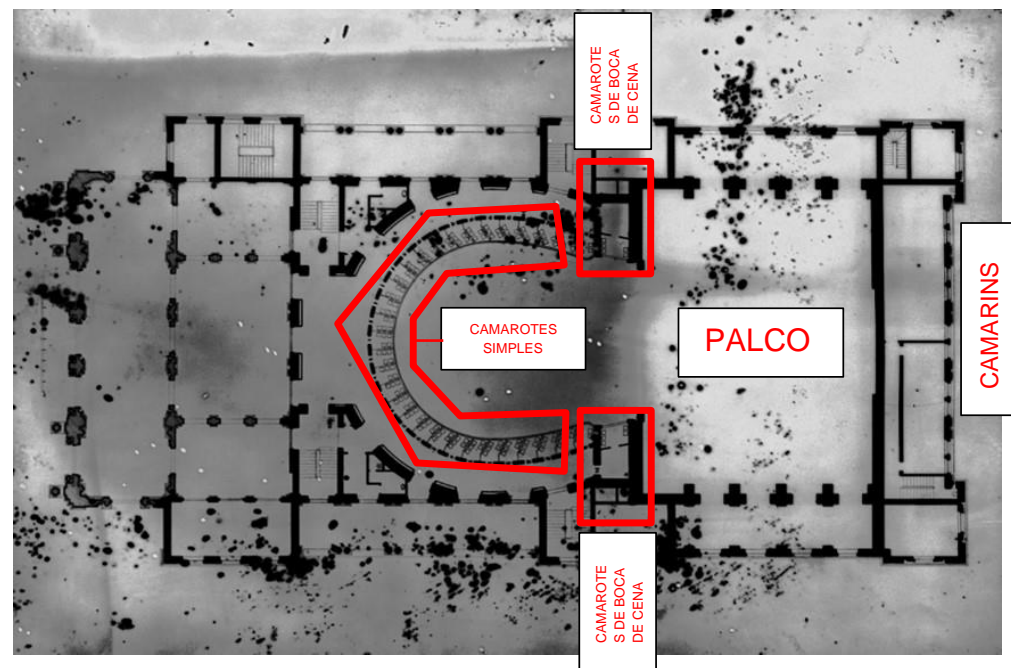

Figura 47: Planta do quarto andar, projeto original do escritório técnico de Ramos de Azevedo. Fonte: Acervo de fontes iconográficas da biblioteca da FAU-USP.

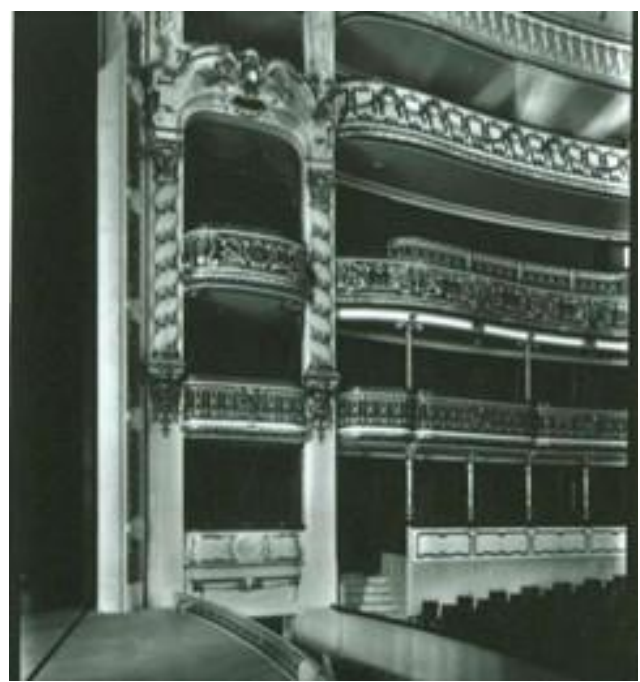

Figura 48: Fotografia do camarote do proscênio em 1911. Esse conjunto de camarotes seria removido, para execução do aumento de largura da boca de cena, durante a intervenção de 1950. O espaço restante permaneceria vago para a implantação do órgão na década seguinte. Chama a atenção o fato de que suas paredes foram as únicas remanescentes do perímetro original da Sala, tendo sido usadas nas prospecções da década de 1980 para definir a escolha da coloração interna do ambiente (Ver Capítulo 3-Reconhecimento).

Fonte: Biblioteca da FAU/USP. 


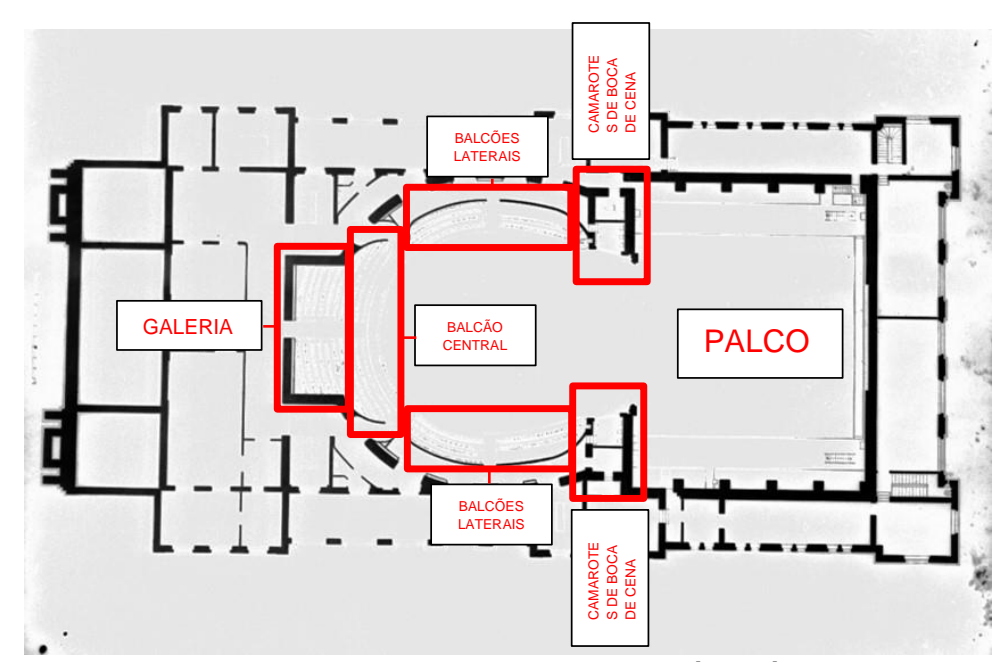

Figura 49: Planta do quinto andar, projeto original do escritório técnico de Ramos de Azevedo. Fonte: Acervo de fontes iconográficas da biblioteca da FAU-USP.

Entender, de maneira descritiva e detalhada, a composição formal e tipológica do edifício do Theatro auxilia na compreensão de sua relação com o modelo europeu. A historiografia da arquitetura tende a destacar a relação de modelo e cópia entre a Ópera Garnier de Paris e o Theatro Municipal de São Paulo, respectivamente. Para pesquisadores como Costa, no entanto, essa interpretação é incompleta. Apesar da Ópera de Paris ter se concretizado como o "protótipo por excelência do teatro monumental das grandes capitais europeias" (COSTA, 2017, p. 626), ao chegar na América, o modelo estabelece novos diálogos.

No Municipal de São Paulo, são inúmeras as referências ao legado de Garnier. A própria configuração volumétrica do exterior do edifício, com embasamento rusticado, andar nobre com foyer e coroamento com balaustrada e grupos escultóricos, além da evidenciação da divisão funcional em três corpos distintos são exemplos desses empréstimos. Internamente, a distribuição dos espaços e sua característica monumental também fazem referência ao modelo francês.

Outras características, como a adoção de tons terrosos para a coloração geral das fachadas, remetem mais a uma herança italiana "do mediterrâneo ensolarado e não à solenidade dos mármores brancos de Garnier" (COSTA, 2017, p. 628). Há também aproximações com o modelo alemão, sobretudo da obra do ateliê de Fellner \& Helmer ${ }^{23}$, de onde pode ter vindo a inspiração para a

\footnotetext{
${ }^{23}$ Fellner \& Helmer foi um ateliê fundado em 1873 pelos arquitetos austríacos Ferdinand Fellner e Hermann Helmer, reponsável por muitas das casas de ópera projetadas ao longo do último
} 
adoção dos atlantes na fachada principal, das loggias laterais e das portas e janelas e arco dos andares térreo e nobre (COSTA, 2017).

O entendimento dessa complexidade constitutiva do edifício, associado ao conhecimento minucioso de seus ambientes, materiais e técnicas construtivas originais, lança as bases para a análise das intervenções às quais ele foi submetido ao longo de sua história. A seguir, será analisada a primeira grande obra realizada no edifício do Theatro, suas bases teóricas - ou ausência das mesmas -, e sua relação com o incipiente contexto nacional da preservação.

quarto do século XIX na Europa (HAIKO, Peter. THEATRE ARCHITECTURE OF THE LATE 19TH CENTURY IN CENTRAL EUROPE, 1993, Cracóvia. Public theatre versus court theatre: the Vienna Deutsches Volkstheater of Fellner and Helmer as a model of middle class theatre architecture. Cracóvia: Bibliographie D'Histoire de L'Art, 1993). 


\section{A DÉCADA DE 1950: SEGUNDA MODERNIDADE}

No presente capítulo, será analisada a intervenção arquitetônica empreendida no edifício do Theatro Municipal de São Paulo entre os anos de 1952 e 1955, à luz das teorias de restauro coetâneas e também da atuação do Serviço do Patrimônio Histórico e Artístico Nacional (SPHAN), o primeiro - e até então único - órgão nacional voltado à preservação do patrimônio. $O$ cotejamento entre intervenção, teoria e prática restaurativa oficial será utilizado como recurso metodológico de análise neste e nos demais capítulos, mesmo diante do fato de que o Theatro Municipal não era tombado pelo SPHAN à época ${ }^{24}$.

Foram analisados documentos primários na forma de projetos (plantas, cortes e elevações) consultados no Acervo do Arquivo Histórico Municipal de São Paulo, bem como uma série de publicações simultâneas que tematizam a intervenção na Revista Acrópole, escritas pelo arquiteto responsável pela obra, Tito Pistoresi. Esses documentos foram cotejados com a bibliografia correspondente ao campo epistemológico da teoria da restauração (BOITO, 2014; DVORAK, 2013; RIEGL, 2014; GIOVANNONI, 2013 e Carta de Atenas) e como exemplo da atuação prática do SPHAN à época, em São Paulo (FONSECA, 1997; CHUVA, 2003; MAYUMI, 2006).

\subsection{A primeira metade do século $X X$}

A primeira metade do século $X X$ foi marcada internacionalmente pelas discussões do chamado Restauro Filológico, expressas nos escritos de Camilo Boito, Max Dvorak, Alois Riegl e condensadas na Carta de Atenas (1931). No Brasil, o incipiente cenário da preservação contava apenas com o SPHAN como órgão responsável pelo patrimônio nacional. A seguir, serão comentados esses contextos que, tanto em âmbito nacional como internacional, permearam a execução da intervenção no Theatro Municipal de São Paulo, empreendida durante a década de 1950.

\footnotetext{
${ }^{24} \mathrm{O}$ tombamento do Theatro Municipal de São Paulo pelo IPHAN foi oficializado apenas em 2014, no período imediatamente posterior à realização de todas as intervenções aqui analisadas. Surpreende o fato de um reconhecimento tão tardio do edifício do Theatro a nível federal, sendo que seu congênere carioca havia sido tombado pelo mesmo órgão em 1973 (Livro do Tombo das Belas Artes - Volume 1, inscrição no: 503, folha 92. Processo n: : 860-T-72. Acervo: Arquivo Noronha Santos/IPHAN).
} 


\subsubsection{Contexto internacional: o Restauro Filológico e a Carta de Atenas}

O debate interno ao campo epistemológico da teoria da restauração durante a primeira metade do século XX é devedor das formulações oitocentistas de Eugène Emannuel Viollet-le-Duc e John Ruskin. $O$ arquiteto francês, estudioso do gótico, lança bases para uma atuação sobre o monumento que almeja alcançar um estado completo idealizado, a partir da unidade de estilo (KÜHL 2013). O britânico John Ruskin, por sua vez, tece suas considerações, baseadas no respeito pela matéria original e pelas marcas da passagem do tempo, ancoradas na visão romântica do pitoresco (PINHEIRO, 2013).

No final do século XIX, o arquiteto italiano Camillo Boito colocava-se criticamente frente às formulações de Viollet-le-Duc e Ruskin, sintetizando e dialogando com ambas as posições, ao mesmo tempo em que fornecia fundamentos para o que ficaria conhecido como Restauro Filológico ${ }^{25}$. Para Boito, o embate entre ambas as visões se resolveria pela ênfase no valor documental da obra, como fica explícito pela citação de Merimée usada por ele para sintetizar sua postura: Nunca se repete suficientemente que, em relação à restauração, o
primeiro e inflexível princípio é este: não inovar, mesmo quando se
fosse levado à inovação pelo louvável intento de completar ou de
embelezar. Convém deixar incompleto e imperfeito tudo aquilo que se
encontra incompleto e imperfeito. Não é necessário permitir-se corrigir
as irregularidades, nem alinhar os desvios, porque os desvios, as
irregularidades, os defeitos de simetria são fatos históricos repletos de
interesse, os quais frequentemente fornecem os critérios
arqueológicos para confrontar uma época, uma escola, uma ideia
simbólica. Nem acréscimos, nem supressões.

(MERIMÉE, 1837 In. BOITO, 2014, p. 59-60).

Durante o Congresso dos Engenheiros e Arquitetos em Roma, de 1883, Boito apresenta os postulados fundamentais de sua teoria: a ênfase no valor documental, o uso ponderado de acréscimos e renovações, a distinção entre completamentos, a limitação das obras de consolidação ao mínima necessário, o respeito às várias fases do monumento e o registro da data e autoria das obras realizadas. Dessa forma, enuncia princípios que constituem a base da

25 "A denominação Restauro Filológico vem justamente do fato de a ação assemelhar-se a edições críticas de textos, pois, ao tratar as lacunas do documento, as interpolações e interpretações são feitas através de elementos diferenciados: tipo e cor da letra, notas à margem do escrito" (KÜHL, 2013). 
restauração até os dias de hoje, conhecidos como distinguibilidade e mínima intervenção (KÜHL, 2014).

Assim sendo, o que Boito se propõe a fazer é o cotejamento entre os valores artísticos do monumento, preconizados pela teoria de Viollet-le-Duc, e os valores históricos, preconizados por Ruskin. Essa questão hierárquica entre os diferentes valores circunscritos a uma mesma obra é objeto de análise do austríaco Alois Riegl ${ }^{26}$, que dedica seu ensaio $O$ Culto Moderno dos Monumentos, de 1903, a essa temática ${ }^{27}$.

Para Riegl, todo monumento de arte é, ao mesmo tempo, monumento de história e vice-versa. Dessa forma, cada obra circunscreve em si dois conjuntos de valores diferentes: os valores de memória e os valores de atualidade.

Constituem os valores de memória o valor de antiguidade (Alterswert), o valor histórico (Historischer Wert) e o valor volitivo da memória (Erinnerungswert). Os valores de atualidade, por sua vez, são constituídos pelo valor de uso (Gebrauchswert), o valor de novidade (Neuheitswert) e o valor artístico (Kunstwert).

Os valores analisados pelo historiador austríaco, no entanto, não se articulam de maneira linear em importância. Ou seja, existe uma hierarquia de valores, na qual o valor de antiguidade (Alterwert), na grande maioria dos casos, deve assumir a posição de maior importância:

Uma conservação moderna dos monumentos deverá, por isso, considerar em primeira linha o valor de antiguidade, sem negligenciar, não obstante, os outros valores de um monumento, tanto os valores de memória como os de atualidade, em face dos quais, ela deve ponderar a importância relativa do valor de antiguidade e quando esse último parecer insignificante, privilegiar os primeiros (RIEGL, 2014, p. 55).

O valor de antiguidade é explícito pela materialização das forças destruidoras da natureza e das marcas do curso do tempo sobre a matéria. Esse aspecto

\footnotetext{
26 Alois Riegl (1858-1905) foi um historiador da arte da primeira Escola de Viena. Sua contribuição para o campo da restauração, aqui explorada, foi acompanhada pela sua inovadora abordagem interdisciplinar da história da arte, que renunciava a noção de decadência e a separação entre "arte maior" e "arte menor" (FABRIS, 2014).

${ }^{27}$ O ensaio O Culto Moderno dos Monumentos foi encomendado a Riegl pela Comissão Central de Arte e de Monumentos históricos, como parte do projeto de execução de um plano para reorganização da conservação pública dos monumentos na Áustria (RIEGL, 2014).
} 
"incompleto" oferece-se imediatamente à percepção sensorial e pode ser percebido pela grande massa de espectadores. Daí surge outro conceito, cuja importância vem sendo explorada desde as formulações de Ruskin no século XIX, a pátina:

A antiguidade se exprime mais pelo efeito óptico da decomposição da superfície - influência do tempo, pátina -, do desgaste de ângulos e cantos, que revela, portanto, a inexorável e implacável ação de dissolução provocada pela natureza (RIEGL, 2014, p. 51).

Do ponto de vista da preservação, partindo do reconhecimento do valor de antiguidade como valor preponderante, Riegl assume uma postura conservativa. Para ele, devem-se evitar as intervenções arbitrárias, os acréscimos, reduções e restituições daquilo que a passagem do tempo tenha alterado ${ }^{28}$.

Ao contrário do valor de antiguidade (Alterwert), o valor histórico (Historischer Wert) é apenas identificado por meio do conhecimento de bases científicas, o que o torna menos perceptível para o público de maneira geral, alheio às discussões do campo da pesquisa histórico-científica. O valor histórico resulta da representação que determinado monumento performa, como "estágio evolutivo individual de um domínio qualquer da atividade humana" (RIEGL, 2014).

A análise do valor volível da memória, por sua vez, parte da separação conceitual efetuada por Riegl entre "monumentos" e "monumentos históricos". De acordo com o autor, os "monumentos" são aquelas obras concebidas originalmente com a intenção de permanecerem no tempo, "sempre presente e vivo". Os "monumentos históricos", por sua vez, são aqueles sobre os quais o valor de monumento Ihes é atribuído posteriormente a sua feitura.

Uma vez analisados os valores de memória e a sua relação com o culto moderno dos monumentos, passa-se à análise dos valores de atualidade. Esse grupo de valores caracteriza-se pela satisfação de necessidades "sensíveis ou

\footnotetext{
28 "Do ponto de vista do culto da antiguidade, um fator deve ser absolutamente evitado: a intervenção arbitrária do homem na existência do monumento. Ele não pode sofrer acréscimos nem reduções, nem restituições daquilo que as forças naturais desagradaram com o tempo e sequer a supressão do que, Ihe tendo sido acrescentado, tenha alterado a forma original" (RIEGL, O Culto Moderno dos Monumentos: a sua essência e a sua origem. São Paulo, Perspectiva, 2014, p. 52).
} 
espirituais", ancoradas no presente. A primeira, relacionada ao valor de uso (Gebrauchswert); e a segunda, ao valor de arte (Kunstwert), expresso, por sua vez, pelo valor de arte relativo e de novidade (Neuheitswert).

A conservação do valor de novidade (Neuheitswert) essencialmente contradiz o valor de antiguidade, uma vez que o seu reconhecimento se dá pela integridade da obra. Porém, da mesma forma que o valor de antiguidade, pode ser apreciado por todos, já que seu reconhecimento depende apenas de fatores puramente sensoriais $^{29}$.

Se, dentro dos valores de memória, o valor de antiguidade encontrava seu contraponto no valor histórico, como seu correspondente de bases científicas; dentro dos valores de atualidade, está o valor de arte relativo para o valor de novidade. O reconhecimento do valor de arte relativo de determinada obra se dá pela correspondência (ou não) daquela obra ao "querer da arte" (Kuntswollen) moderno. O entendimento e apreciação de sua especificidade, com relação a sua concepção, forma e cor, se dá por um contingente menor de pessoas, mais eruditas e conhecedoras da trajetória da história da arte.

Uma vez entendida a confluência dos diversos valores em um mesmo monumento, nota-se que a postura de conservação ao longo do século XIX, baseada na aparência original e na unidade de estilo, privilegiava o culto do valor histórico e de novidade. Em contraposição, surge o culto do valor de antiguidade, que não se preocupa nem com a originalidade nem com a integridade de estilo, mas, pelo contrário, com a ruptura de ambos.

Apesar da ausência de menção direta por parte de Riegl a Viollet-le-Duc ou Ruskin, fica evidente que suas colocações sobre as principais posturas que regiam o debate sobre a conservação dos monumentos no século XIX diz respeito às formulações desses autores. Em procedimento semelhante, ao

\footnotetext{
29 "A integralidade daquilo que é novo e recém-surgido, que se caracteriza pelos critérios mais simples, como forma inalterada e policromia pura, pode ser apreciada por todos, mesmo por aqueles de pouca cultura (...) A massa sempre apreciou o que obviamente parecia novo. Ela prefere enxergar nas obras humanas a força criativa e vencedora do homem, ao invés da força destruidora e inimiga da natureza" (RIEGL, O Culto Moderno dos Monumentos: a sua essência e a sua origem. São Paulo, Perspectiva, 2014, p. 71).
} 
salientar a postura sintetizada no final do século XIX, em conformação com o culto do valor histórico, Riegl está se referindo ao valor de documento conferido à obra pelo restauro filológico de Boito.

Após a análise dos diferentes grupos de valores dos monumentos, deve ficar claro que não cabe ao restaurador e/ ou conservador eleger qual deles receberá a primazia sobre os demais. Na visão do autor, pelo contrário, o caminho da conservação dos monumentos no século XX deve, sempre que possível, apontar para o imperativo do culto ao valor de antiguidade (KÜHL, 2013).

Se, para Riegl, o valor de novidade transformado em "absoluto e eterno" dificulta a aproximação ao culto do valor de antiguidade, é através do respeito pelo valor histórico que a população amadurecerá a ponto de compreendê-lo ${ }^{30}$. Nesse sentido, as formulações de seu contemporâneo Max Dvorak, assumem um papel importante (LIMA, 2013).

Conhecido pela sua obra "O catecismo da preservação dos monumentos", publicada em 1916, o historiador da arte da Escola de Viena ${ }^{31}$ Max Dvorak (1874 - 1921) lança as bases para o despertar do sentido da preservação e sua importância, tanto civil como espiritual. No entanto, Dvorak não é o primeiro a explicitar a importância do respeito pelos monumentos por meio de termos religiosos. Riegl já havia formulado que o culto ao valor de antiguidade advém justamente da "humilde submissão à vontade do Todo-Poderoso, que o homem não deve ter o sacrilégio e audácia de enfrentar".

Apesar das afinidades entre Riegl e Dvorak, a visão de arte de ambos se diferencia na medida em que o segundo se afasta da análise puramente formalista, para tratar de questões relativas ao contexto e ao conteúdo da obra. Uma vez que o estilo deixa de imperar como característica que rege a originalidade de dada obra de arte, abre-se espaço para que o próprio conceito

30 Postura bastante semelhante à de Camillo Boito, que enunciava: "Para bem restaurar é necessário amar e entender o monumento". O que sugere uma aproximação da obra em questão por meio de duas vias: a sensorial (amar), explícita pelo valor de antiguidade; e a científica (entender), explícita pelo valor histórico.

${ }^{31}$ Assim como Riegl, Dvorak participa da primeira Escola Histórica de Viena, inserida no contexto da mudança de paradigmas na história da arte a partir de 1885, que leva à ruptura com o cânone clássico, a ideia do indivíduo genial e a distinção entre o que é belo e o que não o é (BAUMGARTEN, 2013). 
de originalidade seja revisto. A originalidade passa a ser entendida como a relação de intimidade entre a obra e o espírito de determinada época (LIMA, 2013).

Redefinidas as bases teóricas da originalidade, 0 autor se coloca terminantemente contrário às restaurações integrais, alinhado com a visão que preconiza o respeito absoluto pelo valor documental da obra. Não se trata, portanto, de conhecer para conservar, mas de conservar para conhecer (KÜHL, 2013).

Nesse mesmo contexto, as questões relativas aos monumentos assumem outra escala na obra do italiano Gustavo Giovannoni (1873-1947), cujas preocupações se alargam ao que abranger o ambiente urbano. Figura central da autonomização do campo da arquitetura em relação ao da engenharia e da consolidação do urbanismo como disciplina arquitetônica na Itália ${ }^{32}$, Giovannoni tece uma série de considerações que mais tarde ficam conhecidas como "restauro urbano" (KÜHL, 2013).

Seu texto A Restauração dos Monumentos na Itália, de 1931, originalmente publicado no volume das atas do Congresso que deu origem à Carta de Atenas ${ }^{33}$, demonstrava uma clara herança do pensamento intermediário de Camillo Boito $^{34}$, acrescida da preocupação com a paisagem, os aspectos naturais e o ambiente urbano (PANE, 2013). Conceitos presentes nesse texto, como a importância da manutenção periódica, a consolidação estrutural a partir de técnicas modernas, a mínima intervenção, a distinguibilidade, o respeito pelas

\footnotetext{
32 Gustavo Giovannoni é uma figura de importância, não só no campo da preservação e da históri30a da arquitetura, como no didático. Foi um dos principais promotores da criação da Escola Superior de Arquitetura em Roma, de 1919, visando a autonomia do campo do ensino arquitetônico em relação à engenharia (KÜHL, 2013).

33 O Congresso foi organizado pelo Escritório Internacional de Museus da Sociedade das Nações, criado pela Comissão de Cooperação Intelectual, que, por sua vez, surge em 1922 para tratar, entre outras coisas, dos problemas relacionados ao patrimônio cultural que havia sido atingido pela Primeira Guerra Mundial (KÜHL, 2013).

34 "Entre os dois conceitos antitéticos acima expostos, abriu caminho uma teoria intermediária, sustentada na Itália por $\mathrm{C}$. Boito e G. Giovannoni. Preconiza dar a máxima importância às obras de manutenção e consolidação, voltadas a salvar o próprio organismo da obra; limita os casos de repristinação àqueles em que seja demonstrada a legitimidade e utilidade, mas, mais do que com a unidade arquitetônica, preocupa-se com a salvaguarda, no monumento, de todas as obras de tempos variados que tenham um caráter artístico (GIOVANNONI, 2013).
} 
várias fases do monumento e a documentação de toda intervenção que recai sobre dado monumento, também aparecem no corpo da Carta (KÜHL, 2013).

A Carta de Atenas, mais uma vez, explicita o abandono das "reconstituições integrais" e a sua substituição pela "manutenção regular e permanente". Dessa forma, sintetiza o que vinha sendo proposto por Boito desde $1833 \mathrm{com}$ as formulações de Giovannoni a respeito das condições de ambientação dos monumentos.

Apesar da importância desses autores italianos na conceituação que serve de base para o documento, a Carta de Atenas estende sua importância para além das fronteiras europeias. É através dela que as formulações do Restauro Filológico adquirem caráter internacional, e passam a operar como instrumental teórico-metodológico durante a primeira metade do século XX. A seguir, detalhar-se-á a recepção e incorporação - ou não - dos postulados da Carta de Atenas e do Restauro Filológico na atuação prática brasileira do mesmo período.

\subsubsection{Contexto nacional: o Sphan e as restaurações em estilo}

Na década de 1950, o primeiro órgão de preservação brasileiro já contava com quase duas décadas de existência, configurando uma prática mais afeita ao contexto teórico oitocentista de Viollet-le-Duc do que aos postulados coetâneos do Restauro Filológico. Sua origem foi marcada pelo contexto político da instauração do Estado Novo e pelo contexto cultural do movimento modernista. Apesar de não se tratar de um grupo homogêneo, a preocupação comum entre os modernistas voltava-se à questão da identidade nacional, suas origens e seu destino (FONSECA, 1997).

O patrimônio, nesse contexto, passa a ser discutido como esse elemento de coesão entre passado e futuro, definidor da identidade brasileira. A corrente modernista que consolida a visão oficial sobre o patrimônio, encabeçada por Rodrigo Franco de Melo Andrade, Carlos Drummond de Andrade e Lucio Costa, que mais tarde conformariam o quadro profissional do IPHAN, fundamenta-se na concepção universalista de cultura (CHUVA, 2003). 
O universalismo defendia que existiria uma única origem comum à toda arte $\mathrm{e}$ cultura brasileiras, fixada na tradição colonia| ${ }^{35}$. Essa concepção eleva o barroco a estilo estruturante da almejada identidade nacional. Se existia uma origem comum da cultura brasileira no barroco, seu destino comum estaria no modernismo. Para o Estado Novo, também interessavam as questões relativas a uma identidade de bases homogeneizantes:

\begin{abstract}
O objetivo era criar uma cultura nacional homogênea, que propiciasse a identificação dos cidadãos com a nação. Pois "o que preponderou no autoritarismo brasileiro, no entanto, não foi a busca de raízes mais populares e vitais do povo (...) e sim a tentativa de fazer do catolicismo tradicional e do culto aos símbolos e líderes da pátria a base mítica do Estado forte que se tratava de construir" (FONSECA, 1997, p. 91).
\end{abstract}

Criado em 1937 pelo Decreto-Lei 25, de autoria de Rodrigo Franco de Melo Andrade, o órgão nacional de preservação instituía o tombamento de bens vinculados a "fatos memoráveis da história do Brasil" e de "excepcional valor artístico" ${ }^{36}$. Essa visão de história e de arte não estava em conformidade com o que se discutia nos campos da teoria de restauro ou da história da arte, cujos preceitos se enunciavam na Carta de Atenas, de poucos anos antes. De acordo com a Carta, deveriam ser salvaguardadas as obras que constituíssem "a expressão de uma cultura anterior", fosse ela uma obra monumental ou não.

Se o tombamento recaia sobre as obras de "excepcional valor", referentes a "fatos memoráveis" da história, cabe perguntar quais fatos são esses, e qual história nacional se pretendia contar. Tendo sido eleito o período colonial como o momento de gênese da identidade brasileira e o estilo barroco como constituinte dessa, as obras tombadas e restauradas pelo IPHAN nesse primeiro momento eram, em sua maioria, exemplares de arquitetura colonial.

Entre a sua criação e o final da década de 1960, período conhecido como a "fase heroica" da instituição, foram reconhecidas e restauradas diversas obras pertencentes a esse recorte temporal-estilístico. Em São Paulo, os exemplares

\footnotetext{
35 Ao contrário da corrente indianista, por exemplo, que considerava a origem plural e a diversidade cultural contida no território nacional (CHUVA, 2003).

${ }^{36} \mathrm{O}$ anteprojeto de lei para criação de um órgão nacional de preservação do patrimônio é de autoria de Mario de Andrade, e apresenta uma visão de arte e cultura mais alargada do que aquela contida no Decreto-Lei 25 . Sobre as semelhanças e diferenças entre ambas as propostas, ver FONSECA, 1997.
} 
desse período tomavam forma de moradias unifamiliares rurais, que mais tarde ficam conhecidas como "casas bandeiristas" (CUNHA, 2010).

O arquiteto Luis Saia, superintendente do quarto distrito do Iphan, foi quem cunhou esse termo, durante o processo de restauração da Casa do Butantã para fins comemorativos do IV Centenário de São Paulo ${ }^{37}$. Nesse período, a figura do bandeirante fora eleita como símbolo paulista ${ }^{38}$ :

Os bandeirantes eram os próprios industriais paulistas que em tempos adversos, protagonizaram naquele momento as novas bandeiras da expansão industrial capitalista. A combatível e espoliada classe operária necessitava, tal qual os índios dos anos iniciais da colonização, cumprir também a sua conversão ao novo ritmo acelerado do trabalho (QUARENTA, 2009, p.50).

Essa tipologia de moradia rural já havia sido identificada e registrada por Mário de Andrade em 1937, que as descreve como sendo de interesse puramente histórico e não artístico, uma vez que vários exemplares se encontram "completamente deformados". A identificação de constantes tipológicas desse tipo de construção ${ }^{39}$, identificadas por Mário, encorajam Saia em sua tese sobre o "apogeu" e a "decadência" desse tipo de forma arquitetônica (MAYUMI, 2017).

Dentro dessa chave evolutiva, Saia entendia que existiam exemplares "puros" e "tardios" do que ele mesmo batizara como "casas bandeiristas". A Casa do Butantã, restaurada em 1954, foi considerada como um exemplar desse segundo grupo.

\footnotetext{
${ }^{37}$ A primeira vez que o termo "casa bandeirista" aparece é em um texto de autoria de Luis Saia, publicado pela Comissão da Comemoração do IV Centenário em1955, sobre a Casa do Butantã, intitulado "A casa bandeirista: uma interpretação (MAYUMI, 2017).

38 Para além da questão das "casas bandeiristas", a figura do bandeirante é recuperada também, naquele momento, pela construção dos monumentos que compõem o conjunto do lbirapuera, como é o caso do Monumento às Bandeiras e do Monumento ao Soldado Constitucionalista de 1932 (MARINS, 2003); e pela Exposição de História de São Paulo no Quadro da História do Brasil, organizada pelo historiador português Jaime Cortesão em um dos pavilhões do Ibirapuera, para a comemoração do IV Centenário (RIBEIRO, 2018).

${ }^{39}$ Entre as constantes tipológicas das "casas bandeiristas" estão: a planta retangular organizada em três faixas (social, familiar e serviço), paredes de taipa de pilão, telhado de quatro águas com telhas de canal, implantação próxima a riacho e presença de alpendre (MAYUMI, 2017).
} 
A intervenção inaugura o ciclo de restaurações de casas de mesma tipologia e de propriedade da Prefeitura de São Paulo ${ }^{40}$, lançando-se as bases para sua abordagem teórico-metodológica. A Casa havia sido doada à Prefeitura pela Companhia City em 1950, e estava ocupada por famílias de baixa renda, que permaneceram ali até o início das obras (MAYUMI, 2006).

O estado de conservação da construção era precário (Figura 50): 0 madeiramento central havia sido removido (Figura 51), as paredes periféricas apresentavam erosões devido à água de chuvas, paredes primitivas haviam desaparecido e novas paredes haviam sido erguidas, a cobertura havia sido alterada e o revestimento, ausente ou desagregado (Figura 52).

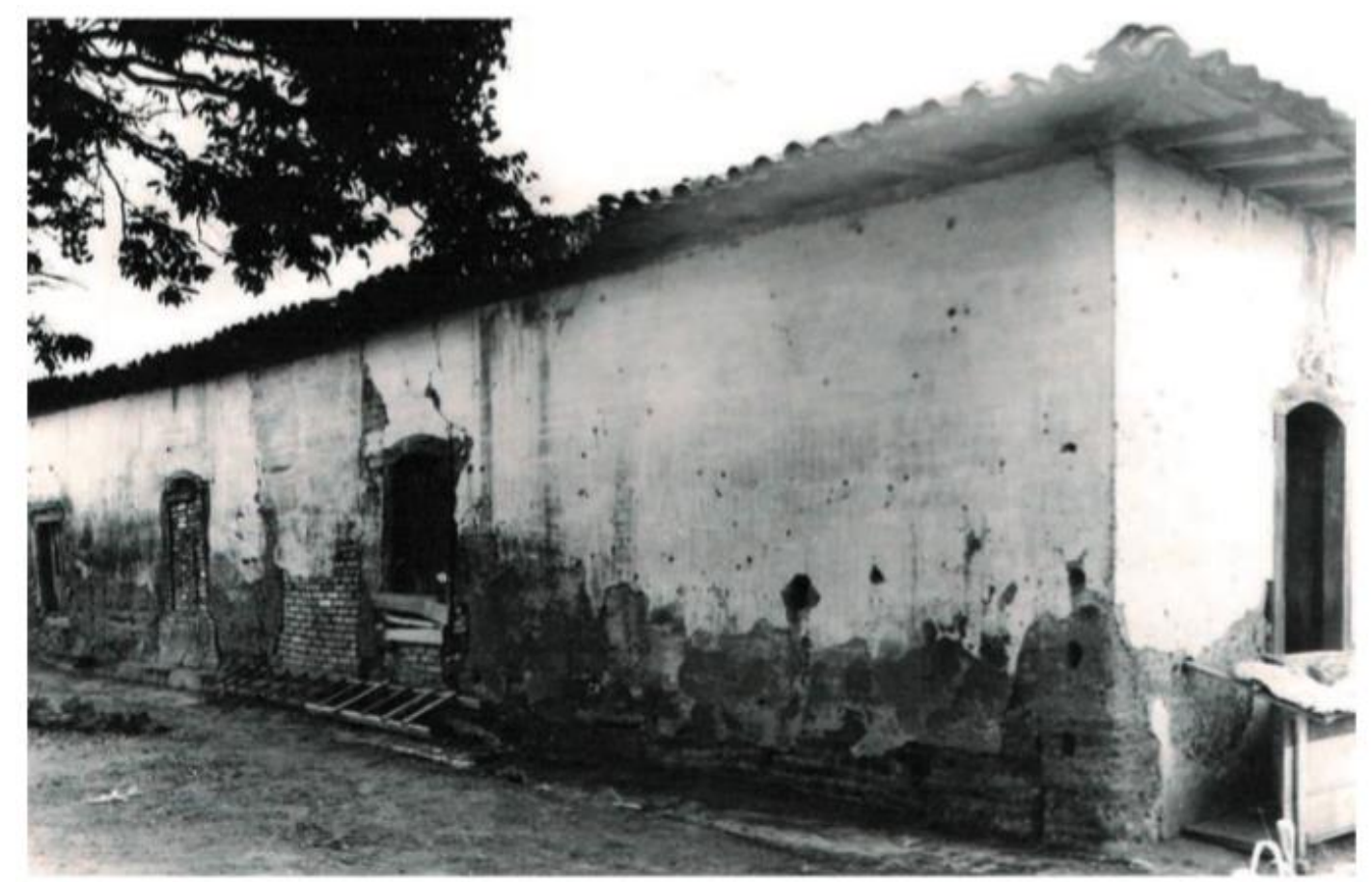

Figura 50: Aspecto externo da Casa do Butantã em 1954, antes do início da obra de restauro. A falta de manutenção se faz visível pelo mau estado de conservação do embasamento da construção, e o fechamento irregular de aberturas com alvenaria. Fonte: MAYUMI, 2006.

40 No total, existem cinco obras dessa tipologia pertencentes à Prefeitura de São Paulo: a Casa do Butantã, a Casa do Caxingui, o Sítio da Ressaca, a Casa do Tatuapé e o Sítio Morrinhos (MAYUMI, 2006). 


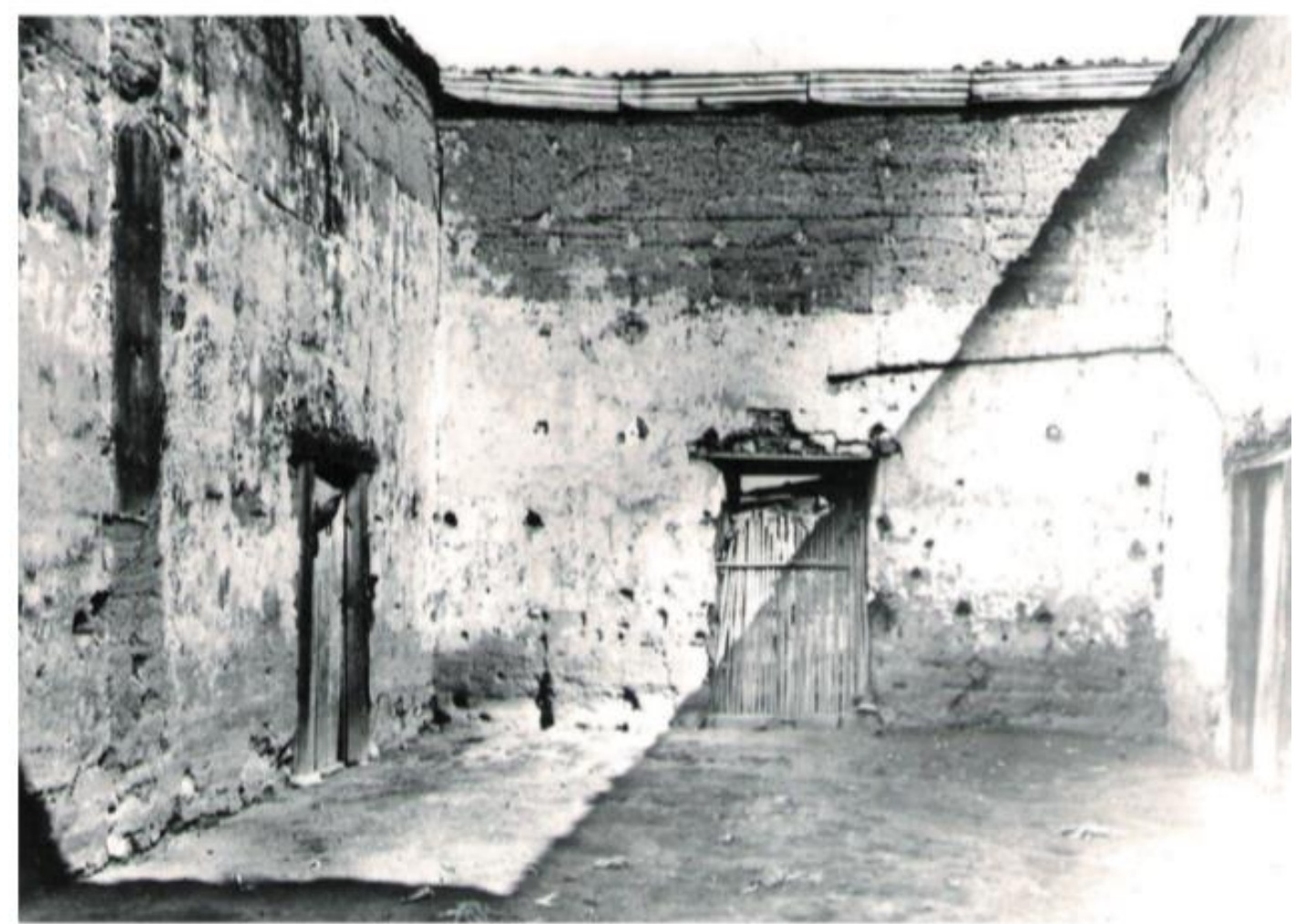

Figura 51: Aspecto interno da Casa do Butantã em 1954, antes do início da obra de restauro. Nota-se a ausência de cobertura no cômodo central da edificação. Fonte: MAYUMI, 2006.

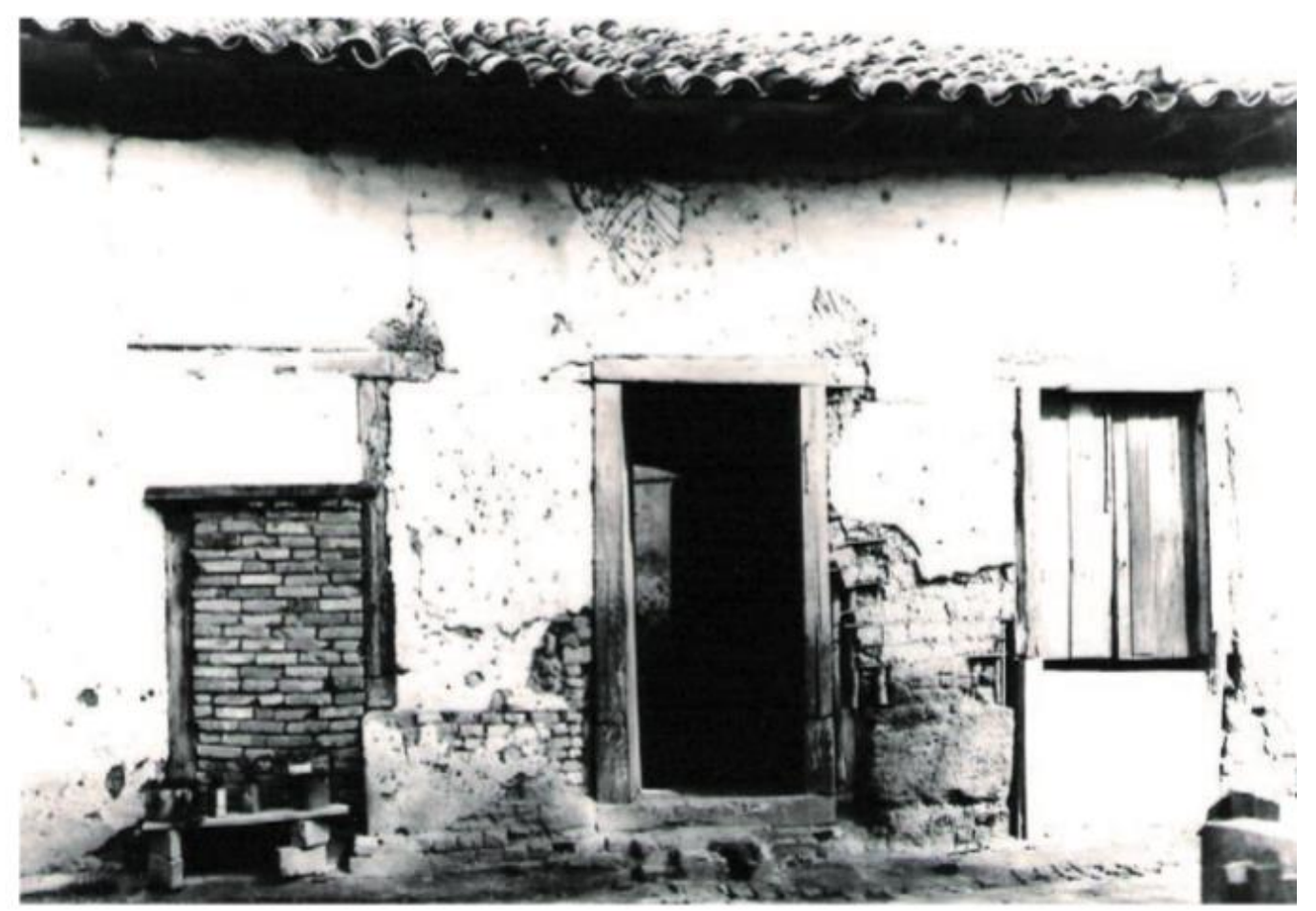

Figura 52: Detalhe de aspecto externo da Casa do Butantã em 1954, antes do início da obra de restauro. Mais uma vez, a falta de manutenção periódica se vê pelo estado precário de conservação do edifício.

Fonte: MAYUMI, 2006. 
O trabalho de restauração se dividiu em duas etapas. Em primeiro lugar, a estrutura seria consolidada e o edifício seria investigado em busca de vestígios. Depois da análise exploratória ${ }^{41}$, começaria efetivamente a restauração da casa.

$\mathrm{Na}$ primeira etapa, foram eliminados todos os acréscimos intermediários e descobertos vestígios para a recomposição das estruturas primitivas. Foi adotada uma única medida de consolidação estrutural, uma vez que os estudos no local comprovaram a ausência de problemas estruturais mais sérios, que consistiu na introdução de uma cinta de concreto sobre o respaldo das paredes concêntricas (Figuras 53 e 54).
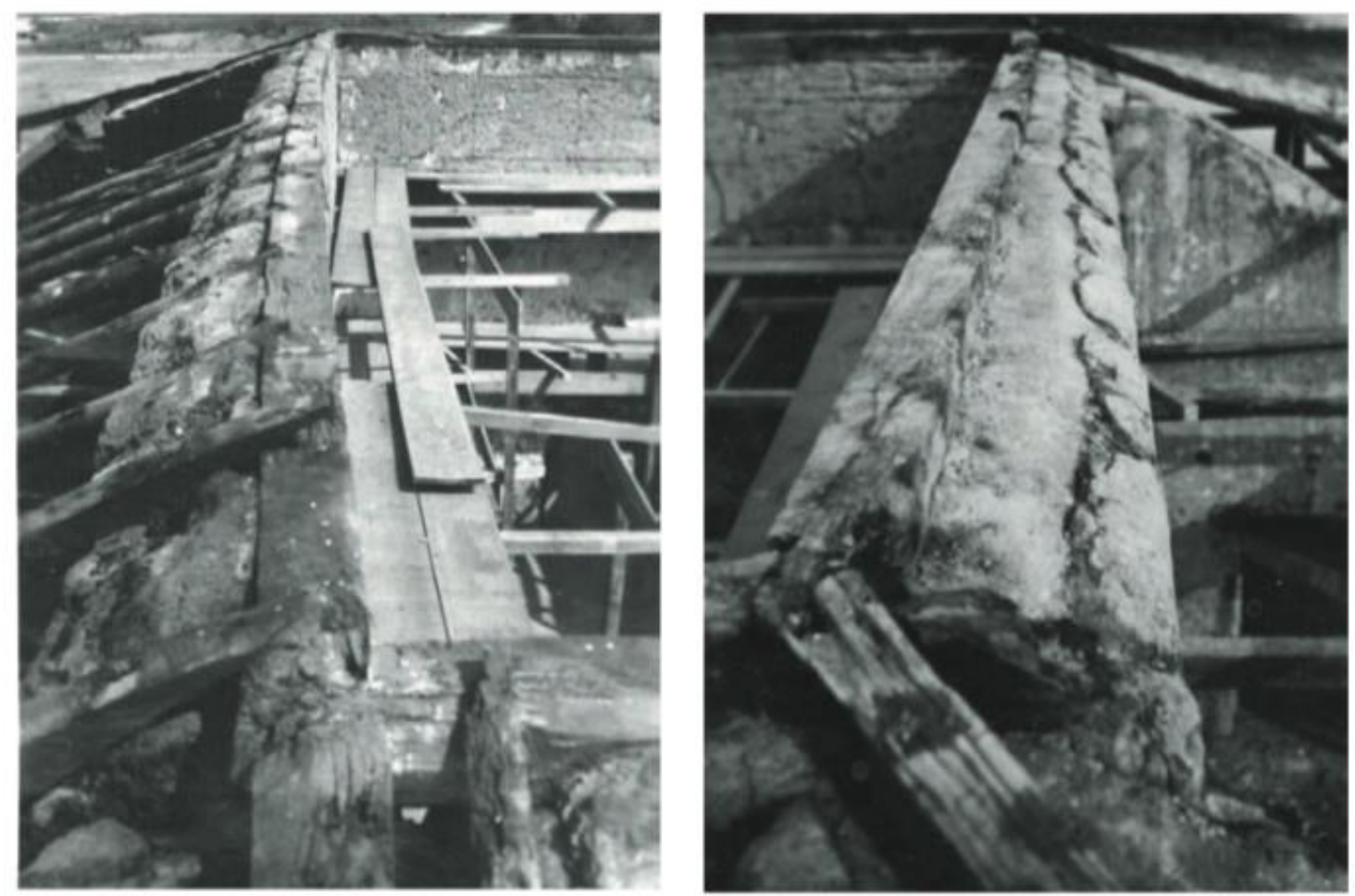

Figura 53 (à esq.) e 54 (à dir.): Respaldo das paredes concêntricas antes da execução da cinta de concreto (à esq.) e depois (à dir.) Fonte: MAYUMI, 2006.

Para solucionar o problema da erosão, foi construída uma base de concreto para as paredes externas (Figura 55) e as pequenas lacunas de superfície foram preenchidas com argamassa cimentícia (Figura 56). Finalmente, as paredes foram revestidas com argamassa e pintura à base de cal (Figura 57).

\footnotetext{
${ }^{41}$ Sobre o caráter dessa investigação, destaca-se: "Essa investigação, embora tivesse caráter arqueológico, pretendia exclusivamente encontrar os vestígios mais primitivos, ignorando e descartando vestígios de épocas intermediárias entre o imaginado "primitivo" e o presente visível" (MAYUMI, 2017).
} 


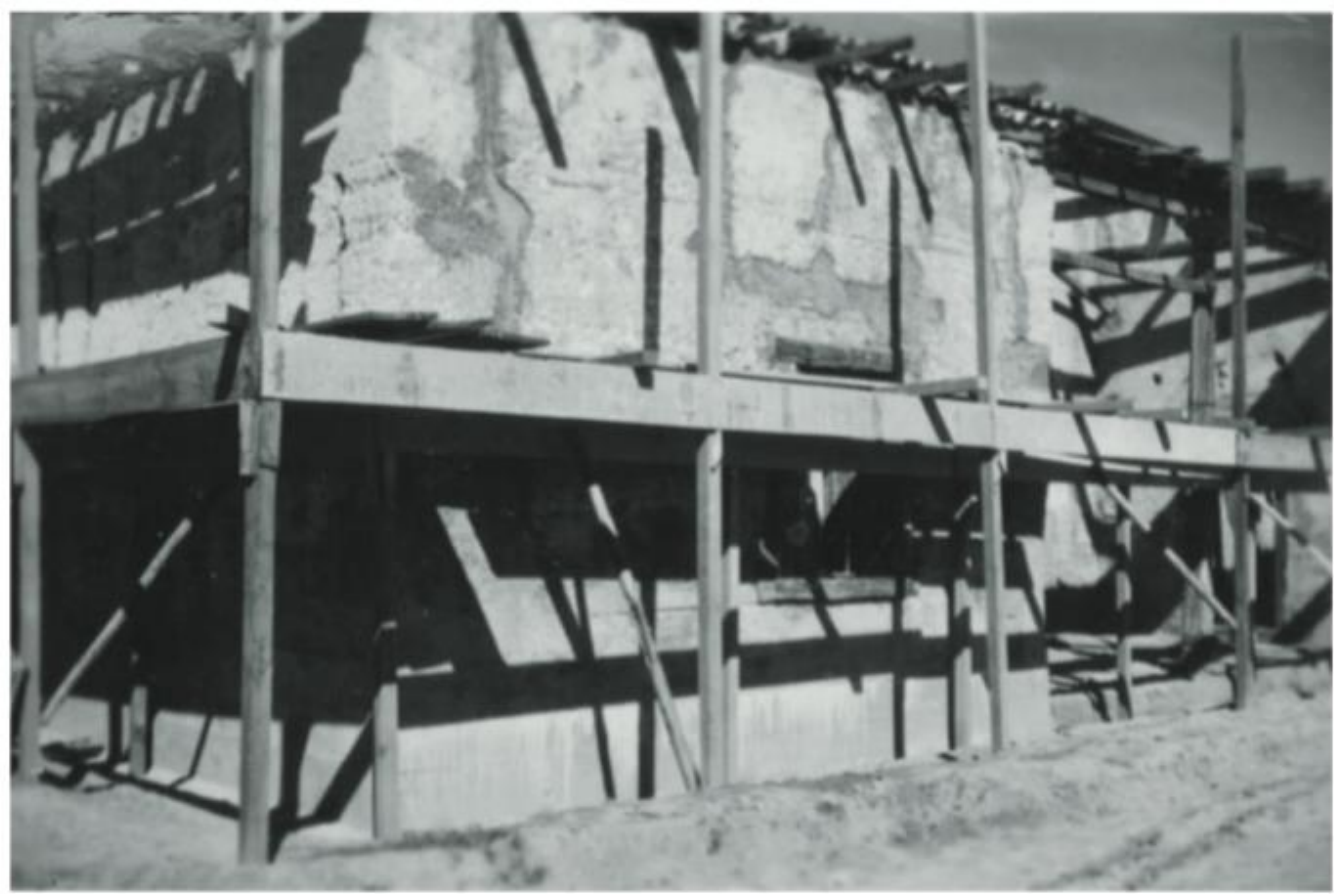

Figura 55: Construção da base de concreto como solução para o problema de erosão por água da chuva.

Fonte: MAYUMI, 2006.

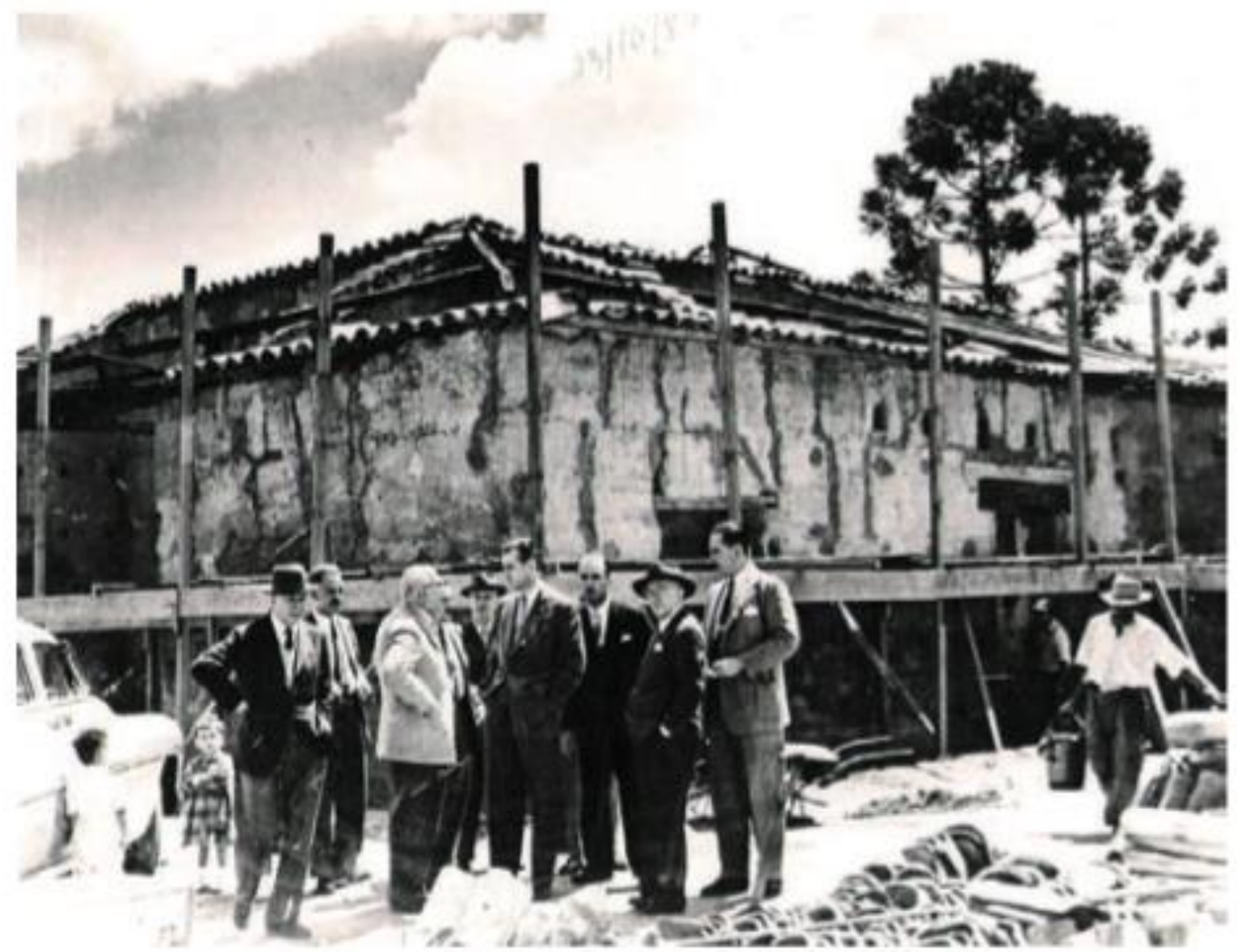

Figura 56: Preenchimento de lacunas nas fachadas por argamassa cimentícia. Fonte: MAYUMI, 2006. 
Vig, 53. Fachaba Love (brincipol) antes de restas. rachlo.

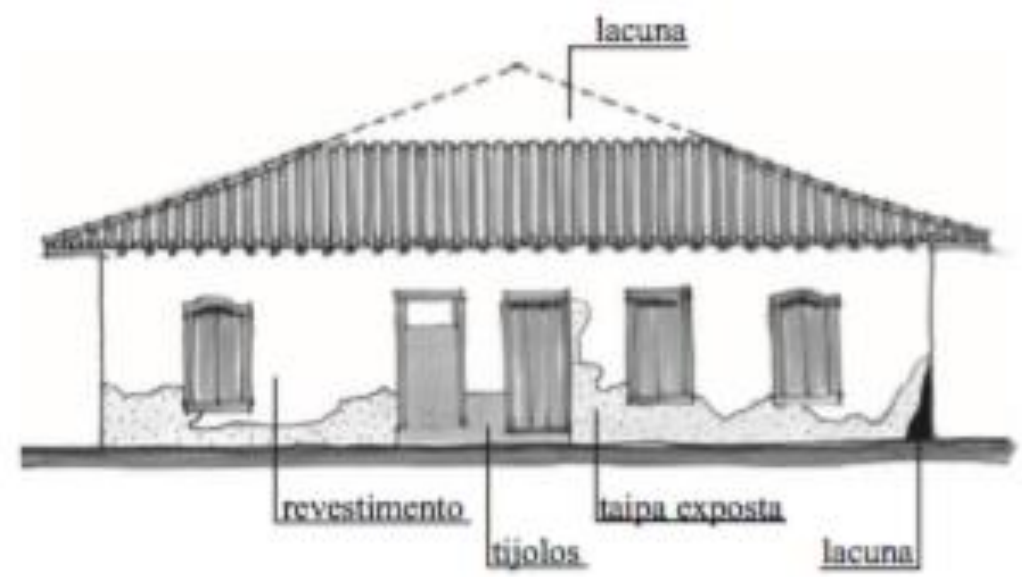

Pig. S4. Pachada Leste dapois da restimiceclov, sem argamass de tevestimitute.

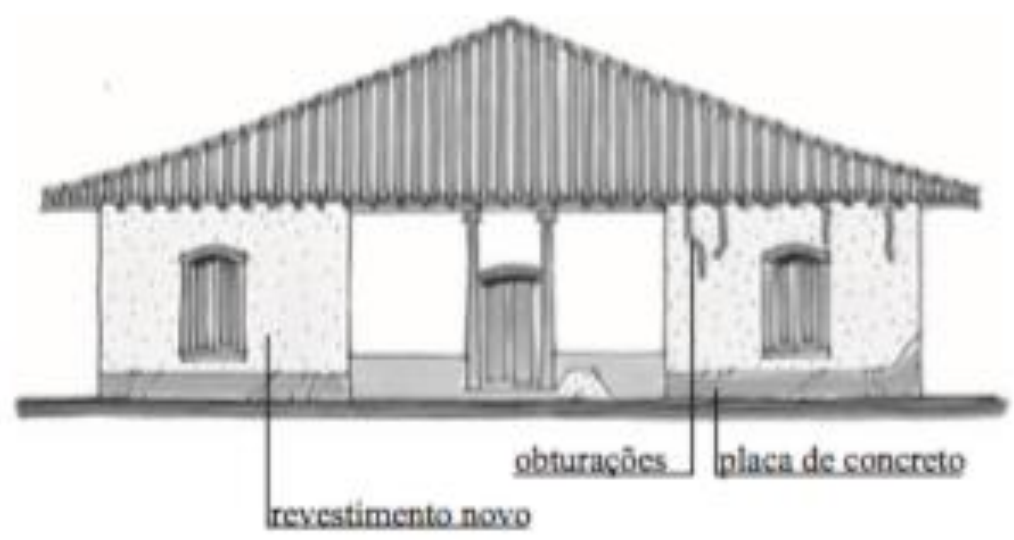

Fig. 55. Fachada Leste de pois da restauracto, revestida e caiada.

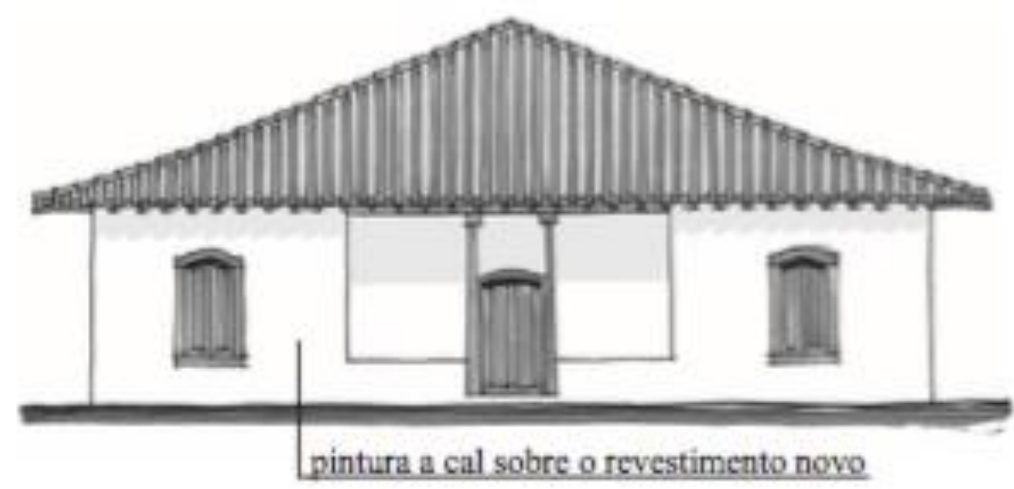

Figura 57: Esquema do processo de restauro, que culmina no revestimento das fachadas por argamassa e pintura à base de cal.

Fonte: MAYUMI, 2006.

Apesar do emprego de materiais e técnicas modernas, como é o caso do concreto, estar de acordo com as considerações da Carta de Atenas e do Restauro Filológico, a busca por um estado idealizado e original da obra 
aproxima a restauração de Luis Saia das concepções do Restauro Estilístico de Viollet-le-Duc (MAYUMI, 2017) ${ }^{42}$. Esse procedimento, que visa o resgate da configuração primitiva da obra a ser restaurada, acaba tornando-se um padrão na atuação do Iphan em sua fase heroica:

\begin{abstract}
Ao longo da chamada "fase heróica" do SPHAN, juntamente com a proeminência dos arquitetos dentre os técnicos da instituição, prevaleceram soluções oriundas do campo da arquitetura, seja no que se refere aos critérios de seleção de bens a serem tombados, seja no partido e método adotados nas obras de restauração e conservação. Não se pensava nos problemas a serem enfrentados como afeitos ao campo da restauração, mas como questão de arquitetura. $O$ comprometimento com os preceitos da Carta de Atenas de Restauração (1931), à qual Rodrigo Melo Franco fazia alusão, cedia lugar aos conceitos emanados da Carta de Atenas do CIAM (1933), buscando equacionar a preservação do passado com a construção do futuro (CUNHA, 2010, p. 156).
\end{abstract}

A seguir, será tratada a intervenção de mesmo período ocorrida no Theatro Municipal de São Paulo. Para que seja possível cotejá-la com os contextos nacional e internacional, tomar-se-ão como parâmetros situacionais o Restauro Filológico, a Carta de Atenas e o caso do restauro da Casa do Butantã.

\title{
2.2 A intervenção (1952-1955): IV Centenário da Cidade de São Paulo
}

Se, no início do século XX, a construção do Theatro Municipal havia respondido à demanda de cosmopolitização das elites paulistas ${ }^{43}$; em meados do mesmo século, a intervenção sofrida pelo edifício marca um segundo olhar modernizador sobre o mesmo. Com a aproximação dos festejos do IV Centenário da cidade, vários equipamentos culturais paulistanos passam por reformas e melhoramentos, como é o caso da Casa Bandeirista do Butantã (MAYUMI, 2006; SODRÉ, 2003), do Pátio do Colégio (KUHN, 2016; CANADO JUNIOR, 2014), do Jockey Clube de São Paulo e do próprio Theatro Municipal. Outros equipamentos estão sendo construídos ou finalizados naquele momento, como é o caso do Parque do Ibirapuera e seus monumentos adjacentes (MARINS, 2003) e da Catedral Metropolitana da Sé (FARIAS, 2004).

\footnotetext{
42 Ver ANDRADE, Antonio Luiz Dias de. Um Estado completo que pode jamais ter existido. São Paulo, FAU-USP, Tese de Doutorado, 1993.

${ }^{43}$ Ver Capítulo 1 - Prelúdio da Modernidade, sobre a concepção do projeto original do TMSP.
} 
A intervenção no edifício do Theatro, no entanto, destoa tanto desse momento áureo da construção de uma cidade modernizada como das demais intervenções realizadas no contexto, que recaíram sobre bens de origem colonial. Por se tratar de um edifício eclético, altamente rejeitado pelo cânone moderno, o estudo dessa intervenção torna-se ainda mais interessante para compreender, na prática, o olhar modernista sobre aquele objeto que era ao mesmo tempo negado e valorizado.

O prefeito Armando Arruda Pereira criou, em 1952, a Comissão de Reforma do Teatro Municipal (CRTM), presidida pelo engenheiro Alberto Zagottis. Compunham a comissão os engenheiros Horácio Marassá, Milton Costa e Gunther Sarfet, além do arquiteto Tito Pistoresi, a quem se atribui a autoria do projeto. A reforma foi administrada pelo escritório "Severo \& Villares Cia Ltda"44 e teve como principal objetivo a melhora do desempenho acústico e visual da sala de espetáculos ${ }^{45}$ :

Tudo estava precisando ser mudado: o madeiramento deteriorado sob o efeito do tempo; o material elétrico estava apodrecido, arcaico e deficiente; o palco pequeno, de recursos técnicos insuficientes, não atendia mais aos reclamos da evolução artística.

Tornava-se necessário, por outro lado, que fossem corrigidos os "pontos-cegos" e os "pontos-surdos" do teatro, etc.

Tornava-se preciso dar novos efeitos arquitetônicos e decorativos; um caráter diverso e mais empolgante no relevo de todo ambiente, até aos mais delicados detalhes.

(Revista Engenharia Municipal (6): p. 26, 1957)

A obra foi dividida em três etapas, realizadas em sequência. A primeira etapa correspondia ao palco e suas dependências; a segunda, à parte reservada ao público e, em especial, à sala de espetáculos; a terceira, à parte administrativa do edifício. Cada uma dessas etapas foi descrita e comentada pelo arquiteto Tito

\footnotetext{
${ }^{44} \mathrm{O}$ engenheiro português Ricardo Severo foi convidado a integrar o escritório técnico de Ramos de Azevedo como sócio em 1908. Com a morte de Ramos, em 1928, Severo assume a direção do escritório, ao lado de seu sobrinho Arnaldo Dumont Villares, que passa a chamar-se "Escritório Técnico de F.P. Ramos de Azevedo \& Villares e Cia Ltda". Dez anos mais tarde, o escritório passa por uma segunda mudança de nome, e fica conhecido como "Severo \& Villares Cia Ltda" (SILVA, 2005).

45 Desde a década de 1930, circulam propostas de melhoramento acústico e visual da sala de espetáculos do Theatro Municipal, porém não há evidências ou documentação que comprovem sua realização (KATCHVANTANIAN, 2014).
} 
Pistoresi, em artigos publicados na revista Acrópole entre setembro de 1953 e janeiro de 1956.

$\mathrm{Na}$ ausência de um Memorial Descritivo do Projeto, que não pôde ser localizado pela autora, essas transformações foram analisadas a partir dos documentos iconográficos levantados no Acervo do Arquivo Municipal de São Paulo e dos artigos publicados à época na revista Acrópole. Os ambientes sobre os quais se pôde aferir mais informações correspondem aos Camarins, Palco, Cúpula, Saguão, Bilheteria e Sala de Espetáculos e Restaurante, que serão tratados a seguir.

\subsubsection{Camarins}

Os camarins, que ocupavam originalmente quatro andares, passaram a ocupar seis. Para que fosse possível realizar o acréscimo de dois pavimentos, foram demolidas as lajes intermediárias e diminuídos os pés-direitos. Também foram instalados dois elevadores de serviço que efetuavam a transposição entre 0 primeiro pavimento (Figura 58), correspondente à portaria, aos pavimentos seguintes, que abrigavam os camarins individuais (segundo e terceiro pavimentos - Figuras 59 e 60), os camarins coletivos (quarto e quinto pavimentos - Figuras 61 e 62) e os depósitos e salas específicas (sexto e sétimo pavimento - Figuras 63 e 64).

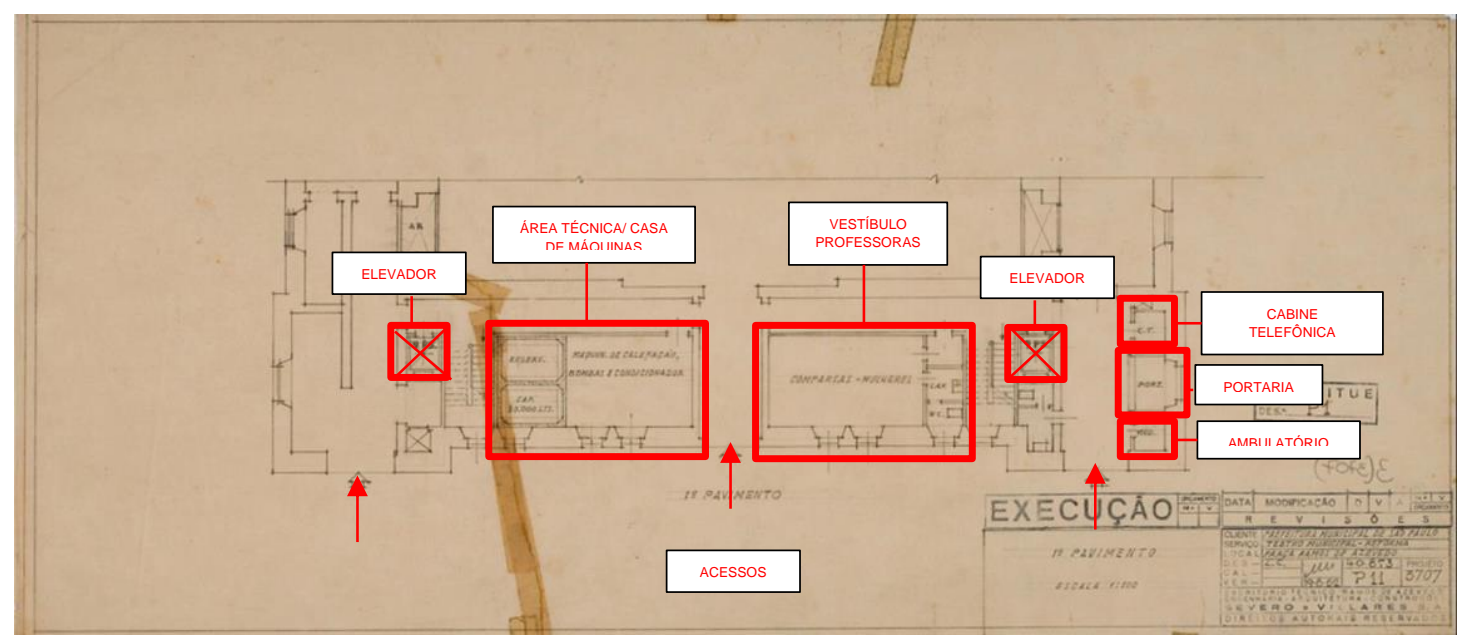

Figura 58: Planta do primeiro pavimento da área de camarins, correspondente à portaria, cabines telefônicas, ambulatório, relógio de ponto, rouparia de serviço e vestíbulo para professores da orquestra.

Fonte: Arquivo Histórico Municipal de São Paulo (AHM-SP). 


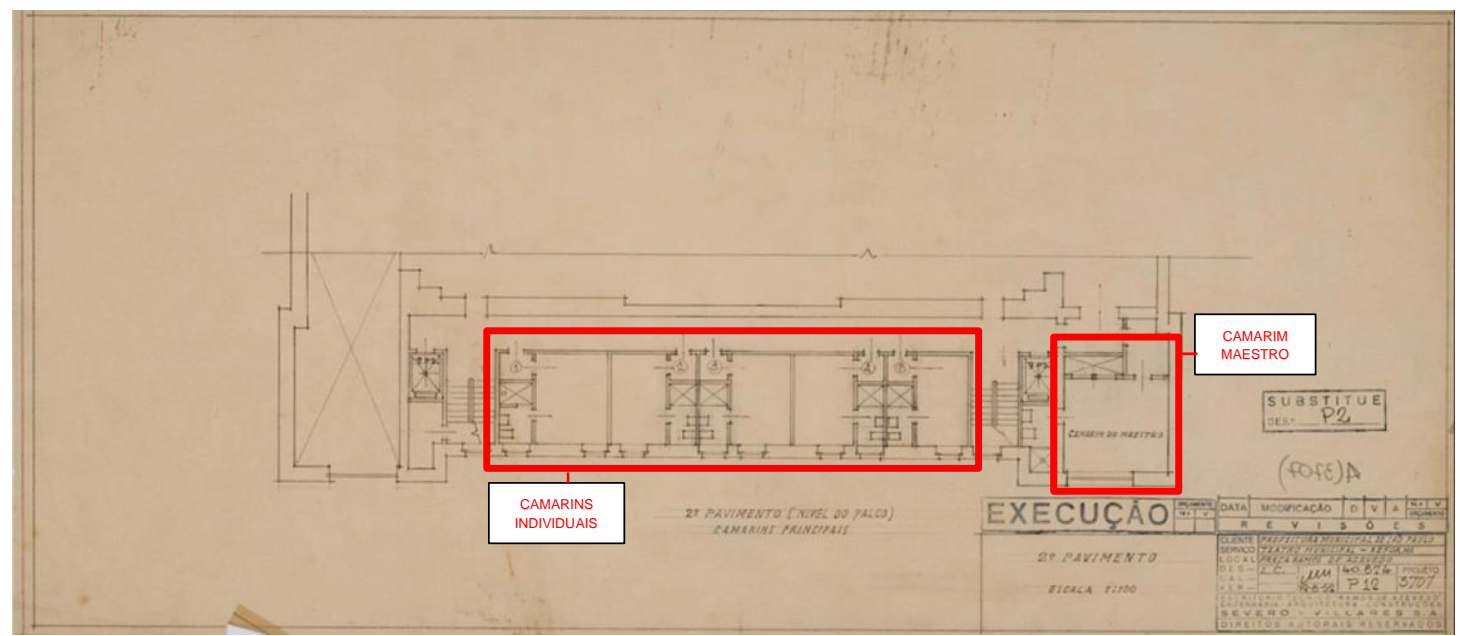

Figura 59: Planta do segundo pavimento da área de camarins, que abrigava seis camarins individuais, incluído o do Maestro, com instalações sanitárias próprias.

Fonte: Arquivo Histórico Municipal de São Paulo (AHM-SP).

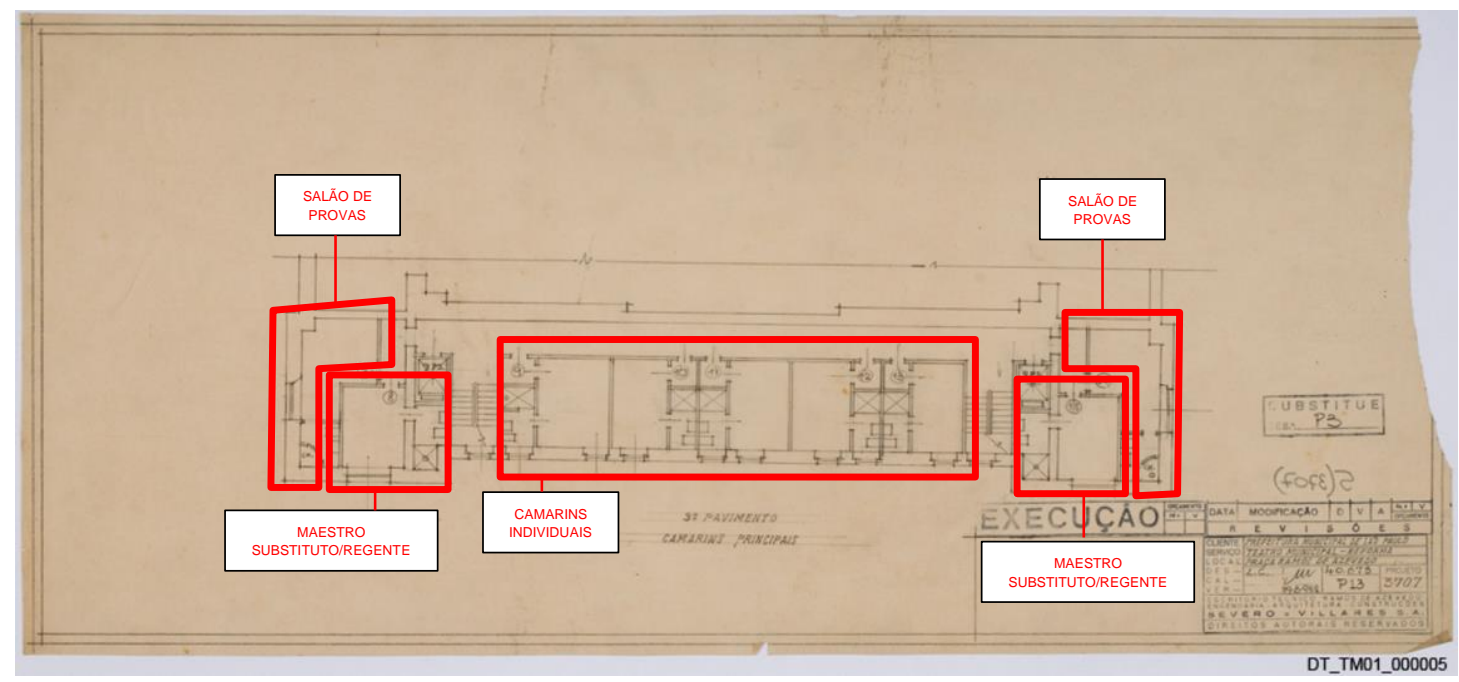

Figura 60: Planta do terceiro pavimento da área de camarins, que abrigava sete camarins individuais, incluídos o do Maestro substituto e do Maestro regente, com instalações sanitárias próprias; além de dois salões de provas.

Fonte: Arquivo Histórico Municipal de São Paulo (AHM-SP).

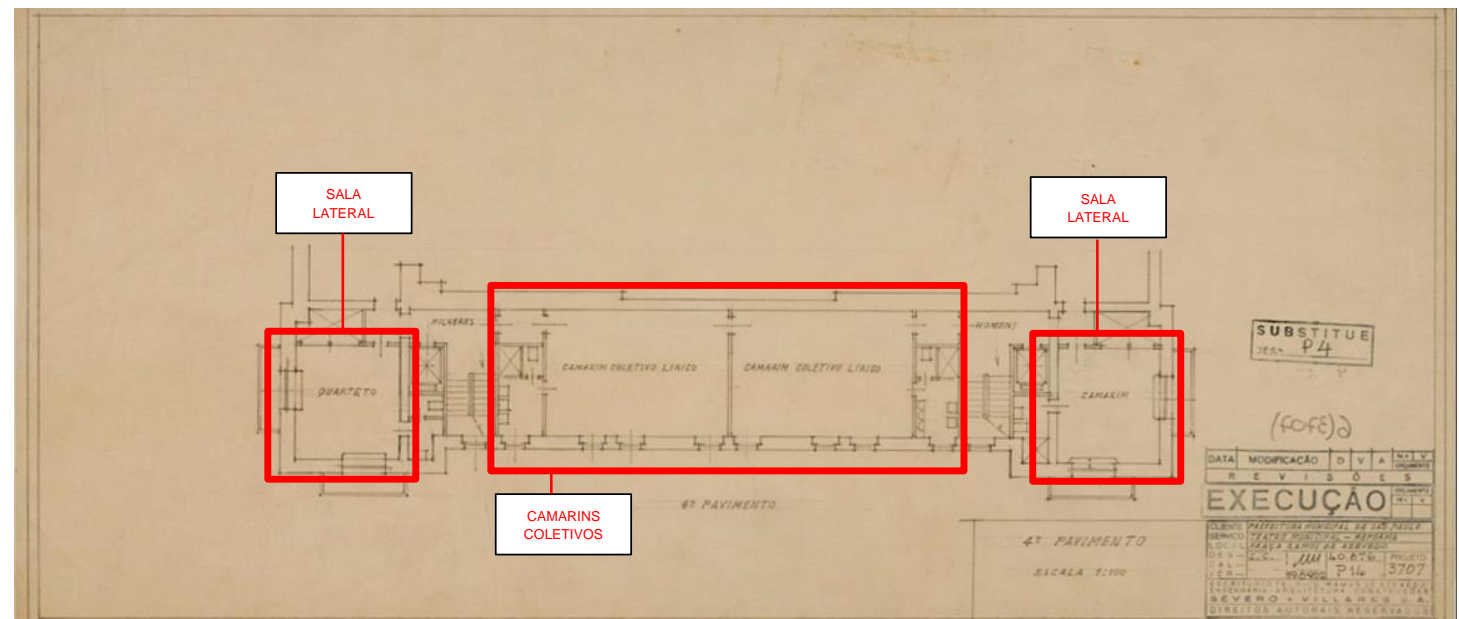

Figura 61: Planta do quarto pavimento da área de camarins, que abrigava dois camarins coletivos, com instalações sanitárias próprias; além de duas salas laterais para os corpos estáveis.

Fonte: Arquivo Histórico Municipal de São Paulo (AHM-SP). 


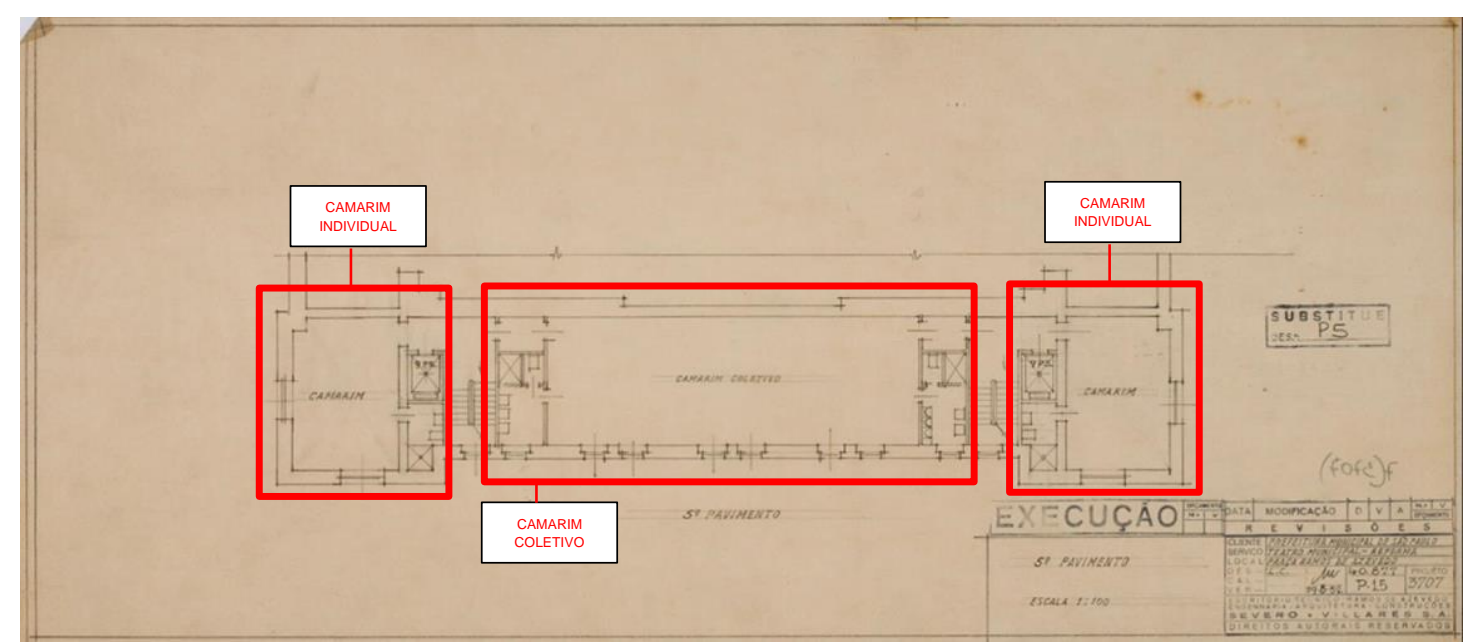

Figura 62: Planta do quinto pavimento da área de camarins, que abrigava um camarim coletivo, que serviria como depósito de móveis e cenários, com instalações sanitárias próprias; além de dois camarins individuais nas laterais, que serviriam como salas para joalheria e "perrucchiére". Fonte: Arquivo Histórico Municipal de São Paulo (AHM-SP).

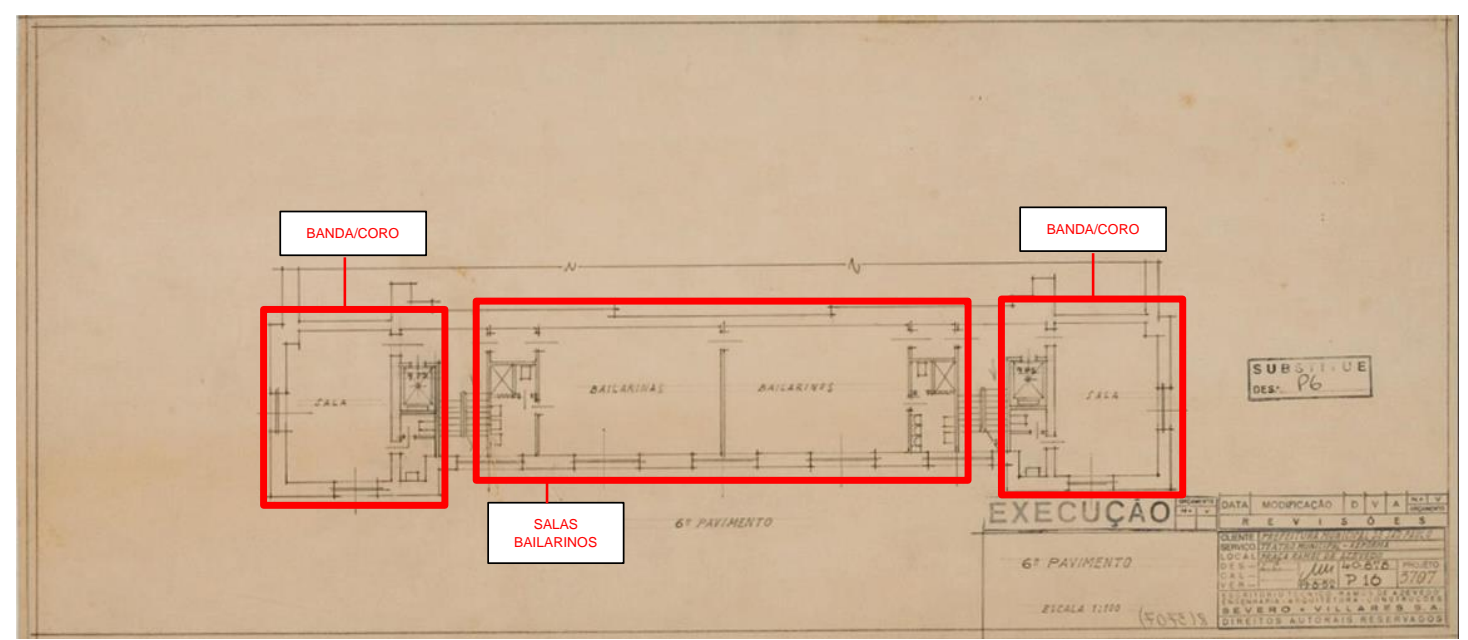

Figura 63: Planta do sexto pavimento da área de camarins, que abrigava duas salas para bailarinos, com instalações sanitárias próprias; além de duas salas laterais para banda e coro. Fonte: Arquivo Histórico Municipal de São Paulo (AHM-SP). 


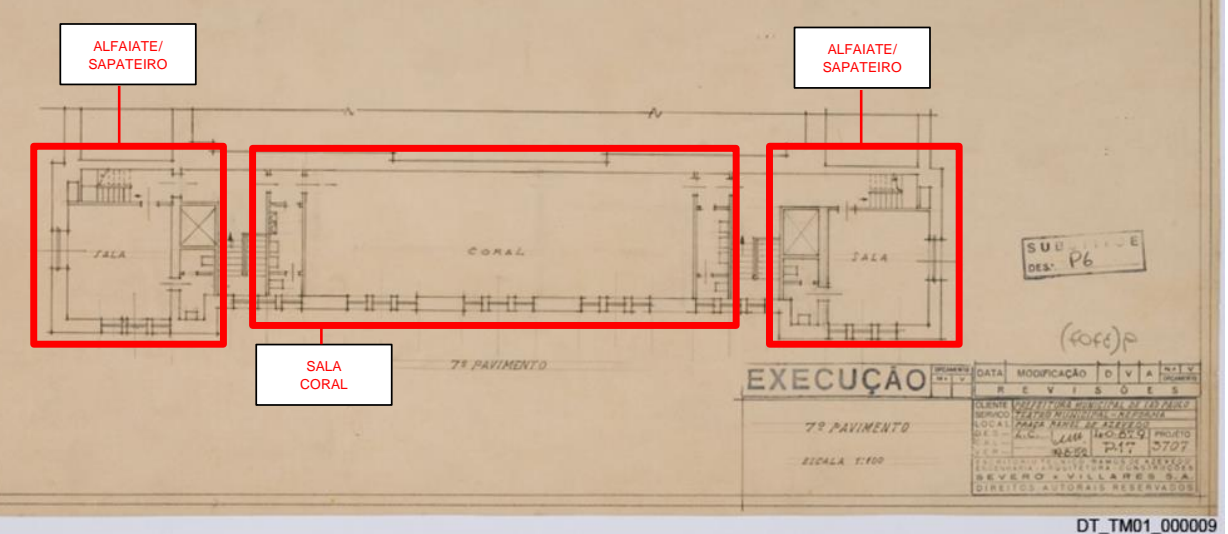

Figura 64: Planta do sétimo pavimento da área de camarins, que abrigava uma grande sala para o coral, com instalações sanitárias próprias; além de duas salas laterais para sapateiro e alfaiate.

Fonte: Arquivo Histórico Municipal de São Paulo (AHM-SP).

Estruturalmente, essa ampliação implicou na construção de novos pilares e um sistema de sapatas isoladas em concreto armado, que substituiria aquele que originalmente funcionava por meio do trabalho combinado entre paredes e lajes (KATCHVARTANIAN, 2014). Para além da alteração invasiva no sistema construtivo, a preocupação central do arquiteto era não comprometer o equilíbrio e a harmonia do conjunto, de forma que a intervenção interferisse o mínimo possível na fachada, no sentido de "disfarçá-la":

(...) qualquer excesso de andares ou pavimentos além desses, viria inapelavelmente desequilibrar a harmonia de conjunto, quer interna como externamente, dando em qualquer época e qualquer ângulo de visão, mesmo ao observador leigo, a certeza de ter havido "reforma" do edifício (PISTORESI, 1953, p. 229).

Apesar da manifesta preocupação do arquiteto, a intervenção fez-se sentir nas fachadas laterais e posterior, pela obstrução de janelas por lajes, vigas e patamares de escadas (Figura 65). De fato, essa não foi a única modificação que alterou o aspecto da fachada posterior, que também sofreu o aumento da quantidade de portas externas de serviço no primeiro pavimento, que passou de uma para três (Figura 66). As portas laterais davam acesso à área de camarins e à porta central, à área relativa ao palco cênico. 


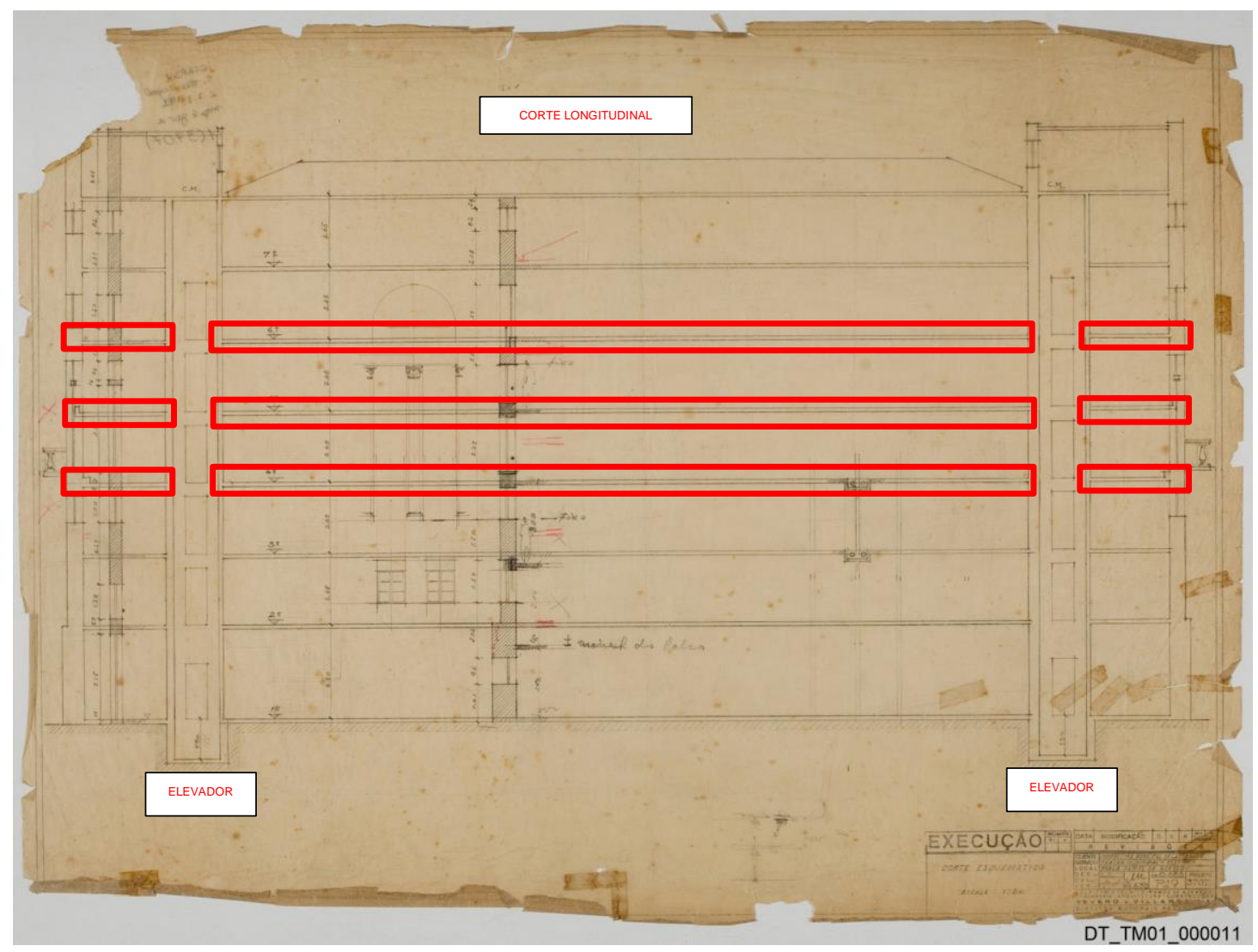

Figura 65: Corte longitudinal do novo corpo de camarins. Destaque em vermelho para as novas lajes que seccionam as janelas da fachada posterior.

Fonte: Arquivo Histórico Municipal de São Paulo (AHM - SP) 


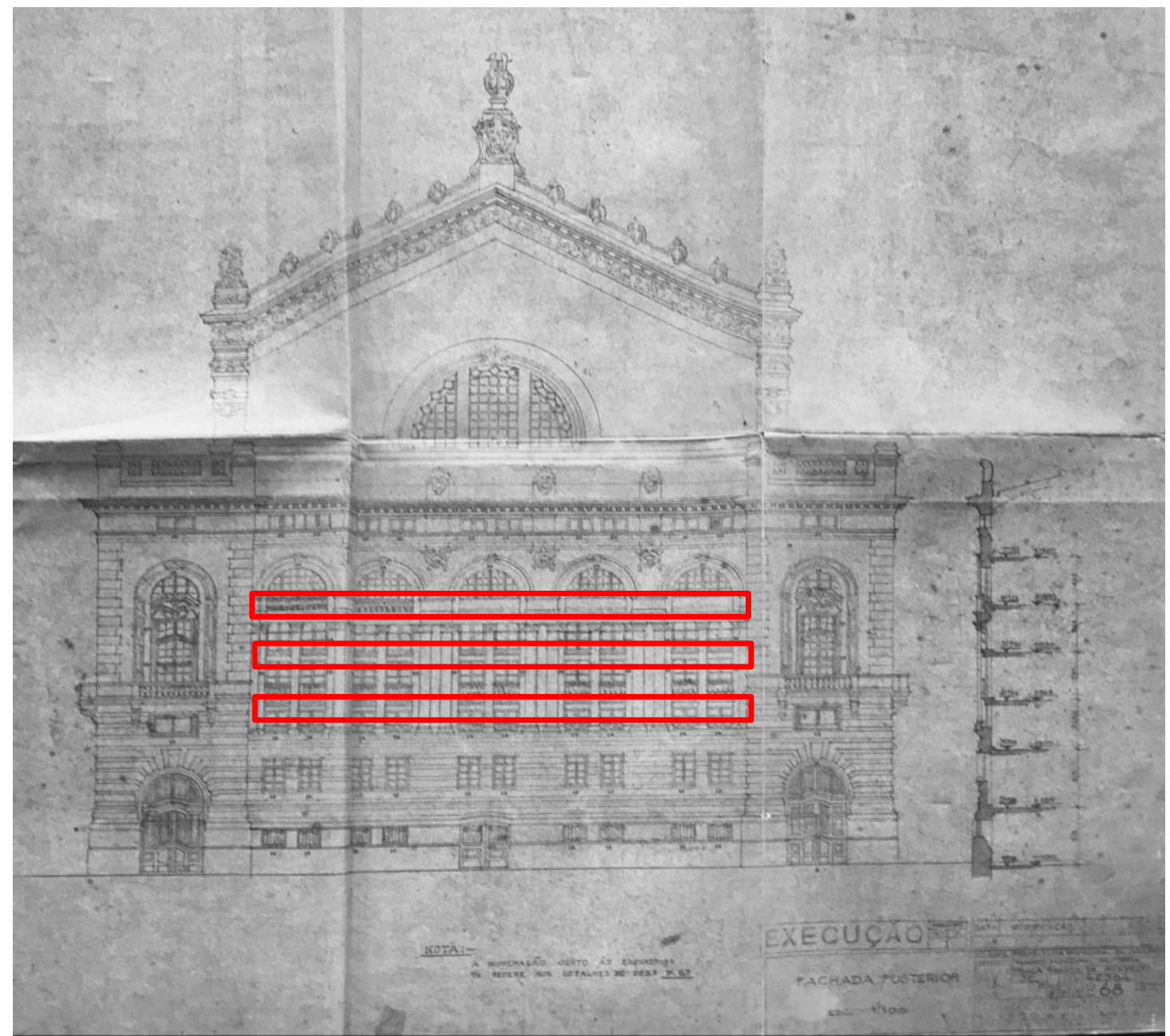

Figura 66: Elevação posterior do TMSP. Destaque em vermelho para as novas lajes, que seccionam as aberturas originais horizontalmente.

Fonte: Acervo da Fundação Theatro Municipal de São Paulo.

\subsubsection{Palco}

A reforma do palco, por sua vez, se deu primeiramente pelo aumento da boca de cena, através da retirada dos camarotes de proscênio (Figuras 67, 68, 69 e 70). Essa passou de 15, 8 metros de largura para 18,5 metros, garantindo melhor visibilidade e deixando espaço para instalação posterior do órgão, que realizouse em 1969 pela empresa italiana G. Tamburini. 

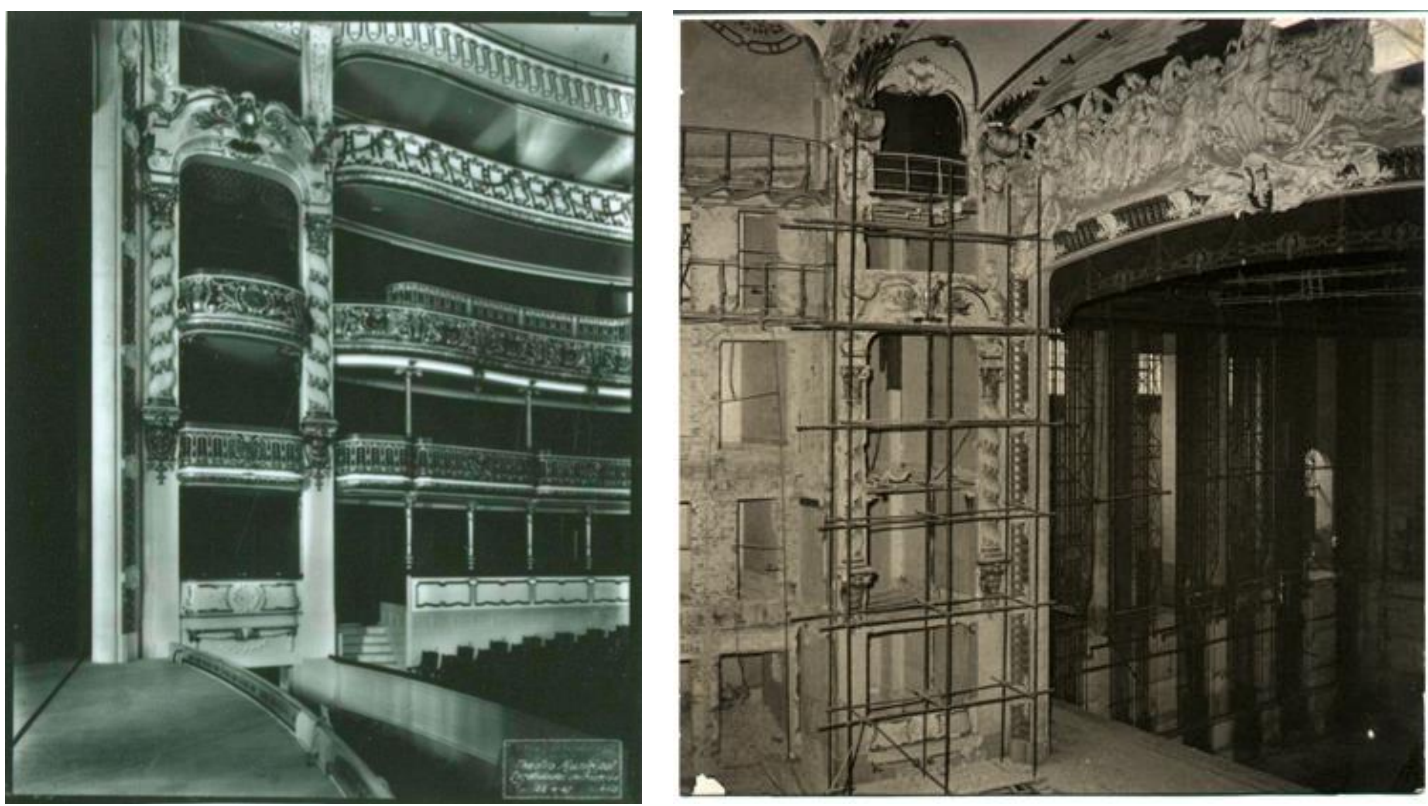

Figura 67 e 68: Respectivamente, fotografia sem data dos camarotes do proscênio, antes de sua retirada (esq.) e durante a demolição (dir.).

Fonte: Acervo da bibliiteca da FAUUSP, In. COSTA, 2017 (esq.) e Acervo de Fotografias do Arquivo Histórico Municipal de São Paulo (dir.).

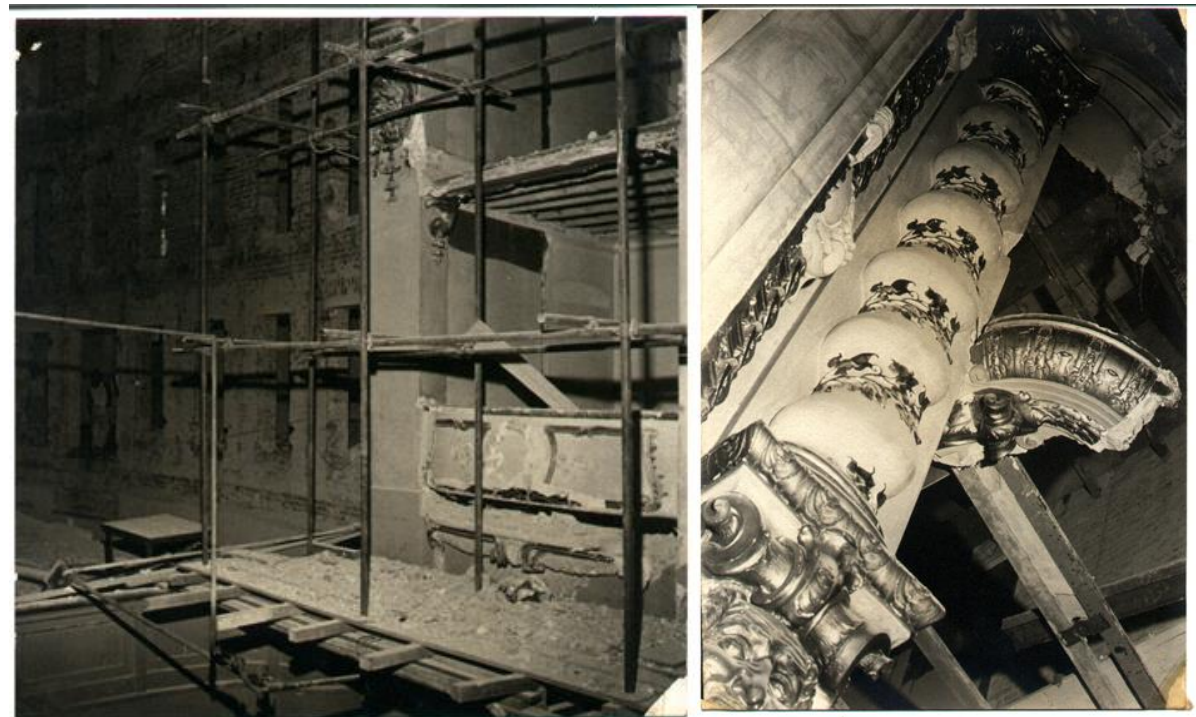

Figuras 69 (esq.) e 70 (dir.): Detalhes da demolição dos camarotes do proscênio. Fonte: Acervo de Fotografias do Arquivo Histórico de São Paulo.

A ampliação da boca de cena acarretou implicações estruturais, uma vez que, das quatro colunas que sustentavam a carga da cúpula e da cobertura, duas tiveram de ser removidas e substituídas, criando-se uma viga treliça de aço (Figura 71), com as dimensões de uma ponte (KATCHVARTANIAN, 2014). 


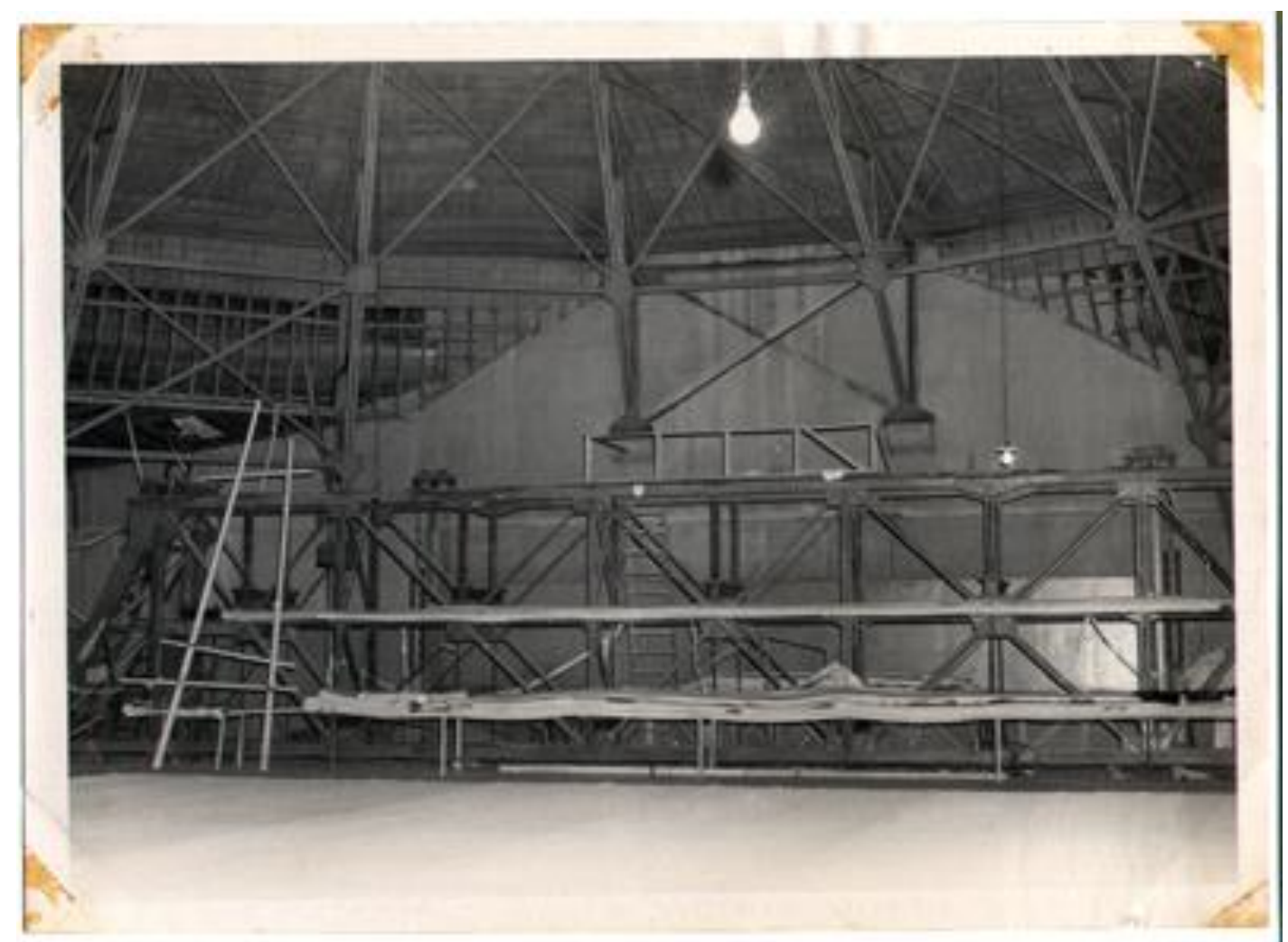

Figura 71: Viga treliça de aço, construída para sustentação da cúpula e localizada no salão sob ela

Fonte: Acervo de Fotografias do Arquivo Histórico de São Paulo.

O projeto de modernização do palco cênico, por sua vez, foi de responsabilidade do técnico Pericles Ansaldo, e contempla melhorias de instalações e equipamentos. Foi instalado um ciclorama semielíptico ${ }^{46}$ (Figuras 72 e 73), que tinha como função servir como suporte para projeções de cenário e iluminação, assim como melhorar o desempenho acústico da sala.

${ }^{46}$ O ciclorama é um elemento de cenografia em forma de tela semicircular usado para projetar cenários e iluminação, assim como para melhorar a acústica da apresentação. 

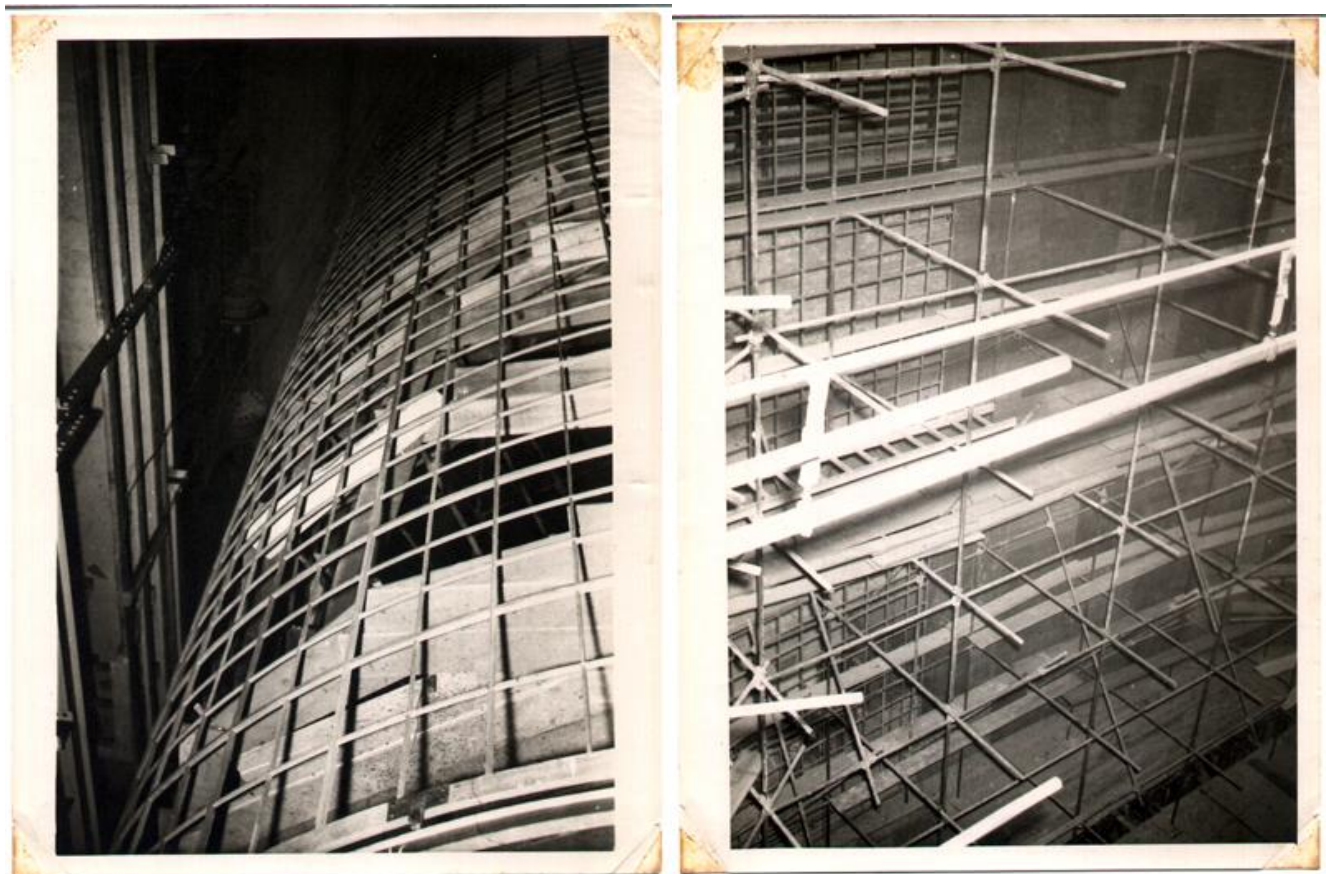

Figuras72 (esq.) e 73 (dir.): Estrutura do ciclorama (esq.) e detalhe da estrutura do ciclorama (dir.).

Fonte: Acervo de Fotografias do Arquivo Histórico de São Paulo.

O piso do fosso da orquestra foi substituído por um sistema hidráulico móvel, adaptável ao nível mais adequado ao tipo de música executado (Figura 74). Quanto a isso, destaca-se a seguinte preocupação do arquiteto:

Durante os estudos de visibilidade e da acústica na sala de espetáculos, o autor procurou manter dentro daquele equilíbrio arquitetônico o caráter de RESTAURAÇÃO (grifo do autor) - Com a retirada dos proscênios de ambas prumadas laterais, deu lugar, não só ao aumento de espaço útil para maior número de figuras da orquestra e localização do corpo do coral, como também, lugar, pelas laterais, para a colocação das tubulações do grande órgão (PISTORESI, 1953, p. 231/2). 


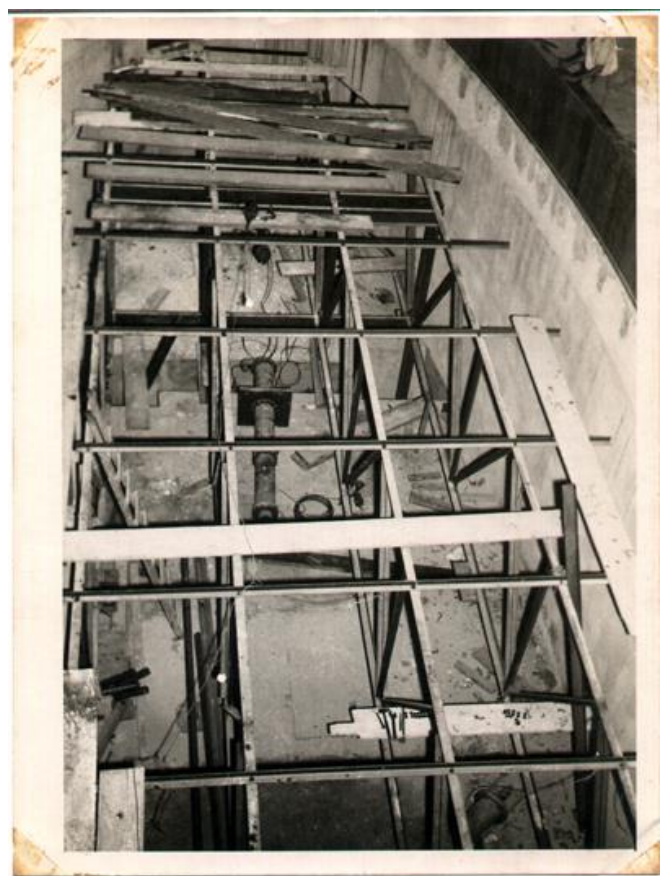

Figura 74: Fosso da orquestra com sistema de elevação.

Fonte: Acervo de Fotografias do Arquivo Histórico de São Paulo.

O piso do palco foi dividido em doze pontes transversais que se moviam por meio de um sistema de pistões hidráulicos, podendo subir ou descer três metros com relação ao nível original do palco (Figuras 75 e 76). As instalações elétricas, em estado precário, seriam integralmente substituídas por materiais importados pela Galanti de Milão e o sistema de iluminação, tanto do placo como da plateia, controlado por controlador eletrônico (Figuras 77 e 78), contando com luzes de emergência alimentadas por um conjunto de geradores de $120 \mathrm{KW}$.

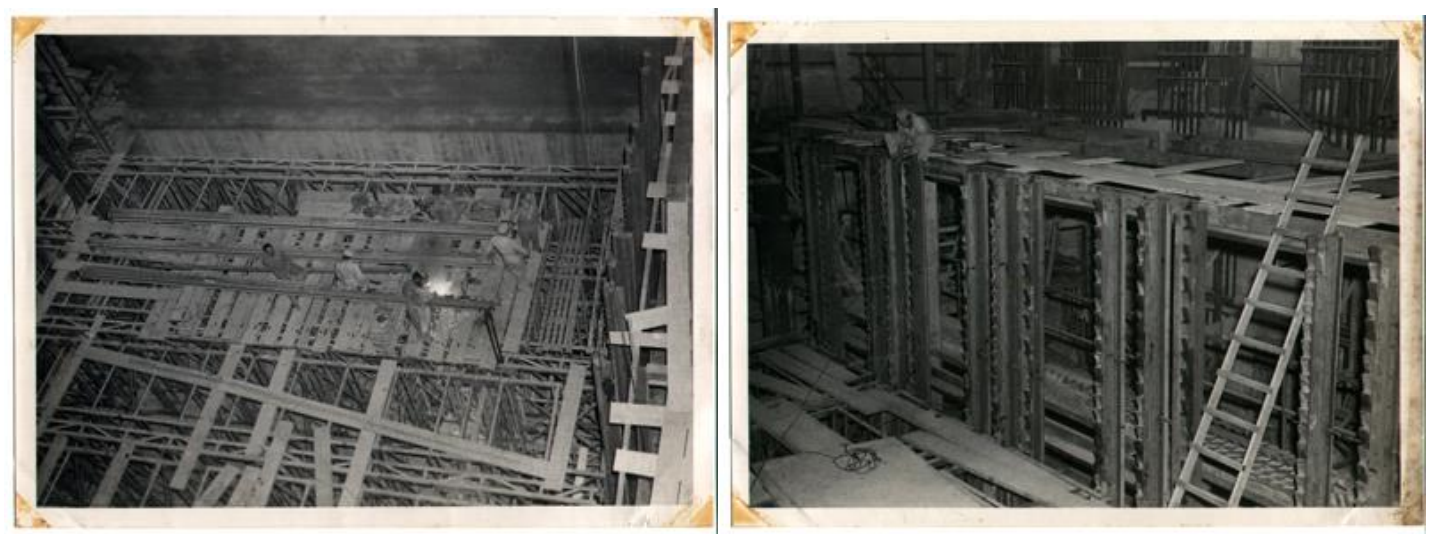

Figuras 75 (esq.) e 76 (dir.): Sistema de elevação do palco cênico. Fonte: Acervo de Fotografias do Arquivo Histórico de São Paulo. 


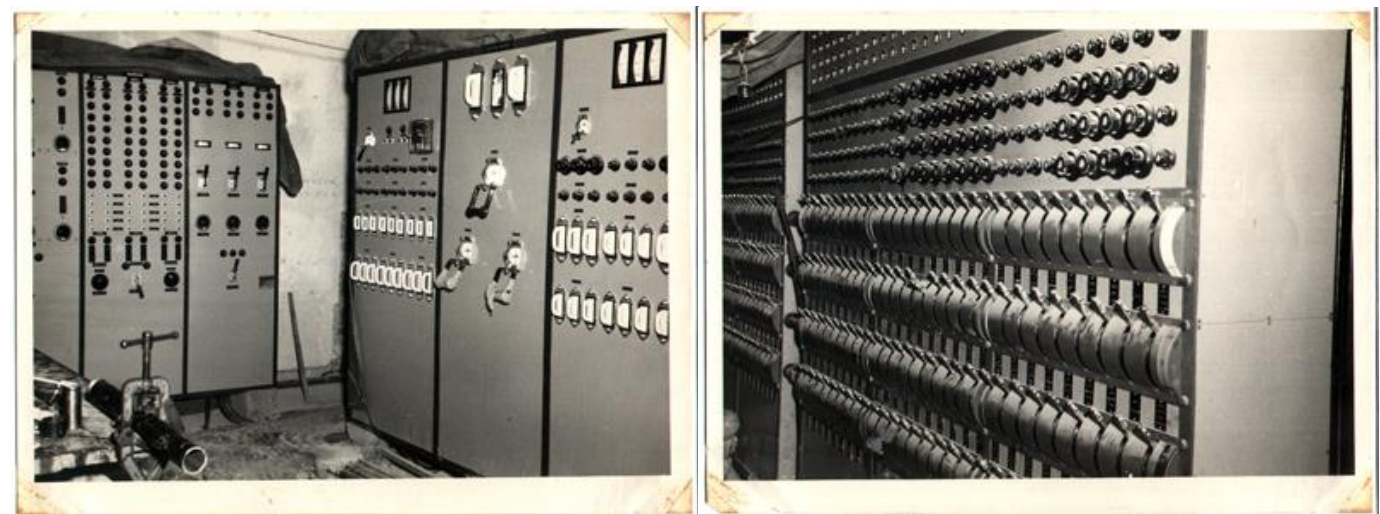

Figuras 77 (esq.) e 78 (dir.): Respectivamente, quadro de manobras e efeitos na cabine do palco (esq.) e manipuladores na cabine do palco (dir.)

Fonte: Acervo de Fotografias do Arquivo Histórico de São Paulo.

As escavações para obra de modernização do palco atingiram nível abaixo das fundações do edifício e do lençol freático (Figuras 79 e 80). O nível da água do terreno teve de ser rebaixado por meio de bombeamento a vácuo e foram executados escoramentos com estacas de ferro e tábuas de peroba para proteção da escavação (Figuras 81 e 82) (ACRÓPOLE, 1956).
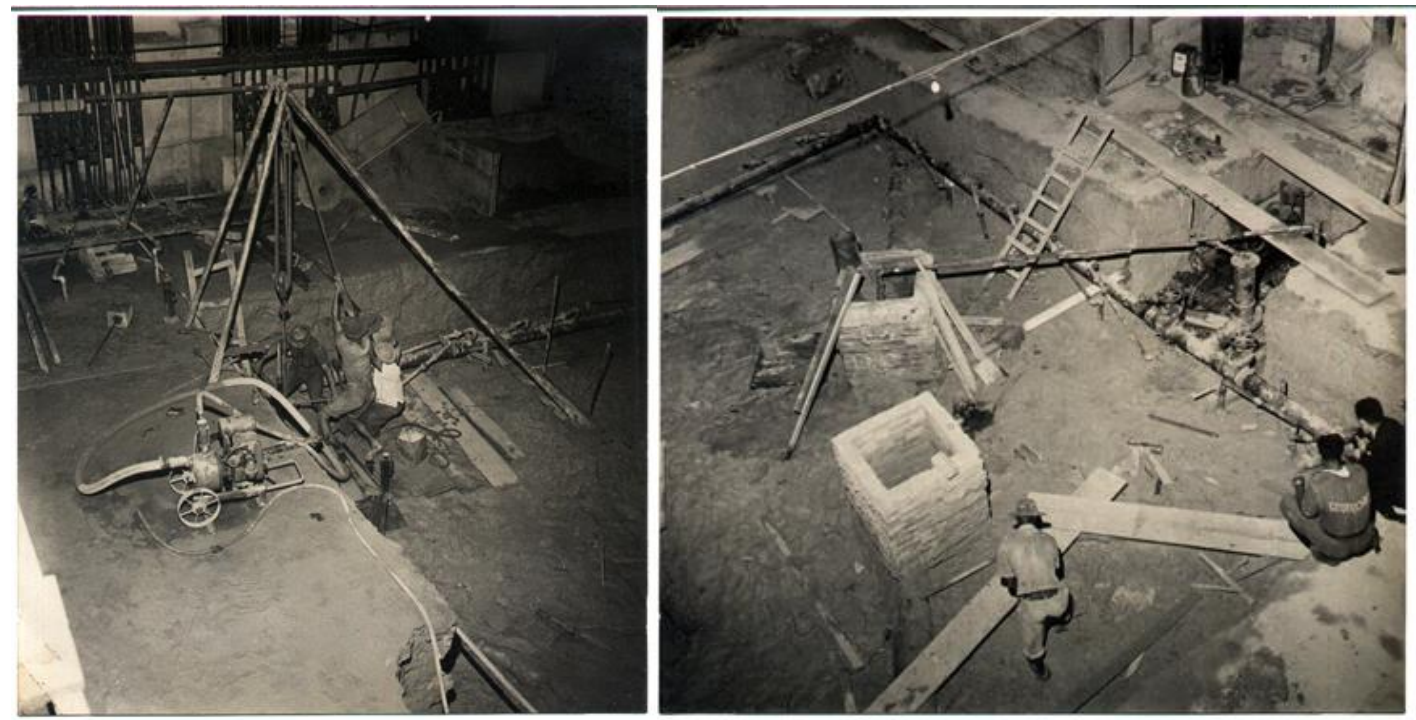

Figuras 79 (esq.) e 80 (dir.): Respectivamente, escavações para rebaixamento do lençol freático (esq.) e rebaixamento do lençol freático por meio de bombeamento a vácuo (dir.) Fonte: Acervo de de Fotografias do Arquivo Histórico de São Paulo. 


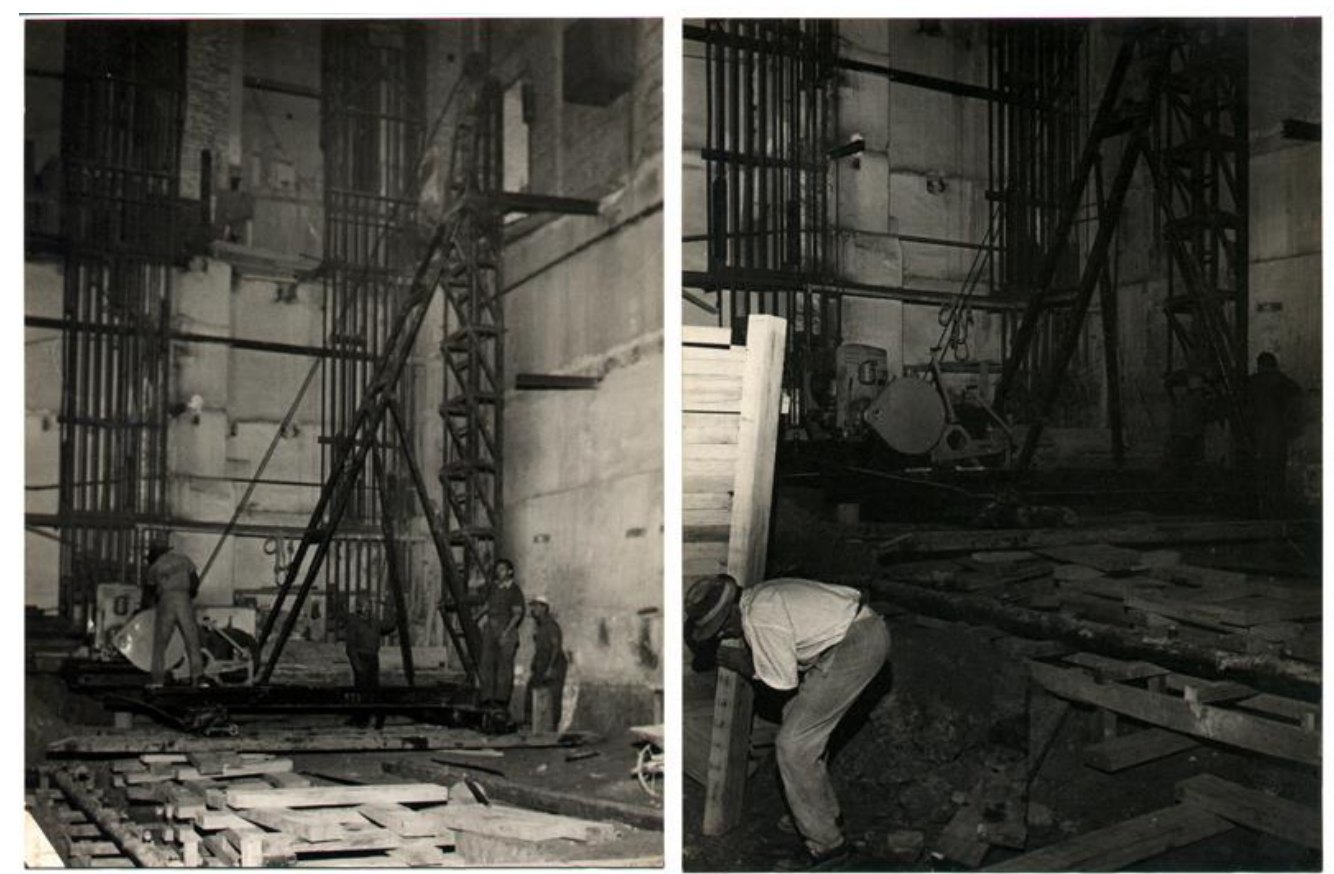

Figuras 81 (esq.) e 82 (dir.): Escoramentos com estacasde ferro e tabuas de peroba para proteção das escavações.

Fonte: Acervo de Fotografias do Arquivo Histórico de São Paulo.

\subsubsection{Cúpula}

Uma vez pensados os espaços de camarins e palco, faltava um problema a ser resolvido pela primeira etapa da intervenção: o uso da sala sob a cúpula. A ocupação do espaço, que se dava até então pela cenografia, seria compartilhada com uma sala para ensaio da orquestra e do balé, através da construção de um mezanino (Figura 83). Cada um desses ambientes teria acesso direto ao fosso da orquestra ou palco, por meio de um elevador (PISTORESI, 1953). No entanto, esse projeto não foi levado a cabo e a proposta foi retomada apenas na década de 1980, durante a segunda grande intervenção do edifício. 


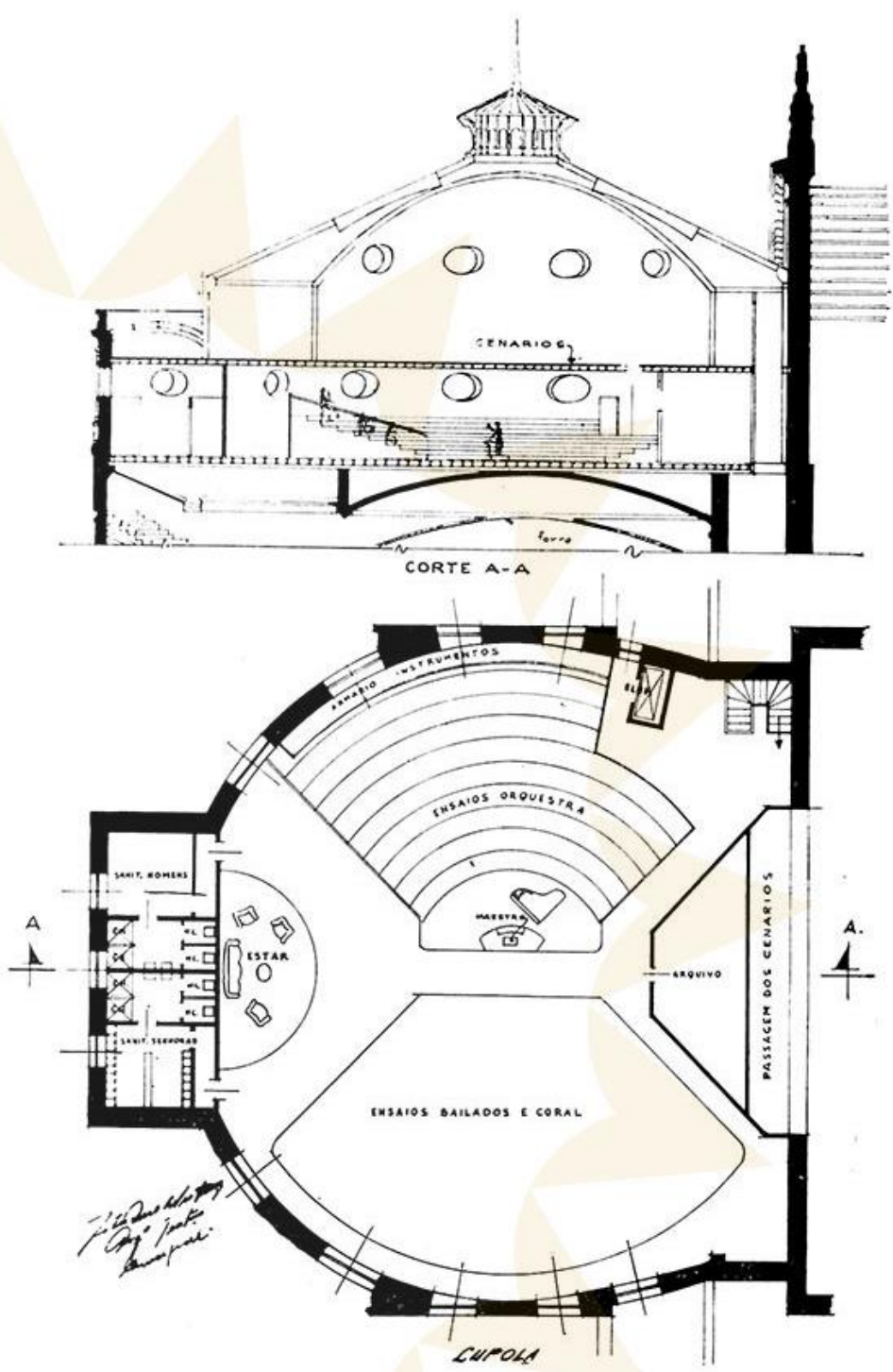

Figura 83: Desenhos esquemáticos da proposta de construção de mezanino sob a cúpula. Fonte: PISTORESI, 1953.

\subsubsection{Saguão e Escadaria Principal}

A segunda etapa de intervenção, correspondente à parcela central do corpo do edifício, coloca mais uma vez a modernização e a inovação como pontos centrais:

Tudo será guardado no seu tradicional testemunho de Arte. Apenas a Restauração das obras de arte, e das partes deterioradas pelo tempo e pelos estragos causados por infiltrações (...) bem como, a conclusão dos ambientes que não foram levados a termo por circunstâncias financeiras daquela época acrescentando-se a tudo isso as modernas concepções da acústica, visibilidade, parte social e parte estética (PISTORESI, 1953). 
A preocupação com a harmonia e o equilíbrio dos ambientes internos se manifesta aqui por meio de completamentos e substituições, que destacam a ênfase na visão criativa do arquiteto restaurador. A pintura do teto do saguão, sobre a escadaria nobre, foi completada no estilo do resto do ambiente, sob a justificativa de promover o equilíbrio cromático (Figuras 84 e 85). A pintura das paredes também recebeu tratamento análogo, "a fim de formarem um só ambiente, isto é, em harmonia" e promover a "homogeneidade do ambiente local" (PISTORESI, 1953).

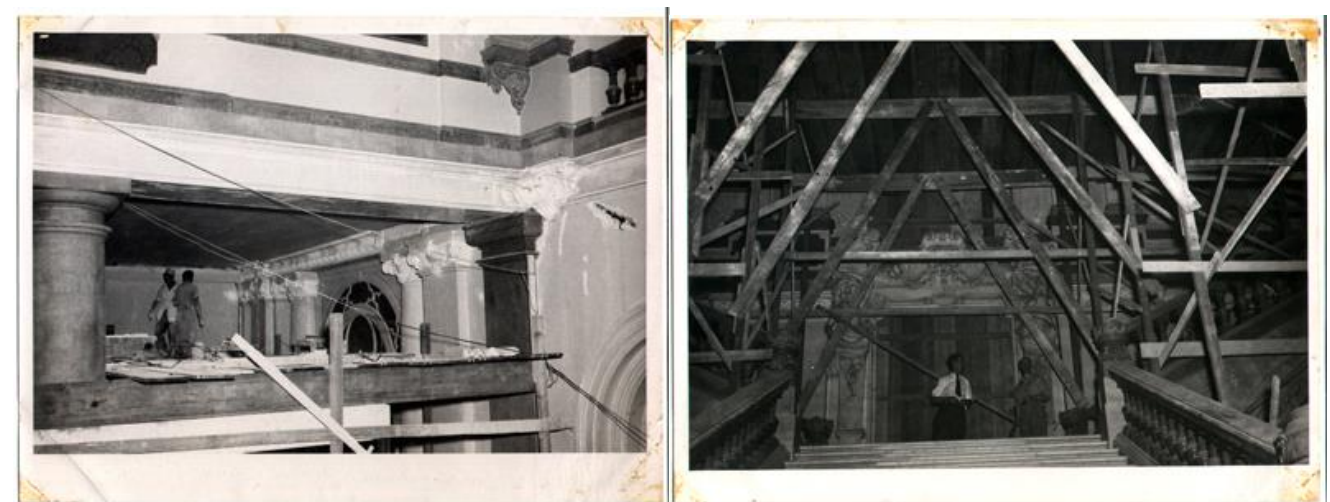

Figura 84 (esq.) e 85 (dir.): Respectivamente, pintura do forro e paredes do Saguão principal (esq.) e estrutura montada para pintura do forro sobre a escadaria principal (dir.) Fonte: Acervo de Fotografias do Arquivo Histórico de São Paulo.

O ímpeto criativo da proposta também se vê refletido no estudo para a reformulação da escadaria principal, apresentado pelo autor nessa mesma edição da revista Acrópole (Figura 86). Por falta de recursos financeiros e tempo, a ideia acaba sendo posta de lado pela Comissão de Reforma do Teatro. 

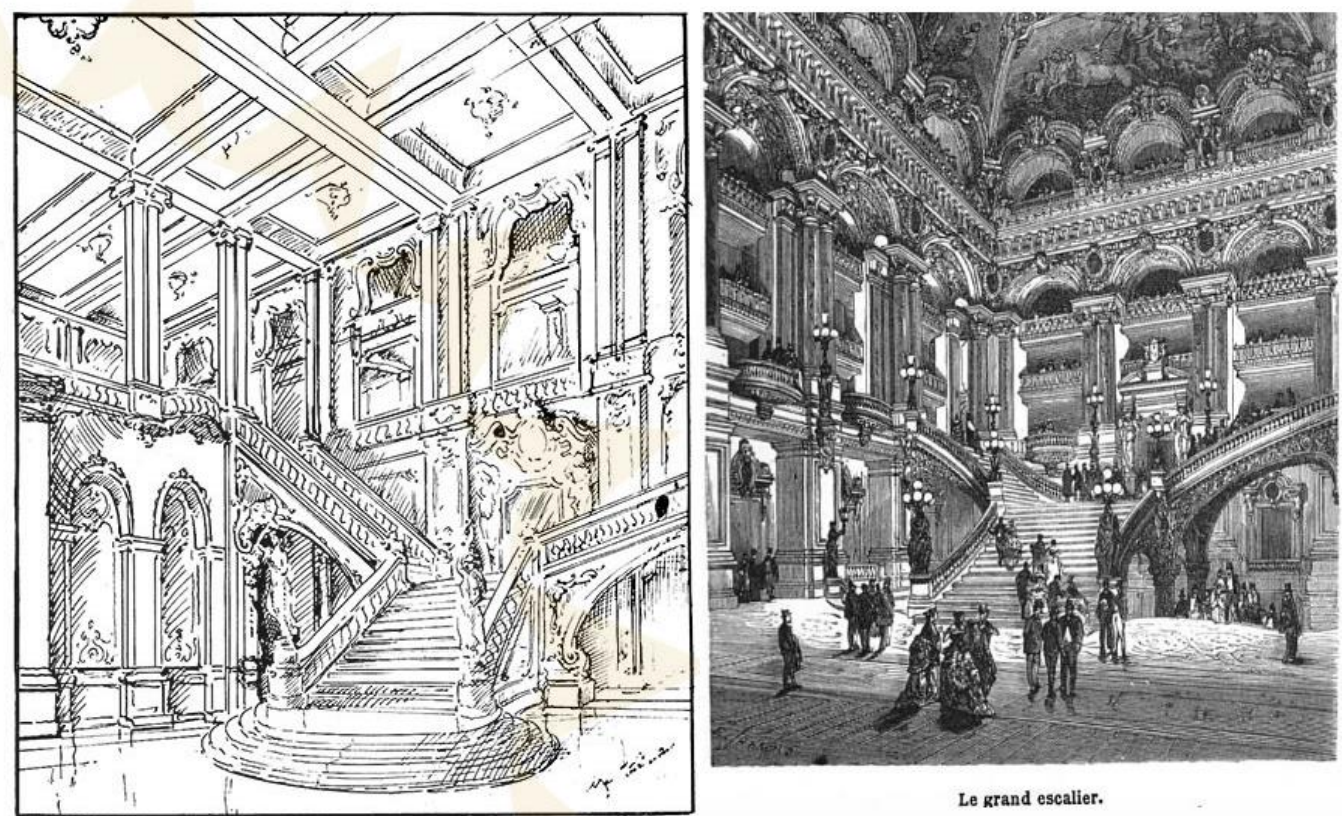

Figura 86: (à esq.) Desenho da proposta de remodelação da escadaria principal, que pressupõe a supressão das duas colunas de granito cinza do saguão, elaborada por Tito Pistoresi (à dir) Desenho da escadaria principal da Ópera de Paris.

Fonte: (à esq) PISTORESI, 1953 (à dir.) NUITTER, 1875.

No entanto, apesar de não ter sido materializada, a proposta de remodelação da escadaria principal elaborada por Pistoresi não deve ser ignorada. Ao tomar a Ópera de Paris, de Charles Garnier, como o modelo de casa de ópera da virada do século, entendemos que a escadaria principal cumpre o papel de destaque na arquitetura interna do edifício (Figura 87). Sua escala monumental, seus materias de acabamento e sua posição central the conferem protagonismo (NUITTER, 1875).

Não por acaso, ao remodelar um elemento de tamanho destaque arquitetônico, Pistoresi acaba aproximando-se do modelo parisiense em sua proposta. A supressão das colunas monumentais, que atravessam o pé direito do saguão, $e$ o arrendondamento dos degraus do início da escada resultariam em uma maior semelhança do Theatro brasileiro com relação ao francês (Figura 88). 


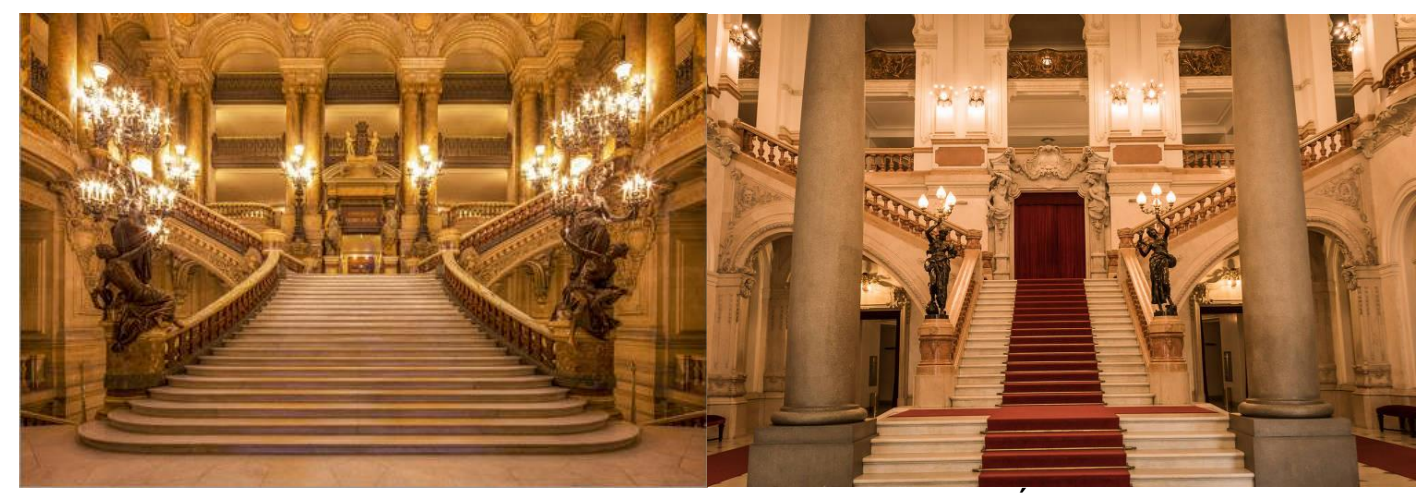

Figuras 87 (esq.) e 88 (dir.): Fotografia da escadaria principal da Ópera de Paris, de Charles Garnier (esq.) Fotografia da escadaria principal do Theatro Municipal, de acordo com projeto original (dir.).

Fonte: (esq.) Jan Christopher Becke (dir.) https://guia.folha.uol.com.br/ .

Foi apresentada no capítulo 1 do presente trabalho a discussão sobre os pontos de divergência e convergência entre o projeto original Theatro Municipal e a Ópera de Paris. Apesar das possíveis divergências, é inegável que a tipologia da casa de ópera foi importada do modelo europeu oitocentista.

Sob essa perspectiva, interessa ressaltar que a proposta de Pistoresi para 0 Saguão Principal adquire caráter corretivo, coerente com a postura adotada de maneira geral pela intervenção. Essa correção, no entanto, por vezes adquire caráter estético, como é o caso do Saguão, e por outras, caráter funcional, como já foi visto no caso dos camarins; e na Sala de Espetáculos e bilheteria, que serão analisadas a seguir.

\subsubsection{Bilheteria}

A bilheteria também foi alvo de criação projetual, no que diz respeito a sua organização espacial. $O$ fato de existir apenas uma bilheteria para todos os setores foi tomado como um problema e foram apresentadas duas propostas de solução à CRTM. Ambas as propostas foram comentadas na revista Acrópole de setembro de 1953, porém, no momento de sua publicação, a segunda já havia sido aprovada e estava em execução.

O primeiro estudo, refutado pela Comissão, pressupunha a instalação da bilheteria na varanda do primeiro andar da Rua Conselheiro Crispiniano e o aproveitamento das varandas dos demais pavimentos, que dariam acesso independente a cada um dos setores, dotados de salões de exposição e fumoirs. 
A partir daí, criou-se um segundo problema de fechamento das varandas, que alterariam o aspecto original da fachada (Figura 89).
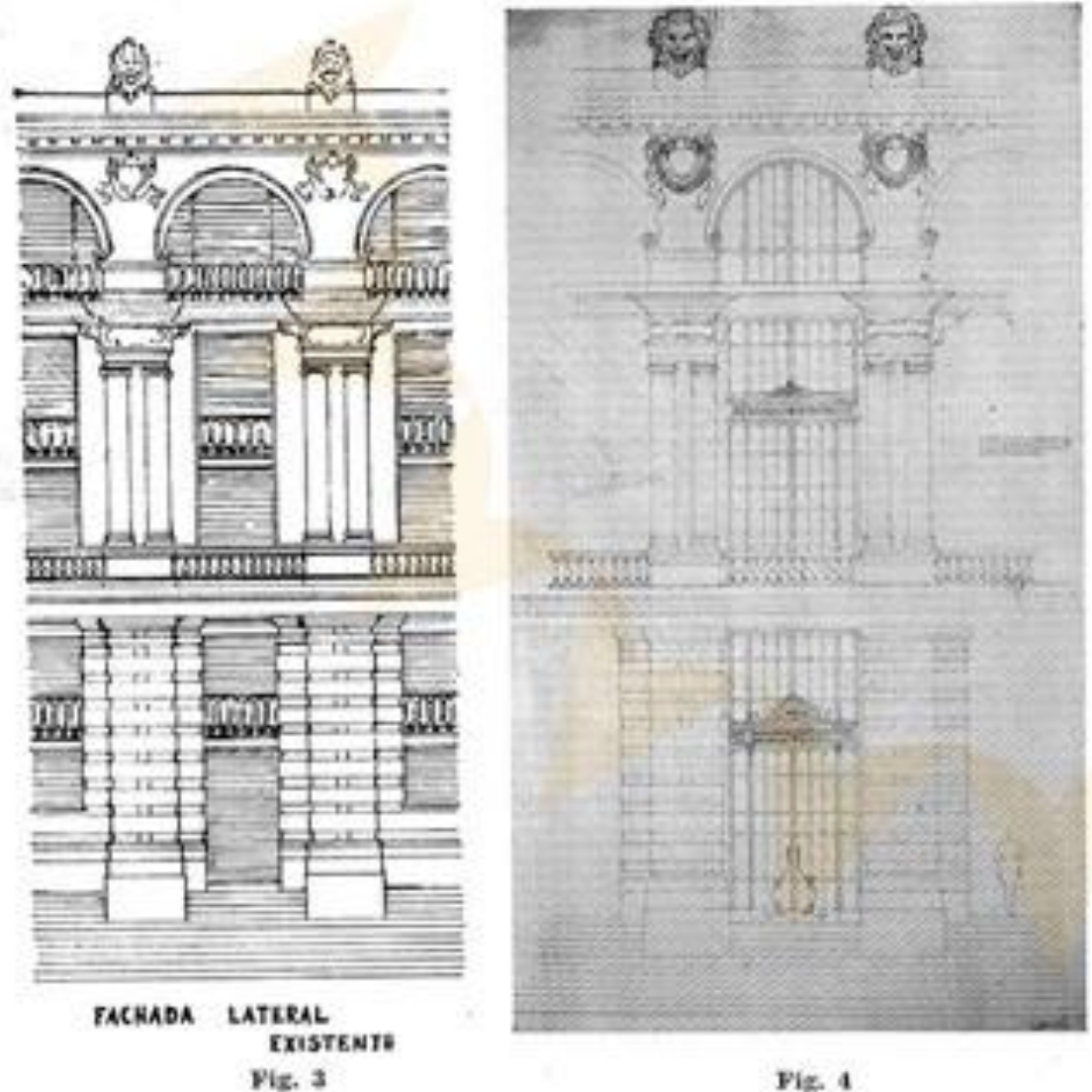

Figura 89: Desenho da proposta de fechamento das varandas laterais, por meio de caixilhos de ferro batido.

Fonte: PISTORESI,1953.

A proposta aceita tem caráter menos invasivo e propõe a utilização das portas já existentes na fachada principal como forma de setorização da entrada. No primeiro andar, seriam instaladas as bilheterias relativas às frisas, plateia e camarotes; a bilheteria da galeria e anfiteatro, por sua vez, estaria localizada no local da antiga escadaria desses setores, que seria demolida e reconstruída em outro local (Figuras 90 a 94). 


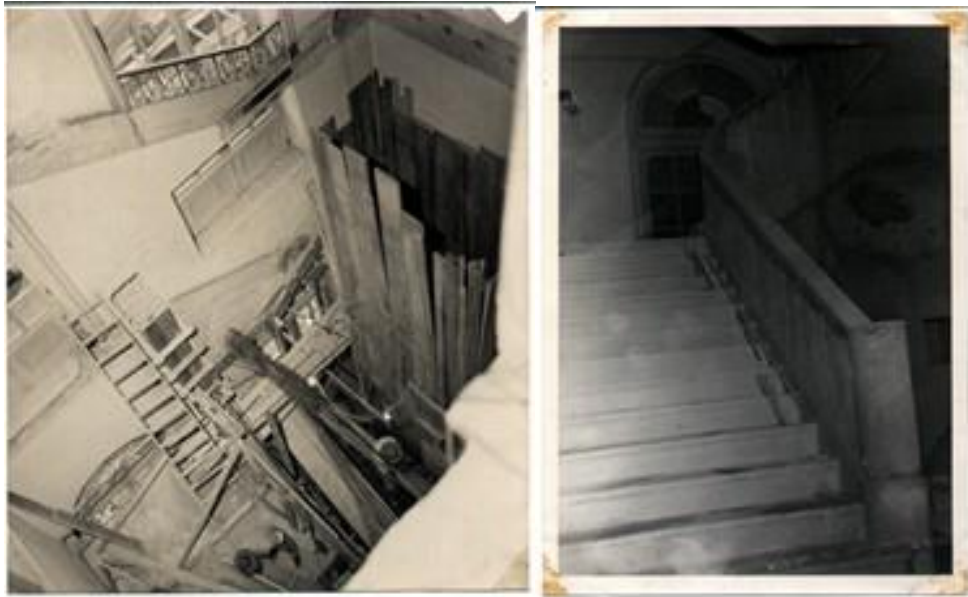

Figuras 90 (esq.) e 91 (dir.): Estrutura da escada da galeria (esq.) e escada da galeria em construção (dir.).

Fonte: Acervo de Fotografias do Arquivo Histórico Municipal de São Paulo.
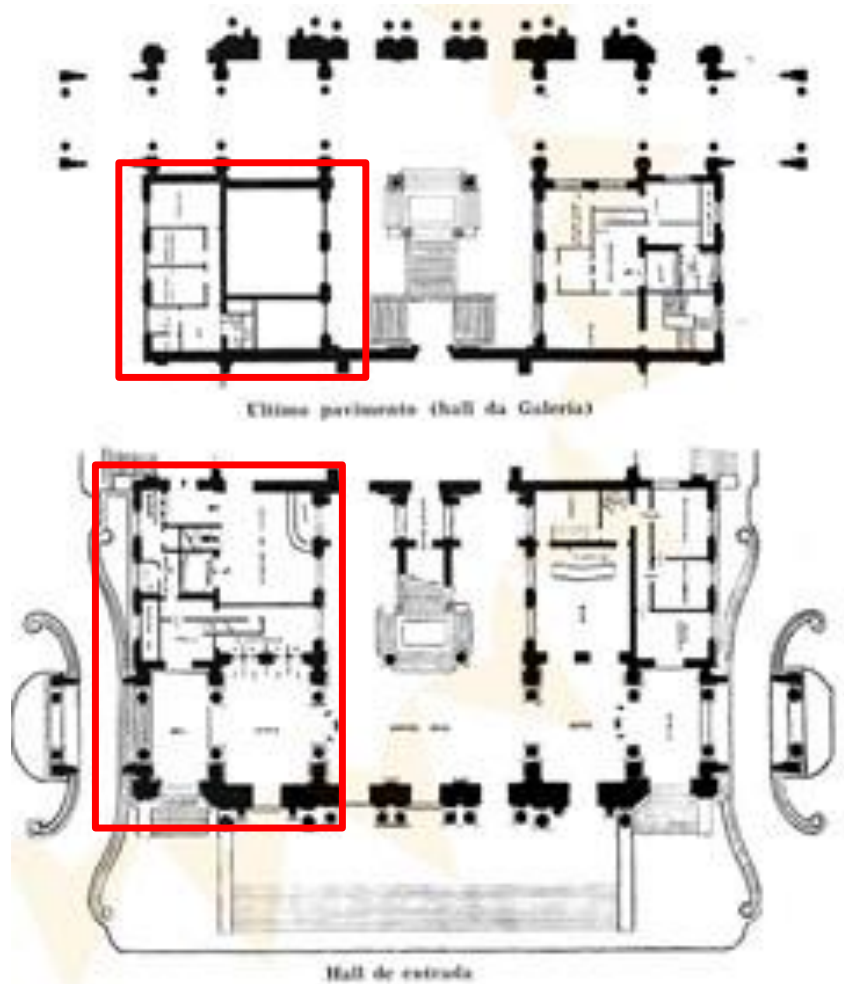

Figura 92: Plantas esquemáticas da proposta de bilheteria aceita pela CRTM (destaque em vermelho).

Fonte: PISTORESI, 1953. 


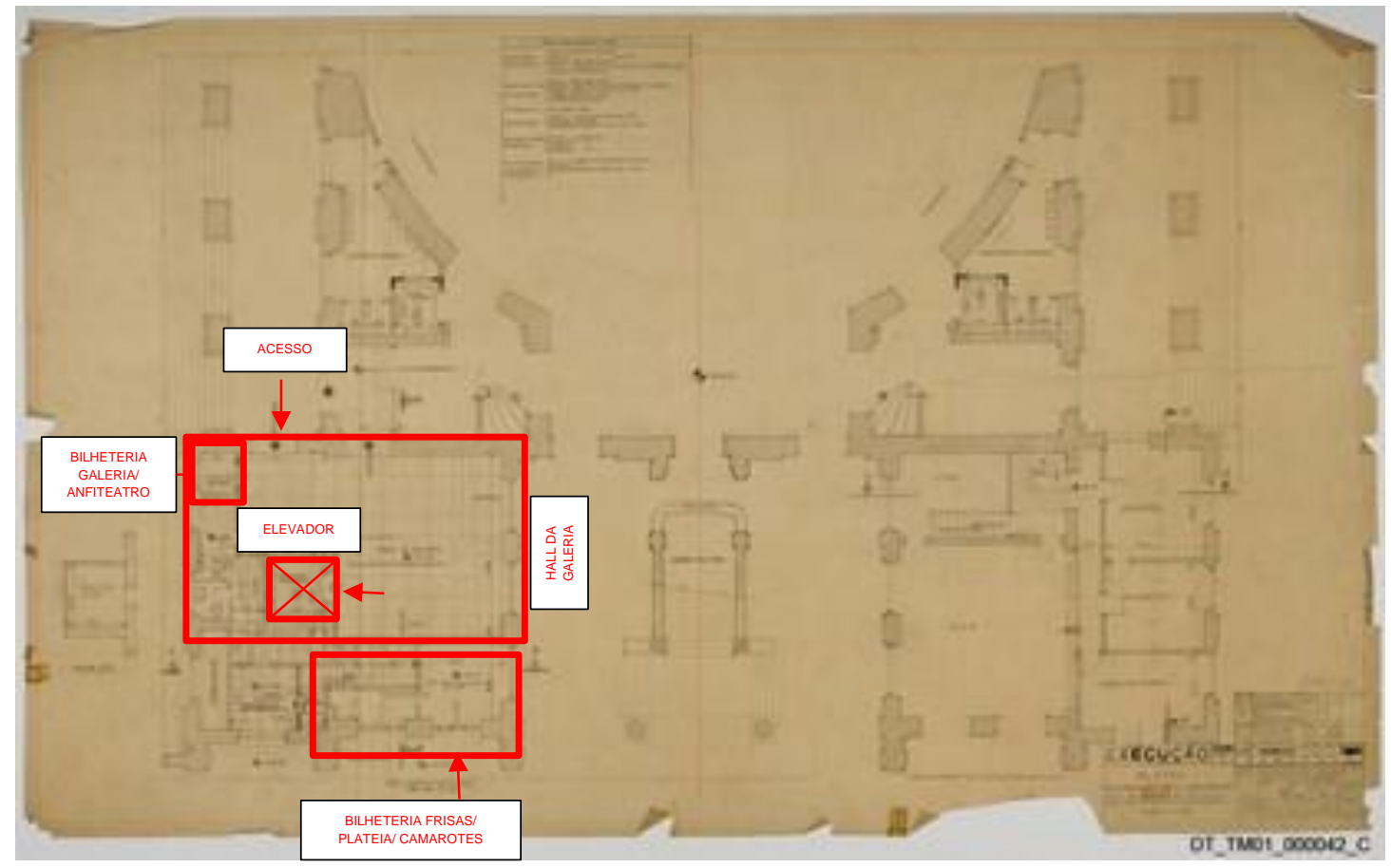

Figura 93: Planta do projeto executivo da bilheteria (primeiro pavimento).

Fonte: Acervo do Arquivo Histórico Municipal Washington Luís (AHM- WL)

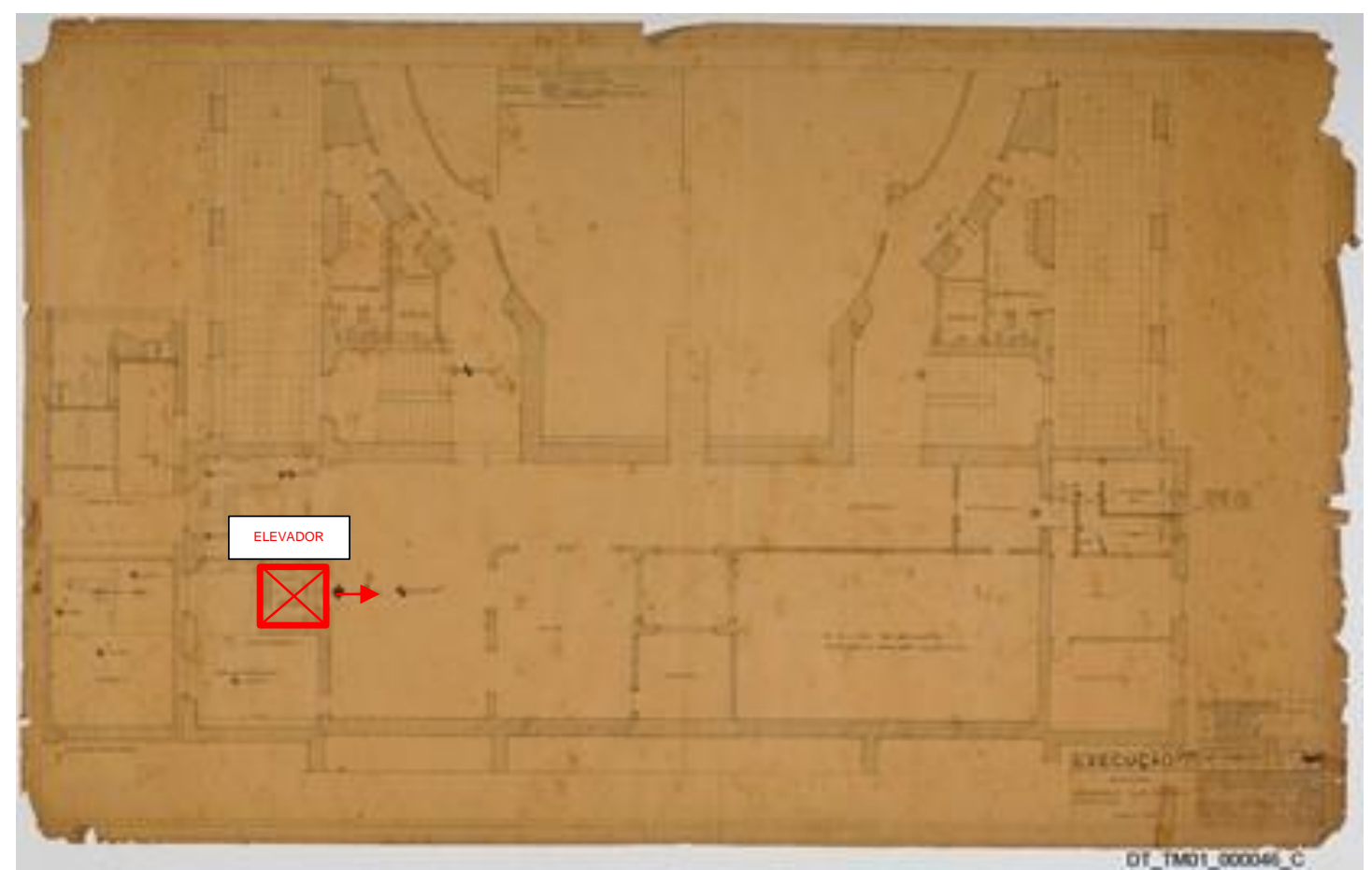

Figura 94: Planta do projeto executivo da bilheteria (quinto pavimento - galeria) Fonte: Acervo do Arquivo Histórico Municipal Washington Luís (AHM- WL)

\subsubsection{Sala de Espetáculos}

Mais uma vez sob o signo da modernização, o arquiteto pretende solucionar os problemas de visibilidade e acústica verificados na Sala de Espetáculos. Com 
aproximadamente quinhentos e quarenta pontos "cegos", o ambiente demandava soluções que resolvessem tanto a visibilidade horizontal como a vertical.

A eliminação das colunas das frisas e dos camarotes de "primeira classe" seria suficiente para solucionar a primeira, no entanto, a conformação da sala em formato de ferradura dificultaria a solução da segunda, que só se resolveria com a inclinação dos pisos em função das curvas de cada setor. Após exaustivos estudos de visibilidade, propõe-se a remodelação completa de todos os setores (Figuras 95, 96 e 97), que são demolidos e reconstruídos de acordo com novo projeto. Foram executadas novas fundações para a sala, que teve sua parede perimetral reforçada com uma capa de concreto (Figuras 98 e 99) para apoio das estruturas em balanço das novas ordens (PISTORESI, 1954).

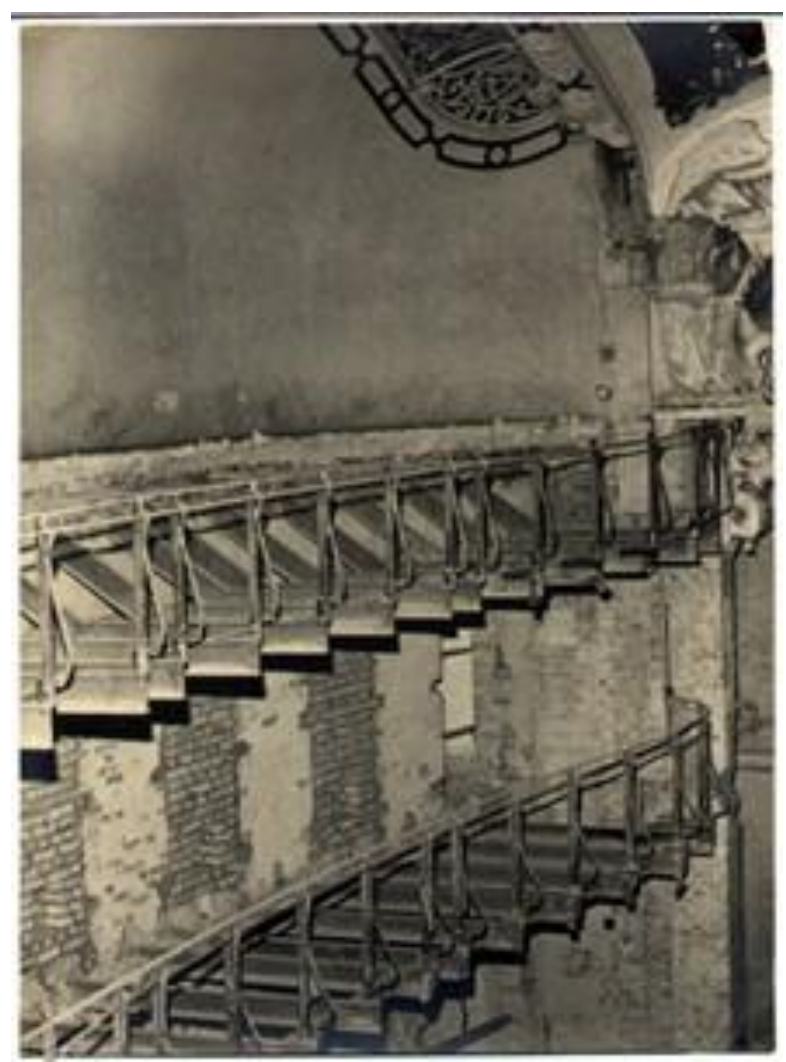

Figura 95: Armação da antiga estrutura da segunda ordem e galeria, em processo de demolição.

Fonte: Acervo de Fotografias do Arquivo Histórico Municipal de São Paulo. 

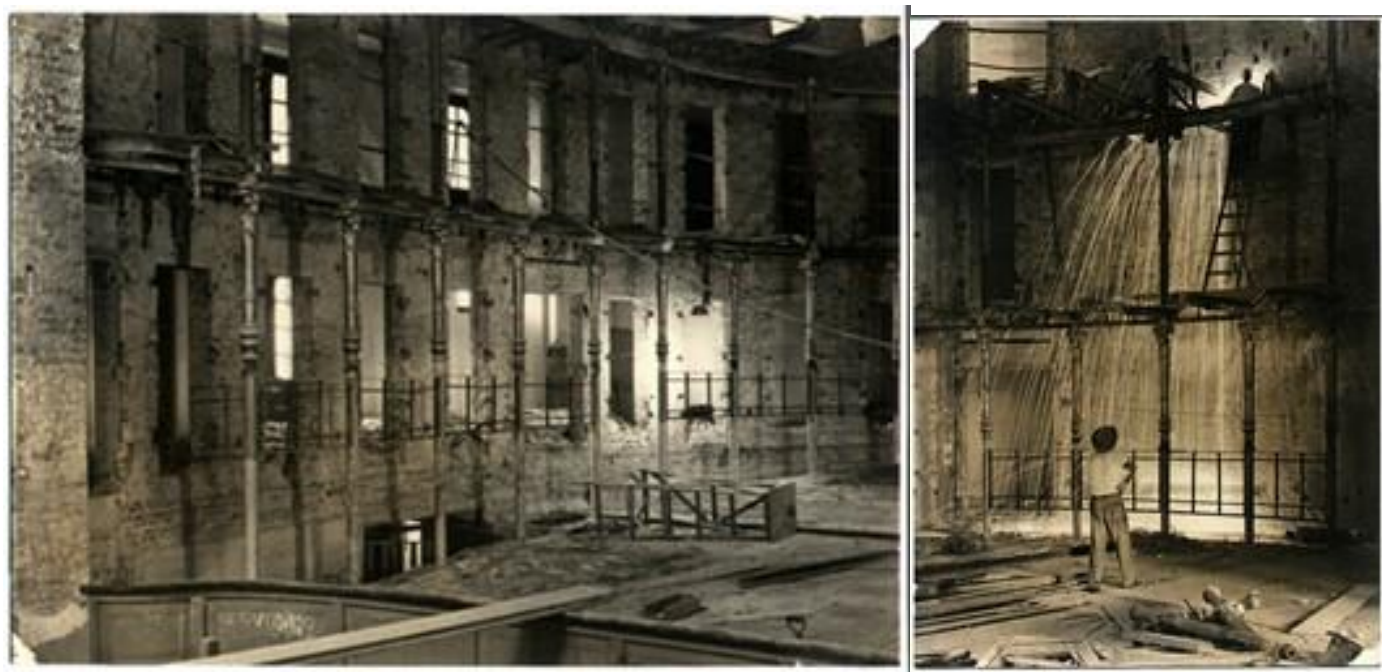

Figuras 96 (esq.) e 97 (dir.): Respectivamente, estrutura dos setores antes da demolição (esq.) e demolição da estrutura dos setores (dir.)

Fonte: Acervo de Fotografias do Arquivo Histórico Municipal de São Paulo.
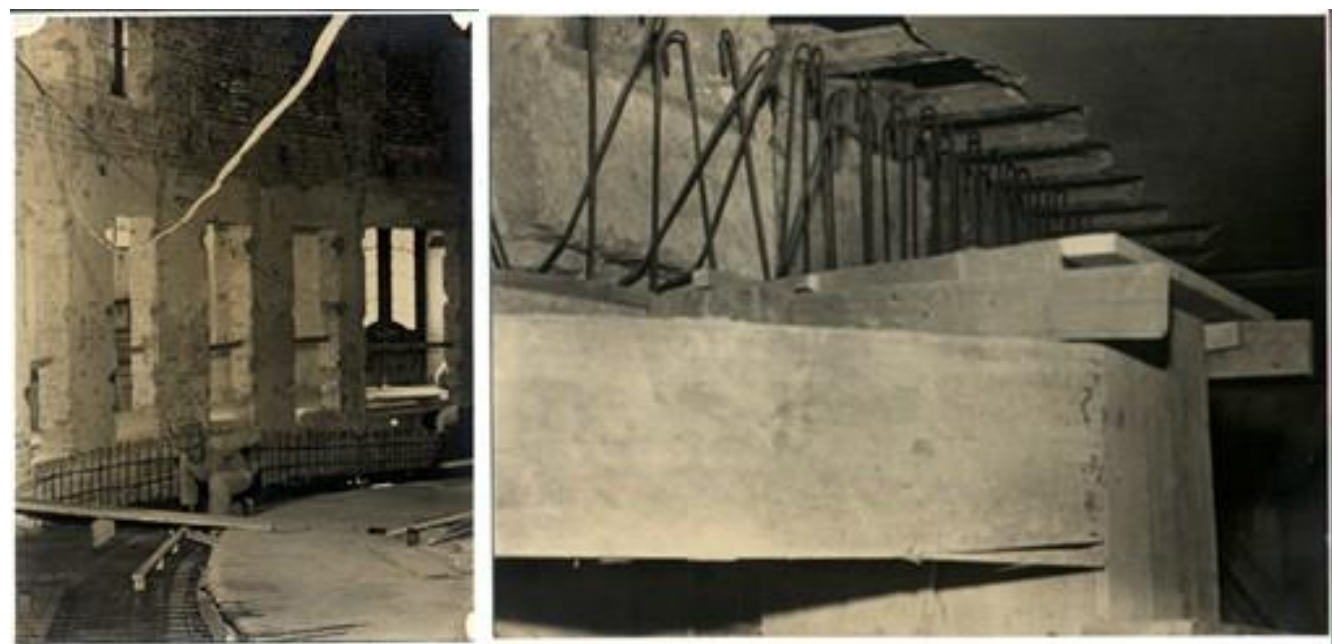

Figuras 98 (esq.) e 99 (dir.): Respectivamente, construção da nova laje das frisas (esq.) e pilares e armação da nova estrutura perimetral de concreto (dir.)

Fonte: Acervo de Fotografias do Arquivo Histórico Municipal de São Paulo.

Os parapeitos das ordens superiores (atualmente Galeria e Balcão Simples) foram executados em gesso e decorados com folhas de ouro (Figuras $100 \mathrm{e}$ 101). Já os parapeitos das duas ordens inferiores (atualmente Balcão Nobre e Foyer) foram reaproveitados, desmontados, rebatidos e montados novamente de acordo com as novas curvas e inclinações (Figuras 102 a 117) ${ }^{47}$.

\footnotetext{
47 Interessa destacar que, em algum momento do processo de desmontagem e remontagem dos parapeitos das duas ordens inferiores, os gradis orginalmente instalados no foyer passaram para a primeira ordem e vice-versa (COSTA, 2017).
} 

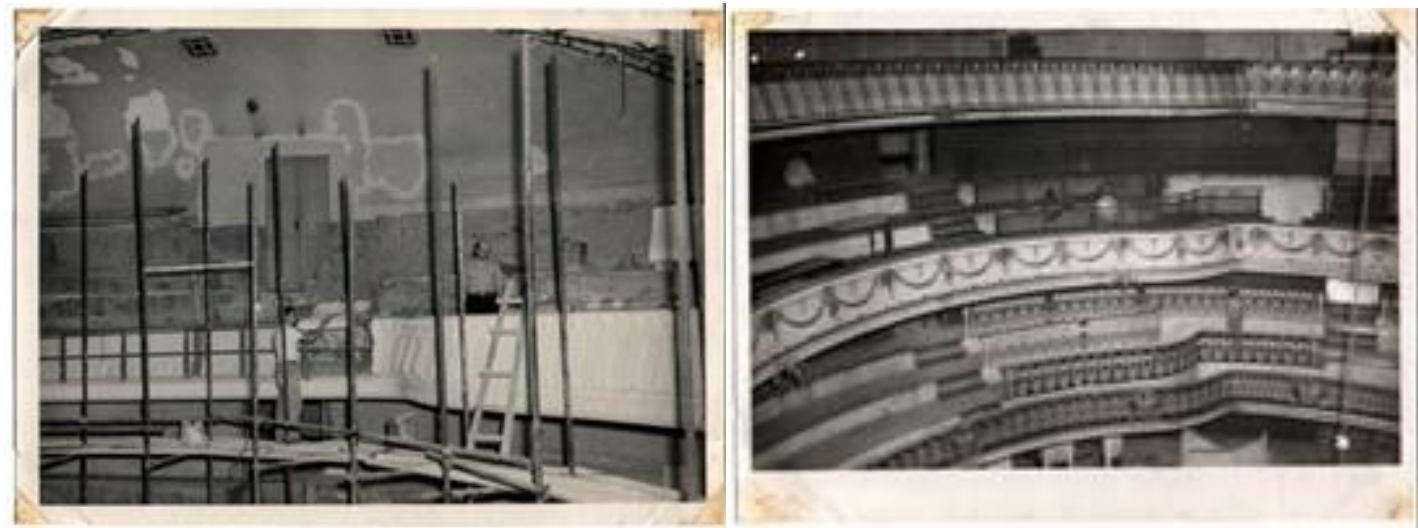

Figuras 100 (esq.) e 101 (dir.): Colocação dos parapeitos superiores em gesso (esq.) e aspecto final dos parapeitos decorados com folhas de ouro (dir.)

Fonte: Acervo de Fotografias do Arquivo Histórico Municipal de São Paulo.
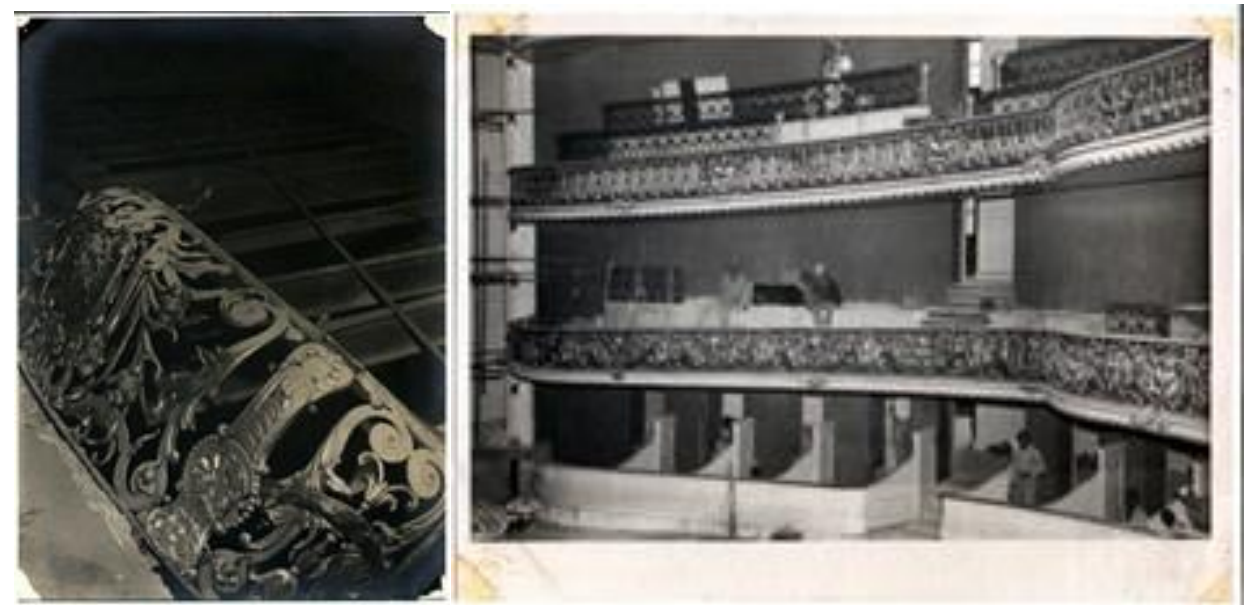

Figura 102 (esq.) e figura 103 (dir.): Parapeito metálico desmontado (esq.) e montagem dos parapeitos metálicos inferiores, já remodelados (dir.)

Fonte: Acervo de Fotografias do Arquivo Histórico Municipal de São Paulo. 


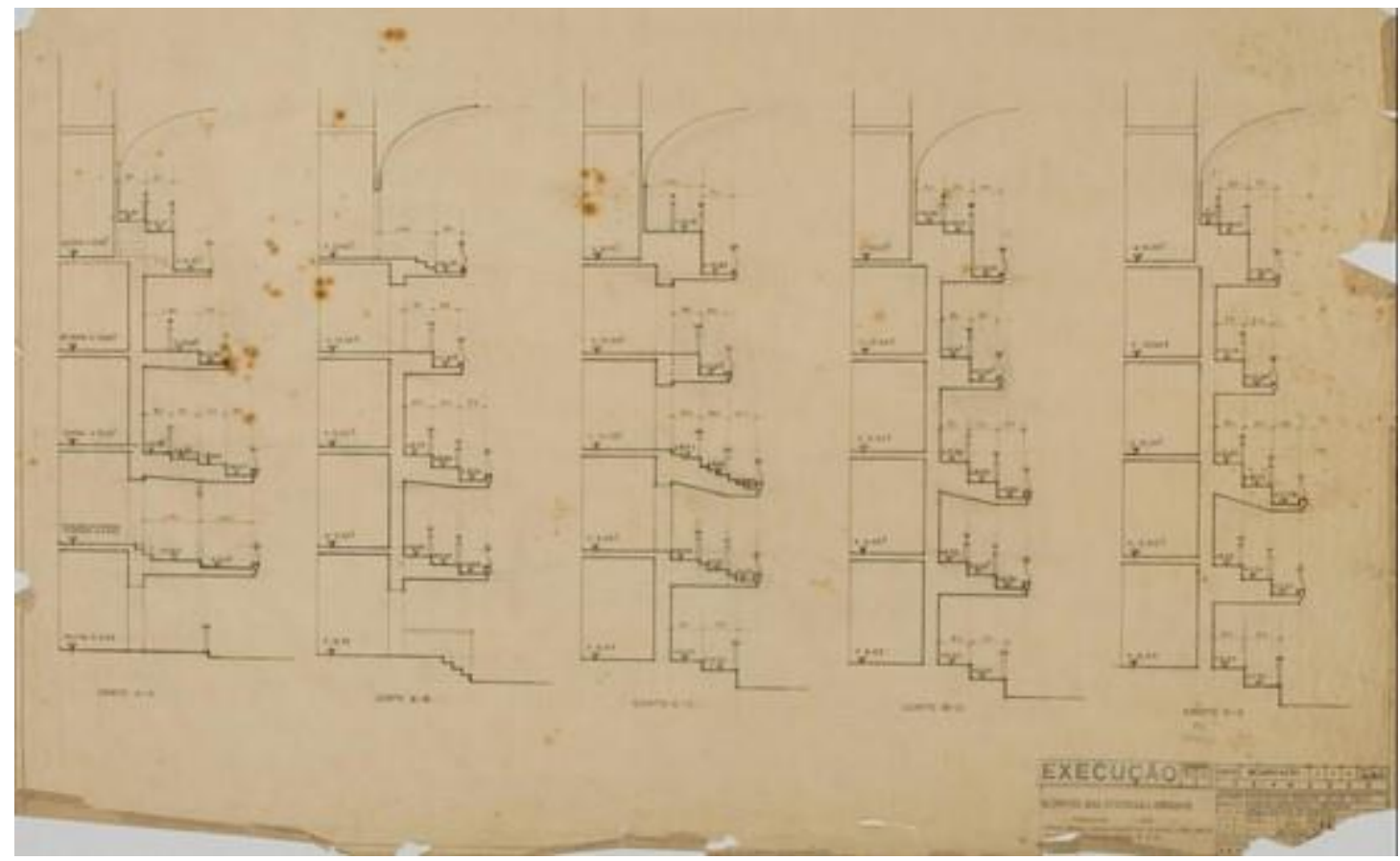

Figura 104: Cortes transversais do projeto executivo de remodelação das ordens da sala de espetáculos.

Fonte: Acervo do Arquivo Histórico Municipal de São Paulo.

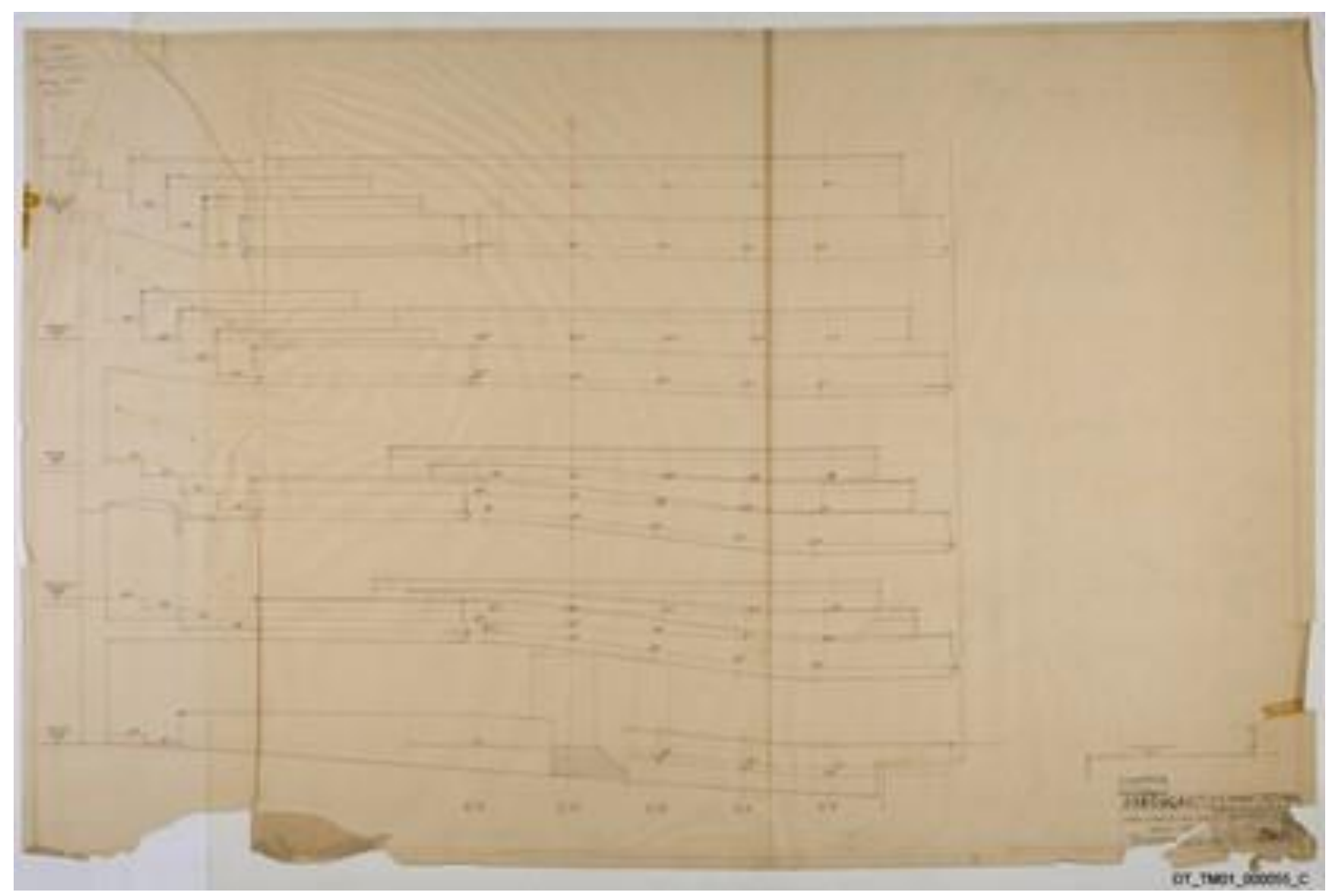

Figura 105: Corte longitudinal do projeto executivo de remodelação das ordens da sala de espetáculos.

Fonte: Acervo do Arquivo Histórico Municipal de São Paulo. 


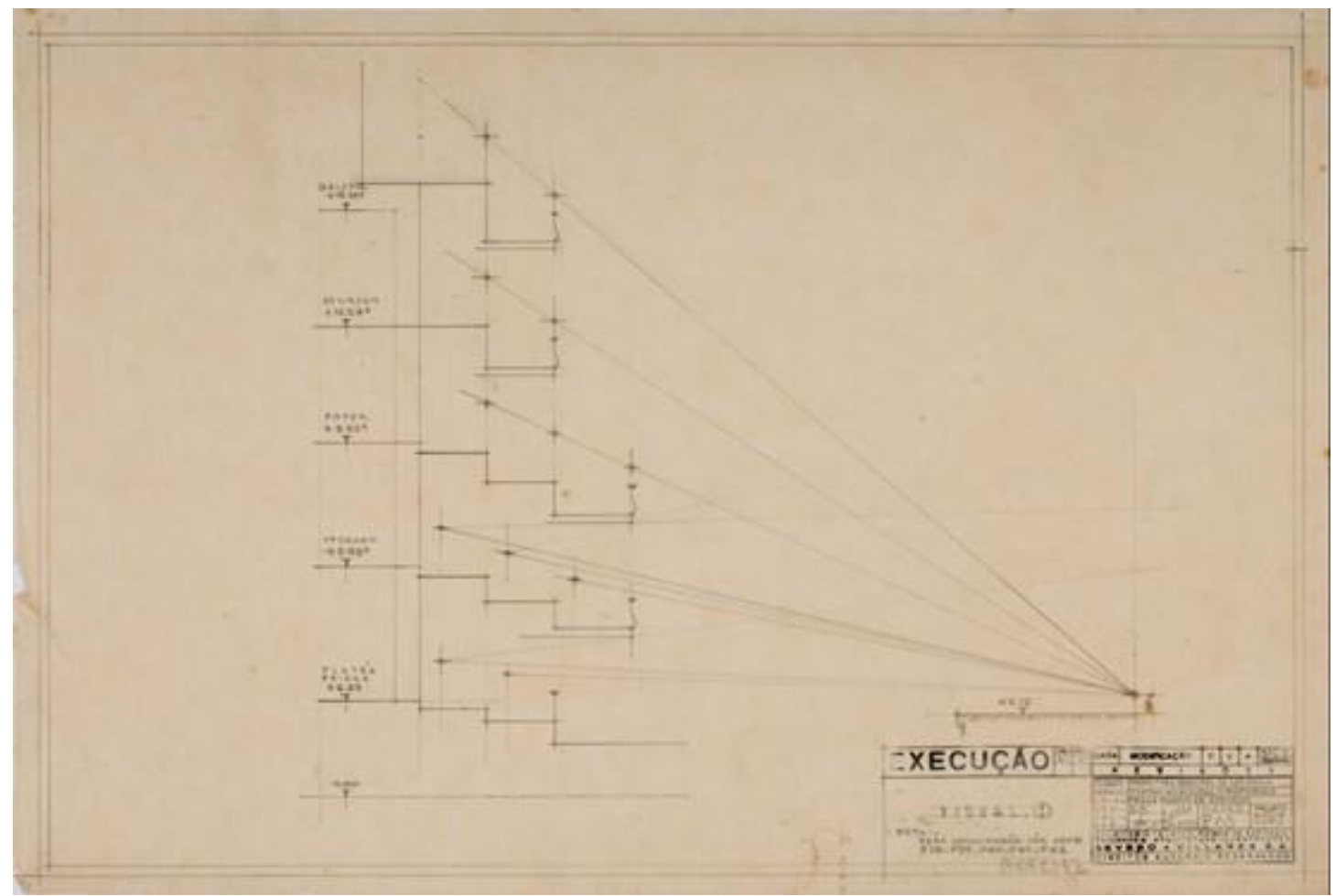

Figura 106: Corte transversal do projeto executivo de remodelação das ordens da sala de espetáculos.

Fonte: Acervo do Arquivo Histórico Municipal de São Paulo.

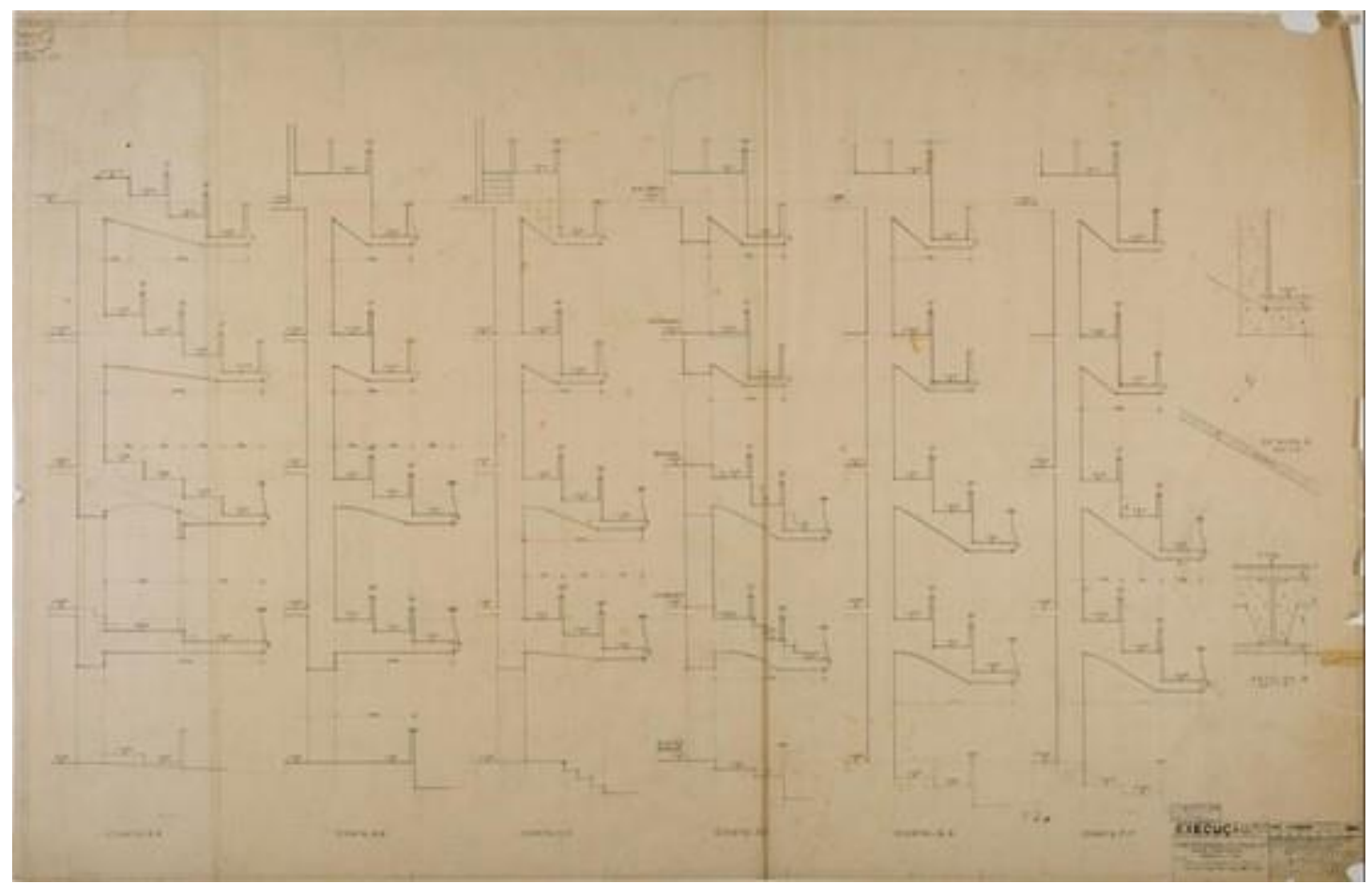

Figura 107: Cortes transversais do projeto executivo de remodelação das ordens da sala de espetáculos.

Fonte: Acervo do Arquivo Histórico Municipal de São Paulo. 


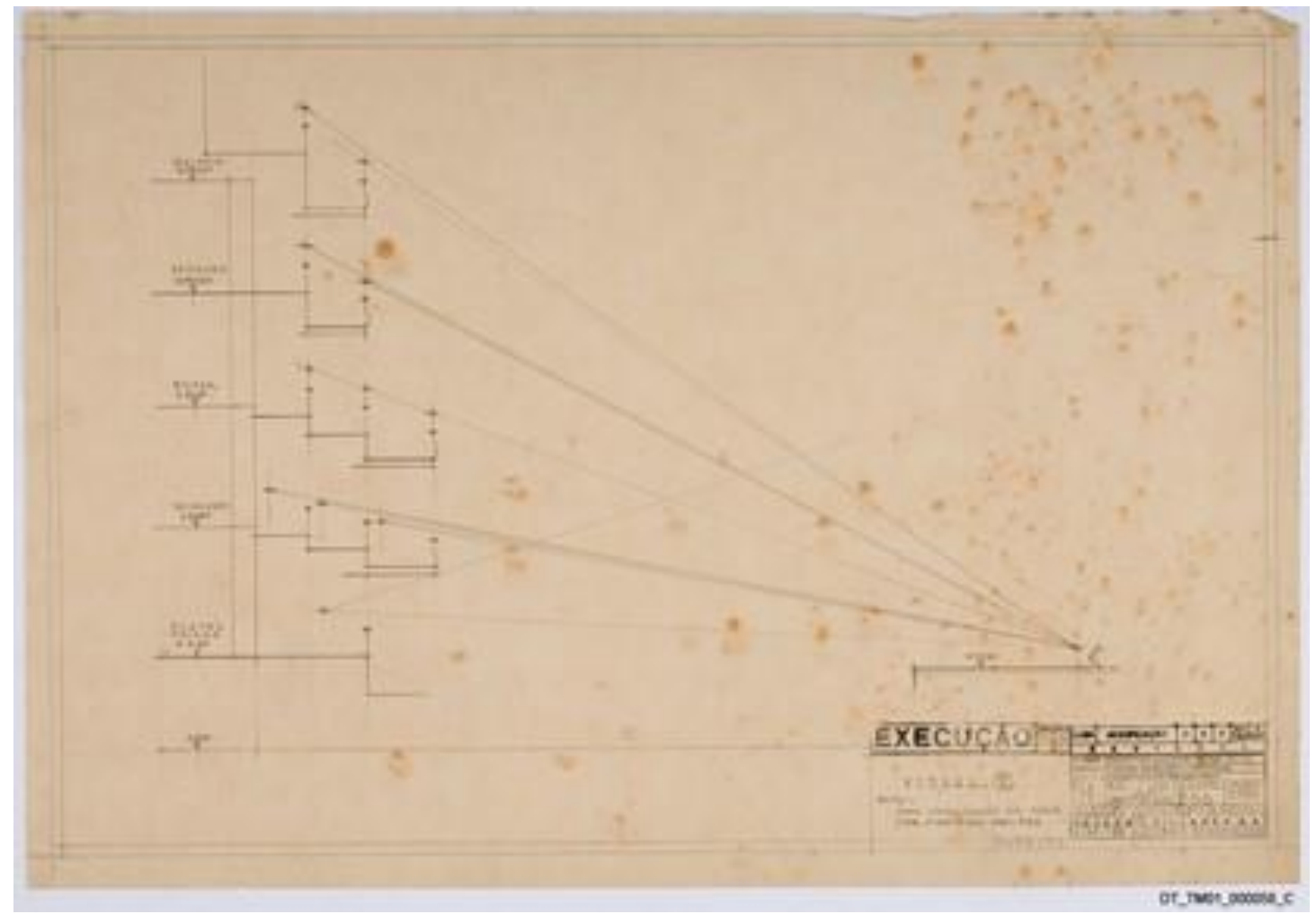

Figura 108: Corte transversal do projeto executivo de remodelação das ordens da sala de espetáculos.

Fonte: Acervo do Arquivo Histórico Municipal de São Paulo. 


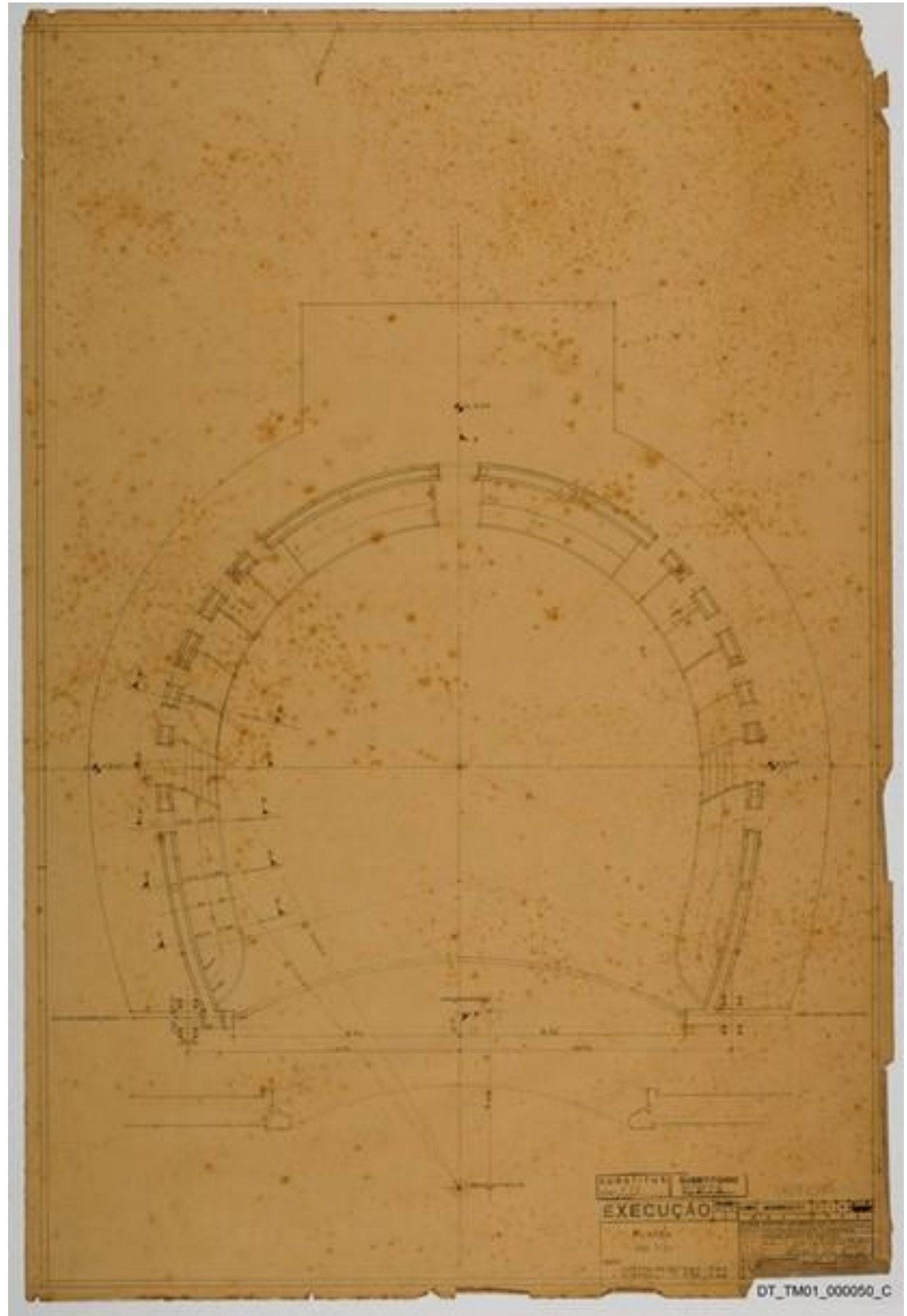

Figura 109: Planta do projeto executivo de remodelação da plateia. Fonte: Acervo do Arquivo Histórico Municipal de São Paulo. 


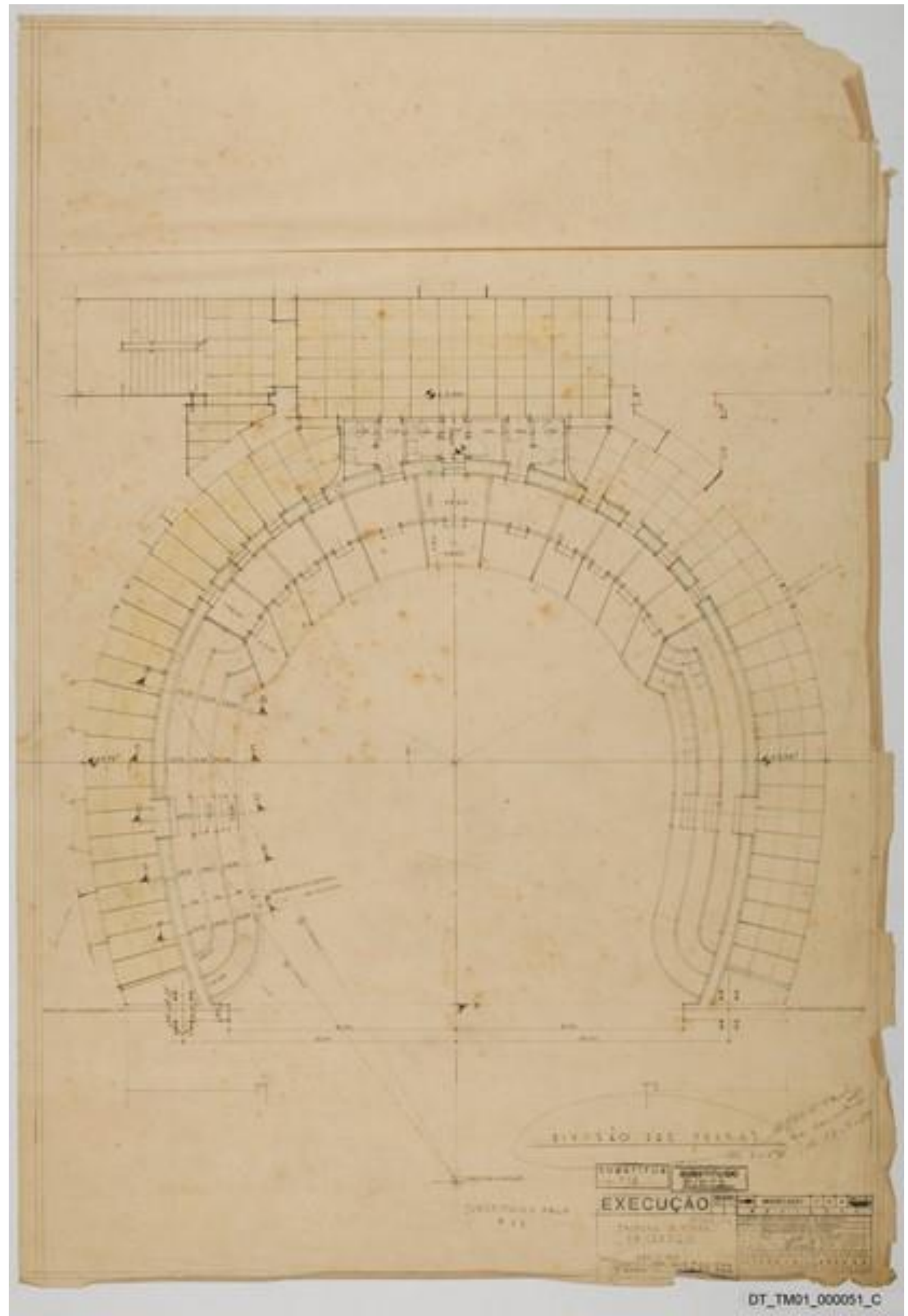

Figura 110: Planta do projeto executivo de remodelação da primeira ordem. Fonte: Acervo do Arquivo Histórico Municipal de São Paulo. 


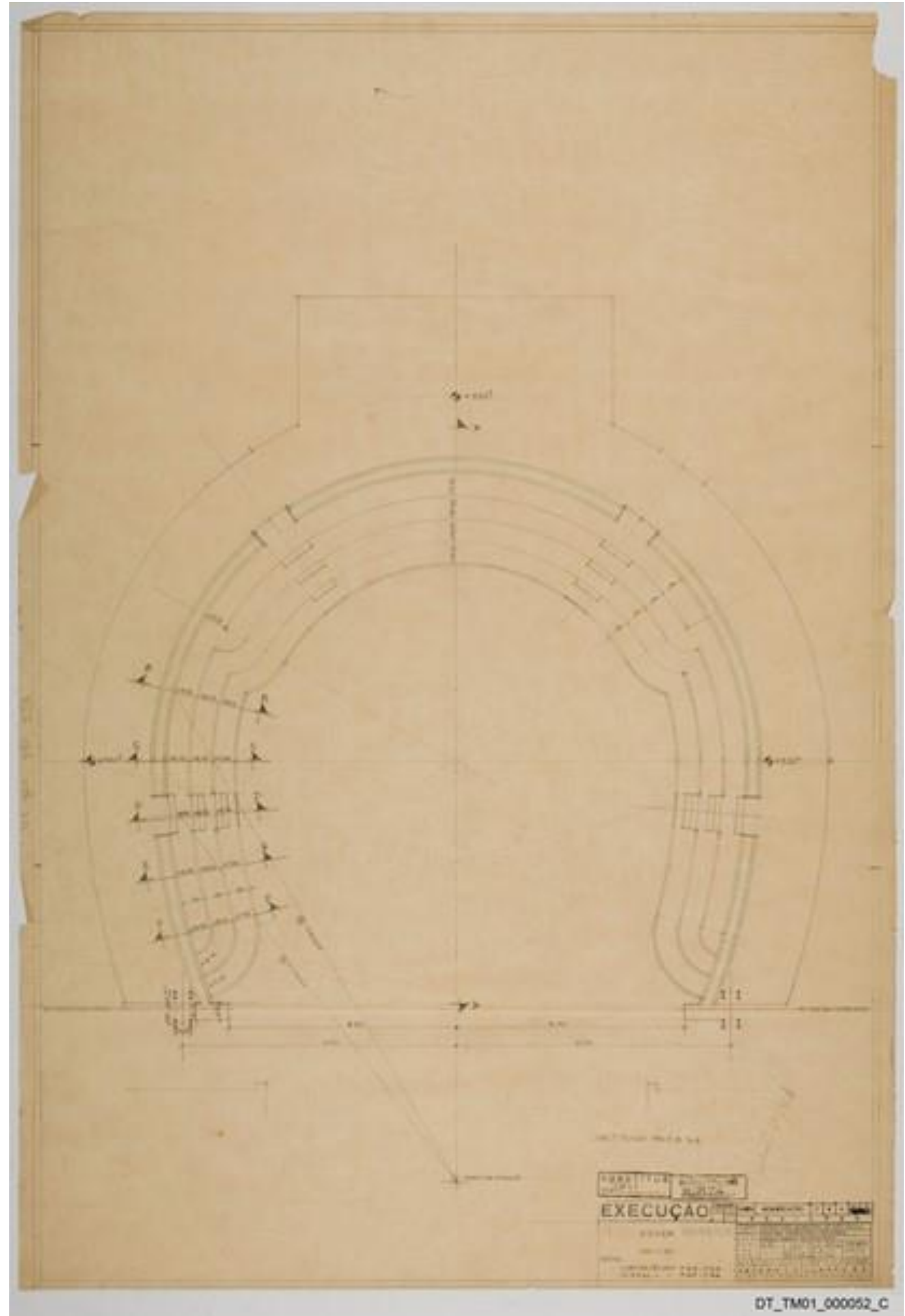

Figura 111: Planta do projeto executivo de remodelação do foyer. Fonte: Acervo do Arquivo Histórico Municipal de São Paulo. 


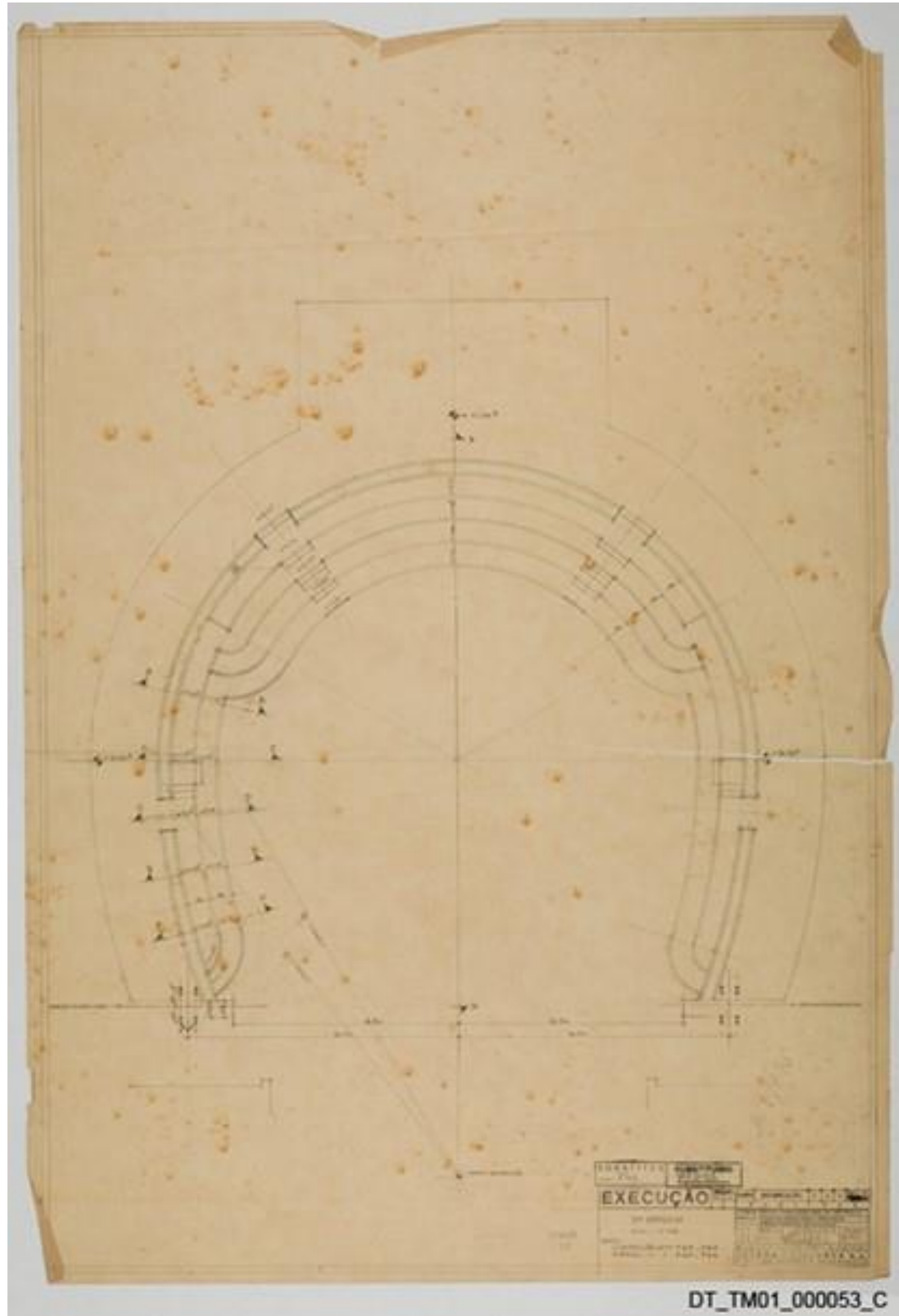

Figura 112: Planta do projeto executivo de remodelação da segunda ordem. Fonte: Acervo do Arquivo Histórico Municipal de São Paulo. 


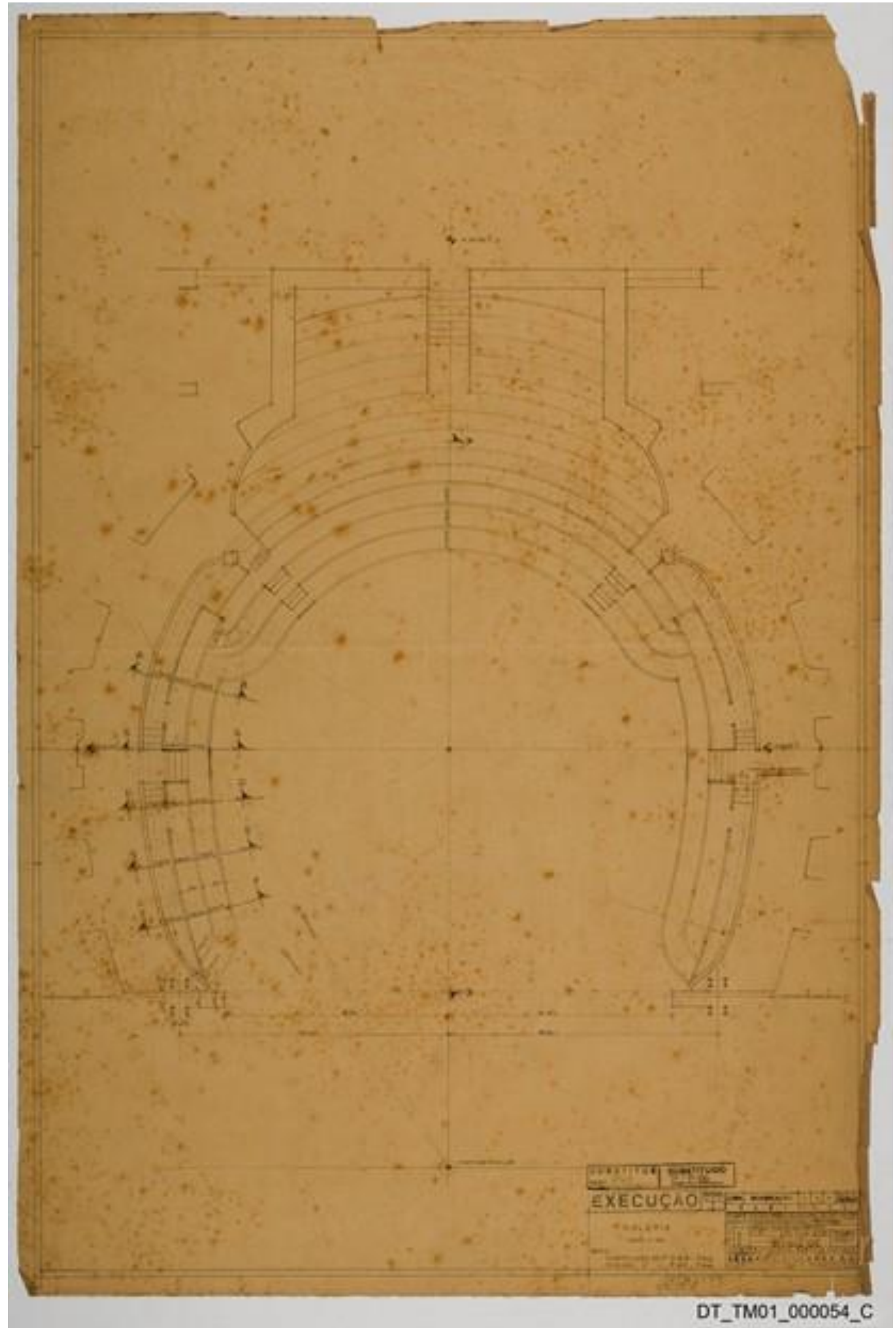

Figura 113: Planta do projeto executivo de remodelação da galeria. Fonte: Acervo do Arquivo Histórico Municipal de São Paulo. 


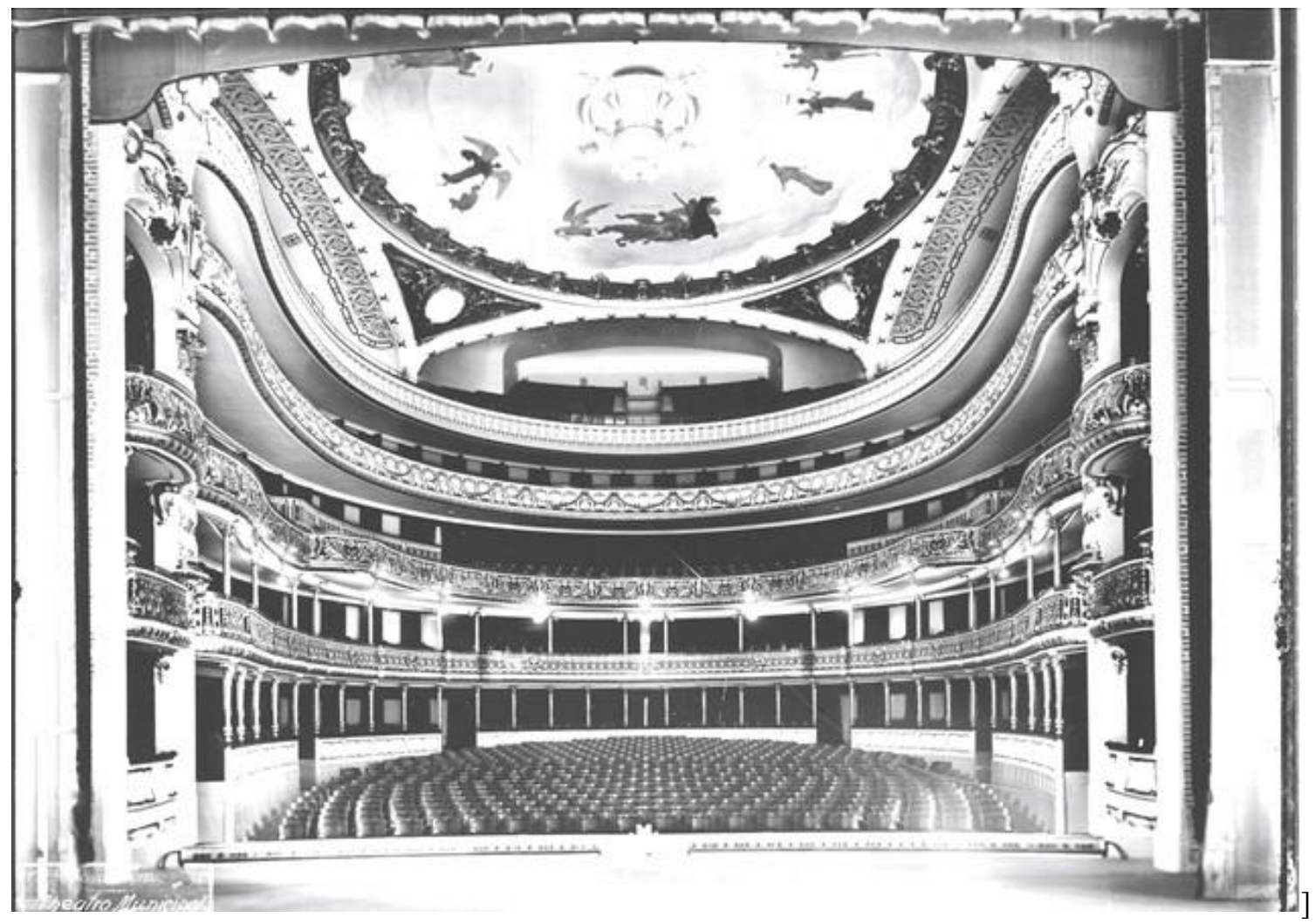

Figura 114: Fotografia interna do aspecto original da sala de espetáculos. Fonte: Acervo de material iconográfico da biblioteca da FAUUSP

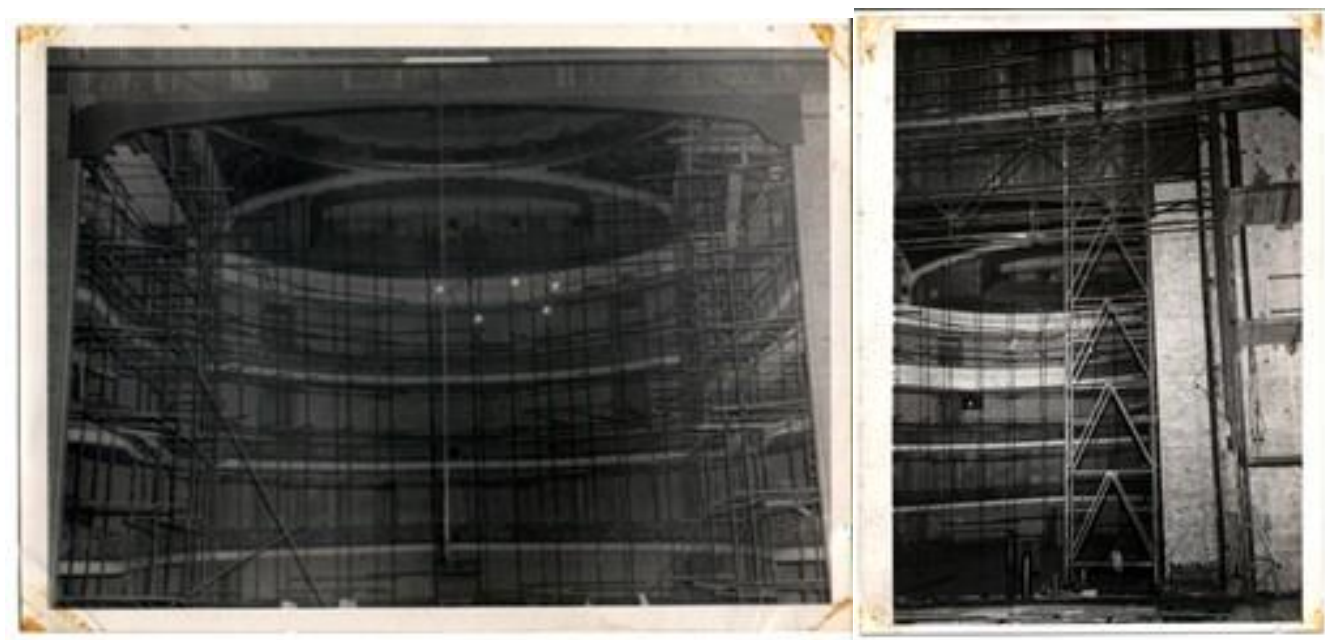

Figuras 115 (esq.) e 116 (dir.): Fotografias internas da sala de espetáculos com os andaimes, durante a obra da década de 1950.

Fonte: Acervo de Fotografias do Arquivo Histórico de São Paulo. 


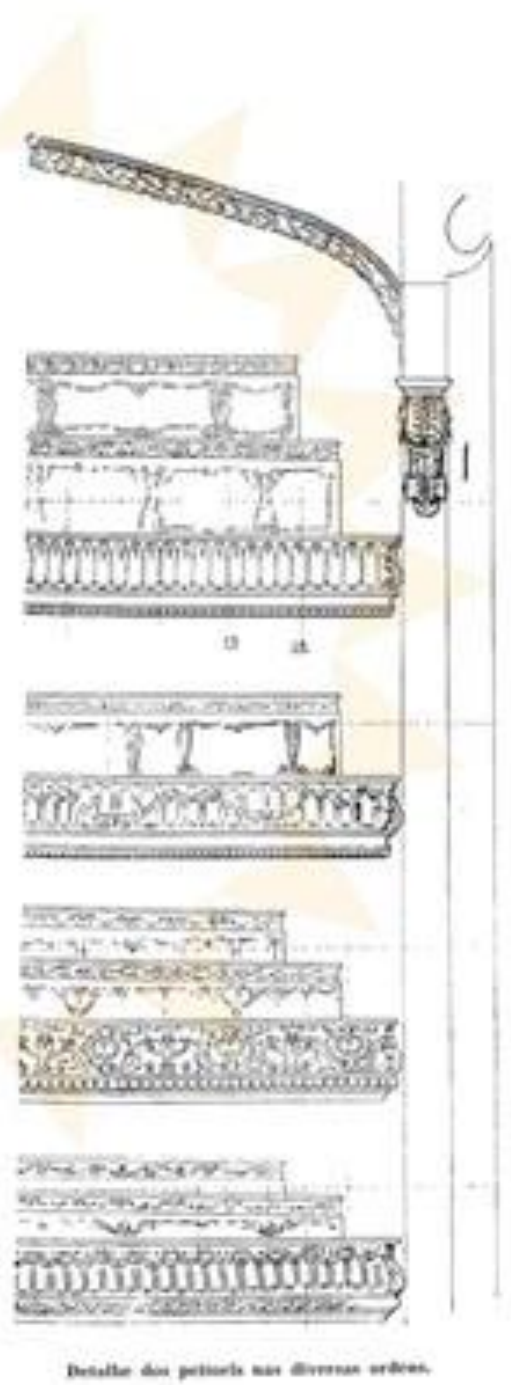

Figura 117: Elevação dos parapeitos das novas ordens da sala de espetáculos.

Fonte: PISTORESI, Tito Roucht. A Reforma do Teatro Municipal de São Paulo. Acrópole, São Paulo, v. 189, n.16, pp. 419-420, jan. 1954.

O mobiliário, por sua vez, foi inteiramente substituído. Foram executadas novas cadeiras e poltronas em perobinha clara, com estofado de veludo grená idêntico ao utilizado nos peitoris de todas as ordens (Figuras 118 e 119). Sobre o aspecto cromático dessa intervenção, o autor coloca que:

O mesmo veludo teremos nos peitoris de todas as ordens e nos reposteiros das arquibancadas. O complexo da sala de espetáculos será tratado com bastante coerência. Toda a decoração será baseada no pano de boca em contraste as várias tonalidades de ouro velho aí existentes como as aplicações no teto, nos estuques ou metal (PISTORESI, 1954, p. 420). 

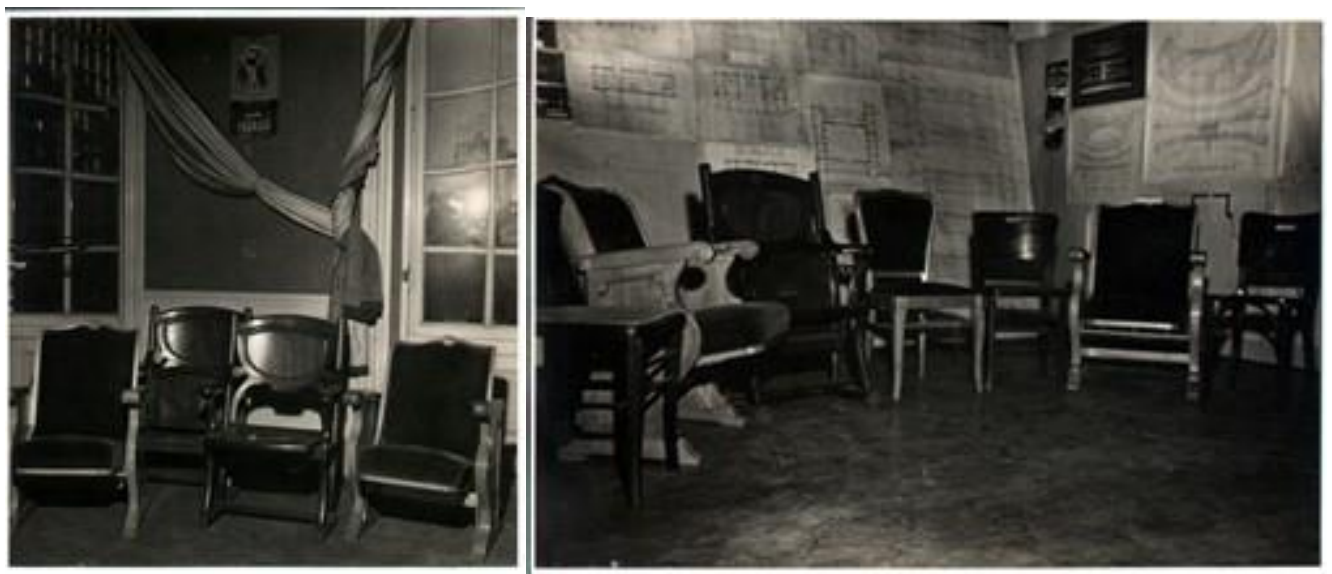

Figuras 118 (esq.) e 119 (dir.): Comparação entre o mobiliário original e o mobiliário novo. Fonte: Acervo de Fotografias do Arquivo Histórico de São Paulo.

Apesar da total remodelação do interior da sala de espetáculos, o arquiteto responsável pela obra reitera sua preocupação com a conservação do "valor original" do teatro ${ }^{48}$. Destaca-se aqui uma certa dissonância entre o discurso do autor e a realidade da intervenção, referida indistintamente pelo mesmo ora como "reforma", ora como "restauro".

Para além das modificações espaciais analisadas até aqui, a intervenção realizada na década de 1950 também contou com a instalação de equipamentos, na forma de elevadores e ar-condicionado. Foram instalados cinco elevadores, sendo eles três para público - dois para as diversas ordens e um que servia o anfiteatro e galeria - e dois para serviço, localizados na ala dos camarins.

Para o ar-condicionado foram aproveitadas as instalações de ar originais, datadas da inauguração do edifício ${ }^{49}$. Também foram construídos novos dutos e redes de distribuição, porém o aparelho de ar-condicionado não pôde ser importado e sua instalação ficara prevista para a futura colocação das máquinas. O sistema serviria a sala de espetáculos, os corredores, palco e camarins.

Nota-se que o discurso empregado por Pistoresi nessas publicações possui uma tônica comum, conduzida pela ideia de modernização, que está ancorada, por

48 "Para solucionar os dois grandes problemas (acústica e visibilidade), seria necessário modernizar o teatro, o que seria contra todos os preceitos inerentes a uma tradição histórica. Por isso, procurou-se obter os resultados desejados, sem destruir completamente o valor original da estrutura do teatro" (PISTORESI, 1954). Essa modernização, no entanto, veio as custas de extensas demolições e remodelações.

49 O sistema de ventilação mecânica do projeto original do Teatro consistia em dutos e redes de ventilação, filtragem de ar, aquecimento a vapor, umidificação e resfriamento por esguichos de água (REVISTA ACRÓPOLE. São Paulo, jan. 1956.) 
sua vez, na evolução da técnica construtiva e no ímpeto criativo do arquiteto. Por outro lado, não existe coerência no emprego dos termos "restauro" e "reforma", que são usados alternadamente para referir-se a um mesmo procedimento de intervenção.

\subsubsection{Restaurante}

O Restaurante foi um dos espaços mais modificados durante a reforma dos anos 1950. Sua configuração original, em dois ambientes delimitados por um par de colunas de ferro aparentes (Figura 120), ${ }^{50}$ foi transformada pela construção de uma parede e três divisórias, que separariam os ambientes administrativos a serem implementados (Figura 121).

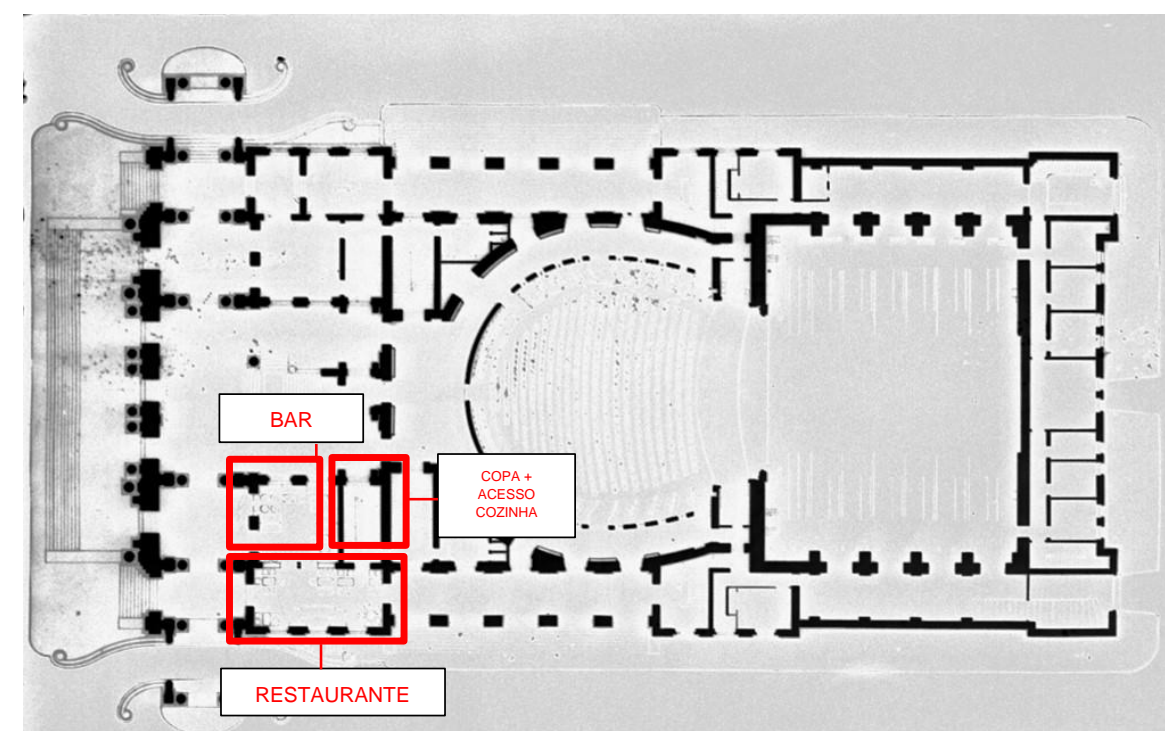

Figura 120: Planta original do primeiro andar (1903-1911), com destaque em vermelho para a área do restaurante.

Fonte: Acervo de Fontes Iconográficas da Biblioteca da FAUUSP.

50 Ver Capítulo 1 - Prelúdio da Modernidade. 


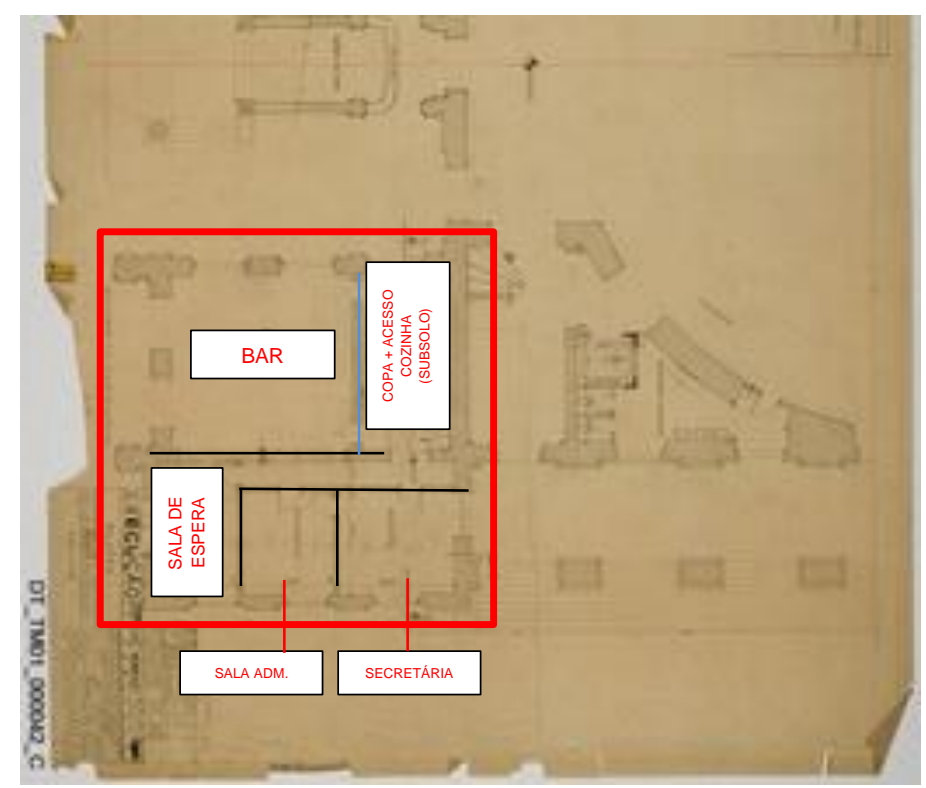

Figura 121: Planta do primeiro andar do projeto executivo de 1952-1955, com destaque em vermelho para a área do restaurante. As linhas em preto representam as paredes que seriam construídas como divisórias das áreas administrativas a serem implementadas e a linha azul, a parede existente.

Fonte: Acervo do Arquivo Histórico Municipal de São Paulo (AHM-SP).

Além de ter sua espacialidade profundamente transformada, o ambiente também padeceu com a perda de suas pinturas murais decorativas, sobre as quais foi aplicada uma repintura de tons lisos ${ }^{51}$. É importante destacar que, apesar de significativa, não há referências a intervenção sofrida pelo restaurante em nenhuma das publicações coetâneas analisadas.

A autoria dessas publicações, de punho do próprio arquiteto responsável pelo projeto, colabora com a hipótese de que não interessava divulgá-la, uma vez que o comprometimento da espacialidade e ambiência do restaurante evidenciaria o ímpeto destrutivo da intervenção que, ao contrário da proposta igualmente agressiva para os ambientes da Sala de Espetáculos e dos Camarins, não encontraria respaldo nem na modernização prevista para o primeiro e nem tampouco na menor importância dentro da hierarquia formal dos espaços do segundo.

51 Como já mencionado anteriormente, a impossibilidade de localizar o memorial descritivo do projeto limitou a obtenção de informações sobre as transformações sofridas pelo restaurante nos anos 1950. No entanto, durante a intervenção da década de 1980, como se verá a seguir, foram realizadas prospecções exploratórias a partir das quais foram redescobertas as pinturas decorativas do restaurante e estimou-se sua repintura como parte integrante do conjunto de modificações implementado na reforma anterior. 


\subsection{Balanço Crítico da Intervenção: Nova Cidade, Novos Monumentos}

$\mathrm{Na}$ esfera municipal, já a situação se torna mais complexa no momento, devido à série de erros cometidos anteriormente, com a absurda reforma do Teatro Municipal e a construção precipitada de teatrinhos de bairro sem um plano prévio para sua utilização (SILVEIRA, 1953, p.5).

A prefeitura entrega ao povo não um teatro reformado mas perfeitamente aparelhado para funcionar (FOLHA DA NOITE, 25 de outubro de 1955, p.3).

A recepção da intervenção da década de 1950 no Theatro Municipal não foi unânime. A opinião pública referiu-se a ela nos jornais ora como absurda reforma (SILVEIRA, 1953) ora como perfeito aparelhamento (FOLHA DA NOITE, 1955). Mais uma vez, vêem-se confundidos, assim como as publicações especializadas da época, os termos restauração e reforma (Figura 122) (FOLHA DA MANHÃ, 1955). No entanto, apesar da confusão semântica, deve-se destacar que o caráter daquela intervenção não tinha nada de restaurativo.

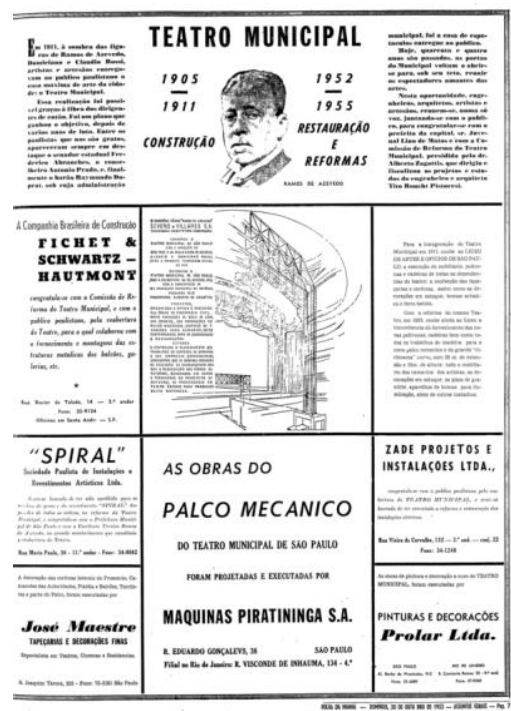

Figura 122: Encarte de página inteira sobre final da obra de intervenção do Theatro Municipal de São Paulo no qual misturam-se os termos restauração e reforma para designar o mesmo processo.

Fonte: FOLHA DA MANHÃ, 1955.

Tendo analisado as bases teórico-metodológicas do Restauro Filológico, percebe-se que a intervenção realizada no edifício do Theatro Municipal de São Paulo durante a década de 1950 não responde a esse referencial. Como concluído no item anterior deste capítulo, a intervenção da década de 1950 é pensada em torno de três conceitos chave: modernização, inovação e adequação funcional. 
Ao contrário do que preconizava o Restauro Filológico, que prezava pelo valor documental da obra, a intervenção sofrida pelo edifício do Theatro Municipal nesse período não apresentou preocupação em constituir falsos históricos ou artísticos. Buscou-se, de certa forma, uma unidade de estilo e harmonia formal que se daria através do impulso inovador do arquiteto, assim como a atualização funcional da sala de espetáculos, da bilheteria, do restaurante e dos camarins.

Apesar das discrepâncias, não é possível afirmar que o corpus teórico sistematizado contemporaneamente tenha sido - ou não- mobilizado pela intervenção, uma vez que fica claro tratar-se de uma reforma, não comprometida em absoluto com qualquer teoria de restauro. Resta indagar se essa prática era recorrente ou específica ao caso do Theatro Municipal de São Paulo. Aventa-se a possibilidade de que, por se tratar de um edifício de arquitetura eclética, ainda não reconhecido como monumento ou institucionalizado formalmente por meio do tombamento, não houvesse rigor teórico-metodológico envolvido na proposta.

No entanto, mesmo dentro da atuação prática do Iphan - único órgão responsável pela preservação do patrimônio na época-, a desconformidade com os postulados da Carta de Atenas marcou o que ficaria conhecido como sua fase "heróica". A partir daí, pode-se traçar um paralelo entre o caso da intervenção no Theatro, dentro de sua informalidade, e a atuação oficial do órgão no mesmo período: em ambos os casos, não houve preocupação em se constituírem falsos, sejam eles históricos ou artísticos, - ou ainda, nos termos de Viollet-le-Duc -, em atingir um estado anterior que pode nunca ter existido.

No quadro da Casa do Butantã, Luis Saia estava preocupado em atingir certa coerência com a tipologia da casa bandeirista, idealizada pelo próprio em suas pesquisas e hipóteses. No Theatro Municipal, no entanto, havia uma preocupação corretiva, tanto do ponto de vista funcional como estético, através de sua aproximação com o modelo da Ópera de Paris. Se a Casa era entendida como um exemplar de uma história que interessava ser contada de determinada maneira, o Theatro, por sua vez, o era como equipamento urbano indispensável a uma metrópole moderna. 
De acordo com Alois Riegl, todo monumento histórico é também, e ao mesmo tempo, monumento de arte. O que se verifica a partir da análise desses dois casos é que eles não foram entendidos dentro dessa dupla função, mas como expoentes de um único valor que sobrepuja os demais.

Também verificou-se que em ambos casos o valor de antiguidade, que deveria assumir o papel de destaque no ato de restaurar, fica esquecido. Na restauração de Luis Saia, as escolhas foram feitas exclusivamente a partir do valor histórico52, que buscava vincular aquele objeto à evolução de determinada tipologia ao longo do tempo. Na reforma de Pistoresi, por sua vez, buscou-se a harmonia da composição arquitetônica e funcional, partindo do valor artístico e de uso do objeto em questão.

Ao ignorar-se o valor documental da materialidade dos monumentos, tão preconizado pelo Restauro Filológico, sua restauração promove a implementação de falsos, tanto históricos, como artísticos. O olhar modernizador do apogeu das elites industriais pairava sobre essas intervenções (QUARENTA, 2009) e pretendia, ora refundar a identidade paulista, ora sua cultura artística.

O papel da construção identitária por meio de uma história revisada e exemplificada por objetos coerentes e excepcionais coube aos agentes "oficiais", vinculados à instituição de salvaguarda do patrimônio (Casa do Butantã). Quanto aos agentes "não-oficiais", ligados a iniciativas voltadas a bens não reconhecidos (Theatro Municipal de São Paulo), coube o papel de modernizar e revisar os parâmetros estéticos constituintes do cenário cultural paulista.

\footnotetext{
52 Entende-se aqui por valor histórico a concepção de Riegl, sendo ela: "O valor histórico de um monumento resulta, para nós, do fato de ele representar um estágio evolutivo de um domínio qualquer da atividade humana" (RIEGL, 2014, p. 55).
} 


\section{A DÉCADA DE 1980: RECONHECIMENTO}

No presente capítulo, será analisada a intervenção arquitetônica empreendida no edifício do Theatro Municipal de São Paulo entre os anos de 1982 e 1991, à luz das teorias de restauro coetâneas e da atuação do CONDEPHAAT como órgão estadual voltado à preservação do patrimônio paulista - desde sua criação às práticas empreendidas durante a década de 1980, tomando como estudo de caso a restauração da Cinemateca Brasileira empreendida na mesma época.

Foram analisados documentos primários na forma de projetos (plantas, cortes e elevações) e memoriais descritivos consultados no Acervo da Fundação Theatro Municipal de São Paulo, bem como uma série de relatórios elaborados à época pelo IPT, referentes ao estado de conservação do edifício, e uma série de fotografias e registros de obra organizados pela Método Construtora.

Também foram analisadas as publicações coetâneas que tematizavam a intervenção em questão, que foram veiculadas pela mídia especializada (Revista Projeto, Revista $A u$, Revista $A$ Construção), e pela mídia geral. Esses documentos foram cotejados com a bibliografia correspondente ao campo epistemológico da teoria da restauração (BRANDI, 2013; CARBONARA, 2006; KÜHL, 2007/ 2011 e Carta de Veneza) e da atuação prática do Condephaat (NASCIMENTO, 2016; MARINS, 2016; PISANI, CORRÊA, 2009; MARCON, ALMEIDA, 2012; JACCOUDJUNIOR, 2019).

\subsection{A segunda metade do século $X X$}

A segunda metade do século $X X$ foi marcada internacionalmente pelas discussões do chamado Restauro Crítico e da teoria de Cesare Brandi, que foram condensadas na Carta de Veneza (1964). No Brasil, o cenário da preservação adentrava em um período de alargamentos conceituais ${ }^{53}$, que correspondeu à criação de órgãos estaduais, como é o caso do Condephaat. A seguir, serão comentados esses contextos que, tanto em âmbito nacional como

\footnotetext{
${ }^{53}$ Pode-se dizer que a adoção desses alargamentos vem se dando de maneira demorada, dentro de uma progressão que se estende até os dias de hoje.
} 
internacional, permearam a execução da intervenção no Theatro Municipal de São Paulo, empreendida durante a década de 1980.

\subsubsection{Contexto Internacional: Restauro Crítico, Cesare Brandi e Carta de Veneza}

A segunda metade do século $X X$ serve como pano de fundo para intensas discussões e transformações dentro da disciplina da preservação do patrimônio. Com o pós II Guerra Mundial, o Restauro Filológico preconizado pelos teóricos da primeira metade do século encontra seus limites de atuação. A ênfase no caráter documental da obra de arte ignorava aspectos importantes do campo epistemológico da estética e da percepção formal do objeto, o que não oferecia ferramentas suficientes para lidar com as destruições massivas da última guerra (KÜHL, 2007).

É nesse contexto, e a partir da transposição dessas barreiras, que surge a corrente do Restauro Crítico, fundamentalmente elaborada por Roberto Pane e Renato Bonelli. A posição de Roberto Pane, à frente do movimento, se manifesta justamente na superação dos limites do restauro filológico com base na estética de Croce.

Para Pane, a singularidade de cada obra de arte evidenciava a necessidade de efetuar escolhas complexas no ato do restauro, baseadas em um juízo crítico (CABRAL, ANDRADE, 2012). A visão de singularidade da obra de arte, também presente em Bonelli, o conduz ao pensamento da restauração como "ato de cultura", que é ao mesmo tempo crítico e criativo ${ }^{54}$, alicerçado no presente (KUHL, 2010).

Para além desses dois teóricos, uma das figuras centrais desse contexto foi o crítico e historiador da arte italiano Cesare Brandi. Seus princípios, compilados na Teoria da Restauração, inicialmente publicada em 1963, efetuam o

\footnotetext{
${ }^{54}$ Essa criatividade, no entanto, não pressupõe o retorno a unidade de estilo, como defendido pelo restauro estilístico de Viollet-le-Duc, mas sim a recomposição da unidade figurativa da obra no momento presente, que será abordada com maior detalhe a seguir (CUNHA; KUHL, 2012).
} 
alargamento conceitual e a comprovação da postura crítica em relação ao restauro, que se assumiria a partir daquele momento ${ }^{55}$ (CARBONARA, 2004).

O destaque de Brandi deve-se em parte à amplitude de sua experiência, não só em elaborações teórico-conceituais, como na comprovação prática das mesmas. Sua posição como presidente do ICR (Instituto Central de Restauração), desde sua fundação em 1939 até a década de 1960, possibilitou a experimentação exaustiva de suas teorias, em especial nos campos da escultura e da pintura (CARBONARA, 2006). Sua relevância naquele período se alarga até os dias de hoje, quando suas formulações continuam referência no campo da restauração ${ }^{56}$.

O eixo condutor da teoria de Brandi é o reconhecimento da obra de arte como unidade e sua manifestação na matéria, no espaço e no tempo. Sua definição de restauração parte justamente desse entendimento de obra como "produto especial da atividade humana", a partir do qual o restauro seria "(...) o momento metodológico do reconhecimento da obra de arte, na sua consistência física e na sua dúplice polaridade estética e histórica, com vistas à sua transmissão para o futuro" (BRANDI, 2004, p. 30).

Nesse esquema, a instância estética sempre tem prevalência sobre a histórica e a obra de arte é concebida como inteiro, ou seja, sua lógica difere daquela verificada na unidade orgânico-funcional da realidade circundante. Dada sua singularidade, uma obra jamais pode ser lida como um todo composto por partes. É partindo desse ponto de vista que Brandi se coloca terminantemente contra intervenções por analogia, uma vez que "o procedimento por analogia exigiria como princípio a equiparação da unidade intuitiva da obra de arte com a unidade lógica com a qual se pensa a realidade existencial” (BRANDI, 2004, p. 47).

\footnotetext{
${ }^{55}$ Apesar da proximidade cronológica que o cenário do pós segunda guerra mundial europeu Ihes proporcionava, Brandi e os teóricos do restauro crítico divergiam em certos postulados conceituais. Por exemplo, com relação à inserção de arquitetura moderna em malhas urbanas historicizadas, ao que Brandi se opunha fortemente e Pane se posicionava de maneira mais flexível. Também o conceito de instância psicológica da obra de arte que, para Pane se sobrepõe às instâncias histórica e artística, não é sequer mencionada na teoria de Brandi (CABRAL; ANDRADE, 2012).

${ }^{56} \mathrm{~A}$ atualidade e aplicabilidade da teoria de Cesare Brandi será elaborada com maior detalhe no Capítulo 4 da presente dissertação, no qual serão tratadas as questões relativas à intervenção sofrida pelo edifício do Theatro Municipal de São Paulo na década de 2010.
} 
Essa noção de unidade também é fundamental para entender a postura do autor quanto ao problema das lacunas. A compreensão de determinada obra pode ser prejudicada no caso de uma ruptura figurativa que, de acordo com a teoria da Gestalt, faria com que a relação figura-fundo se invertesse. A postura corrente ao tratar esse problema costumava ser o uso de tinta neutra, ao qual Brandi se opõe. Para ele, o conceito da neutralidade cromática não existe, devendo ser substituído pelo rebaixamento ótico.

Entre as diversas maneiras de se preencher as lacunas a partir do princípio do rebaixamento ótico, o ICR desenvolveu a técnica do Trattegio. Essa metodologia consiste no completamento por meio de traços finos verticais, que se diferenciam do original por meio da técnica e material empregados.

Dito isso, fica claro que a restauração da obra de arte é indissociável da matéria, sendo a última o tempo e o lugar da primeira. Para Brandi, a divisão entre imagem e matéria não existe, mas sim sua constituição em estrutura e aspecto, sendo esse caracterizado pela epifania da imagem. Em uma intervenção de restauro, o aspecto teria sempre prevalência sobre a estrutura.

O espaço também se enquadra na perspectiva de meio físico para transmissão da imagem, sendo ele dividido entre a espacialidade autônoma da obra e o espaço físico da existência. O problema da restauração, agravado no caso da arquitetura devido a maior coincidência entre ambos, estaria justamente no seu ponto de sutura.

O tempo da obra de arte, por sua vez, é entendido em três momentos distintos: o tempo da sua feitura, o tempo da fruição e o intervalo entre ambos. Existia até então a tendência de considerar, tanto na historiografia da arte como na restauração, apenas o primeiro e segundo tempos. No último caso, a intervenção que se insere no passado, ou seja, no tempo de execução da obra, torna-se uma restauração fantasiosa; a intervenção que se insere no transcurso do tempo, ou seja, no intervalo entre a feitura e a fruição da obra, é considerada repristinação. Desse modo, o único momento legítimo para uma intervenção de restauro seria 
o presente, sem que se ignorem, no entanto, as outras duas temporalidades constituintes da obra.

Outra noção cara ao pensamento brandiano, a pátina, era entendida justamente como o testemunho material do tempo transcorrido. Para Brandi, a pátina era uma adição que deveria ser preservada tanto do ponto de vista da historicidade como da estética, uma vez que "está ligada de forma intrínseca ao respeito da unidade potencial da obra de arte que a restauração propõe a si própria" (BRANDI arte, 2004, p. 72).

O problema das adições extrapola os limites conceituais da pátina e ganha maiores contornos teóricos ao serem abordadas as já referidas instâncias estética e histórica. Sob o ponto de vista da história, a preservação da adição é incondicionalmente legítima, enquanto a remoção deve ser sempre justificada. Já do ponto de vista da estética, a adição clama pela sua remoção. Dessa forma, é "sempre um juízo de valor que determina a prevalência de uma ou de outra instância na conservação ou na remoção das adições" (BRANDI, 2004, p. 85).

Um ano depois da publicação da Teoria de Brandi, é realizado o /l Congresso Internacional de Arquitetos e Técnicos dos Monumentos Históricos, que tem como resultado a redação da Carta de Veneza. Assim como o Restauro Crítico e o pensamento teórico de Brandi haviam se preocupado em revisar alguns dos conceitos do Restauro Filológico, ultrapassados pelas contingências históricas, a Carta de Veneza se propunha a fazê-lo com relação à de Atenas.

O já mencionado arquiteto Roberto Pane teve papel importante na redação da Carta. Apesar das divergências conceituais específicas com relação ao pensamento de Brandi, ele se detém na sua obra durante seu discurso de abertura do Congresso de Veneza, em concordância com os princípios da Teoria publicada no ano anterior (KÜHL, 2010).

Como documento, a Carta reconhece a universalidade do patrimônio e a necessidade da unidade de princípios que deve reger a sua conservação e restauração, em escala internacional. Nesse cenário, "a Carta de Veneza é 
herdeira direta do restauro crítico e, indiretamente, também da teoria de Brandi." 57

A principal contribuição de Pane para a redação da Carta de Veneza foi a ampliação do conceito de monumento, expressa no artigo $1^{\circ}$ do documento, que passa a abarcar não só "a criação arquitetônica isolada, bem como o sítio urbano ou rural que dá testemunho de uma civilização particular, de uma evolução significativa ou de um acontecimento histórico." 58 Esse postulado reflete a preocupação com o tema do ambiente, que já afligia Giovannoni no primeiro pós guerra, e que passa a ser uma questão ainda mais proeminente durante 0 segundo pós guerra.

Uma vez definido o conceito de monumento histórico, a Carta expõe a finalidade da sua conservação e restauração como sendo uma forma de salvaguardá-lo para as gerações futuras. Os artigos que se encabeçam a seguir são divididos entre aqueles que dizem respeito a conservação e a restauração, separadamente ${ }^{59}$.

A conservação compreende a manutenção permanente dos monumentos, a destinação de um uso adequado e a indissociabilidade com o sítio e os bens imóveis integrados ${ }^{60}$. Quanto à restauração, fica explícito o seu caráter excepcional, que deve levar em consideração a dialética entre artisticidade e historicidade, a questão da matéria original e da documentação autêntica.

Também fica evidente a posição favorável a respeito da incorporação de técnicas modernas em atos de restauro, quando as tradicionais se mostrarem inadequadas; e a obrigatoriedade de manutenção das marcas da estratificação do tempo na obra. Quanto às substituições, essas devem integrar-se harmoniosamente enquanto distinguem-se das partes originais. A posição em

\footnotetext{
57 KÜHL, Beatriz Mugayar. Notas sobre a Carta de Veneza. Anais do Museu Paulista, Dez 2010, vol. 18, n. 2, p. 295.

${ }^{58}$ Carta de Veneza. Revista do Patrimônio Histórico e Artístico Nacional, 1987, n.22, pp. 106107.

${ }^{59}$ A separação entre conservação e restauração é um dos principais pontos de desencontro entre a Carta de Veneza e a Teoria de Brandi. Para o teórico, toda intervenção em uma obra de arte é considerada restauração.

${ }^{60}$ Artigos $4^{\circ}$ a $8^{\circ}$ da Carta de Veneza. Ver: Carta de Veneza. Revista do Patrimônio Histórico e Artístico Nacional, 1987, n.22, pp. 106-107.
} 
relação aos acréscimos é mais radical, sendo apenas "tolerados" se respeitarem todas as partes do edifício ${ }^{61}$.

Em relação aos sítios monumentais, fica estabelecida a necessidade de sua salvaguarda, saneamento, manutenção e valorização, que devem seguir os princípios enunciados nos artigos referentes à conservação e restauração ${ }^{62}$. 0 artigo sobre escavações, referente ao patrimônio arqueológico, postula sua salvaguarda através da manutenção e conservação das ruínas, sendo excluída, a princípio, a possibilidade de reconstruções, admitindo-se no máximo a anastilose ${ }^{63}$.

Finalmente, são colocadas as questões referentes à documentação dos trabalhos de conservação, restauração e escavação mencionados à cima. Esses processos devem ser acompanhados pela elaboração de uma documentação composta por relatórios, desenhos e fotografias, que registrem as intervenções sofridas pela obra ${ }^{64}$.

\subsubsection{Contexto Nacional: Condephaat e alargamentos conceituais}

Após quase trinta anos de sua criação, o IPHAN sofreu um transbordamento de demandas, que acabou contribuindo para a criação dos primeiros órgãos estaduais de preservação, que atuariam no sentido de considerar as heranças culturais regionais. Além do CONDEPHAAT, é criado também, nesse mesmo período, o INEPAC - Instituto Estadual do Patrimônio Cultural, no Rio de Janeiro, em 1965 (NASCIMENTO, 2016).

A criação do CONDEPHAAT - Conselho de Defesa do Patrimônio Histórico, Arqueológico, Artístico e Turístico - a partir da Lei n. 10.247 de 22 de outubro de 1968, se dá em um contexto diferente daquele que contingenciou a criação do IPHAN. O próprio nome da instituição denota uma visão mais alargada daquilo

${ }^{61}$ Artigos $9^{\circ}$ a $13^{\circ}$ da Carta de Veneza. Ver: Carta de Veneza. Revista do Patrimônio Histórico e Artístico Nacional, 1987, n.22, pp. 106-107.

62 Artigo $14^{\circ}$ da Carta de Veneza. Ver: Carta de Veneza. Revista do Patrimônio Histórico e Artístico Nacional, 1987, n.22, pp. 106-107.

63 Artigo $15^{\circ}$ da Carta de Veneza. Ver: Carta de Veneza. Revista do Patrimônio Histórico e Artístico Nacional, 1987, n.22, pp. 106-107.

${ }^{64}$ Artigo 16을 da Carta de Veneza. Ver: Carta de Veneza. Revista do Patrimônio Histórico e Artístico Nacional, 1987, n.22, pp. 106-107. 
que se consideraria patrimônio, para além dos limites dos bens de "excepcional valor", defendidos pelo seu correspondente a nível federal.

Para além das questões de escala regional, os órgãos estaduais foram criados em um momento de ampliação de abordagens com relação ao patrimônio, muito influenciada pela releitura historiográfica da Escola dos Annales e o conceito de bem cultural preconizado pela Carta de Veneza (1964). Essa revisão conceitual alarga o conceito de bem cultural, concebido originalmente pelo IPHAN no sentido de documento histórico, e permite que sejam considerados para salvaguarda outros objetos, que não o de "excepcional valor", como é o caso da "arquitetura menor" e dos conjuntos urbanos. Representantes de outras etapas da gênese da cultura arquitetônica nacional, que não o barroco ou o moderno, passam a ser consideradas merecedoras de preservação, como nos casos do ecletismo e da arquitetura industrial (MARINS, 2016).

Em 1975 é finalmente criado o DPH - Departamento do Patrimônio Histórico, órgão municipal de salvaguarda ao patrimônio, cuja origem remonta ao antigo "Departamento de Cultura", idealizado por Mário de Andrade durante a década de 1930. Mas apenas na década seguinte é que seria criado seu respectivo conselho, o CONPRESP - Conselho Municipal de Preservação do Patrimônio Histórico, Cultural e Ambiental da Cidade de São Paulo, pela Lei 10.032 de 27 de dezembro de 1985 - o que possibilitou a institucionalização do tombamento municipal.

A criação dos órgãos estaduais e municipais também vai no bojo das transformações do pensamento a respeito do patrimônio histórico, que, na esteira da Carta de Veneza, expande seus interesses e passa a considerar outras heranças, que não a homogeneizante identidade nacional buscada pelo IPHAN nas suas origens.

Na década de 1980, com a redemocratização do país, acontece uma segunda mudança de rumo na trajetória dos órgãos de preservação. Os bens culturais, já entendidos como documento, passam a ser considerados não apenas como "o testemunho no sentido da prova documental da história nacional que se narrava, 
mas, sim, como fonte documental da história passível de interpretação, questionamento, perguntas e problematização pelo historiador"65.

É nesse momento que o Theatro Municipal de São Paulo, tão distante daquela "história nacional que se narrava", é tombado pelo CONDEPHAAT e, posteriormente, pelo CONPRESP (1991/ ex-oficio). A Resolução SC 49/81, de 23 de dezembro de 1981, responsável pelo tombamento do Municipal na escala estadual, reconhece seu valor histórico-arquitetônico, sobretudo no tangente a sua importância paisagística e cultural:

Fica tombado como bem cultural de interesse histórico-arquitetônico o Teatro Municipal de São Paulo, edifício que, por sua importância, desde sua inauguração em 1911, participou tradicionalmente da leitura da paisagem do núcleo central urbano, comportando manifestações das mais significativas do campo musical e das artes cênicas em nossa Capital (RESOLUÇÃO SC 49/81, p. 1).

Nesse mesmo contexto, outros bens culturais distantes do cânone barroco, não só relacionados ao ecletismo como à arquitetura industrial, foram reconhecidos na escala regional. Em situação análoga ao Theatro, o edifício do matadouro da Vila Mariana - atual Cinemateca Brasileira - foi tombado e restaurado no decorrer dos anos 1980. No começo da década, o DPH encaminhara um pedido de tombamento que foi aprovado pelo CONDEPHAAT em 1985, apenas quatro anos depois da resolução de proteção do Municipal.

A resolução SC 07/85, responsável pelo tombamento da Cinemateca, destaca a qualidade do projeto e seus materiais, mas sobretudo enfatiza sua importância como exemplar da arquitetura industrial de finais do século XIX. Simultaneamente ao reconhecimento do Theatro Municipal a nível municipal, o edifício do matadouro é tombado ex-ofício pelo CONPRESP em 1991.

Adentrar as semelhanças e diferenças entres os processos de intervenção sofridos por ambos os edifícios, dada a afinidade do contexto, pode informar

65 NASCIMENTO, Flávia Brito do. Patrimônio Cultural e escrita da história: a hipótese do documento na prática do Iphan nos anos 1980. Anais do Museu Paulista, São Paulo, v. 24, n. 3 , p.121-147, set./dez. 2016, p. 128. 
sobre uma postura mais geral dos órgãos de preservação do patrimônio a nível estadual e municipal. Essa informação, combinada com o aporte teórico do campo epistemológico do restauro, pode enriquecer a análise pretendida pelo presente trabalho.

O edifício em questão, fruto de um concurso ganho pelo arquiteto alemão Alberto Kuhlmann, foi inaugurado em 1887 (Figura 123). O anterior matadouro do município, localizado no que hoje configura o bairro da Liberdade, havia sido construído em 1852, mas com o crescimento da população e a expansão da cidade de São Paulo, passou a ser insuficiente e mal situado66.

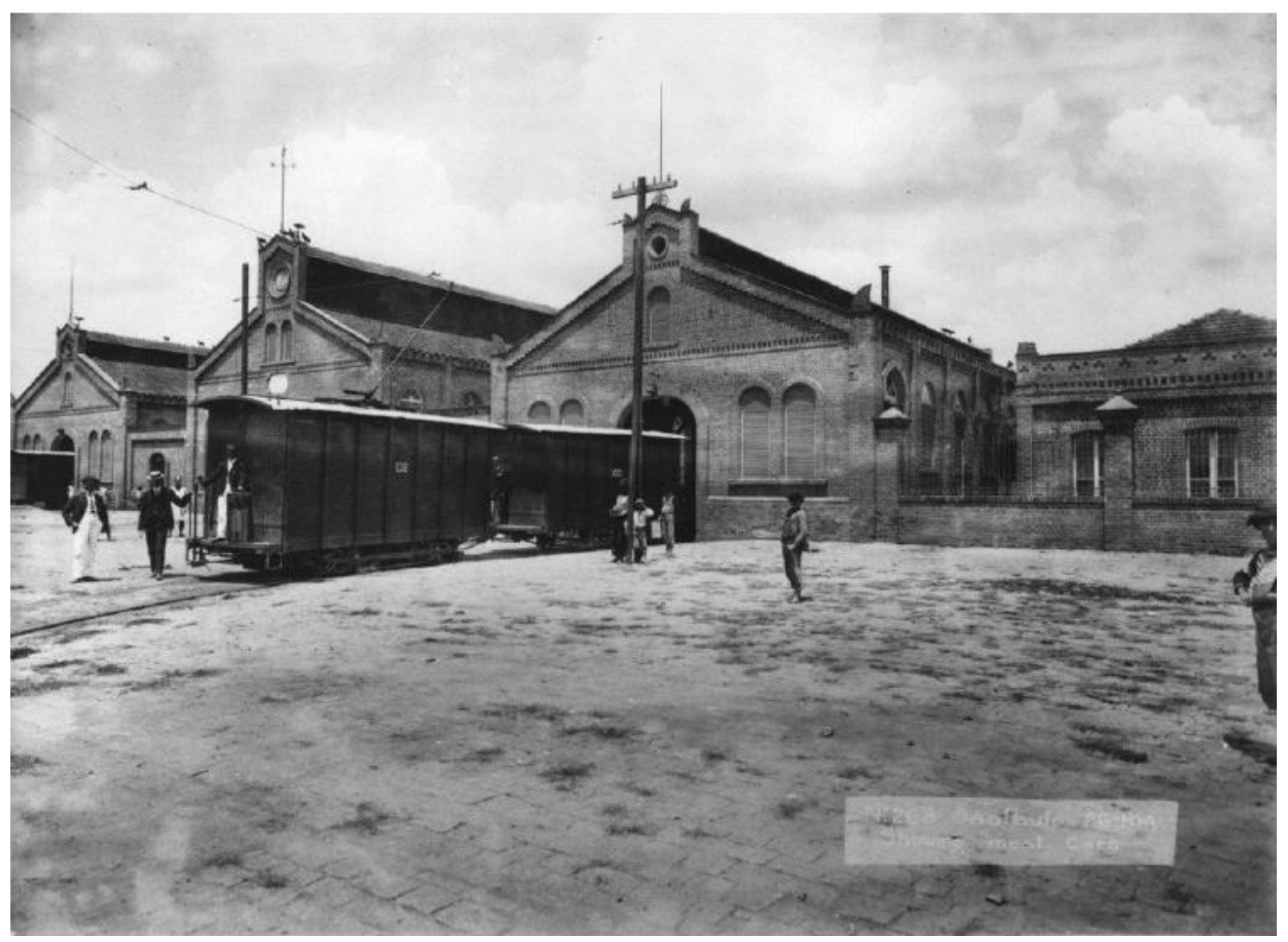

Figura 123: Exterior dos galpões que compunham o matadouro da Vila Mariana em 1900. Fonte: <https://www.flickr.com/photos/cinematecabrasileira/5055335890/>. Acesso em: 12 ago. 2020.

${ }^{66}$ A localização ideal para matadouros urbanos tendia para a periferia, fora dos centros das cidades. Com a expansão de São Paulo, bairros antes mais afastados, como o caso da atual Liberdade, passaram a integrar a centralidade. O despejo de dejetos advindos da atividade do matadouro passou a sobrecarregar o Córrego do Anhangabaú, na vizinhança, o que também configurou um motivo para a mudança de localização (MURILHA, 2011). 
Cada um de seus três galpões em alvenaria de tijolos aparentes foram cobertos por telhados de duas águas e telhas cerâmicas, sustentadas por tesouras de madeira e presença de lanternim central. Essa tipologia, marcadamente industrial - como destacado pelo ofício de tombamento -, aponta para o processo de substituição da arquitetura em taipa pela de tijolos, que coincide com a intensificação da chegada de imigrantes europeu (PISANI; CORRÊA, 2009).

A partir do começo do século XX, com os novos processos de crescimento da população e expansão urbana de São Paulo, o matadouro passa a se tornar obsoleto. O despejo excessivo de dejetos no córrego do Sapateiro, que ladeava sua construção, aliado ao desgaste natural do edifício, intensificaram esse processo de inadequação (Figuras 124 e 125). Em 1927, é desativado e passa a ser ocupado por diversos órgãos municipais que acabam por descaracterizálo para atender suas necessidades programáticas próprias (MARCON; ALMEIDA, 2012).

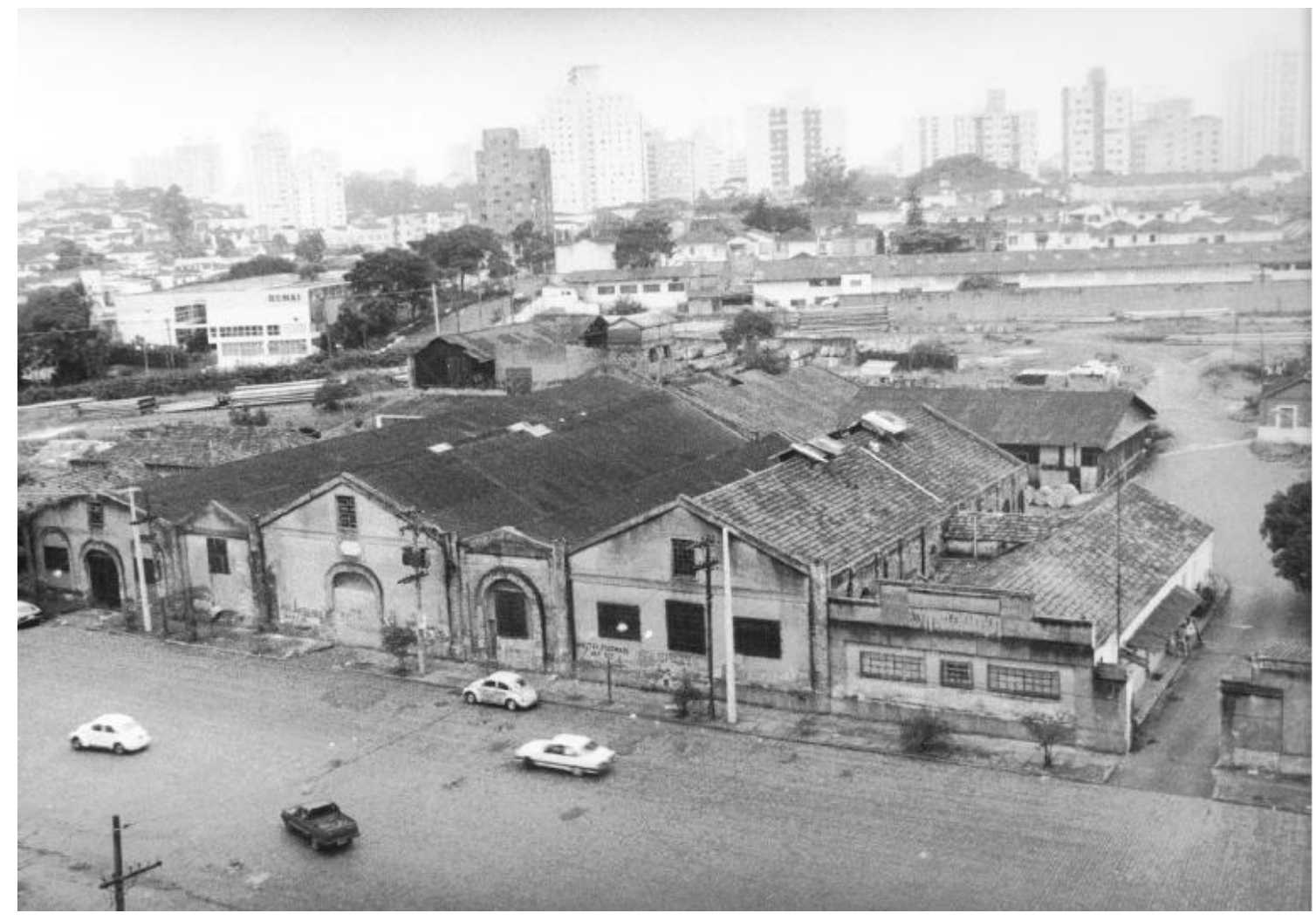

Figura 124: Vista aérea do conjunto do Matadouro da Vila Mariana após a sua desativação. Fonte: <https://www.flickr.com/photos/cinematecabrasileira/5054716397/>. Acesso em: 12 ago. 2020. 


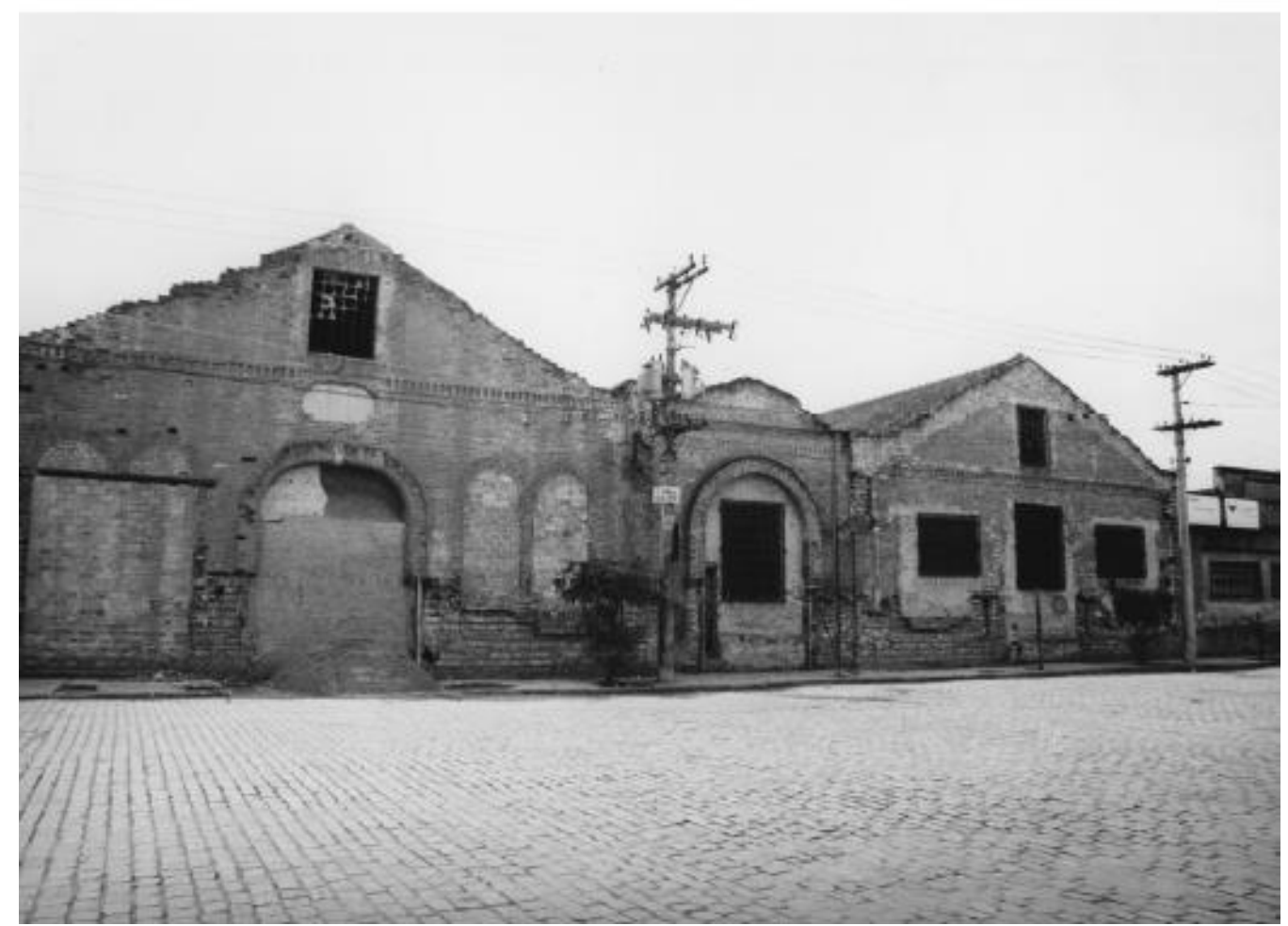

Figura 125: Fachada do conjunto antes da restauração na década de 1980.

Fonte: <https://www.flickr.com/photos/cinematecabrasileira/5054716545/>. Acesso em: 12 ago. 2020.

Desde a sua desativação como matadouro, o edifício passa por três intervenções diferentes. Para o fim do presente trabalho e devido ao recorte temporal da análise principal, cabe dedicar maior atenção à primeira, empreendida pelo DPH contemporaneamente à elaboração da proposta de restauro do Theatro Municipal pelo mesmo órgão.

Essa proposta, idealizada pela equipe formada pelos arquitetos Fernando José Martinelli e José Osvaldo Vilela, visava a "reconstituição das características originais do conjunto por meio de investigação histórica", o que configura essencialmente um procedimento a-histórico. Para cumprir com tal objetivo, foi sugerido que se removessem todas as alterações feitas a partir de 1938, período no qual a descaracterização do edifício se manifestara de forma mais intensa.

Ao cotejarmos as fotografias tiradas antes da intervenção com o projeto de restauro das fachadas (Figuras 126 e 127), concluímos que em grande parte, a "reconstituição" almejada pelo DPH durante a década de 1980 consistia na reconstrução dos lanternins centrais e na recuperação das aberturas, que 
haviam se perdido. Apesar dessa postura, que esbarra na pretensão de tomar o tempo como reversível, assim contradizendo o Restauro Crítico e os postulados da Carta de Veneza, o projeto se preocupa em evidenciar as construções e acréscimos realizados a partir de 1938. Além disso, propõe-se a implantação de um museu para exposição pública de material iconográfico referente a cada etapa da trajetória do edifício em sua materialização ao longo da história.

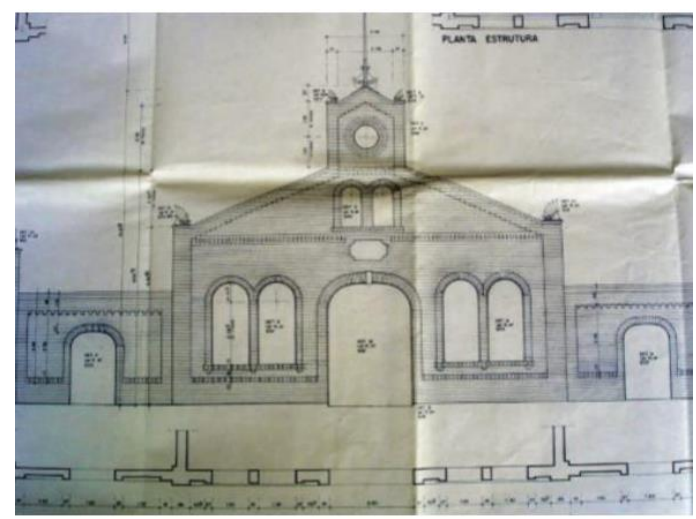

Figura 126: Detalhe da elevação do projeto de restauro das fachadas elaborado pelos arquitetos do DPH.

Fonte: Condephaat, 1989; In. JACCOUDJUNIOR, 2019, p. 141

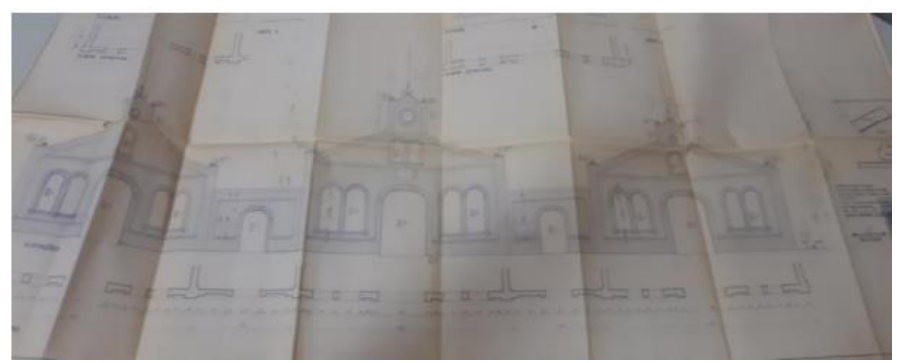

Figura 127: Elevação do projeto de restauro das fachadas elaborado pelos arquitetos do DPH. Fonte: Condephaat, 1989; In. JACCOUDJUNIOR, 2019, p. 141.

O projeto do DPH, no entanto, não é concluído e o conjunto passa a ser utilizado como almoxarifado da secretaria de vias públicas, até sua posterior incorporação pela Cinemateca Brasileira em 1988, quando é elaborada a segunda proposta, cuja autoria remonta ao escritório GMR Arquitetos Associados ${ }^{67}$. As obras relativas a esse projeto, agenciado pelo Ministério da Cultura, não chegaram a ser finalizadas, no entanto, foram realizadas reconstruções de paredes de

67 A equipe responsável pelo projeto de intervenção no edifício da Cinemateca, dentro do escritório, era composta pelos arquitetos Marlene Gurgel, Lúcio Gomes e Eduardo Rodrigues. Em 1993, ainda em meio à elaboração do projeto, o escritório é desmembrado e ficam responsáveis pelo projeto apenas Lúcio e Eduardo. 
alvenarias que visavam a recuperação da unidade formal original do edifício, sem preocupações com o critério de distinguibilidade.

É só no começo dos anos 2000, que uma terceira proposta de projeto recai sobre o edifício, dessa vez de autoria do arquiteto Nelson Dupré, também responsável pela intervenção praticamente coetânea na Sala São Paulo. Dessa vez, o arquiteto opta por manter as restaurações realizadas até então, intervindo pontual e visivelmente a partir do uso de materiais modernos como o aço e os panos de vidro (PISANI, CORRÊA, 2009).

\subsection{A intervenção (1982-1991): Tombamento}

O contexto da intervenção sofrida pelo edifício do Theatro Municipal de São Paulo durante a década de 1980 é muito diferente daquele que permeou a reforma dos anos 1950. Nesse segundo momento, o Theatro já havia sido reconhecido como patrimônio cultural pelo Condephaat, através da resolução de tombamento SC 49/81, de 23 de dezembro de198168:

\footnotetext{
O término da restauração interna do Teatro Municipal de São Paulo coincide com um período em que os valores estéticos e conceituais, antes delegados ao movimento eclético, começam a ser reavaliados. Onde a obra é um exemplo vivo desta retomada de valores e consequente reformulação de conceitos até o momento "congelados" na crítica arquitetônica (...)

"A correta compreensão do ecletismo na arquitetura sugere o exame do meio e da época que o produziu", escreveu o arq. Alex Nicolaeff, e o Teatro Municipal emerge como exemplo arquitetônico deste "meio produtor", refletindo o modo de agir, pensar e fazer a cidade paulistana do início deste século (...) (ESPÍRITO SANTO, 1988, p. 81)
}

Nos anos seguintes ao seu reconhecimento a nível estadual, o edifício foi submetido a uma série de procedimentos que buscavam determinar seu estado

\footnotetext{
${ }^{68}$ Os preâmbulos da resolução de tombamento do edifício do Theatro Municipal de São Paulo, relacionados à mudança de postura dos órgãos oficiais de preservação do patrimônio brasileiro durante a década de 1980 serão abordados em maior detalhe no item 3.3 Condephaat e alargamentos conceituais do presente capítulo.
} 
de conservação. Foram realizados levantamentos fotogramétricos das fachadas e de suas patologias pelo corpo técnico do DPH e emitidos laudos por parte do IPT e da SEHAB, que colocaram a edificação em estado de alerta, acarretando seu fechamento preventivo (KATCHVARTANIAN, 2014).

Ao ser noticiado pela mídia, o fechamento do Theatro para execução das obras de restauro é justificado especialmente pelo risco de incêndio e desabamento do forro do Salão Nobre. Desde o princípio, as preocupações mobilizadas pela imprensa a respeito da intervenção estavam centradas na questão do tempo e do dinheiro, e nas implicações que o prolongamento do primeiro poderia ter no segundo e vice versa. Os impactos do custo e duração do fechamento do Municipal para a realização das obras era medido pelas suas consequências no cenário da cultura artística da cidade, e não nos resultados materiais da restauração no edifício ${ }^{69}$ (Figuras 128 - 134).

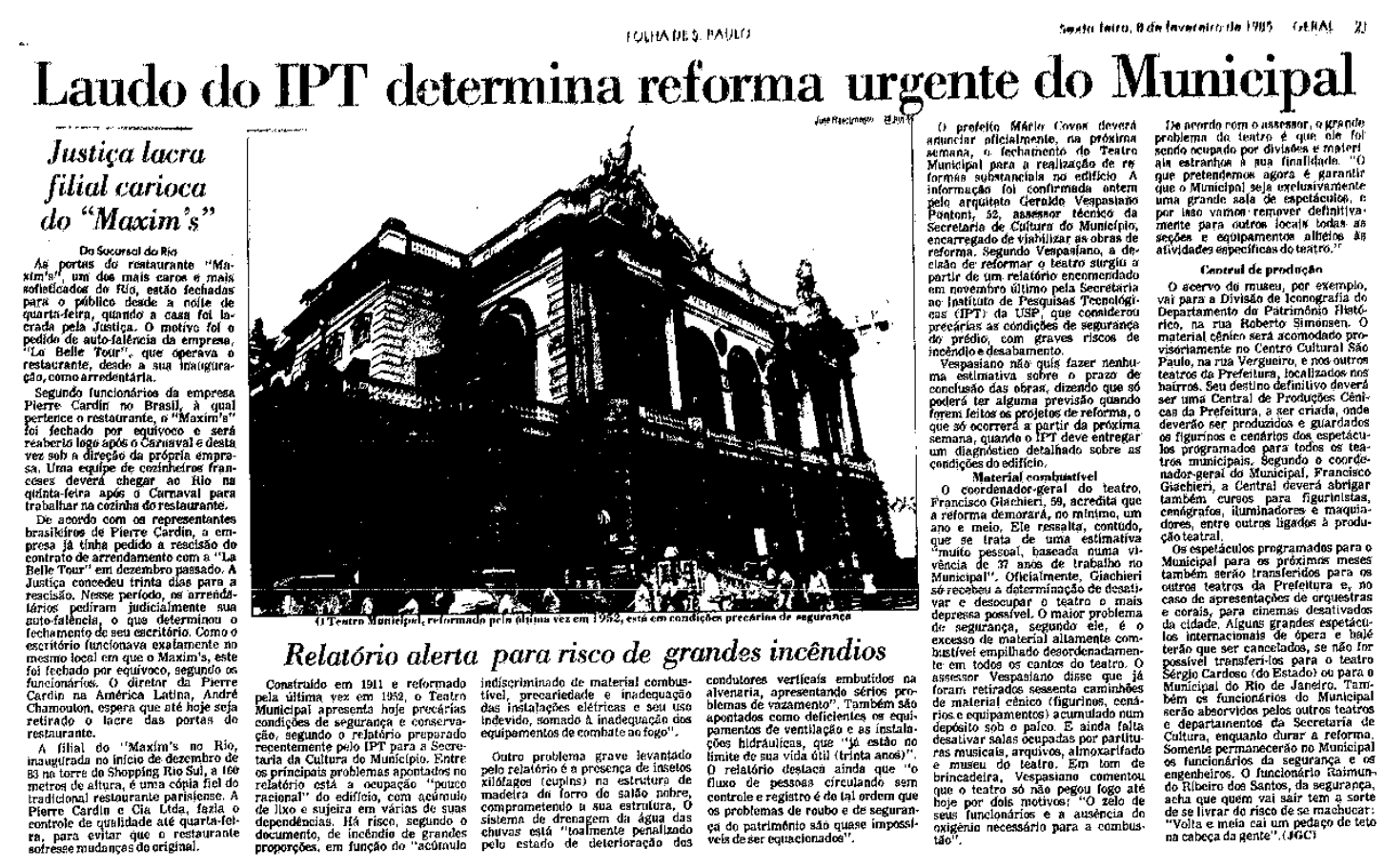

Figura 128: Manchete do jornal da Folha de S. Paulo, do dia 8 de fevereiro de 1985, anuncia importância de intervenção urgente no Theatro Municipal de São Paulo, após laudo do IPT.

Fonte: A FOLHA DE S. PAULO. Caderno Geral, p. 21, 8 fev. 1985.

69 Entre 1985 e 1988, ano da reabertura do Theatro após a conclusão das obras internas, vários foram os artigos publicados na mídia impressa comum sobre a demora e o custo da restauração do Municipal. Com títulos apelativos, como "Sem Municipal não tem Bolshoi", "A música de concerto não tem onde morar", "Uma pobre e triste temporada", "Cultura musical sem rumo em São Paulo", "Municipal sem verba para o fim das reformas" ou "Orçamento alto afasta investidores do Municipal" (ver figuras 129 - 134). 


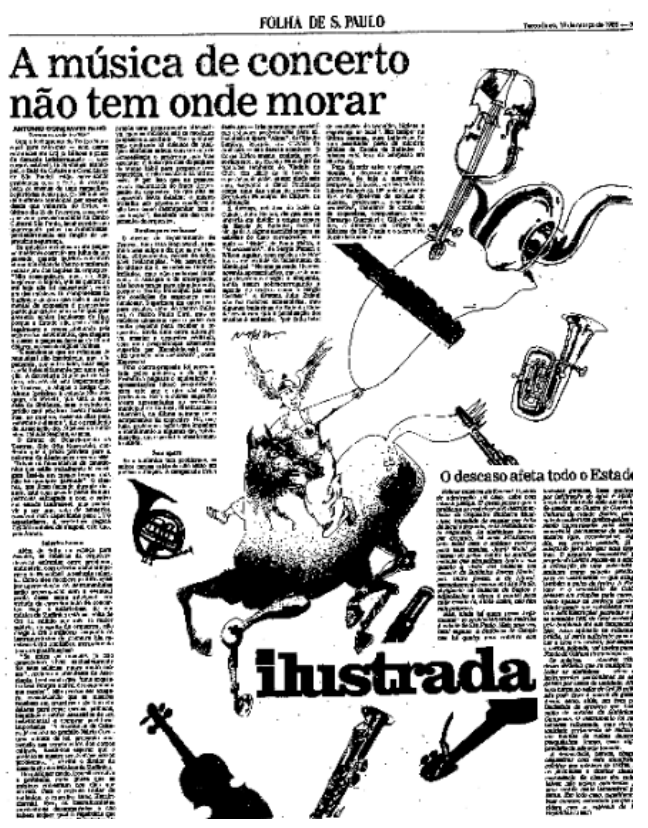

Sem Municipal, não tem Bolshoi

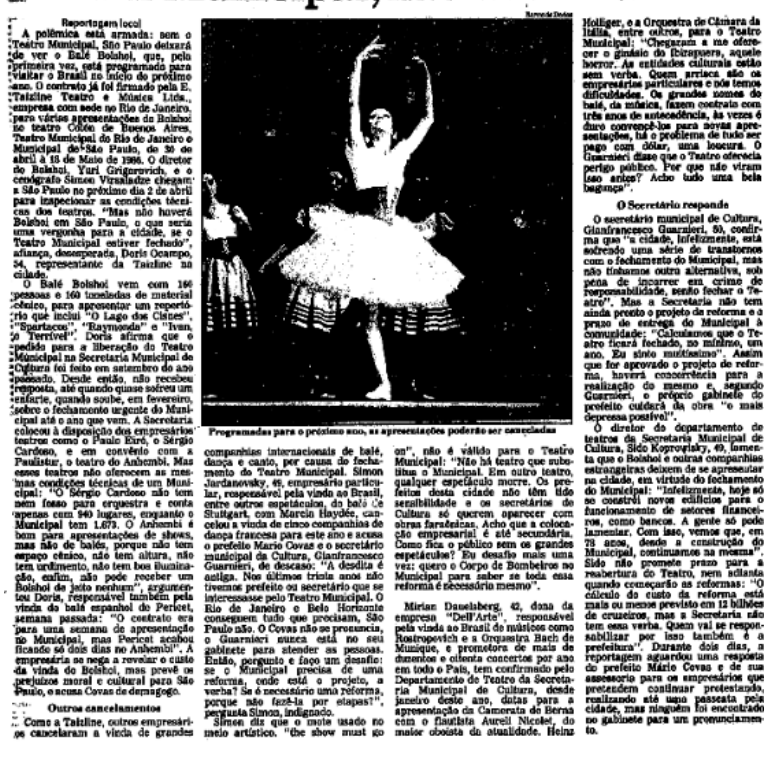

Figura 129 (esq.) e 130 (dir.): Manchetes de jornal que lamentam a ausência do Theatro Municipal em funcionamento, e demonstram preocupação com a duração das obras.

Fonte: A FOLHA DE SÃO PAULO. Caderno llustrada, p. 31,19 de março de 1985 (esq.); A FOLHA DE SÃO PAULO. Caderno llustrada, p. 39, 21 de março de 1985 (dir.)
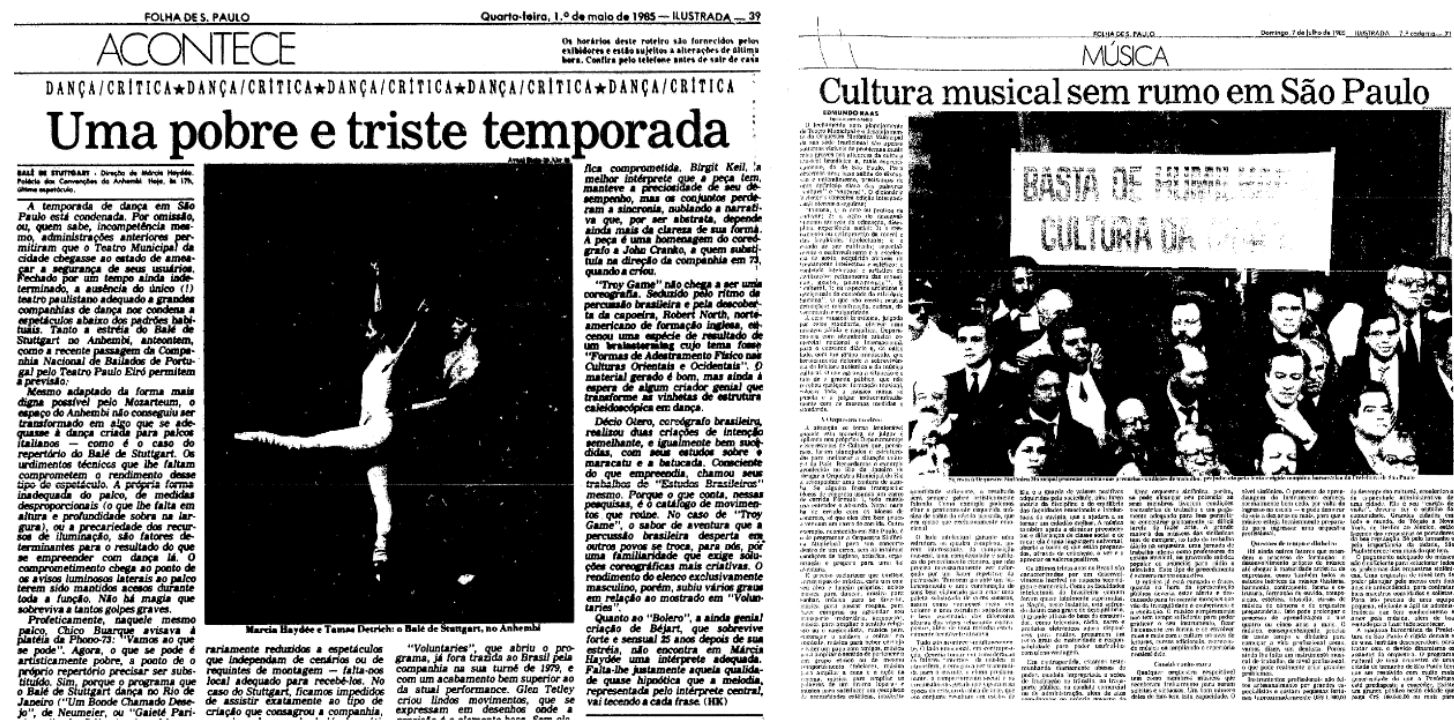

Figura 131 (esq.) e 132 (dir.): Manchetes de jornal que denotam preocupação com o fechamento do Theatro e seu impacto na cultura artística da cidade.

Fonte: A FOLHA DE SÃO PAULO. Caderno llustrada, p. 39,1 de maio de 1985 (esq.); A FOLHA DE SÃO PAULO. Caderno llustrada, p. 71, 7 de julho de 1985 (dir.). 

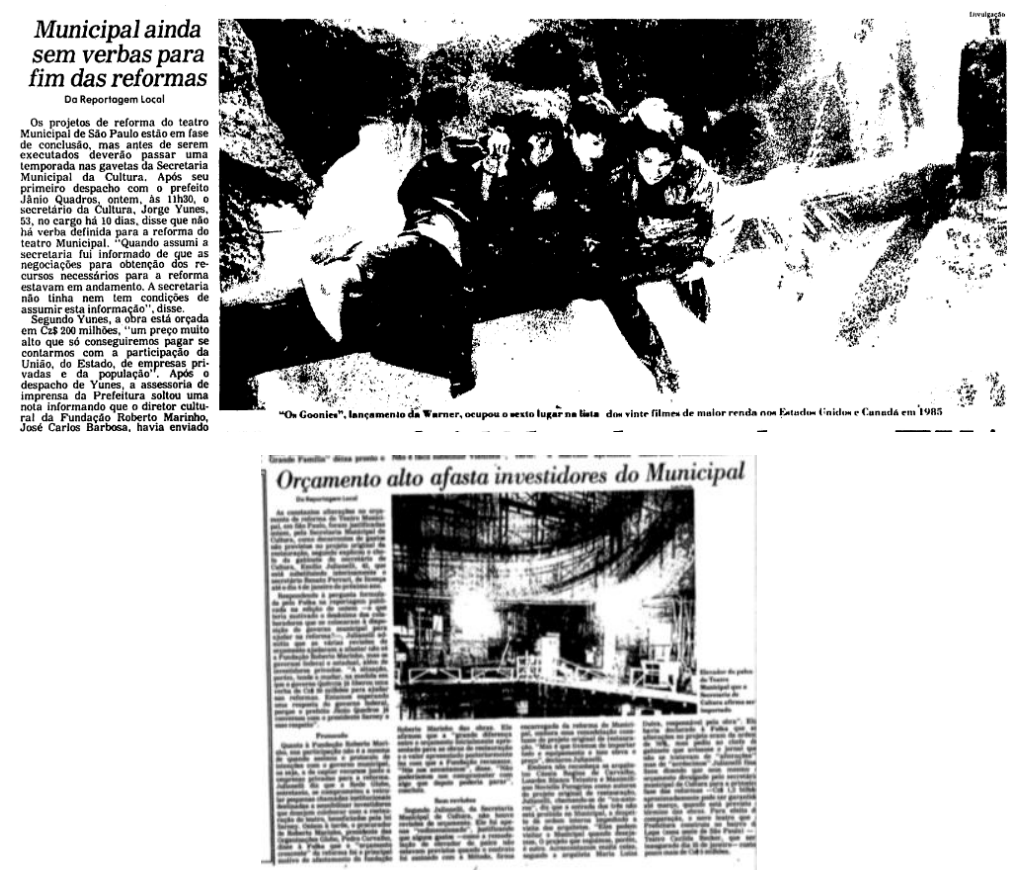

Figura 133 (esq.) e 134 (dir.): Artigos de jornais cujas manchetes expressam preocupação financeira com relação às obras de restauro do Theatro Municipal.

Fonte: A FOLHA DE SÃO PAULO. Caderno llustrada, p. 41, 27 de março de 1986 (esq.); A FOLHA DE SÃO PAULO. Caderno llustrada, p. 40, 22 de dezembro de 1987 (dir.).

A obra de restauro se deu em duas etapas: a primeira, entre 1985 e 1988, tratou do interior do edifício; e a segunda, entre 1988 e 1991, das fachadas. Conforme os memoriais descritivos relativos a ambas as fases, as orientações do IPT foram respeitadas, tendo sido apenas acrescentados maiores detalhes quanto aos materiais e técnicas a serem empregados nas intervenções específicas. A seguir, essas intervenções serão abordadas de forma mais minuciosa (Figura 135). 


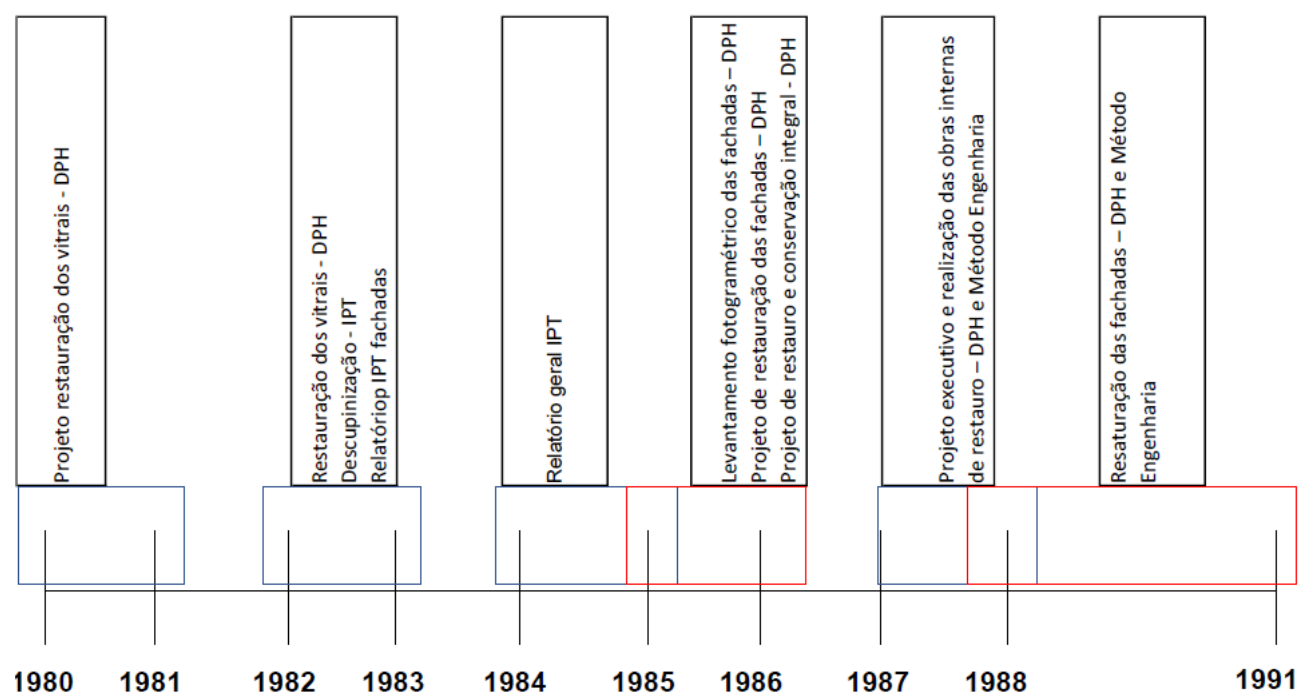

Figura 135: Esquema das etapas cronológicas da intervenção sofrida pelo edifício do Theatro durante a década de 1980 .

Fonte: realizado pela autora.

\subsubsection{Restauro externo}

Em 1983, o Agrupamento de Tecnologia Orgânica da Divisão de Química e Engenharia Química do IPT elaborou, a pedido da prefeitura e do departamento de teatros da SMC, um documento que diagnosticava o estado das fachadas do Theatro e recomendava medidas específicas de conservação ${ }^{70}$. Nesse primeiro momento, foram avaliados seus componentes materiais, por meio de inspeção visual e coleta de amostras para espectrofotometria infravermelha. Além disso, foram realizados ensaios para limpeza e impermeabilização das superfícies, em função da resistência dos revestimentos e do desempenho dos produtos aplicados.

\subsubsection{Pintura e cantaria}

A espectrofotometria determinou que a tinta aplicada à superfície de argamassa era a base de PVA (poliacetato de vinila), e os ensaios de resistência apontaram o jateamento de água quente sob pressão controlada como o método mais adequado para limpeza, tanto da argamassa pintada, como da cantaria. Para

\footnotetext{
70 INSTITUTO DE PESQUISAS TECNOLÓGICAS. Relatório IPT n. 19.557: Deterioração das
} fachadas. São Paulo, dez. 1983. 
além da limpeza, foi recomendada a repintura das superfícies de argamassa, com duas demãos de tinta tipo látex acrílico "na cor próxima à da argamassa original", precedida de uma demão de selador acrílico (Figuras 136 e 137).
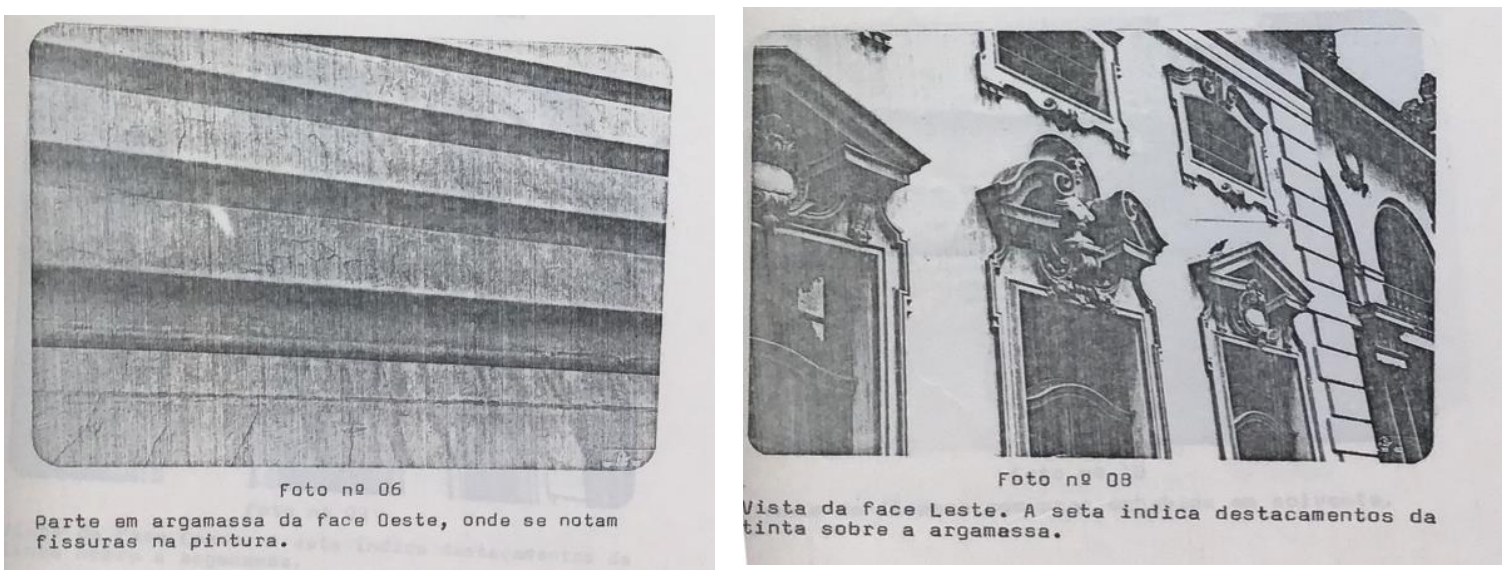

Figuras 136 (esq.) e 137 (dir.): Respectivamente, fotografias de superfícies de pintura fissuradas e destacadas.
Fonte: INSTITUTO DE PESQUISAS TECNOLÓGICAS. Relatório IPT n. 19.557: Deterioração das
fachadas. São Paulo, 1983.

Para além da limpeza, foi recomendada a aplicação de impermeabilizantes nas superfícies de arenito das fachadas. Por se tratar de uma pedra especialmente porosa e frágil, os testes foram realizados em amostras retiradas tanto do Theatro quanto da jazida da Fazenda Ipanema, de onde fora extraído o material para a construção original do edifício.

Os resultados dos testes, em ambas as amostras, indicaram que o melhor método para impermeabilização do arenito seria a aplicação de uma demão de solução aquosa de silicone. Para os bustos de mármore, localizados nas fachadas laterais, ficou recomendada a aplicação de duas demãos de verniz de poliuretano alifático bicomponente a revólver e, para as colunas de granito vermelho polido, a aplicação de uma camada de cera contendo silicone. Quanto às demais superfícies em granito cinza de Itaquera, não foi identificada a necessidade de aplicação de nenhum produto. 


\subsubsection{Esquadrias}

Para as esquadrias de madeira, ficou recomendado o lixamento para remoção de todos as tintas e vernizes envelhecidos, seguido da aplicação de esmalte sintético em três demãos e envernizamento com duas demãos de verniz poliuretânico alifático bicomponente. Para as peças de bronze, sugeriu-se a remoção de toda pátina e aplicação de aguarrás mineral, antes da pintura ou envernizamento.

O Memorial descritivo das obras e serviços das fachadas ${ }^{71}$ indica que as sugestões do Instituto com relação à postura interventiva nos materiais das fachadas foram acatadas por completo.

\subsubsection{Estatuária metálica}

A questão da estatuária externa é, nesse primeiro momento, abordada superficialmente. São feitos apontamentos apenas sobre os grupos de bronze da Praça Ramos, sugerindo a aplicação de pintura de poliuretano alifático bicomponente "na cor escura semelhante à apresentada pelas estátuas com os produtos de oxidação (pátina)" (INSTITUTO DE PESQUISAS TECNOLÓGICAS. Relatório IPT n. 19.557: Deterioração das fachadas, 1983, p. 12).

Os conjuntos escultóricos adjacentes ao exterior do edifício são abordados em um relatório posterior, dedicado exclusivamente à avaliação das obras de arte, assinado pela Divisão de Metalurgia do IPT ${ }^{72}$. O documento descreve o estado superficial dos componentes metálicos das estátuas, de elementos do telhado e dos pilares externos, a partir de amostras dos materiais e de seus produtos de corrosão ${ }^{73}$. O estado superficial das obras em questão foi sistematizado por meio

\footnotetext{
71 Departamento do Patrimônio Histórico. Memorial descritivo das obras e serviços de restauro das fachadas do Teatro Municipal de São Paulo. São Paulo, 1986.

72 INSTITUTO DE PESQUISAS TECNOLÓGICAS. Relatório IPT n. 19.665: Avaliação das obras de arte. São Paulo, janeiro 1984.

73 Para além dos componentes metálicos adjacentes ao edifício, o Relatório IPT n. 19.665 também faz apontamentos sobre os conjuntos escultóricos da Praça Ramos de Azevedo. A presente pesquisa, no entanto, não trata das questões levantadas fora do âmbito do edifício, de maneira que as considerações tecidas na escala da Praça não serão apresentadas em detalhe, mas apenas cotejadas com as informações pertinentes à escala arquitetônica.
} 
da tabela a seguir, elaborada pela autora com base no material fornecido pelo relatório (Figura 138):

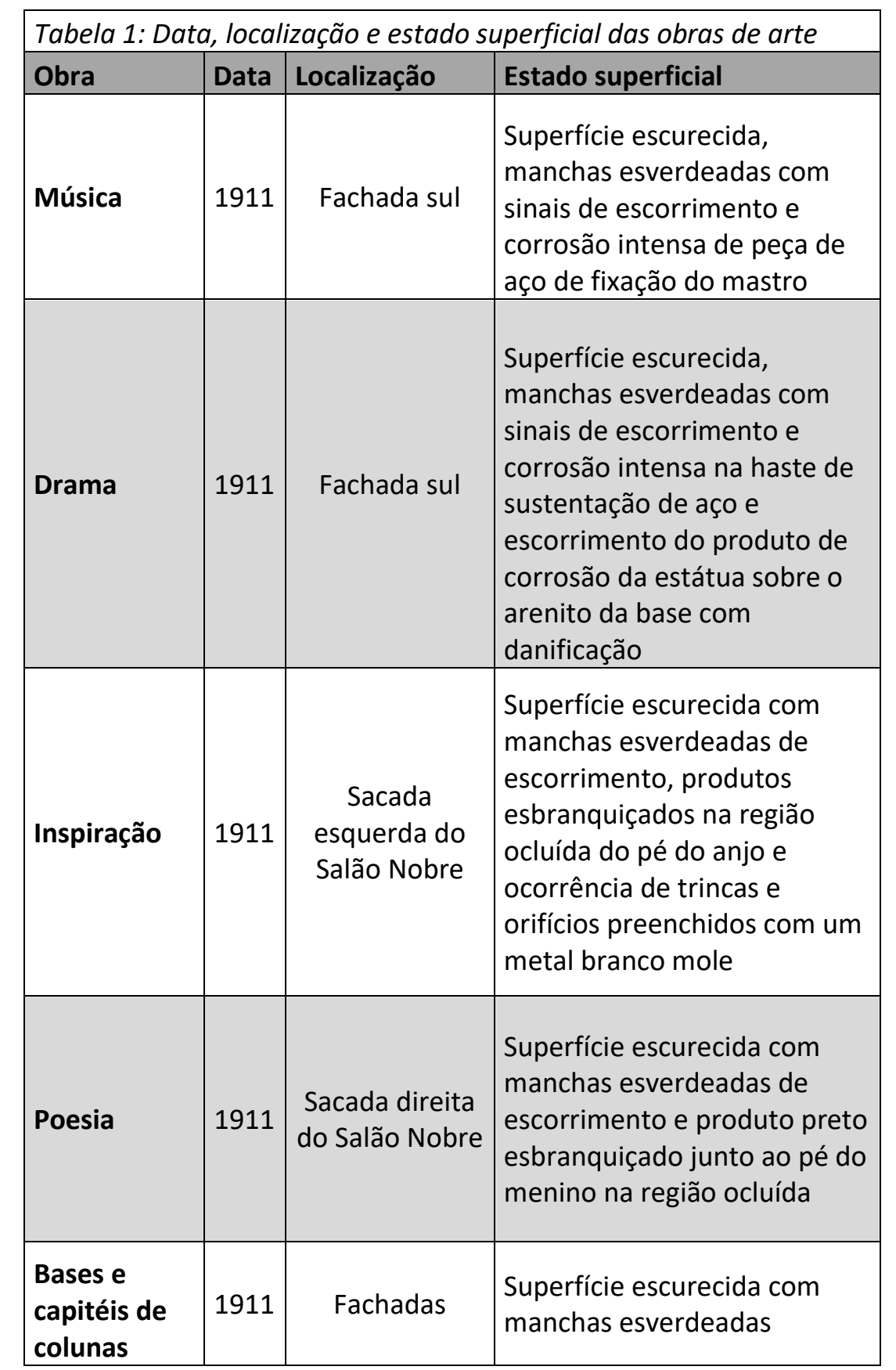

Figura 138: Tabela dos estados superficiais dos componentes metálicos do exterior do edifício. Fonte: produzido pela pesquisa.

As amostras dos metais foram retiradas através de broca e cortes, e passaram por testes de espectroscopia de raios x fluorescente, quantometria e dispersão de energia, que revelaram sua composição em liga de cobre-zinco-estanhochumbo. As chapas de cobre do telhado foram analisadas em microscópio após 
aplicação de solução de cloreto férrico, o que revelou intenso ataque intergranular.

Já as amostras dos produtos de corrosão foram obtidas através de raspagem e submetidas à análise por espectrografia de emissão, dispersão de energia e difração de raios $x$. As análises químicas desses produtos foram sistematizadas por meio da tabela a seguir, elaborada pela autora com base no material fornecido pelo relatório (Figura 139): 


\begin{tabular}{|c|c|c|c|c|c|}
\hline \multirow[b]{2}{*}{ Obra } & \multirow[b]{2}{*}{ Natureza da amostra } & \multicolumn{3}{|c|}{ Elementos detectados } & \multirow[b]{2}{*}{ Difração de raios -x } \\
\hline & & Preponderante & $\begin{array}{l}\text { Pequenas } \\
\text { proporções }\end{array}$ & Traços & \\
\hline \multirow[b]{2}{*}{ Drama } & $\begin{array}{l}\text { Produto raspado da } \\
\text { estátua }\end{array}$ & $\begin{array}{l}\text { Cobre, silício e } \\
\text { zinco }\end{array}$ & $\begin{array}{c}\text { Ferro, enxofre e } \\
\text { cálcio }\end{array}$ & $\begin{array}{l}\text { Alumínio, } \\
\text { titânio, } \\
\text { níquel, } \\
\text { chumbo, } \\
\text { estanho, } \\
\text { potássio, } \\
\text { manganês e } \\
\text { cromo }\end{array}$ & $\begin{array}{l}\text { Cobre, quartzo alfa, } \\
\text { sulfato de cálcio } \\
\text { hidratado e } \\
\text { substâncias amorfas }\end{array}$ \\
\hline & $\begin{array}{l}\text { Produto raspado da } \\
\text { haste de sustentação }\end{array}$ & Ferro & Silício e titânio & $\begin{array}{c}\text { Cobre, } \\
\text { alumínio, } \\
\text { enxofre, } \\
\text { zinco, } \\
\text { chumbo, } \\
\text { cálcio, } \\
\text { potássio, } \\
\text { manganês e } \\
\text { cromo }\end{array}$ & $\begin{array}{l}\text { Goetita, magnetita, } \\
\text { lepidocrocita, } \\
\text { hematita e } \\
\text { substâncias amorfas }\end{array}$ \\
\hline Inspiração & $\begin{array}{l}\text { Produto raspado da } \\
\text { estátua }\end{array}$ & Cálcio e enxofre & $\begin{array}{l}\text { Silício, ferro e } \\
\text { cobre }\end{array}$ & $\begin{array}{l}\text { Magnésio, } \\
\text { alumínio, } \\
\text { cromo e } \\
\text { potássio }\end{array}$ & $\begin{array}{l}\text { Sulfato de cálcio } \\
\text { hidratado }\end{array}$ \\
\hline Poesia & $\begin{array}{c}\text { Produto raspado da } \\
\text { estátua }\end{array}$ & $\begin{array}{l}\text { Cálcio, enxofre e } \\
\text { silício }\end{array}$ & Ferro e cobre & $\begin{array}{l}\text { Magnésio, } \\
\text { alumínio, } \\
\text { estanho, } \\
\text { níquel, } \\
\text { cromo, } \\
\text { titânio e } \\
\text { potássio }\end{array}$ & $\begin{array}{c}\text { Sulfato de cálcio } \\
\text { hidratado e quartzo } \\
\text { alfa }\end{array}$ \\
\hline Telhado & Produto raspado & Ferro & $\begin{array}{l}\text { Cobre, silício e } \\
\text { enxofre }\end{array}$ & $\begin{array}{c}\text { Alumínio, } \\
\text { zinco, titânio, } \\
\text { chumbo, } \\
\text { cálcio, níquel, } \\
\text { potássio, } \\
\text { manganês e } \\
\text { cromo }\end{array}$ & $\begin{array}{c}\text { Goetita, magnetita, } \\
\text { hematita, } \\
\text { lepidocrocita e } \\
\text { substâncias amorfas }\end{array}$ \\
\hline
\end{tabular}

Figura 139: Tabela das análises químicas dos produtos de corrosão dos componentes metálicos do exterior do edifício.

Fonte: produzido pela pesquisa.

Após as análises, foram identificados três níveis de corrosão: generalizada, localizada e galvânica. A corrosão generalizada, ou seja, presente em toda a extensão da superfície corroída, foi encontrada apenas em duas estátuas da Praça Ramos de Azevedo, intituladas Salvador Rosa e Guarany. De acordo com 
o relatório, o processo tem efeito estético desagradável, mas não compromete as obras. Dessa forma, foi recomendada apenas a limpeza superficial com lavagem, sem necessidade de intervenções mais invasivas.

A corrosão localizada, ou seja, presente apenas em uma parcela da superfície corroída, foi encontrada em algumas chapas de cobre do telhado e na estátua da Inspiração, para além dos conjuntos dos Cavalos da Fonte, Homenagem à Itália, Homenagem ao Brasil, Salvador Rosa e Guarany, alocados na Praça Ramos de Azevedo. Esse processo foi responsável pela formação de trincas que poderiam comprometer a integridade das obras, caso permitissem a penetração da água de chuva, que provocaria corrosão do lado interno das peças. Foi sugerido que essas fissuras fossem eliminadas por meio de soldas com a composição do material da estátua, ou pela obturação com ceras ou chumbo.

A corrosão do telhado, por sua vez, foi provocada pelos ions de ferro, que são o produto da corrosão da estrutura de aço da cumeeira. Assim, ficou recomendada a substituição dos metais ferrosos, empregados tanto em elementos da cobertura como em estátuas e parafusos e fixação, por latão 60/40 (metal Muntz).

Os conjuntos escultóricos Música e Drama, para além da Estátua de Carlos Gomes na Praça Ramos e alguns componentes do telhado confeccionados em aço, foram vítimas da corrosão galvânica. Esse processo eletroquímico corresponde à corrosão que um metal provoca no outro, quando ambos estão em contato elétrico e na presença de um eletrólito. Nos casos supracitados, os produtos de corrosão do aço são agressivos ao cobre e suas ligas, de forma que a sua substituição foi bastante recomendada.

Apesar de sua localização estrangeira ao corpo do edifício, cabe aqui destacar a especificidade do caso de dois conjuntos situados na Praça Ramos de Azevedo, a Estátua do Condor e os Cavalos da Fonte ${ }^{74}$. De acordo com a lenda

\footnotetext{
${ }^{74}$ A estátua do Condor, baseada no personagem da obra homônima de Carlos Gomes, e os Cavalos da Fonte fazem parte do conjunto realizado pelo arquiteto italiano Luiz Brizzolara para a Praça Ramos de Azevedo em 1922, intitulado Fonte dos Desejos. A obra foi inspirada na
} 
urbana, o dedo da mão esquerda do Condor confere sorte a quem o toca, o que provoca um desgaste proveniente da abrasão do toque, que pode comprometer a integridade da obra. O relatório IPT n. 19.665 sugeriu então que "neste caso, devido ao seu valor histórico, em termos do mito criado, não é recomendável a sua restauração, mas apenas uma aplicação do verniz transparente, nas regiões desgastadas, para preservar o estado atual" (INSTITUTO DE PESQUISAS TECNOLÓGICAS. Relatório IPT n. 19.665: Avaliação das obras de arte, 1984, p. 13).

No caso dos Cavalos da Fonte, a preservação torna-se necessária pela lixiviação permanente pela água da fonte. Em ambos os casos, destaca-se a relação quase antitética traçada entre os processos de restauração e conservação, tendo sido a segunda elegida em detrimento da primeira. Além disso, foram mobilizados os conceitos de mito e valor histórico, que serviram como embasamento e justificativa para essa escolha. As especificações de pintura para ambas as obras foram reiteradas do Relatório IPT n. 19.557, comentadas anteriormente.

O Memorial descritivo das obras e serviços de restauro das fachadas indica que essas sugestões quanto as posturas a serem adotadas na intervenção das esculturas metálicas adjacentes foram completamente acatadas ${ }^{75}$. $\mathrm{O}$ mesmo ocorre com os elementos metálicos do telhado.

\subsubsection{A Questão do Arenito}

Nesse mesmo ano, dois meses após a realização da análise dos componentes metálicos do exterior do edifício, a integridade das fachadas como um todo foi alvo de um segundo relatório, dessa vez elaborado pelas divisões de Minas e Geologia Aplicada, e Engenharia Civil do IPT. Apesar de traçar os mesmos objetivos que o primeiro, ou seja, identificar o estado de conservação dos

Fontana di Trevi, projetada por Nicola Salvi em 1762 para a cidade de Roma. (ASSEMBLÉIA LEGISLATIVA DO ESTADO DE SÃO PAULO. Condor e a lenda. 2008. Disponível em: https://www.al.sp.gov.br/noticia/?id=297843. Acesso em: 9 jun. 2020).

75 Departamento do Patrimônio Histórico. Memorial descritivo das obras e serviços de restauro das fachadas do Teatro Municipal de São Paulo. São Paulo, 1986. 
materiais que compõem as fachadas e propor posturas interventivas, esse documento apresenta um panorama muito mais completo, sobretudo no que diz respeito aos elementos de cantaria.

Esse relatório propõe uma matriz de classificação do estado da matéria, que distribui os materiais em cinco níveis distintos, levando em consideração a presença de modificações em suas superfícies e geometria. De acordo com essa classificação, os panos de granito e argamassa pintada encontravam-se em bom estado de conservação, sem qualquer tipo de alteração aparente. Para esses materiais, ficou recomendada apenas a limpeza por jateamento de água quente sob pressão e aplicação de cera impermeabilizante, no caso do granito; e pintura, no da argamassa.

O arenito, que por sua vez já havia sido identificado como o material mais vulnerável das fachadas, apresentou maior variação de estados de conservação. A classificação do estado do arenito e suas respectivas recomendações foram sistematizados pela tabela a seguir (Figura 140):

\begin{tabular}{|l|l|l|l|l|l|l|}
\hline Classificação & Estado da Matéria & Geometria & Superfície & Recomendações & Limpeza & Recuperação \\
\cline { 2 - 5 } & Alteração & Não apresenta & Mantida & Condições adequaduadas & Jateamento superficial & Não precisa \\
\hline Nível A & Sinais incipientes & Mantida & $\begin{array}{l}\text { Ligeiras manchas e } \\
\text { pequenas irregularidades }\end{array}$ & Jateamento controlado & \\
\hline Nível C & Apresenta & Modificada & $\begin{array}{l}\text { Mancha, protuberâncias } \\
\text { e saliências }\end{array}$ & $\begin{array}{l}\text { Jateamento } \\
\text { rigorosamente } \\
\text { controlado }\end{array}$ & \multirow{2}{*}{ Argamassa } \\
\cline { 1 - 4 } Nível D & Apresenta & Modificada & $\begin{array}{l}\text { Manchas evidentes, } \\
\text { depósitos desagregáveis } \\
\text { e protuberâncias e } \\
\text { saliências evidentes }\end{array}$ & $\begin{array}{l}\text { Jatemaento altamente de resina } \\
\text { rigoroso }\end{array}$ & \\
\hline Nível E & Material desagregado mecanicamente e com fissuras & Substituição com arenito da Fazenda Ipanema \\
\hline
\end{tabular}

Figura 140: Tabela de classificação do estado da matéria e respectivas recomendações. Fonte: elaborada pela autora.

Em suma, as recomendações de limpeza variavam entre os diferentes graus de classificação da pedra, sendo a pressão do jateamento de água cada vez mais controlada, de acordo com o estado de degradação da rocha (Figuras 141 144). Quanto às demais diretrizes, fica recomendada a recuperação com argamassa onde houver sinais de alteração, a não ser no caso do material mais degradado, para o qual sugere-se a substituição integral com arenito de mesma procedência. A aplicação de resina como medida de manutenção preventiva fica prevista em todos os casos e independe do estado de conservação da pedra. 

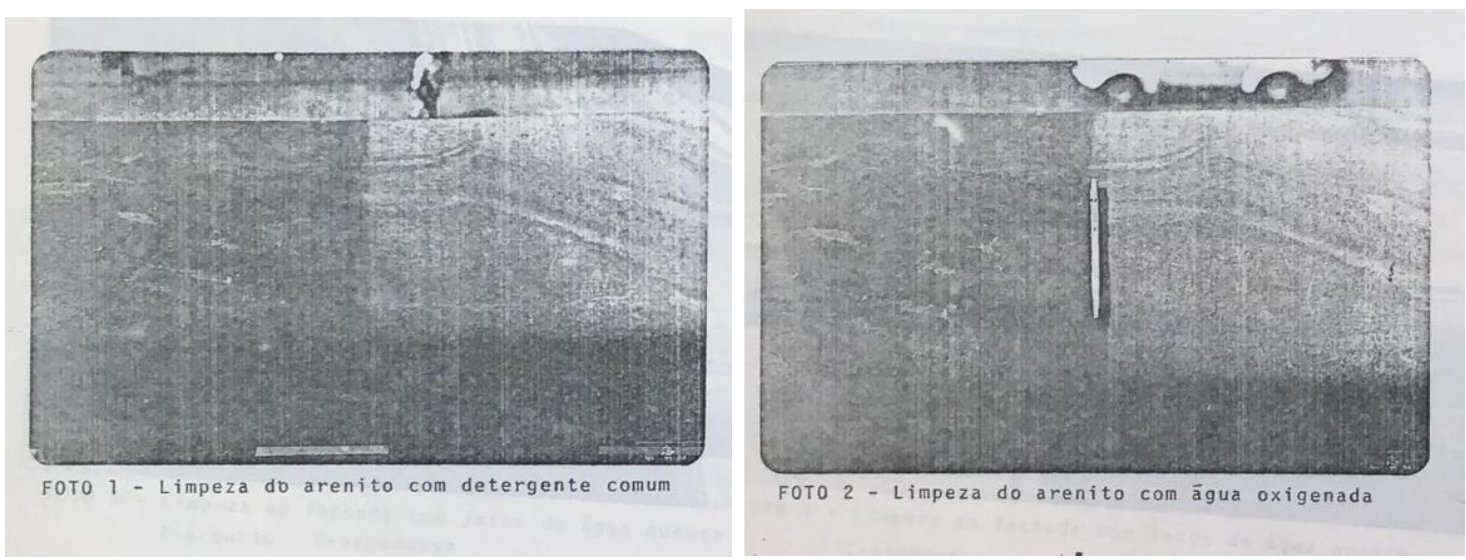

Figuras 141 (esq.) e 142 (dir.): Respectivamente, fotografias dos testes de limpeza do arenito com

detergente e água oxigenada.

Fonte: INSTITUTO DE PESQUISAS TECNOLÓGICAS. Relatório IPT n. 19.701: Deterioração das

fachadas. São Paulo, 1984.
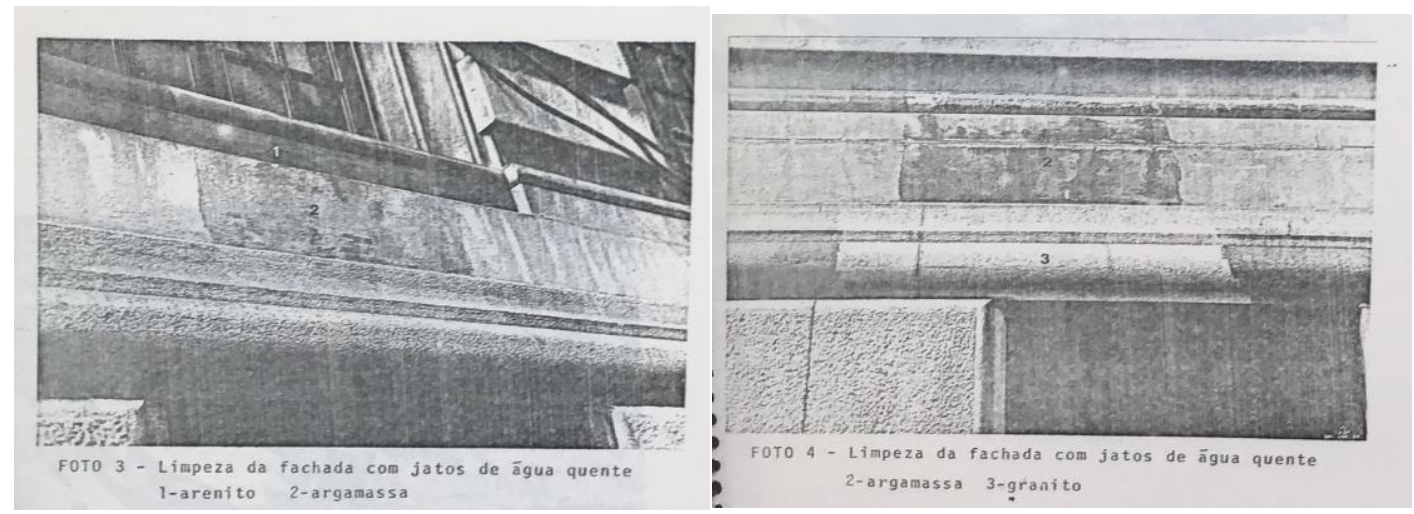

Figuras 143 (esq.) e 144 (dir.): Fotografias dos testes de limpeza do arenito, granito e argamassa com jato de água quente sob pressão.

Fonte: INSTITUTO DE PESQUISAS TECNOLOGICAS. Relatório IPT n. 19.701: Deterioração das

fachadas. São Paulo, 1984.

Também fica recomendado que se inspecionem os sistemas de drenagem e captação de águas pluviais periodicamente, uma vez que as bases de arenito das estátuas metálicas apresentam manchas provocadas pela água que escorre das mesmas e que contém sais de cobre. Para solucionar esse problema de forma direta, sugere-se a instalação de sistemas de drenagem próprios para essas peças.

A partir de 1984, o IPT passou a realizar vistorias internas no edifício do Theatro. Para isso, contou com uma equipe multidisciplinar composta por trinta e dois 
funcionários oriundos de dez divisões técnicas diferentes. O trabalho envolvia, para além da vistoria, a elaboração de diagnósticos e sugestões de intervenção, que contemplavam as áreas de fundações, estruturas, alvenarias e revestimentos, fogo, acústica, instalações elétricas e hidráulicas, ventilação, equipamentos, mobiliário, tintas, vidros, metais e pedras.

\subsection{2 $\underline{\text { Restauro interno }}$}

Em fevereiro de 1985, o IPT apresentou o relatório final da vistoria de todas as quinhentas e trinta e oito salas do Theatro, seus diagnósticos, conclusões e recomendações ${ }^{76}$. Para efeito da vistoria, os ambientes foram divididos em quatro setores, de acordo com seus respectivos aspectos construtivos e usos. $O$ setor A (Setor Nobre), correspondia ao corpo da fachada principal, saguão, escadaria e Salão Nobre; O setor B (Setor do Auditório), à sala de espetáculos e suas respectivas áreas de apoio e circulação; o setor C (Setor Palco), ao palco e suas dependências e o setor $D$, à ala de camarins (Figuras 145 - 157).

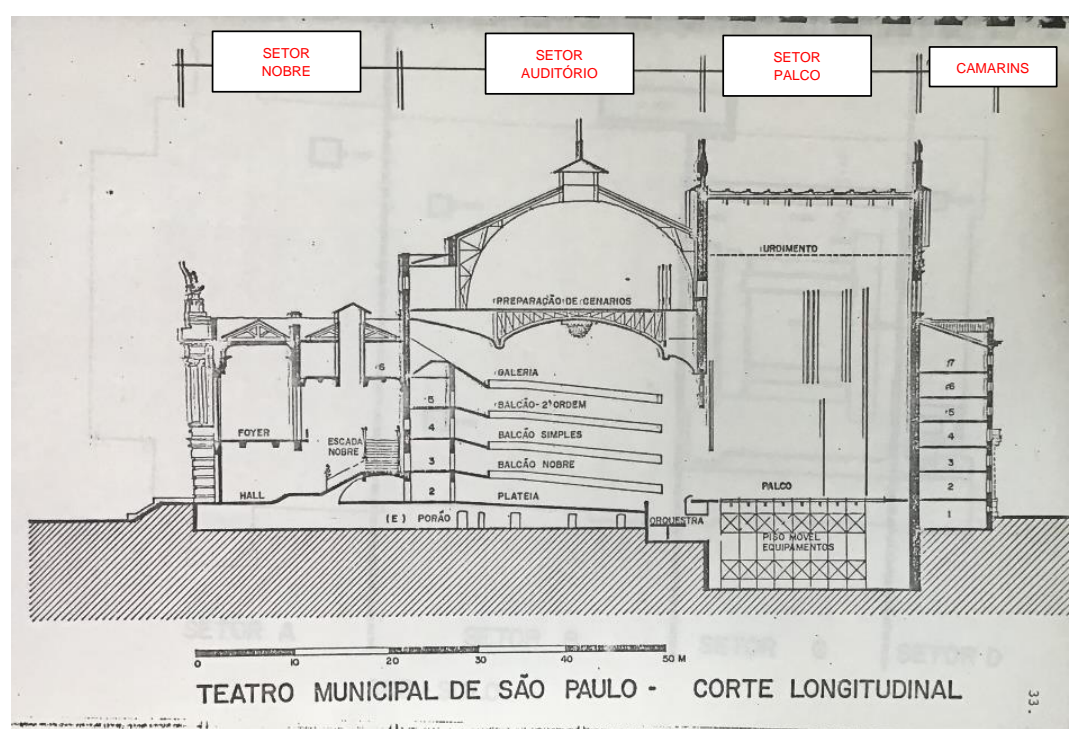

Figura 145: Corte longitudinal do edifício do TMSP, dividida em quatro setores.

Fonte: INSTITUTO DE PESQUISAS TECNOLÓGICAS. Relatório Geral de todas as áreas técnicas IPT n. 21.737: Volume I-IV. São Paulo, fevereiro 1985.

76 INSTITUTO DE PESQUISAS TECNOLÓGICAS. Relatório Geral de todas as áreas técnicas IPT n. 21.737: Volume I-IV. São Paulo, fevereiro 1985. 


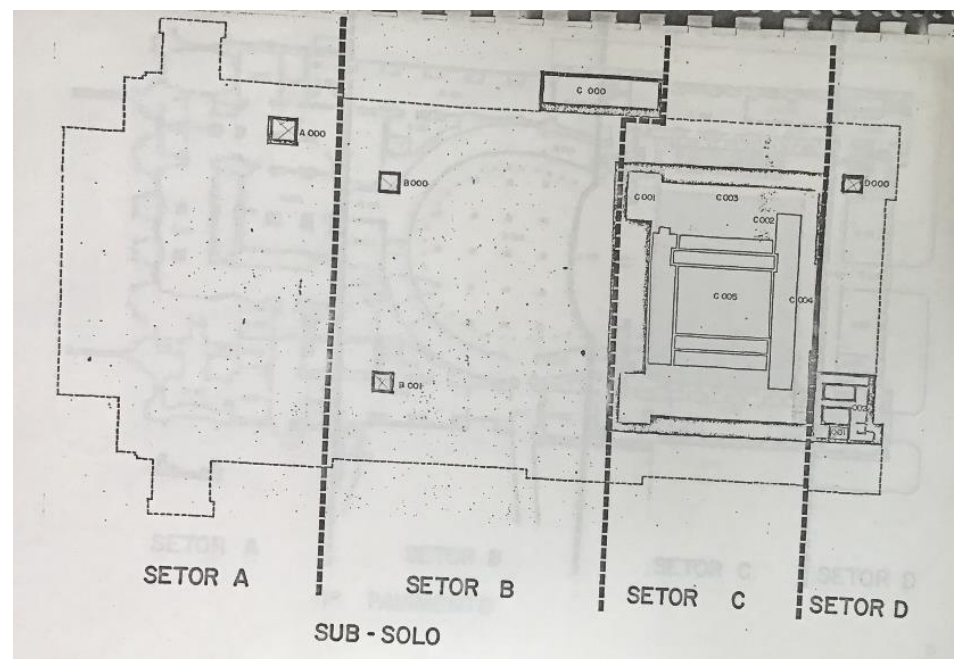

Figura 146: Planta do subsolo do edifício do TMSP, dividido em quatro setores. Fonte: INSTITUTO DE PESQUISAS TECNOLÓGICAS. Relatório Geral de todas as áreas técnicas IPT n. 21.737: Volume I-IV. São Paulo, fevereiro 1985.

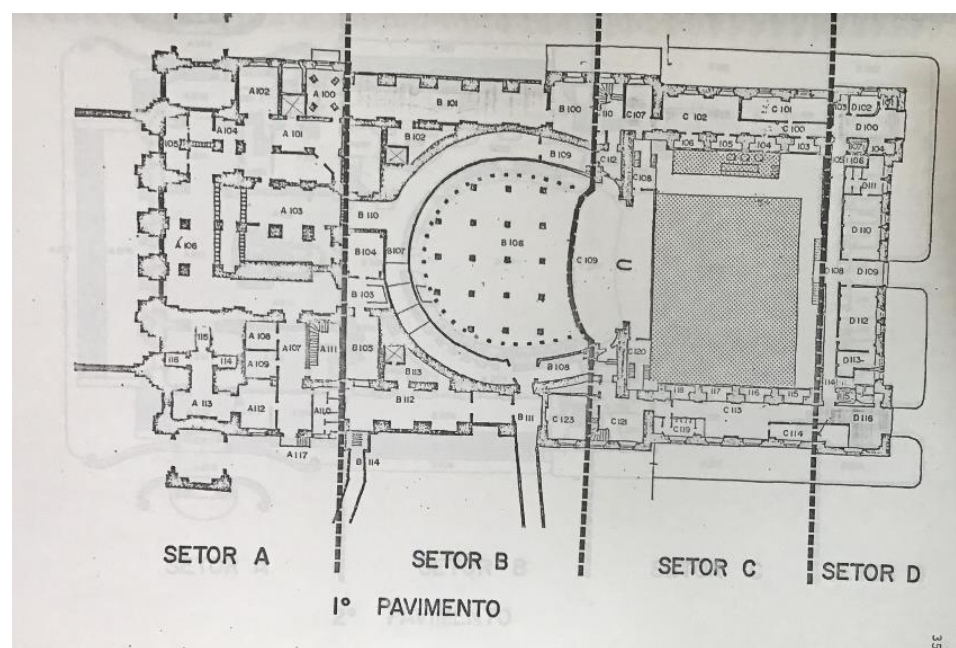

Figura 147: Planta do primeiro pavimento do edifício do TMSP, dividido em quatro setores. Fonte: INSTITUTO DE PESQUISAS TECNOLÓGICAS. Relatório Geral de todas as áreas técnicas IPT n. 21.737: Volume I-IV. São Paulo, fevereiro 1985.

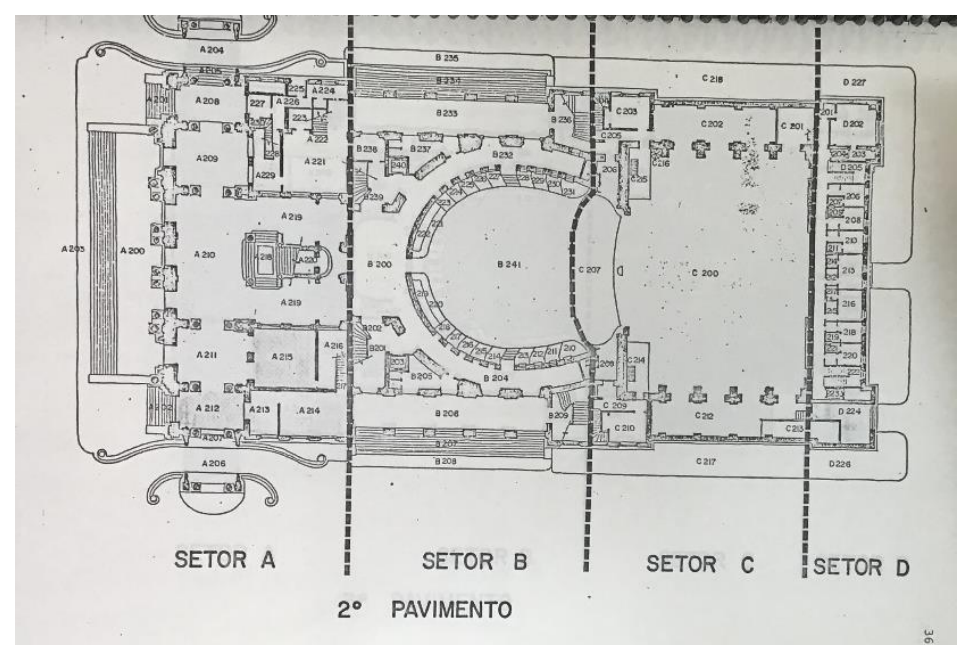

Figura 148: Planta do segundo pavimento do edifício do TMSP, dividido em quatro setores. Fonte: INSTITUTO DE PESQUISAS TECNOLÓGICAS. Relatório Geral de todas as áreas técnicas IPT n. 21.737: Volume I-IV. São Paulo, fevereiro 1985. 


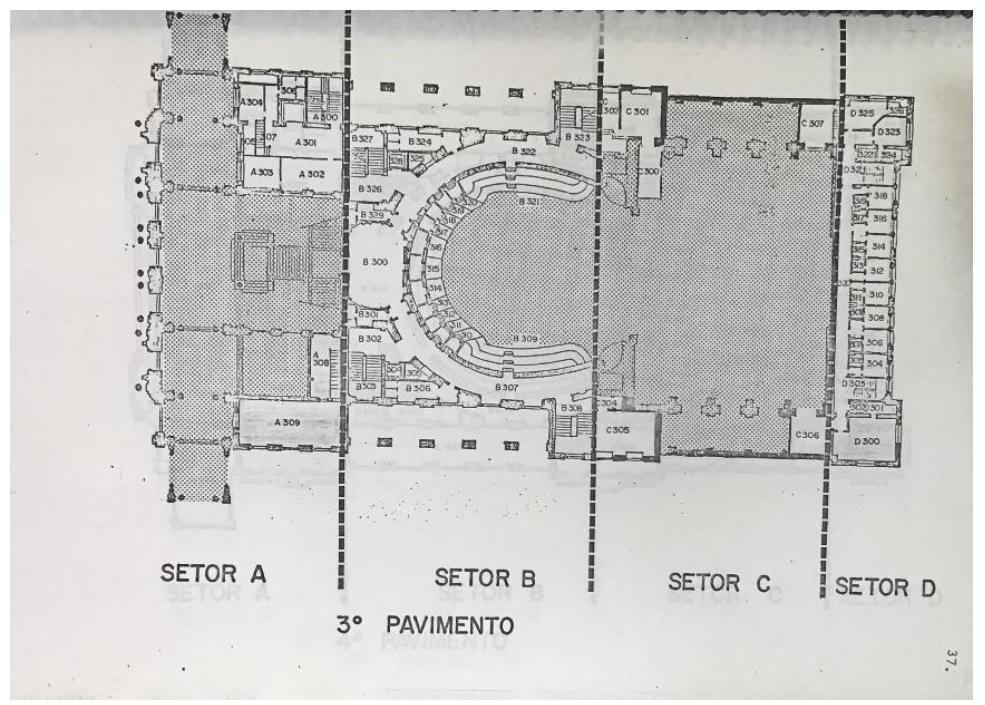

Figura 149: Planta do terceiro pavimento do edifício do TMSP, dividido em quatro setores. Fonte: INSTITUTO DE PESQUISAS TECNOLÓGICAS. Relatório Geral de todas as áreas técnicas IPT n. 21.737: Volume I-IV. São Paulo, fevereiro 1985.

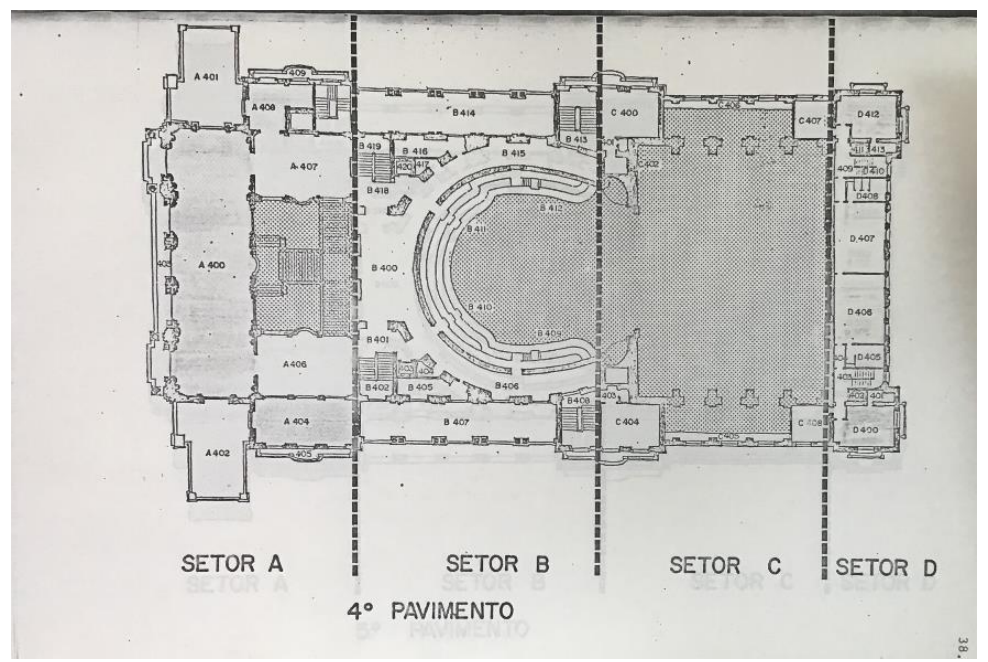

Figura 150: Planta do quarto pavimento do edifício do TMSP, dividido em quatro setores. Fonte: INSTITUTO DE PESQUISAS TECNOLÓGICAS. Relatório Geral de todas as áreas técnicas IPT n. 21.737: Volume I-IV. São Paulo, fevereiro 1985. 


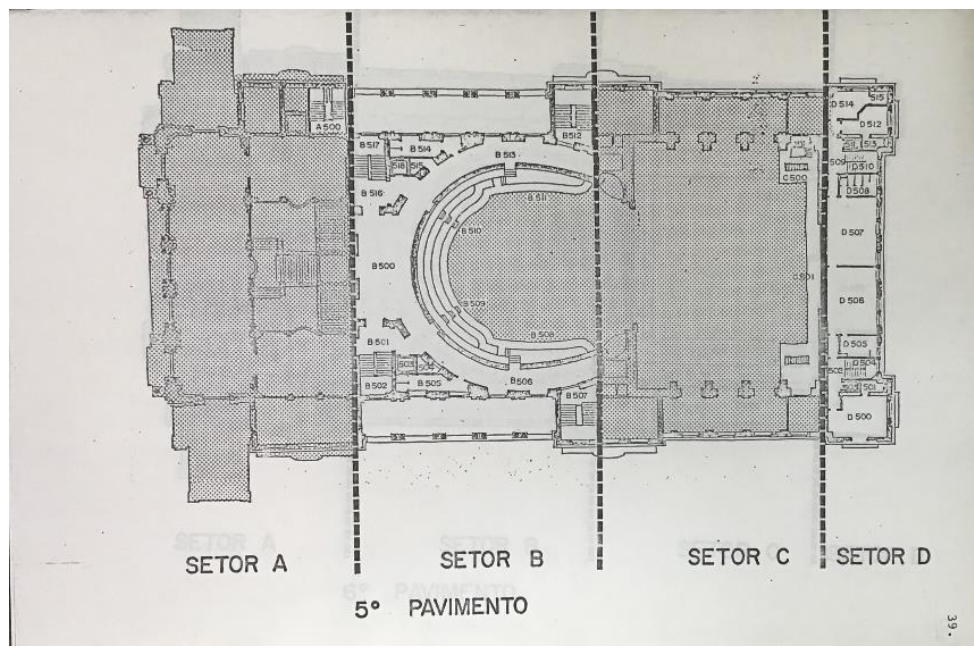

Figura 151: Planta do quinto pavimento do edifício do TMSP, dividido em quatro setores. Fonte: INSTITUTO DE PESQUISAS TECNOLÓGICAS. Relatório Geral de todas as áreas técnicas IPT n. 21.737: Volume I-IV. São Paulo, fevereiro 1985.

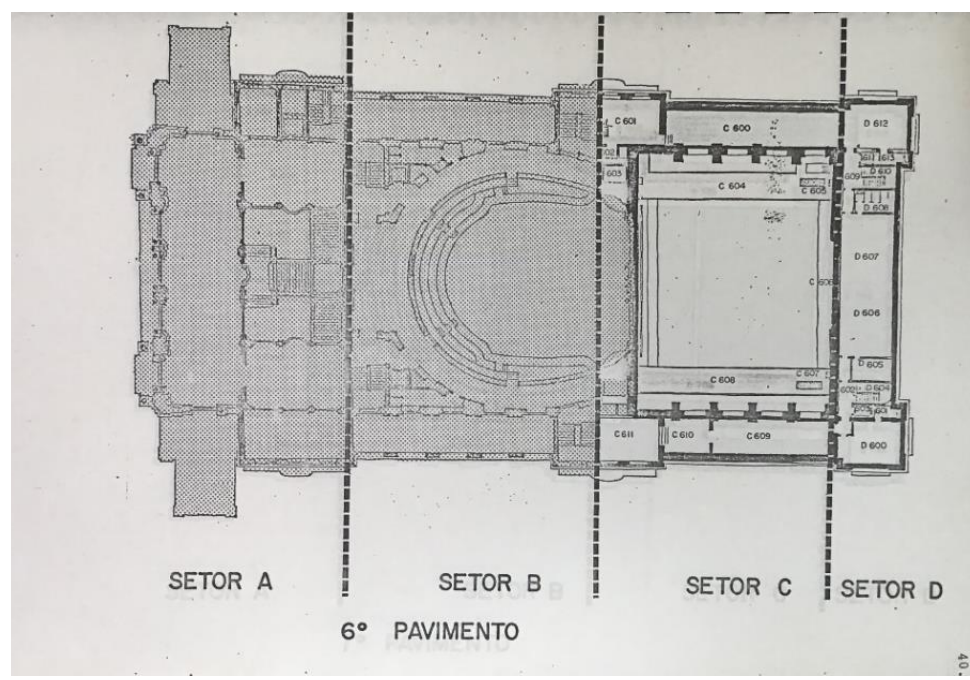

Figura 152: Planta do sexto pavimento do edifício do TMSP, dividido em quatro setores. Fonte: INSTITUTO DE PESQUISAS TECNOLÓGICAS. Relatório Geral de todas as áreas técnicas IPT n. 21.737: Volume I-IV. São Paulo, fevereiro 1985. 


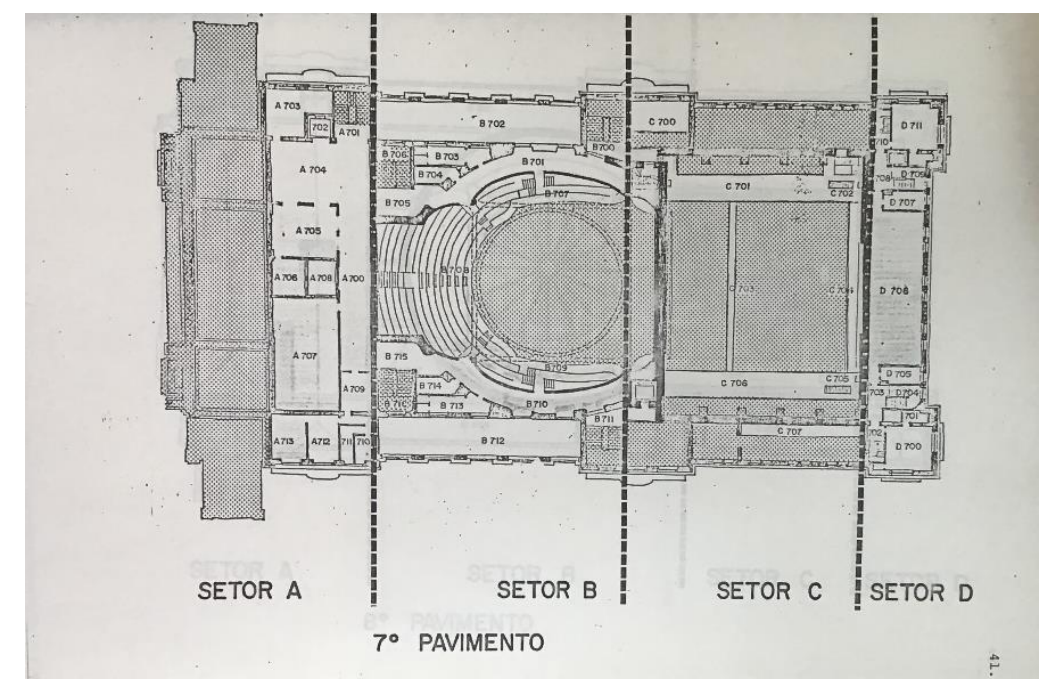

Figura 153: Planta do sétimo pavimento do edifício do TMSP, dividido em quatro setores. Fonte: INSTITUTO DE PESQUISAS TECNOLÓGICAS. Relatório Geral de todas as áreas técnicas IPT n. 21.737: Volume I-IV. São Paulo, fevereiro 1985.

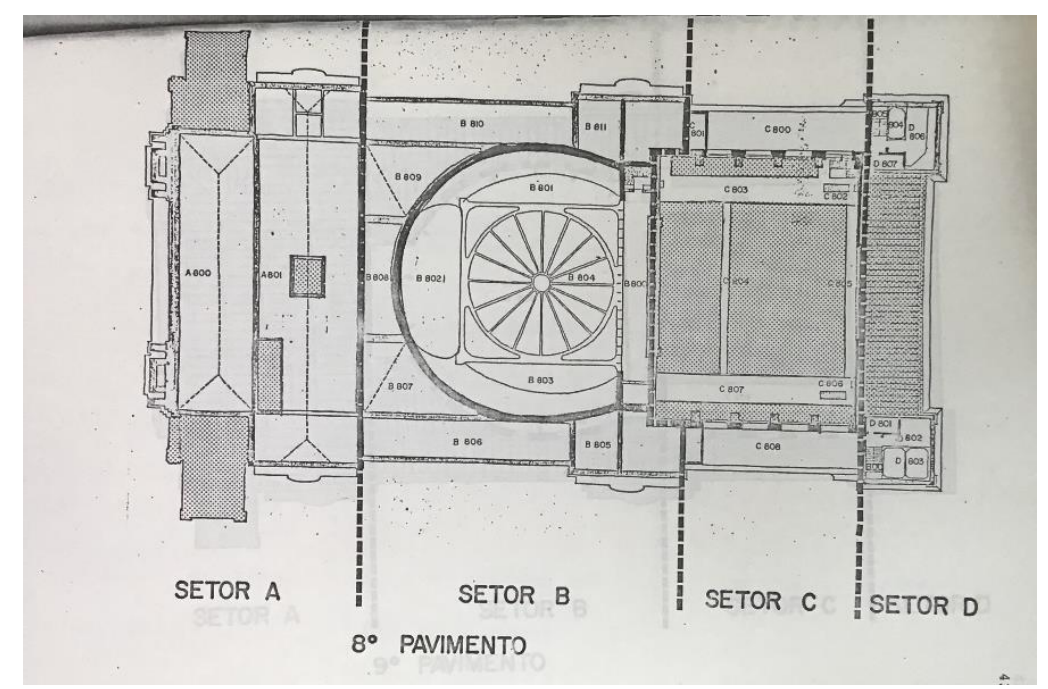

Figura 154: Planta do oitavo pavimento do edifício do TMSP, dividido em quatro setores. Fonte: INSTITUTO DE PESQUISAS TECNOLÓGICAS. Relatório Geral de todas as áreas técnicas IPT n. 21.737: Volume I-IV. São Paulo, fevereiro 1985. 


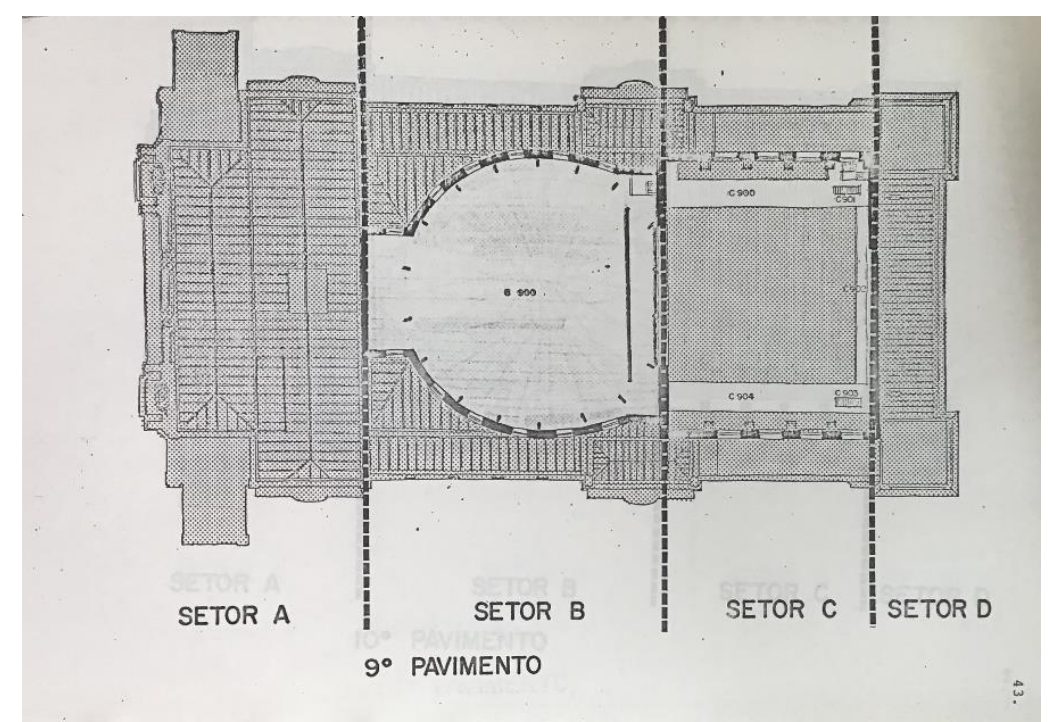

Figura 155: Planta do nono pavimento do edifício do TMSP, dividido em quatro setores. Fonte: INSTITUTO DE PESQUISAS TECNOLÓGICAS. Relatório Geral de todas as áreas técnicas IPT n. 21.737: Volume I-IV. São Paulo, fevereiro 1985.

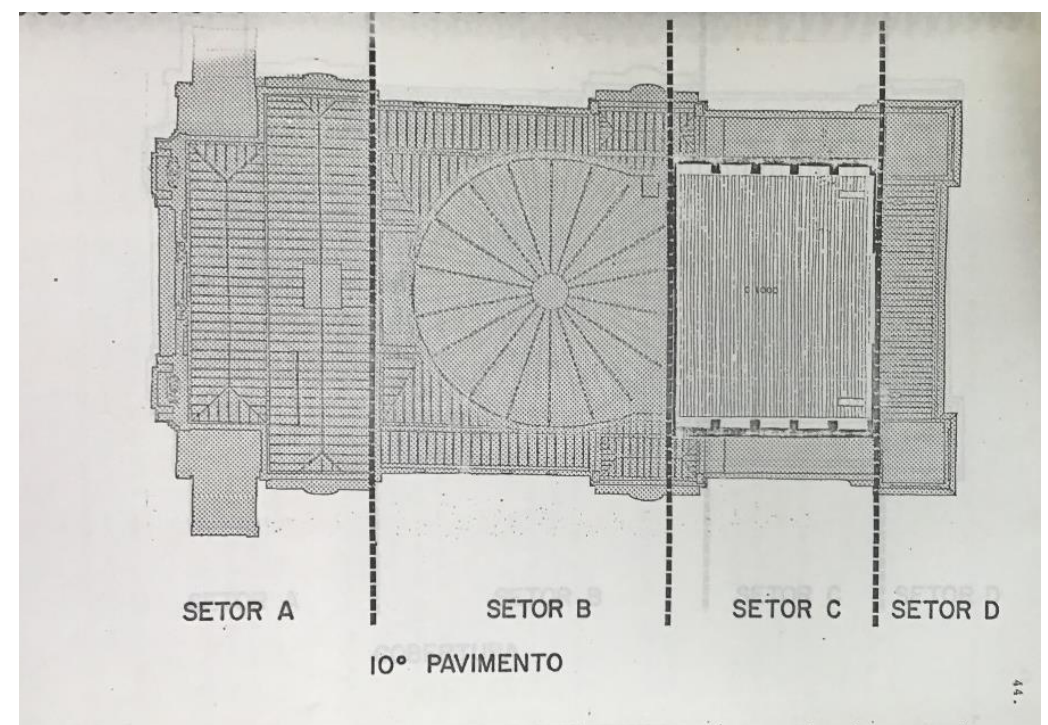

Figura 156: Planta do décimo pavimento do edifício do TMSP, dividido em quatro setores. Fonte: INSTITUTO DE PESQUISAS TECNOLÓGICAS. Relatório Geral de todas as áreas técnicas IPT n. 21.737: Volume I-IV. São Paulo, fevereiro 1985. 


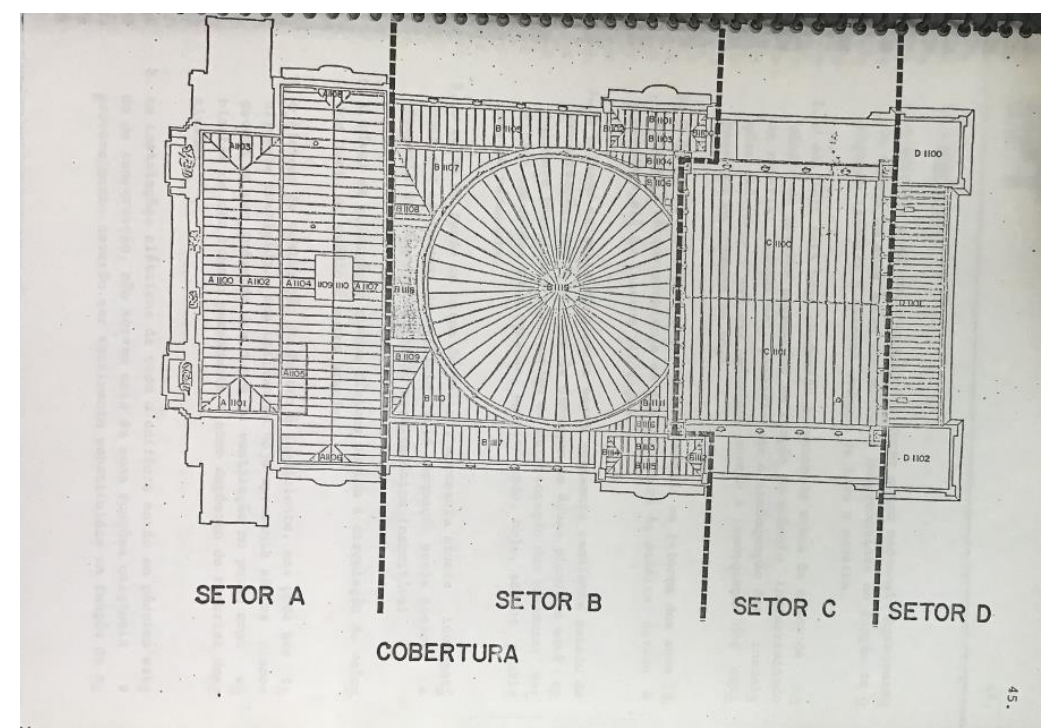

Figura 157: Planta da cobertura do edifício do TMSP, dividida em quatro setores.

Fonte: INSTITUTO DE PESQUISAS TECNOLÓGICAS. Relatório Geral de todas as áreas técnicas IPT n. 21.737: Volume I-IV. São Paulo, fevereiro 1985.

O relatório preliminar, de janeiro de $1985^{77}$, adverte a ausência de documentação adequada sobre as obras de reforma sofridas pelo Theatro durante a década de 1950, fato que já havia sido mencionado nos relatórios precedentes, relativos às fachadas. Dito isso, o Instituto se compromete em realizar uma análise pautada no estado atual do edifício, fazendo uso de uma base gráfica de autoria própria, na ausência de um levantamento métrico detalhado prévio.

Para realização dessa análise, foram criadas fichas de registro da vistoria (Figura 158), que indicavam a avaliação de adequação, integridade e estado de manutenção de cada ambiente, além das recomendações de intervenção específicas. Nesse momento, os principais riscos à segurança e integridade do edifício identificados estavam ligados ao comprometimento estrutural, resultante da ação de insetos xilófagos; e à possibilidade de incêndio, devido ao armazenamento inadequado de material inflamável, aliado à distribuição pouco racional dos ambientes de apoio e à inadequação das instalações elétricas e de combate ao fogo. 77 INSTITUTO DE PESQUISAS TECNOLÓGICAS. Relatório IPT n. 21.441: Vistoria Técnica. São
Paulo, janeiro 1985. 


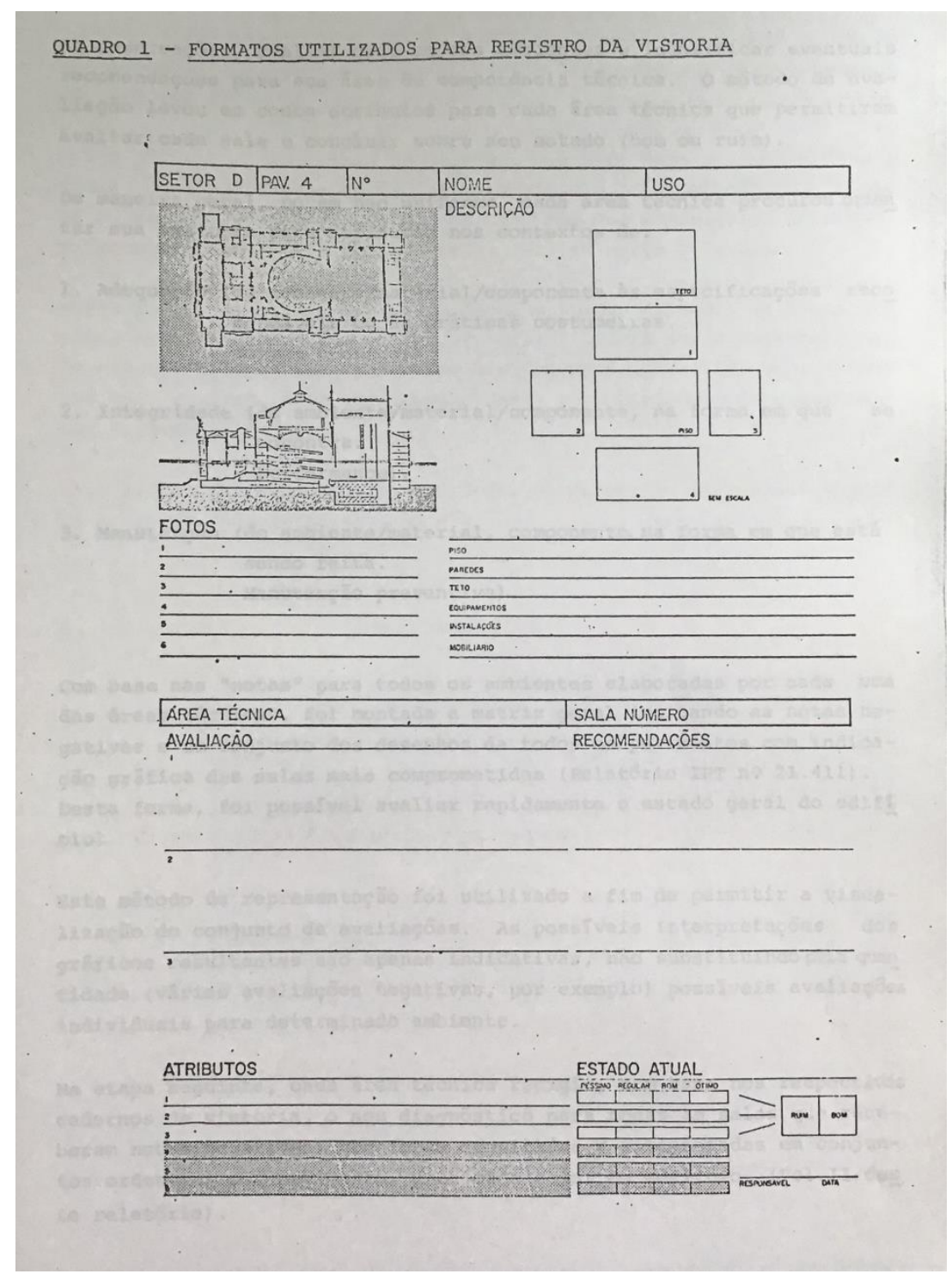

Figura 158: Ficha para registro de vistoria. No canto superior esquerdo, o ambiente avaliado era localizado em planta e em corte. No canto superior direito, um diagrama planimétrico de suas superfícies servia para especializar patologias e observações. Abaixo, eram descritas as avaliações e recomendações de preservação, assim como seu estado geral de conservação.

Fonte: INSTITUTO DE PESQUISAS TECNOLÓGICAS. Relatório Geral de todas as áreas técnicas IPT n. 21.737: Volume I-IV. São Paulo, fevereiro 1985

\subsubsection{Estruturas, Instalações e Equipamentos}

A estrutura do edifício, de modo geral, foi bem avaliada. Apenas foram reconhecidas pequenas trincas nas fundações, que não comprometiam 0 funcionamento geral do sistema e, consequentemente, não ofereciam riscos. As alvenarias, que compõem $36 \%$ do total da área construída, apresentavam desequilíbrio com relação à regularidade da manutenção. Nas áreas nobres (setores $A / B$ ), procedimentos conservativos eram mais frequentes, sendo raros ou inexistentes na área de palco (setor $\mathrm{C}$ ) e razoavelmente frequentes na área 
de camarins (setor D). Apesar da elevada frequência de manutenção nas áreas nobres, algumas de suas salas figuravam na lista de casos agudos de necessidade de intervenção imediata, como o Bar e a Sala Branca.

De acordo com o Artigo 341, referente a teatros, do código de edificações vigente (Lei n. 8.266 de 20.06.1975), as instalações do Municipal eram inadequadas no que tange ao combate de incêndios, como já mencionado anteriormente. A cobertura do palco deveria dispor de chaminé e todas as aberturas de acesso a esse deveriam ser dotadas de dispositivos de fechamento resistentes ao fogo. Os depósitos de material cênico sob o palco também feriam as recomendações do código, assim como a ausência de tratamento contra incêndio nos cenários e cortinas. Para além dessas questões mais superficiais, o edifício Theatro apresentava problemas de ordem projetual, como a má compartimentação, a ausência de saídas e escadas de emergência e a dificuldade de acesso aos extintores.

A acústica do Theatro, por sua vez, teve uma boa avaliação geral. A sala de espetáculos apresentava boa performance acústica, exceto nas frisas e nos últimos assentos da plateia. O Hall de entrada e a sala sob a Cúpula não eram adequados para espetáculos ou atividades de longa permanência, sendo o tráfego a principal fonte de ruído ${ }^{78}$. Dessa forma, a solução proposta pelo relatório, dotada de bastante ousadia, consistia na retirada da circulação de automóveis no entorno próximo e a transformação das vias lindeiras em calçadões ou jardins.

As soluções que incidiriam diretamente no edifício consistiam na colocação de "tapadeiras acústicas" no palco e o uso do ciclorama, na ocasião de apresentações de ópera, além do aperfeiçoamento da sua caixilharia. Também foi recomendado que as janelas e portas dos corredores, voltadas para 0 exterior, permanecessem fechadas durante os espetáculos.

$78 \mathrm{O}$ ruído de fundo proveniente do tráfego atingia, no interior do Theatro, $55 \mathrm{~dB}$, quando o recomendado seria que não ultrapassasse os $35 \mathrm{~dB}$ (INSTITUTO DE PESQUISAS TECNOLÓGICAS. Relatório Geral de todas as áreas técnicas IPT n. 21.737: Volume I-IV. São Paulo, fevereiro 1985). 
Apesar da evidente não adoção da retirada de circulação de automóveis do entorno, o memorial descritivo do projeto indica que foi realizada a correção acústica da sala de espetáculos e o tratamento da cúpula e demais salas de ensaio.

As instalações hidráulicas foram analisadas por grupos. O alimentador predial de água fria não tinha vazão suficiente para cobrir os dias de alto consumo, ao que foi sugerida a instalação de um sistema de recalque do reservatório inferior para o superior, e o aumento da seção da vazão do alimentador ${ }^{79}$. A tubulação de ferro maleável galvanizado, assim como os barriletes, colunas e ramais, haviam chegado ao final de sua vida útil e estavam próximos ao colapso.

As instalações de combate ao fogo (hidrantes) estavam em bom estado de conservação e de acordo com as exigências da Prefeitura e do Corpo de Bombeiros. As únicas falhas encontradas foram a ausência de uma brigada de incêndio treinada e a impossibilidade de renovação dos cem mil litros de água do reservatório de incêndio.

As instalações de água quente apresentavam tubulações de distribuição com vida útil ultrapassada, mas os ramais de cobre estavam em bom estado. $O$ sistema de aquecimento central a óleo havia sido abandonado, devido ao avançado nível de corrosão da caldeira e o consequente risco de explosão (Figuras 159 e 160). O sistema de água pluvial, por sua vez, estava em boas condições. Alguns vazamentos foram localizados, no entanto, como resultado do transbordamento provocado pelo acúmulo de detritos nas calhas e condutores.

\footnotetext{
${ }^{79}$ As instalações de água fria do edifício do Theatro funcionavam a partir de uma entrada da Sabesp que fornecia, por gravidade, um total de 76.000 I de água para dois reservatórios inferiores e cinco superiores. $O$ total dos reservatórios superiores $(46.000 \mathrm{~L})$, perdia $50 \%$ de seu volume devido ao desnível entre os reservatórios, que funcionavam como vasos comunicantes (INSTITUTO DE PESQUISAS TECNOLÓGICAS. Relatório Geral de todas as áreas técnicas IPT n. 21.737: Volume I-IV. São Paulo, fevereiro 1985).
} 

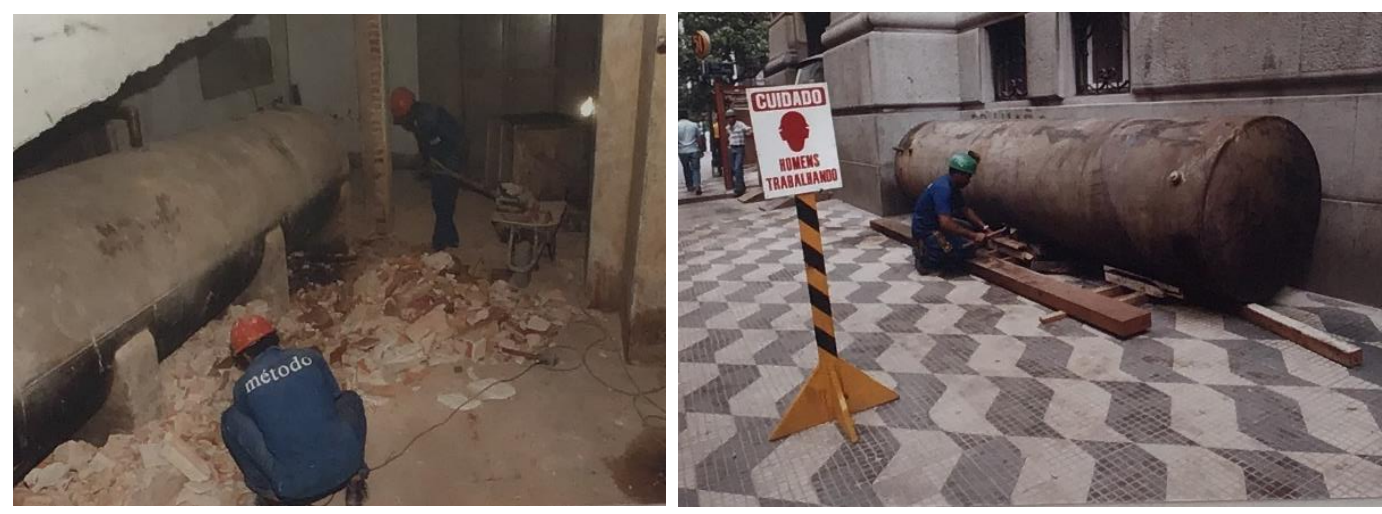

Figuras 159 (esq.) e 160 (dir.): Remoção do tanque de óleo do subsolo. Fonte: MÉTODO ENGENHARIA, 1988.

Assim como o escoamento de água pluvial do edifício estava comprometido pelo acúmulo de sujeira, o funcionamento das bocas de lobo e bocas de leão do entorno padecia do mesmo problema. O esgoto sanitário apresentava outros problemas de ordem específica, como a ligação direta entre o ramal dos mictórios e o ralo sifonado, que ocasionava extremo mau cheiro; e o avançado estado de corrosão das tubulações em ferro galvanizado e ferro fundido, que provocou a diminuição da seção de vazão.

No geral, foi proposta a execução de novo projeto e novas instalações para os sistemas de água fria, quente e esgoto, com a intenção de solucionar seu subdimensionamento e obsolescência. A substituição do sistema de aquecimento central foi fortemente recomendada, assim como a substituição integral dos aparelhos sanitários, registros e torneiras. Quanto ao sistema de águas pluviais e de combate ao fogo, respectivamente, recomendou-se a manutenção e reparo das calhas, rufos e condutores; e a conexão do sistema de recalque do reservatório de incêndio com os demais reservatórios prediais, além de melhor tratamento da água e exame de sua potabilidade.

As instalações elétricas, assim como as hidráulicas, apresentavam uma série de problemas relacionados a sua insuficiência e inadequação. A cabine de barramentos estava abaixo das especificações da Eletropaulo; o painel de distribuição, obsoleto; e a precariedade das instalações provisórias, muitas vezes expostas, representavam perigo de incêndio. A ausência de manutenção ficava evidente nas más condições das tomadas, interruptores e placas de 
proteção, que também contribuíam para a situação de risco. Dessa forma, foi sugerida a substituição integral do sistema elétrico e da tubulação de toda e qualquer instalação aparente (Figuras 161 e 162).

O memorial descritivo da obra atestou que essas sugestões propostas pelo Instituto, quanto à substituição das instalações hidráulicas e elétricas, bem como $o$ incremento dos equipamentos de segurança contra incêndios foram acatadas pelo projeto ${ }^{80}$.
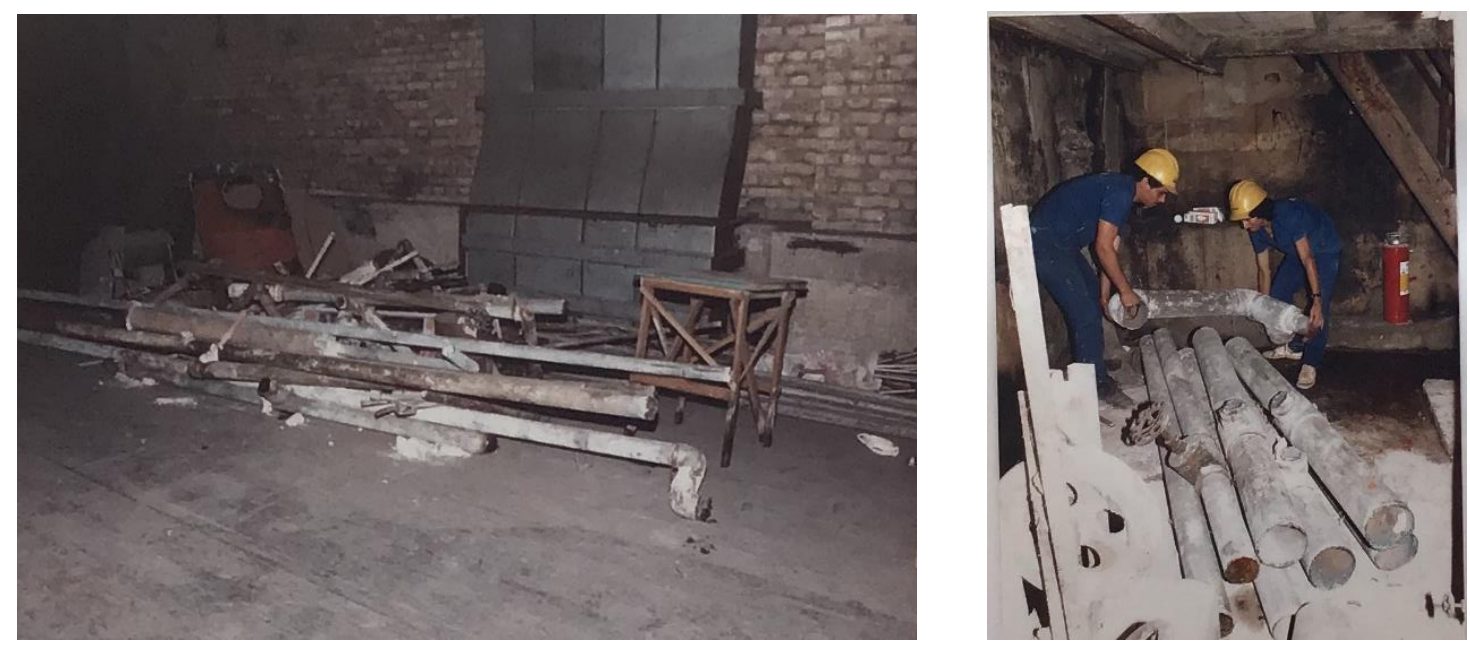

Figuras 161 (esq.) e 162 (dir.): Retirada de tubulação inservível. Fonte: MÉTODO ENGENHARIA, 1988.

A ventilação do edifício se dava tanto por meios naturais, a partir do "efeito chaminé" proporcionado pela circulação de ar pelas escadas e corredores da plateia, como mecânicos. Esses últimos constituíam três sistemas independentes, que funcionavam respectivamente por combinação entre ventilação diluidora e exaustora. Uma vez que o ar externo era filtrado, ele circulava por um ventilador centrífugo no subsolo e era transportado por galerias para ventiladores auxiliares, para que difusores distribuíssem o ar ao longo da periferia de cada nível da sala de espetáculos.

O sistema de exaustão promovia pressão negativa no subsolo, em comunicação com o piso da plateia, através de pequenas aberturas. $O$ ar era então conduzido

${ }^{80}$ Memorial descritivo dos projetos (obra de reforma do teatro municipal - obra civil - 1. Etapa), novembro de 1985. 
por galerias subterrâneas até a fonte da Praça Ramos de Azevedo. A ventilação do palco e camarins era feita por meio de um sistema de dutos independente, pelo qual circulava $o$ ar proveniente de outros dois ventiladores centrífugos, alocados no subsolo. Algumas áreas de apoio, além do sistema de dutos e ventiladores individuais, dispunham de condicionadores de ar de janela.

A avaliação geral do sistema de ventilação do edifício é boa, uma vez que a renovação do ar viciado por ar fresco se dá de maneira correta. No entanto, foi detectada a necessidade de implementar um sistema de condicionamento do ar externo introduzido. Além disso, foi apontada a inadequação do uso dos dutos de ventilação subterrâneos como espaço de permanência ou até mesmo depósito de material. O memorial descritivo do projeto aponta que ambas as sugestões foram acatadas, e foi feita a instalação de equipamentos de arcondicionado para plateia, camarins, cúpula e salas de ensaio e administrativas.

Quanto aos demais equipamentos, foram avaliados os mecanismos de elevação de palco e orquestra, assim como os elevadores de público e pessoal. No primeiro grupo, detectou-se a má distribuição de cargas, sendo necessária a reforma e colocação de novos pistões.

O segundo grupo apresentava bom estado de conservação, ficando apenas aconselhadas manutenções periódicas por parte das próprias empresas fornecedoras das máquinas. Os equipamentos de elevação e descida do urdimento também estavam em boas condições, sendo apenas necessária a colocação de polias de passagem e a mudança de local do quadro geral, devido à dificuldade de acesso (Figuras 163 e 164). O memorial descritivo da obra aponta que essas sugestões foram acatadas integralmente. 

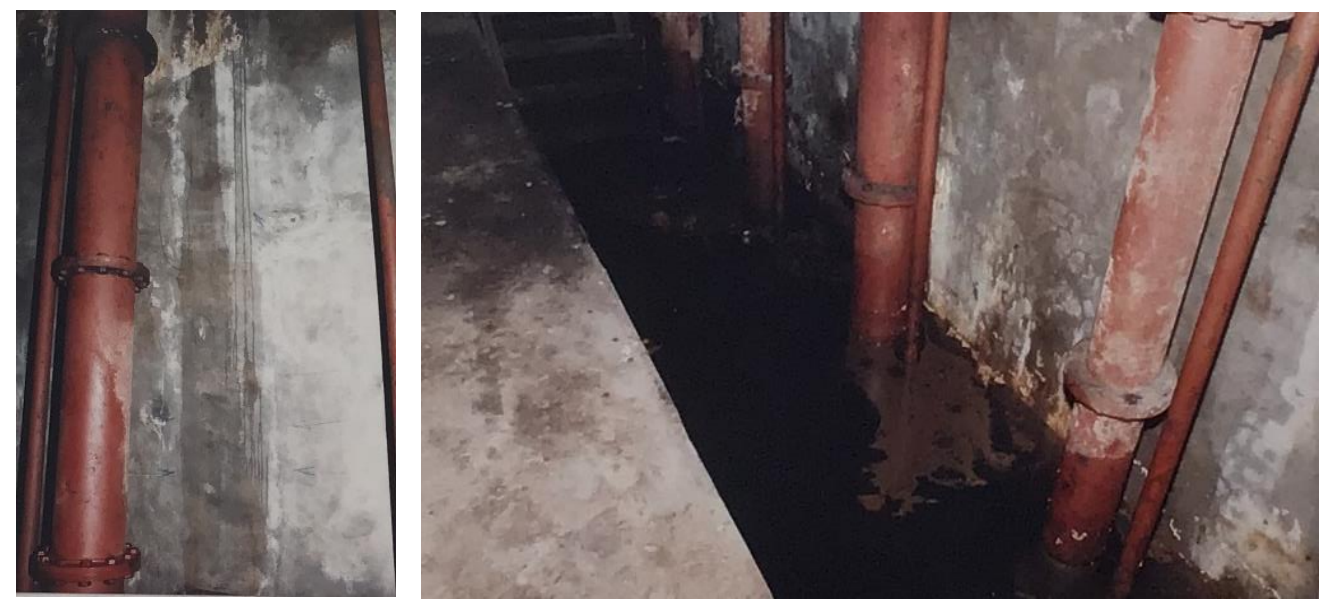

Figuras 163 (esq.) e 164 (dir.): Pistões hidráulicos do mecanismo de elevação do palco e infiltrações.

Fonte: MÉTODO ENGENHARIA, 1988.

\subsubsection{Camarins e mobiliário}

O mobiliário do salão nobre e da sala de espetáculos, composto por cadeiras móveis e poltronas fixas se mostrou adequado, mas apresentava desgaste considerável e exigia a recuperação dos estofados e mecanismos. O mobiliário dos camarins, oficinas e depósitos, para além do mau estado de conservação, não atendia à demanda funcional e sua inadequação denotava a falta de planejamento da ocupação.

Nesse último caso, foi recomendada a elaboração de um plano racional de ocupação, seguido pela substituição integral do mobiliário. O memorial descritivo da obra aponta que foi realizada a reforma completa dos camarins e demais espaços de apoio, conforme sugerido pelo IPT (Figuras 165 - 168). 


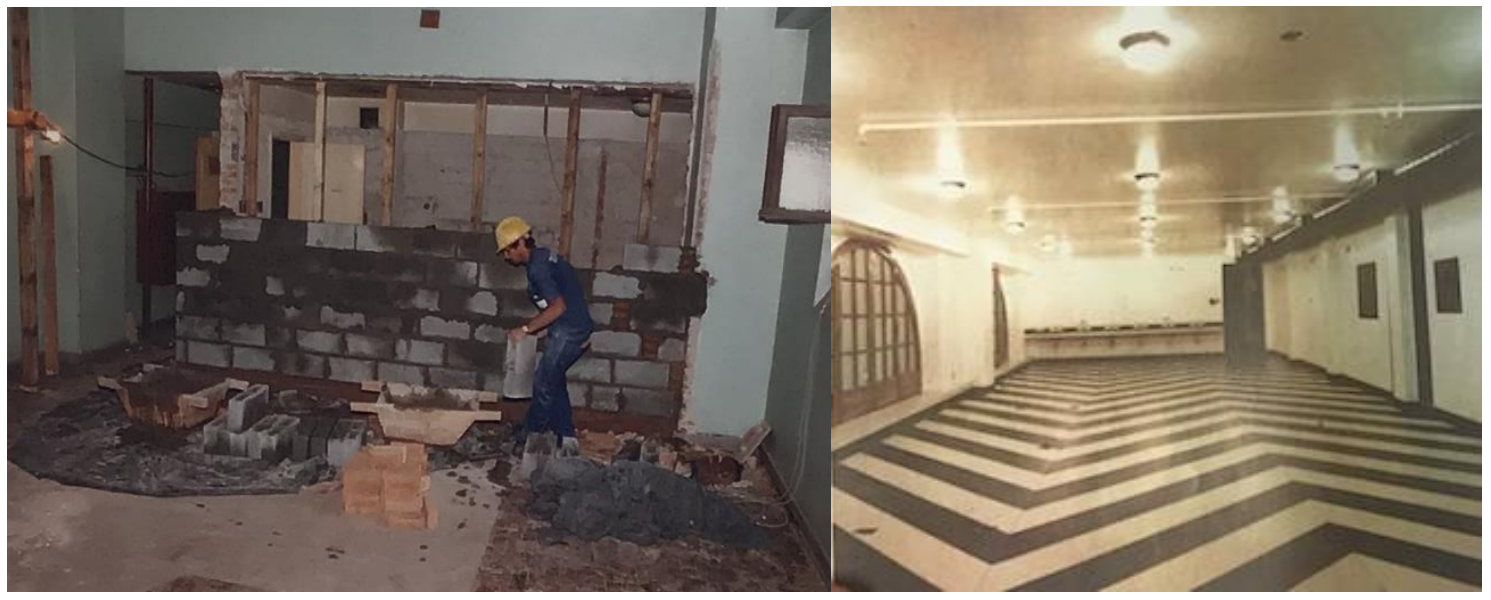

Figuras 165 (esq.) e 166 (dir.): Interiores do setor de camarins durante (esq.) e depois da reforma (dir.).

Fonte: MÉTODO ENGENHARIA, 1988.
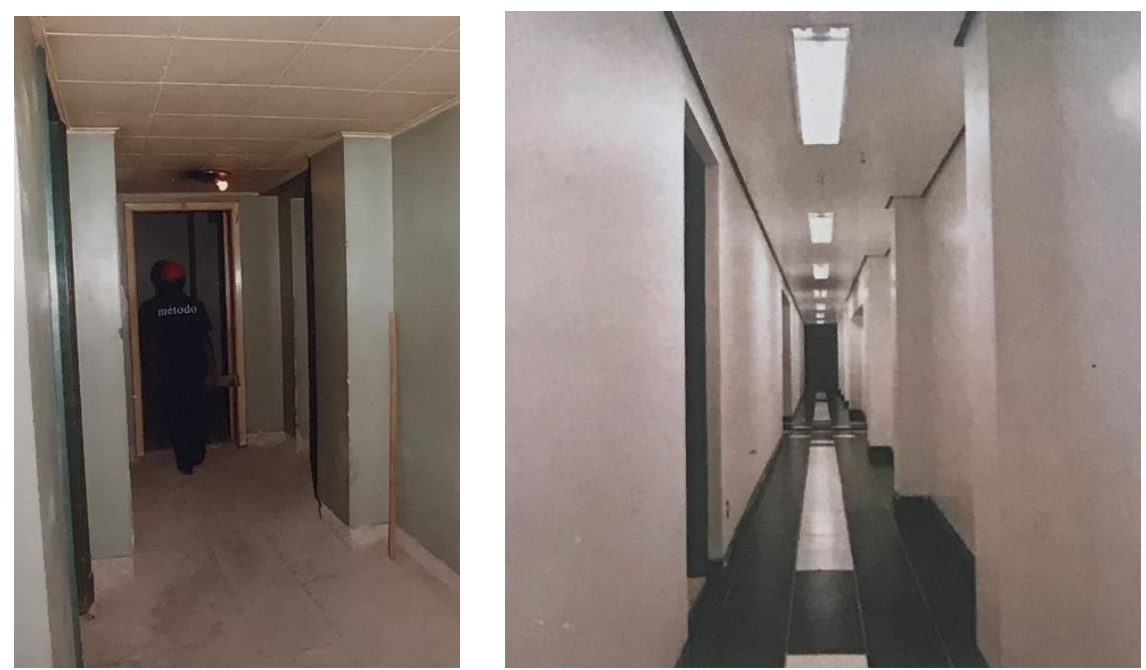

Figuras 167 (esq.) e 168 (dir.): Corredor do setor de camarins durante (esq.) e depois da reforma (dir.)

Fonte: MÉTODO ENGENHARIA, 1988.

As coberturas de madeira apresentavam deterioração devido à ação de cupins de solo e de madeira seca, que já haviam sido detectados pelo IPT entre 1982 e 1983, tendo recebido, na ocasião, tratamento químico que fez com que a infestação sofresse um aparente decréscimo. Algumas áreas estavam apodrecidas, devido a penetração de água de chuva e a consequente ação de fungos, e as peças substituídas na última reforma haviam sido introduzidas sem nenhum tratamento prévio. 


\subsubsection{Salão Nobre e Insetos Xilófagos}

Dentre esse grupo, a cobertura do Salão Nobre foi identificada como aquela que apresentava problemas de maior gravidade, tendo sido sugerido o reforço estrutural e a substituição das peças danificadas, além da aplicação de tratamento químico periódico. A periculosidade da ação de cupins não foi detectada apenas na cobertura, mas se estendeu para os pisos e passarelas do palco.

A detecção da ação superficial de cupins subterrâneos nos pisos do quarto e sétimo pavimentos do setor nobre suscitou a necessidade de inspeção, por meio de retirada das tábuas do assoalho, e verificação do estado das vigas de sustentação. Para essas áreas, foi recomendado reforçar, substituir ou tratar todo o piso.

De acordo com o memorial descritivo da obra, foi realizada a reconstituição do forro do Salão Nobre, após reforço estrutural na forma de suportes metálicos (Figura 169). Os pisos do palco também foram reformados e os demais assoalhos de madeira foram devidamente tratados.

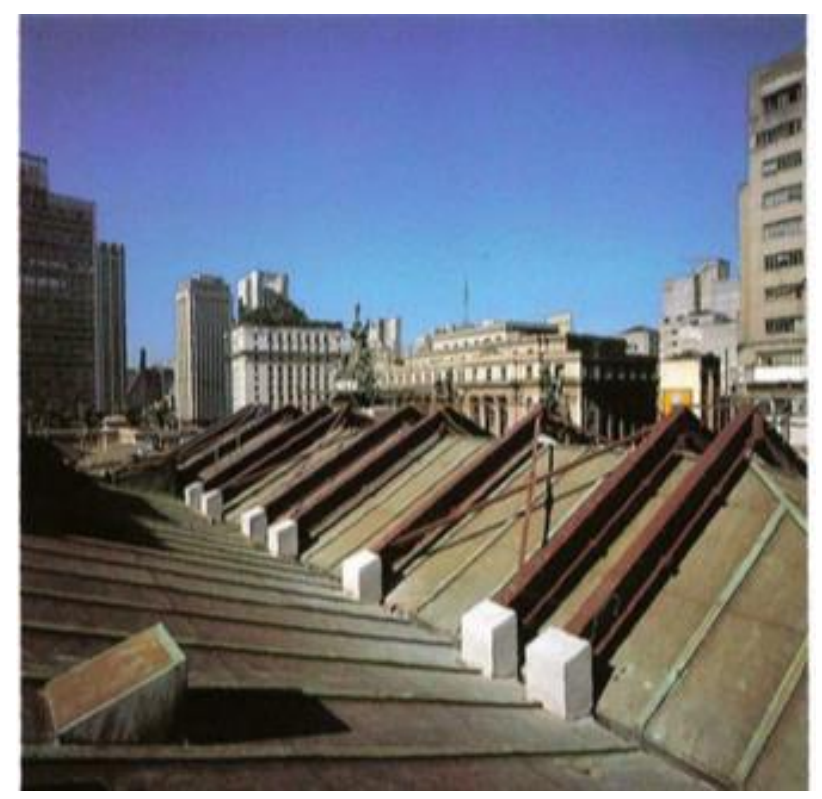

Figura 169: Estrutura metálica de reforço construída na cobertura do Salão Nobre, pelo lado externo.

Fonte: KATCHVARTANIAN, 2014. 
O piso do salão sob a cúpula (Figura 170) estava bastante deteriorado pela ação de cupins e brocas, sendo necessária a substituição integral das tábuas do assoalho e substituição parcial das vigas de sustentação. De acordo com o memorial, essa intervenção se deu como parte da adaptação do salão sob a cúpula como espaço de ensaios, tendo sido instalado um piso de drywall sobre estrutura metálica.

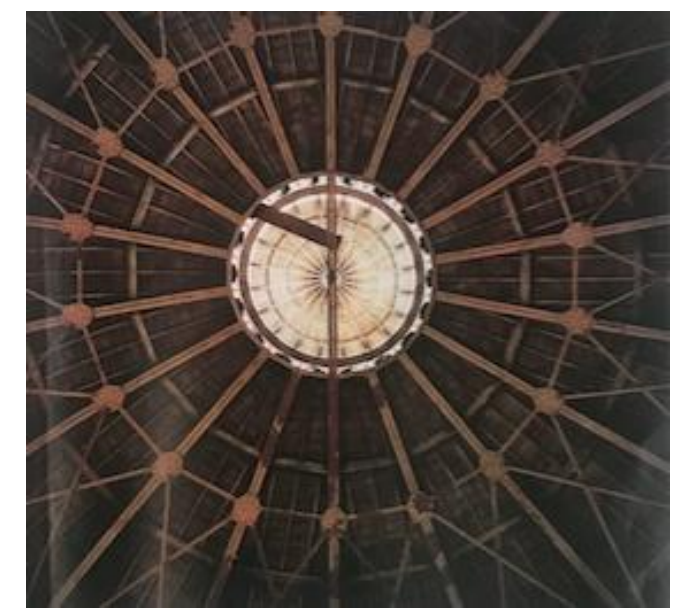

Figura 170: Fotografia da estrutura da cobertura da cúpula. Fonte: Revista Projeto 112, 1988.

\subsubsection{Pinturas}

Quanto às superfícies pintadas, foi feita uma avaliação minuciosa de cada sala. De maneira geral, as pinturas apresentavam bom desempenho, excetuando-se os casos nos quais havia manchas provenientes de vazamentos, trincas, destacamentos ou sujeira. A maioria dos desgastes identificados poderia ter sido evitada pela manutenção periódica, que foi insuficiente.

Outro problema identificado pela inspeção foi a aplicação de tinta látex sobre pintura artística de algumas superfícies, principalmente das paredes e teto do restaurante, das salas adjacentes ao palco e das acomodações de imprensa (Figura 171). Apesar das recomendações para recuperação da pintura em superfícies, caixilharias, conduítes e demais estruturas metálicas, pautadas pela raspagem, lixamento, limpeza e aplicação de duas demãos de tinta alquídica 
semi-brilhante a revólver ${ }^{81}$; o documento não estipula diretrizes para recuperação da pintura decorativa.

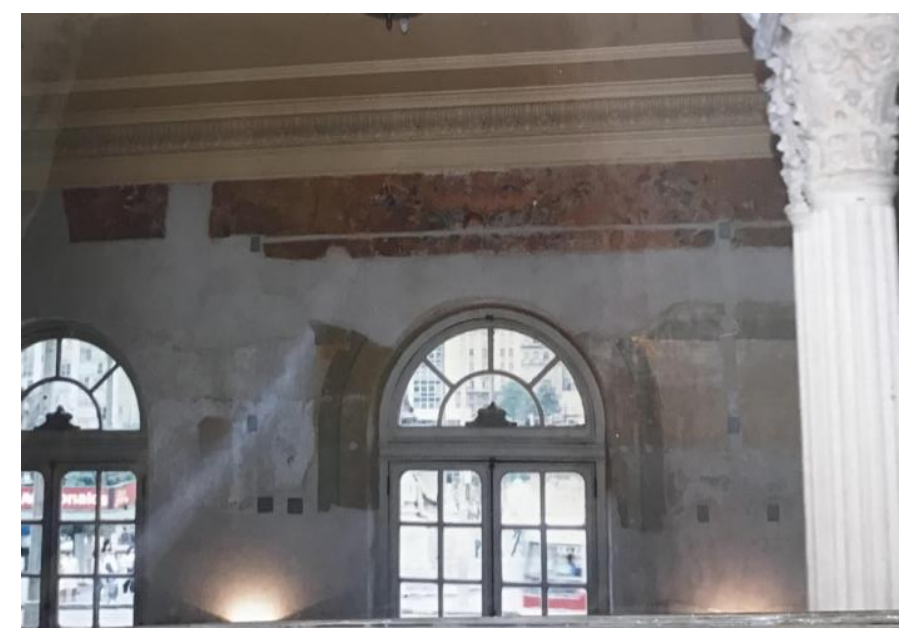

Figura 171: Fotografia do interior do restaurante. Fonte: MÉTODO ENGENHARIA, 1988.

O memorial descritivo das intervenções em elementos decorativos, no entanto, propõe diretrizes claras de atuação no tangente à recuperação dessas pinturas. Sugere-se a execução de prospecções exploratórias e estratigráficas, para localizar e verificar as camadas pictóricas ${ }^{82}$. Em seguida, deveria se realizar a identificação cromática dos extratos originais e seu estado de conservação e aderência, para definir a possibilidade de decapagem total. Apenas no caso da impossibilidade dessa, fica recomendada a recuperação ótica, mantendo-se a capa original recoberta. Uma vez adotada a postura mais adequada, seria definido "eticamente" o tipo de retoque a ser executado (trattegio, cor neutra uniforme, pontilhado, reposição idêntica ou textura sobre verniz).

\subsubsection{Vidros e Vitrais}

Os fechamentos de vidro também foram cautelosamente vistoriados, porém não foram revelados grandes problemas. Os espelhos do Salão Nobre apresentavam

\footnotetext{
${ }^{81} \mathrm{~A}$ tinta alquídica semi-brilhante apresenta melhor resistência à lavagem, em comparação com as tintas látex à base de PVA e a aplicação com revolver permite maior uniformidade (INSTITUTO DE PESQUISAS TECNOLÓGICAS. Relatório Geral de todas as áreas técnicas IPT n. 21.737: Volume I-IV. São Paulo, fevereiro 1985).

82 Departamento do Patrimônio Histórico. Memorial descritivo da obra de intervenção nos elementos decorativos do Teatro Municipal de São Paulo. São Paulo, 1986.
} 
envelhecimento dos respectivos filmes refletores, devido à alta exposição à luz natural. Os vidros da fachada, que dão para o placo, haviam sido pintados, tendo assim descaracterizado o exterior do edifício. De acordo com o documento, essas condições poderiam ser facilmente resolvidas por meio de manutenções e limpezas programadas.

Os vitrais decorativos, por sua vez, estavam em bom estado de conservação, tendo em vista a recente restauração a que haviam sido submetidos. Em 1981, o DPH havia elaborado um levantamento diagnóstico do estado dos vitrais, que revelou os problemas particulares de cada peça e suas possíveis soluções ${ }^{83}$. No ano seguinte, eles foram submetidos a um processo de restauração executado pela Conrado Vitrais e Cristais ${ }^{84}$ e orientado pelo próprio DPH.

O edifício do Theatro é composto por três grupos de vitrais, divididos de acordo com suas peculiaridades em termos de estrutura, localização e suporte, totalizando vinte e cinco peças. O primeiro conjunto, localizado no exterior do pavimento térreo, é montado sobre estrutura de ferro. O segundo e o terceiro, respectivamente no Salão Nobre e no interior do Saguão Principal, têm caixilharia em madeira.

Os danos mapeados, a serem enfrentados pela restauração, eram de duas ordens distintas. Havia peças cuja estrutura de fixação estava comprometida, e precisava de uma intervenção mais invasiva; mas também havia peças cuja única necessidade era a reposição de alguns vidros e retoques na pintura ornamental.

\footnotetext{
83 WALTER ARRUDA DE MENEZES. Departamento do Patrimônio Histórico. Levantamento/ diagnóstico do estado de conservação dos vitrais do Teatro Municipal de São Paulo. São Paulo, 1981.

84 Os vitrais utilizados na construção do Municipal são provenientes de duas oficinas distintas: a V. Saile, de Stuttgart; e a Conrado Sorgenicht Filho, cuja sede funcionava no bairro do Belenzinho. As esquadrias de madeira e ferro que receberam tais vitrais foram confeccionadas pelo Liceu de Artes e Ofícios. Os vitrais do salão nobre são assinados pela V. Saile, mas não existem registros ou confirmações de quais foram os vitrais confeccionados pela Casa Conrado (CONTIER, 2014). No entanto, a restauração de todos os conjuntos, na década de 1980, foi realizada pela Conrado Sorgenicht, sob a orientação e supervisão do DPH (WALTER ARRUDA DE MENEZES, 1981).
} 
Os problemas identificados nos vitrais do primeiro grupo são de ordem menos crítica, uma vez que seu comprometimento estrutural não os coloca em risco. Por outro lado, foi levantado um número significativo de peças quebradas, o que segundo o autor, se explicaria pela proximidade dos elementos com o passeio público. A quebra dessas peças, por sua vez, ocasionara danos pontuais no chumbamento de ligação entre elas. De maneira geral, o arquiteto recomendou que fosse feita uma limpeza e revisão das ferragens, assim como a reintegração da pintura ornamental que, em alguns pontos, se encontrasse esmaecida ou completamente desaparecida (Figuras 172 e 173). 


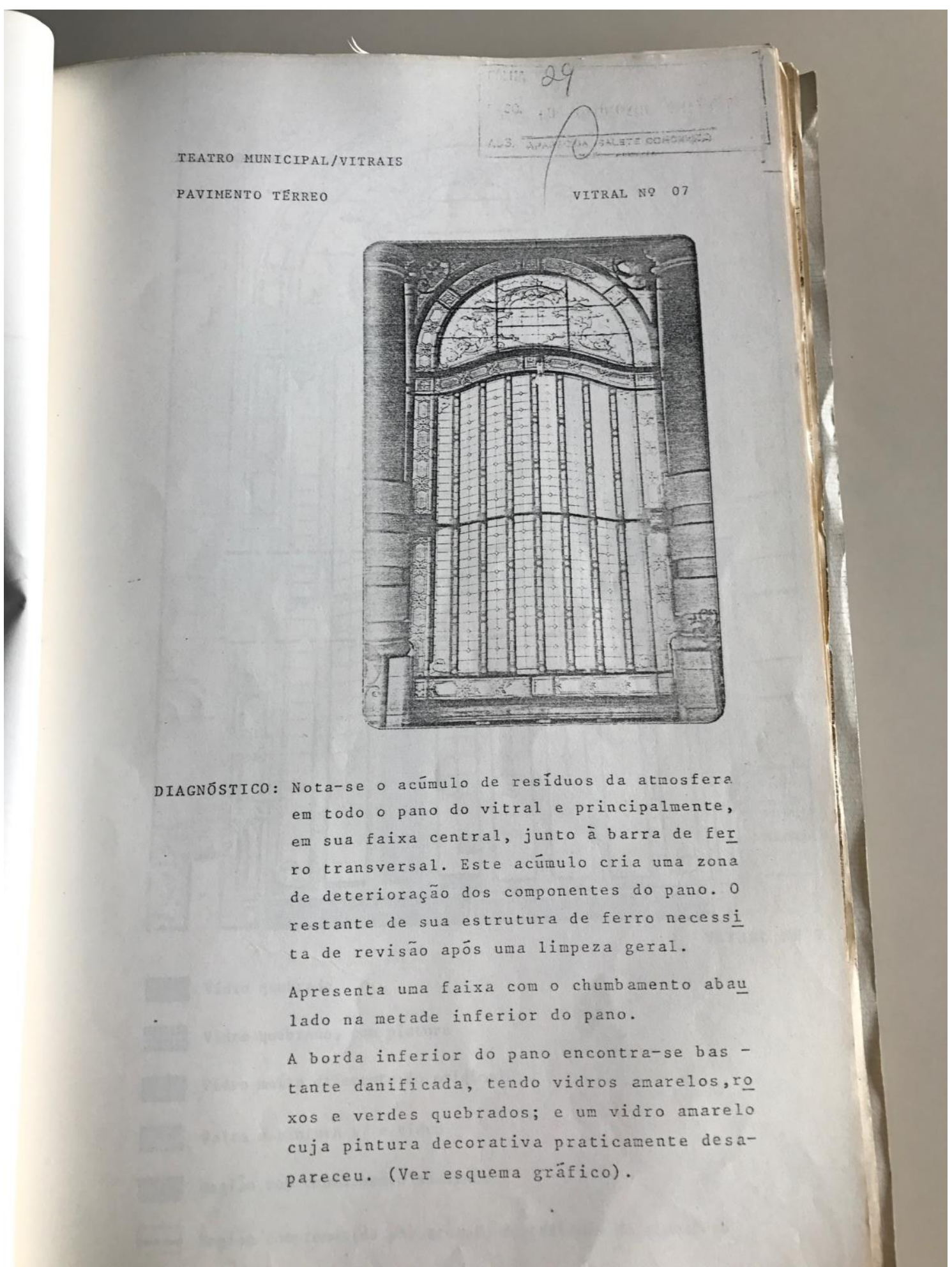

Figura 172: Exemplo de ficha de análise diagnóstica do estado de conservação dos vitrais. $O$ documento assinala a localização da peça, acompanhada de seu registro fotográfico e respectivo diagnóstico.

Fonte: WALTER ARRUDA DE MENEZES. Departamento do Patrimônio Histórico. Levantamento/ diagnóstico do estado de conservação dos vitrais do Teatro Municipal de São Paulo. São Paulo, 1981. 


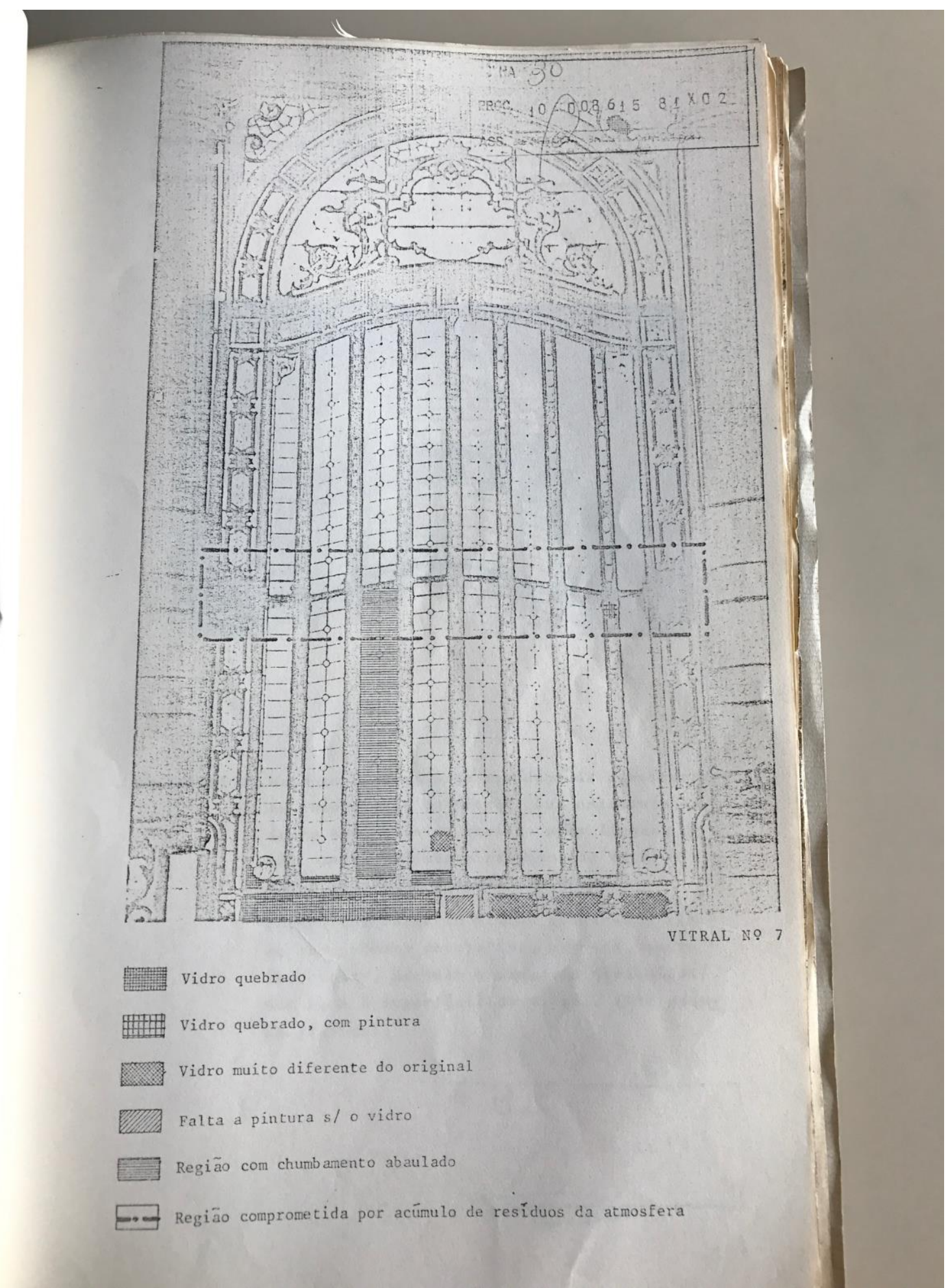

Figura 173: Exemplo de ficha de análise diagnóstica do estado de conservação dos vitrais. Cada peça foi reproduzida iconograficamente por meio de um desenho, no qual cada patologia correspondia a uma textura/ legenda distinta.

Fonte: WALTER ARRUDA DE MENEZES. Departamento do Patrimônio Histórico. Levantamento/ diagnóstico do estado de conservação dos vitrais do Teatro Municipal de São Paulo. São Paulo: 1981 
Em relação ao segundo grupo de vitrais, o autor identifica problemas estruturais decorrentes do próprio sistema de fixação das peças. Diferente do que acontecera nos vitrais do primeiro grupo, esses são fixados em enormes caixilhos de madeira, instalados em portas de duas folhas. Devido à sua proporção gigantesca, às características do material de suporte e a movimentação decorrente do abrir e fechar das portas, foram empregados elementos de reforço estrutural, na forma de peças de ferro de seção circular ${ }^{85}$. Em sua maioria, essas peças encontravam-se completamente soltas da caixilharia de madeira, comportando-se mais como sobrecarga para os panos de vidro do que como reforço estrutural (Figura 174).

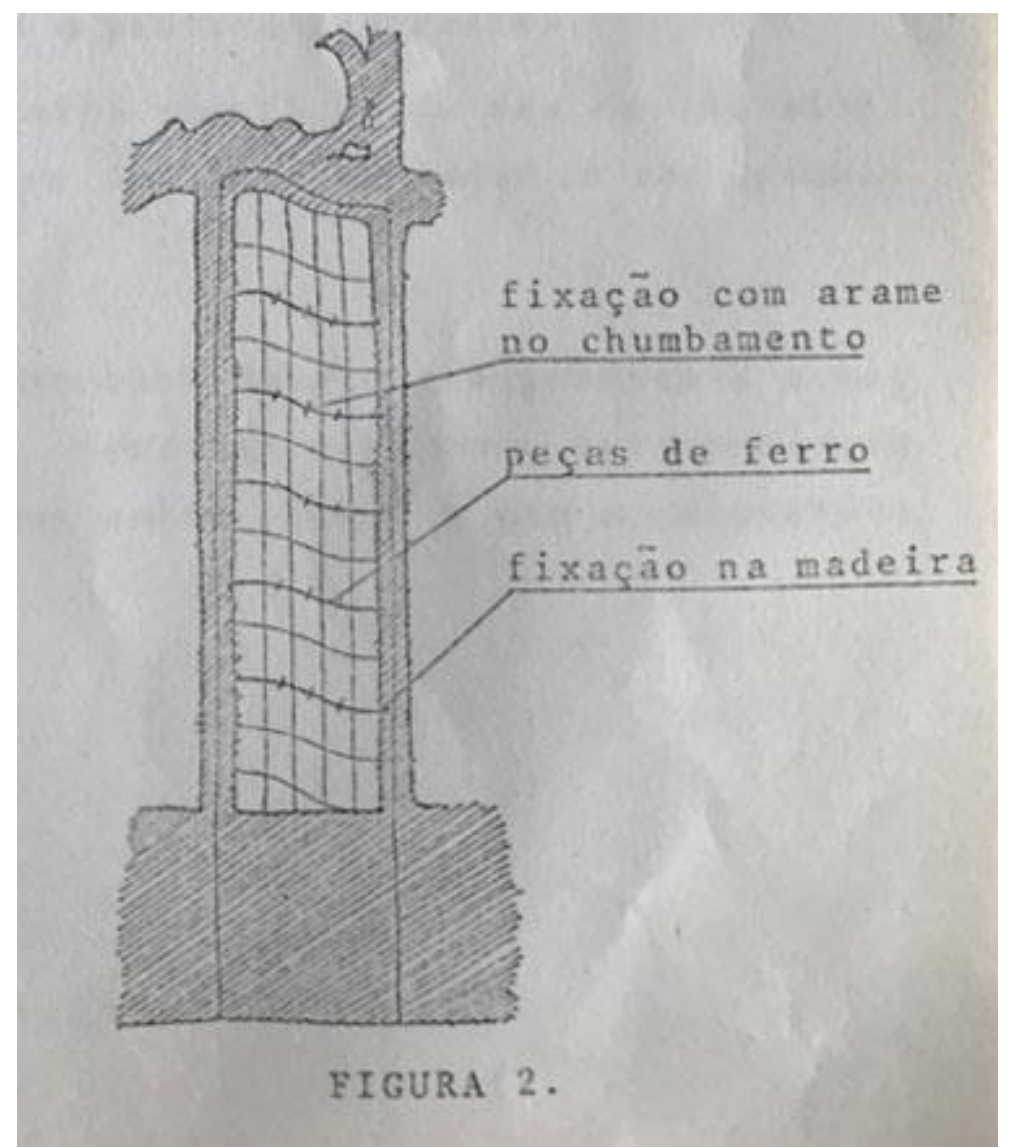

Figura 174: Diagrama de peças de ligação dos vitrais do Salão Nobre.

Fonte: WALTER ARRUDA DE MENEZES. Departamento do Patrimônio Histórico.

Levantamento/ diagnóstico do estado de conservação dos vitrais do Teatro Municipal de São Paulo. São Paulo, 1981.

${ }^{85} \mathrm{O}$ arquiteto Walter Arruda de Menezes deixa claro que não existem registros documentais que comprovem a originalidade de tal solução, aventando a possibilidade de tratar-se de uma intervenção posterior. 
Entre os problemas mais frequentes identificados nesse grupo estão os vidros quebrados e/ou sem pintura, alterações no pigmento da pintura decorativa e o uso de vidro de coloração amarelada nas intervenções anteriores de reposição. Quanto às intervenções de restauro sofridas pelas peças do grupo e identificadas visualmente pelo levantamento, afirma-se:

\footnotetext{
Nota-se também grande quantidade de peças que sofreram restaurações nas pinturas decorativas, provavelmente em várias épocas distintas por causa das diferentes formas de reintegração encontradas, simplificação dos desenhos, escalas de cores utilizadas, tendo também em alguns casos, reintegração de pintura feita no verso do vidro (MENEZES, 1981, p. 26).
}

A caixilharia de madeira dos vitrais que compõem o terceiro grupo difere dos caixilhos do segundo pelo quadriculamento das folhas por baguetes, que garante maior estabilidade estrutural. Os problemas encontrados nesse conjunto, para além do esmaecimento da pintura ornamental e do abaulamento dos elementos de ligação em chumbo, eram relativos à maior frequência de quebra de vidros com pintura decorativa. Sobre possíveis intervenções anteriores nesse grupo, foi dito:

\footnotetext{
Grande parte dos vitrais deste grupo já sofreram intervenções de caráter restaurador, notados pela diferenciação de alguns dos vidros usados e também pelas características da ornamentação repintada (MENEZES, 1981, p. 42).
}

Os vitrais utilizados na construção do Municipal são provenientes de duas oficinas distintas: a V. Saile, de Stuttgart; e a Conrado Sorgenicht Filho, cuja sede funcionava no bairro do Belenzinho. As esquadrias de madeira e ferro que receberam tais vitrais foram confeccionadas pelo Liceu de Artes e Ofícios. Os vitrais do salão nobre são assinados pela $V$. Saile, mas não existem registros ou confirmações de quais foram os vitrais confeccionados pela Casa Conrado (CONTIER, 2014). No entanto, a restauração de todos os conjuntos, na década de 1980, foi realizada pela Conrado Sorgenicht, sob a orientação e supervisão do $\mathrm{DPH}$. 
Os elementos de metal internos estavam em bom estado geral de conservação. Os materiais decorativos denotavam sinais de manutenção constante, assim como as luminárias, corrimãos e maçanetas da ala nobre. Os lugares que apresentavam algum grau de corrosão, como a estrutura de sustentação do palco e as escadas e corrimãos do depósito da fonte, sugeriam defasagem na manutenção preventiva e corretiva. Ficou previsto, dessa forma, a proteção da estrutura metálica do palco por pintura e o incremento das práticas de manutenção sistemática.

\subsubsection{Elementos decorativos}

Conforme o memorial descritivo do projeto de intervenção nos elementos decorativos, as sugestões do IPT quanto à manutenção dos elementos metálicos internos foram acatadas. A maior investida, nesse sentido, foi a recuperação do lustre central da Sala de Espetáculos (Figura 175). Suas peças metálicas foram embaladas em caixas com forro anti-oxidante e proteção anti-traumática; os elementos de cristal grandes, embalados em papéis macios e caixas com proteção contra traumatismos e os elementos de cristal pequenos, em caixas preenchidas com grânulos de isopor. Foi realizado o mapeamento e fotografia de cada um dos elementos e a reconstituição integral da parte elétrica. Além disso, as peças substituídas deveriam conter informações referentes à data e ao fabricante, de modo a facilitar sua identificação em intervenções futuras.
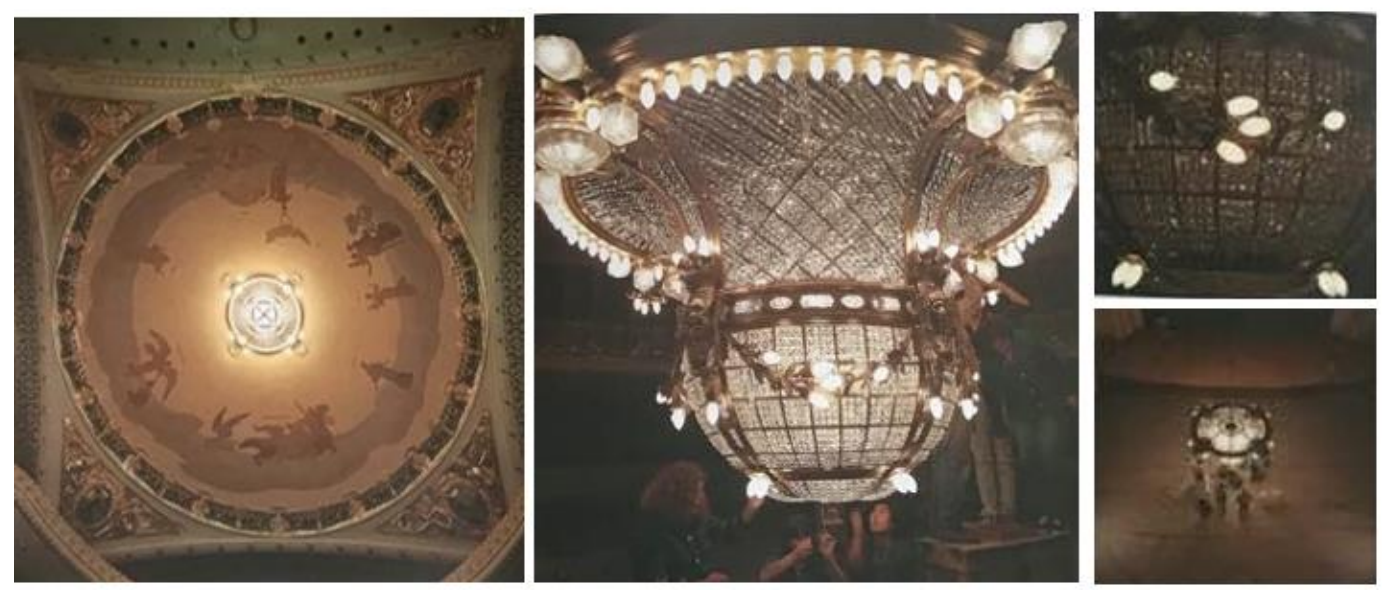

Figura 175: Montagem de fotografias da restauração do lustre central da Sala de Espetáculos. Fonte: Revista Projeto 112, 1988. 
A cantaria do interior do edifício do Theatro é composta por três tipos de pedra. O mármore, utilizado em pisos, paredes, soleiras, pias e elementos decorativos; o granito, presente em revestimentos e escadas; e as ardósias, presentes apenas em alguns pisos. Todas elas apresentam excelente estado de conservação, sem manifestar problemas de ordem estrutural ou estética.

Para além das intervenções previstas pelos relatórios do IPT, a restauração da década de 1980 foi também caracterizada por quatro opções projetuais bastante ousadas. A recuperação do restaurante, cuja espacialidade original havia sido sacrificada na década de 1950 em prol da divisão funcional dos espaços administrativos; a reforma da bilheteria, que também havia padecido do mesmo fenômeno ${ }^{86}$; a criação do Salão dos Arcos a partir da escavação do subsolo; e a substituição da cor vermelha da decoração interior da Sala de espetáculos por verde. Tais escolhas audaciosas serão analisadas a seguir, sendo posteriormente cotejadas com os conceitos teóricos do restauro crítico e com a intervenção sofrida pela Cinemateca Brasileira na mesma época.

\subsubsection{Bilheteria}

Para a bilheteria, foi proposta a demolição das paredes construídas na intervenção anterior, que a dividiam entre bilheteria da galeria e bilheteria dos demais setores ${ }^{87}$ (Figura 176). Além disso, foi implementado um banheiro adaptado para pessoas com necessidades especiais, reflexo de uma preocupação até então inédita de acessibilidade do edifício ${ }^{88}$.

\footnotetext{
86 O restaurante, originalmente composto por dois ambientes contínuos, separados por meio de colunas geminadas, teve seus espaços setorizados por meio da construção de divisórias, com a finalidade de criar salas administrativas. A bilheteria, por sua vez, havia sido remodelada em função da distribuição dos setores da Sala de Espetáculos (Ver Capítulo 2 - Segunda Modernidade).

87 Ver Capítulo 2 - Segunda Modernidade.

${ }^{88}$ Foi também na década de 1980 que foi instalada a plataforma elevatória de acesso para cadeirantes, no exterior do vestíbulo lateral da bilheteria, que continua em funcionamento até os dias atuais.
} 


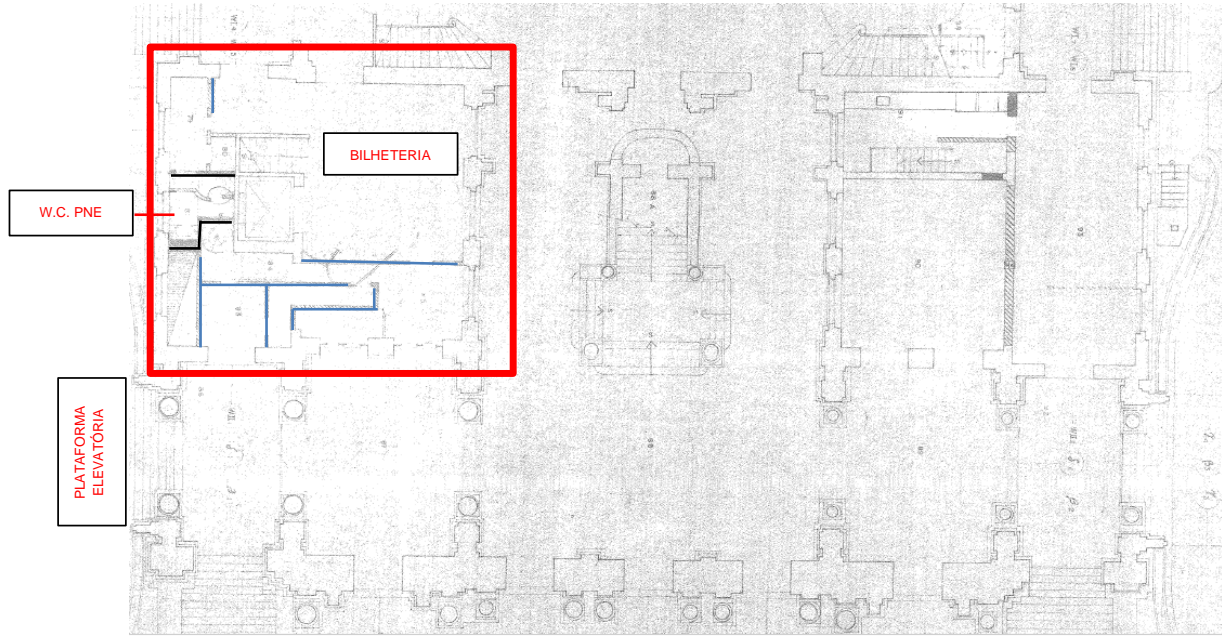

Figura 176: Planta do primeiro andar do projeto executivo da década de 1980. Destacado em vermelho o ambiente da bilheteria. Em azul, paredes a serem demolidas e em preto, construídas.

Fonte: Acervo da Fundação Theatro Municipal de São Paulo.

Quanto ao projeto novo dos guichês, foi concebida uma divisória espiralada em latão e vidro, que permite tanto atendimento voltado para o exterior, como para o interior do ambiente (Figuras 177 e 178). Como se verá a seguir, a escolha por uma estrutura leve e de linhas simplificadas se justificou a partir dos princípios da distinguibilidade e retrabalhabilidade.

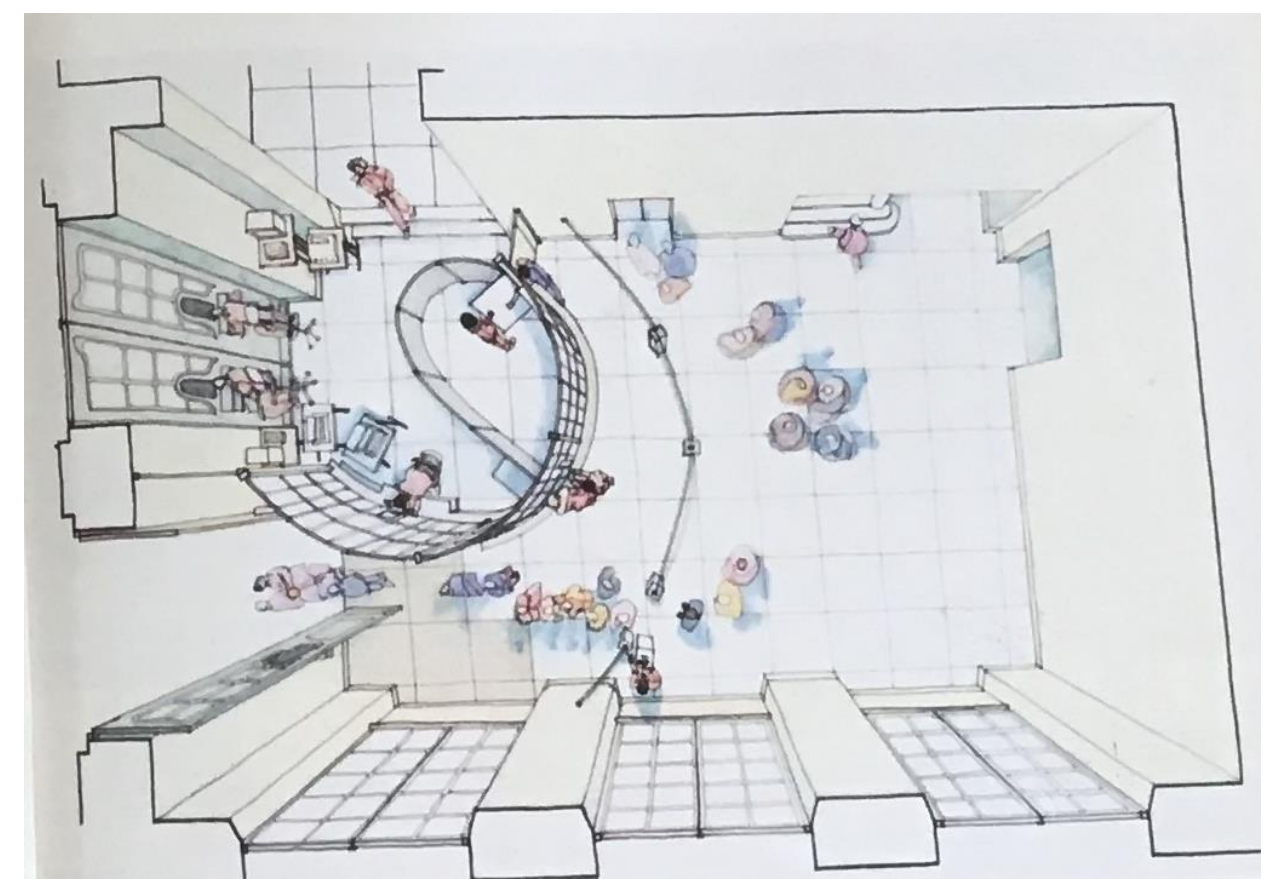

Figura 177: Desenho da proposta de intervenção para a bilheteria. Fonte: SECRETARIA MUNICIPAL DA CULTURA, 1988. 


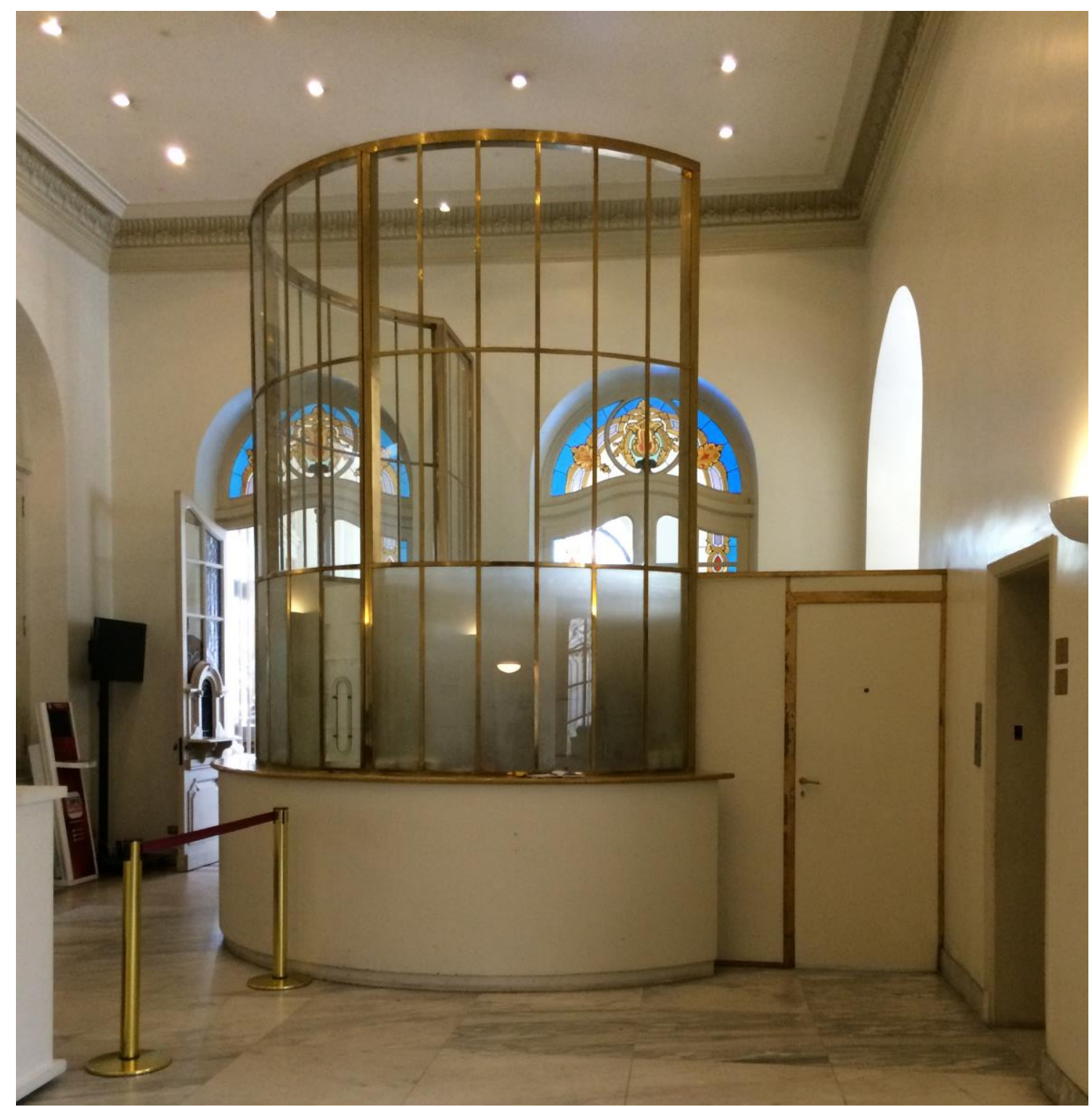

Figura 178: Fotografia do projeto da bilheteria implementado.

Fonte: fotografia da autora, 2017.

\subsubsection{Restaurante}

O restaurante, profundamente modificado pela intervenção anterior, havia sido subdividido em ambientes administrativos menores. O projeto da década de 1980 pressupõe a retirada de tais divisórias, bem como a demolição da parede que havia sido construída entre os ambientes que originalmente correspondiam ao bar e ao restaurante, e daquela que delimitava a sala de espera da administração ${ }^{89}$ (Figura 179).

89 Ver Capítulo 2 - Segunda Modernidade. 


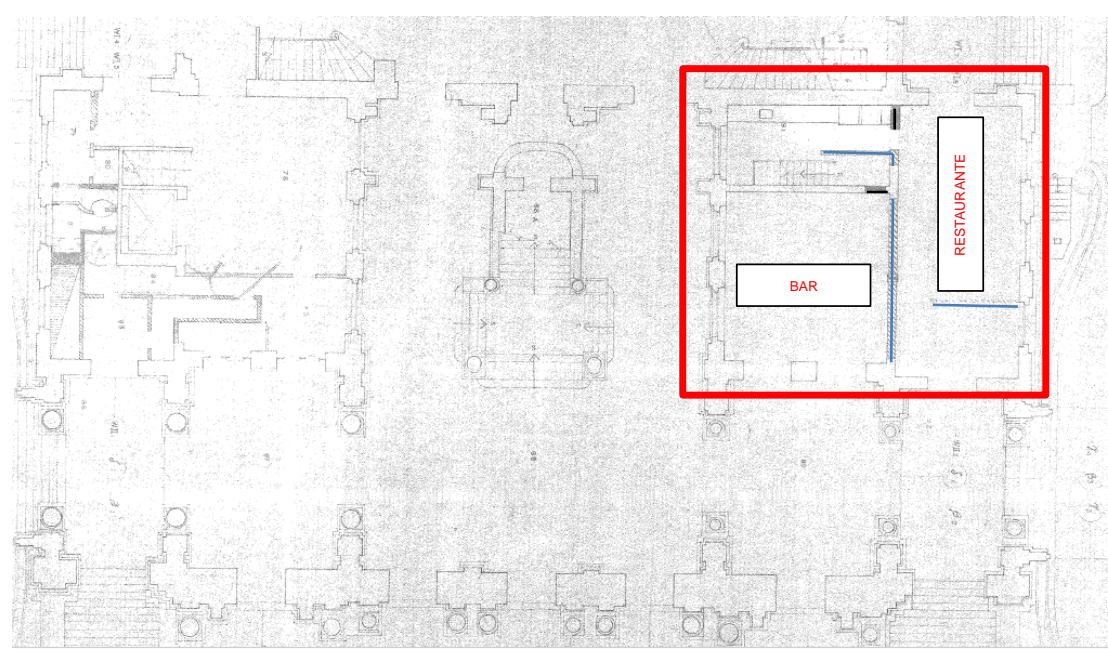

Figura 179: Planta do primeiro andar do projeto executivo da década de 1980. Destacado em vermelho o ambiente do restaurante. Em azul, paredes a serem demolidas e em preto, construídas.

Fonte: Acervo da Fundação Theatro Municipal de São Paulo.

Tal proposta visava a recuperação da ambiência original do restaurante e pressupunha a restauração de suas pinturas decorativas, sobre as quais havia sido aplicada uma repintura em tons lisos ${ }^{90}$. Foi nesse momento em que começaram a realizar-se as prospecções exploratórias que revelariam esses elementos pictóricos, que só seriam plenamente recuperados na intervenção seguinte ${ }^{91}$.

\subsubsection{Salão dos Arcos}

A escavação do subsolo durante a intervenção da década de 1980 resultou na criação de um novo espaço, batizado então de Salão dos Arcos. A intenção era que alí funcionasse uma sala de exposições, com objetos relativos à história do Theatro, como peças de cenografia, figurinos e fotografias.

Foi prevista a demolição de paredes que subdividiam o espaço, cujo pé direito teve de ser drasticamente aumentado, para que fosse possível a livre circulação (Figura 180). O projeto tomou partido da volumetria original das fundações, constituídas por grandes bases de pedra que suportam arcadas de alvenaria aparente (Figura 181).

\footnotetext{
${ }^{90}$ Ver subitem 3.2.2.4 Pinturas do presente capítulo.

91 Ver Capítulo 4 - Contemporaneidade.
} 


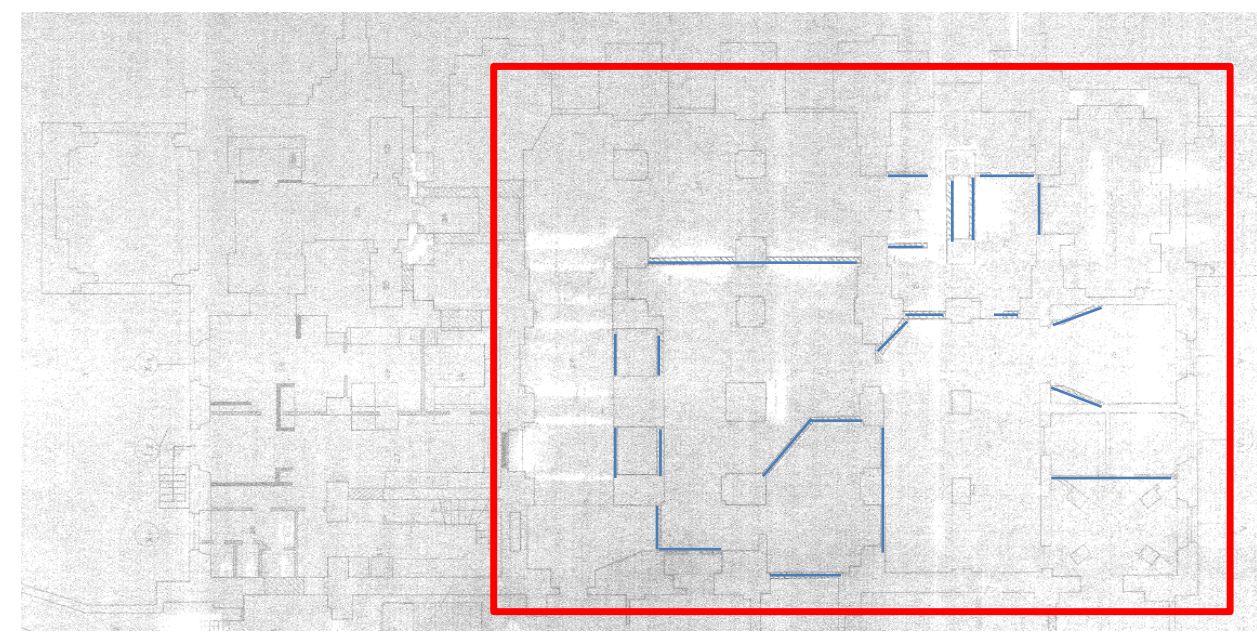

Figura 180: Planta do subsolo do projeto executivo da década de 1980. Destacado em vermelho o ambiente do Salão dos Arcos. Em azul, paredes a serem demolidas. Fonte: Acervo da Fundação Theatro Municipal de São Paulo.
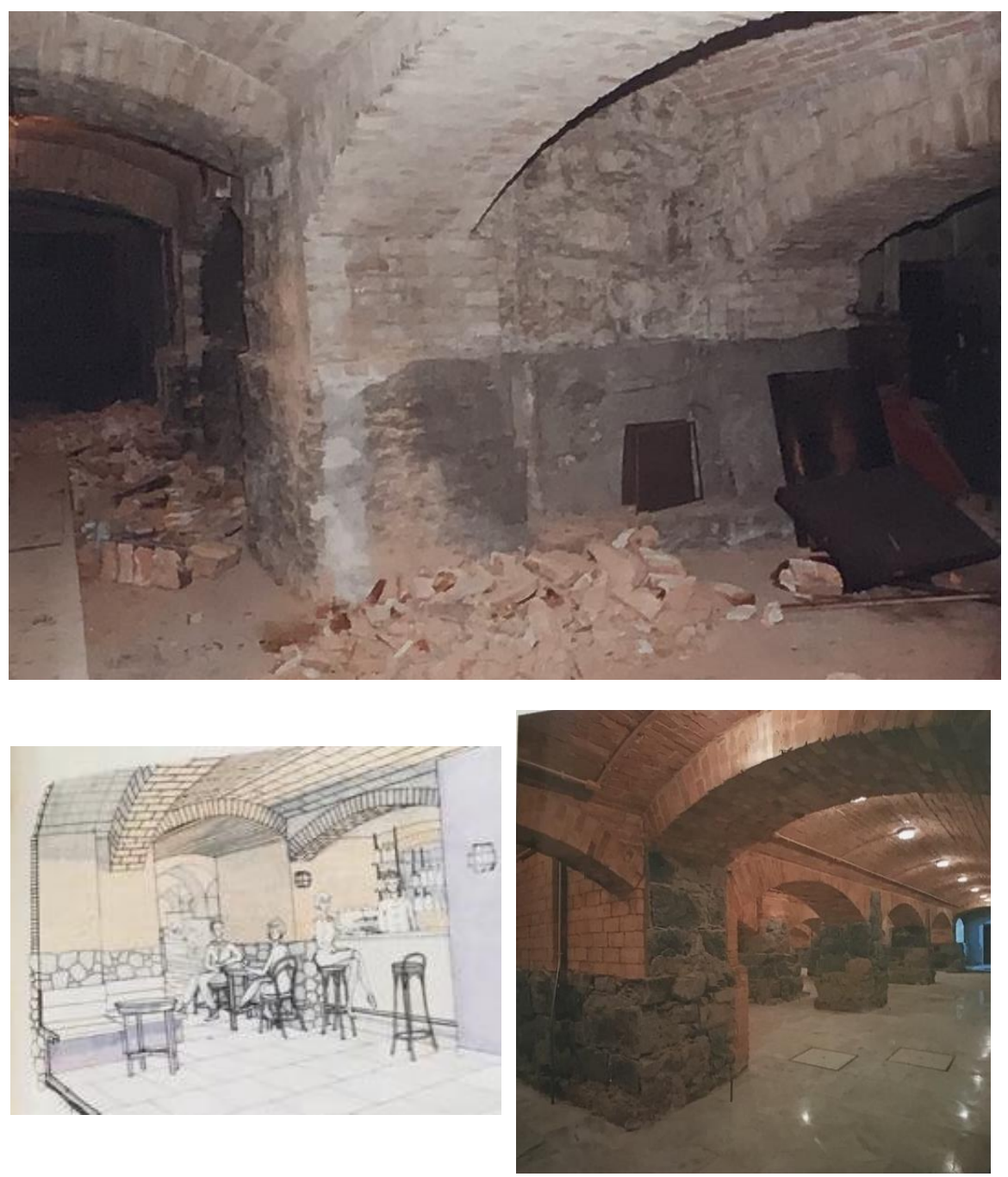

Figura 181: Intervenção no subsolo (acima), Figura 182: Projeto (esq.) e Figura 183: resultado da implantação do Salão dos Arcos (dir.)

Fonte: MÉTODO ENGENHARIA, 1988 (acima); SECRETARIA MUNICIPAL DA CULTURA, 1988 (esq., dir.) 


\subsubsection{Sala de Espetáculos}

A Sala de Espetáculos que chegou às mãos da equipe de restauração na década de 1980 já havia sido profundamente remodelada e reformada pela intervenção anterior ${ }^{92}$. Suas paredes, estofados, cortinas e tapetes apresentavam coloração avermelhadas, herança do projeto de 1950.

A despeito da ausência de informações sobre o aspecto cromático original do ambiente e do transcurso de mais de três décadas durante as quais o auditório sustentou a coloração vermelha, a equipe optou pela sua transformação. O argumento, a princípio sustentado pela falta de coerência entre o aspecto interior da Sala e o resto dos ambientes do Theatro, foi reforçado pela descoberta de um pigmento esverdeado por meio de uma prospecção realizada na parede posterior do compartimento do órgão (SECRETARIA MUNICIPAL DA CULTURA, 1988).

Escolheu-se essa superfície para realizar a prospecção pois, com a remodelação integral das paredes perimetrais na década de 1950, era a única remanescente original do momento da construção. A partir daí, a cor encontrada foi replicada por analogia a todos os revestimentos internos do auditório (Figuras 184 e 185), escolha que será problematizada do ponto de vista da teoria contemporânea da restauração no subitem a seguir.

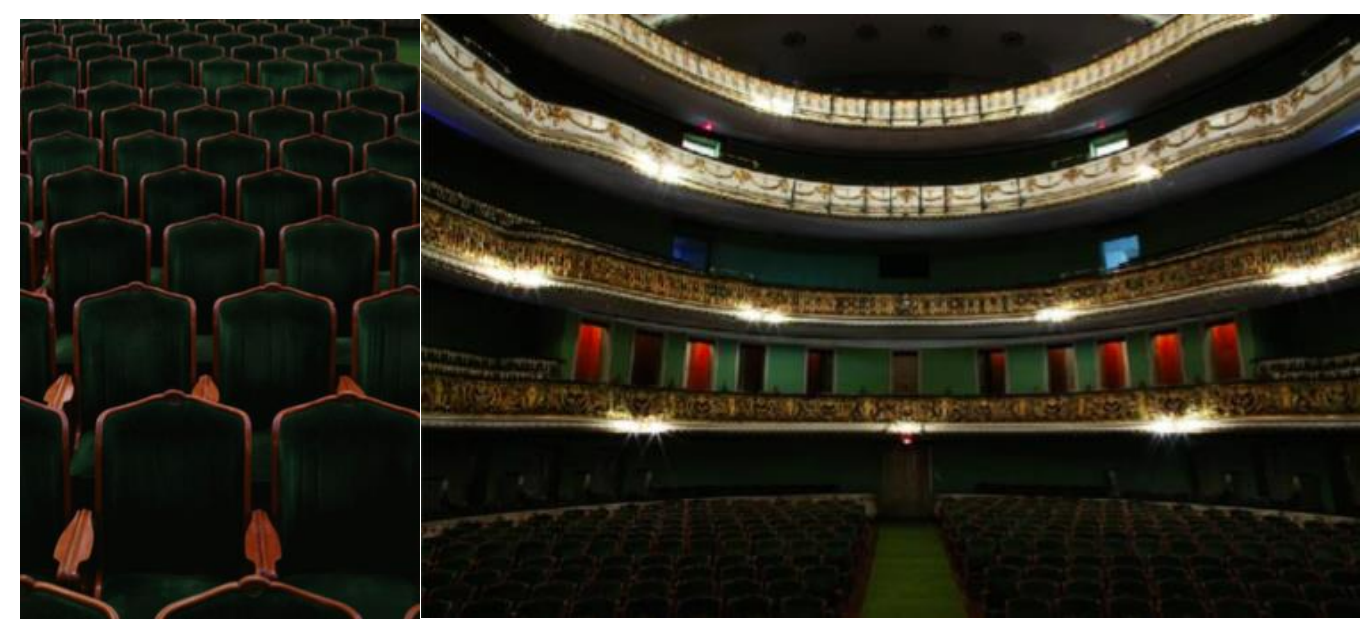

Figuras 184 (esq.) e 185 (dir.): Detalhe das poltronas da Sala de Espetáculos depois da mudança cromática (esq.); Resultado geral da troca de cor do interior da Sala de Espetáculos para o verde (dir.). Fonte: COSTA, 2017.

92 Ver Capítulo 2 - Segunda Modernidade. 


\subsection{Balanço Crítico da Intervenção: Consonâncias e Dissonâncias}

Após a leitura cuidadosa dos princípios do Restauro Crítico, do pensamento brandiano e de seus equivalentes na Carta de Veneza, percebe-se que a intervenção sofrida pelo edifício do Theatro Municipal de São Paulo durante a década de 1980 tem pontos de afinidade e distanciamento com o escopo teórico coetâneo. À primeira vista, a preocupação com o reconhecimento dos valores e do estado de conservação do bem, assim como a profusão de registros referentes ao seu processo de restauração, em forma de relatórios, memoriais, desenhos e fotografias estão em consonância com os postulados da Carta.

No entanto, essa documentação foi elaborada de maneira bastante fragmentada, por setores e equipes especializadas diferentes. A falta de diálogo entre as equipes, perceptível pela existência de análises repetidas realizadas por divisões técnicas distintas, vai contra o princípio da interdisciplinaridade do restauro e acaba dificultando a análise da compatibilização de projetos e instalações.

No entanto, a preocupação com a manutenção e conservação do edifício expressa nessa documentação, volta a concordar com o escopo teórico analisado. Tal preocupação inclusive vê-se evidenciada na fala do cenógrafo Aldo Calvo, responsável pela modernização cenotécnica do palco, em entrevista à revista Projeto $^{93}$ :

Tudo isso contribuirá para transformar o Municipal no melhor teatro "mozartiano" do Brasil. Mas ainda não é o bastante para tranquilizar o experiente Aldo Calvo. (...) Na Europa, teatros dessa categoria fecham de dois a três meses por ano para manutenção. O Municipal, seja por questões políticas (...) ou pela falta de um cronograma definido com antecedência, dificilmente fecha o suficiente para sua conservação (CARRASCOSO, 1988, p.69).

Em entrevista para o jornal $A$ Folha de São Paulo94, o arquiteto e historiador da arquitetura Benedito Lima de Toledo também manifesta sua posição favorável à

\footnotetext{
${ }^{93}$ CARRASCOSA, João. Uma restauração que destacou a funcionalidade. Projeto, São Paulo, v. 1 , n. 112, p.67-72, jul. 1988.

${ }^{94}$ A FOLHA DE SÃO PAULO. Caderno llustrada, "Projeto de restauração do Municipal já está pronto", p.4. São Paulo, 28 de março de 1985.
} 
conservação contínua, não só do Theatro como de todos os edifícios públicos. O empresariado teatral, no entanto, explicita sua opinião quanto a falta de manutenção do Theatro até então em tom mais agressivo. Em outra edição do mesmo jornal95, a empresária Mirian Dauelsberg questiona: “(...) ० Guarnieri (secretário) disse que o Teatro oferecia perigo público. Por que não viram isso antes? Acho tudo uma bela bagunça".

Para além das questões de documentação e manutenção, outra postura consonante com o escopo da teoria foi o projeto da nova bilheteria. A escolha recaiu na construção de uma nova estrutura, em latão e vidro, que não imita as feições originais do ambiente, mas conversa harmoniosamente com sua linguagem. A opção pela distinguibilidade e retrabalhabilidade fica evidente no depoimento de Maria Luiza Duarte e Walter Arruda de Menezes, arquitetos do DPH envolvidos no projeto de restauração, para a revista Projeto ${ }^{96}$ :

\footnotetext{
Para a construção de divisórias e sistemas estruturais necessários utilizaram-se elementos móveis que não caracterizassem uma permanência e que, concebidos em linguagem contemporânea de maneira a datar claramente a intervenção, tivessem sempre em vista a harmonia com o ambiente, princípio geral que norteou todas as intervenções desse gênero no teatro (SANTOS, 1988, p. 57-58).
}

Essa colocação é duplamente significativa, na medida em que fornece material para constatar o conhecimento dos postulados teóricos da época por meio dos idealizadores do projeto de restauro, ao mesmo tempo em que permite indagar sobre a pretensa coerência no acato ou não desses princípios nas outras intervenções do período. Ao contrário do que acontece no projeto da bilheteria, também implementado, a proposta para a sala de espetáculos destoa dos postulados do Restauro Crítico e da Carta de Atenas.

A escolha de implementar a coloração verde aos revestimentos de parede, estofados e cortinas, no lugar do vermelho que havia chegado até aquele momento, foi descrita como tendo sido "bastante estudada e amplamente

${ }^{95}$ A FOLHA DE SÃO PAULO. Caderno llustrada, "Sem Municipal não tem Bolshoi", p. 39. São Paulo, 21 de março de 1985.

96 SANTOS, Cecília Rodrigues dos. Teatro Municipal de São Paulo: caderno de obras. Projeto, São Paulo, v. 1, n. 112, p.52-65, jul. 1988; 
apoiada em dados técnicos"97. No entanto, o que se comprova através da pesquisa documental é que essa opção foi amparada pela análise da integração e harmonia cromática dos interiores do edifício, através da qual se chegou à hipótese de que, por falta de coerência, o vermelho não deveria ter sido a cor original dos revestimentos da sala de espetáculos. Chegada a essa conclusão, foi realizada a prospecção de uma das paredes internas do órgão ${ }^{98}$, e assim encontrou-se uma amostra do tom verde que foi aplicado no momento da intervenção:

\begin{abstract}
A única exceção a esta postura foi o retorno às relações cromáticas, o que se buscou recuperar conforme o original, harmonizando-as à identidade visual do edifício. $O$ verde presente nas guirlandas da grelha, que se desenvolve ao redor do forro decorado da sala, foi uma primeira indicação das pesquisas que se efetuaram através de prospecções e depoimentos.

Sobre o estabelecimento desta família cromática, as prospecções feitas nada revelaram, pois não havia reboco remanescente das paredes originais, dado o fato de terem sido recobertas nos anos cinquenta pela cinta de concreto para engastamento das vigas que suportam os balcões em balanço. Em seguida, através da confrontação e análise de diversas plantas, percebeu-se que a parede atrás do órgão, espaço que originalmente continha camarotes, poderia ter sido conservada intacta. Confirmou-se a hipótese ao se encontrar parte do revestimento original da parede e do forro daquele camarote. A cor encontrada foi um tom de verde com tendência a um ocre mostarda, nada atraente se visto isoladamente, mas passível de estabelecer um apoio cromático bastante repousante se confrontado com o branco e a profusão de dourados da sala de espetáculos (SECRETARIA MUNICIPAL DA CULTURA, 1988, p. 16-18)
\end{abstract}

Essa mudança, bastante radical, implicou não apenas nas condições materiais de preservação do edifício, como também na ruptura figurativa de transmissão da imagem do Theatro que havia sido consolidada até então. A escolha, quase arbitrária, de estender o uso da cor encontrada na parede do órgão a todas as demais superfícies do ambiente, fere o princípio da unidade da obra de arte de Brandi, a partir do qual não se deve intervir por analogia. Além disso, se considerarmos o fato de que nenhuma dessas superfícies, exceto a da prospecção, existiam no projeto original da construção - ou seja, já haviam sido

97 SANTOS, Cecília Rodrigues dos. Teatro Municipal de São Paulo: caderno de obras. Projeto, São Paulo, v. 1, n. 112, p.60, jul. 1988;

98 Uma vez que a sala de espetáculos havia sido completamente remodelada durante a intervenção da década de 1950, não haviam sobrado paredes internas originais que não as do compartimento do órgão, local onde originalmente estavam localizados os camarotes do proscênio. 
concebidas na coloração vermelha -, mesmo que o verde encontrado fosse de fato acurado, sua aplicação nas paredes "novas" acabaria gerando uma situação anacrônica, uma vez que aquelas superfícies, materialmente, jamais haviam sido daquela cor.

Outra mudança radical sofrida pelo edifício naquele momento foi a reestruturação dos camarins. Assim como no caso do restaurante, profundamente modificado pela última intervenção, não havia documentação suficiente que permitisse indagar qual seria o caráter original daquele espaço. Aqui, no entanto, a postura adotada pela equipe foi diametralmente oposta àquela. Optou-se pela manutenção da nova configuração espacial, que dispunha de mais andares e maior número de dependências, sob o argumento da funcionalidade. Apesar disso, o setor passou por uma "completa reforma das instalações e uma otimização do uso", como explicado em artigo para a revista Projeto 99 :

\begin{abstract}
A inexistência de documentação ou vestígios da construção original, somado à necessidade de manter um número maior de camarins, fez com que se preservassem os novos andares construídos: eles foram submetidos, porém, a completa reforma das instalações e a uma otimização do uso, já que a limpeza e a organização de outras áreas do teatro permitiram que se liberasse para camarins andares inteiros antes ocupados por outros serviços (SANTOS, 1988, 0. 63-64).
\end{abstract}

A opção pela preservação da nova configuração espacial do setor de camarins pode ser amparada pelo referencial teórico, no sentido de se ter respeitado uma etapa - apesar de bastante agressiva -, do transcurso do tempo materializado no bem. A reforma das instalações, no entanto, ocupa um lugar no meio do caminho. Apesar das substituições de parede, forro e piso serem completamente distinguíveis e, assim, não promoverem um falso histórico, a liberdade com a qual se atuou, descartando por completo os componentes de revestimento que haviam chegado até então, faz indagar sobre a hierarquia dos espaços internos do edifício e sua implicação na orientação das posturas adotadas na intervenção.

99 SANTOS, Cecília Rodrigues dos. Teatro Municipal de São Paulo: caderno de obras. Projeto, São Paulo, v. 1, n. 112, p.60, jul. 1988. 
Essa hierarquia, no entanto, foi reconhecida como um valor a ser preservado, o que leva a concluir que talvez essa liberdade esteja de certa forma amparada pelos princípios teóricos aqui analisados:

\begin{abstract}
As diferentes áreas do teatro apresentavam certa hierarquia quanto ao tratamento, principalmente no que diz respeito ao conforto e a qualidade dos materiais de acabamento empregados, distinguindo assim a ala nobre de público da galeria e espaços destinados a artistas e funcionários. Aqui, como nas outras áreas do teatro que passaram por uma reforma radical, a escolha dos materiais utilizados obedeceu a critérios que levaram em conta não só sua funcionalidade, durabilidade e facilidade de manutenção, mas também a qualidade estética e ambiental do conjunto, sem a diminuição dos "privilégios" quanto ao tratamento dos espaços (SANTOS, 1988, p. 64).
\end{abstract}

A última grande transformação sofrida pelo Theatro naquele momento foi a criação do Salão dos Arcos, a partir da escavação do subsolo. Durante a intervenção da década de 1950, havia sido retirado um grande contingente de terra da cota das fundações, devido à necessidade de introduzir melhorias no sistema de circulação de ar. Ao longo do tempo, o subsolo foi se transformando em depósito e os túneis que haviam sido escavados perderam sua função com a instalação, em 1988, do ar-condicionado. Dessa forma, optou-se por escavar até alcançar um pé-direito adequado para circulação e permanência, revelando por completo as fundações de pedra com arcadas em alvenaria. Optou-se também pela remoção do revestimento de argamassa das arcadas, para evidenciar a técnica construtiva e as características arquitetônicas originais:

Este projeto foi desenvolvido visando o aproveitamento máximo da arquitetura, evitando qualquer interferência que prejudicasse suas características arcadas, evidenciando-as e orquestrando um sistema de grandes volumes, num ritmo marcante de cheios e vazios e deixando a nu o choque de texturas e o rude contraste de materiais (SECRETARIA MUNICIPAL DA CULTURA, 1988, p. 30).

Essa proposta, apesar de arrojada, pode estar em consonância com os princípios teóricos, uma vez que visava construir uma nova unidade potencial, partindo do reconhecimento do valor das características originais dos elementos construtivos, evidenciando-os. De maneira alguma se pretende como um falso 
histórico ou artístico, partindo de um refazimento dentro do "adágio nostálgico Como era, onde estava" (BRANDI, 2004, p. 89).

Quanto ao restauro das fachadas, o ímpeto da limpeza e, principalmente, da intervenção de pintura da argamassa buscava o retorno à uma condição cromática original. A escolha de tentar recriar a coloração original da argamassa encontrada em prospecção, através da pintura, pode ser interpretada como um "álibi cômodo", que subtrai da intervenção a responsabilidade do ato crítico que deveria fundamentar qualquer ação de restauro, uma vez que, para Philippot, a função de uma intervenção desse tipo é revelar o aspecto atual da matéria original, e não tentar reestabelecer um aspecto pretensamente original (KÜHL, 2004):

\footnotetext{
Refazer a cor original através do uso de argamassa pigmentada, sem acabamento de pintura, exigiria um trabalho longo e oneroso de descascar todo o edifício e refazer seu revestimento, processo que não oferece maiores garantias contra novas fissuras. Decidiu-se portanto por manter a argamassa obturada e voltar ao tom original através da aplicação de uma tinta especial, misturada com partículas sólidas de borracha, que apresenta como resultado final uma textura fina, próxima à da argamassa, recobre as fissuras e protege melhor o edifício (SANTOS, 1988, p. 57).
}

A busca pelo aspecto original e a limpeza integral dos materiais coloca em xeque a questão da pátina. Em nenhum momento, no escopo dos documentos elaborados pelo IPT e pelo DPH que foram aqui estudados, menciona-se a questão da manutenção da pátina, salvo quando se trata das ações direcionadas à estatuária de bronze. Nesse caso, aconselha-se a sua preservação por motivos exclusivamente pragmáticos, por ser essa um elemento de proteção do metal. Essa postura, segundo Kühl, evidencia o processo de "rejuvenescimento forçado" pelo qual passam muitos de nossos bens culturais, após intervenções de restauro.

Uma análise a nível tectônico da mesma intervenção, por outro lado, indica a clara inadequação dos produtos escolhidos para o tratamento das superfícies, 
tanto de pintura como impermeabilização. A aplicação de verniz à base de silicone sobre $o$ arenito revelou-se, em pesquisa posterior realizada por Lama em 2008, como uma das causas do acelerado estufamento e escamação da rocha. Já a aplicação de tinta látex à base de PVA sobre as superfícies de argamassa, revelou-se também como elemento catalisador de patologias, uma vez que a característica impermeabilizante do produto ocasiona a desagregação e desprendimento da antiga massa à base de cal (KÜHL, 2004) $)^{100}$.

Conclui-se, portanto, que a opção pela pintura das fachadas do Theatro realizada naquele momento prejudica a tônica da intervenção através da busca pelo seu rejuvenescimento, causando uma ruptura figurativa sensível no tempo-vida da obra, assim como a opção pela mudança cromática da sala de espetáculos o havia feito com o seu interior.

Apesar da clara menção aos princípios teóricos da restauração por parte dos arquitetos responsáveis pelo projeto, concluímos aqui que algumas das grandes intervenções daquele momento as contradiziam, como o próprio caso das fachadas, do restaurante e da sala de espetáculos. Outros, por sua vez, estavam mais alinhados com tal referencial, como era o caso dos projetos da bilheteria, do salão dos arcos e, até certa extensão, dos camarins.

As intervenções menores, de caráter mais conservativo, como a recuperação das luminárias e das superfícies com pinturas decorativas, estão mais afinadas com a teoria. A documentação dos componentes de cada um dos lustres, assim como o registro das peças substituídas com suas respectivas datas e fornecedores respeita o princípio da distinguibilidade presente tanto em Brandi como na Carta de Veneza. Assim como o uso do trattegio, técnica criada pelo próprio Brandi em seus anos de experimentação no ICR, para recompor as pinturas murais.

${ }^{100}$ As patologias detectadas nos materiais de revestimento das fachadas nesse momento serão abordadas em maior detalhe no Capítulo 4 da presente dissertação, no qual será tratada a intervenção de restauro sofrida pelo edifício do Theatro Municipal na década de 2010. 
Apesar dessa consonância, os autores do projeto e o próprio secretário da cultura, nos artigos publicados em revistas especializadas e nos encartes oficiais da prefeitura, tendem a destacar aspectos ligados à volta ao estado original, mesmo que esta não tenha sido a tônica geral da intervenção:

\footnotetext{
Ainda na tentativa de se reproduzir ao máximo possível o ambiente original, foi restaurado o lustre e foram resgatadas quatro mesas originais, às quais se acrescentam mais três, construídas em idêntico padrão (SECRETARIA MUNICIPAL DA CULTURA, 1988, p. 8).
}

Como demonstrado até aqui, a obra realizada durante a década de 1980 apresenta posturas consonantes e dissonantes com o corpus teórico mobilizado pelo Restauro Crítico e pela Carta de Veneza. As intervenções no restaurante e a mudança de cor da sala de espetáculos não encontram respaldo na teoria, ao contrário daquelas sofridas pela bilheteria e salão dos arcos. Intervenções como as das fachadas e camarins encontram-se em um meio termo entre posturas mais ou menos respeitosas com relação à pré-existência.

Assim como na análise da intervenção anterior, é necessário cotejar os princípios teóricos então vigentes em ambiente internacional com o cenário da atuação dos órgãos de preservação brasileiros. Naquele caso, foi fundamental adentrar a postura adotada pelo IPHAN em suas restaurações oficiais, sendo ele o único órgão voltado a salvaguarda patrimonial existente até então no âmbito nacional. Nesse caso, no entanto, interessa especular sobre as posturas do CONDEPHAAT e do CONPRESP em suas respectivas restaurações, uma vez que a intervenção no edifício do teatro se dá no período compreendido entre seu tombamento estadual, em 1981, e municipal, em 1991, e é orientada pelos técnicos do DPH.

No restauro da Cinemateca, assim como no caso do Theatro, confluem em uma mesma proposta aspectos consonantes e dissonantes com relação ao corpus teórico vigente. Nesse sentido, são bastante representativas da prática preservacionista brasileira que, apesar de heterogênea, acaba sendo caracterizada por contradições do gênero. 
Em se tratando de duas intervenções realizadas coetaneamente e pelo mesmo órgão de preservação do patrimônio, interessa mais ainda qualificar a natureza de tais consonâncias e dissonâncias entre teoria e prática. De fato, a tônica da "recuperação" e "reconstituição" do original opera como o eixo condutor de ambas as propostas, a despeito das demais preocupações com possíveis falsos históricos, manifestas pelo impulso documental - seja ele por meio de exposições ou de publicações - e pelo emprego eventual da distinguibilidade. 


\section{A DÉCADA DE 2010: CONTEMPORANEIDADE}

No presente capítulo, será analisada a intervenção arquitetônica empreendida no edifício do Theatro Municipal de São Paulo entre os anos de 2006 e 2011, à luz das teorias de restauro coetâneas e da atuação prática no campo nacional da restauração, tomando como estudo de caso a intervenção sofrida simultaneamente pelo Theatro Municipal do Rio de Janeiro (MACHADO, 2012).

Foram analisados documentos primários na forma de projetos (plantas, cortes e elevações) e memoriais descritivos consultados no Acervo da Fundação Theatro Municipal de São Paulo e no Departamento de Patrimônio Histórico. Também foram analisadas as publicações coetâneas que tematizavam a intervenção em questão que foram veiculadas pela mídia. Esses documentos foram cotejados com a bibliografia correspondente ao campo epistemológico da teoria da restauração (BRANDI, 2013; CARBONARA, 2006; KÜHL, 2007/2011 e Carta de Veneza).

\subsection{O século XXI}

O começo do século XXI foi marcado internacionalmente pelas revisões do Restauro Crítico e da teoria de Cesare Brandi, assim como da atualidade e validade Carta de Veneza (1964). No Brasil, o cenário da preservação refletia de certa forma a pluralidade dessas discussões. A seguir, serão comentados esses contextos que, tanto em âmbito nacional como internacional, permearam a execução da intervenção no Theatro Municipal de São Paulo, concluída na década de 2010.

\subsubsection{Contexto internacional: Revisões e atualizações de Cesare Brandi, do Restauro Crítico e da Carta de Veneza}

Desde o final do século $\mathrm{XX}$, o campo teórico da restauração rumava para um cenário no qual se discutiam a validade e atualidade do Restauro Crítico, dos princípios de Brandi e da Carta de Veneza. Para Beatriz Kühl, esse debate é solucionado pela afirmação de que não houve superação desses postulados, mas releituras devedoras desses: 
$\mathrm{Na}$ atualidade, as tendências da restauração são devedoras dos debates dos últimos dois séculos e, apesar de proporem releituras que apresentam ineditismo, não se colocam como renovação radical ou superação das propostas anteriormente existentes (KÜHL, 2010, p. 299)

A concepção do restauro crítico aliada às formulações de Cesare Brandi, conforme explorado no capítulo anterior, marcou o campo epistemológico da teoria da restauração na segunda metade do século XX. Esse arcabouço teórico serviu como base para as discussões contemporâneas acerca das intervenções realizadas sobre o patrimônio edificado no decorrer do século XXI.

Há uma série de equívocos, no entanto, no que tange à aplicabilidade - ou nãodesse esquema teórico na atualidade (KÜHL, 2007). Para Giovanni Carbonara, julgar que a teoria de Brandi, devedora do restauro crítico e de sua experiência prática no ICR, tenha sido superada é um desacerto ocasionado em grande parte pela má-interpretação de sua Teoria da restauração (CARBONARA, 2006).

A crítica desferida por Marco Dezzi Bardechi, por exemplo, vai no sentido da suposta liberdade que Brandi concederia à destruição da estrutura, dentro da divisão teórica da matéria entre estrutura e aspecto. Essa análise, como aponta Alessandra Melucco Vaccaro, parte de uma concepção falha da estrutura entendida como "categoria b" da matéria, o que não era a intenção de Brandi, que opera na chave dialética entre ambos os conceitos. Para Emilio Garroni, essa interpretação se dá pela confusão da teoria crítica com a pura visibilidade wolffliniana, o que também sinaliza incompreensão (CARBONARA, 2006).

A crítica mais genérica é pautada pela abstração da Teoria, que seria incapaz de responder aos objetivos práticos em sua aplicação. Essa visão, em favor do empirismo, não se sustenta uma vez que o ICR permitiu a Brandi a comprovação de suas concepções através da prática exaustiva. Por outro lado, há quem leia seu legado conceitual como um manual técnico de aplicabilidade imediata, sendo que, na realidade, apenas oferece uma unidade teórico-metodológica que deve ser aplicada caso a caso (KÜHL, 2007).

Existe também certa resistência no que diz respeito à aplicação da Teoria a outros objetos, que extrapolam os campos da pintura e da escultura, aos quais 
Brandi se dedicara com maior frequência, dadas as características do ICR. É o caso da arquitetura, no qual o equívoco encontra-se na afirmação de que a metodologia proposta por ele descuida das questões do uso quando, na verdade, o uso aparece como meio para a preservação e não a finalidade da ação em si (KÜHL, 2007).

Se, por um lado, as críticas feitas à aplicabilidade da Teoria na atualidade derivam de uma leitura enviesada de suas proposições, por outro, o fazem pelos desvios conceituais verificados tanto na própria prática interna do ICR como no resto do mundo. Entre os anos 1970 e 1980, o Instituto passou a operar com prevalência de um "tecnicismo autorreferencial", o que comprometeu o aprofundamento da discussão teórico-metodológica do campo da restauração e permitiu que fenômenos como o fachadismo e as manutenções inovadoras voltassem a despontar. Nas décadas seguintes, verificou-se um aumento de práticas dissonantes em um contexto mais generalizado. As manutenções em chave repristinatória, o funcionalismo e a valorização criativa do livre projetar, que reduz o antigo a mero "estímulo poético" para o novo, são alguns exemplos (CARBONARA, 2006).

Afirmava-se também que, com o alargamento conceitual proporcionado pela alcunha de "bem cultural" dentro do campo da preservação do patrimônio, sua metodologia tenha ficado ultrapassada. Michele Cordaro protesta não haver novas propostas no campo, apenas o "regurgitamento de ideias e tendências que se acreditavam sepultadas para sempre" (CARBONARA, 2006, p. 5) quando, na verdade, verificam-se diferentes posturas e correntes, inclusive antibrandianas, na prática atual.

Segundo Carbonara e Miarelli Mariani, existem três tendências principais observadas nas práticas de restauro contemporânea. A crítico-conservativa, alicerçada na teoria de Brandi e na releitura do Restauro Crítico e dos princípios enunciados na Carta de Veneza; a conservação integral, que dialoga com os postulados de Ruskin; e a hipermanutenção, de certa forma oposta à anterior (KÜHL, 2004). 
A hipermanutenção advoga pela retomada de formas e técnicas do passado por meio de repristinações induzidas por uma lógica pragmática e analógica. Já para conservação integral, as instâncias histórica e estética não são entendidas em chave dialética, sendo a primeira sempre privilegiada. Partindo não só de um diálogo com a postura oitocentista de Ruskin como do compromisso com a revisão historiográfica recente, a partir da qual todo juízo de valor sobre determinada obra é incapaz de hierarquizar seus momentos mais importantes, dá-se primazia à conservação da matéria tal qual chegou aos dias atuais (KÜHL, 2010).

A declinação crítico-conservativa também se concilia com as revisões na historiografia contemporânea, sobretudo em função do alargamento conceitual do que é considerado bem cultural, ao atribuir interesse a testemunhos mais variados em relação à época de formulação da teoria crítica. Ela entende a obra em sua dúplice instância estética e histórica e está fundamentada no juízo crítico e na análise caso a caso, em consonância com a teoria de Brandi, o Restauro Crítico e a Carta de Veneza (KÜHL, 2010).

A Carta de Veneza, analisada no capítulo anterior, também é objeto de dúvidas no que tange a sua aplicabilidade atualmente. O documento, de caráter indicativo, é muitas vezes interpretado erroneamente como um "receituário de aplicação". Outro equívoco, no que tange à aplicabilidade da Carta hoje, é considerá-la superada e substituída pelos documentos que a sucederam ${ }^{101}$, sendo que esta continua a ser o documento base do Icomos (International Council on Monuments and Sites). Esses documentos posteriores são integrativos, ou seja, apenas complementam e aprofundam os temas da Carta, levando em conta o alargamento que o conceito de bens culturais sofreu ao longo do tempo (KÜHL, 2010).

Para além das questões relacionadas à superação do conteúdo da Carta, sua aplicabilidade é muitas vezes posta em cheque sob a alegação de um suposto eurocentrismo quando na verdade, no congresso de Veneza, havia

\footnotetext{
${ }^{101}$ Aqui refere-se especificamente à Carta de Burra (2013) e à "Carta" de Nara, sendo a primeira não referendada pela Assembleia Geral e, a segunda, um documento que nem chega a ser uma carta (KÜHL, 2010).
} 
representantes de vários países do mundo, inclusive do Brasil ${ }^{102}$. Sobre isso, afirma Beatriz Kühl:

É fato que o documento é devedor do debate europeu, em especial italiano, sobre o tema (...). Ser devedor das discussões europeias, não significa, porém, ser eurocêntrico (KÜHL, 2010, p. 294).

No Brasil, a discussão em torno do documento começa a se dar na década de 1970, quando a FAU USP, em cooperação com o Iphan e o Condephaat, oferece um curso de restauração e conservação de monumentos arquitetônicos em cuja bibliografia constava a Carta de Veneza. Ainda de acordo com Kühl, muitas vezes seus preceitos eram interpretados pelos professores de maneira equivocada, usando como base um conceito de restauração em si ultrapassado.

Para adentrar os meandros da recepção e apropriação do corpus teórico da restauração contemporânea em território nacional, e assim construir bases de análise sólidas para interpretação da última grande intervenção realizada no Theatro Municipal se São Paulo, será lançado um olhar crítico sobre o caso contemporâneo do Theatro Municipal do Rio de Janeiro.

Ambos os edifícios, coetâneos em sua gênese, passaram por uma obra de restauro no período imediatamente anterior ao seu centenário, entre os anos de 2007 e 2011. O Municipal carioca foi escolhido como estudo de caso não só pelas coincidências em época e estilo, como por representar um exemplo claro e marcante dos conflitos conceituais envolvidos em uma intervenção desse tipo, no contexto nacional atual.

\subsubsection{Contexto nacional: a Hipermanutenção e o Restauro do Theatro Municipal do Rio de Janeiro}

Assim como seu correspondente paulista, o Theatro Municipal do Rio de Janeiro foi fruto de um momento de reformulação urbana da cidade e transformação de suas características arquitetônicas. Como capital da recém-criada república, o

$102 \mathrm{O}$ representante brasileiro do Congresso de Veneza foi o arquiteto paraense Wladimir Alves de Souza (1908-1994), da Universidade de Brasília. (http://brasilartesenciclopedias.com.br/). 
Rio de Janeiro passou por uma extensa reforma nos anos correspondentes ao mandato do prefeito Pereira Passos (1902-1906).

Uma das maiores mudanças realizadas naquela ocasião foi a abertura da Avenida Central - atual Avenida Rio Branco -, nos moldes de um boulevard afrancesado (Figura 186). Foi realizada uma série de concursos arquitetônicos cujos resultados implicariam na construção de um conjunto de fachadas ecléticas que ladeariam a recém-criada avenida e marcariam suas feições.

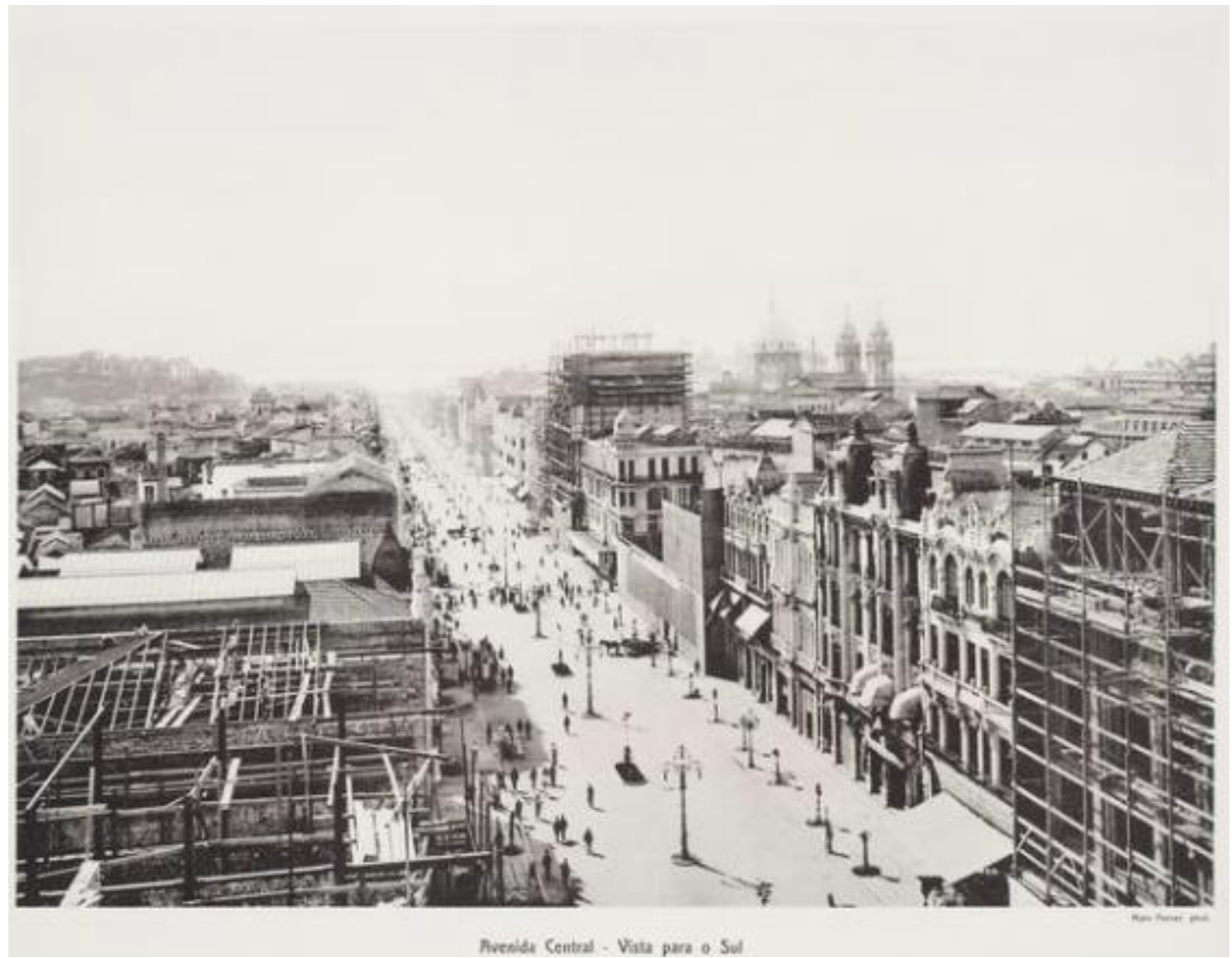

Figura 186: Abertura da Avenida Central.

Fonte: Coleção Marc Ferrez, IMS - Instituto Moreira Salles.

O edifício do Theatro Municipal do Rio de Janeiro, localizado na Avenida Central, foi objeto de uma dessas concorrências, aberta em outubro de 1903, que definiu como um de seus autores o próprio filho do prefeito, Francisco de Oliveira Passos ${ }^{103}$. Sua construção, de linhas ecléticas, data de 1905 a 1909 e foi

${ }^{103}$ O primeiro lugar do concurso aberto para a construção do Theatro Municipal do Rio de Janeiro foi concedido a dois projetos: o de Albert Guilbert e o de Francisco de Oliveira Passos. O projeto construído de fato resultou de uma fusão dos dois ganhadores (http://theatromunicipal.rj.gov.br/o-theatro-municipal/historia/). 
realizada nos moldes da Ópera de Paris, com materiais nobres e diversos (Figura 187).

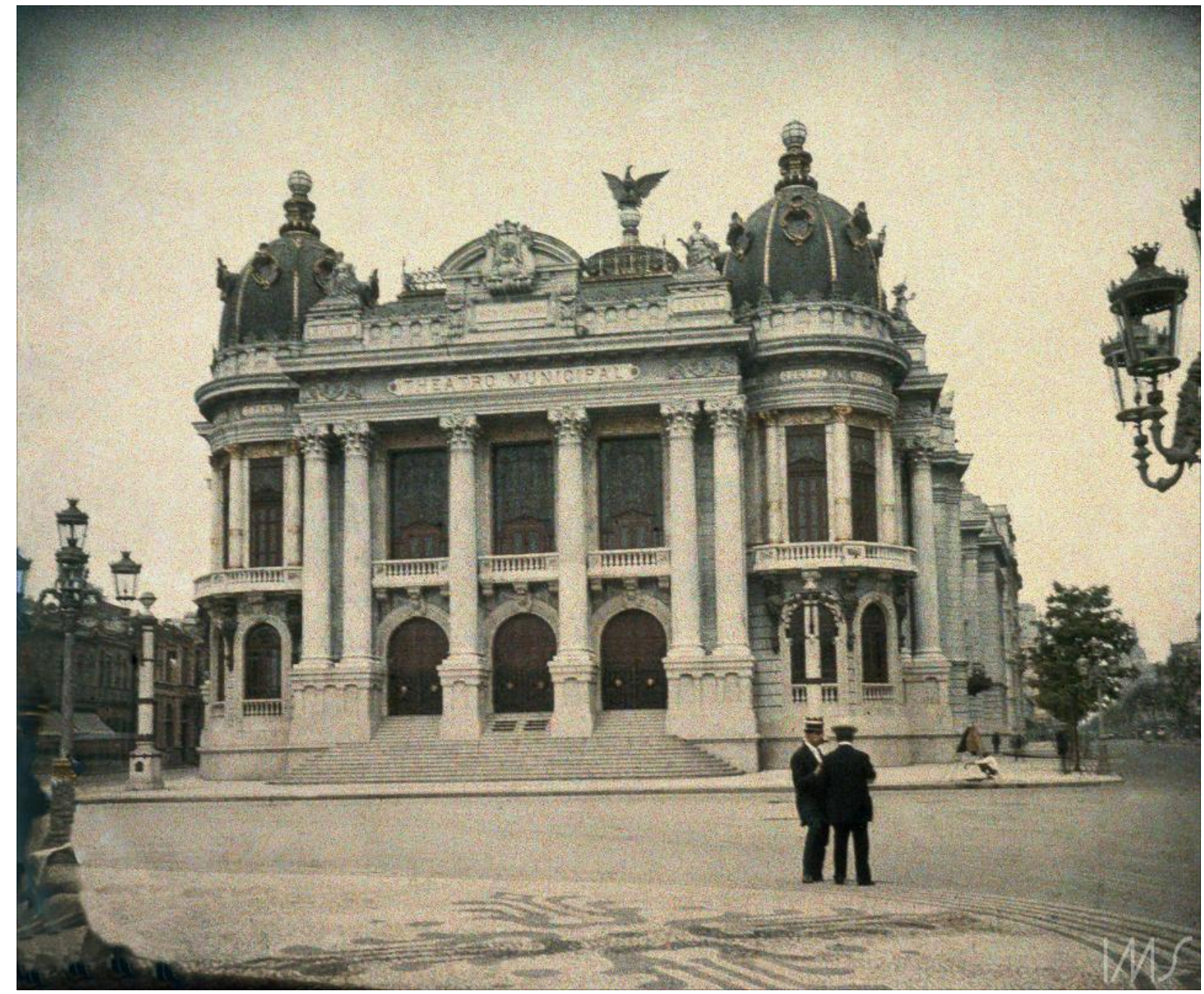

Figura 187: Fotografia de 1912 da fachada principal do Theatro Municipal do Rio de Janeiro. Fonte: Coleção Gilberto Ferrez, IMS - Instituto Moreira (ferrez.ims.com.br).

Ao longo de sua história, foram realizadas quatro grandes intervenções arquitetônicas, que alteraram aspectos estruturais e estéticos do edifício. A primeira delas, realizada na década de 1930, focou-se na reconfiguração espacial da sala de espetáculos, com a intenção de suprir a demanda de ampliação da capacidade de público e da caixa cênica (MACHADO, 2012).

Nessa ocasião, o layout da plateia foi modificado e as colunas de sustentação do Balcão Nobre foram suprimidas, em processo semelhante ao que seria submetido o Municipal paulista duas décadas mais tarde. Assim como em São Paulo, o edifício não contava com nenhuma medida preservacionista. 
A intervenção exigiu que fosse realizado um reforço estrutural em concreto armado, que alteraria permanentemente a configuração externa da cobertura do edifício. O zinco das telhas sobre as escadas laterais foi substituído por cobre e foi criado um plano de alvenaria autoportante entre a cúpula e o telhado da escadaria central, o que promoveu a construção de uma nova água de telhado (Figura 188).

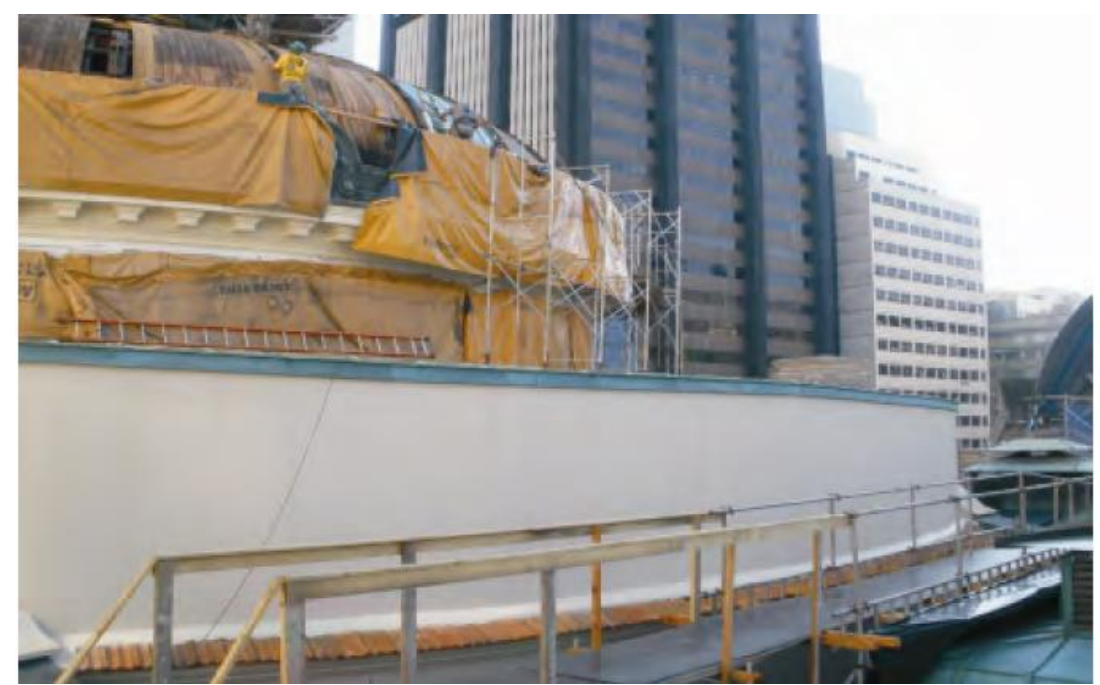

Figura 188: Fotografia do plano de alvenaria autoportante construído durante a intervenção da década de 1930.

Fonte: Foto: Erika Machado, 2009. Acervo: Superintendência do IPHAN-RJ IN: MACHADO, 2012.

A segunda grande intervenção teve lugar no final da década de 1970, entre os anos de 1977 e 1979. Nesse momento, o Theatro já havia sido reconhecido pelo INEPAC e pelo IPHAN como patrimônio arquitetônico, e passa por uma vistoria que identifica as patologias internas e externas do edifício ${ }^{104}$.

Essa inspeção atesta que os maiores problemas de conservação encontrados no Theatro derivam de duas principais causas: o estado precário do sistema de drenagem pluvial da cobertura e o uso do bem para eventos incompatíveis com as suas configurações espaciais, como festas de formatura e de carnaval. De acordo com o parecer técnico do restaurador Edson Motta, que consta no relatório de obras de 1977, a intervenção que se seguiu foi de caráter conservativo, com algumas restaurações pontuais (MACHADO, 2012).

\footnotetext{
104 O reconhecimento do TMRJ, por parte dos respectivos órgãos de preservação estadual e federal, se deu anteriormente ao do edifício análogo em São Paulo. O tombamento deste se deu apenas em 1981 e 2014, respectivamente pelo Condephaat e pelo Iphan.
} 
Os desafios para conservação da cobertura deviam-se a uma série de peculiaridades de ordem morfológica e construtiva. Trata-se de uma estrutura mista em perfis de madeira e metal (original) e concreto armado (intervenção de 1934), forrada por assoalho em réguas de madeira, que serve de base para fixação das telhas de cobre e zinco.

Assim como no Municipal de São Paulo, cada espaço recebe um tipo de cobertura diferente. O foyer do Balcão Nobre é coberto pelo zimbório, ornamentado com guarda-corpo de elementos fitomórficos; a Grande Escadaria, por telhado em dois níveis e claraboia; a Sala de Espetáculos, pela grande cúpula arrematada por uma águia moldada em cobre; a caixa cênica, por telhado de duas águas oblíquas; as rotundas, por domos adornados e, finalmente, os telhados laterais e posteriores, compostos por mansardas (Figura 189).

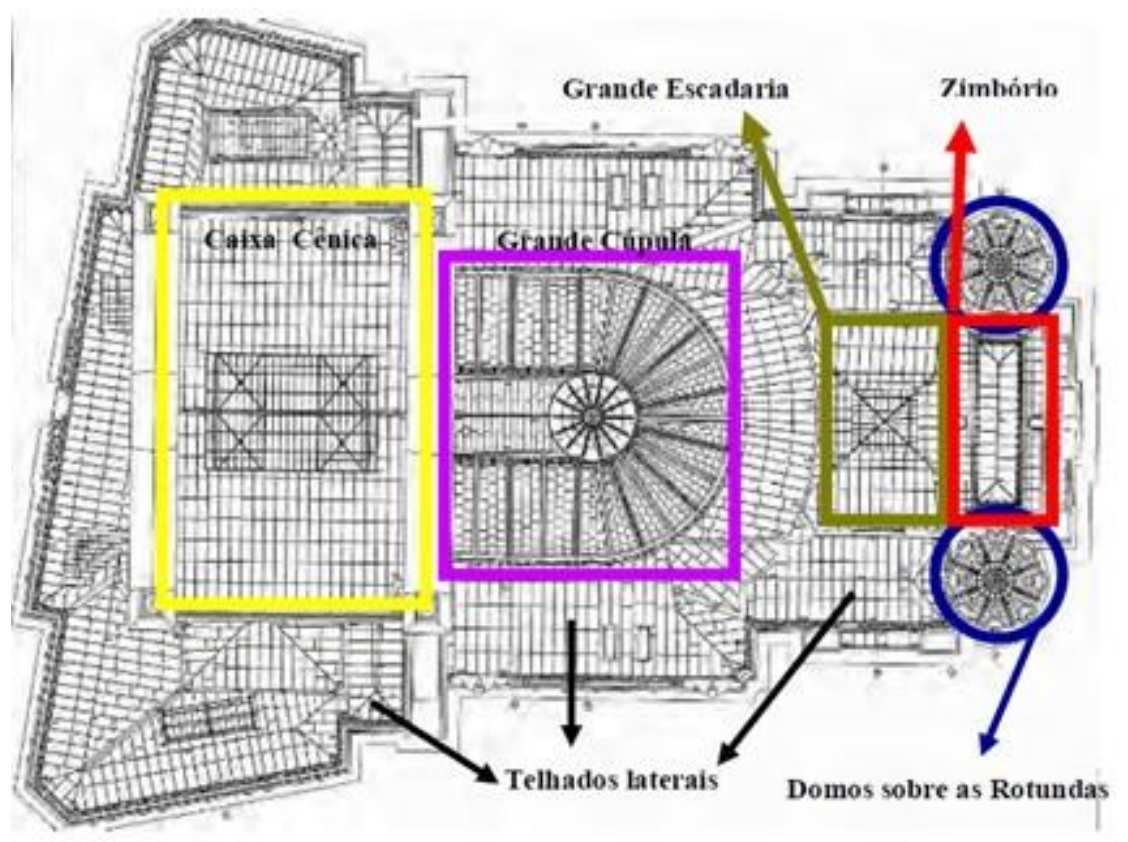

Figura 189: Planta da cobertura do TMRJ.

Fonte: Levantamento cadastral - Fundação TMRJ/empresa Ingenium, 2007/Erika Machado. Acervo: Arquivo da Superintendência do IPHAN-RJ. IN: MACHADO, 2012.

Dez anos mais tarde a cobertura continuava sendo a maior fonte dos problemas a serem enfrentados pela preservação do edifício. É nesse momento, entre 1987 e 1989, que se realiza a terceira intervenção no Municipal carioca, cuja obra estava prevista em três etapas. A primeira etapa seria destinada à restauração das fachadas, telhados, áreas internas e obras de arte integradas; a segunda, à 
modernização das instalações elétricas e a terceira, à modernização do sistema de climatização.

Por uma limitação orçamentária do Estado, a obra não foi concluída. A cobertura, em estado precário, continuava sem receber manutenção, o que acarretou uma série de alagamentos, vazamentos e infiltrações nos anos que se seguiram. Esses acontecimentos não só punham em risco os funcionários e frequentadores do espaço, como ocasionaram o descolamento de pinturas artísticas integradas e a danificação de ornamentos aplicados em estuque armado.

Em 2007, com a aproximação de seu centenário, foi elaborada uma proposta de restauração da cobertura do Theatro pelo Departamento de Arquitetura, Engenharia e Manutenção do TMRJ. No projeto, apenas seriam contemplados os domos sobre as rotundas, para os quais havia sido pensada uma reconstrução total de fechamentos e ornamentação, utilizando-se de técnicas e equipamentos de alta tecnologia empregados na indústria automobilística.

A captação de recursos para a obra foi aprovada através da Lei Rouanet no mesmo ano, mas o grupo de trabalho, composto por uma equipe de fiscalização de patrimônio, membros da gerenciadora da obra e pela Fundação TMRJ, acabou repensando a proposta original. Percebeu-se que essa solução não resolveria os problemas de ordem grave encontrados em toda a extensão da cobertura e que para sua execução seria realizado o descarte de toda a ornamentação original, o que foi entendido pela fiscalização do patrimônio como algo que promoveria uma perda significativa da autenticidade da edificação.

Dessa forma, conclui-se que seria possível restaurar quase toda a extensão da cobertura com o mesmo orçamento, fazendo uso de técnicas tradicionais. Foi pedido o remanejamento e aditivo de recursos para realização da nova proposta, que também foi aprovada.

Devido ao caráter emergencial da intervenção, os levantamentos e projetos foram elaborados de maneira concomitante à obra, o que, como veremos a seguir, prejudicou sobremaneira o resultado final. $O$ diagnóstico do estado de conservação da cobertura, realizado nessa ocasião, aponta que seu mau estado 
se deve em parte à dificuldade de acesso: os técnicos de manutenção eram obrigados a caminhar diretamente sobre os telhados, na ausência de caminhos e passarelas adequados para a realização desse tipo de serviço, o que promovia o agravamento do desgaste natural dos materiais.

O sistema de drenagem, por sua vez, havia sofrido inúmeras intervenções ao longo do tempo, sobretudo na forma de reparos provisórios realizados de maneira incompatível com os materiais originais. O comprometimento do sistema de escoamento de águas pluviais acarretou danos à estrutura da cobertura, que se estenderam para os planos de alvenaria e às pinturas artísticas.

À vista disso, foi elaborado um plano de obras em três etapas, que começaria pela restauração da cobertura, de caráter emergencial, ao qual se seguiria a elaboração dos projetos executivos para as demais restaurações e obras. A proposta contemplava a recuperação da estrutura mista, fechamentos e ornamentação, e a revisão de calhas.

É nesse momento que são tomadas duas importantes decisões, que impactaram profundamente na fruição externa do edifício: a substituição das telhas da cobertura e o douramento de seus elementos decorativos.

A escolha de substituir integralmente as telhas originais de zinco por telhas de cobre se deu pelo alto custo de investimento e a dificuldade de encontrar aquele material, amparada no fato de que, em algumas áreas da cobertura, essa troca já havia sido efetuada em intervenções anteriores. Com essa mudança, surgiram dois problemas de ordem estética. O primeiro deles dizia respeito à paginação das chapas e o segundo, ao seu aspecto cromático.

As chapas originais da cobertura do Theatro dispunham de noventa centímetros de largura, enquanto as chapas fabricadas na ocasião da obra possuíam apenas sessenta centímetros (Figura 190). Essa alteração, de acordo com Erika Machado, prejudicou a fruição exterior do bem: 
redução da largura das novas chapas de cobre, provoca um efeito visual de leve deformação na curvatura dos telhados. Nota-se a alteração de seu aspecto morfológico geral, bastante evidente nos domos das rotundas, sobretudo por serem elementos muito marcantes da fachada principal.

Além disso, as novas chapas tornam-se desproporcionais em relação ao porte dos ornamentos originais, causando uma mudança significativa na modenatura e comodulação dos telhados (...) (MACHADO, 2012, p. 77).
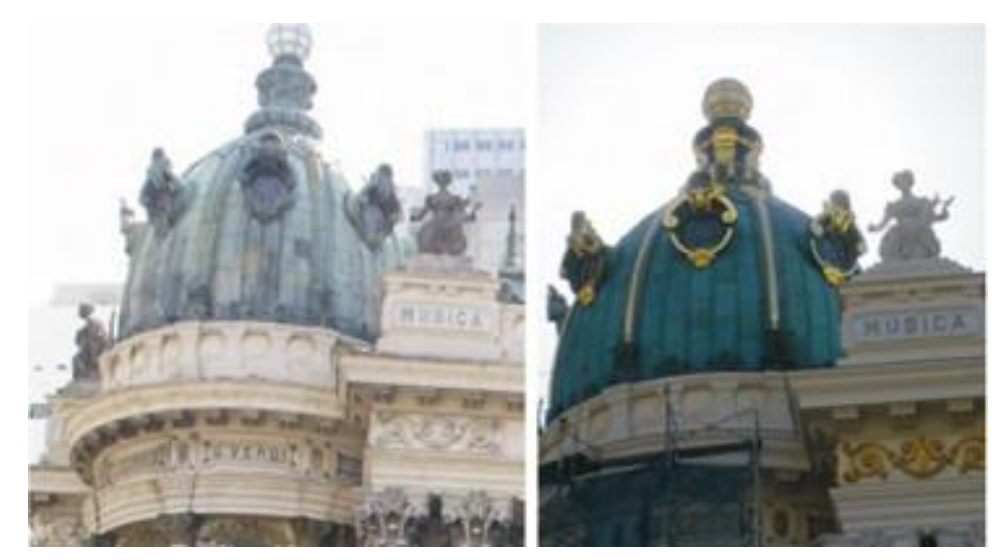

Figura 190: Fotografia da cúpula da rotunda antes da intervenção (à esq.), fotografia da cúpula da rotunda após a intervenção (à dir.).

Fonte: brasildestino.wordpress.com (esq.), Erika Machado, 2009. Acervo: Superintendência do IPHAN-RJ (dir.) IN: MACHADO, 2012.

Ainda segundo a autora, essa situação poderia ser lida de duas formas distintas. Se a enxergamos sob o prisma de uma intervenção incisiva, que implicou no descarte e substituição da matéria original, essa postura estaria desencontrada do corpus teórico da restauração contemporânea, sobretudo no que diz respeito à sua declinação crítico-conservativa e ao valor atribuído por esta à autenticidade da obra. Se, por outro lado, justifica-se a substituição, devido ao péssimo estado de conservação que restringia a funcionalidade e conservação do bem em questão, sem modificar sua volumetria ou ornamentação, essa posição poderia ser admissível sob o julgo dos mesmos parâmetros (MACHADO, 2012).

Quanto ao aspecto cromático, a substituição integral das telhas implicou no debate sobre a pátina. A coloração avermelhada natural do cobre é, com o tempo, recoberta por uma pátina esverdeada. As chapas de cobre que compunham a cobertura naquele momento eram provenientes de intervenções 
anteriores e já haviam sido maculadas pelo passar dos anos. Já as chapas novas ainda apresentavam vermelha original.

Uma vez que se decidiu pela manutenção da pátina esverdeada sobre os ornatos, ficou estabelecido que as chapas novas seriam "patinadas" artificialmente, para estabelecer uma unidade de leitura do conjunto. Afinal, a imagem consolidada do monumento abarcava a coloração esverdeada dos elementos e sua cobertura.

No entanto, o que se verificou foi uma diferença bastante acentuada entre a coloração das pátinas natural e artificial, que acabou por gerar destaque e estranhamento (Figura 191). Novamente, essa situação é interpretada por Machado sob duas chaves distintas.

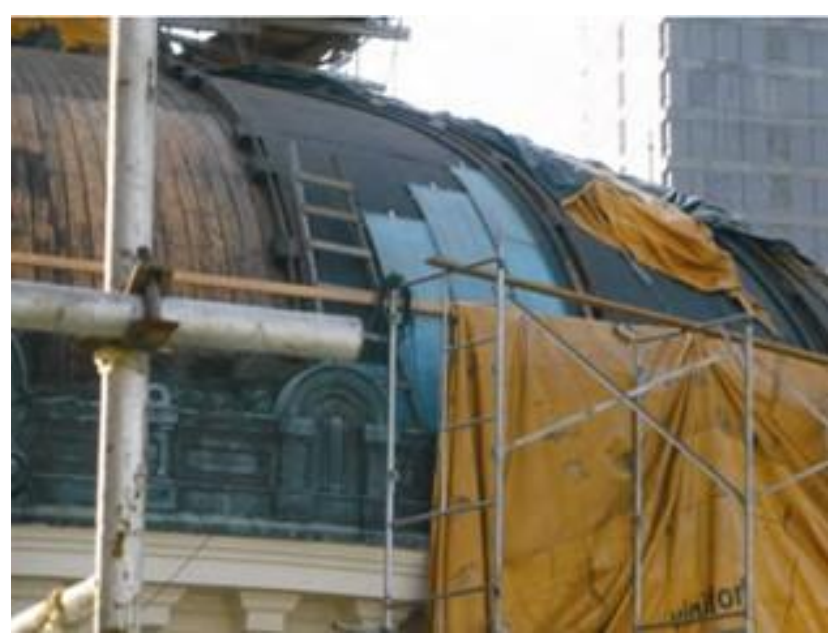

Figura 191: Diferença entre o cobre patinado artificialmente e naturalmente.

Fonte: Erika Machado, 2009. Acervo: Superintendência do IPHAN-RJ IN: MACHADO, 2012.

Se lida através do princípio da distinguibilidade, contido em Brandi e na Carta de Veneza, a solução pode ser aceitável. Se, ao contrário, for entendida como uma repristinação imitativa nos moldes de Viollet-le-Duc, não pode de maneira alguma ser aceita. Até aqui as discussões teóricas a respeito da intervenção podem se dar em diálogo, contemporizando posições contraditórias, o que não pode ser dito da sua etapa final: o douramento dos elementos decorativos da cobertura.

Como já foi mencionado, devido à urgência da intervenção, as análises diagnósticas, pesquisas e projetos foram sendo elaboradas simultaneamente à 
obra. Em uma dessas pesquisas, no decorrer da obra, foi encontrada documentação iconográfica que sugeria a presença de douramentos nos ornatos originais da cobertura (Figura 192).

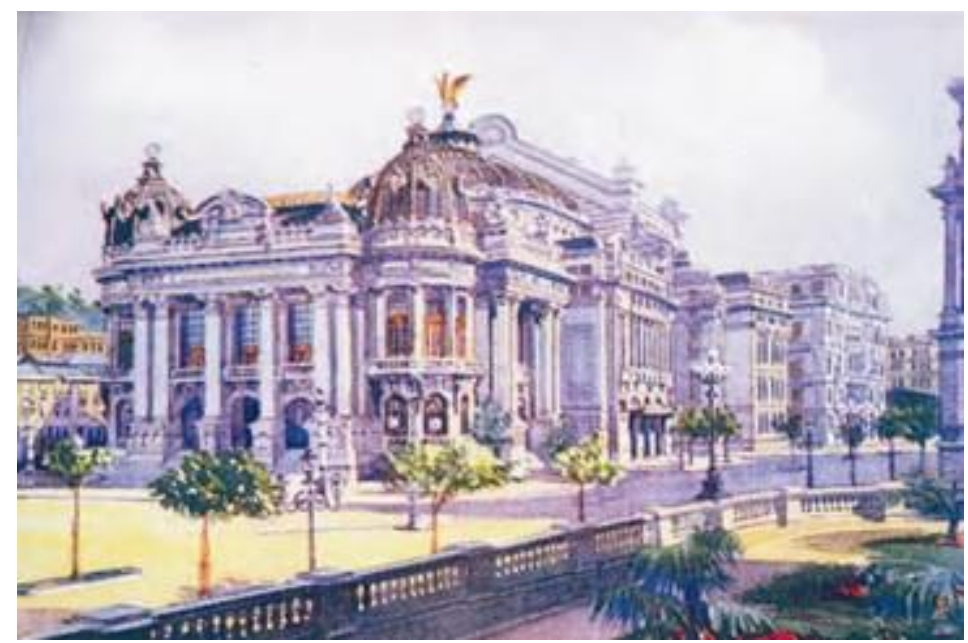

Figura 192: Aquarela que sugere douramento dos elementos decorativos da cobertura. Fonte: Fundação TMRJ, 2008. Acervo: Arquivo Superintendência IPHAN-RJ. IN: MACHADO, 2012.

Para sanar a dúvida de se o douramento havia de fato existido, foram realizados ensaios metalográficos sobre amostras retiradas do lanternim da cúpula. Esses ensaios acusaram a presença de ouro no material, o que levou a equipe a optar pelo refazimento do douramento de todos os elementos decorativos da cobertura (Figura 193).

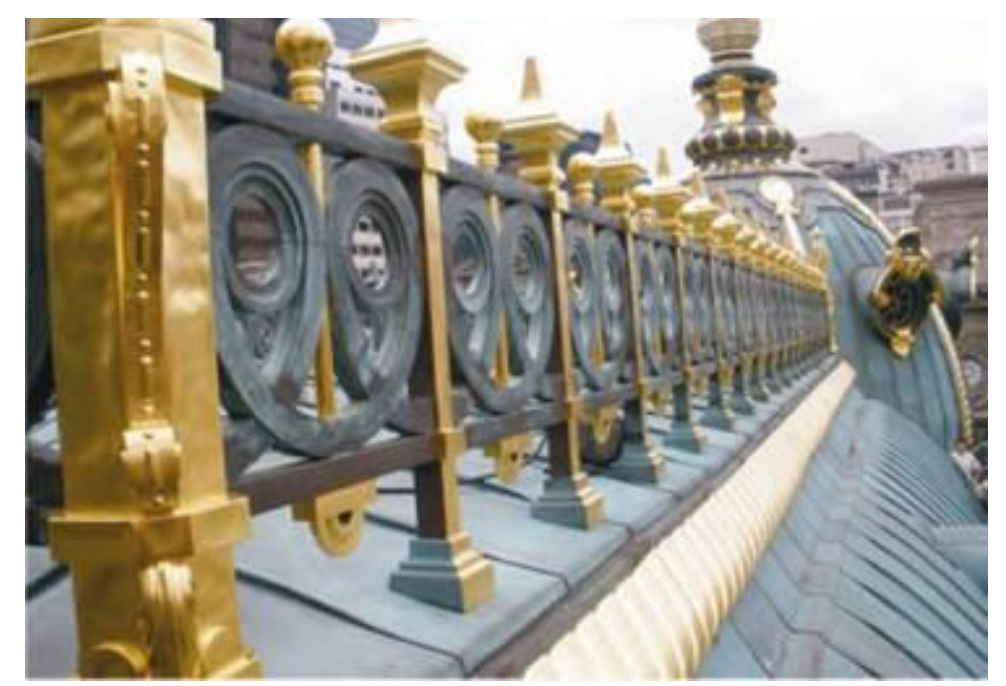

Figura 193: Douramento novo dos elementos decorativos da cobertura.

Fonte: Erika Machado, 2009. Acervo: Superintendência do IPHAN-RJ IN: MACHADO, 2012. 
Essa escolha fez surgir uma situação anacrônica, na medida que o tempo necessário para o surgimento natural da pátina do cobre é maior do que a durabilidade da camada de douração, que evanesceria antes que o telhado adquirisse coloração esverdeada, de forma que "ao longo da existência do bem, o conjunto formado pelo cobre patinado e os ornamentos dourados nunca existiu até então" (MACHADO, 2012, p. 81). Sobre isso, também diz Machado:

\footnotetext{
A urgência de sanar os vazamentos que poderiam vir a condenar as obras de arte integradas à edificação impediu o desenvolvimento dos debates conceituais - imprescindíveis para decidir a linha teórica (ou as linhas teóricas) a serem seguidas e como estas seriam aplicadas na edificação como um todo.

É nesse contexto que aconteceu uma situação inédita no TMRJ: a cobertura em cobre patinada teve seus ornamentos dourados, configurando, assim, uma imagem anacrônica do que teria sido um telhado "original" (MACHADO, 2012, p. 80).
}

Levadas em consideração as tendências contemporâneas do restauro de arquitetura esquematizadas por Carbonara e Mariani, chega-se à conclusão de que a intervenção em questão se aproxima da hipermanutenção em chave repristinatória, uma vez que promove uma reconstrução que, apesar de anacrônica, retoma formas e técnicas do passado.

Uma vez analisadas as bases internacionais da teoria da restauração contemporânea, bem como sua aplicação em um caso brasileiro concreto, resta ingressar no estudo aprofundado da intervenção tema da presente pesquisa - 0 restauro sofrido pelo Theatro Municipal de São Paulo, às vésperas da completude de seus cem anos.

\subsection{A intervenção (2006-2011): Centenário TMSP}

Tendo sido construído nos idos de 1911 (...) está preste a completar o seu centenário. Como todo patrimônio material, não conseguiu passar incólume às injúrias do tempo e do uso (...). Resta-nos, pois, colocar todo o nosso empenho e a nossa inteligência em prolongar, o máximo possível, a vida dos edifícios que são significativos para a nossa memória, particularmente aqueles que ainda estão prestando relevantes serviços à comunidade (Fonte: Memorial Descritivo do Projeto de Restauração do TMSP, DPH, 2006, 2011, p. 6). 
Conforme o centenário da construção se aproximava, começou-se a pensar um plano de conservação e restauro a ser implementado no edifício, cuja última intervenção fora realizada há quase trinta anos. As análises e diagnósticos, realizadas pelo DPH a partir de 2006, estabeleciam diretrizes para os projetos a serem realizados por equipes multidisciplinares (Figura 194).

\begin{tabular}{|c|c|}
\hline Firma encarregada & Estúdio Sarasá/ Arq. Marcelo Ramos Sarasá Martin \\
\hline \multirow{3}{*}{ Coordenação tecnica } & Prof. Arq. Mário Mendonça de Oliveira \\
\hline & Colaboradores: Arq. Karina Matos de Cerqueira \\
\hline & Arq. Alessandra Arduim \\
\hline \multirow{5}{*}{$\begin{array}{l}\text { NTPR - Núcleo de Tecnologia da } \\
\text { preservação e da Restauração } \\
\text { EPUFBA/DCTM/UFBA }\end{array}$} & Prof. Arq. Mário Mendonça de Oliveira \\
\hline & Colaboradores: Prof. Arq. Cybèle Celestino Santiago \\
\hline & Químico Allard Amaral \\
\hline & Bolsistas: Laís Barreto, Tiana Carvalho e Dayane Soares \\
\hline & Mestrando Aqr. Pedro Sahlit \\
\hline \multirow{6}{*}{$\begin{array}{l}\text { Restauro de bens artísticos } \\
\text { integrados }\end{array}$} & Estudio Argôlo/ Prof. José Dirson Argôlo \\
\hline & Colaboradores: Waldemar Silvestre Carlos \\
\hline & Cláudia Maria de Cerqueira Barbosa \\
\hline & Sérgio Luiz Silva dos Santos \\
\hline & Jorge Cardoso dos Santos Filho \\
\hline & Marcelo Juventino Freitas de Santana \\
\hline \multirow{14}{*}{ Projeto de restauração de vitrais } & Estudio Sarasá/Arq. Marcelo Ramos Sarasá Martin \\
\hline & Colaboradores: Maria Graziela Gomes Giorgi Martin \\
\hline & Camila Viana Tilman \\
\hline & Paula Soares Maia Silva \\
\hline & Renata Poliana Cezar Monezzi \\
\hline & Jorge da Silva Oliveira \\
\hline & Marcos Roberto Máximo \\
\hline & José Pereira dos Santos \\
\hline & Gilson Oliveira Santos \\
\hline & Reinaldo Masson de Carvalho \\
\hline & Rogério Ventura Faria \\
\hline & Edinaldo da Conceição Oliveira \\
\hline & José Carlos Colaço \\
\hline & Antonio Luis Ramos Sarasá Martin \\
\hline $\begin{array}{l}\text { Avaliação das estruturas } \\
\text { metálicas e de madeira }\end{array}$ & Eng. Arq. Eduardo Dantas de Cerqueira Filho \\
\hline \multirow{2}{*}{ Avaliação do sistema elétrico } & Pool Engenheiros associados LTDA \\
\hline & Eng. Fernando Lopes Santiago Júnior \\
\hline Projeto de iluminação externa & Atelier Lumière/ Arq. Fabiano Xavier \\
\hline \multirow{3}{*}{$\begin{array}{l}\text { Estudos petrográficos das rochas } \\
\text { ornamentais }\end{array}$} & IPT/ Centro de Tecnologia de Obras de Infra-estrutura \\
\hline & Maria Heloisa Barros de Oliveira Frascá - Geóloga \\
\hline & Mariana Zuquim - Geóloga \\
\hline
\end{tabular}




\begin{tabular}{|c|c|}
\hline \multicolumn{2}{|c|}{ Nirian Cruxên Barros de Oliveira - Geóloga } \\
\hline & Eduardo Brandau Quitete - Geólogo \\
\hline & Eli Arruda Toledo - Técnico \\
\hline & Jilson Cardoso - Técnico \\
\hline & Magno Bueno Pereira - Técnico \\
\hline & Severino José da Silva - Técnico \\
\hline & Valentim José da Silva Filho - Técnico \\
\hline & Rafael Atsushi Kanke - Bolsista \\
\hline \multirow{6}{*}{$\begin{array}{l}\text { Estudo dos metais aplicados ao } \\
\text { edifício }\end{array}$} & USP \\
\hline & Responsáveis: Augusto Câmara Neiva \\
\hline & Hercílio Gomes de Melo \\
\hline & Jeremie Nicolae Dron \\
\hline & Rocio del Pilar Bendezu Hernandez \\
\hline & Cyntia Helena Ravena Pinheiro \\
\hline \multirow{2}{*}{ Estudos históricos do monumento } & Responsáveis: Glaucia Ribeiro de Lima \\
\hline & Alessandra Matheus Cruz \\
\hline
\end{tabular}

Figura 194: Ficha técnica da obra de restauro.

Fonte: Memorial Descritivo do Projeto de Restauração do TMSP, DPH, 2006.

A obra, financiada em $75 \%$ pelo BID (Banco Interamericano de Desenvolvimento) e 25\% pela própria prefeitura de São Paulo, durante a gestão Gilberto Kassab, contemplou tanto a área externa, correspondente às fachadas, como a interna - e todos seus elementos decorativos (KATCHVARTANIAN, 2014). A seguir, serão analisadas as intervenções realizadas em cada um desses âmbitos que serão, por fim, cotejadas com o corpus teórico apresentado no item anterior do presente capítulo.

\subsection{1 $\underline{\text { Restauro interno }}$}

A obra no interior do edifício contemplava uma série de áreas nobres -, Restaurante, Salão Nobre, Sala de espetáculos, Sala de Imprensa e Salas contíguas ao palco -, que tiveram seus pisos, paredes, forros e elementos decorativos revisados e restaurados. Além desses ambientes, foram realizadas intervenções de elétrica, hidráulica e iluminação.

Para efeito da presente pesquisa, serão tratadas apenas das intervenções referentes à configuração arquitetônica dos espaços e sua ambiência. Todas serão abordadas e analisadas de acordo com o que consta no Memorial Descritivo do Projeto, elaborado pelo Departamento do Patrimônio Histórico, e suas respectivas peças iconográficas, na forma de plantas, cortes e elevações, 
cedidas pela Fundação Theatro Muncipal de São Paulo. Também será levado em consideração o relato da arquiteta Lilian Jaha - que participou do projeto da intervenção -, contido na dissertação de Soraya Arida Katchvartanian (KATCHVARTANIAN, 2014).

\subsubsection{Bar e restaurante}

Conforme explorado no segundo capítulo desta dissertação, o restaurante teve suas características espaciais profundamente alteradas pela grande reforma da década de 1950. O que configurava originalmente um ambiente único fora dividido em dois- tanto transversalmente como longitudinalmente - para melhor abrigar as funções administrativas da época.

Para efeito de análise, continuar-se-á a tratá-lo como dois ambientes contíguos, conforme descrito no memorial descritivo da obra (Figuras 195 e 196). Isso posto, após as prospecções realizadas na ocasião da última intervenção ${ }^{105}$, 0 primeiro ambiente encontrava-se em melhor estado de conservação do que o segundo, que continuava completamente descaracterizado e que havia perdido integralmente seu forro original, que desabou por conta da atuação de insetos xilófagos.
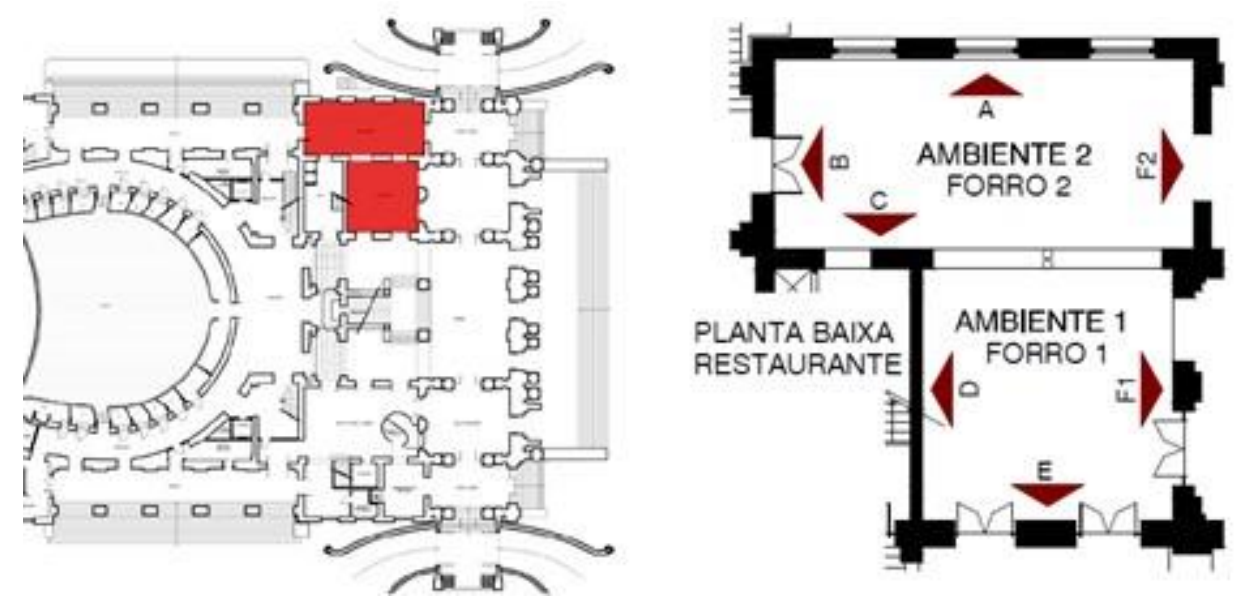

Figuras 195 (esq.) e 196 (dir.): Respectivamente, localização do restaurante na planta do primeiro andar e ampliação de sua planta, dividida em dois ambientes. Fonte: Memorial Descritivo do Projeto de Restauração do TMSP, DPH, 2006.

105 Ver Capítulo 3 - Reconhecimento. 
O desafio encarado pelos profissionais, ao abordar o problema do restaurante, apresentava acentuada complexidade técnica e sobretudo teórica, uma vez que o único documento que resguardava a configuração original daquele espaço era uma fotografia em preto e branco datada de 1911. Além disso, a profunda transformação pela qual havia sido submetido o ambiente, aliada à ausência de manutenção e conservação adequadas, dificultava a identificação dessas características empiricamente. Sobre isso, descreve o memorial:

Os maiores desafios a serem enfrentados pelos restauradores não
residem apenas nas intervenções de ordem prática, mas
principalmente teóricas, uma vez que o ambiente 2 do restaurante
perdeu totalmente seu forro e sanca, ambos já reconstituídos com
placas de gesso há alguns anos, e sua pintura permanece lisa; além
disso, uma média de $50 \%$ da pintura decorativa das barras superiores
das paredes desse mesmo ambiente, à imitação de mosaico, está
desaparecida, sem falar em outros danos ocasionados ao restante de
sua pintura decorativa, em parte mutilada com a inserção de dutos,
caixas de energia elétrica, tomadas etc., para adaptação da iluminação
que hoje ostenta (Memorial Descritivo do Projeto de Restauração do
TMSP, DPH, 2006, p. 54). Essa passagem do memorial deixa claro que a restauração deveria dar conta de dois aspectos principais que compunham aquela ambiência: os forros, paredes e suas respectivas pinturas decorativas. Para além disso, haveria de ser pensada uma solução para as colunas de ferro geminadas entre os dois ambientes, que haviam sido recobertas pela parede que, desde a década de 1950, os separava.

O forro do primeiro ambiente apresentava grande área com presença de reboco novo, resultante de abertura de canaleta para instalação de fiação elétrica (Figura 197). Também continha pontos de descolamento, tanto da camada pictórica como das superfícies douradas (Figura 198). Essas lacunas, no entanto, não comprometiam sua leitura estética. 


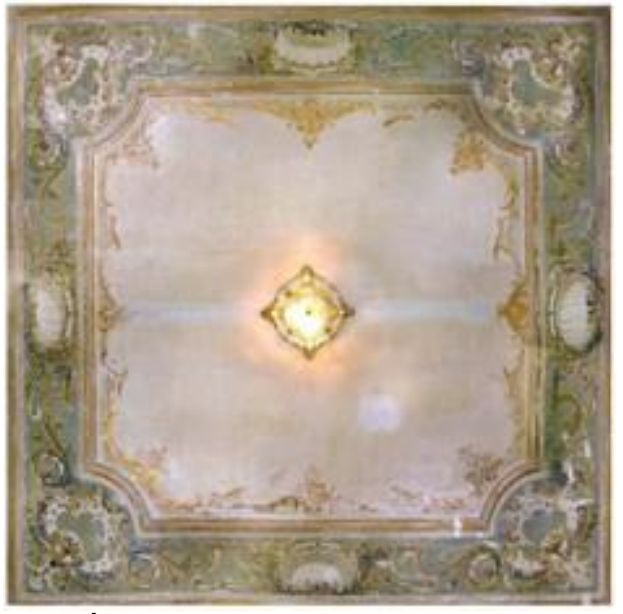

Figura 197: Área do forro que apresenta reboco novo.

Fonte: Memorial Descritivo do Projeto de Restauração do TMSP, DPH, 2006.

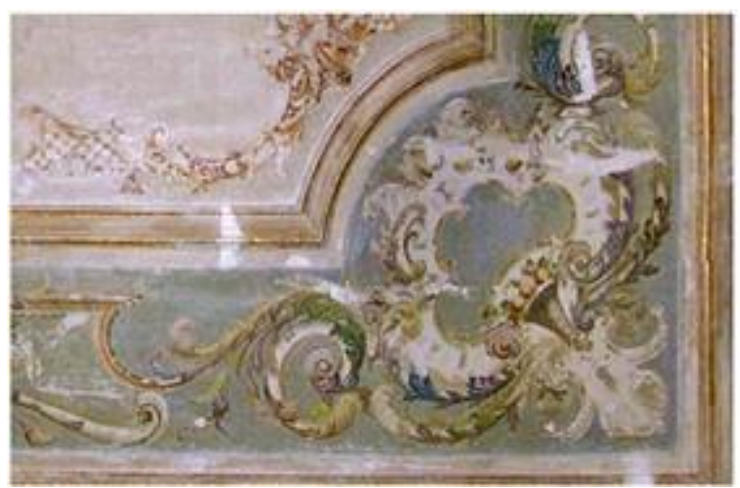

Figura 198: Área do forro que apresenta perda pictórica e no douramento.

Fonte: Memorial Descritivo do Projeto de Restauração do TMSP, DPH, 2006.

Foi decidido que, em primeiro lugar, o forro desse ambiente passaria por uma limpeza superficial, com auxílio de produtos como xilol, essência de petróleo e isso-octano. Uma vez realizado o processo de remoção das sujidades, se daria a fixação da camada pictórica, a remoção da pintura posterior remanescente da última decapagem (Figura 199), a obturação de lacunas e reintegração pictórica e da douração.
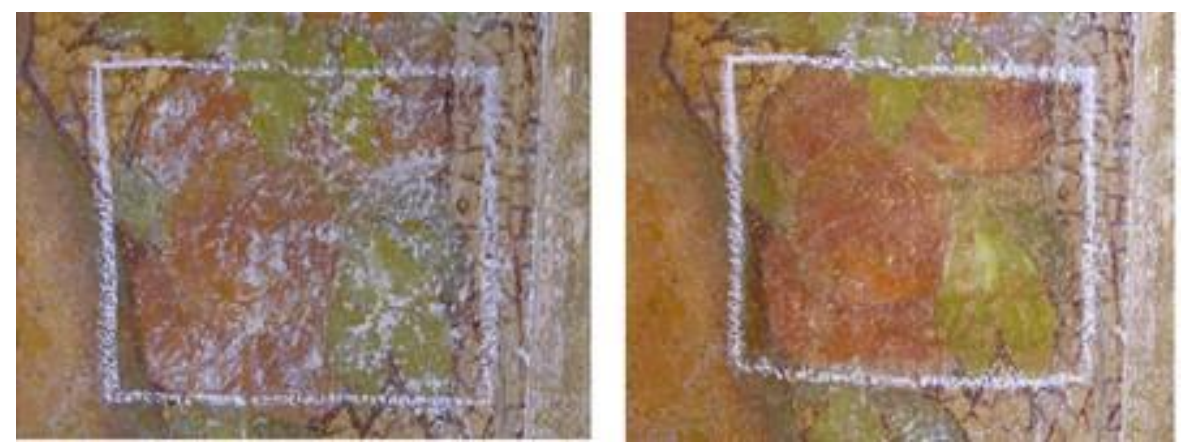

Figura 199: Área antes da remoção de pintura posterior (esq.) e depois do procedimento (dir.). Fonte: Memorial Descritivo do Projeto de Restauração do TMSP, DPH, 2006. 
A fixação da camada pictórica que apresentasse descolamentos se daria por meio de aplicação de colas de cartilagem animal a 5\% na água, Primal AC 33 a $5 \%$ ou solução de acetato de polivinila com álcool etílico e tolueno. A remoção dos resquícios de repintura deveria ser executada mecanicamente, por meio de bisturis cirúrgicos e lupa. Também foram previstos testes com produtos químicos $^{106}$, aplicados através de bastonetes de madeira com algodão hidrófilo, apesar da cautela a ser tomada com relação ao ataque à policromia original.

A obturação das lacunas se daria por meio de preenchimentos com massa artesanal feita com gesso crê e cola de coelho ou massa acrílica industrializada. Depois disso, a lacuna receberia uma camada de verniz à retoucher ${ }^{107}$, aplicado com pincel. A função desempenhada pelo verniz corresponde a impermeabilização dessas lacunas, ao criar um filme entre a pintura original e os retoques, o que facilitaria as intervenções futuras.

A reintegração das pinturas deveria ser feita com aquarela, têmpera, ou tintas à base de verniz. A parte central, de tom liso, receberia repintura em tinta acrílica fosca e os douramentos, reintegrados com folhas de ouro ${ }^{108}$. Após a reintegração, a pintura receberia uma fina camada de verniz protetor, aplicado a pistola.

Quanto ao forro do segundo ambiente, o cenário se complica. Tendo sido confeccionado na década de 1980 em gesso pintado de tom ocre claro e liso, para substituir o original em estuque, que havia sido destruído pela ação de cupins, toda a pintura decorativa se perdera (Figura 200). O novo forro já apresentava algumas irregularidades, como trincas e emendas aparentes entre as placas de gesso.

\footnotetext{
106 O Memorial Descritivo aponta duas fórmulas de agentes químicos que haviam sido testadas com sucesso para tal, ambas consistiam em uma combinação entre proporções de isopropanol, amoníaco e água.

107 Verniz de retoque.

108 O Memorial especifica que apenas as lacunas pontuais poderiam ser reintegradas, não com folha de ouro, mas com oro in conchiglia (ouro em pó misturado a aglutinante) ou tintas douradas importadas.
} 


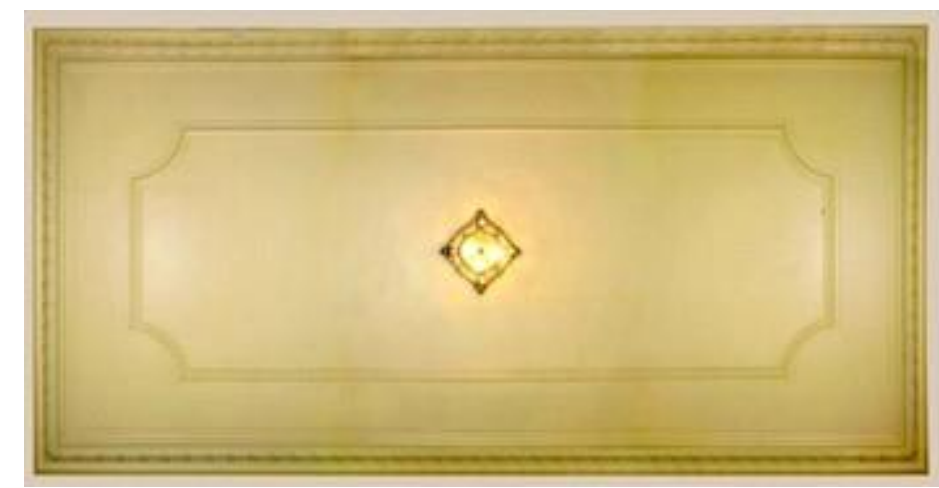

Figura 200: Estado do forro antes da intervenção.

Fonte: Memorial Descritivo do Projeto de Restauração do TMSP, DPH, 2006.

Em primeiro lugar, foi proposta a correção desses problemas, seguida pela aplicação de massa acrílica em toda a extensão do forro. Em seguida, decidiuse pelo refazimento da pintura do forro original, elaborada com base na fotografia de 1911 e em outra imagem capturada antes do restauro de 1980, que foi trabalhada digitalmente para reproduzir o desenho com maior fidelidade (Figura 201). O forro do primeiro ambiente, que permanecera quase intacto, foi usado como referência para as cores dos ornatos e detalhes do douramento.

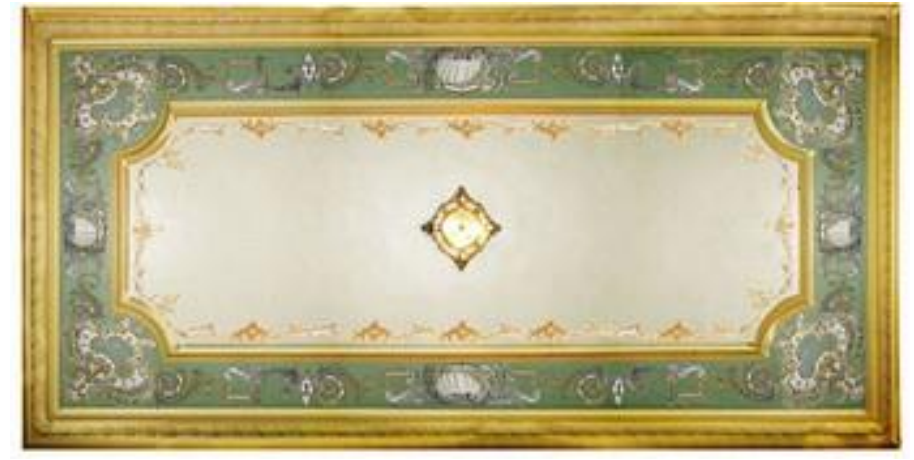

Figura 201: Forro proposto.

Fonte: Memorial Descritivo do Projeto de Restauração do TMSP, DPH, 2006.

Esse desenho deveria ser ampliado e projetado, em escala real, sobre um papel de seda, perfurado de acordo com suas linhas, que serviria de base para a pintura, executava a têmpera. Os douramentos seriam reproduzidos com folhas de ouro, na mesma composição àquele usado originalmente, cuja liga metálica havia sido identificada em laboratório. Finalmente, o forro receberia aplicação de verniz Paralóide B72 a 5\%, para maior proteção e permanência.

Quanto às pinturas decorativas, essas eram divididas em dois grupos, em ambos os ambientes: aquelas correspondentes à barra superior, imitando mosaico (Figura 202); e as demais pinturas com frisos e elementos florais (Figura 203). 0 
primeiro grupo apresentava alguns resquícios de repintura que não haviam sido removidos pela decapagem da intervenção anterior; grandes lacunas de profundidade e policromia, que comprometiam a leitura estética do padrão pictórico; e perda da moldura em relevo que contorna a barra decorativa (Figura 204). O segundo grupo também apresentava grandes áreas de lacunas, sobretudo provocadas pela construção, na década de 1950, da laje que seccionava o ambiente em dois; e pela posterior inserção de instalações elétricas (Figura 205).

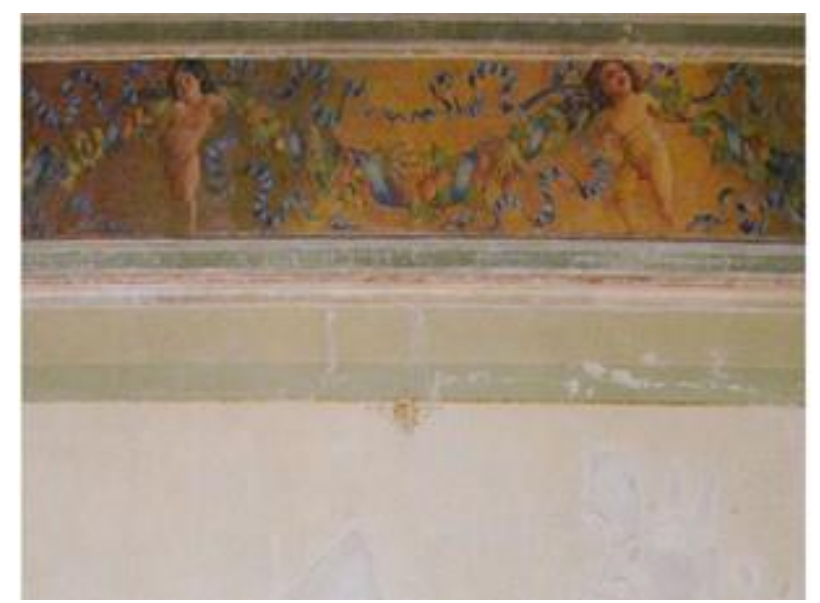

Figura 202: Barra decorativa imitando mosaico.

Fonte: Memorial Descritivo do Projeto de Restauração do TMSP, DPH, 2006.

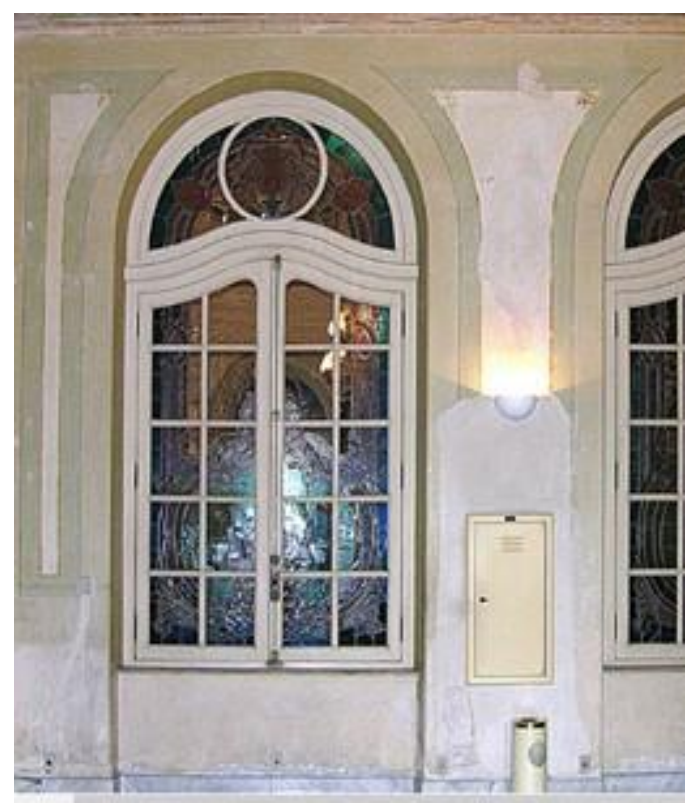

Figura 203: Pintura com frisos e elementos florais.

Fonte: Memorial Descritivo do Projeto de Restauração do TMSP, DPH, 2006. 


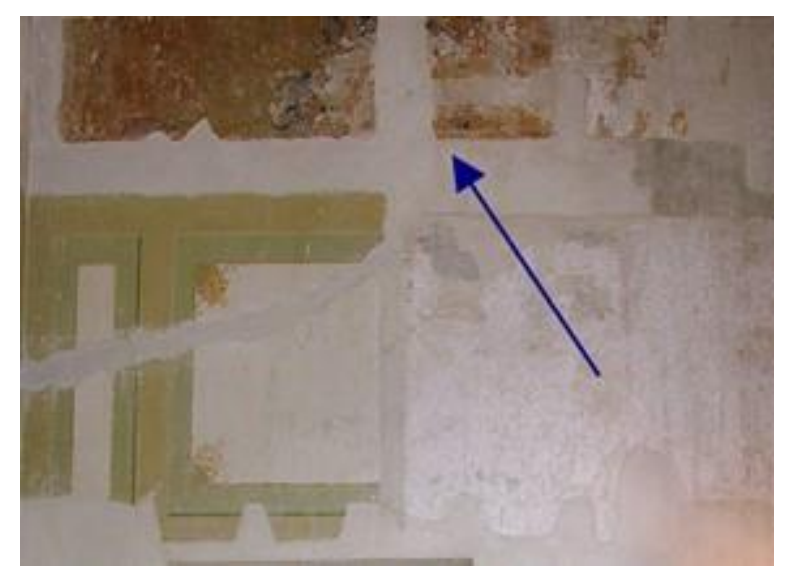

Figura 204: Barra decorativa com área grande de perda pictórica.

Fonte: Memorial Descritivo do Projeto de Restauração do TMSP, DPH, 2006.

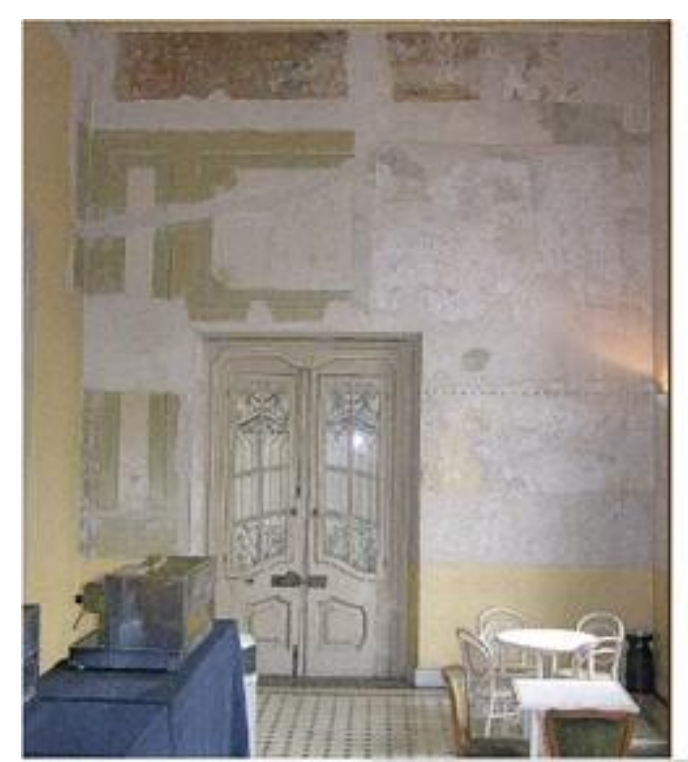

Figura 205: Pintura decorativa com grande área de perda pictórica.

Fonte: Memorial Descritivo do Projeto de Restauração do TMSP, DPH, 2006.

A barra imitativa de mosaico estava mais bem preservada no primeiro ambiente, restando apenas $50 \%$ de sua área original no segundo. Aqui, mais uma vez, a maior integridade do primeiro ambiente serviu como modelo para a intervenção no segundo.

Em linhas gerais, o processo de recuperação desse grupo de pinturas se daria de modo muito semelhante àquele aplicado à restauração dos forros. Em primeiro lugar, seria realizada uma limpeza superficial, seguida da fixação da camada pictórica nas áreas de descolamento, remoção dos resquícios de repintura, obturação das lacunas com massa acrílica e, por fim, sua reintegração pictórica e aplicação de verniz protetor - tudo nos moldes da intervenção ao qual seriam submetidos os forros. 
No entanto, há algumas especificidades do processo de reintegração de lacunas que, nesse caso, merece atenção. As lacunas de menor porte poderiam ser reintegradas na técnica ilusionista, enquanto as maiores seriam realizadas a rigattino $^{109}$. A pintura, a base de têmpora, deveria ser realizada um tom abaixo do original, para garantir a distinguibilidade (Figura 206).
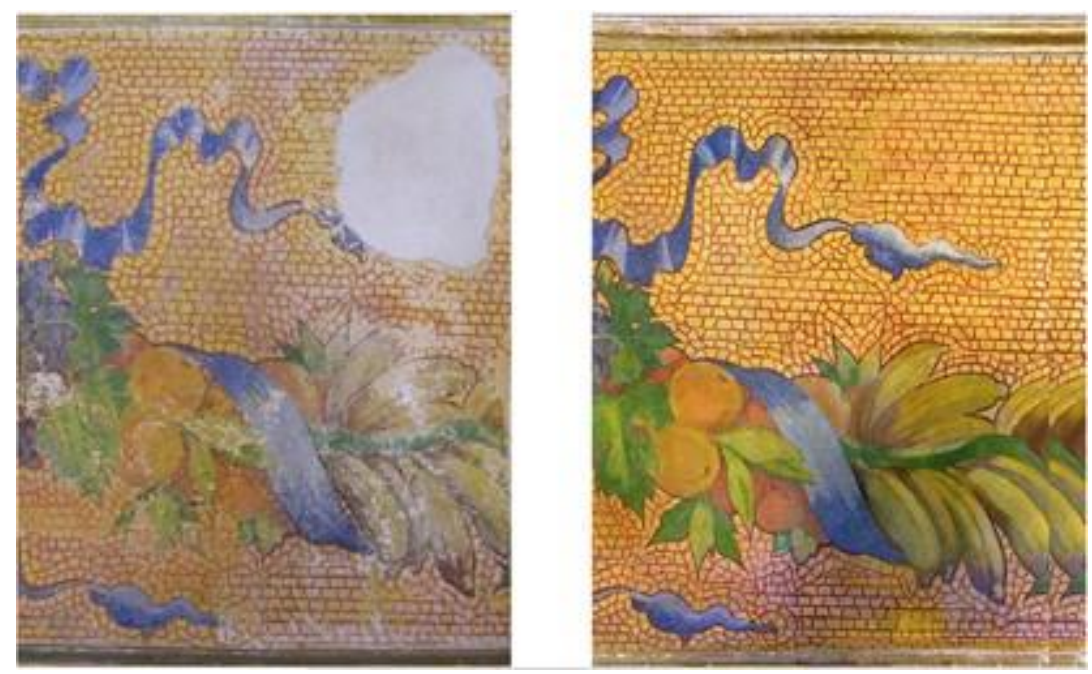

Figura 206: Reintegração das lacunas na barra imitativa de mosaico.

Fonte: Memorial Descritivo do Projeto de Restauração do TMSP, DPH, 2006.

Um estudo das figuras humanas representadas nesse grupo de pinturas, a partir de análise digital da documentação fotográfica, possibilitou a identificação de dezessete figuras infantis diferentes de um total das vinte e oito aparentemente existentes nas barras originais (Figura 207). Devido à repetição dos motivos, foi possível realizar simulações de reconstituição com maior facilidade e fidelidade (Figura 208).

109 Rigattino e ilusionista são técnicas de reintegração pictórica que visam preencher lacunas de maneira harmoniosa porém passível de distinção, com o objetivo de não serem criados falsos históricos ou artísticos (VILLARQUIDE, 2005). 


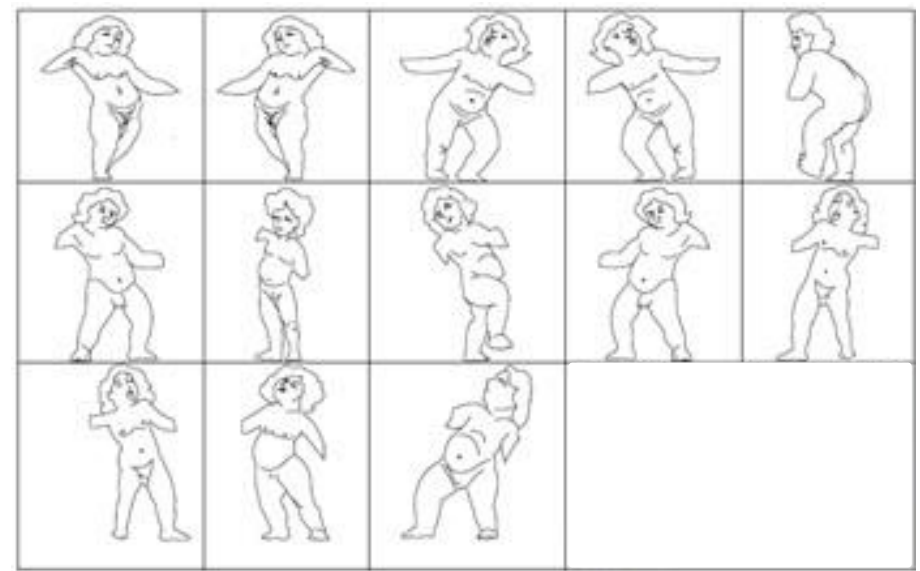

Figura 207: Esquema de algumas das formas antropomórficas identificadas pelo estudo. Fonte: Memorial Descritivo do Projeto de Restauração do TMSP, DPH, 2006.

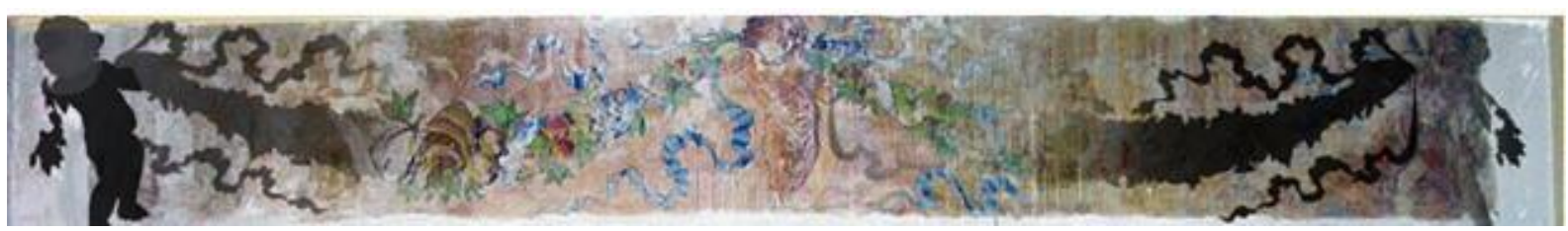

Figura 208: Proposta de reconstituição da barra decorativa de uma das paredes. Fonte: Memorial Descritivo do Projeto de Restauração do TMSP, DPH, 2006.

As molduras das barras do segundo ambiente haviam sido completamente perdidas, ao que se propôs sua reconstituição integral e aplicação de douramento com folhas de ouro, que receberia uma pátina artificial, a fim de dar unidade e equilíbrio à decoração do ambiente (Departamento do Patrimônio Histórico, p. 63). As molduras do primeiro ambiente, por sua vez, apenas tiveram seus douramentos reintegrados, usando-se da mesma qualidade de folhas de ouro.

A intervenção prevista para o segundo grupo de pinturas decorativas era muito mais simples. Tratava-se da remoção dos resquícios de repintura e de obturações grosseiras, repintura das paredes em tons lisos com tinta acrílica na mesma tonalidade da original (Figura 209) e, por fim, da reintegração dos frisos e ornatos com motivos fitomórficos (Figura 210). Essa reintegração deveria ser realizada com folhas de ouro, aplicadas sobre bolo armênio ${ }^{110}$.

\footnotetext{
${ }^{110} \mathrm{~A}$ técnica do bolo armênio consiste na aplicação de uma base de assiette em tom de preto, vermelho ou amarelo, com a finalidade de preparar o fundo para receber o douramento (FERRARI, 2021).
} 

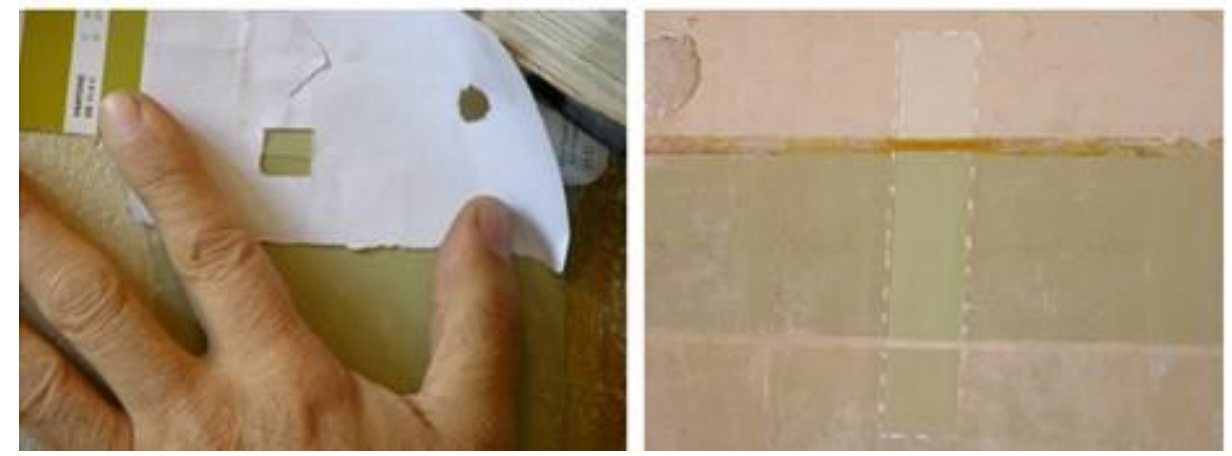

Figura 209: Identificação e testes de tonalidade para pintura lisa das paredes. Fonte: Memorial Descritivo do Projeto de Restauração do TMSP, DPH, 2006.
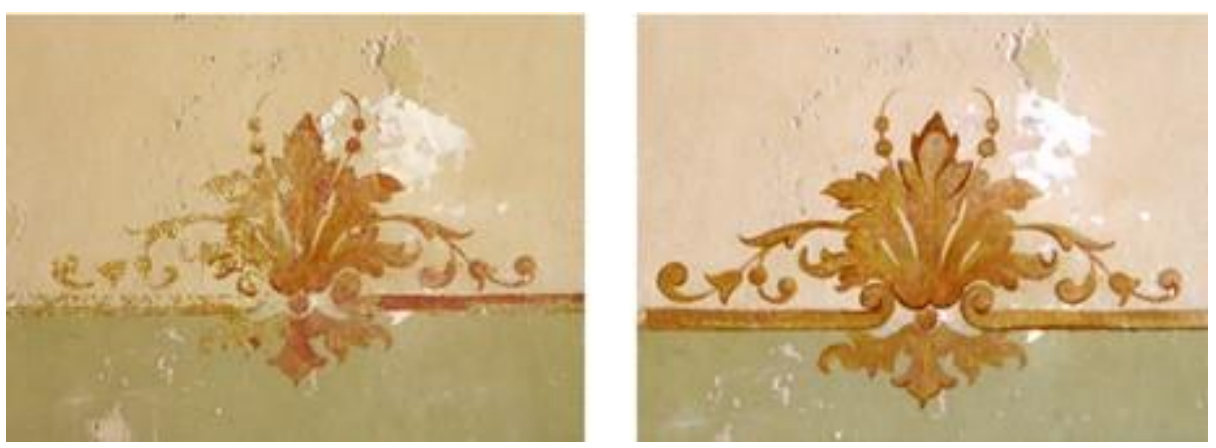

Figura 210: Teste de reintegração de pintura decorativa.

Fonte: Memorial Descritivo do Projeto de Restauração do TMSP, DPH, 2006.

Outro elemento ao qual foi dedicada atenção, para além dos forros e paredes, foram as colunas duplas de ferro entre os dois ambientes, que haviam sido incorporadas à parede construída para dividi-los durante a intervenção da década de 1950 (Figura 211). Nelas, havia resquícios de repintura; lacunas generalizadas na pintura, que deixavam à mostra o ferro fundido; lacunas nos douramentos e presença de oxidação do ferro. 


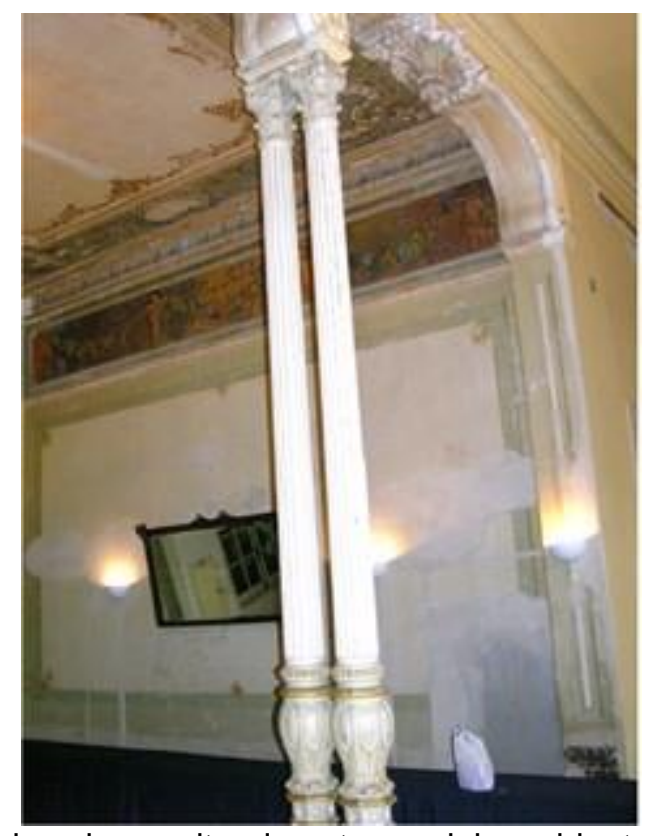

Figura 211: Par de colunas situado entre os dois ambientes do restaurante. Fonte: Memorial Descritivo do Projeto de Restauração do TMSP, DPH, 2006.

Para esses elementos, ficou prevista a remoção dos resquícios de repintura, a obturação das lacunas com massa a base de óleo, repintura em tinta à base de óleo na mesma tonalidade original e reintegração dos douramentos com folhas de ouro (Figura 212). A remoção da oxidação poderia ser feita mecanicamente, com bisturi cirúrgico ou espátula odontológica, podendo ser utilizadas lixas próprias para ferro nas áreas maiores. Finalmente, receberia uma demão de verniz Paralóide B 72 a 10\%, seguida de primer ou zarcão anti-ferruginoso ${ }^{111}$.

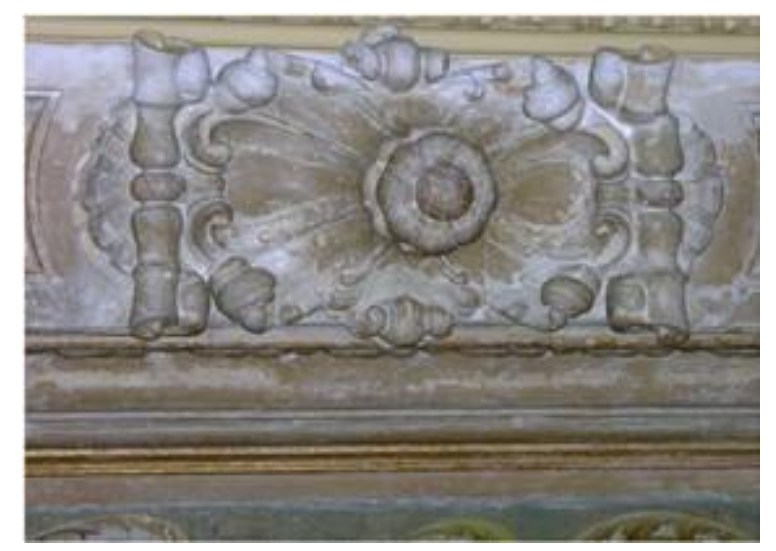

Figura 212: Teto da arcada sobre as colunas, que também apresenta resquícios de repintura e lacunas de douramento.

Fonte: Memorial Descritivo do Projeto de Restauração do TMSP, DPH, 2006.

111 O zarcão é um produto, normalmente de tonalidade alaranjada, que serve como protetor antiferrugem e base uniformizadora para aplicação de tintas de acabamento em superfícies metálicas. 


\subsubsection{Salas contíguas ao palco}

$\mathrm{Na}$ época da intervenção, as duas salas de apoio ao palco funcionavam respectivamente como sala dos assistentes do maestro e sala de guarda de instrumentos (Figuras 213 e 214). Durante o processo de restauração anterior, tiveram suas paredes - que haviam sido repintadas com espessas camadas de tinta - decapadas mecanicamente.
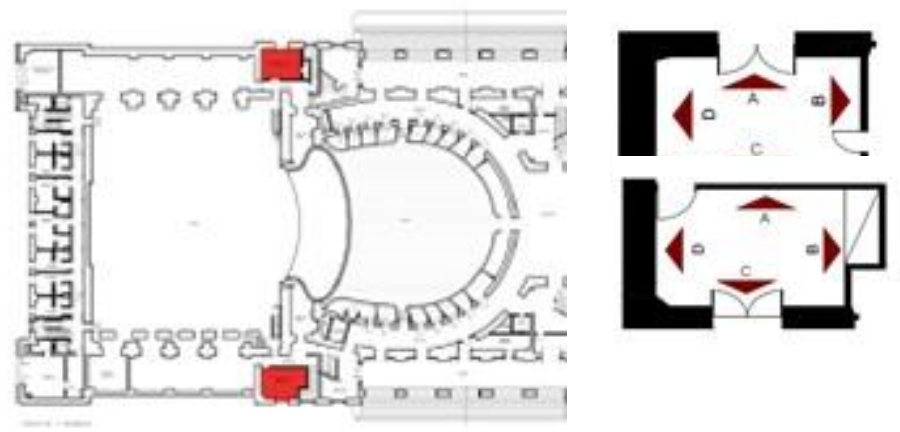

Figuras 213 (esq.) e 214 (dir.): Respectivamente, localização das salas de apoio do palco na planta do primeiro pavimento e ampliação de suas respectivas plantas.

Fonte: Memorial Descritivo do Projeto de Restauração do TMSP, DPH, 2006.

Esse processo revelou a existência de pinturas murais decorativas, com motivos simples de inspiração art nouveau em tons de verde. A decoração de ambas as salas consistia em duas faixas estilizadas, sendo a superior composta por elementos geométricos e a intermediária, por faixas entrelaçadas no centro das quais repousava uma flor de lis estilizada, entre ramos de flores douradas a ouro (Figuras 215 e 216).
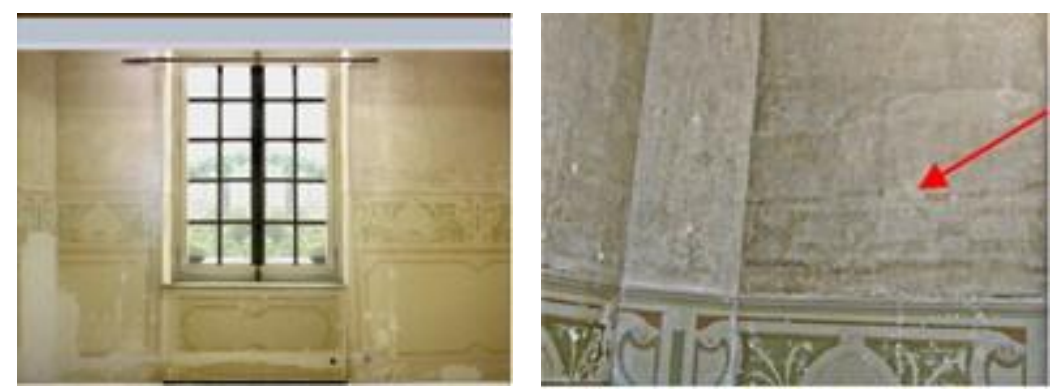

Figuras 215 (esq.) e 216 (dir.): Respectivamente, faixa decorativa com motivos florais e resquícios de faixa superior geométrica.

Fonte: Memorial Descritivo do Projeto de Restauração do TMSP, DPH, 2006.

Essas pinturas haviam sido mutiladas por sucessivas repinturas e recortes, realizados para inserção de instalações elétricas embutidas. Esses danos promoveram uma grande perda da camada pictórica, através de descolamento 
da policromia e abrasões, manifestas na forma de lacunas que prejudicavam a leitura estética dos motivos decorativos (Figuras 217 e 218).
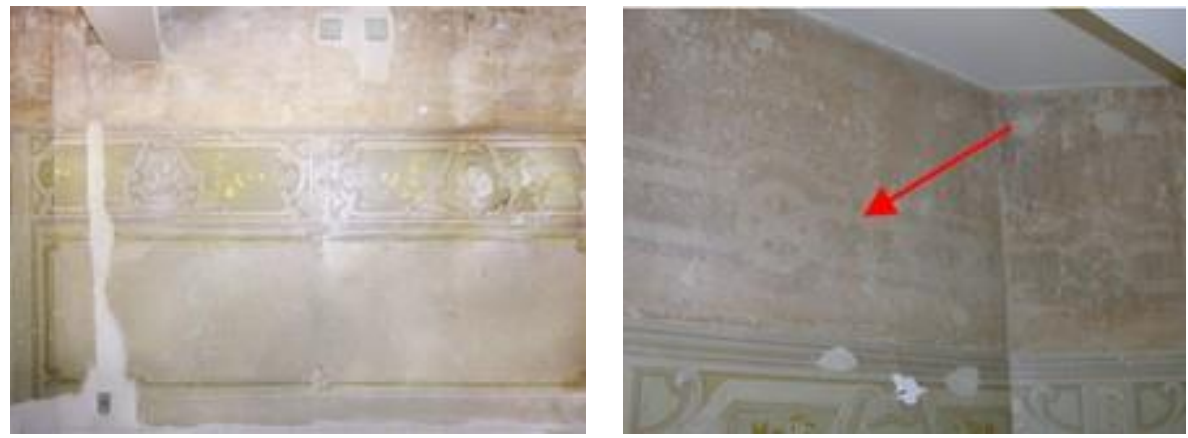

Figuras 217 (esq.) e 218 (dir.): Respectivamente, recortes cobertos com massa e pintura lisa, realizados para embutir instalações elétricas e perda da camada pictórica da faixa superior geométrica.

Fonte: Memorial Descritivo do Projeto de Restauração do TMSP, DPH, 2006.

Uma vez que os motivos revelados pela prospecção e decapagem eram repetitivos, optou-se por reconstituir totalmente os dois ambientes, resgatando assim, sua ambiência original (Memorial Descritivo do Projeto de Restauração do TMSP, DPH, 2006, p. 68). A reconstituição teve auxílio de técnicas digitais, sobretudo nos pontos onde a pintura estava quase ilegível (Figura 219).
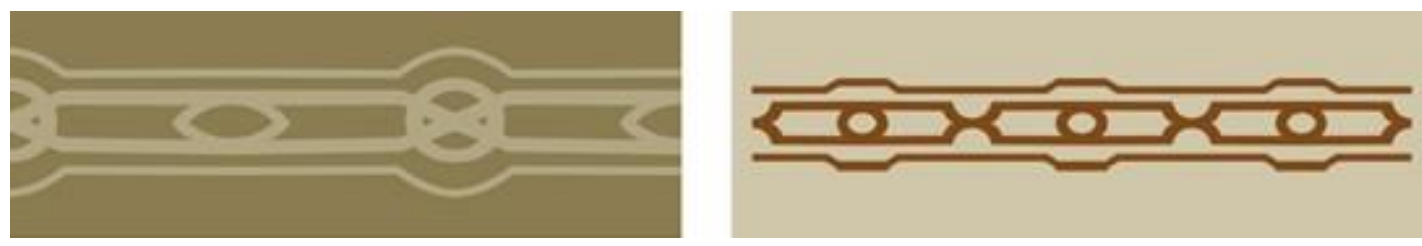

Figura 219: Reconstituição dos motivos geométricos realizados com auxílio digital. Fonte: Memorial Descritivo do Projeto de Restauração do TMSP, DPH, 2006.

Antes disso, no entanto, as paredes deveriam ser submetidas a um processo de limpeza, usando-se de bastonetes de algodão hidrófilo embebidos em essência de petróleo. Após a limpeza, seria realizada a fixação das áreas que apresentavam descolamento, com Primal AC 33 de 5 a $10 \%$ ou usando-se da fórmula de uma parte de cola Cascorez para sete de tolueno e três de álcool etílico ${ }^{112}$, além da obturação e nivelamento das lacunas com massa acrílica.

Finalmente, a reestampa dos elementos geométricos se daria pela técnica do molde vazado (estêncil), no tom original e feita com tinta acrílica. A reconstituição

112 O Memorial especifica que as áreas de descolamento mais complicadas devem ser inicialmente faceadas com papel japonês e carboximetilcelulose e as áreas com bolhas podem ter o fixativo introduzido por seringas hipodérmicas. 
dos motivos florais seria feita seguindo as mesmas orientações, porém aplicada a pincel, assim como a repintura das paredes lisas. Já os elementos dourados deveriam ser reintegrados com folhas de ouro e aplicação de bolo armênio amarelo.

O memorial explicita que, para além das intervenções diretas sobre a materialidade do ambiente, julgava-se necessário elaborar um novo plano de uso e ocupação para as salas contíguas ao palco. $\mathrm{O}$ uso inadequado, como espaço de intensa circulação e armazenamento, contribuía para o mal estado de conservação geral e deveria ser evitado (Figura 220).
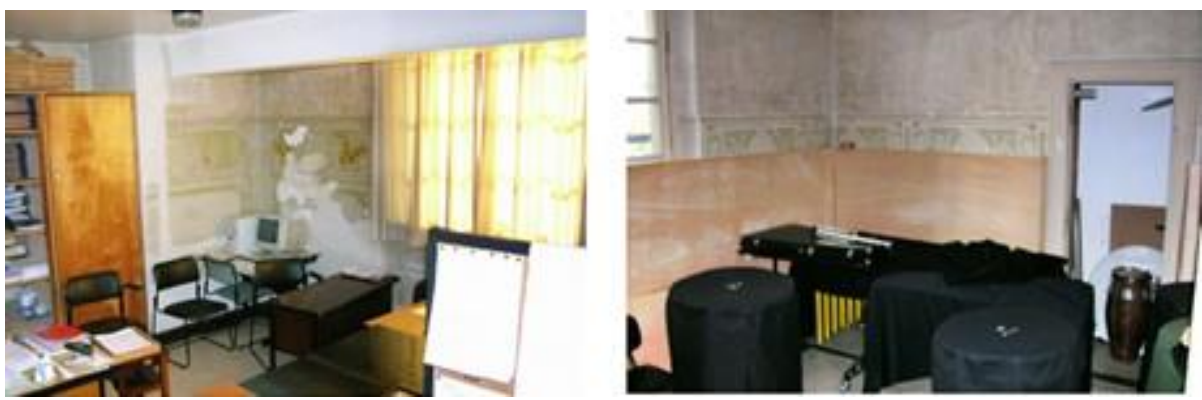

Figura 220: Uso das salas como apoio dos ajudantes do maestro (esq.) e guarda de instrumentos (dir.).

Fonte: Memorial Descritivo do Projeto de Restauração do TMSP, DPH, 2006.

\subsubsection{Sala de Imprensa}

A antiga Sala de Imprensa era então ocupada pelo setor de manutenção que, a exemplo das salas contíguas ao palco, não era o uso mais adequado para conservação da ambiência original do espaço (Figuras 221 e 222). As paredes, decoradas com pinturas em estêncil em tons esverdeados, encontravam-se cobertas por grandes armários metálicos (Figura 223). 


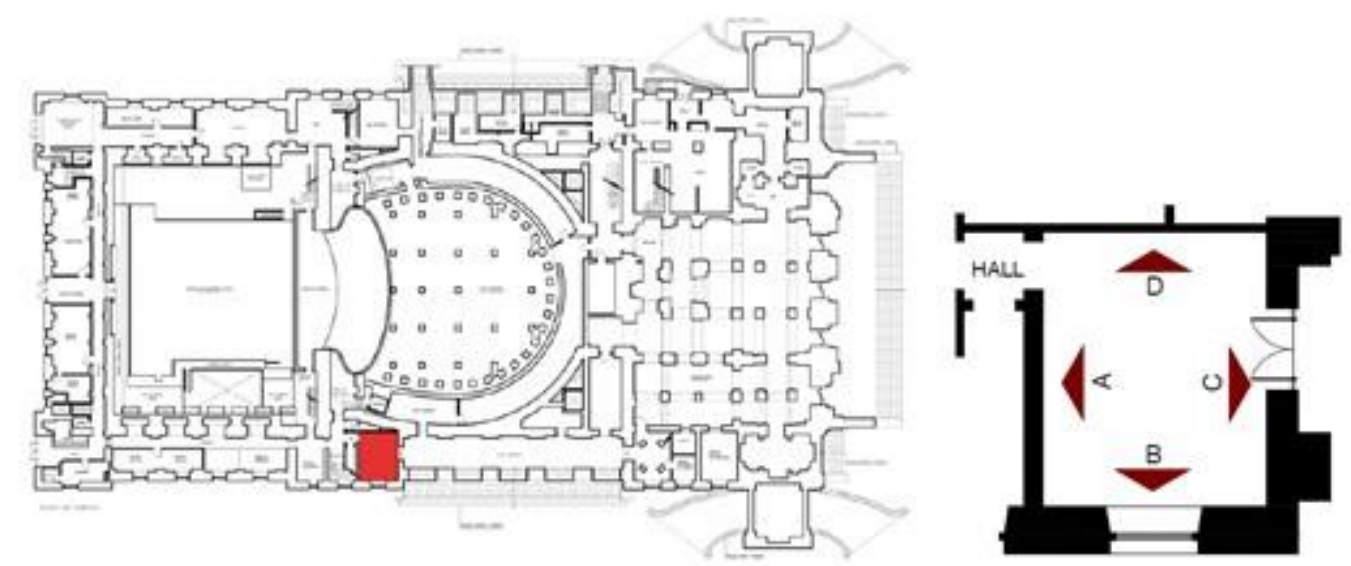

Figuras 221 (esq.) e 222 (dir.): Respectivamente, localização da antiga Sala de Imprensa na planta do subsolo e ampliação de sua planta.

Fonte: Memorial Descritivo do Projeto de Restauração do TMSP, DPH, 2006.
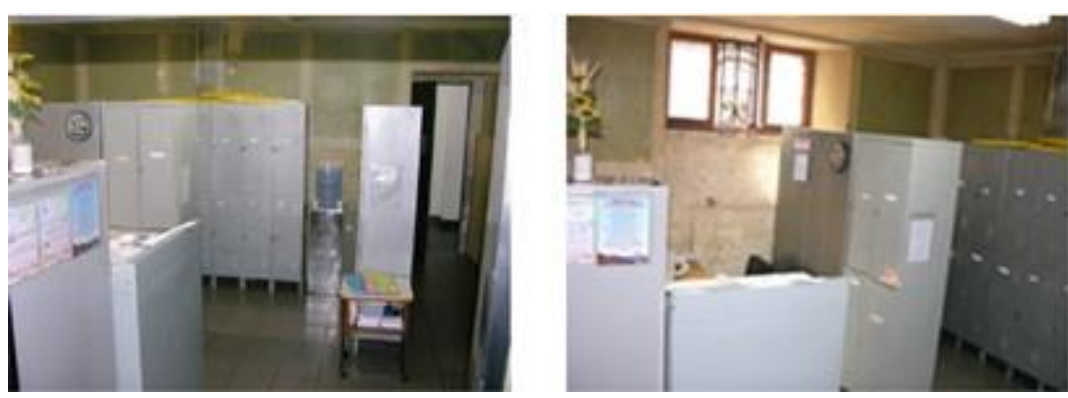

Figura 223: Interior da antiga Sala de Imprensa antes da intervenção.

Fonte: Memorial Descritivo do Projeto de Restauração do TMSP, DPH, 2006.

Originalmente, essas paredes verdes possuíam, em sua parcela superior, uma pintura retangular em estêncil, que imitava papéis de parede e, na inferior, retângulos mais estreitos com pintura lisa. $\mathrm{Na}$ porção intermediária, era ornamentada por faixas bege com elementos florais estilizados e douramentos em folha de ouro (Figura 224).
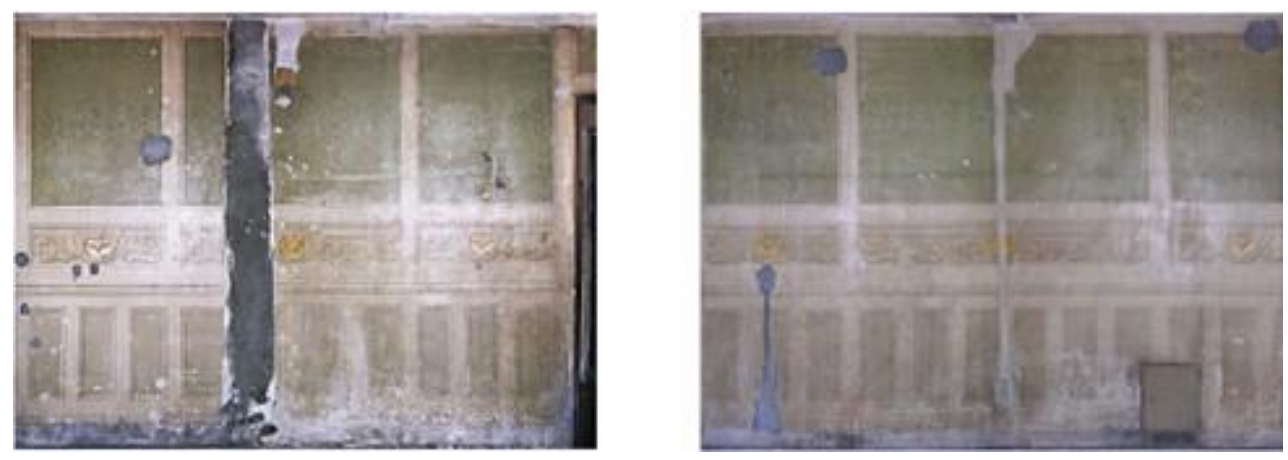

Figura 224: Imagem das paredes da Sala de Imprensa antes da intervenção, nas quais se percebe a divisão tripartida de sua pintura decorativa.

Fonte: Memorial Descritivo do Projeto de Restauração do TMSP, DPH, 2006.

Essas pinturas apresentavam algumas patologias, na forma de lacunas, abrasão, sujidade manchas esbranquiçadas, quinas quebradas e áreas de 
reboco novo cimentado. Assim como no caso das salas contíguas ao palco, devido ao caráter repetitivo dos elementos decorativos, decidiu-se pela sua reconstituição integral.

Em primeiro lugar, deveriam ser removidas as porções de argamassa de cimento usadas para reparos. A seguir, deveriam ser realizadas novas obturações das mesmas lacunas com massa acrílica para, depois, efetuar a limpeza química das pinturas $^{113}$.

A repintura das paredes lisas deveria ser realizada com tinta à base de óleo semi-fosca, com tonalidades idênticas às originais. Para a correção de pequenas lacunas na pintura que simula papel de parede, sugere-se a reintegração com tinta Maimeri per restauro ${ }^{114}$ ou tinta a óleo (Figura 225). Para as grandes lacunas, foi sugerido o teste de tintas de base acrílica industrializadas, sobre a qual se aplicaria uma camada de verniz, para conferir brilho à superfície.
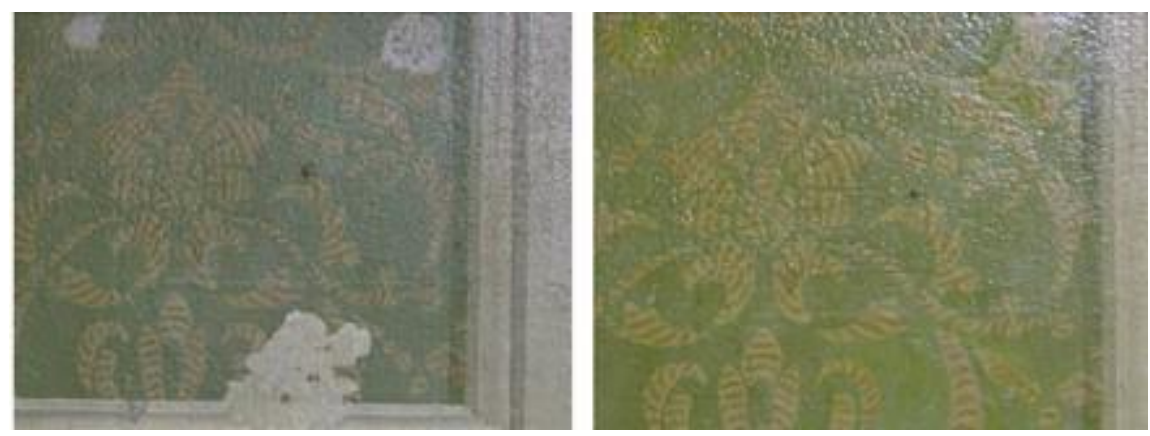

Figura 225: Antes e depois da reintegração de pequenas lacunas.

Fonte: Memorial Descritivo do Projeto de Restauração do TMSP, DPH, 2006.

Outra possibilidade apresentada pelo Memorial seria testar a diluição de tinta a óleo, removendo-se parte do óleo com papel absorvente, em tolueno. Já para os elementos florais estilizados, recomenda-se a reintegração exclusivamente com tinta à base de óleo e folhas de ouro (Figura 226). Fica recomendado, para ambos os casos, que as reintegrações poderiam ser executadas com estêncil ou pincel.

\footnotetext{
113 O Memorial sugere que sejam realizados testes de produtos como citrato básico de amônia, diluído em água destilada ou toluol, acetona, entre outros. Uma vez aprovado, o produto deveria ser aplicado com bastonetes de algodão hidrófilo ou compressas de tecido, também de algodão. Uma segunda limpeza deveria ser realizada nos mesmos moldes, com aplicação de essência de petróleo.

${ }^{114}$ A Maimeri per restauro é a linha de tintas a óleo da marca italiana Maimeri.
} 

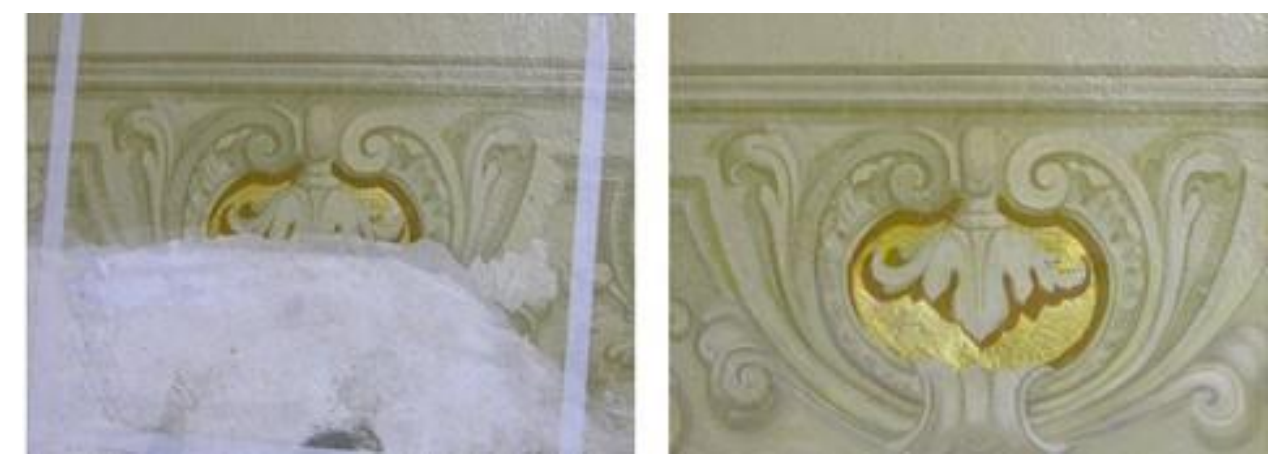

Figura 226: Antes e depois da reintegração dos elementos florais com douramento.

Fonte: Memorial Descritivo do Projeto de Restauração do TMSP, DPH, 2006.

\subsubsection{Salão Nobre}

O ambiente suntuoso do Salão Nobre foi o que apresentava melhor estado de conservação e menor número de problemas, dentre aqueles contemplados pelo projeto de 2006. Devido à atenção a ele dedicada no decorrer da última intervenção, as pequenas deteriorações encontradas implicariam em um processo de caráter mormente conservativo (Figuras 227 e 228).
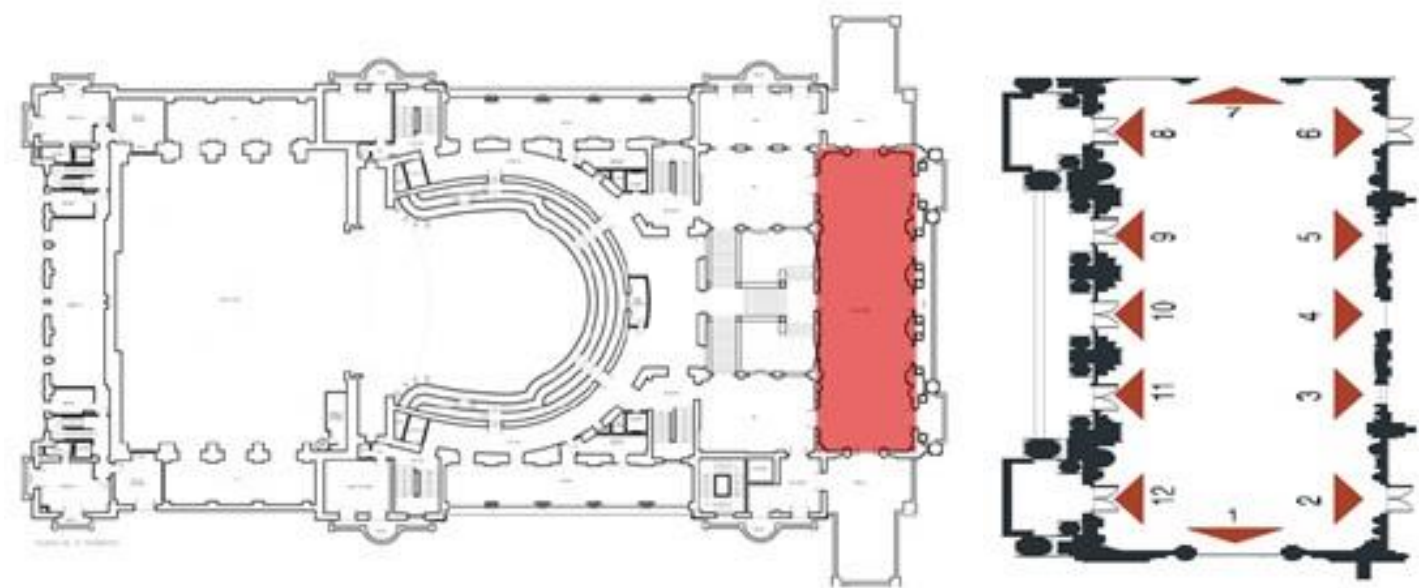

Figuras 227 (esq.) e 228 (dir.): Respectivamente, localização do Salão nobre na planta do terceiro andar e ampliação de sua planta.

Fonte: Memorial Descritivo do Projeto de Restauração do TMSP, DPH, 2006.

Esses pequenos problemas eram em parte resultantes da acomodação do forro à nova estrutura, concebida durante a obra de 1980, e em parte por danos provocados pelo tempo e pelo uso. Além de trincas e rachaduras, provocadas por tal acomodação (Figura 229), o forro apresentava alguns descolamentos pontuais do douramento e da pintura (Figura 230), lacunas pontuais na policromia e alguns retoques anteriores alterados e pouco harmônicos (Figura 231). 

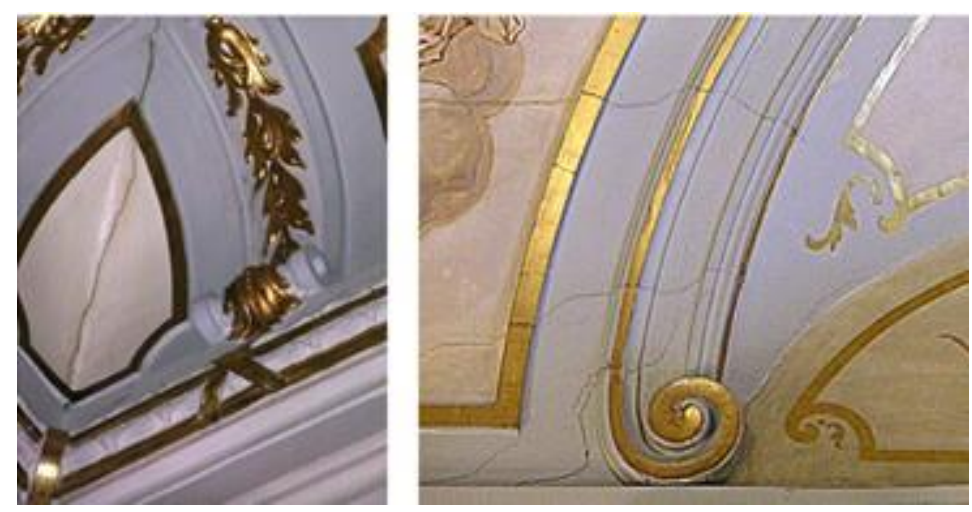

Figura 229: Trincas no forro do Salão Nobre, antes da intervenção.

Fonte: Memorial Descritivo do Projeto de Restauração do TMSP, DPH, 2006.

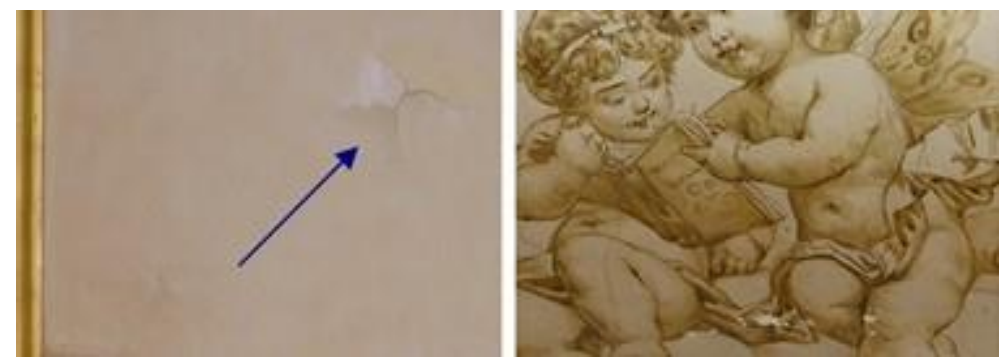

Figura 230: Descolamento da pintura em forma de bolha (esq.) e descolamento da pintura artística (dir.).

Fonte: Memorial Descritivo do Projeto de Restauração do TMSP, DPH, 2006.
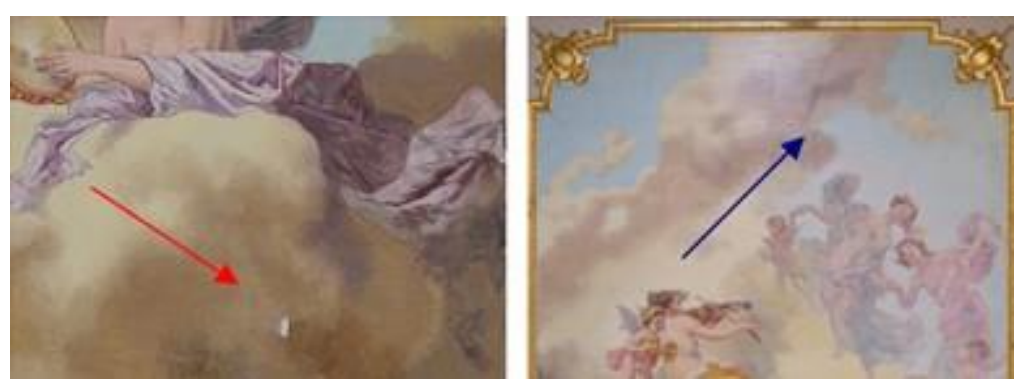

Figura 231: Lacuna na policromia (esq.) e retoque ligeiramente alterado (dir.) Fonte: Memorial Descritivo do Projeto de Restauração do TMSP, DPH, 2006.

O Memorial do projeto sugere que as fissuras e rachaduras sejam primeiramente consolidadas, através de injeções de Primal AC 33 com seringas hipodérmicas, uma vez faceadas com papel japonês e carboximetilcelulose, para evitar escorrimento do produto sobre as pinturas. Depois de consolidadas, as rachaduras mais espessas deveriam receber preenchimento injetado de gesso relativamente líquido e as demais fissuras, obturadas com massa acrílica.

Para a fixação dos descolamentos em áreas de pintura artística, fica sugerida a aplicação de colas de cartilagem de origem animal a 5\% na água, Primal AC 33 a $5 \%$ ou uma fórmula de uma parte de cola Cascorez para três de álcool etílico 
e sete de tolueno. As lacunas deveriam ser preenchidas com gesso cré e colas de cartilagem ou massa acrílica à base de PVA.

Uma vez removidos os retoques alterados, por meio de produtos químicos previamente testados ${ }^{115}$, a reintegração da pintura artística devera se dar com tintas à base de verniz ou aquarela. Em seguida, receberia a aplicação à pistola de verniz protetor à base de Paralóide B 72 a 5\%.

Quanto ao douramento, a fixação dos descolamentos deveria ser executada nos mesmos moldes dos indicados para a pintura artística. As lacunas provocadas por esses, por sua vez, seriam reintegradas com folha de ouro, uma vez removidos os retoques oxidados com tolueno ou dimetilformamida.

As doze portas da sala também foram ponto de enfoque da intervenção, tendo apresentado alguns descolamentos pontuais do douramento, abrasões provocadas por choque e retoques antigos oxidados (Figura 232). A fixação dessas áreas e remoção dos reparos inadequados deveria ser realizada com os mesmos produtos e técnicas indicados para o forro e sua obturação e nivelamento, com massa de base acrílica coberta com folhas de ouro (Figura 233). Após a reintegração, sugere-se a aplicação de verniz à base de Paralóide B 72 a $5 \%$ no toluol.
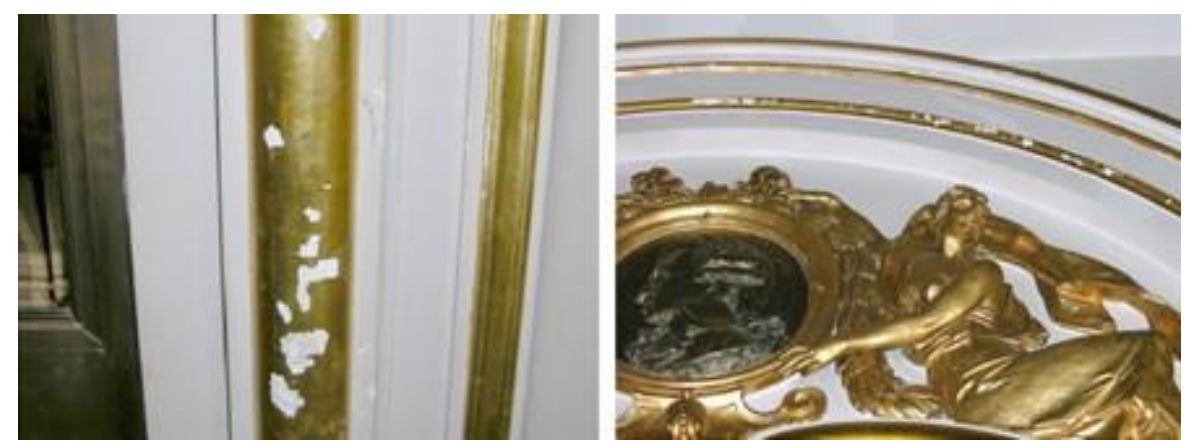

Figura 232: Descolamentos nas áreas das portas do Salão Nobre, antes da intervenção.

Fonte: Memorial Descritivo do Projeto de Restauração do TMSP, DPH, 2006.

115 O Memorial não especifica quais seriam esses produtos químicos destinados à remoção dos retoques antigos, apenas indica sua eficácia e formulação, desenvolvida pela química Liliane Masschelein-Kleiner, do Instituto Real do Patrimônio Artístico de Bruxelas. 

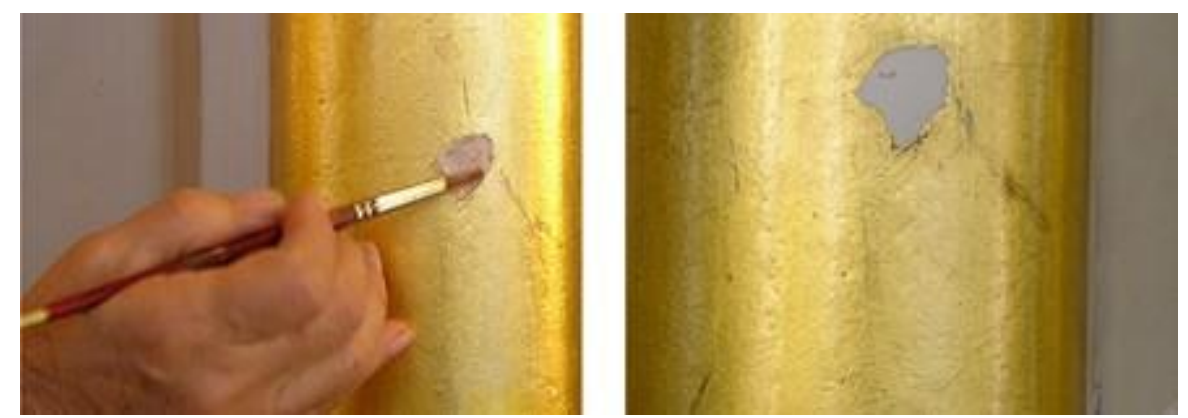

Figura 233: Teste de fixação de descolamento (esq.). e obturação com massa acrílica (dir.).

Fonte: Memorial Descritivo do Projeto de Restauração do TMSP, DPH, 2006.

Após realizado o teste de reintegração com bolo armênio, percebeu-se que o aspecto final diferia em tonalidade do original (Figura 234). Dessa forma, foram realizados alguns exames laboratoriais para identificar quais os traços do metal original e compará-los com aqueles disponíveis no mercado.
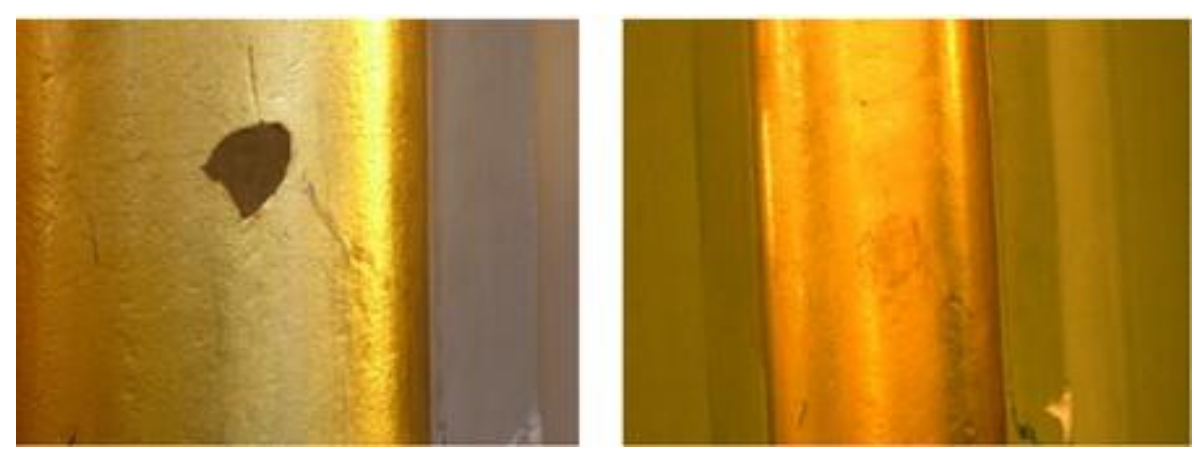

Figura 234: Aplicação de bolo armênio (esq.) e aspecto posterior à reintegração (dir.).

Fonte: Memorial Descritivo do Projeto de Restauração do TMSP, DPH, 2006.

O resultado apontou para uma maior semelhança entre o original e o ouro alemão, mesmo não sendo idênticos. As análises também revelaram a ausência de bolo armênio nos douramentos das portas, sugerindo que as reintegrações deveriam ser feitas com mordente ${ }^{116}$, uma vez que em todo Salão havia sido aplicado ouro fosco.

Para além do forro e das portas, outro elemento ao qual se dedicou atenção naquela ocasião foram os tapetes murais, que apresentavam sujidades pulverulentas e respingos pontuais de tinta (Figura 235). De acordo com o memorial, a limpeza deveria ser executada com aspirador de baixa potência e complementada com pincéis de cerdas macias. Caso os respingos de tinta não

\footnotetext{
116 Mordente é uma substância de origem vegetal ou mineral usada para potencializar a durabilidade da pintura ou douramento de determinada superfície (TURCO, 1987).
} 
fossem removidos com essas técnicas, poderia ser feito uso de bisturis cirúrgicos ou bastonetes de algodão embebidos em essência de petróleo.

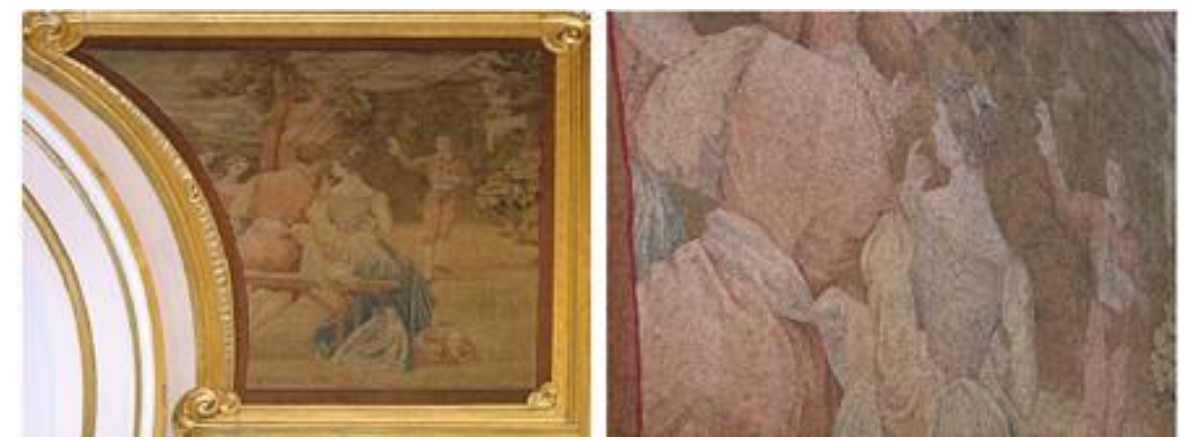

Figura 235: Aspecto dos tapetes murais antes da intervenção.

Fonte: Memorial Descritivo do Projeto de Restauração do TMSP, DPH, 2006.

\subsubsection{Sala de Espetáculos}

O corredor central do piso da plateia apresentava um rangido com a movimentação dos espectadores. Esse problema, resultado da montagem do piso em réguas paralelas em peroba rosa com encaixe macho e fêmea sobre estrutura metálica sem fixação, seria resolvido por meio da instalação de uma estrutura secundária em madeira, entre a existente e os caibros de sustentação.

Uma vez solucionada a questão da produção de ruído, seriam tomadas medidas que garantiriam sua durabilidade e integridade. As peças danificadas deveriam ser substituídas por outras de mesma essência botânica e o piso passaria por processo de lixamento mecânico e manual, para posterior aplicação de produto de acabamento e proteção (Figura 236).

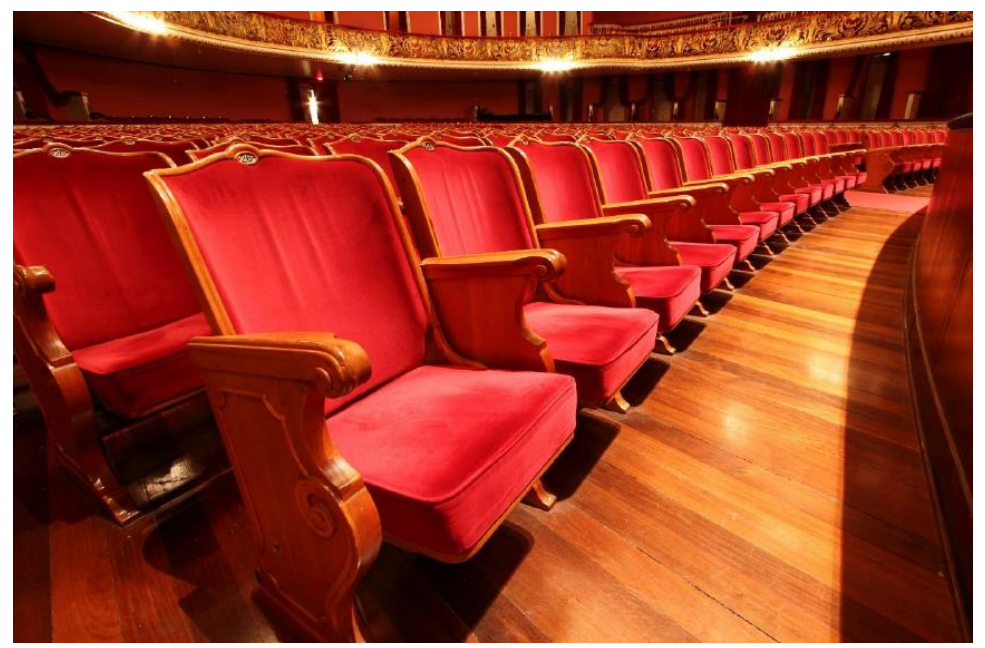

Figura 236: Aspecto do piso da plateia após a restauração. Fonte: COSTA, 2017. 
Apesar de não constar no Memorial descritivo do projeto, o interior da Sala de Espetáculos também passou por uma transformação cromática. Conforme visto no capítulo anterior, durante a restauração da década de 1980, o ambiente havia recebido cortinas, tapetes e estofamentos esverdeados, devido ao resultado de uma prospecção realizada na parede posterior do órgão ${ }^{117}$. Durante a intervenção de 2010, por sua vez, optou-se pelo retorno da tonalidade vermelha correspondente ao estado anterior à última intervenção (Figuras 237 e 238). Essa escolha, bastante ousada, será problematizada à luz da teoria contemporânea da restauração no item 4.3 do presente capítulo.
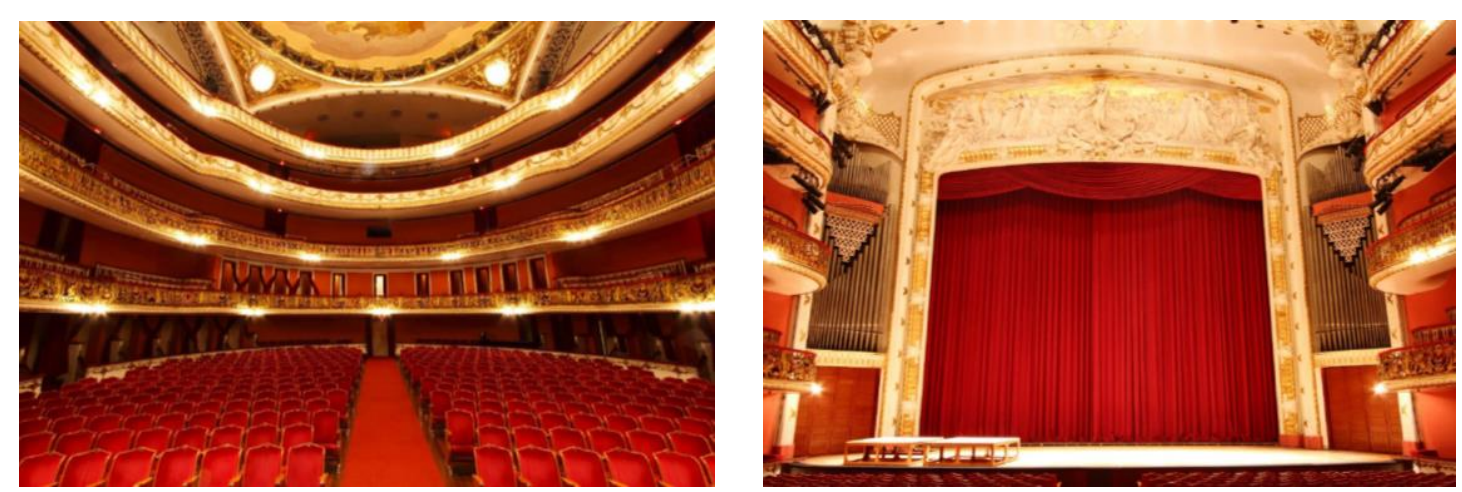

Figuras 237 (esq.) e 238 (dir.): Respectivamente, aspecto geral da Sala de Espetáculos vermelha e das cortinas do palco.

Fonte: COSTA, 2017.

\subsubsection{Mobiliário Irmãos Campana}

Após concluídos os procedimentos de restauro e conservação do interior do edifício, a intervenção é finalizada com a implementação de um projeto de mobiliário assinada pela dupla de designers Humberto e Fernando Campana. Os ambientes contemplados pelo projeto foram o restaurante e o Salão Nobre.

Para o Salão Nobre, a dupla desenhou um extenso tapete em tons de vermelho, laranja e verde, com motivos abstratos na forma de circunferências concêntricas (Figura 239). Ao mesmo tempo em que as figuras geométricas conferem à peça uma qualidade contemporânea, seu esquema cromático de cores quentes integra-se harmoniosamente com o resto do ambiente, sendo um exemplo bemsucedido do emprego do princípio de distinguibilidade. A proposta para o tapete não foi apenas acertada pela sua afinação com a teoria contemporânea, mas

117 Ver Capítulo 3 - Reconhecimento. 
pela proteção que confere ao piso de madeira do Salão que, após intenso uso e sucessivos lixamentos, encontrava-se já fragilizado.

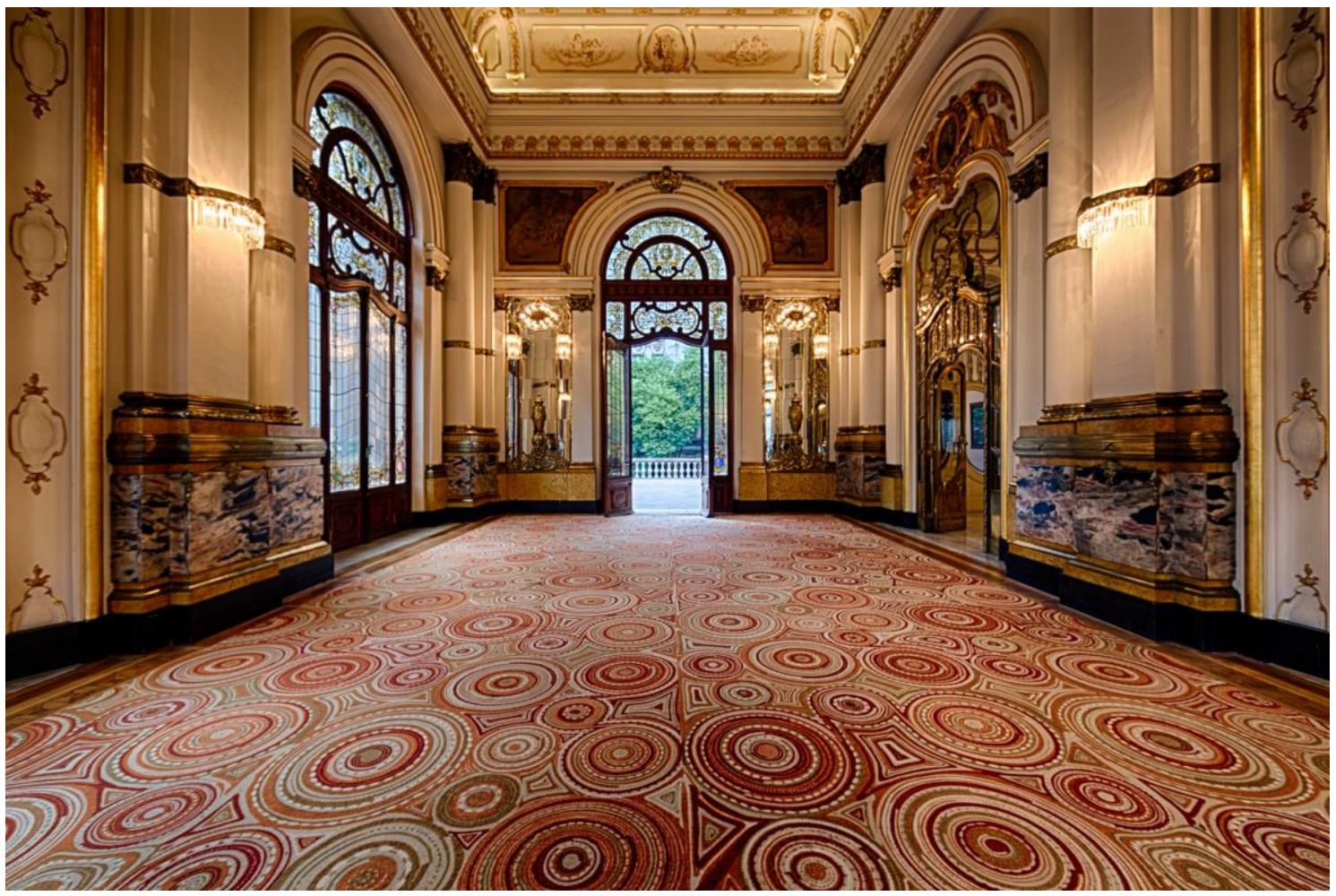

Figura 239: Tapete desenhado pelos Irmãos Campana para o Salão Nobre.

Fonte: theatromunicipal.org.br

Já o projeto do restaurante contemplava mobiliário composto por mesas, luminárias, espelhos e um grande balcão curvilíneo (Figura 240) ${ }^{118}$. Os materiais predominantes escolhidos foram o latão e a madeira escura. Em entrevista concedida à Folha de São Paulo, em junho de 2011, Humberto Campana justifica a escolha desses acabamentos em respeito à arquitetura original do edifício ${ }^{119}$ :

Quisemos manter diálogo com a arquitetura, respeitando a obra do Ramos de Azevedo. Pensamos em mesas de alumínio, mas a decisão foi usar materiais mais nobres. O teatro merece (CAMPANA, 2011).

\footnotetext{
118 De acordo com artigo publicado no jornal Folha de São Paulo, no dia 4 de junho de 2011, a dupla de designers havia cedido gratuitamente o projeto de mobiliário do restaurante para 0 Municipal (LONGMAN, 2011).

119 LONGMAN, Gabriela. Irmãos Campana em clima Art Nouveau: para criar o novo restaurante do teatro municipal, dupla de designers precisou dialogar com a arquitetura histórica. Folha de São Paulo. São Paulo, p. 9-9. 04 jun. 2011.
} 

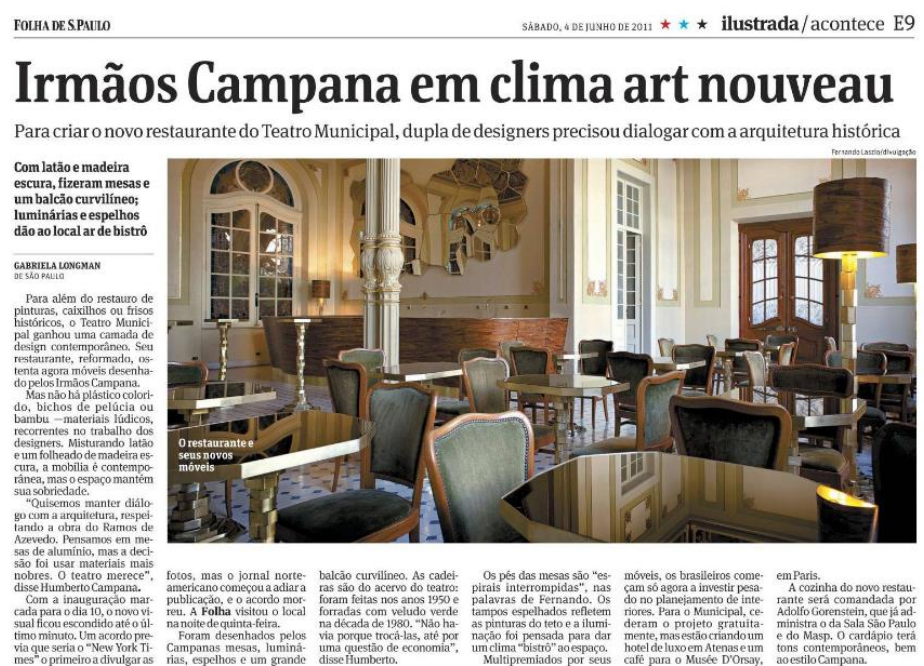

Figura 240: Artigo publicado na Folha de São Paulo que tematiza o projeto de mobiliário dos Irmãos Campana para o restaurante do Theatro Municipal. Chama atenção o uso equivocado do termo art nouveau para descrever a arquitetura do edifício.

Fonte: LONGMAN, 2011.

A escolha por superfícies espelhadas, como os tampos das mesas e o painel sobre o balcão, se justifica pela possibilidade de refletir as pinturas decorativas dos forros e paredes, que haviam sido recém-restauradas. As cadeiras, por sua vez, já compunham o acervo de mobiliário do próprio Theatro, tendo sido confeccionadas pelo Liceu de Artes e Ofícios durante a intervenção dos anos 1950 e revestidas em veludo vermelho na década de 1980.

Essa opção é justificada pelos autores do projeto a partir de uma chave econômica, mas não deixa de ser interessante o fato de que tais cadeiras não apenas eram remanescentes como sintetizavam as sucessivas intervenções pelas quais o Theatro havia sido submetido até então. Essa situação confere certa complexidade na compreensão da sobreposição de camadas históricas daquele ambiente que vinha sendo objeto de profundas transformações há décadas.

\subsubsection{Restauro externo}

A obra no exterior do edifício contemplava as fachadas em sua integridade, considerando-se os conjuntos de vitrais, esquadrias e ferragens, elementos em cantaria, panos de argamassa pintada, elementos decorativos e cobertura. Também foi realizado, nessa ocasião, um extenso projeto de iluminação externa 
que, devido a sua alta tecnicidade, será apenas analisado do ponto de vista arquitetônico - de sua influência na materialidade e figuratividade do edifício.

Assim como para o restauro interno, todas as intervenções serão abordadas e analisadas de acordo com o que consta no Memorial Descritivo do Projeto, elaborado pelo Departamento do Patrimônio Histórico, e suas respectivas peças iconográficas, na forma de plantas, cortes e elevações, cedidas pela Fundação Theatro Muncipal de São Paulo. Também será levado em consideração o relato da arquiteta Lilian Jaha - que participou do projeto da intervenção -, contido na dissertação de Soraya Arida Katchvartanian (KATCHVARTANIAN, 2014).

\subsubsection{1 $\underline{\text { Vitrais }}$}

Conforme descrito no capítulo anterior, os vitrais que compõem o conjunto interno e externo do Theatro Municipal haviam sido restaurados entre 1982 e 1983 pela Casa Conrado, sob orientação do DPH. Na ocasião, o elaborado mapeamento de danos e diagnósticos que levou à proposição de diretrizes específicas não foi suficiente para impedir o que mais tarde seria descrito pelo memorial do projeto de 2006 como descaracterização da leitura do conjunto (Figura 241). Naquele momento, o mercado brasileiro não oferecia vidros com características próximas ao original. Ao se utilizar dos vidros disponíveis, a intervenção acabou prejudicando a fruição estética dos vitrais.

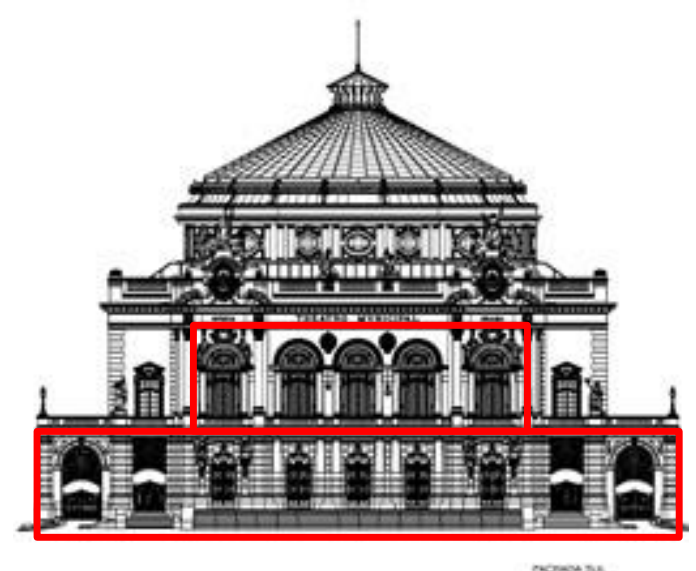

Figura 241: Identificação dos vitrais na fachada principal.

Fonte: Projeto de restauração do TMSP, Departamento de Patrimônio Histórico, 2006.

Para identificação desse e dos demais problemas que maculavam o conjunto, foi elaborado um processo em três etapas, que consistiam no levantamento, 
avaliação do estado de conservação e proposição dos critérios restaurativos. 0 levantamento começou pela identificação descritiva, gráfica e fotográfica das peças, que foram diagnosticadas levando-se em consideração os aspectos de seus vidros, chumbo, tratamento decorativo, estrutura de suporte e sistema de fixação e proteção.

Com relação aos vidros, observaram-se as peças quebradas, classificadas entre trincadas ou estilhaçadas. No chumbo, foi analisada a presença de fadiga mecânica, corrosão, eflorescências e existência de remendos. Nas pinturas decorativas, buscou-se observar despigmentação ou fragilização e, na estrutura, presença de oxidação, rupturas e abaulamento. Foram classificados entre aqueles fixados por massa direta, silicone ou baguete, e entre os que receberam ou não proteção externa, na forma de tela ou vidro.

Foram acrescidas a essas observações alguns outros parâmetros, para elaboração de uma análise diagnóstica mais completa, que levaria a diretrizes precisas. Entre eles figuravam a presença de umidade e as possíveis causas para ruptura dos vidros, desgaste da pintura e demais patologias estruturais.

Chegou-se à conclusão de que a ruptura dos vitrais acontecia de três formas distintas: por impacto - acidental, na ocasião de manutenção descuidada ou chuva, ou intencional, provocado por vandalismo -, por estresse - vinculado ao processo de fabricação e pintura da peça -, ou por processos ligados à oxidação da estrutura metálica - como esmagamento, flambagem, flexão e torção.

A presença de remendos, além de indicativa da necessidade de intervenção, acaba por acelerar o processo de degradação das peças. Uma vez que a estrutura é alterada de maneira parcial, as diferenças de comportamento entre os elementos velho e novo, em estágios distintos de fadiga mecânica, provoca desestruturação que pode levar a um abaulamento precoce.

Outra causa de abaulamento é o próprio estilo dos desenhos que um vitral pode apresentar. Na presença de várias linhas paralelas ou convergentes ao mesmo ponto, a peça fica menos estável e mais susceptível a esse tipo de alteração. Quanto às pinturas, a porosidade da superfície pintada muitas vezes a mantém 
mais exposta à ação da poluição, que causa apagamento do esquema cromático original.

Todos esses aspectos combinados servem como base para a proposta de intervenção que, de acordo com o Memorial, deveria manter caráter reparatório e preventivo. Para dar início aos procedimentos, foram separadas as peças comprometidas que compunham os vitrais entre aquelas que apresentavam lacunas parciais, que deveriam ser reparadas, e lacunas totais, a serem substituídas $^{120}$.

Primeiramente, sugeriu-se que os vidros fossem removidos, acomodados em caixas de madeira e protegidos com plástico bolha e isopor, para que fossem transportados com segurança até o ateliê de restauro. Em segundo lugar, as peças seriam submetidas a um processo de limpeza por aspiração, combinado ao uso de escovas com cerdas macias, panos de algodão e esponjas, embebidos em água, água sanitária, amônia e detergente neutro.

Uma vez limpos, aqueles que apresentavam lacunas parciais seriam restaurados. O chumbo seria integralmente substituído por material novo de mesmas características, reforçado com liga de estanho soldado a quente. Os vidros trincados seriam corrigidos com fita de cobre autoadesiva dupla face em ambos os lados - onde não houvesse comprometimento da leitura estética - e as pinturas desgastadas pontualmente receberiam repintura com tinta para vitral diluída em base de óleo de copaíba.

Já as peças que apresentavam lacunas totais, deveriam ser integralmente substituídas por peças novas, executadas a partir de moldes em cartolina das originais, em mesma dimensão, cor e textura. Ambos os vidros, reparados ou substituídos, seriam pintados com utilização de grisalhas ${ }^{121}$ diluídas em óleo copaíba e queimados em forno adequado a seiscentos graus.

\footnotetext{
120 De acordo com classificação do Memorial, entende-se por lacuna parcial a peça que apresentavam menos de $40 \%$ de comprometimento ou aquelas que possuíam intervenção inadequada. Por lacuna total, entendem-se as peças que, por terem um comprometimento maior que $40 \%$, deveriam ser integralmente substituídas.

${ }_{121}$ As grisalhas são um tipo de pigmento usado para pintura sobre vitrais (WERTHEIMER, Mariana G.; GONÇALVES, Margarete R. F., O processo de produção de vitrais sob a ótica da tradição. Revista Cpc, São Paulo, v. 1, n. 12, p. 127-149, mai./out. 2011).
} 
Fica sugerida realização de testes comparativos entre as peças originais e as confeccionadas, para serem instaladas apenas após a aprovação da amostra. Essa recolocação deveria ser feita forma cautelosa, dando prioridade para instalação das peças originais.

Uma vez instalados, os vitrais seriam novamente limpos com uso de panos macios e secos e, finalmente, receberiam vidros de proteção externa com três milímetros de espessura, recobertos com película de tipo filme transparente. Esses vidros teriam como função não apenas a proteção contra impactos, mas também contra os raios ultravioleta, que podem ocasionar danos à policromia das peças (Figuras 242 e 243).
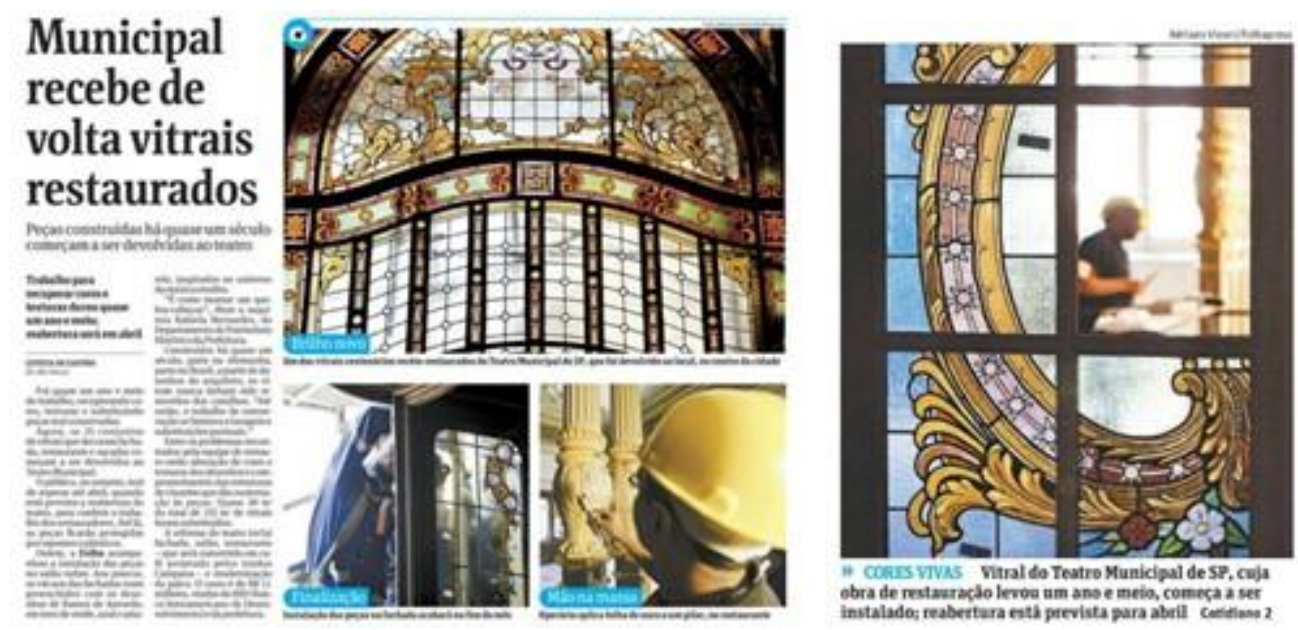

Figuras 242 (esq.) e 243 (dir.): Fotografias retiradas da edição de 23 de outubro de 2010 do jornal A Folha de São Paulo, que anunciam o início da instalação dos vitrais já restaurados no TMSP.

Fonte: A FOLHA DE SÃO PAULO, 23 de outubro de 2010.

\subsubsection{Esquadrias e ferragens}

O conjunto de esquadrias de madeira que compõe as fachadas do edifício e necessitava de restauração teve de ser identificado e mapeado, de acordo com sua tipologia, estado de conservação e localização. Dividiram-se as peças, dentro dessas categorias, em cinco grupos diferentes: as portas externas do Salão Nobre, as portas externas da Sala Branca e da Sala Rosa, as portas e janelas basculantes das fachadas norte, leste e oeste, e os óculos da sala de ensaio sob a cúpula (Figuras 244 - 247). 

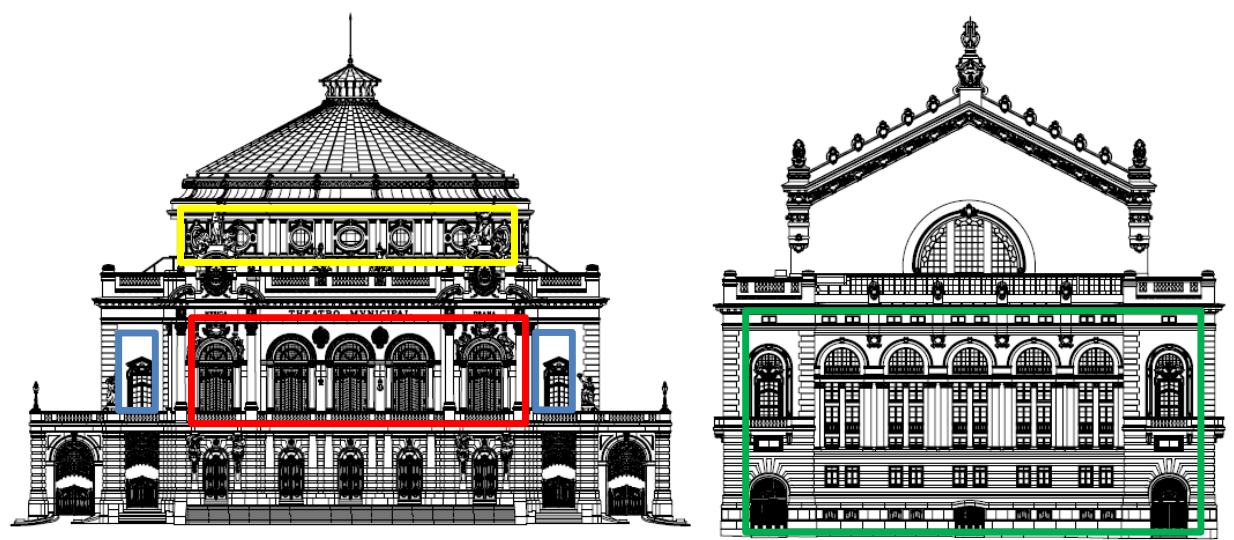

Figura 244 (esq.) e 245 (dir.): Respectivamente, elevação da fachada sul e norte. Em vermelho, esquadrias do Salão Nobre; em amarelo, óculos sob a cúpula; em azul, portas externas das salas Branca e Rosa; em verde, esquadrias da fachada posterior.

Fonte: Projeto de restauração do TMSP, Departamento de Patrimônio Histórico, 2006.
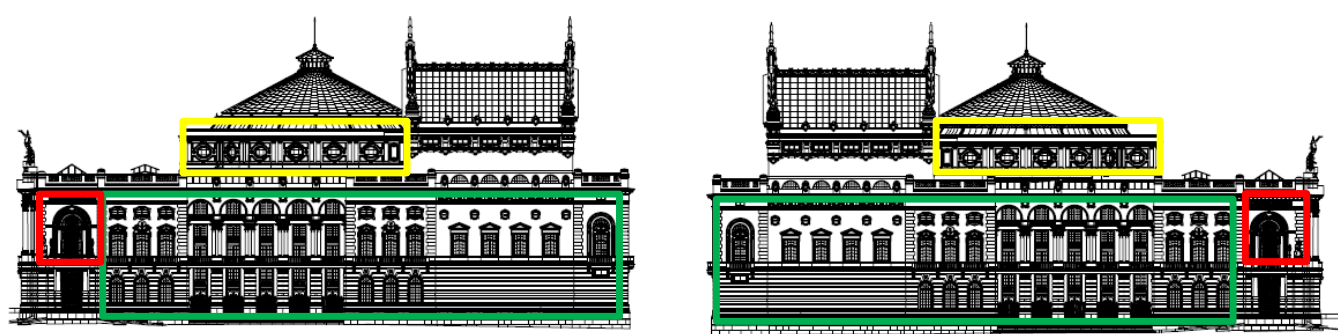

Figuras 246 (esq.) e 247 (dir.): Respectivamente, elevação da fachada leste e oeste. Em vermelho, esquadrias do Salão Nobre; em amarelo, óculos sob a cúpula; em verde, esquadrias das fachadas laterais.

Fonte: Projeto de restauração do TMSP, Departamento de Patrimônio Histórico, 2006.

As sete portas de acesso do Salão Nobre à varanda frontal foram, de acordo com análise realizada em amostra pelo IPT, executadas em Jacarandá (Machaerium sp.). Apesar de não estarem submetidas à incidência direta de raios solares, por se tratar da fachada sul, estavam expostas a intempéries e apresentavam degradação na porção inferior, relativa ao acúmulo de umidade.

O mesmo sucedia com as portas externas da Sala Branca e da Sala Rosa, devido à semelhante composição e localização. Já as esquadrias das demais fachadas, além das intempéries, recebiam a incidência dos raios solares de maneira direta e, por isso, apresentavam avançado estado de degradação, que não só prejudicavam seu funcionamento como também sua apreciação estética. Nesse caso, algumas peças manifestavam ausência ou descolamento de pintura, além de apodrecimento da madeira e falta de elementos constituintes. 
Os onze óculos basculantes da sala sob a cúpula, por sua vez, executados em pinho-de-riga (Pinus sp.) pintado, apresentavam poucas patologias que necessitariam de reparos. $\mathrm{O}$ mesmo para as esquadrias internas que, devido à proteção contra intempéries, mantinham-se em melhor estado de conservação.

O plano de restauro das esquadrias apresentado pelo Memorial do Projeto consistia em seis etapas. Em primeiro lugar, as peças deveriam ser retiradas para execução dos serviços; as partes deterioradas deveriam ser substituídas usando-se confecções com as mesmas essências botânicas identificadas pelo IPT $^{122}$, para depois serem lixadas manualmente e receberem aplicação de preservante ${ }^{123}$.

Uma vez protegidas da ação de insetos xilófagos, as peças pintadas receberiam emassamento com massa plástica e aplicação de uma base seladora (primer), que precederia a repintura das mesmas. Finalmente, seriam pintadas com duas demãos de esmalte sintético e, uma vez recolocadas em seus lugares de origem, envernizadas ou enceradas (dependendo do tipo de acabamento original da peça).

Todos esses processos deveriam estar em consonância com as restaurações executadas nas suas respectivas ferragens que, por sua vez, também haviam sido desmontadas, reparadas e substituídas quando necessário. Uma vez assentadas, receberiam limpeza e lubrificação com pasta de grafite, no intuito de ampliar sua vida útil e restituir seu bom aspecto.

Já as portas de acesso ao Saguão Principal, assim como os gradis e portões externos, em estrutura de aço, apresentavam desprendimento da pintura e pontos de corrosão. Para esses elementos ficou prevista a remoção da pintura

\footnotetext{
122 O IPT identificou as seguintes essências botânicas nas esquadrias internas e externas do Theatro: Cabriúva-vermelha (Miroxylom balsamum), Peroba-rosa (Aspidosperma polyneuron), Cedro (Cedrela sp.), Jacarandá (Machaerium sp.) e pinho-de-riga (Pinus sp.) (Memorial Descritivo do Projeto de Restauração do TMSP, DPH, 2006).

${ }^{123} \mathrm{O}$ produto preservante sugerido pelo Memorial era produzido pela Otto Baumgart-Vedacit e ficara conhecido comercialmente como Penetrol Cupim. O produto, de comprovada eficácia no combate à infestação de insetos xilófagos e fungos, era composto basicamente por deltametrina e querosene, na forma de um líquido incolor e inflamável com alto poder de penetração e absorção. Deveria ser aplicado em duas demãos por meio de broxas ou pincéis em no caso da presença de pequenos orifícios provocados por infestações anteriores, por seringas injetáveis.
} 
com jateamento de areia, seguida de aplicação de tinta antiferruginosa e pintura de acabamento em esmalte sintético semifosco ou acetinado.

\subsubsection{Cobertura}

O conjunto da cobertura do edifício do Theatro Muncipal de São Paulo é composta por estruturas de madeira, metal ou mistas, revestidas em sua integridade por telhas de cobre (Figura 248). Conforme abordado no Capítulo 1 - Prelúdio da modernidade, da presente dissertação, a cada função do programa do edifício corresponde uma volumetria e, por sua vez, uma cobertura independente.

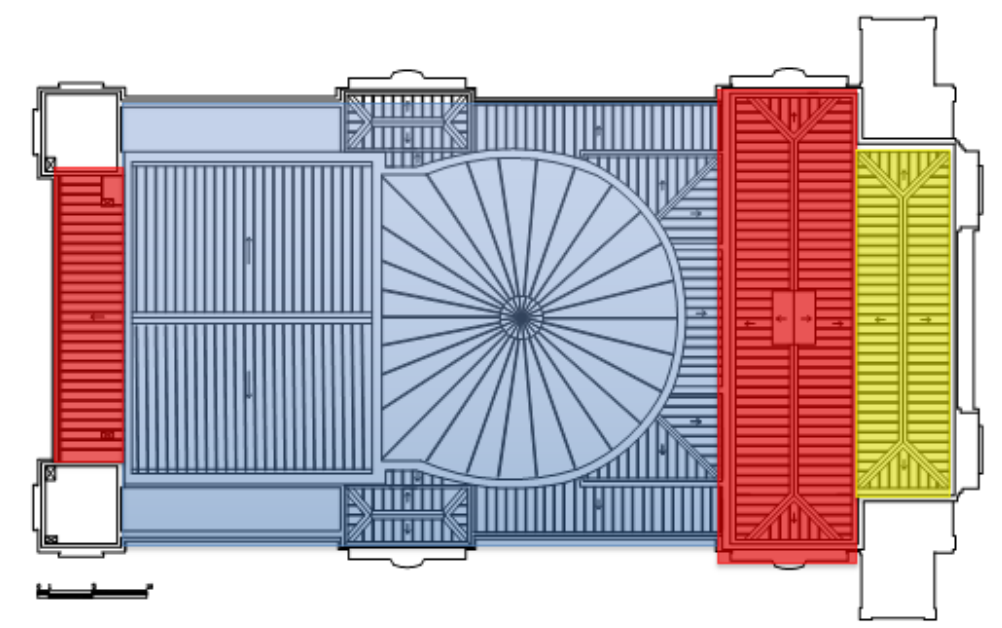

Figura 248: Planta de cobertura do TMSP, na qual se destacam as estruturas de madeira (vermelho), metal (azul) e mistas (amarelo).

Fonte: Acervo digital da FTMSP - Fundação Theatro Municipal de São Paulo.

O Salão Nobre, equivalente à parcela frontal da fachada principal, recebe originalmente uma estrutura em treliças simples de Pinho-de-riga (Pinus sp.), apoiadas nas alvenarias. É dotada de elementos de travamento e mãosfrancesas, também do mesmo material, que apoiam os demais elementos estruturais.

Essa retícula, além de suportar a estrutura principal acima descrita, suporta também a estrutura de sustentação do forro em estuque, realizada durante a intervenção da década de $1980^{124}$ que, por sua vez é constituída por pórticos metálicos intertravados, apoiados nas alvenarias existentes e em elementos novos de concreto.

\footnotetext{
124 Ver Capítulo 3-Reconhecimento.
} 
Após a inspeção, verificou-se a integridade material e estrutural de ambos os sistemas, tanto metálico como de madeira. Ficou apenas sugerida a verificação dos elementos de ligação para eventuais ajustes, caso houvesse indícios de folgas, corrosão ou outras patologias ${ }^{125}$.

Uma vez verificadas e ajustadas, as peças de madeira deveriam ser lixadas e preparadas para aplicação de produtos de preservação de mesma especificação daqueles utilizadas sobre as esquadrais e descritos no subitem 4.3.1.7 do presente capítulo. As peças metálicas também passariam por lixamento e receberiam proteção na forma de tratamento anticorrosivo ${ }^{126}$ e aplicação de tintas e solventes ${ }^{127}$.

A cobertura do Saguão, por sua vez, é composta por uma estrutura em treliças de Peroba-rosa (Aspidosperma polyneuron), que apoiam peças tanto da mesma essência botânica como de Pinho-de-riga (Pinus sp.). A estrutura em Pinho-doParaná que sustenta o forro de gesso também é por ela suportada. Sobre o conjunto, repousa uma clarabóia sustentada por perfis metálicos.

Ambos os sistemas apresentavam integridade material e estrutural, ficando recomendadas as mesmas diretrizes relativas ao Salão Nobre. A única irregularidade verificada por meio da inspeção se deu na forma de fios elétricos energizados, com emendas precárias, enrolados na barra diagonal de uma das treliças. Para essa situação, que provoca risco de incêndio na ocasião de um curto-circuito, ficou sugerida a remoção dos fios, conduzindo-os por meio de eletrodutos e caixas.

As coberturas laterais das fachadas leste e oeste, que tomam forma de telhados de madeira de uma ou quatro águas, também encontravam-se íntegras e

\footnotetext{
${ }^{125}$ Esses ajustes se dariam na forma de substituições parciais ou totais, executadas em material e forma idênticos ao original.

126 Para remoção da corrosão, o Memorial do Projeto de Restauração especifica o uso de escova de aço e/ou lixa de número 50, para posterior tratamento com fundo anticorrosivo. Para incrustações grossas, fica prevista a aplicação de desoxidante ou jato de areia.

127 O Memorial sugere que a pintura dos elementos metálicos seja realizada de acordo com o método SSPC-PA-1 do Steel Structures Painting Council, sendo antes dissolvidas nas devidas proporções e aplicadas por meio de trincha ou pistola de pulverização. Se desencoraja sua aplicação em dias de chuva, neblina, fortes ventos, temperatura abaixo de dez graus celsius ou umidade relativa superior a $85 \%$.
} 
possuíam bom aspecto. Para essas, recomendaram-se as mesmas medidas de verificação e aplicação de produtos preventivos de possíveis deteriorações.

A área correspondente aos camarins também recebe cobertura mista, cujas peças da estrutura principal foram executadas em terças e frechais de Perobarosa (Aspidosperma polyneuron), suportadas por perfis metálicos transversais, apoiados na alvenaria. O conjunto mostrou-se íntegro e bem conservado, sem indícios de patologias, sendo assim recomendadas apenas as medidas padrão de verificação e tratamento de superfícies e, para os metais, aplicação de pintura nos moldes prescritos para o Salão Nobre.

A estrutura da cúpula, em meias treliças metálicas apoiadas sobre paredes circulares, e do palco, em tesouras do mesmo material, encontravam-se em perfeito estado de conservação, não apresentando sinais de corrosão ou demais deformações, de forma que apenas se sugere a inspeção, lixamento, tratamento e repintura, nos moldes prescritos para a estrutura metálica do Salão Nobre.

Toda a superfície do conjunto de coberturas, recoberta por telhas de cobre, apresentava aspecto heterogêneo, resultante da camada de pintura e pátina de composição cromática esverdeada, marrom ou preta (Figura 249). Em seus variados depósitos, observou-se a presença em elevados teores de cobre, carbono e oxigênio; mas também, em certos casos, de silício, ferro, alumínio e enxofre. Seu bom estado de conservação geral impulsiona a decisão por uma limpeza com água e escova de nylon, que preserve a pátina depositada sobre 0 material. 


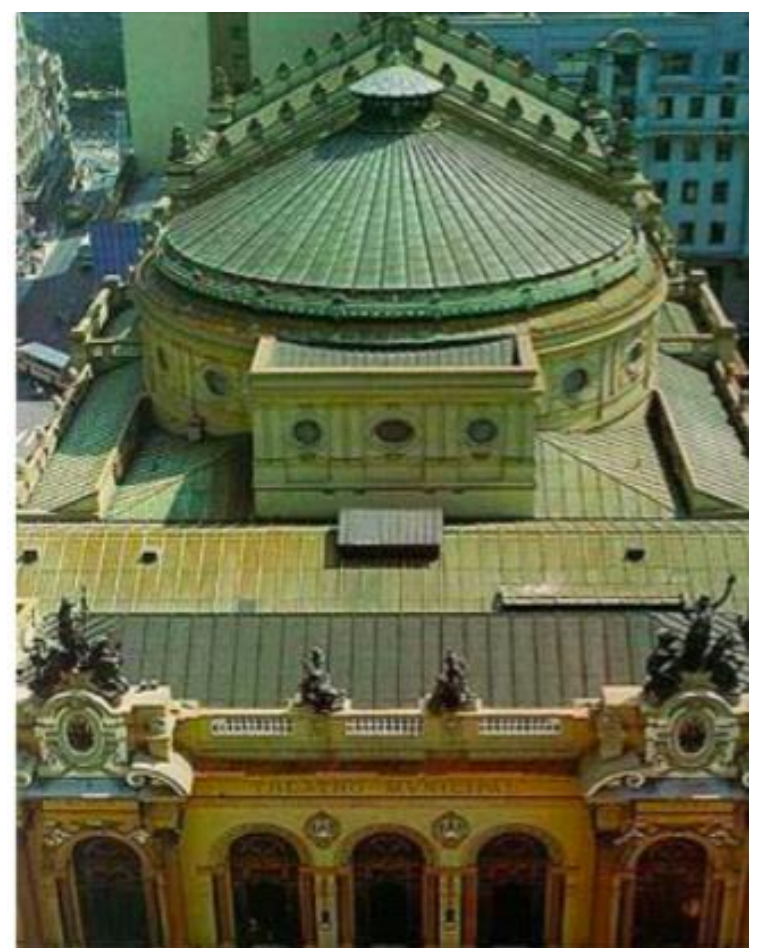

Figura 249: Fotografia aérea da cobertura, na qual se notam os diferentes tons de pátina sobre as telhas de cobre, com predomínio do verde.

Fonte: COSTA, 2017.

\subsubsection{Argamassa e pintura}

A maior parte da superfície das fachadas, tomadas em conjunto, é revestida por argamassa e pintada com plasticôte ${ }^{128}$. Para verificar o traço original da argamassa, foram realizados, naquela ocasião, uma série de análises a partir de amostradas retiradas com broca-copo diamantada (Figura 250). O resultado dessas análises revelou que sua composição era de cal com certa dosagem de material argiloso, aplicada em duas camadas, sendo uma de reboco e outra de emboço ${ }^{129}$.

\footnotetext{
128 Trata-se de um composto de copolímeros sintéticos de alto peso molecular, aplicado em duas ou mais demãos sobre o revestimento de argamassa (Memorial descritivo do Projeto de Restauração do TMSP, Departamento de Patrimônio Histórico, 2006).

${ }^{129}$ A suspeita inicial, antes da realização dos testes, era de que se trataria de um revestimento de cimento penteado ou pó-de-pedra, o que apenas se verificou em uma parte da fachada principal (Memorial descritivo do Projeto de Restauração do TMSP, Departamento de Patrimônio Histórico, 2006).
} 


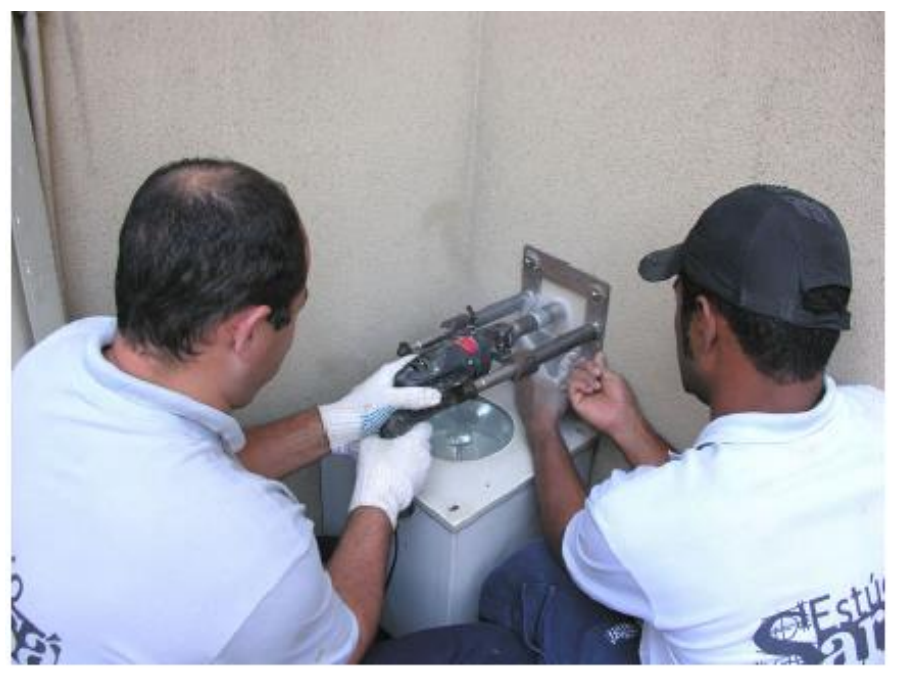

Figura 250: Processo de remoção das amostras de argamassa, efetuada com broca-corpo. Fonte: Memorial descritivo do Projeto de Restauração do TMSP, Departamento de Patrimônio Histórico, 2006.

Em seguida, realizou-se um levantamento da aderência dessa argamassa ao substrato, através da percussão com martelo de borracha (Figura 251). Foi contatado que, apesar da aderência ser pouco efetiva, não havia ameaças de desprendimentos imediatos na maior parte da superfície.

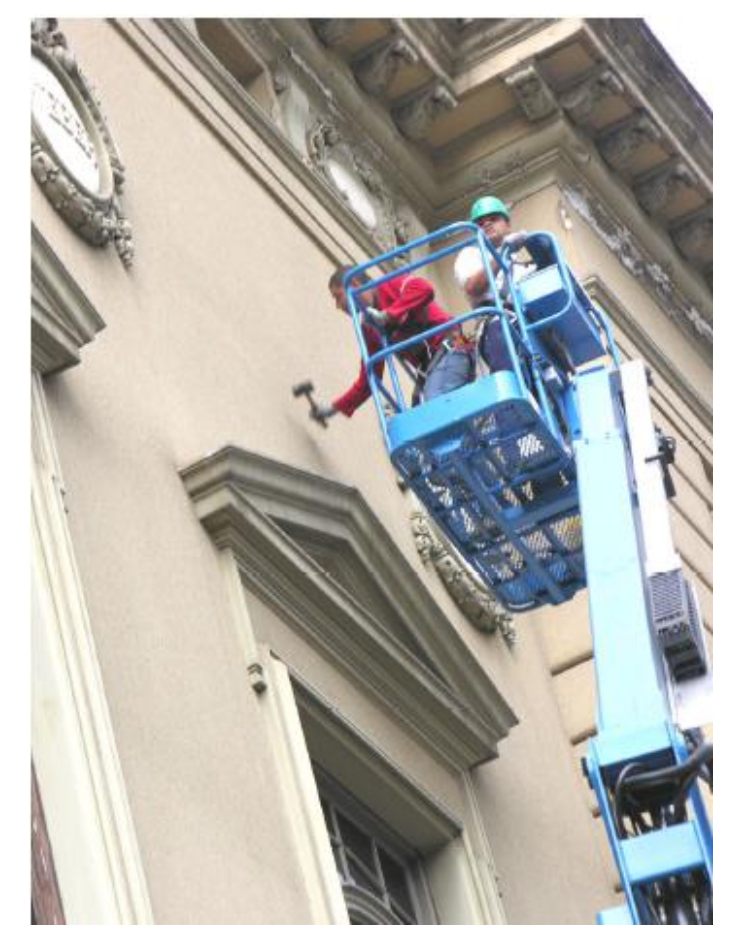

Figura 251: Inspeção da aderência da argamassa, realizada com martelo de borracha. Fonte: Memorial descritivo do Projeto de Restauração do TMSP, Departamento de Patrimônio Histórico, 2006.

O mesmo não se pôde dizer das cornijas que, afetadas pelos vazamentos da cobertura, tiveram seus revestimentos submetidos a infiltrações e eflorescências 
de sais solúveis, que provocaram desprendimentos consideráveis. A área também padecia com destacamentos do plasticôte e deterioração de alguns ornatos, pelo mesmo motivo (Figuras 252 e 253).
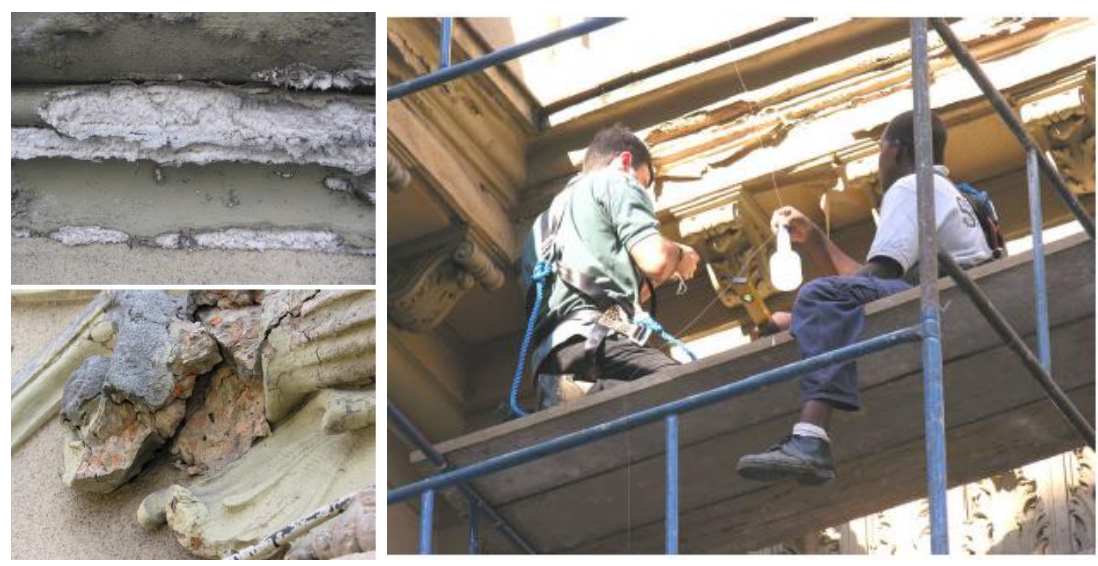

Figuras 252 (esq.) e 253 (dir.): Respectivamente, deterioração da cornija e seus elementos decorativos e desprendimento do plasticôte da cornija.

Fonte: Memorial descritivo do Projeto de Restauração do TMSP, Departamento de Patrimônio Histórico, 2006.

O revestimento plasticôte do restante das superfícies que compõem as fachadas, por sua vez, também apresentava destacamentos, principalmente nas áreas acometidas por infiltrações (Figura 254). Na análise realizada durante a intervenção, atestou-se sua inadequação como revestimento de antigas construções, uma vez que sua característica impermeável não permite a saída da água sob a forma de vapor.
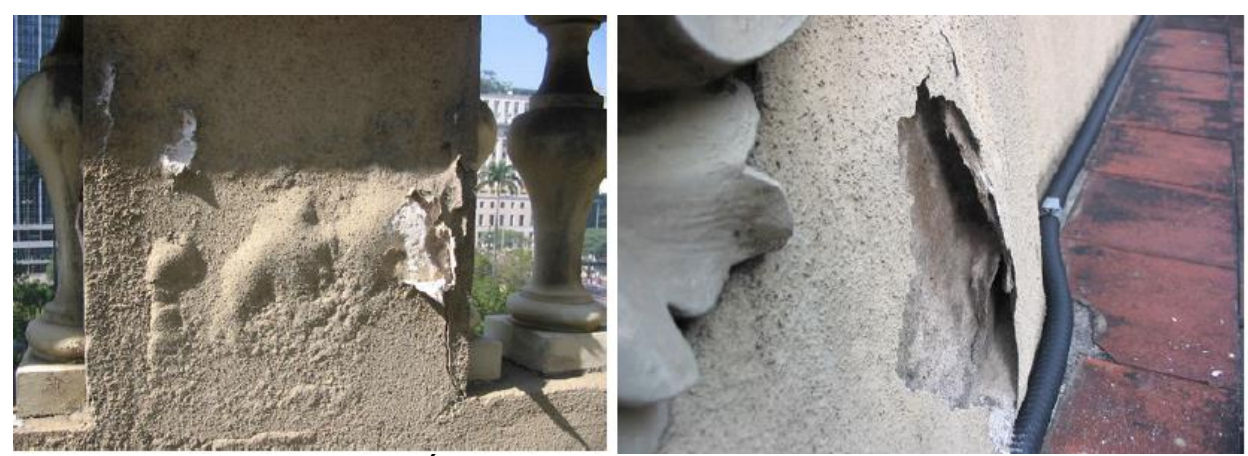

Figura 254: Áreas de desprendimento do plasticôte.

Fonte: Memorial descritivo do Projeto de Restauração do TMSP, Departamento de Patrimônio Histórico, 2006.

A presença de infiltrações acarreta o fenômeno da eflorescência salina, provocada pela tensão da cristalização de sais solúveis na presença de água. 0 
estudo da composição desses sais indicou a presença de ions de sulfatos e nitratos, que são bastante expansivos e acabam provocando os destacamentos.

Todos esses fatores, aliados às vibrações do tráfego circundante, contribuem para o destacamento da argamassa com plasticôte. Por se tratar de uma área bastante extensa recoberta por esse material, o Memorial do Projeto fez uma opção conservativa de preservá-la, tratando de suas patologias pontuais.

Tendo a água papel premente em sua degradação, grande parte da intervenção deveria se dar no sentido de evitar a ocorrência de infiltrações e vazamentos. Para tal, deveria realizar-se a revisão das calhas de cobre e dutos verticais de escoamento da água pluvial da cobertura, além da restauração e impermeabilização da cornija de coroamento do edifício. Nos casos em que houvesse comprometimento total do revestimento, esse deveria ser substituído por argamassa de saneamento, removendo-se o plasticôte e aplicando pintura mineral à base de silicato de potássio.

Quanto à aderência do revestimento nas demais áreas, previu-se aplicação de injeções de Mowilith ou Moviol ${ }^{130}$ para consolidação, realizada no decorrer da obra, caso fosse encontrada alguma situação que oferecesse risco imediato de destacamento. Toda superfície da pintura em plasticôte deveria ser lavada com água e sabão neutro, sendo suas partes faltantes reintegradas com material similar não especificado, mas de mesmo valor cromático.

Após a limpeza, seria borrifada uma solução de algicida que, uma vez seca, receberia uma camada de verniz acrílico. As demais lacunas, em partes não comprometidas do reboco, deveriam ser preenchidas com argamassa de mesmo traço.

\subsubsection{5 $\underline{\text { Cantaria }}$}

A cantaria do exterior do edifício do Theatro, como já foi visto no Capítulo 1 Prelúdio da Modernidade, é composta majoritariamente por granito cinza de Itaquera (embasamento), granito vermelho de Ituparanga (colunas geminadas

130 Mowilith ou Moviol são tipos de adesivos selantes. 
do Salão Nobre) e arenito (grande parte da fachada principal). Os elementos em granito encontravam-se em bom estado, sendo apenas necessários limpeza, pequenos reparos e aplicação de produto protetor.

A situação do arenito, por sua vez, preocupou os restauradores que batizaram sua conservação como o "calcanhar de aquiles de toda a construção do theatro"131. Essa preocupação levou à execução de testes por difratometria de raios-x, realizados pelo IPT, para caracterizar seus componentes argilominerais $^{132}$.

Os testes revelaram a presença de argilo-minerais do grupo das esmetictitas, que são argilas muito absorventes e expansivas quando penetradas por água. De fato, a fragilidade da rocha e seu precário estado de preservação estavam intimamente relacionados à sua elevada porosidade, que fez aflorar uma gama de diferentes patologias.

Foram verificados esfoliações e desprendimento de placas, ocasionados pela expansão do material argiloso presente em sua composição; o desenvolvimento de um biofilme de cianobactérias, em virtude do armazenamento de água permitido por sua elevada porosidade ${ }^{133}$; o crescimento de espécies vegetais em suas juntas e a ruptura por choques acidentais ou vandalismo, facilitada pela sua fragilidade, além do desgaste natural provocado pela abrasão do uso. Também chamou a atenção dos técnicos a presença de reintegrações e próteses inadequadas, feitas com argamassa polimérica de tonalidade muito distinta da original, sem se procurar a forma mais orgânica de preencher as lacunas ou na forma de pinturas sobre a cantaria (Figuras 255 - 258).

\footnotetext{
131 Memorial descritivo do Projeto de Restauração do TMSP, Departamento de Patrimônio Histórico, 2006, p. 27.

132 Para maiores especificidades sobre as características minerais do arenito, ver estudo geológico realizado por AMA, 2008.

${ }^{133} \mathrm{~A}$ hipótese de que o biofilme era composto por cianobactérias foi comprovada pelo laudo emitido pelo Instituto de Biologia da UFBA (Memorial descritivo do Projeto de Restauração do TMSP, Departamento de Patrimônio Histórico, 2006).
} 

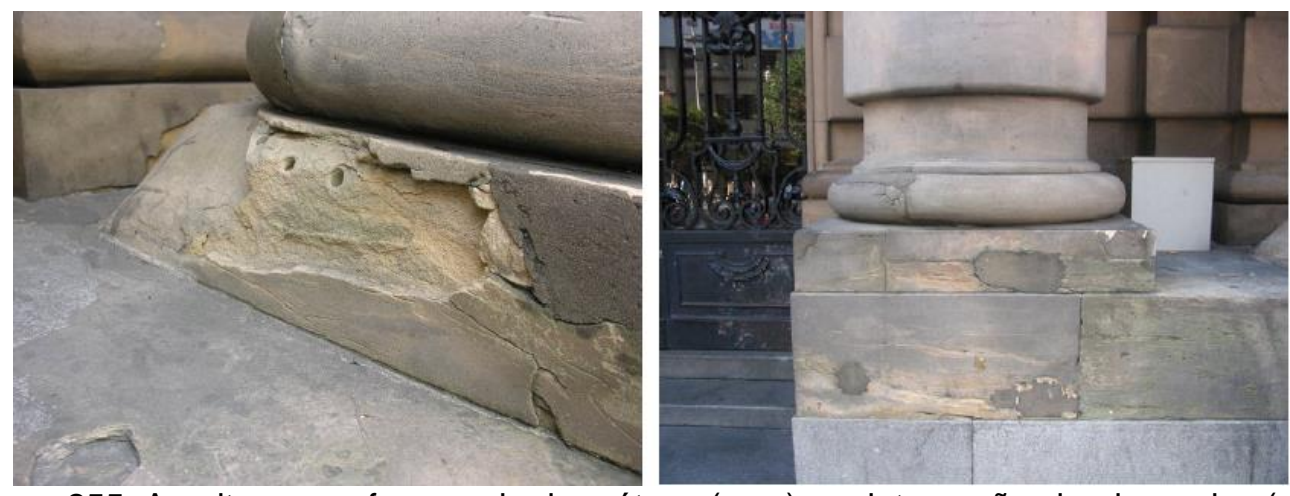

Figura 255: Arenito que sofreu perda de prótese (esq.) e reintegrações inadequadas (dir.). Fonte: Memorial descritivo do Projeto de Restauração do TMSP, Departamento de Patrimônio Histórico, 2006.
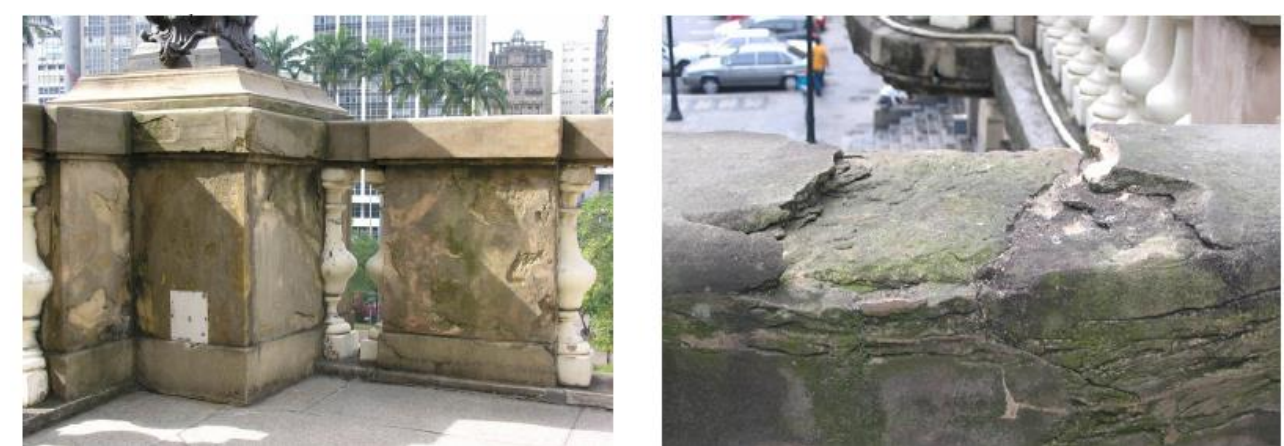

Figura 256: Esfoliação do arenito (esq.) e presença de biofilme (dir.).

Fonte: Memorial descritivo do Projeto de Restauração do TMSP, Departamento de Patrimônio Histórico, 2006.
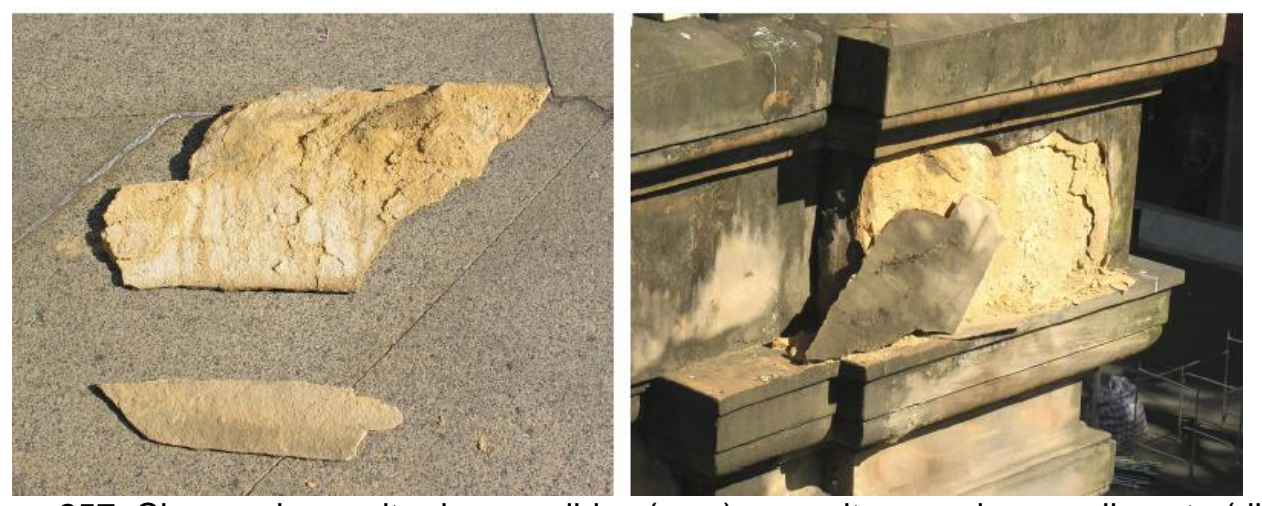

Figura 257: Chapas de arenito desprendidas (esq.) e arenito com desprendimento (dir.). Fonte: Memorial descritivo do Projeto de Restauração do TMSP, Departamento de Patrimônio Histórico, 2006. 

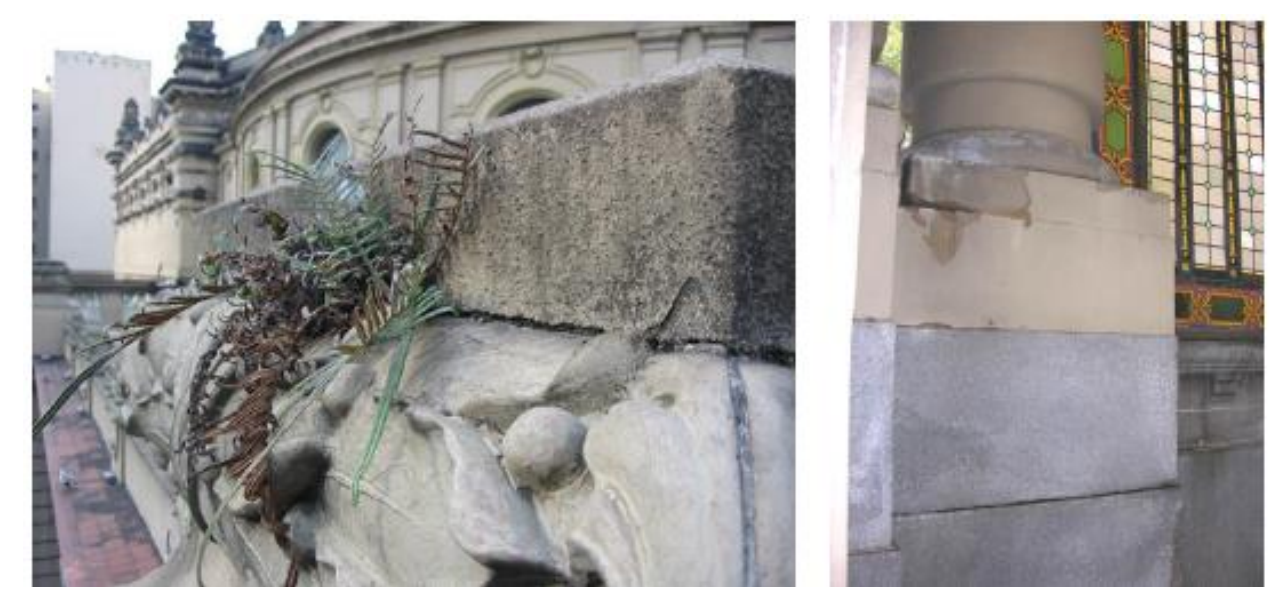

Figura 258: Vegetação nas juntas do arenito (esq.) e pintura sobre cantaria (dir.). Fonte: Memorial descritivo do Projeto de Restauração do TMSP, Departamento de Patrimônio Histórico, 2006.

Apesar de, na maioria das vezes, as reintegrações mais recentes terem se utilizado do material original ${ }^{134}$, observou-se que essas aparentavam estar em pior estado do que aquelas que não haviam sido substituídas. Foram duas as hipóteses levantadas pelos restauradores para explicar o fenômeno: a primeira dizia respeito à possível extração da pedreira não ter sido realizada do interior da rocha, mas sim da sua camada mais externa e, consequentemente, mais intemperizada e alterada; a segunda, a de que reintegrações feitas com placas com determinada disposição no estrato da pedreira poderiam alterar-se mais rapidamente ${ }^{135}$.

\subsubsection{Elementos decorativos em metal}

As seis esculturas de bronze, distribuídas pela fachada principal, também foram objeto de restauração. Apresentavam camadas heterogêneas de corrosão com tonalidades que variavam entre verde, preto e branco, além de outras patologias como furos, recortes e ausência de pequenos componentes.

Para o reparo de seus componentes faltantes, o Memorial sugeriu o uso de soldas compatíveis com a liga metálica constituinte da peça ${ }^{136}$. Para limpeza,

\footnotetext{
${ }_{134}$ As reintegrações realizadas durante a intervenção da década de 1980, por exemplo, usaramse de arenito da mesma origem, composição e esquema cromático do original (Ver Capítulo 3 Reconhecimento).

${ }^{135}$ Empiricamente, percebeu-se que as peças aplicadas com os veios na posição vertical tendem a apresentar mais desprendimentos do que aquelas aplicadas na horizontal (Memorial descritivo do Projeto de Restauração do TMSP, Departamento de Patrimônio Histórico, 2006).

136 O bronze usado para a fundição das estátuas tinha como composição $92 \%$ de cobre, $5 \%$ de zinco, $2 \%$ de estanho e $1 \%$ de chumbo, o que é considerado usual para esse tipo de aplicação
} 
preconizou-se a manutenção da pátina, por meio de lavagem com água e sabão neutro seguida da aplicação de emplastro AB - 57 ou NTR. Finalmente, deveria ser aplicada uma fina camada de paralóide puro, em solução de $10 \%$ de xilol a pistola ou pincel.

\subsubsection{Projeto Luminotécnico das fachadas}

O projeto de iluminação das fachadas foi elaborado pelo arquiteto Fabiano de Oliveira Xavier, tendo como colaboradores Alain Maitre, Marcus Vinícius Dias e Leonardo Harth, responsáveis pelo projeto de iluminação externa do Theatro Municipal do Rio de Janeiro, realizado em 2004 ${ }^{137}$. O sistema de iluminação existente na época era resultado de um projeto do escritório Senzi e Godoy implementado no ano 2000.

O sistema, composto por fontes de vapor de sódio, lâmpadas de vapor metálicas e lâmpadas refletoras halógenas, produzia uma iluminação geral do volume em uma tonalidade amarelo dourada, que não era capaz de transmitir a complexidade da policromia de materiais empregados nas fachadas do edifício (Figura 259). Na ocasião da intervenção de 2011, também foram localizadas algumas patologias e incompatibilidades do sistema com relação à construção, que necessitavam de correção.

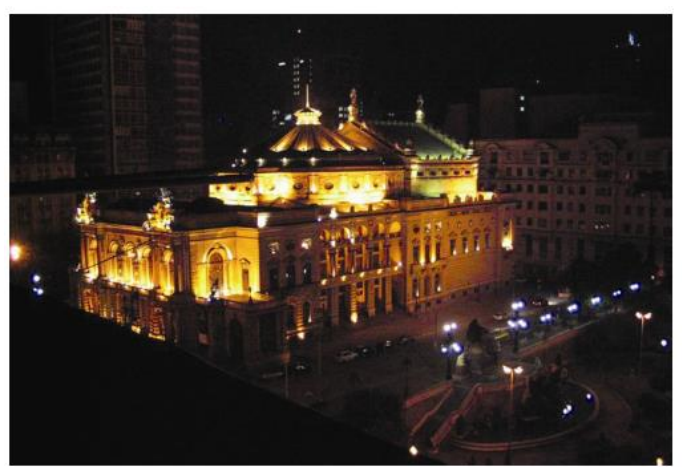

Figura 259: Iluminação externa do Theatro Municipal antes da intervenção de 2011. Destaque para a coloração uniformemente amarelada, incapaz de realçar as nuances cromáticas de elementos compositivos como o verde da cobertura de cobre, o vermelho das colunas de granito polido ou o branco dos bustos de mármore.

Fonte: Memorial descritivo do Projeto de Restauração do TMSP, 2006.

(Memorial descritivo do Projeto de Restauração do TMSP, Departamento de Patrimônio Histórico, 2006).

137 Ver figura 262. 
Entre essas incompatibilidades, que feriam material e figurativamente o edifício, estavam a visibilidade excessiva dos aparelhos, a corrosão de seus componentes metálicos, sua fixação direta em elementos de cantaria e o avançado estado de degradação dos refletores de piso (Figura 260). Dito isso, o partido do projeto se organizou em torno de três diretrizes principais: a restituição da imagem do Theatro, a fixação dos equipamentos apenas sobre alvenarias e a reversibilidade da intervenção.
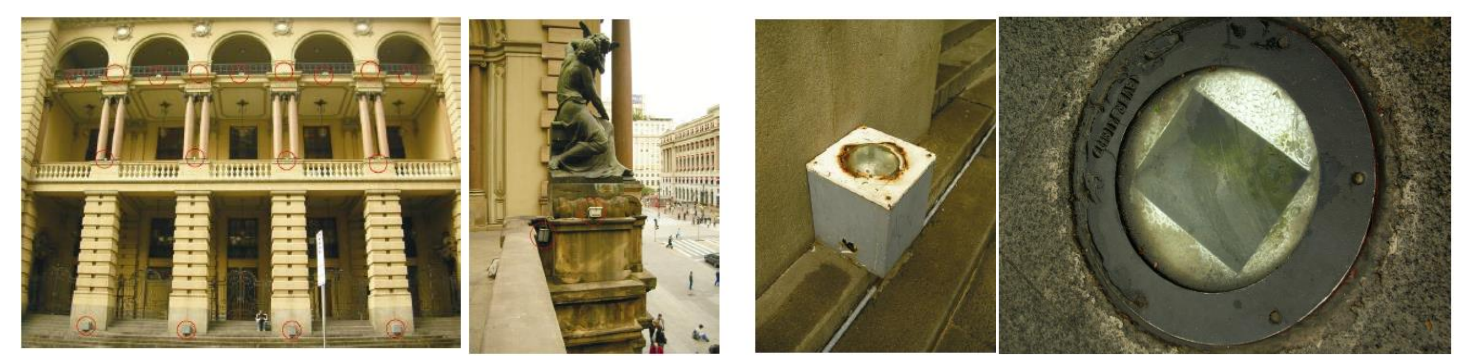

Figura 260: Da esquerda para a direita: destaque para visibilidade excessiva dos aparelhos de iluminação, fixação em cantaria, corrosão de elementos metálicos e péssimo estado de conservação dos refletores de piso.

Fonte: Memorial descritivo do Projeto de Restauração do TMSP, 2006.

Para tal, foram escolhidos equipamentos mais discretos, cuja tecnologia seria capaz de ressaltar a complexidade de elementos compositivos como sombras, contrastes, volumes e texturas (Figura 261). Sua fixação se daria preferencialmente em alvenarias ou, quando não fosse possível, nas juntas entre dois blocos de cantaria. Caso a fixação fosse realizada sobre estrutura metálica, seria dada especial atenção a superfícies de isolamento contra corrosão. Quanto à reversibilidade, o Memorial deixa claro:

Os sistemas de iluminação são relativamente efêmeros em relação à longevidade do monumento, portanto devem ser passíveis de atualização e revisão conceitual (Memorial descritivo do Projeto de Restauração do TMSP, Departamento de Patrimônio Histórico, 2006, p. 148). 

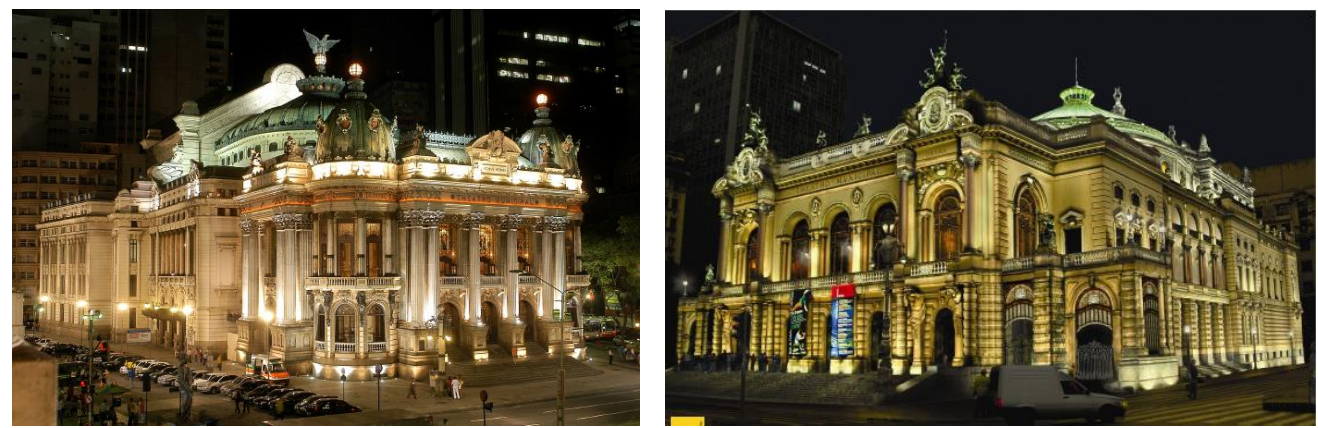

Figura 261: Iluminação externa do Theatro Municipal do Rio de Janeiro, 2004 (esq.) e simulação do projeto de iluminação do Theatro Municipal de São Paulo, 2006 (dir.), ambas concebidas pela mesma equipe. Nota-se a inspiração que o primeiro exerceu sobre o segundo, em termos de valorização volumétrica e cromática de edifício análogo.

Memorial descritivo do Projeto de Restauração do TMSP, 2006.

As especificações técnicas dos aparelhos de iluminação propostos no Memorial confirmam a escolha pela reversibilidade. Grande parte deles foi instalada em postes ou pendentes existentes, quando não sobrepostos aos elementos arquitetônicos ou embutidos no piso das calçadas circundantes.

\subsection{Balanço crítico da intervenção: confusões teóricas}

(...) Enquanto, no passado, a restauração era sinônimo de refazer, remodelar e repintar, sem nenhuma preocupação com a manutenção das características originais, como o próprio theatro (sic) foi vítima nos anos 50 do século passado, quando seus espaços arquitetônicos foram em parte adulterados, a restauração moderna está mais preocupada em salvar o monumento e as obras de arte a ele integradas, mantendo suas características originais e melhorando ao máximo suas condições físicas (Memorial descritivo do Projeto de Restauração do TMSP, Departamento de Patrimônio Histórico, 2006, p. 46).

Abordadas em conjunto, as restaurações internas e externas às quais o Theatro foi submetido durante o período da última intervenção prezam pela preservação de sua história e materialidade. De maneira geral, os procedimentos encampados respeitaram a lógica conservativa, sobretudo no que tange à restauração das fachadas e de ambientes pouco ou nada deteriorados, como foi o Salão Nobre. Essa preocupação com a matéria original, principalmente com relação às fachadas, fica explícita no Memorial do Projeto:

(Sobre restauro externo) Estamos conscientes do primeiro axioma brandiano, e acreditamos piamente que se restaura somente a matéria da obra de arte. Isto posto, reafirmaremos que as nossas propostas de intervenção vão se constituir em recomendar ações para conservar a matéria que constitui o edifício do Theatro Municipal da Cidade de São Paulo procurando, sempre, conservar a constituição da matéria 
primitiva da construção ou que se encontra incorporada legitimamente ao processo de sua história. Temos, porém, consciência de que, também, poderemos ser obrigados a sacrificar, no edifício, uma parte daquela sua consistência material para não só atendermos aquilo que exige a instância estética como também os problemas da durabilidade, da conservação e da segurança do fabricado, como um todo, e dos seus usuários (Memorial descritivo do Projeto de Restauração do TMSP, Departamento de Patrimônio Histórico, 2006, p. 37).

Tal passagem é inclusive reveladora do referencial teórico adotado na intervenção, que vai ao encontro dos postulados de Cesare Brandi e, consequentemente, coloca-se de maneira coerente frente ao respectivo cenário de discussões epistemológicas coetâneas. A Carta de Veneza também é referida nominalmente, quando se enunciam os princípios da reversibilidade e do emprego de materiais e técnicas modernas:

Na medida do possível, procuraremos sugerir soluções reversíveis de tratamento, mas não poderemos garantir que todas as soluções propostas tenham a desejada reversibilidade, mesmo aquelas que sejam teoricamente reversíveis (...). Por outro lado, os materiais modernos, de emprego necessário para colagem, consolidação e proteção, para o aumento de longevidade da construção, serão aqueles indicados como de eficácia comprovada, como já admitia a velha Carta de Veneza no seu Art. 10 (Memorial descritivo do Projeto de Restauração do TMSP, Departamento de Patrimônio Histórico, 2006, p. 37).

No tocante às intervenções internas, o Memorial também explicita seu referencial teórico, fazendo menção, para além de Brandi, a Bernard Feilden ${ }^{138}$ e Umberto Baldini ${ }^{139}$, ambos adeptos da filologia crítica, que vai ao encontro da declinação crítico-conservativa da teoria contemporânea (SILVA, 2020):

(Sobre o restauro interno) Definindo a restauração moderna, Bernard M. Feilden, ex-diretor do Centro Internacional dos Bens Culturais, sediado em Roma, escreveu: "A restauração moderna tem como objetivo revitalizar a concepção original da obra de arte, ou seja, a legibilidade do objeto". A restauração e a reconstituição de parte ou detalhes que caracterizam uma obra ou um ambiente, como é o caso do restaurante, baseiam-se no respeito ao material original, no conhecimento estético e histórico do restaurador e, principalmente nos

\footnotetext{
138 Bernard Feilden (1919-2008) foi diretor geral do International Centre for the Study of the Preservation and Restauration of Cultural Property (ICCROM). Defende a tese de que a conservação é ação preventiva, que se dá de maneira dinâmica com a finalidade de prolongar a vida do monumento.

139 Umberto Baldini (1921-2006) foi historiador da arte da Universidade Internacional de Arte de Florença, conhecido por teorizar os três estados da obra de arte frente a restauração: destruição, prolongamento da vida e restituição.
} 
documentos autênticos encontrados nos arquivos, descrições, fotografias etc (Memorial descritivo do Projeto de Restauração do TMSP, Departamento de Patrimônio Histórico, 2006, p. 46).

Como o maior desafio, tanto técnico como conceitual, a ser enfrentado pelos restauradores da ocasião se materializou no preenchimento de lacunas - e muitas vezes, em extensos refazimentos - para recuperação de pintura decorativa, em especial nos ambientes da Sala de Imprensa, das Salas Contíguas ao Palco e do Restaurante, muito se teorizou a respeito no Memorial:

(...) Como a restauração moderna recomenda que a recomposição de partes que faltam, ou que se deterioraram, deve integrar-se harmoniosamente com o todo, mas é necessário que, por meio de uma observação atenta, essas partes possam ser distinguidas, a fim de que a restauração não engane o espectador, nem falsifique a autenticidade histórica do objeto restaurado, essas áreas com grandes perdas poderão ser repintadas com um desenho mais simplificado, e a reintegração das grandes lacunas executada na técnica rigattino, ficando evidente que se trata de uma intervenção.

Os modernos conceitos de restauro, difundidos principalmente pelos filósofos da restauração italiana, a exemplo de Cesare Brandi e Umberto Baldini, recomendam a não complementação aleatória de uma lacuna em um bem cultural. Na opinião de Cesare Brandi, "uma lacuna no que se refere à obra de arte é a mesma coisa que uma interrupção num texto literário que não pode ser transmitido integralmente". Na verdade não se trata apenas da interrupção, já que a lacuna adquire uma característica própria atuando como um elemento estranho, alheio à obra (...). No nosso caso, como se verá adiante, quando tratarmos das pinturas da barra decorativa do restaurante, a complementação poderá ser feita, uma vez que se trata de uma pintura decorativa com temática repetitiva, onde a perda de um elemento (...) tomará como base um exemplar semelhante que aparece íntegro no mesmo recinto (...). Neste caso, trata-se de um ato de manutenção e não de um ato crítico, já que as partes faltantes não serão uma criação do restaurador, mas uma mera repetição da obra do artista, encontrada na mesma composição. Sendo assim, temos certeza de não estar cometendo um falso histórico, principalmente porque essas áreas serão diferenciadas, através de um desenho mais simplificado, ficando evidente o ato de restauro (Memorial descritivo do Projeto de Restauração do TMSP, Departamento de Patrimônio Histórico, 2006, p. 46 - 47).

O ambiente mais desafiador, dentro da problemática das lacunas, foi 0 restaurante, uma vez que se tratava de um espaço profunda e estruturalmente modificado, tendo restado poucos ou nenhum vestígio da pintura original, como é o caso de um de seus forros. Sobre isso, o Memorial deixa clara a intenção de 
resgate de seu aspecto original sem, no entanto, desrespeitar os princípios contemporâneos da restauração:

\begin{abstract}
(Sobre o restaurante) Como é intenção do DPH resgatar a decoração original dos ambientes objeto deste projeto, como forma de restituir à cidade de São Paulo um dos seus monumentos mais valiosos, com todos os seus cômodos plenamente restaurados e exibindo toda a sua elegância de outrora, quando foi inaugurado em 1911, fizemos o maior esforço, tomando por base a parca documentação existente, a fim de elaborar uma proposta de restauro que contemplasse a orientação daquele órgão, sem ferir a ética do restauro, à qual estamos, de certa forma subordinados (Memorial Descritivo do Projeto de Restauração do TMSP, DPH, 2006., p. 58).
\end{abstract}

De fato, o alto grau de complexidade técnica e teórica dos procedimentos pôde ser verificado. No entanto, apesar das discussões teóricas do Memorial Descritivo mencionarem o referencial coetâneo e seus postulados, a intervenção resultou em um falso histórico, a partir da reconstrução integral de um elemento que havia se perdido há quase seis décadas e do qual não haviam sobrado vestígios.

A despeito do uso de técnicas digitais de reprodução e projeção de padrões ornamentais da pesquisa documental e iconográfica, a reconstituição da leitura figurativa do ambiente implicou na construção de uma cópia por analogia que, de acordo com a teoria contemporânea do restauro, é inaceitável. Percebe-se, nesse caso, que a justificativa técnica da intervenção acabou eclipsando o papel crítico dos restauradores, o que talvez explique a quantidade muito superior de informações disponíveis no Memorial sobre o restauro das pinturas ornamentais a partir de um viés tecnicista com relação àquelas sobre o projeto de restauro arquitetônico geral.

Ainda referente ao interior do edifício, outra decisão ousada foi tomada: a recuperação do esquema cromático em tons de vermelho no interior da Sala de Espetáculos. Como visto anteriormente, a mudança de coloração sofrida pelo ambiente durante a intervenção anterior se deu de forma praticamente arbitrária, tendo sido o vermelho substituído pelo verde ${ }^{140}$.

140 Ver Capítulo 3-Reconhecimento. 
A partir da ausência de material documental preciso a respeito da coloração original da Sala de Espetáculos e tendo em vista a arbitrariedade na implementação da última transformação, decidiu-se pelo resgate das superfícies vermelhas, das quais se tem o registro mais antigo, datado da intervenção de 1950. Embora a tentativa de solucionar um falso estético e histórico promovido pelo restauro anterior possa ser justificável, essa escolha é discutível, uma vez que houve um hiato de mais de trinta anos entre as duas situações.

Coetaneamente, o Municipal carioca passava por uma intervenção que promoveu, não apenas um falso, como uma situação completamente anacrônica. Como já foi discutido, a coexistência de douramento e da pátina do cobre na cobertura nunca existiu nem poderia existir, devido à diferença temporal entre a deterioração do primeiro e o aparecimento da segunda.

Novamente, como concluído a respeito da intervenção da década de 1980, as posturas assumidas pela equipe de restauração do Theatro Municipal de São Paulo ora se aproximavam e ora se distanciavam do corpus teórico correspondente. $O$ discurso afinado apresentado pelo memorial, com referências nominais aos teóricos e documentos do campo da restauração, nem sempre correspondiam à prática verificada.

O refazimento do forro do restaurante e a mudança de cor do interior da Sala de Espetáculos são exemplos claros dessa discordância. No primeiro caso, afirmase que a proposta não pretende "ferir a ética do restauro" 141 quando, na verdade, a reconstrução vai contra todos os postulados da teoria contemporânea. No segundo caso, a própria ausência de menção da transformação cromática do auditório pelo Memorial Descritivo faz questionar sua pertinência e amparo teórico com relação às fontes citadas.

Em outras situações, como no caso da reintegração das pinturas murais do restaurante, faz-se uma distinção equivocada entre manutenção e o ato crítico do restauro, ao afirmar que a ação "é um ato de manutenção e não um ato

${ }^{141}$ Memorial Descritivo do Projeto de Restauração do TMSP, DPH, 2006., p. 58. 
crítico". ${ }^{142}$ Se tomarmos como base a concepção de Cesare Brandi, na qual o processo de restauração engloba ações de manutenção, essa afirmação é inadmissível. Mesmo se concebidos o restauro e a manutenção como procedimentos distintos, como preconiza a Carta de Veneza, tal colocação não se justifica, uma vez que o preenchimento de lacunas figurativas, como qualquer outra intervenção sobre superfícies arquitetônicas (KÜHL, 2004), configura um ato crítico.

A respeito da intervenção anterior, havia-se concluído que a multiplicidade de equipes técnicas envolvidas no diagnóstico e no estabelecimento de diretrizes para o restauro do edifício, sem a comunicação interdisciplinar preconizada pela teoria contemporânea, acabou gerando situações nas quais, sobre um mesmo objeto recaiam diferentes análises. Na presente intervenção, apesar da afinação geral do discurso com a teoria, a multiplicidade de equipes de projeto, responsáveis pelas diferentes partes do edifício (ver Ficha técnica da obra Figura 191), proporcionou diferentes resultados no que tange às diferentes propostas.

É o caso do projeto de iluminação externa e de mobiliário para o restaurante, por exemplo. Ambos os projetos, desenvolvidos por equipes fora do âmbito do DPH - respectivamente pelo Ateliê Lumière e pela dupla de designers Irmãos Campana -, resultaram em propostas coerentes com os princípios teóricos enunciados pelos autores. A reversibilidade e a mínima intervenção, nos dois casos, e a distinguibilidade, sobretudo no caso do desenho de mobiliário, foram respeitadas com sucesso.

Dito isso, concluiu-se que, de maneira geral, a afinação do discurso da intervenção no Theatro Muncipal com o contexto internacional da discussão epistemológica em torno da restauração aumentou, mas não foi refletida integralmente em todas as escolhas e procedimentos realizados na prática. Apesar dessa dissonância, a intervenção sofrida pelo Municipal paulista nos anos 2010 apresentou mais afinidades com esse contexto do que com a

\footnotetext{
142 Memorial descritivo do Projeto de Restauração do TMSP, Departamento de Patrimônio Histórico, 2006, p. 46 - 47.
} 
experiência nacional coetânea analisada, ou seja, o caso do Municipal do Rio de Janeiro. Essa conclusão será cotejada com aquelas respectivas às demais etapas cronológicas compreendidas pela análise para que seja possível entendê-las de maneira diacrônica. 


\section{CONSIDERAÇÕES FINAIS}

A análise das sucessivas intervenções pelas quais o edifício do Theatro Municipal de São Paulo vem sendo submetido ao longo de sua história fornece uma dupla entrada para o estudo do campo epistemológico da preservação do patrimônio: a aproximação das formulações teóricas internacionais e de sua aplicabilidade em território nacional. Assim sendo, e levando-se em consideração o recorte analisado, podem-se verificar exemplos de maior ou menor coincidência entre ambas.

Em meados do século $X X$, a experiência brasileira das intervenções no Theatro Municipal e na Casa do Butantã, encomendados por ocasião da comemoração do IV Centenário da Cidade, se distancia dos postulados do Restauro Filológico, que haviam adquirido validade internacional por meio da Carta de Atenas. Apesar do distinto estado de conservação e estatuto patrimonial em que se encontravam os edifícios, as posturas de intervenção então adotadas convergiam na falta de preocupação com sua autenticidade material.

Na segunda metade do mesmo século, os restauros do Theatro Municipal e da Cinemateca Brasileira, acompanhados por equipes do DPH, também se aproximam entre si. No entanto, passam a dialogar em alguns pontos com a teoria do Restauro Crítico e os princípios da Carta de Veneza, como é o caso da preocupação com a distinguibilidade, a reversibilidade e a profusa documentação do processo.

No século XXI, a aproximação da intervenção do Theatro com as teorias vigentes, sobretudo de maneira discursiva, se estreita. Em maior ou menor grau, as posturas adotadas pelos restauradores se alinharam com a declinação conservativa do Restauro Crítico, principalmente no que tange à conservação das fachadas e dos ambientes internos mais preservados. O Theatro Municipal carioca, por sua vez, foi simultaneamente repristinado nos moldes das restaurações oitocentistas de Viollet-le-Duc, que impuseram, para além de um falso, uma situação completamente anacrônica. 
Essas duas intervenções, encomendadas na ocasião dos respectivos centenários dos edifícios em questão, evidenciam posturas diversas que são em si indicativas do cenário contemporâneo de revisões das teorias de restauro. Acabam por manifestarem-se nelas diferentes tendências, dentre as quais a crítico-conservativa e a hipermanutenção.

Assim sendo, a análise simultaneamente sincrônica e diacrônica das intervenções do Theatro Municipal permite observar que sua trajetória não é necessariamente reveladora de uma crescente aproximação entre a experiência nacional da prática restaurativa e as teorias de restauro vigentes. Fica claro que, a exemplo da restauração da cobertura do Municipal do Rio de Janeiro, este é um exercício que não se realiza de maneira homogênea dentro de um mesmo recorte espaço-temporal.

Apesar dessas transformações, evidentes tanto no campo epistemológico da restauração como no contexto de sua aplicação nacional, algumas questões se fizeram presentes em todas as intervenções no Theatro Municipal de São Paulo aqui analisadas. Todas elas, por exemplo, são atravessadas por uma leitura tecnicista do edifício que acaba, muitas vezes, por prejudicar a postura crítica do arquiteto perante a obra.

Em um primeiro momento, durante a reforma dos anos 1950, essa tecnicidade se vê manifesta na preocupação quase que exclusiva nos melhoramentos funcionais do edifício, que vão desde a remodelação completa do interior da Sala de Espetáculos e dos camarins, assim como a redistribuição da bilheteria e a subdivisão do ambiente do restaurante para abrigar parte do setor administrativo. Compreende-se essa preocupação como parte de uma leitura do edifício na chave do uso, uma vez que, naquele momento, não se tratava de uma obra reconhecida como patrimônio e muito menos tombada oficialmente pelo único órgão competente de então.

Nos restauros das décadas de 1980 e 2010, apesar da mudança paradigmática pela qual passara o edifício ao ser tombado pelas instâncias municipal (1981) e 
estadual (1991), a perspectiva sobre algumas das intervenções propostas continuava impregnada por uma supervalorização dos aspectos técnicos em detrimento do juízo crítico dos arquitetos envolvidos na tomada de decisões projetuais, ao qual os primeiros deveriam estar subordinados. São exemplos dessa subversão de valores os procedimentos de recuperação de superfícies, tanto internas como externas, que reproduzem deslizes de hipermanutenção e repristinação, amparados pela justificativa técnica, como é o caso das fachadas durante a intervenção de 1980 e das pinturas decorativas, sobretudo do restaurante, em 2010.

Outra questão que se apresenta repetidamente nas intervenções analisadas é o problema da Sala de Espetáculos. Novamente, em 1950, o desafio encarado era de ordem funcional, o que acarretou a remodelação completa de seus setores. Nas duas intervenções seguintes, a problemática que envolvia o ambiente era relativa ao seu aspecto cromático.

Em 1980, a escolha arbitrária de mudança de cor, do vermelho para o verde, introduziu a questão do falso, com a qual se deparariam as equipes responsáveis pela intervenção seguinte. A escolha das últimas, apesar de discutível, foi por reverter a transformação e devolver à sala sua coloração avermelhada.

Pelo fato do Theatro ter se mantido um edifício plenamente funcional durante todas essas épocas, além de um elemento marcante na paisagem urbana e cultural da cidade, não é à toa que um dos ambientes centrais das polêmicas que envolveram suas restaurações fosse seu auditório. Afinal, esse ambiente sintetiza a principal função de sua tipologia, e sobre ele sempre recaíram todos os olhares - dos mais técnicos aos mais preocupados com sua recepção estética.

Os restauros de 1980 e 2010 tem entre si outra afinidade. A falta de material sobre a compatibilização entre os projetos de instalações (sistema de escoamento de águas pluviais, atualização das instalações elétricas e hidráulicas, etc.) e o projeto de restauro propriamente dito leva a acreditar na ausência de interdisciplinaridade e comunicação entre as equipes responsáveis 
pelos diferentes aspectos da construção. Essa hipótese se vê endossada pelas posturas diversas assumidas em cada parte das intervenções em questão, explícitas por meio de suas afinidades ou divergências teóricas.

No campo da teoria, para além das considerações tecidas anteriormente, vale destacar que o discurso oficial, envolvendo os agentes responsáveis pelos projetos de intervenção - seja por meio de memoriais descritivos ou por publicações especializadas -, sempre esteve mais afinado com o corpus teórico coetâneo do que a prática. Mesmo na década de 1950, quando a teoria ainda não se colocava como problema, dado o caráter não restaurativo da intervenção, - arquiteto responsável pelo projeto chegou a expressar - apenas discursivamente - sua preocupação com "manter dentro daquele equilíbrio arquitetônico o caráter de restauração" (PISTORESI, 1953).

Em 1980, mencionam-se a Carta de Veneza e seus princípios como justificativa de certas opções projetuais. No entanto, é nesse momento que algumas escolhas pouco embasadas foram tomadas, como é o caso da já mencionada implementação por analogia da cor verde no interior da Sala de Espetáculos.

Em 2010, o referencial teórico mobilizado pelo projeto em seu respectivo memorial descritivo é ainda mais amplo: para além da Carta, são citados nominalmente Cesare Brandi, Bernard Feilden e Umberto Baldini. Todavia, esses pensadores são usados para justificar posturas nada alinhadas com seus postulados, como a reconstrução integral do forro do restaurante

Assim sendo, resta indagar se as dissonâncias entre discurso e prática são fruto de uma confusão teórica, resultante da má interpretação e aplicação equivocada dos princípios de restauro, ou se são um artifício consciente para justificar o injustificável. Também interessa saber se essas incoerências entre os campos teórico e prático se expressam de maneira igualmente irregular nos demais cantos do mundo ou se essa é uma peculiaridade do contexto brasileiro. A análise pretendida pelo presente trabalho tem o intuito de colocar tais questões em debate, para que possam ser futuramente esclarecidas por outras pesquisas. 


\section{BIBLIOGRAFIA}

Acervo do Departamento de Patrimônio Histórico - DPH

Acervo de Fotografias do Arquivo Histórico Municipal Washington Luis - AHMWL

Acervo da Fundação Theatro Municipal de São Paulo - FTMSP.

Acervo de Material Iconográfico da Biblioteca da FAU-USP

Acervo de Projetos do Arquivo Histórico Municipal Washington Luis - AHM-WL

A llustração Brasileira, n.4, 15/07/1909

A llustração Paulista, Edição Especial, São Paulo, n.35, São Paulo, 11/09/1911, ano I

ALMEIDA, Eneida de. Aspectos Teórico-Metodológicos da Reutilização do Patrimônio Industrial. Uma Apreciação Acerca do Caso do Antigo Matadouro Municipal, Atual Sede da Cinemateca Brasileira. Disponível em:<http://portal.iphan.gov.br/uploads/ckfinder/arquivos/VI_coloquio_t1_aspect os_teoricos.pdf>. Acesso em: 12 ago. 2020.

AMA, Eliane Aparecida del et al. Impacto do Intemperismo no Arenito de revestimentos do Teatro Municipal de São Paulo. Revista do Instituto de Geociências da USP, São Paulo, v. 8, n.1, p. 75-86, abr. 2008. Disponível em: http://www.revistas.usp.br/guspsc/article/view/27444/29216. Acesso em: 06 de junho de 2017.

AMADO, Marina Rodrigues. Teatros em São Paulo (1890-1911): cultura, arquitetura e cidade a partir de fontes primárias. 2016. $313 \mathrm{f}$. Dissertação (Mestrado) - Curso de Arquitetura e Urbanismo, Universidade de São Paulo, São Paulo, 2016.

AMARAL, A. B. D. - História dos Velhos Teatros de São Paulo: Governo do Estado de São Paulo, 1979.

ANDRADE, Antonio Luiz Dias de. Um Estado completo que pode jamais ter existido. São Paulo, FAU-USP, Tese de Doutorado, 1993.

APÓS uma espera de três anos o povo paulista pode ir ao Teatro Municipal. Folha da Noite. São Paulo, p. 3. 25 out. 1955.

BASILE, Giuseppe. "A Atualidade da Teoria da Restauração de Cesare Brandi: Alguns Exemplos", Pós, 2004, n. 16, pp. 143-146. 
BAUMGARTEN, Jens. Max Dvořák entre a Primeira e a Segunda Escola de Viena. In: DVORÁK, Max. Catecismo da Preservação de Monumentos. 2. ed. Cotia: Ateliê, 2013. p. 19-33.

BERNARDES, Maria Elena. O Estandarte Glorioso da Cidade: Teatro Municipal de São Paulo (1911-1938). 2004. 318 p. Tese (doutorado) - Universidade Estadual de Campinas, Instituto de Filosofia e Ciências Humanas, Campinas, SP. Disponível em: < http://libdigi.unicamp.br/document/?code+vtls000314870>. Acesso em: 28 mar 2017.

BOITO, Camillo. Os restauradores. Cotia, Aleliê, 2014, 4. Ed. (1. Ed. 2002).

BRANDI, Cesare. Teoria da Restauração. Cotia, Ateliê, 2013, 4. ed. (1. ed. 2004).

BRANDÃO, Ignácio de Loyola. Teatro Municipal de São Paulo: grandes momentos. São Paulo: Dórea Books and Art, 1993.

BRENNA, Giovanna Rosso del. Ecletismo no Rio de Janeiro (séc. XIX-XX). In: FABRIS, Annateresa. Ecletismo na arquitetura brasileira. São Paulo: Nobel/ Edusp, 1987. p. 28-67.

CABRAL, Renata Campello; ANDRADE, Carlos Roberto Monteiro de. Roberto Pane, entre história e restauro, arquitetura, cidade e paisagem. Risco: revista de pesquisa em arquitetura e urbanismo programa de pós-graduação do instituto de arquitetura e urbanismo iau-usp, São Paulo, v. 1, n. 15, p.105-111, jan. 2012.

CAMARGOS, Marcia. Theatro Municipal de São Paulo 100 anos: Palco e plateia da sociedade paulistana. São Paulo: Dado Macedo Edições, 2011.

CAMPOS, Eudes. São Paulo em recinstrução: A formação de uma cenografia urbana para o centro paulistano entre 1899 e 1926. Arquivo Histórico de São Paulo, São Paulo, 2016. Disponível em: http://www.arquipaulistana.com, p. 110.

CANADO JUNIOR, Roberto dos Santos. Embates pela memória: a reconstrução do conjunto jesuítico do Pátio do Colégio (1941-1979). 2014. 243 f. Dissertação (Mestrado) - Curso de Arquitetura e Urbanismo, História e Fundamentos da Arquitetura e do Urbanismo, Universidade de São Paulo, São Paulo, 2014.

CAPELLER, Ivan. Introdução à arqueologia da escuta - Do Som e da voz como objetos de enunciação. Ciberlegenda: Revista Eletrônica do Programa de Pósgraduação em Comunicação, Rio de Janeiro, v. 2, n. 24, p. 7-15, jan. 2011. Disponível em: http://www.ciberlegenda.uff.br/index.php/revista/article/viewFile/446/271\#page= 7. Acesso em: 15 fev. 2019.

CARBONARA, Giovanni. Brandi e a restauração arquitetônica hoje, Desígnio, 2006, n. 6, p. 35-47.

CARRASCOSA, João. Uma restauração que destacou a funcionalidade. Projeto, São Paulo, v. 1, n. 112, p.67-72, jul. 1988. 
Carta de Veneza, Revista do Patrimônio Histórico e Artístico Nacional, 1987, n. 22, pp. 106-107.

CARVALHO, Maria Cristina Wolff de. Ramos de Azevedo. São Paulo: Edusp, 2000.

CASTANHO, Cesar Arruda; DUTRA, Maria Luiza; CALIXTO, Nilva Leda; MENEZES, Walter de Arruda. Memorial descritivo dos elementos decorativos, DPH, 1986.

CASTRO, Leticia de. Municipal recebe de volta vitrais restaurados. A Folha de São Paulo. São Paulo, p. 10. 23 out. 2010.

CERTEAU, Michel de. A invenção do cotidiano. 1. Artes de fazer. Petrópolis, Vozes, 1994.

CHAMIE, E. Teatro Municipal 70 anos. São Paulo: Secretaria Municipal de São Paulo, 1982.

CHUVA, Márcia. Fundando a nação: a representação de um Brasil barroco, moderno e civilizado. Topoi, v.4, n.7, jul-dez. 2003, pp. 313-333

COSTA, Richard Santiago. PARNASO PAULISTANO: história, arquitetura e decoração do Teatro Municipal de São Paulo. 2017. 795 f. Tese (Doutorado) Curso de Filosofia e Ciências Humanas, História da Arte, Universidade Estadual de Campinas, Campinas, 2017.

CUNHA, Cláudia dos Reis e. Restauração: diálogos entre teoria e prática no Brasil nas experiências do IPHAN. 2010. $171 \mathrm{f}$. Tese (Doutorado) - Curso de Arquitetura e Urbanismo, História e Fundamentos da Arquitetura e do Urbanismo, Universidade de São Paulo, São Paulo, 2010.

Decreto Lei 25 do IPHAN

D'ELBOUX, Roseli Maria Martins. Joseph-Antoine Bouvard no Brasil: os melhoramentos de são paulo e a criação da companhia city: ações interligadas. 2015. 846 f. Tese (Doutorado) - Curso de Arquitetura e Urbanismo, Planejamento Urbano e Regional, Universidade de São Paulo, São Paulo, 2015.

DONATO, Célia Cristina Rodrigues de; MARTINS, Mirian Celeste Ferreira Dias (orient.). Teatro Municipal de São Paulo: da percepção do patrimônio à experiência estética. 2012. 200 f. Dissertação (mestrado em Educação, Arte e História da Culura). Universidade Presbiteriana Mackenzie, São Paulo, 2012.

Departamento do Patrimônio Histórico. Memorial descritivo das obras e serviços de restauro das fachadas do Teatro Municipal de São Paulo. São Paulo, 1986.

DVORÁK, Max. O Catecismo da Preservação de Monumentos. Cotia, Ateliê, 2013, 2. ed. (1. ed. 2008). 
ENCONTRO ESTADUAL DE HISTÓRIA - ANPUH-SP, 21., 2012, Campinas. O imigrante italiano e o patrimônio cultural paulistano no pós Segunda Guerra Mundial. Campinas, 2012, 12 p.)

ESPÍRITO SANTO, José Marcelo do. Municipal, de volta à paisagem. Revista Au, São Paulo, v. 1, n. 19, p.81-85, ago. 1988.

FABRIS, Annateresa (Org.). Ecletismo na arquitetura brasileira. São Paulo: Nobel/ Edusp, 1987. 296 p.

Os Valores do Monumento. In: RIEGL, Alois. O Culto Moderno dos Monumentos: A sua essência e a sua origem. São Paulo: Perspectiva, 2014. p. 9-21.

FERRARI, Caetano. O dourado com bolo armênio a base de água. Disponível em: http://manualdoartista.com.br/o-dourado-com-bolo-armenio-base-de-agua/. Acesso em: 06 jan. 2021.

FILIPE, Pedro José Leal. O Anel do Nibelungo: Reinterpretação pictórica da tetralogia de Wagner. 2011. 1 v. Dissertação (Mestrado) - Curso de Comunicação, Cultura e Arte, Estudos da Imagem, Universidade do Algarve, Algarve, 2011.

A FOLHA DE S. PAULO. Caderno Geral, "Laudo IPT determina reforma urgente do Municipal”, p. 21, São Paulo, 8 fev. 1985.

. Caderno llustrada, "A música de concerto não tem onde morar”, p. 31, São Paulo, 19 de março de 1985.

. Caderno llustrada, "Sem Municipal, não tem Bolshoi", p. 39, São Paulo, 21 de março de 1985.

Caderno llustrada, "Projeto de restauração do Municipal já está pronto", p. 4, São Paulo, 28 de março de 1985.

Caderno llustrada, "Uma pobre e triste temporada", p. 39, São Paulo, 1 de maio de 1985.

Caderno Ilustrada, "Sinfônica realizou concerto de protesto", p. 39, São Paulo, 16 de maio de 1985.

. Caderno llustrada, "Cultura musical sem rumo em São Paulo", p. 71, São Paulo, 7 de julho de 1985.

Caderno Cidades, "Teatro Municipal só será reaberto em março de 1987", p. 23, São Paulo, 8 de outubro de 1985.

Caderno llustrada, "Municipal ainda sem verba para o fim das reformas", p. 41, São Paulo, 27 de março de 1986. 
- Caderno Cidades, "Fechado desde 85, Teatro Municipal só deve reabrir em março de 1988”, p. 16, 26 de novembro de 1987.

. Caderno llustrada, "Prefeitura promete municipal em março", p. 51, São Paulo, 17 de dezembro de 1987.

. Caderno llustrada, "Municipal reabre com CZ\$1,2 bi", p. 28, São Paulo, 21 de dezembro de 1987.

Caderno llustrada, "Orçamento alto afasta investidores do Municipal”, p. 40, São Paulo, 22 de dezembro de 1987.

- Caderno Ilustrada, "Protesto contra Sarney marca reabertura do Municipal”, p. 33, São Paulo, 18 de julho de 1988.

. Caderno Cotidiano, "Municipal comemora 80 anos de fundação e o fim da reforme", p. 4, São Paulo, 11 de setembro de 1991.

Caderno Cotidiano, "Pichadores rondam o Teatro Municipal", p. 4, São Paulo, 13 de setembro de 1991.

AGOSTINHO, Victor. Restauração Prometida. A Construção, São Paulo, v. 1, n.2092, p.14-16, mar. 1988. Semanal;

2110, p.8-12, jul. 1988. Semanal.

. Restauração Prometida. A Construção, São Paulo, v. 1,n.

FONSECA, Maria cecilia Londres. O Patrimônio em Processo. Trajetória Política Federal de Preservação no Brasil, Rio de išpepjaneiro, UFRJ/Minc/IPHAN, 1997, pp. 85-146.

GIOVANNONI, Gustavo. Verbete: Restauro dos Monumentos. Cotia, Ateliê, 2013, pp. 191 - 204.

GONÇALVES, Cristiane Souza. Metodologia para a Restauração Arquitetônica. A experiência do Serviço do Patrimônio Histórico e Artístico Nacional em São Paulo, 1937- 1975. São Paulo, FAU/USP, Dissertação de Mestrado, 2004.

HAIKO, Peter. THEATRE ARCHITECTURE OF THE LATE 19TH CENTURY IN CENTRAL EUROPE, 1993, Cracóvia. Public theatre versus court theatre: the Vienna Deutsches Volkstheater of Fellner and Helmer as a model of middle class theatre architecture. Cracóvia: Bibliographie D'Histoire de L'Art, 1993.

INSTITUTO DE PESQUISAS TECNOLÓGICAS. Deteriorização das fachadas. São Paulo, 1983.

Avaliação das obras de arte. São Paulo, janeiro 1984.

.Relatório IPT n. 19.665:

- Proposta de trabalho $n$.

4820/84 - Agosto 1984.

Relatório IPT

n.

19.701:Deteriorização das fachadas. São Paulo, 1984. 
21.441:Vistoria Técnica. São Paulo, janeiro 1985.

.Relatório

IPT

n.

.Relatório Geral de todas as áreas técnicas IPT n. 21.737: Volume I. São Paulo, fevereiro 1985.

JACCOUD JUNIOR, Eduardo Adalberto. Intervenções contemporâneas em patrimônio edificado: obras do arquiteto Nelson Dupré. 2019. 196 f. Dissertação (Arquitetura e Urbanismo) - Universidade Presbiteriana Mackenzie, São Paulo. Disponível em: <http://tede.mackenzie.br/jspui/handle/tede/4054>. Acesso em: 12 ago. 2020.

KATCHVARTANIAN, Soraya Arida. Teatro Municipal de São Paulo: Histórico de Projetos e Análise da Estrutura. 2016. 165 f. Dissertação (mestrado) - Curso de Engenharia, Universidade de São Paulo, São Paulo, 2014. Disponível em: <http://www.teses.usp.br/teses/disponivel/3/3144/TDE - 112953/pt-br.php>. Acesso em: 06 jun. 2017.

KÜHL, Beatriz Mugayar. Observações sobre as Propostas de Alois Riegl e de Max Dvořák para a Preservação de Monumentos Históricos. In: DVORÁK, Max. Catecismo da Preservação de Monumentos. 2. ed. Cotia: Ateliê, 2013. p. 35-57. Perspectiva, 2014.

Observações sobre os Textos de Gustavo Giovannoni Traduzidos nesta edição. In: KUHL, Beatriz (org.). Gustavo Giovannoni: Textos Escolhidos. São Paulo: Ateliê, 2013. p. 11-29.

Cesare Brandi e a teoria da restauração., Pós.

Revista do programa de pós-graduação em arquitetura e urbanismo da FAUUSP, 2007,

n. 21 , pp. $198-211$

Notas sobre a Carta de Veneza. Anais do Museu Paulista, Dez 2010, vol. 18, n. 2, pp. 287-320.

O tratamento das superfícies arquitetônicas como problema teórico da restauração, Anais do Museu Paulista, 2004, v.12, pp. 309330.

Os restauradores e o Pensamento de Camillo Boito sobre a Restauração. In: BOITO, Camillo. Os Restauradores. 4. ed. Cotia: Ateliê, 2014. p. 9-28.

KUHN, João Carlos Santos. Resistências Sagradas: Pátio do Colégio, Secularização e Reconstrução. 2016. 146 f. Dissertação (Mestrado) - Curso de Arquitetura e Urbanismo, História e Fundamentos da Arquitetura e do Urbanismo, Universidade de São Paulo, São Paulo, 2016.

LEMOS, Carlos. Ramos de Azevedo e seu escritório. São Paulo: Pini, 1993.

LONGMAN, Gabriela. Irmãos Campana em clima Art Nouveau: para criar o novo restaurante do teatro municipal, dupla de designers precisou dialogar com a arquitetura histórica. Folha de São Paulo. São Paulo, p. 9-9. 04 jun. 2011. 
LIMA, Valéria Alves Esteves. O Catecismo de Max Dvořák: Algumas notas. In: DVORÁK, Max. Catecismo da Preservação de Monumentos. 2. ed. Cotia: Ateliê, 2013. p. 11-17.

MACHADO, Erika Pereira. A cobertura do Theatro Municipal do Rio de Janeiro: restauração ou reconstrução. 2012. 99 f. Dissertação (Mestrado) - Curso de Preservação do Patrimônio Cultural, Instituto do Patrimônio Histórico e Artístico Nacional, Rio de Janeiro, 2012.

MARCON, Mariana; ALMEIDA, Eneida de. (Orientadora). Patrimônio arquitetônico da industrialização: a intervenção contemporânea no antigo matadouro de São Paulo. São Paulo, 2012. 76 f. Dissertação (mestrado em Arquitetura e Urbanismo) - Universidade São Judas Tadeu, São Paulo, 2012. Disponível em:<http://usjt.br/biblioteca/mono_disser/mono_diss/2013/222.php>. Acesso em: 12 ago. 2020.

MARINS, Paulo Cézar Garcez. O Parque do Ibirapuera e a construção da identidade paulista. Anais do Museu Paulista, São Paulo, v. 6/7, p.9-36, jan. 2003.

Novos patrimônios, um novo Brasil? Um balanço das políticas patrimoniais federais após a década de 1980. Estudos Históricos, Rio de Janeiro, v. 29, n. 57, p.9-28, jan./abr. 2016.

Matadouro de Vila Mariana. CONDEPHAAT. Disponível em: <http://condephaat.sp.gov.br/benstombados/matadouro-de-vila-mariana/>.

Acesso em: 05 jun. 2020.

MAYUMI, Lia. Restauração de Casas Bandeiristas: Experimentações e permanências. Revista Cpc, São Paulo, n. 22, p.62-114, abr. 2017.

. Taipa, canela preta e concreto: um estudo sobre a restauração de casas bandeiristas em São Paulo. 2006. Tese (Doutorado em Estruturas Ambientais Urbanas) - Faculdade de Arquitetura e Urbanismo, Universidade de São Paulo, São Paulo, 2006.

Memorial descritivo dos projetos (obra de reforma do teatro municipal - obra civil - 1. Etapa), novembro de 1985.

Memorial Descritivo do projeto de restauração do TMSP, Departamento do Patrimônio Histórico, 2006.

MÉTODO ENGENHARIA. Caderno de fotografias da primeira fase da obra, 1988 (Relatório disponível no Acervo da Fundação Theatro Municipal de São Paulo).

MONTEIRO, Michelli Cristine Scapol. Fundação de São Paulo, de Oscar Pereira da Silva: trajetórias de uma imagem urbana. 2012. 177 f. Dissertação (Mestrado) - Curso de Arquitetura e Urbanismo, História e Fundamentos da Arquitetura e do Urbanismo, Universidade de São Paulo, São Paulo, 2012. 
MURILHA, Douglas. O Higienismo e a construção dos matadouros e mercados públicos. 2011. 292 p. Dissertação (Mestrado em Urbanismo) - Pontifícia Universidade Católica de Campinas, Campinas, 2011. Disponível em: $<$ http://tede.bibliotecadigital.puc-

campinas.edu.br:8080/jspui/handle/tede/90 >.Acesso em: 12 ago. 2020.

NASCIMENTO, Flávia Brito do. Patrimônio Cultural e escrita da história: a hipótese do documento na prática do Iphan nos anos 1980. Anais do Museu Paulista, São Paulo, v. 24, n. 3, p.121-147, set./dez. 2016.

NUITTER, Charles. Le Nouvel Opéra. Paris: Librairie Hachette, 1875.

OLIVEIRA, Nildo Carlos. A palavra do maestro nesta orquestra que restaura o municipal. Projeto, São Paulo, v. 1, n. 112, p. 66-67, jul. 1988.

PANE, Andrea. Atualidade de Gustavo Giovannoni. In: KUHL, Beatriz (org.). Gustavo Giovannoni: Textos Escolhidos. São Paulo: Ateliê, 2013. p. 3152.

PANE, Roberto. Attualitá e dialettica del restauro. Chieti, 1987.

PATETTA, Luciano. Considerações sobre o Ecletismo na Europa. In: FABRIS, Annateresa (Org.). Ecletismo na arquitetura brasileira. São Paulo: Nobel/ Edusp, 1987. p. 8-27.

PISANI, Maria Augusta Justi e CORRÊA, Paulo Roberto. "Matadouro da Vila Mariana: três intervenções em três décadas (resultados parciais)". In: III Seminário do PGAUR da USJT, 2009.

PISTORESI, Tito Roucht. A reforma do Teatro Municipal de São Paulo. Acrópole, São Paulo, v. 185, n. 16, p.229-232, set. 1953. Disponível em: <http://www.acropole.fau.usp.br/edicao/185>. Acesso em: 08 maio 2017.

. A reforma do Teatro Municipal de São Paulo. Acrópole, São Paulo, v. 187, n. 16, p.329-331, nov. 1953. Disponível em: <http://www.acropole.fau.usp.br/edicao/187>. Acesso em: 08 maio 2017.

.A reforma do Teatro Municipal de São Paulo. Acrópole, São Paulo, v. 189, n. 16, p.419-420, jan. 1954. Disponível em: <http://www.acropole.fau.usp.br/edicao/189>. Acesso em: 08 maio 2017.

QUARENTA, Ednilson Aparecido. O Apóstolo pregresso e as alegorias da fundação: Anchieta, um mito fundador no IV centenário da cidade de São Paulo. 2009. 150 f. Tese (Doutorado) - Curso de História Social, História, Universidade de São Paulo, São Paulo, 2009.

Reforma do Teatro Municipal requer competência e técnica - Projeto (96): 43, fev. 1987. 
Resolução SC 07/85 Tombamento do Matadouro Municipal. Condephaat, 1985.

Resolução SC 49/81. Tombamento do Theatro Municipal de São Paulo. Condephaat, 1981.

REVEL, Jacques. Jogos de escalas: a experiência da microanálise. Rio de Janeiro: Ed. FGV, 1996, p. 14.

REVISTA ACRÓPOLE. São Paulo, jan. 1956. Mensal. Disponível em: <http://www.acropole.fau.usp.br/>. Acesso em: 21 mar. 2019.

Revista Engenharia Municipal (6): 26-7, 1957..

Revista Projeto, n. 112, 1988.

RIBEIRO, David William Aparecido. Uma exposição para o IV Centenário de São Paulo: um historiador português narra a "história bandeirante". Anais do Museu Paulista, São Paulo, v. 26, p.1-65, jan. 2018.

RIEGL, O Culto Moderno dos Monumentos: a sua essência e a sua origem. São Paulo, Perspectiva, 2014.

SANTOS, Cecília Rodrigues dos. Teatro Municipal de São Paulo: caderno de obras. Projeto, São Paulo, v. 1, n. 112, p.52-65, jul. 1988;

1, n. 112, p.46-51, jul. 1988.

Quando a arquitetura era o espetáculo. Projeto, São Paulo, v.

SECRETARIA MUNICIPAL DA CULTURA. O Pano sobe: Exposição Retrospectiva da Obra da Reforma e Restauro do Teatro Municipal. São Paulo; SMC, 1988.

SEGAWA, Hugo. Prelúdio da Metrópole: arquitetura e urbanismo em São Paulo na passagem do século XIX ao XX. São Paulo: Ateliê Editorial, 2004.

SEVERO, R. Monographia do Theatro Municipal de São Paulo. São Paulo: Pocai \& Weiss, 1911.

SCHORSKE, Carl E.. Viena fin-de-siècle: Política e Cultura. Campinas: Editora da Unicamp - Companhia das Letras, 1988.

SILVA, Joelmir Marques da. Restauro e integridade: do concreto ao efêmero. Anais do Museu Paulista, São Paulo, v. 28, n. 1, p. 1-35, jan. 2020.

SILVEIRA, Miroel. Problemas do Teatro Paulista. Folha da Manhã. São Paulo, p. 5.16 maio 1953.

SIMÕES JÚNIOR, José Geraldo. Anhangabaú: história e urbanismo. São Paulo: Editora Senac; Imprensa Oficial do Estado de São Paulo, 2004. 
TEATRO Municipal. Folha da Manhã. São Paulo, p. 7-7. 30 out. 1955.

Teatro Municipal: Nova fachada completa obras. Projeto, São Paulo, v. 1, n. 145, p.82-82, jan. 1991.

TOLEDO, Benedito Lima de. Anhangabahú. São Paulo: Fiesp, 1989.

TURCO, Antonio. Il doratore: doratura--argentatura--platinatura--alluminiatura ... [S.I.]: Ulrico Hoepli Editore. SpA. 61 páginas, 1987.

VILLARQUIDE, A. Alterações, materiais e tratamentos de restauração. Nerea, 2005. P. 366 - 376

WALTER ARRUDA DE MENEZES. Departamento do Patrimônio Histórico. Levantamento/ diagnóstico do estado de conservação dos vitrais do Teatro Municipal de São Paulo. São Paulo, 1981.

WERTHEIMER, Mariana G.; GONÇALVES, Margarete R. F., O processo de produção de vitrais sob a ótica da tradição. Revista $C p c$, São Paulo, v. 1, n. 12, p. 127-149, mai./out. 2011. 


\section{ANEXOS}

\section{ANEXO 1: Cronograma da obra de construção do TMSP}

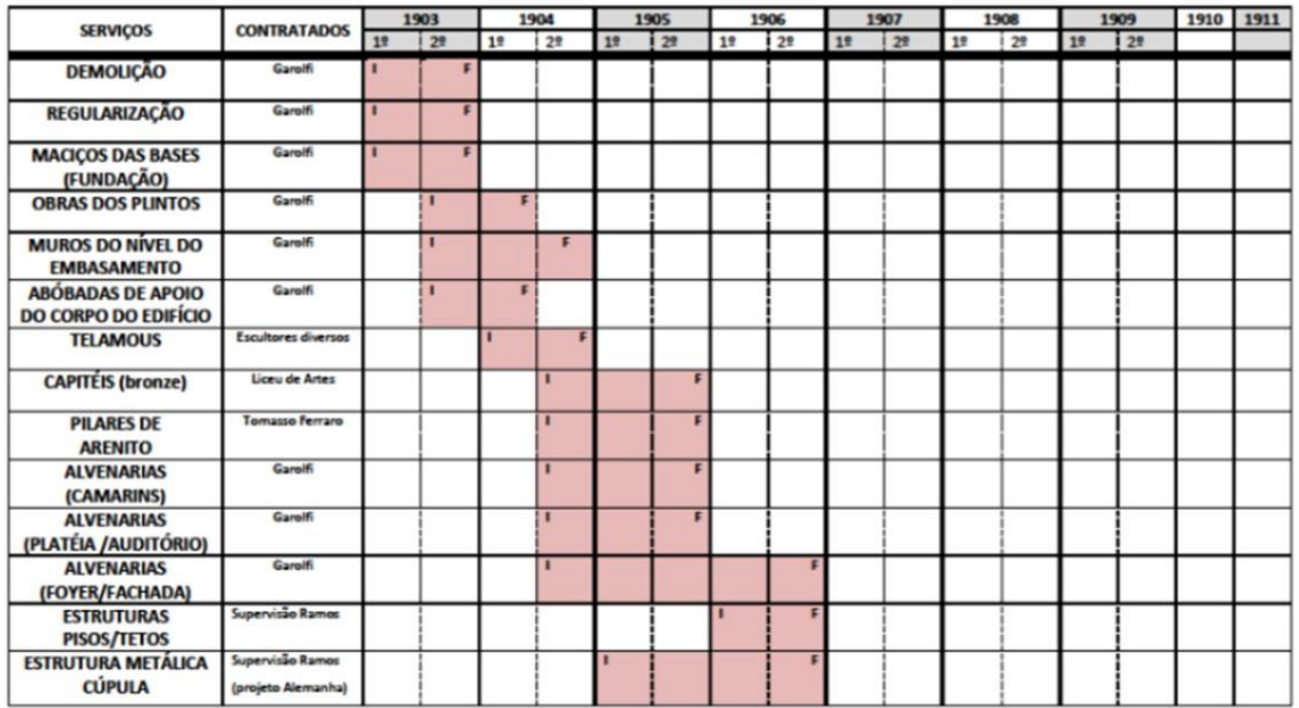

\begin{tabular}{|c|c|c|c|c|c|c|c|c|c|c|}
\hline sernocos & COATRATINOS & $3 \times 01$ & $3 \times 04$ & 1305 & $1 \times 06$ & $3 \times 01$ & $1 \times 00$ & 302 & 190 & 1211 \\
\hline seningos & Contearinous & E & III & II & 11 & 11 & II & E & & \\
\hline ECWOAS LITEM & $\operatorname{sen}$ & & & & & & & & & \\
\hline ECABA Notatit & $\sin$ & & & & & & & & & \\
\hline 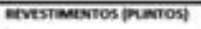 & fomotelens & & & & & & & & & \\
\hline 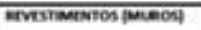 & 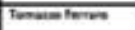 & & & & & & & & & \\
\hline 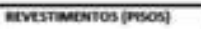 & fonsenteren & & & & & & & & & \\
\hline 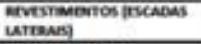 & Tomaneferive & & & & & & & & & \\
\hline 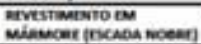 & 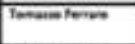 & & & & & & & & & \\
\hline 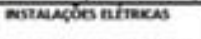 & 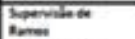 & & & & & & & & & \\
\hline 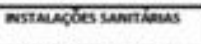 & nombin & & & & & & & & & \\
\hline 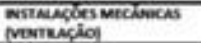 & 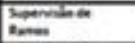 & & & & & & & & & \\
\hline conomplata & orentes & & & & & & & & & \\
\hline कecosents & bonstes & & & & & & & & & \\
\hline morituas & 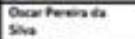 & & & & & & & & & \\
\hline woves & 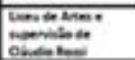 & & & & & & & & & \\
\hline
\end{tabular}

Fonte: KATCHVARTANIAN, 2014. 


\section{ANEXO 2: Ficha técnica da obra de construção do TMSP}

PRESIDENTE DO ESTAD0: Dr. Manuel Joaquim de Albuquerque Lins

PREFEITO DO MUNICIPIO: Barão Raymundo Duprat

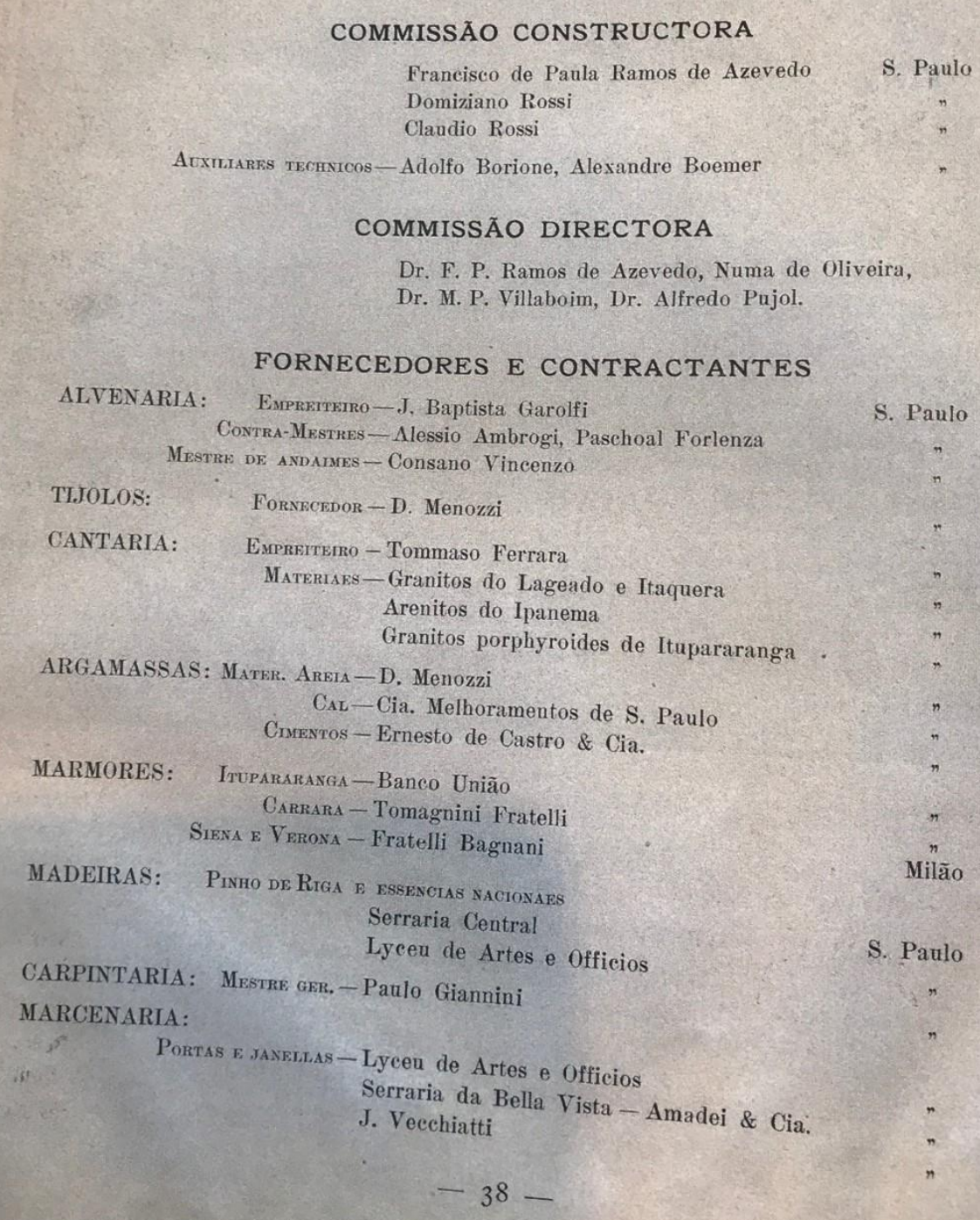




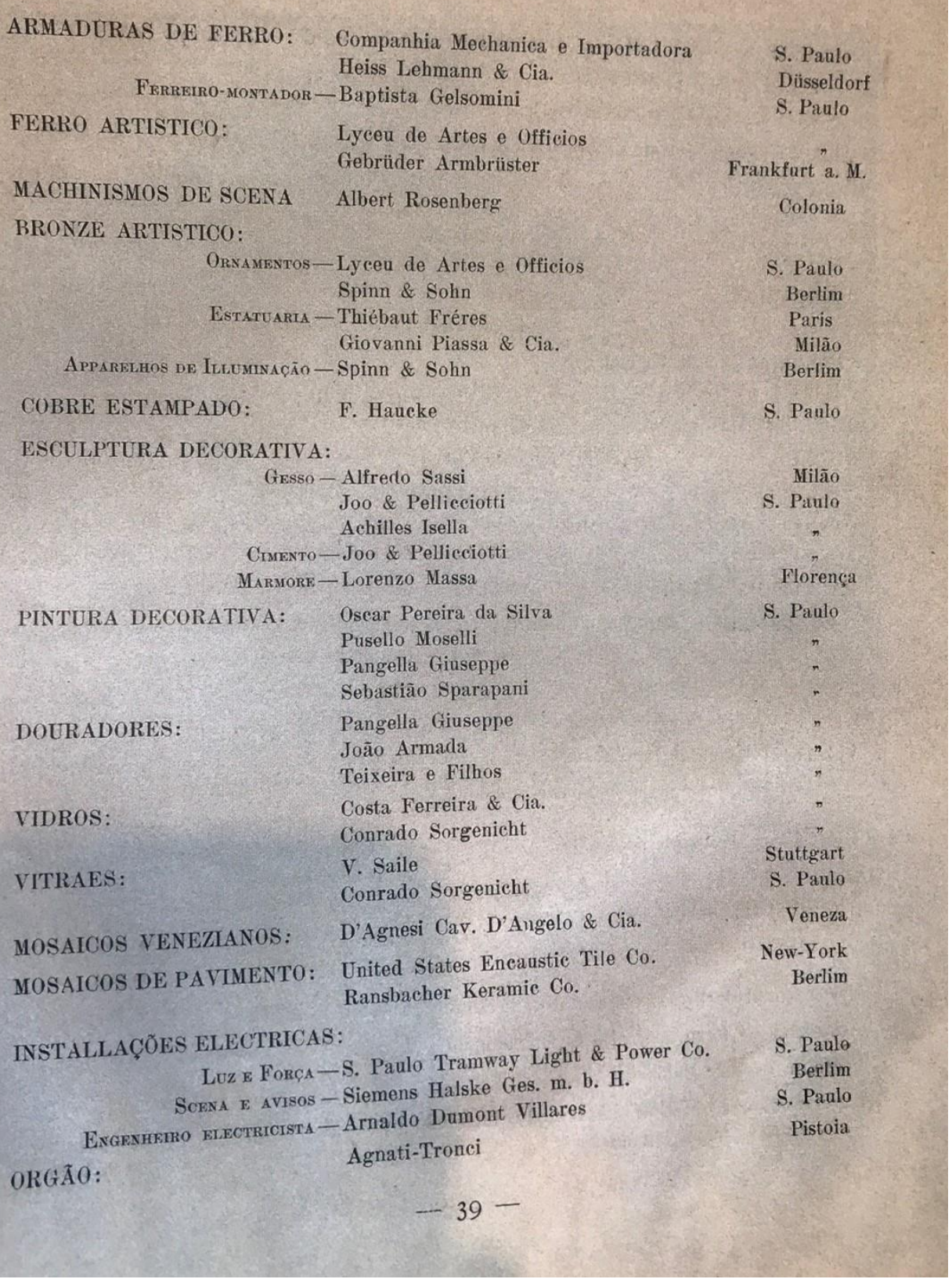


MACHINAS de VENTILAÇÃO: Humboldt Ges. M. b. H.

Frankfurt

"

"REFRIGERAÇÃO

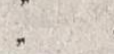

$n$

S. Paulo

PARA-RAIOS: InstaLAADor-- Franciseo Galizio

MOBILIARIO:

Lyceu de Artes e Officios

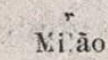

Ducrot \& Cia.

Fratelli Bagnani

Richter Weil \& Via

Frankfurt

s Paulo

Milão

TAPECGARIA:

Solei Hebert \& Cia.

S. Paulo

CANALISAC̣OEES E INSTALLA-

CÕES SANITARIAS: J. Simões

ARMADOR DE SCENA: Celestino Facchini

GUARDA:

Agniello Corvino

\section{SERVIÇOS EXTERIORES}

CANALISACQÃO DE AGUAS E ESGOTOS:

Obras Publicas do Estado

PARQUE E JARDIM:

Obras Publicas da Prefeitura

ILLUMINAÇÃO EXTERNA:

Gaz Systema Auerbach S. Paulo Gas Comp. Ltd.

Electricidade - Systema regenerativo

Tramway Light \& Power Comp. Ltd.

\section{NOTAS DE CONSTRUCÇÃO}

Volume das alvenarias de granito:

Fundacões
Embasamento
Total
Corpo e Coroamento
Total das Alvienarias
Em granto
Em arentto
Total

$2.780 \mathrm{mc}$

2.665

5.445

Volume das alvenarias de tijolo:

Numero total de tijolos empregados, incluindo as obras externas

$\frac{7.680}{13.125}$

Superficies de cantaria

EM GRANITO

$948 \mathrm{mq}$

$\frac{1.804}{2.752}$,

4.500 .000

Armaduras de ferro laminado e perfilado

700 ton.

Peças de ferro fundido

50

Importancia das obras de construeção, incluindo os

serviços da esplanada, réis 
MACHINAS dE VENTILAÇÃO: Humboldt Ges. M. b. H

Frankfurt

- AQUECIMENTO

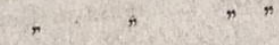

S. Paulo

PARA-RAIOS:

MOBILIARIO:

INSTALLADOR--

Lycen

Ducrot \& Cia.

Fratelli Bagnani

Richter Weil \& Cia

TAPECARIA:

Lyceu de Artes e Officios.

Solei Hebert \& Cia.

Kìào

Frankfurt

S Paulo

Milão

S. Paulo

CANALISACOOEES E INSTALLA-
CÕES SANITARIAS:
J. Simões
ARMADOR DE SCENA:
Celestino Facchini

GUARDA :

Agniello Corvino

\section{SERVIÇOS EXTERIORES}

CANALISACQÃO DE AGUAS E

ESGOTOS:

Obras Publicas do Estado

PARQUE E JARDIM:

Obras Publicas da Prefeitura

ILLUMINAÇÃO EXTERNA:

Gaz Systema Auerbach S. Paulo Gas Comp. Ltd.

Electricidade - Systema regenerativo

Tramway Light \& Power Comp. Ltd.

\section{NOTAS DE CONSTRUCÇÃO}

Volume das alvenarias de granito:

Volume das alvenarias de tijolo:

Superficies de eantaria

Numero total de tijolos empregados, incluindo as obras externa Armaduras de ferro laminado e perfilado

Peças de ferro fundido

Importancia das obras de construeção, incluindo os serviços da esplanada, réis

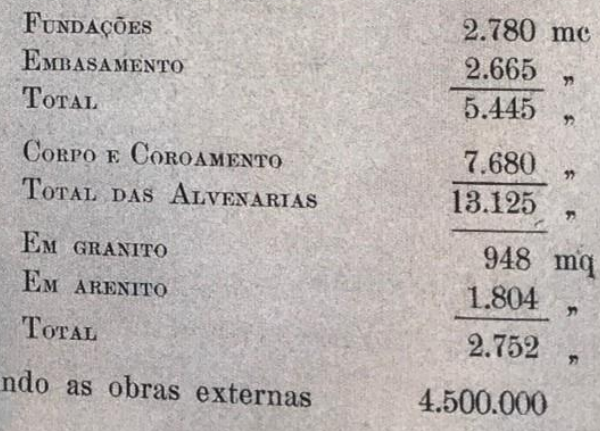

700 ton. 50

4.500:000\$000

Fonte: SEVERO, 1911. 
ANEXO 3: Desenhos técnicos do projeto de 1952-1955

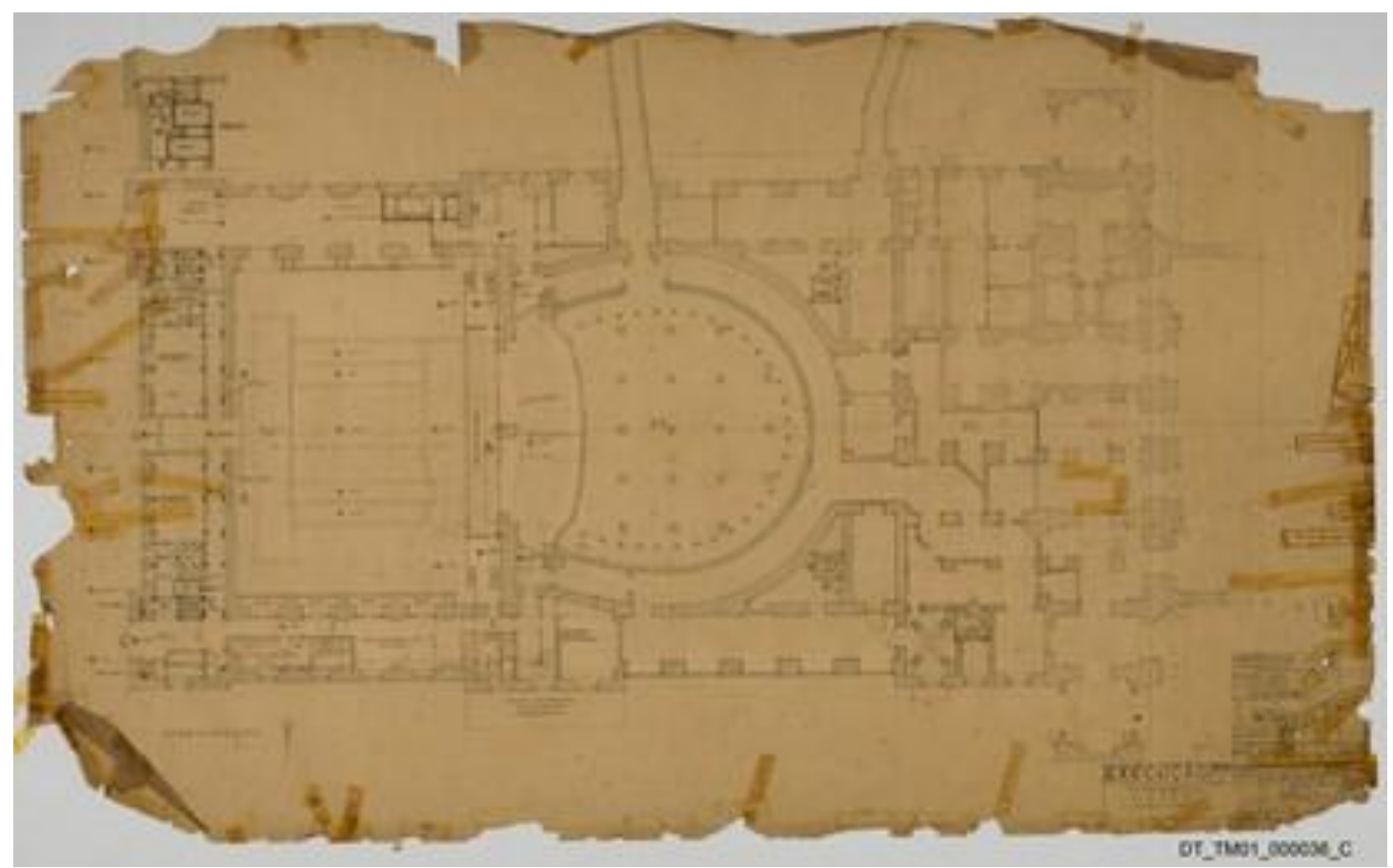

Anexo 3.1:Planta do subsolo.

Fonte: Acervo do Arquivo Histórico Municipal de São Paulo.

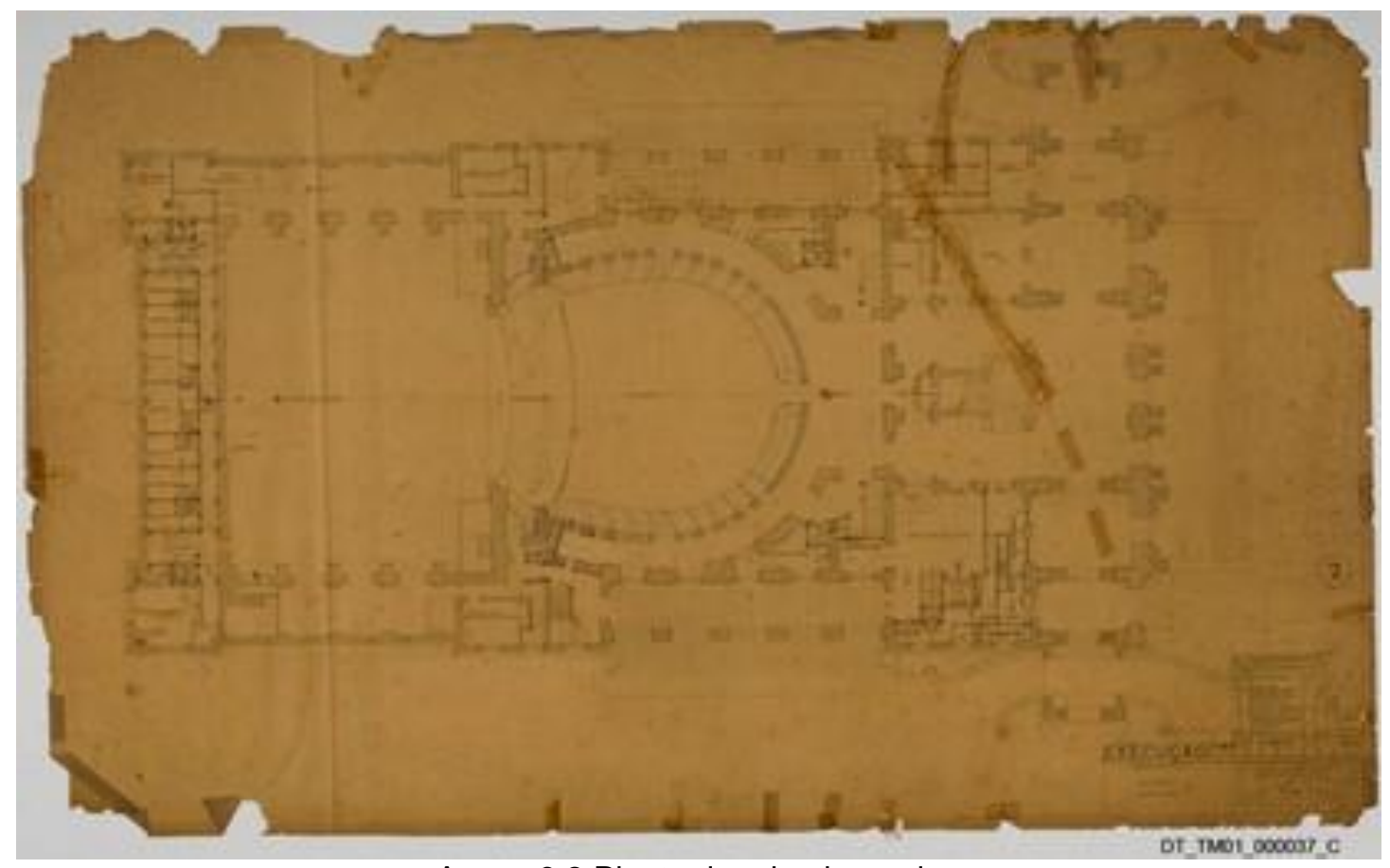

Anexo 3.2:Planta do primeiro andar.

Fonte: Acervo do Arquivo Histórico Municipal de São Paulo. 


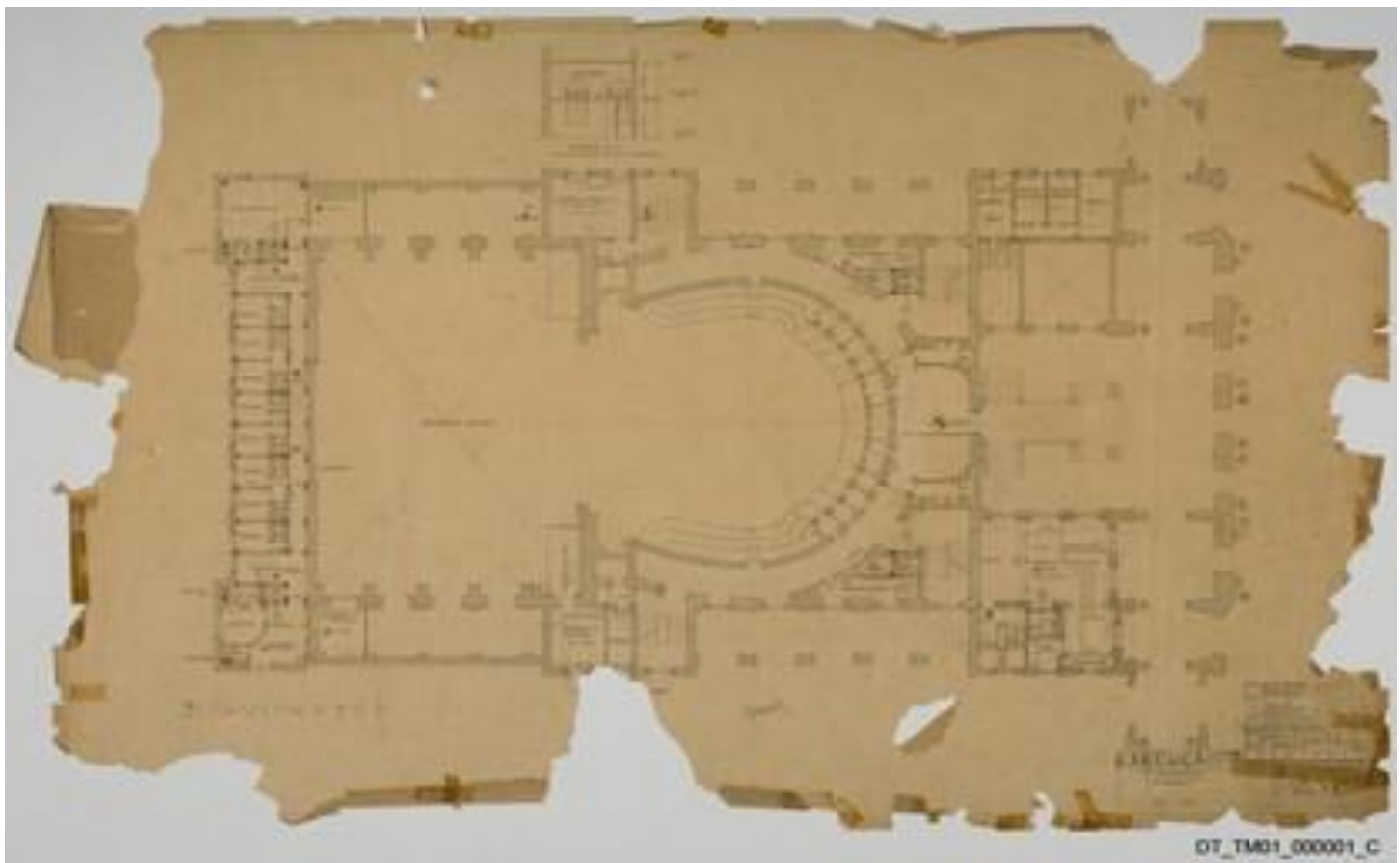

Anexo 3.3:Planta do segundo andar.

Fonte: Acervo do Arquivo Histórico Municipal de São Paulo.

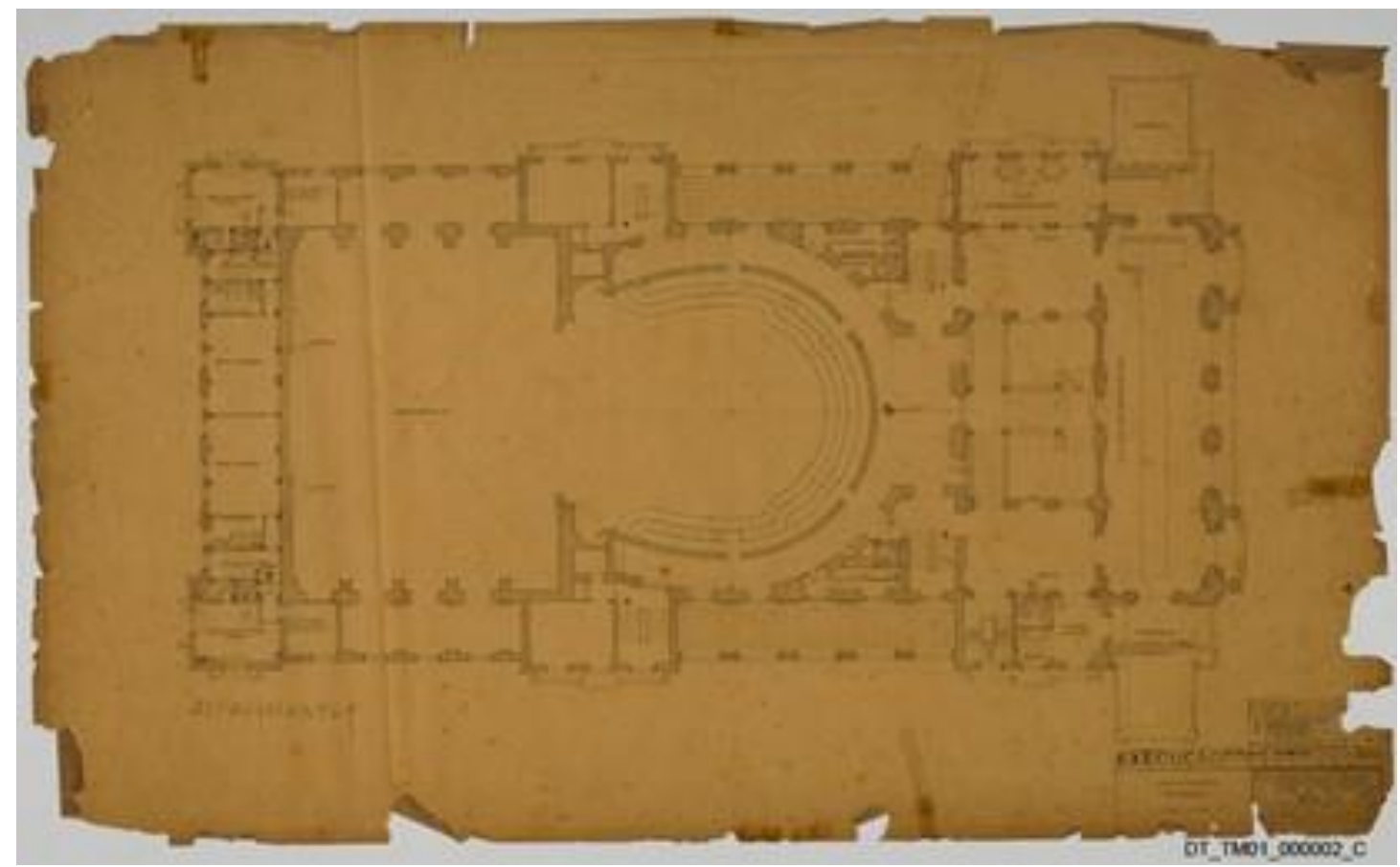

Anexo 3.4:Planta do terceiro andar.

Fonte: Acervo do Arquivo Histórico Municipal de São Paulo. 


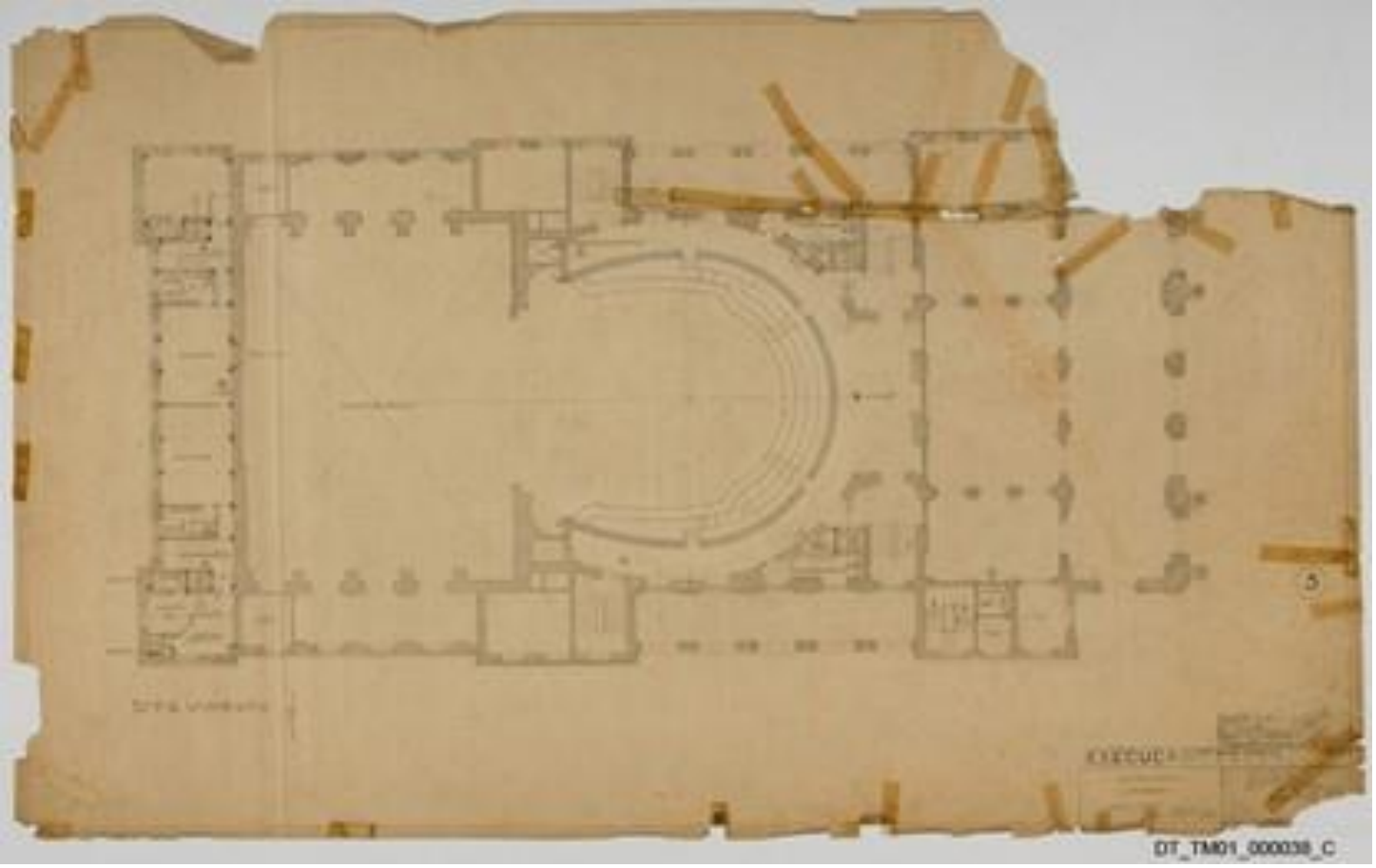

Anexo 3.5: Planta do quarto andar.

Fonte: Acervo do Arquivo Histórico Municipal de São Paulo.

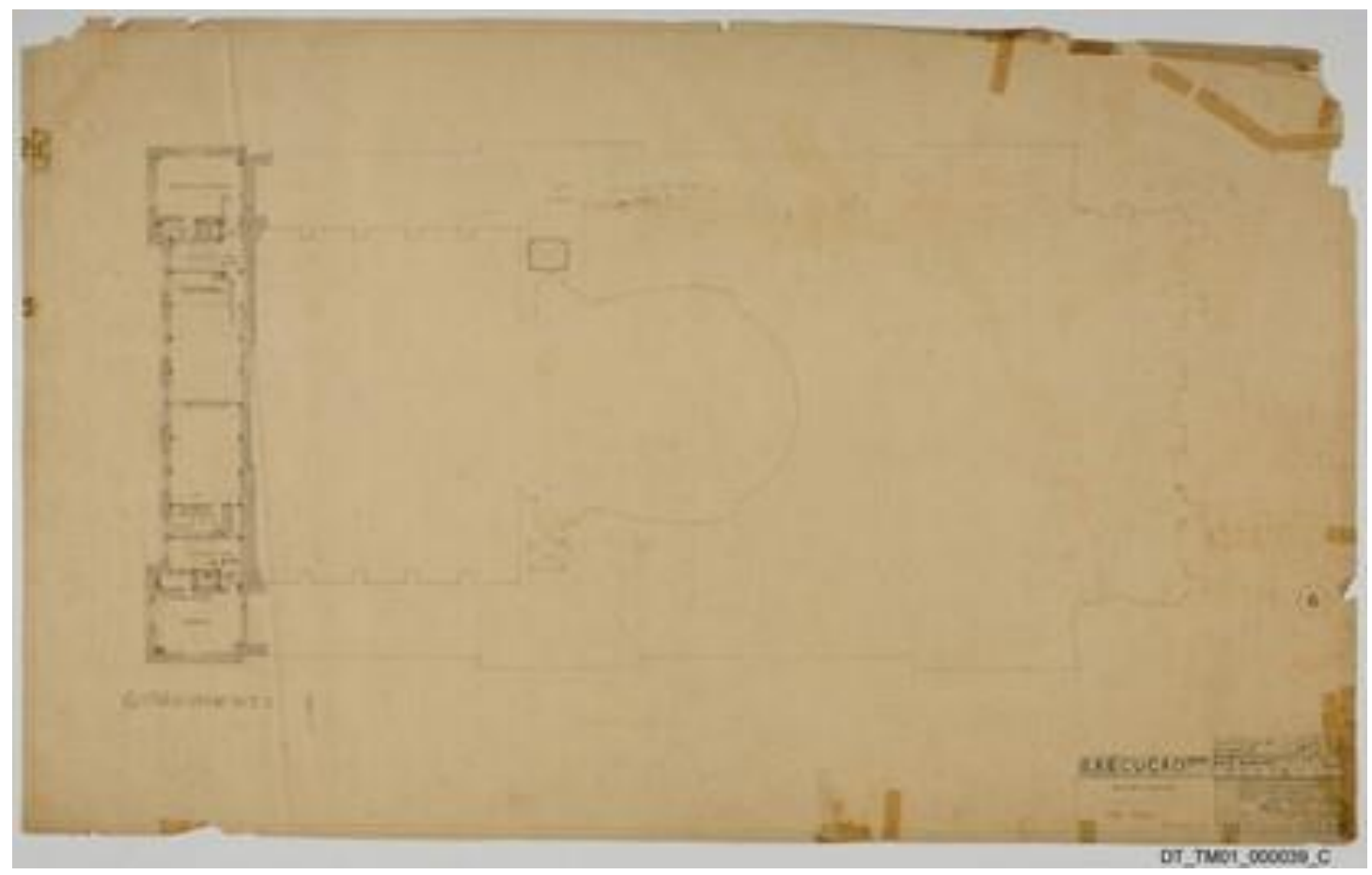

Anexo 3.6: Planta do quinto andar.

Fonte: Acervo do Arquivo Histórico Municipal de São Paulo. 


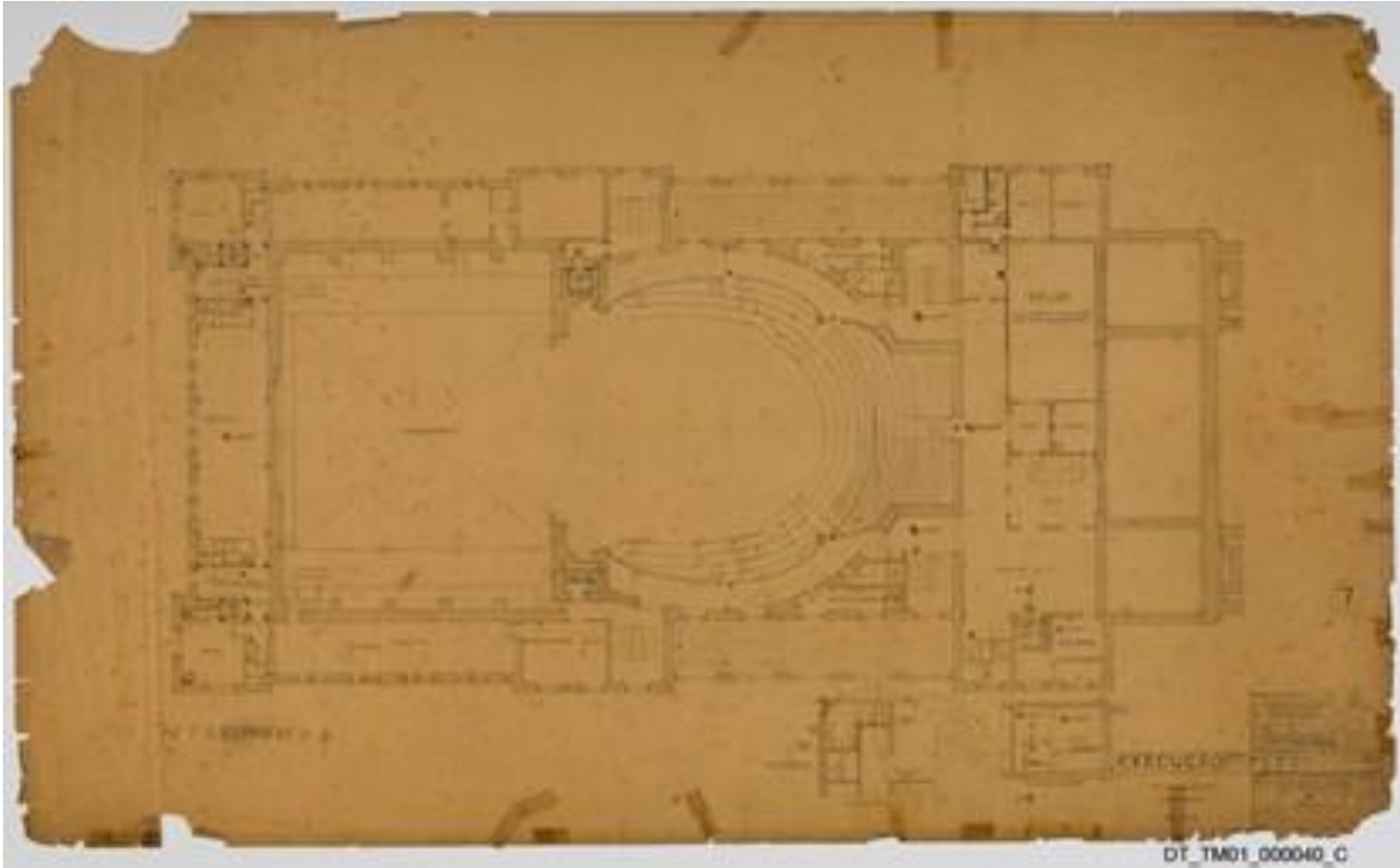

Anexo 3.7 :Planta do sexto andar.

Fonte: Acervo do Arquivo Histórico Municipal de São Paulo.

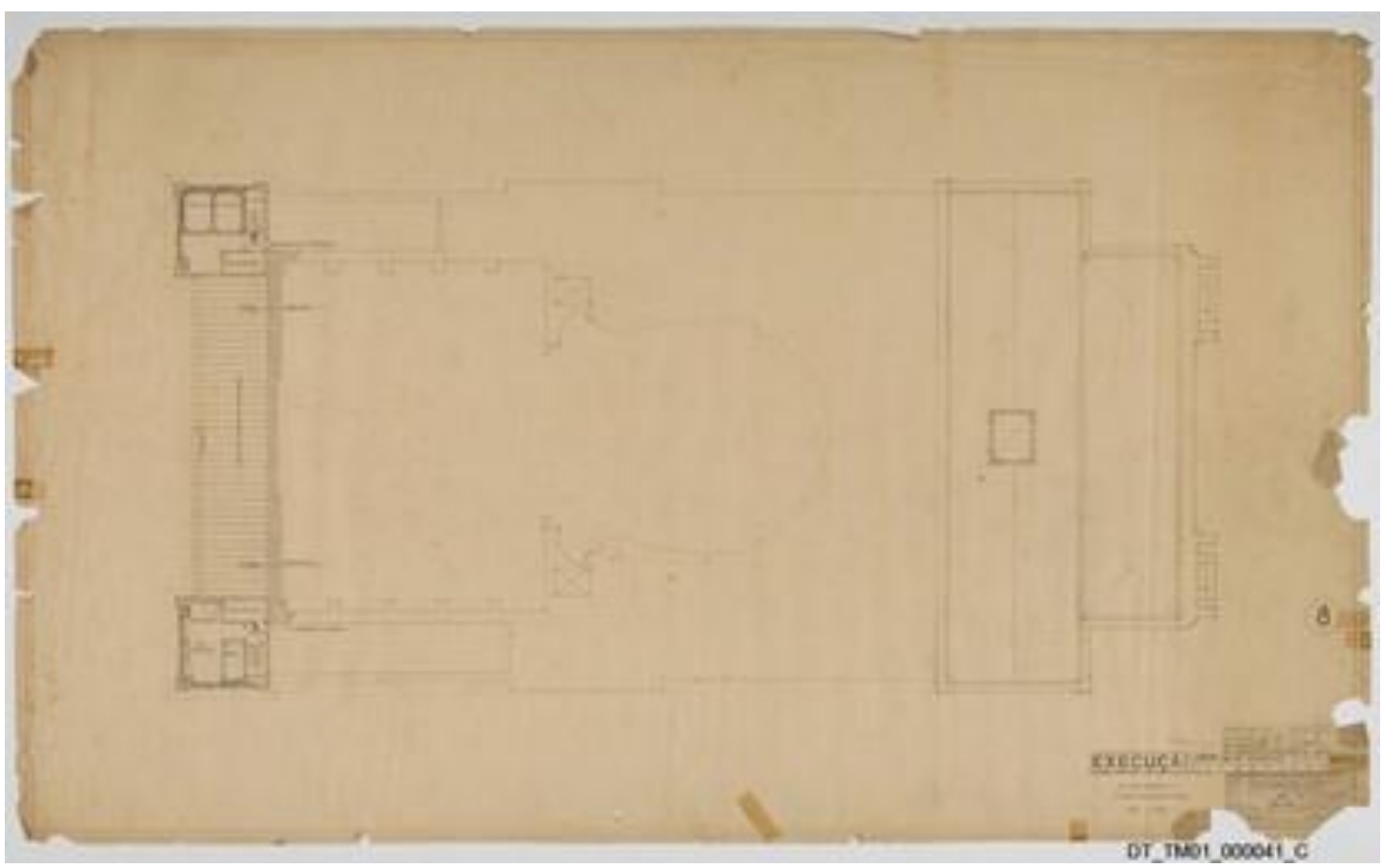

Anexo 3.84:Planta do sétimo andar.

Fonte: Acervo do Arquivo Histórico Municipal de São Paulo. 
ANEXO 4:Desenhos técnicos do projeto de 1988-1991

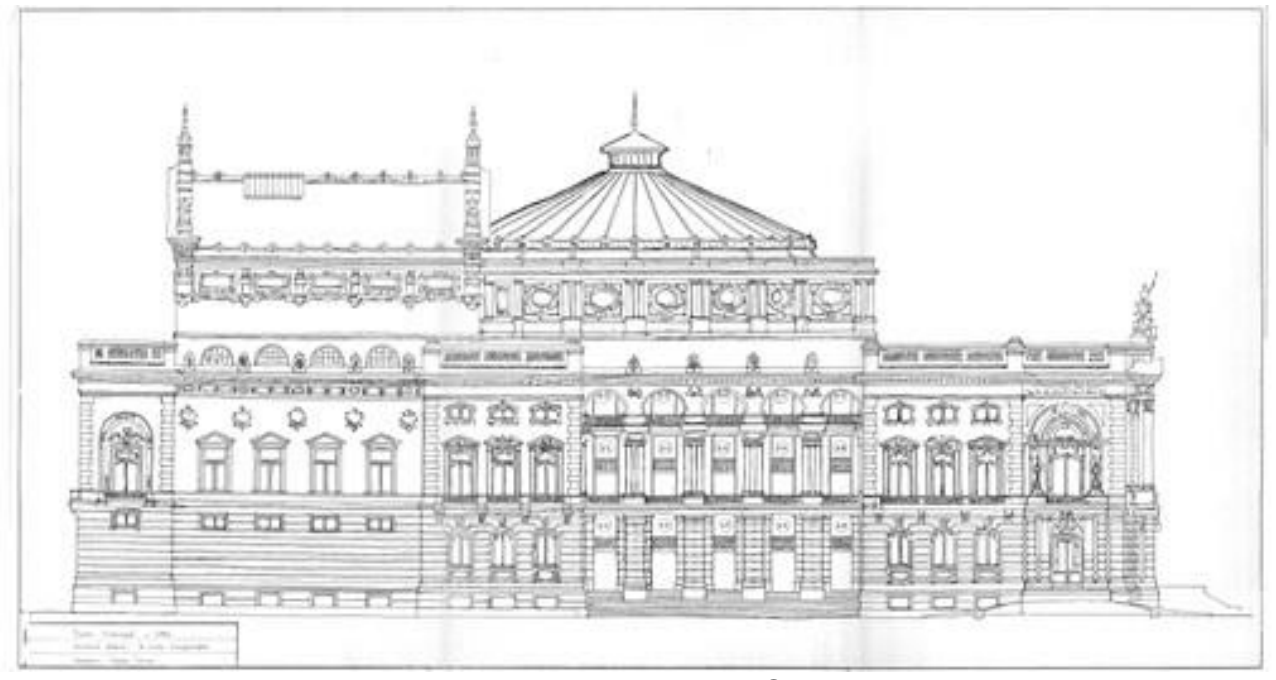

Anexo 4.1: Elevação Oeste

Fonte: Acervo da Fundação Theatro Municipal de São Paulo

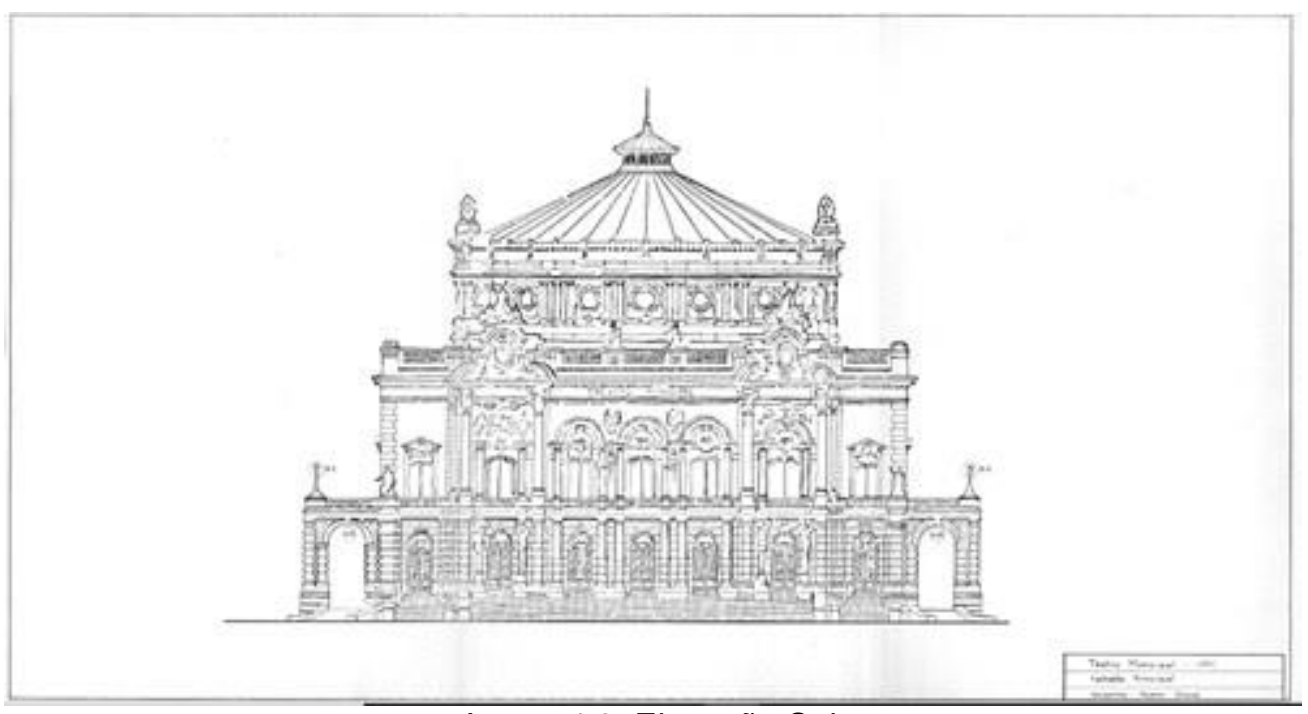

Anexo 4.2: Elevação Sul.

Fonte: Acervo da Fundação Theatro Municipal de São Paulo 


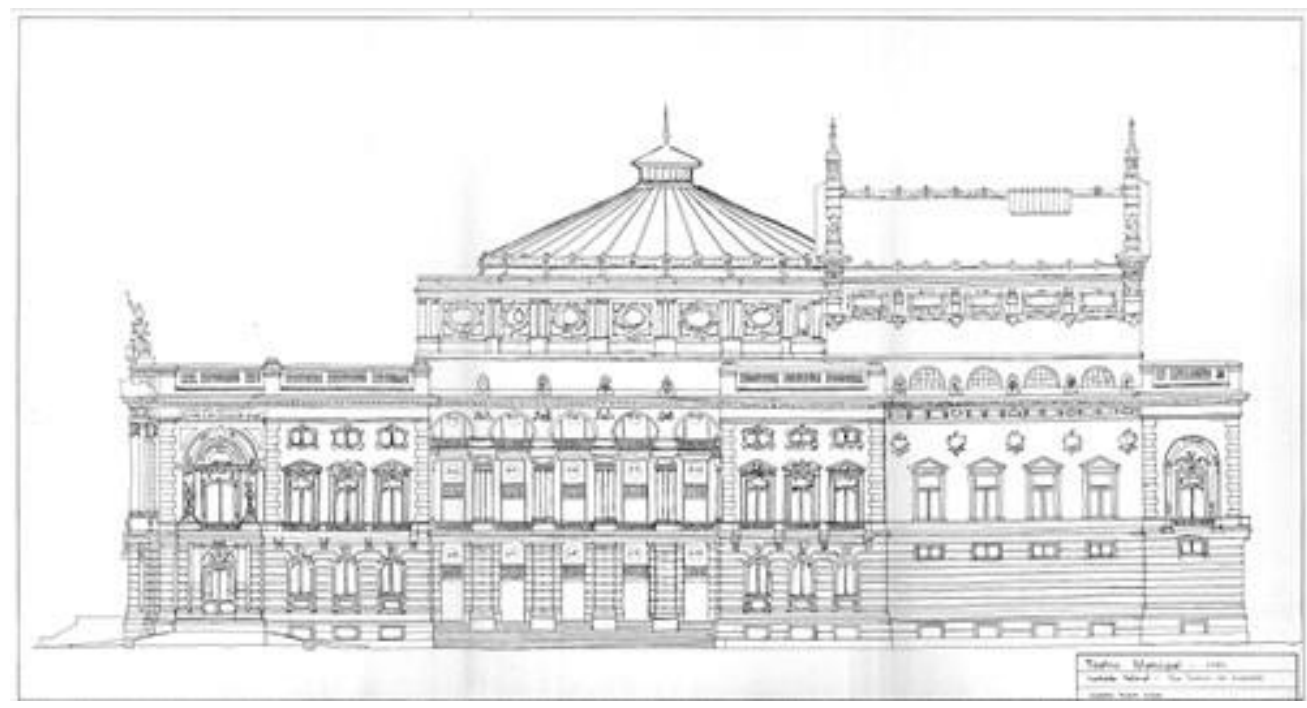

Anexo 4.3 Elevação Leste.

Fonte: Acervo da Fundação Theatro Municipal de São Paulo

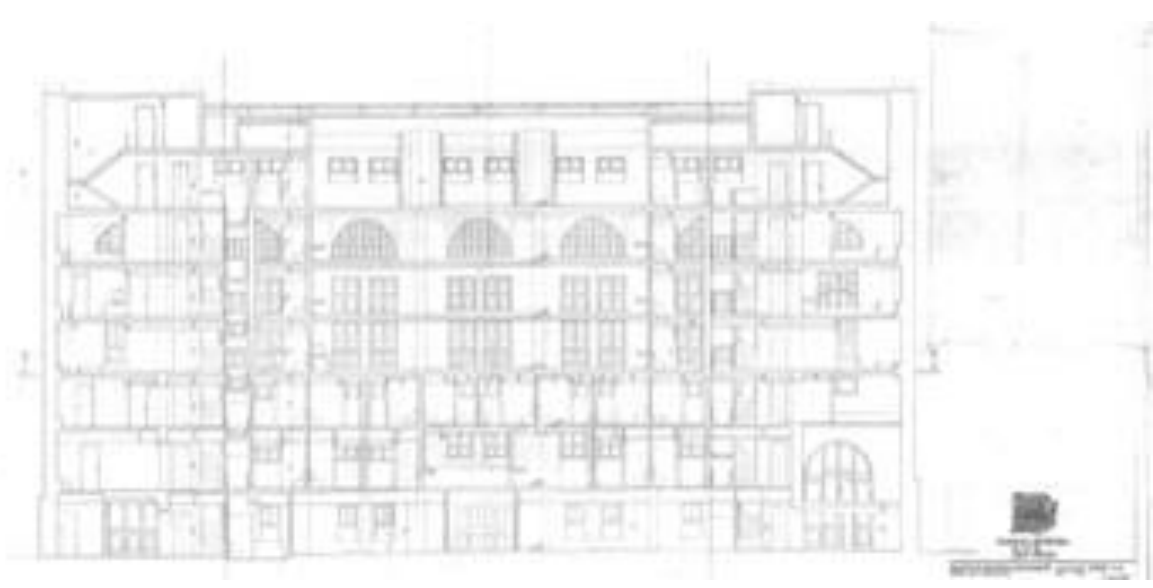

Anexo 4.4: Corte transversal.

Fonte: Acervo da Fundação Theatro Municipal de São Paulo 


\section{ANEXO 5: Ficha técnica da intervenção de 1981 - 1991}

\section{$1980 / 81$}

Projeto de restauração dos vitrais

- DPH - Divisão de preservação: Arq. Maria Luíza Dutra, arq. Luiz Alberto do Prado Passaglia e arq. Walter Arruda de Menezes;

Diagnóstico do estado de conservação das esquadrias externas

- DPH - Divisão de preservação: Arq. Maria Luíza Dutra e arq. Walter Arruda de Menezes;

\section{$1982 / 83$}

Restauração dos vitrais

- DPH - Divisão de preservação + Conrado Vitrais e Cristais: Arq. Maria Luíza Dutra e arq. Walter Arruda de Menezes;

Descupinização geral

- IPT - Divisão de Madeiras

Diagnóstico do estado de conservação das fachadas e propostas de tratamento

- IPT: Arq. Ricardo Flores (coordenador);

- Orientação DPH: arq. Maria Luíza Dutra, bióloga Cleide Aparecida José, arq. Evelyn Eboli, Lourdes Blanes Teixeira, Maximiliano Peregrina e Walter Arruda de Menezes;

Plano preliminar de obras de reforma e restauro

- TMSP;

- DPH - Divisão de Preservação: Arq. Maria Luíza Dutra, Lúcia Soeiro do Nascimento, Walter Arruda de Menezes, Evelyn Eboli, Lourdes Blanes Teixeira, Maximiliano Peregrina;

\section{$1984 / 85$}

Diagnóstico do estado de conservação geral

- IPT: Arq. Ricardo Flores (coordenador);

$1985 / 86$

Levantamento fotogramétrico das fachadas

- Execução: Terrafoto ;

- Orientação: DPH - Divisão de preservação: Arq. Maria Luíza Dutra, historiadora Maria Lúcia Perrone, arquitetos David Ventura, Fernando Martinelli, Cássia Magaldi, Lourdes Blanes, Lucinda Prestes e Rosana Gornatti;

$\underline{\text { Primeiro projeto de restauração das fachadas }}$ 
- DPH- Divisão de Preservação: Maria Lucia Perrone;

- Seção de Laboratório de Restauro: Walter Arruda de Menezes;

- Seção Técnica de Projetos, Restauro e Conservação: Lúcia Soeiro do Nascimento;

\section{Primeiro projeto de restauro, reforma e conservação}

- PMSP/ SMC: Coordenação geral: engenheiro Oswaldo Aly;

- DPH-Divisão de Preservação: Projeto de Aquitetura - Maria Lúcia Perrone, Maria Luíza Dutra;

- Coordenação arq. Tereza Katinsky;

- Equipe: arquitetos Ana Beatriz Galvão, Cássia Magaldi, Evelyn Eboli, Fernando Martinelli, Lourdes Blanes, Marco Antônio Winther, Paulo Del Picchia;

- Desenhistas: José Queijo Félix, Ronaldo de Souza Geraldo;

- Estagiários: Carlos Warchavchic, Eduardo Docema, Gerson Bilezikjian, Rita Salem, Rosângela Piments;

- Participação posterior: arquietos Celso Eduardo Ono, José Oswaldo de Araújo Vilela, Mauro tadeu Sanchez, Maximiliano Peregrina, eng. Maria Raquel Angelini, Monica Citti de Paula, Márcia Tuyako;

- Acústica: Igor Scerezinsky;

- Ar-condicionado: Thermoplan Engenharia Térmica;

- Cenotécnica: Aldo Calvo Consultor Cenotécnico;

- Estruturas: Escritório Técnico Feitosa e Cruz;

- Instalações Elétricas e hidráulicas: Eurico Freutas Marques;

\section{$1987 / 88$}

\section{Projeto executivo e acompanhamento das obras}

- Coordenação: arquitetos Maria Luíza Dutra e Walter Arruda Menezes;

- Projeto de arquitetura: arquitetos Lacy Mitico Andrade, Lia Mayumi, Lilian Jaha, Normando José Martinez Santos e artista plástico Ronaldo de Souza Geraldo;

- Projeto de valorização do entorno: arquitetos Silvana Pitombo Bixilia, Eduardo de Oliveira Elias e Rosana Pierri;

- Documentação: historiadora Patrícia Servilha;

- Estagiários de arquitetura: Rosana Navarro, Vera Wilheim;

- Auxiliar de restauração: R. Félix Pereira;

- Departamento de teatros;

- Cenotécnica: Antônio Campos;

- Ar-condicionado: Thermoplan Engenharia Térmica;

- Cenotécnica: Aldo Calvo Consultor Cenotécnico;

- Estruturas metálicas: Jorge Kurkdjian - Escritório Técnico Azevedo Noronha;

- Orçamentos e fiscalização: Secretaria de Serviços e Obras do Departamento de Edificações;

- Coordenação: engenheiro Aparecido Pires; 
- Orçamentos: engenheiro Francisco Luiz Tori;

- Fiscalização: engenheiro W. de Oliveira e Uraci Cavalcante de Lima;

- Execução: Método Engenharia

- Diretor de obras: eng. Ricardo Solera;

- Superintendente da obra: eng. Marcelo Mendes Rodrigues;

- Engenheiros residentes: H. Manole Videira Rodrigo e R. Prado Scuoppo;

- Engenheiro da obra: Arthur Traldi;

- Engenheiro de instalações: Bianco Júnior;

- Engenheiro de planejamento: César Jorge Malouf;

- Encarregado administrativo: Severino Ferreira da Silva;

- Mestre de obras: Benedito Marcolino da Silva;

- Consultores: Semeghini Arquitetos, Oficina de Projetos Solé e Castro, Escritório Técnico Feitosa e Cruz e Falcão Bauer;

Fonte: Elaborada pela autora 
ANEXO 6: Desenhos técnicos do projeto de 2006-2011

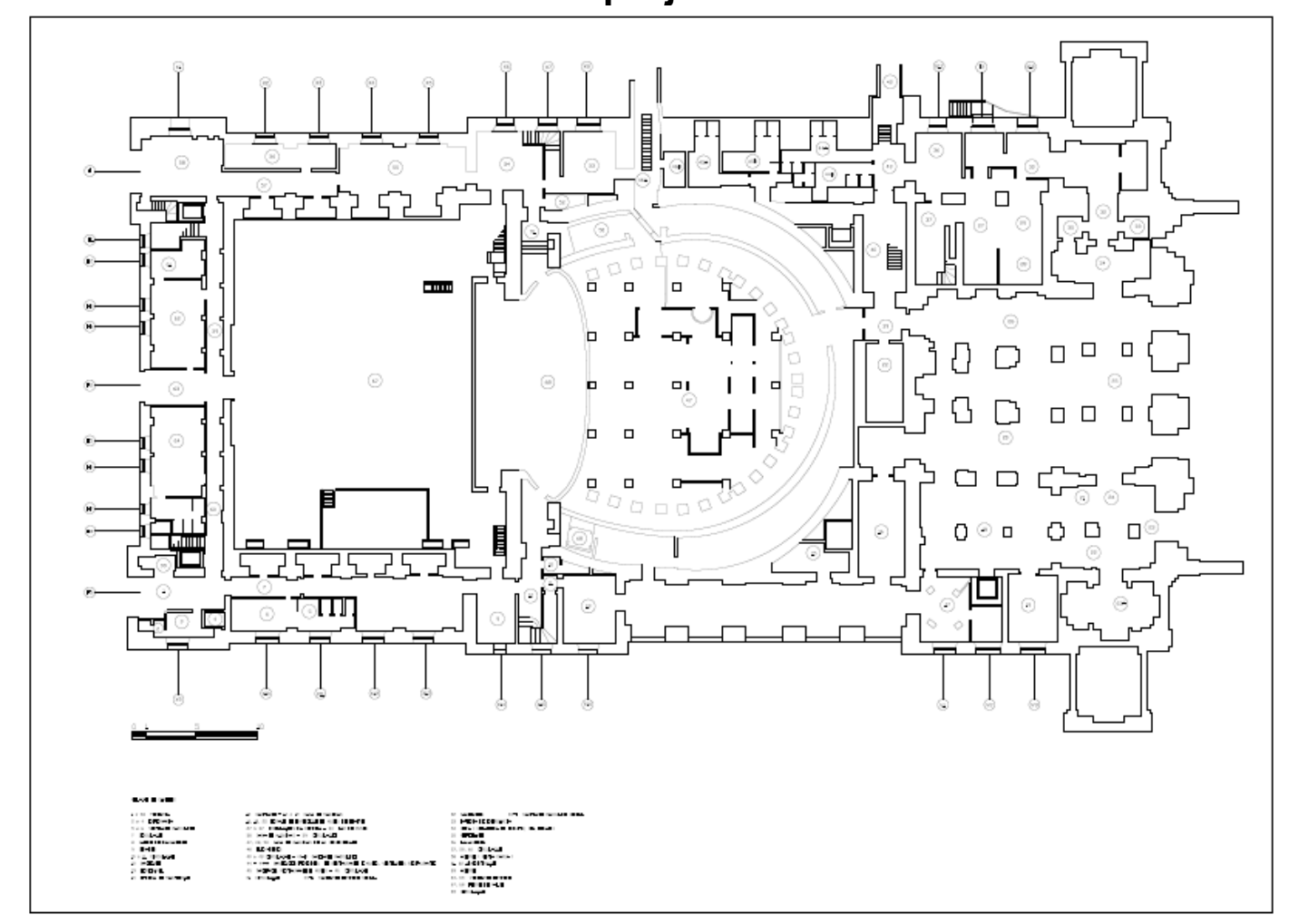

Anexo 5.1: Planta do subsolo.

Fonte: Acervo da Fundação Theatro Municipal de São Paulo.

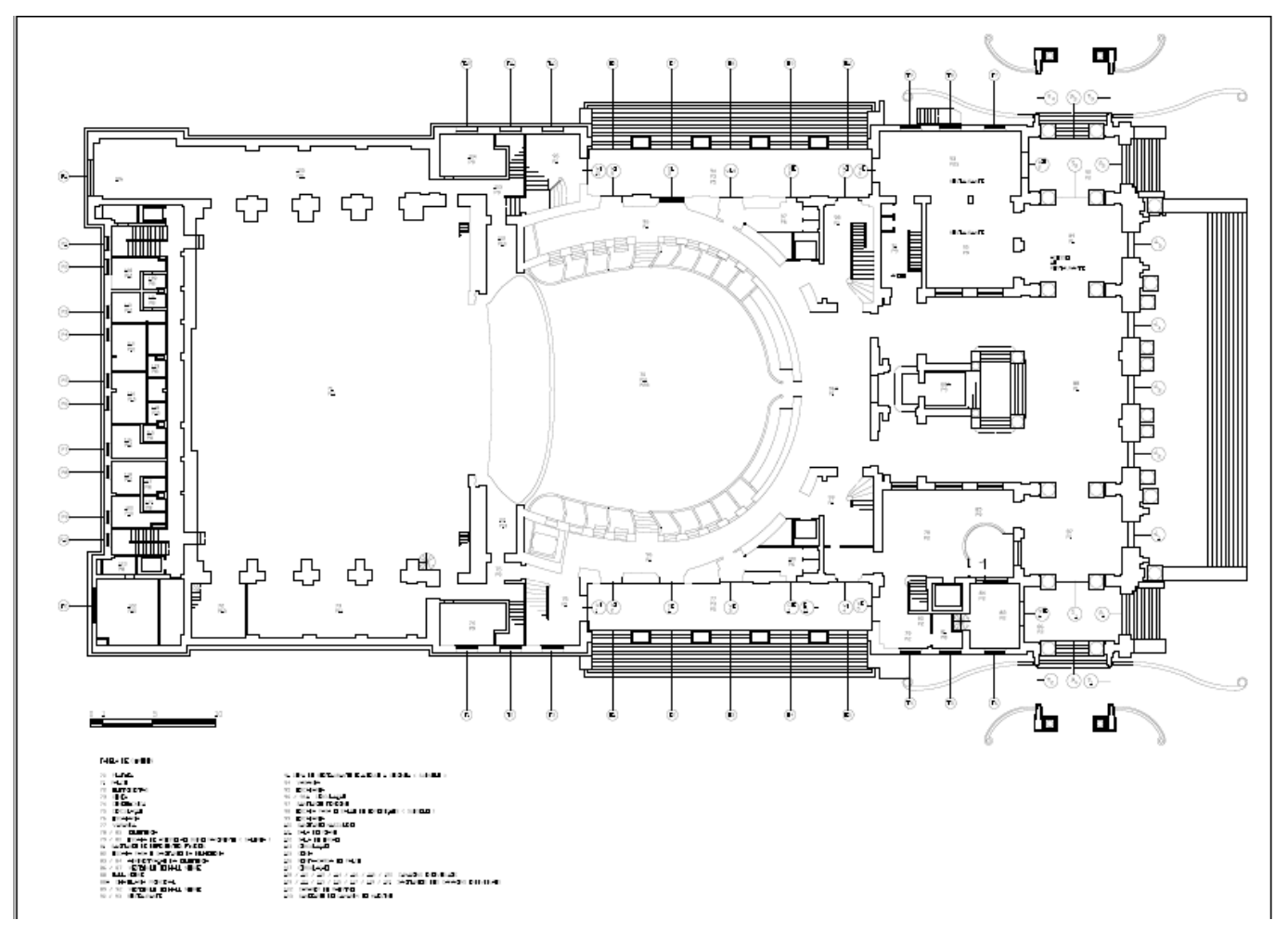

Anexo 5.2: Planta do primeiro andar.

Fonte: Acervo da Fundação Theatro Municipal de São Paulo. 

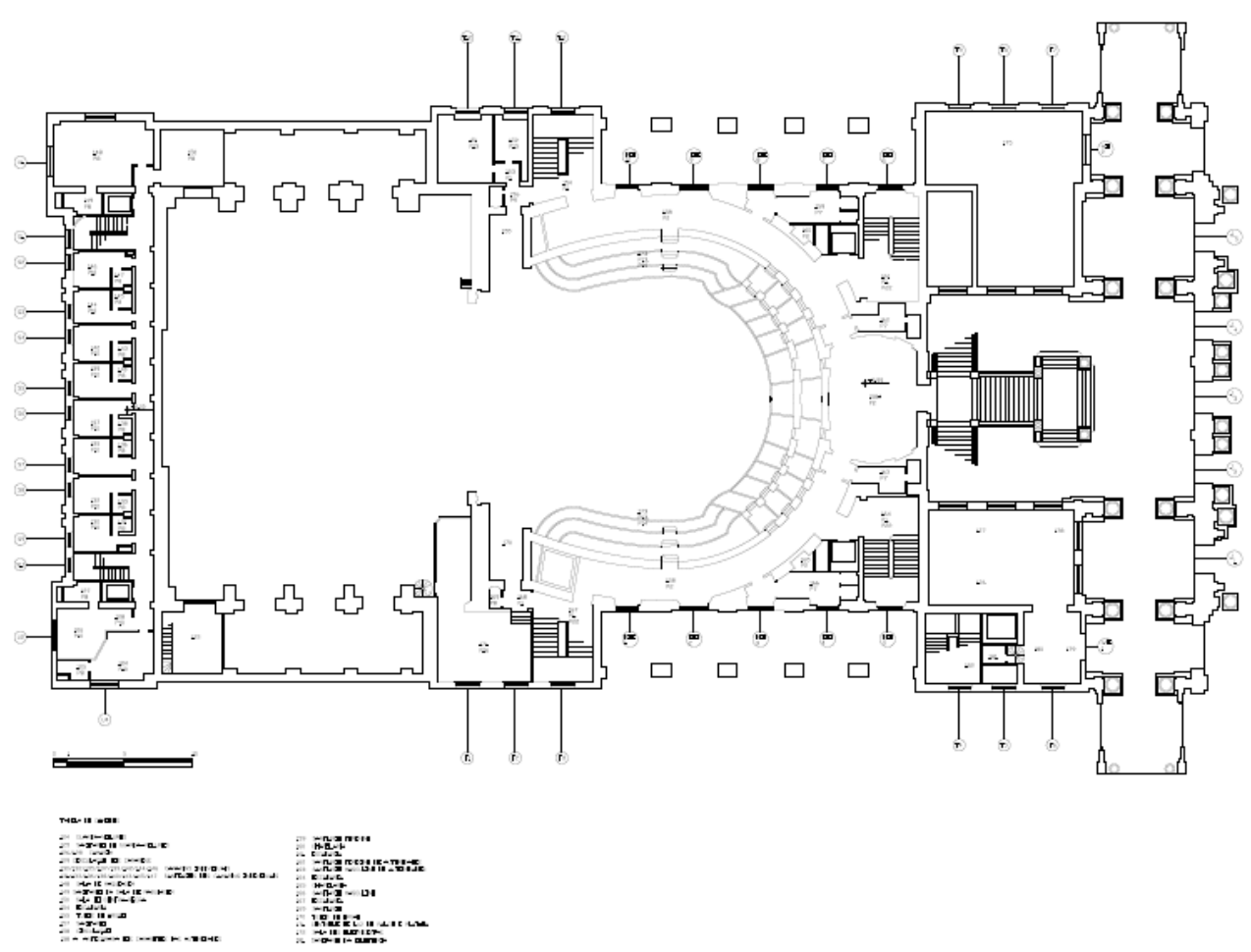

Anexo 5.3: Planta do segundo andar.

Fonte: Acervo da Fundação Theatro Municipal de São Paulo.

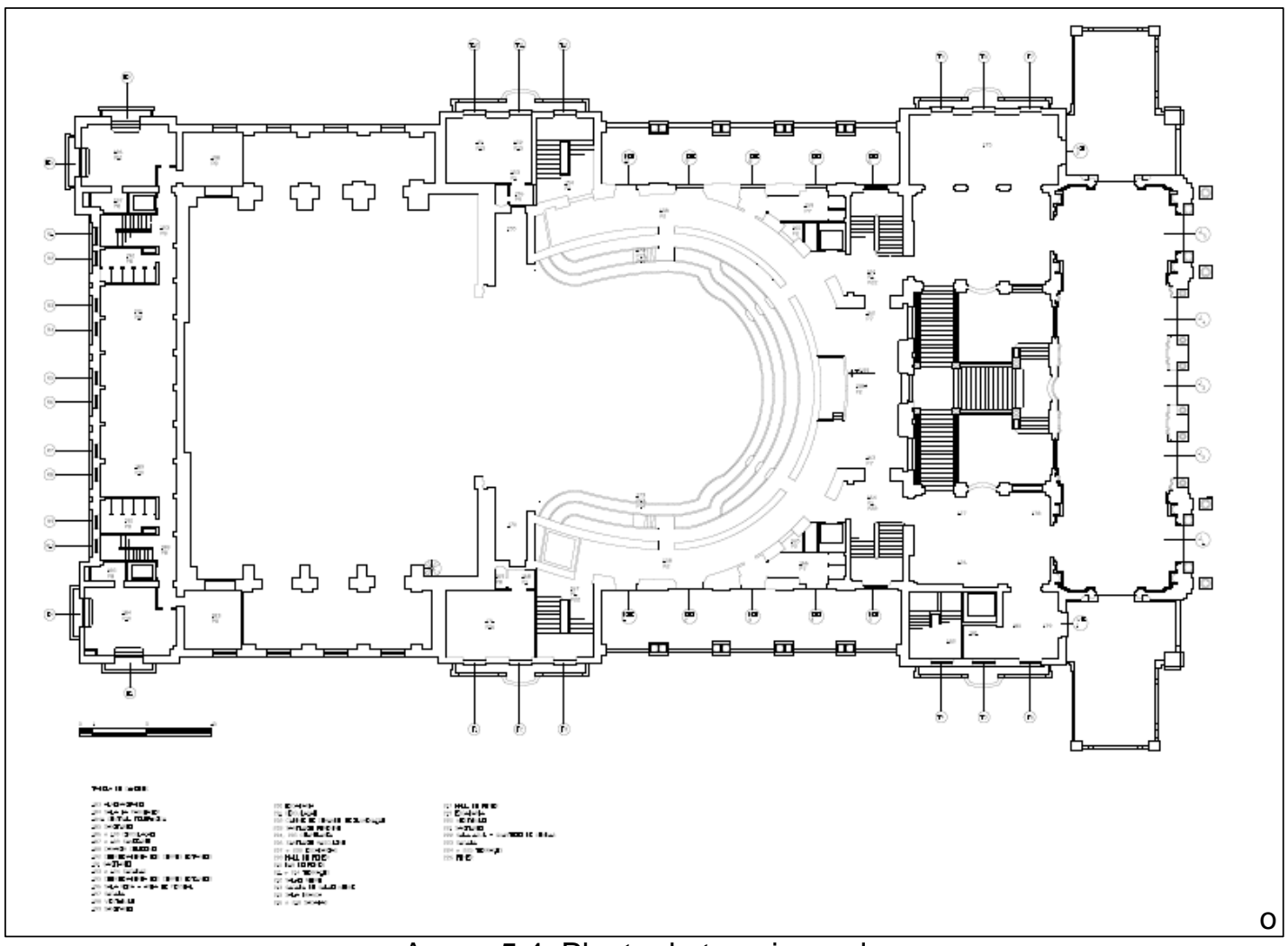

Anexo 5.4: Planta do terceiro andar.

Fonte: Acervo da Fundação Theatro Municipal de São Paulo. 


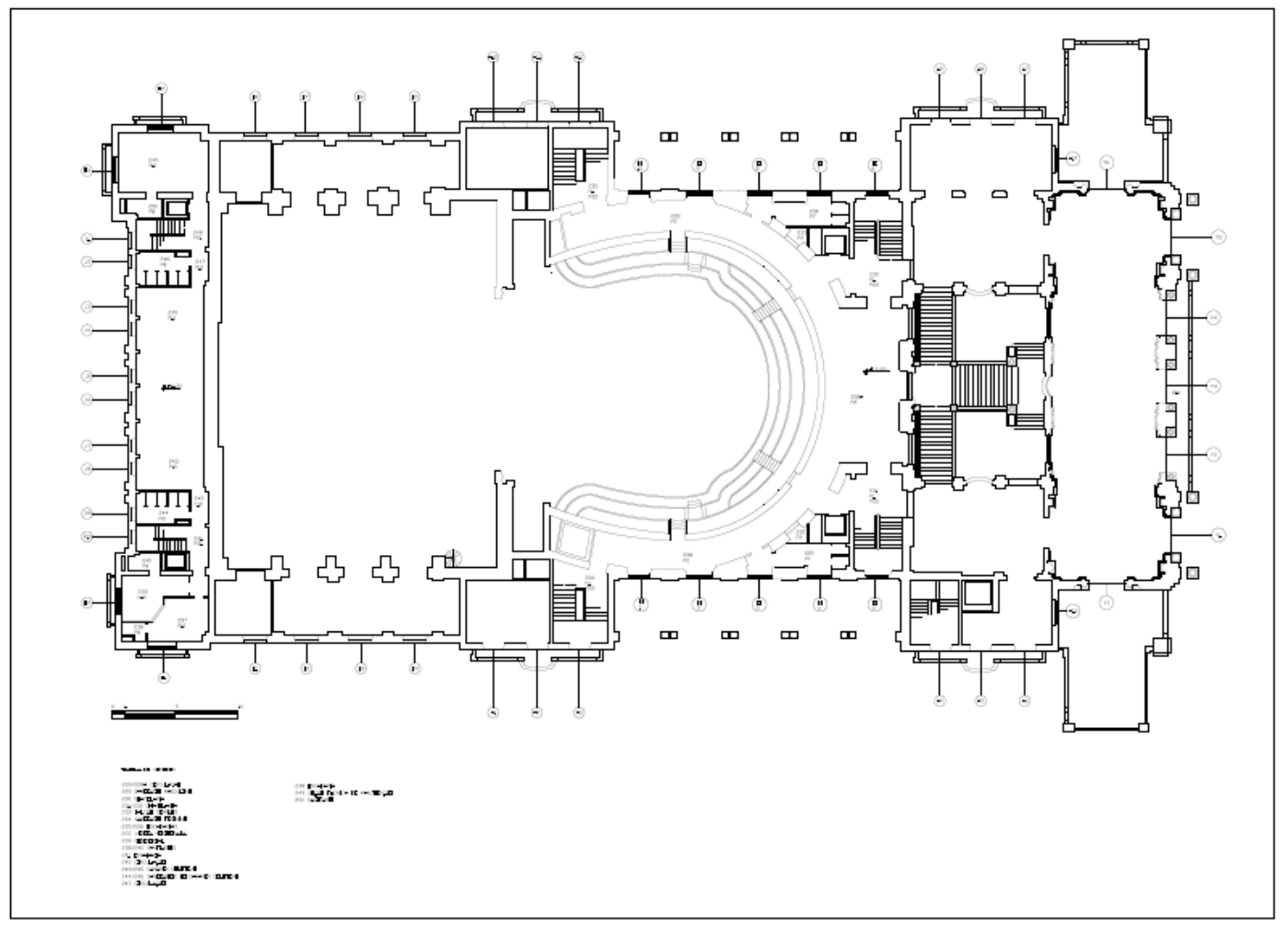

Anexo 5.5: Planta do quarto andar.

Fonte: Acervo da Fundação Theatro Municipal de São Paulo.

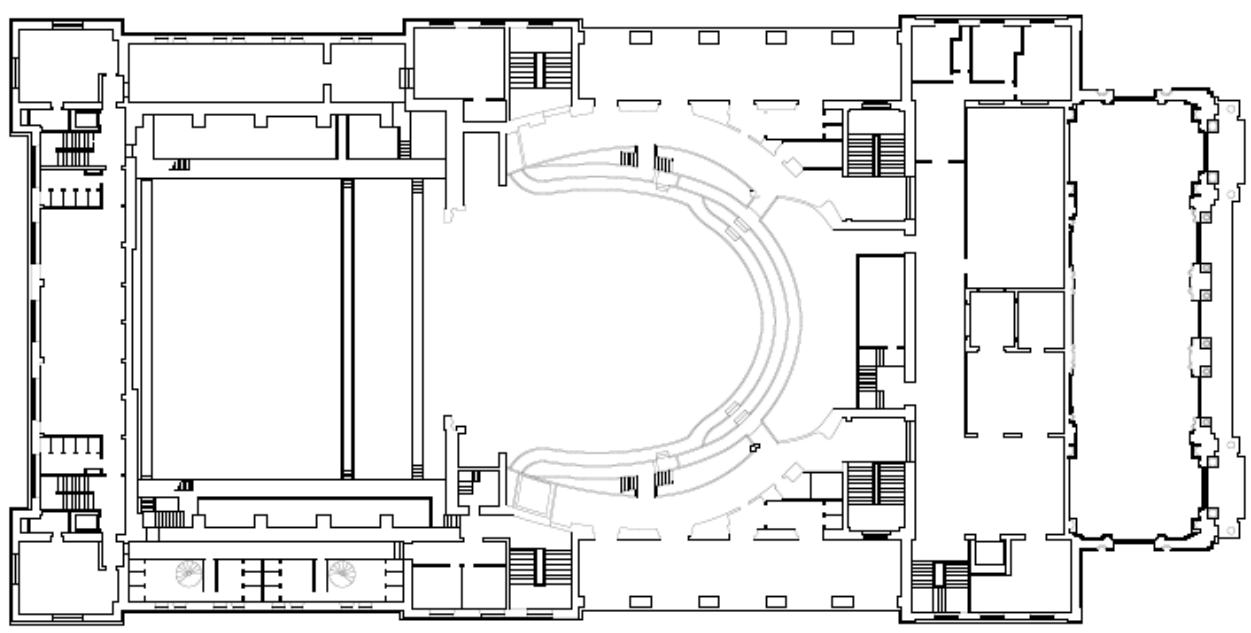

Anexo 5.6: Planta do quinto andar.

Fonte: Acervo da Fundação Theatro Municipal de São Paulo. 


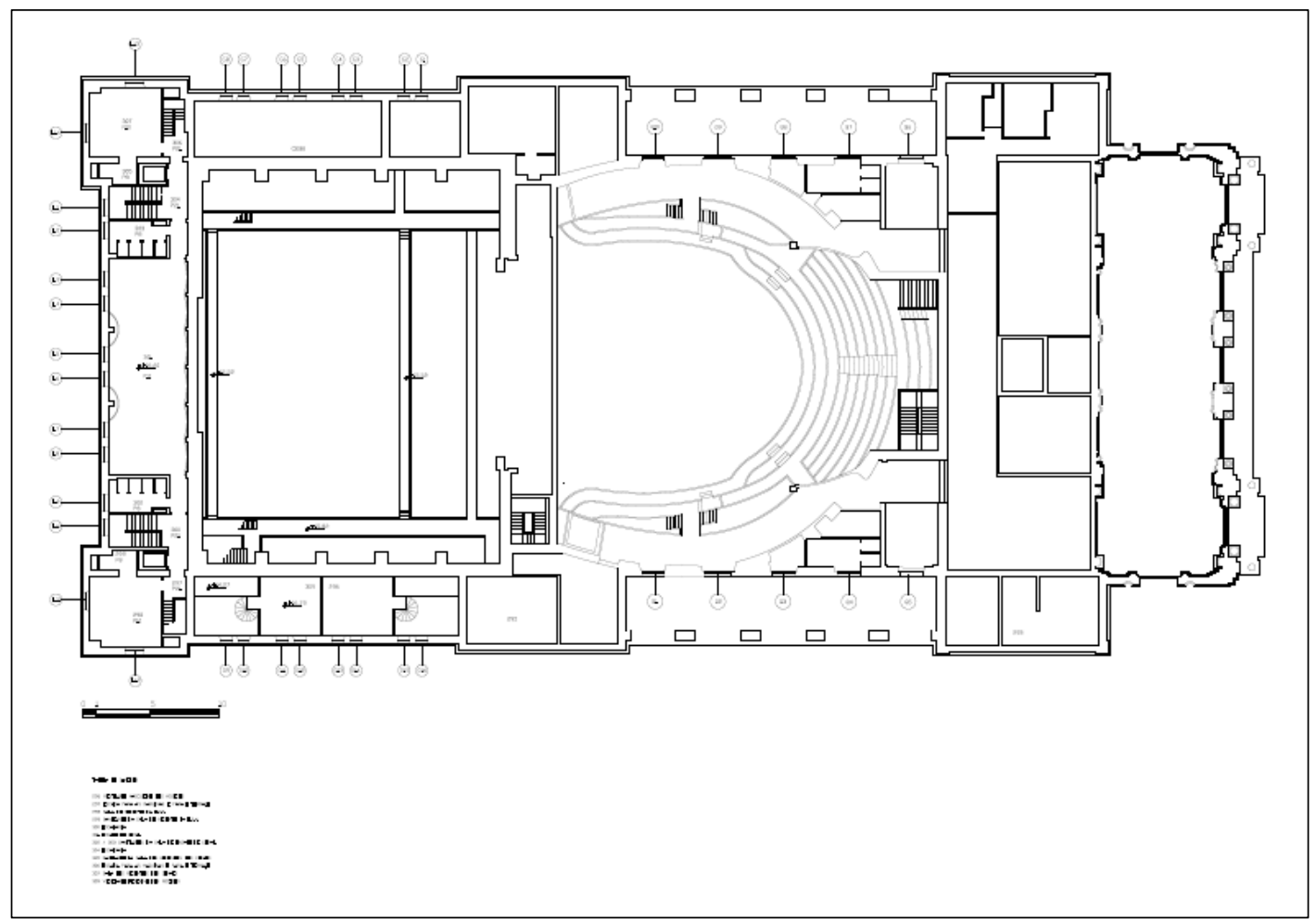

Anexo 5.7: Planta do sexto andar.

Fonte: Acervo da Fundação Theatro Municipal de São Paulo

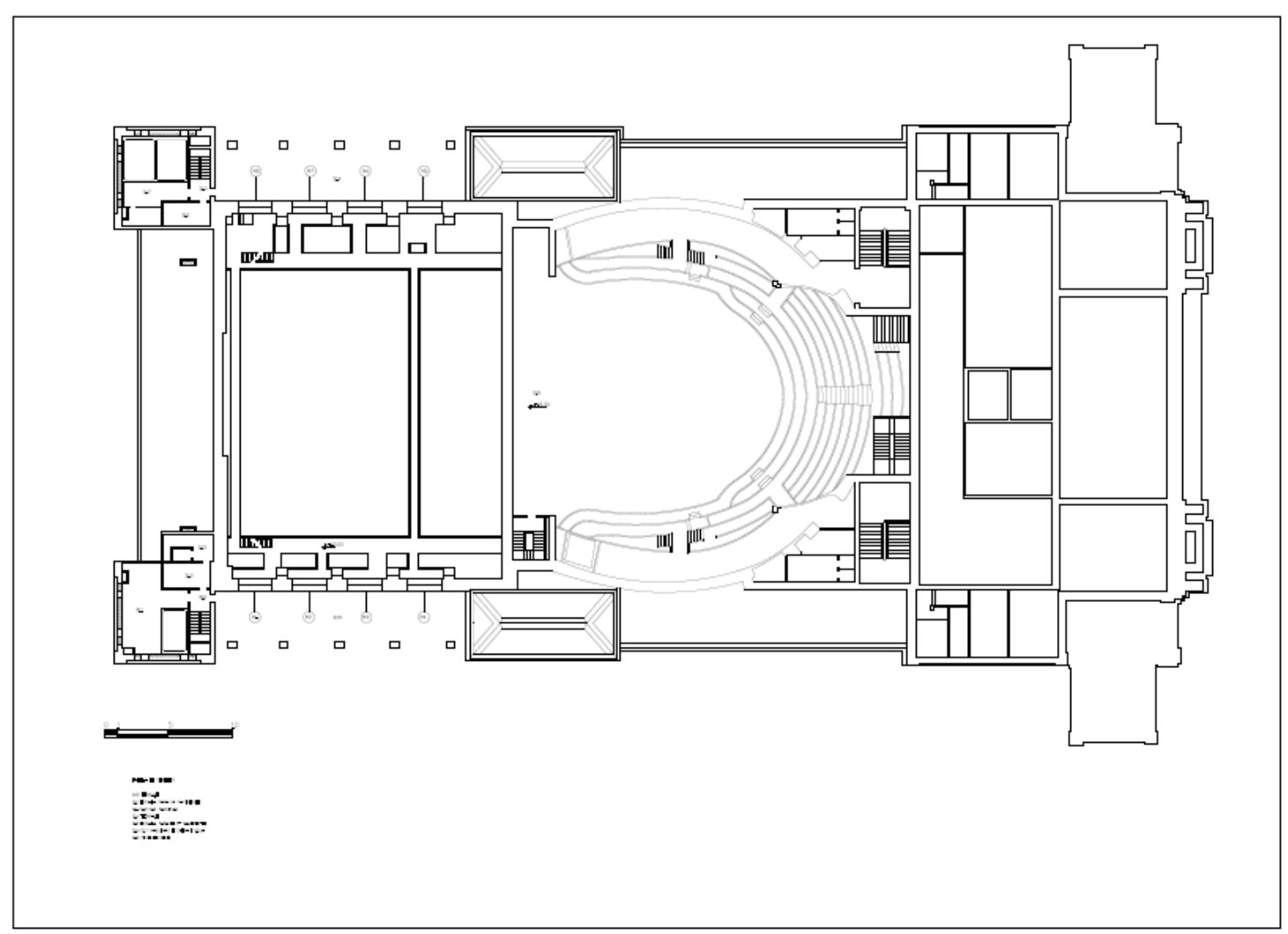

Anexo 5.8: Planta do sétimo andar.

Fonte: Acervo da Fundação Theatro Municipal de São Paulo 


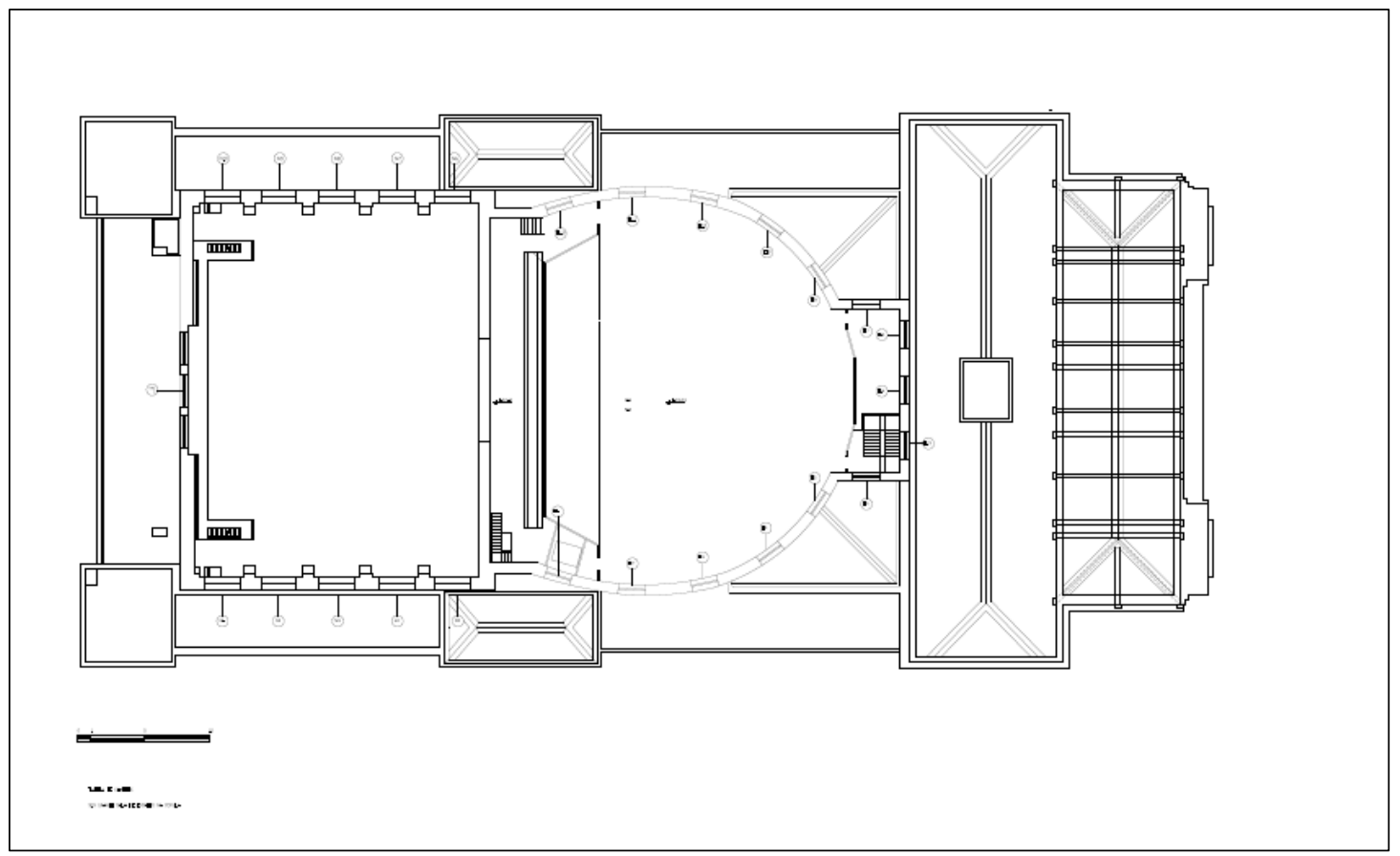

Anexo 5.9: Planta do oitavo andar.

Fonte: Acervo da Fundação Theatro Municipal de São Paulo

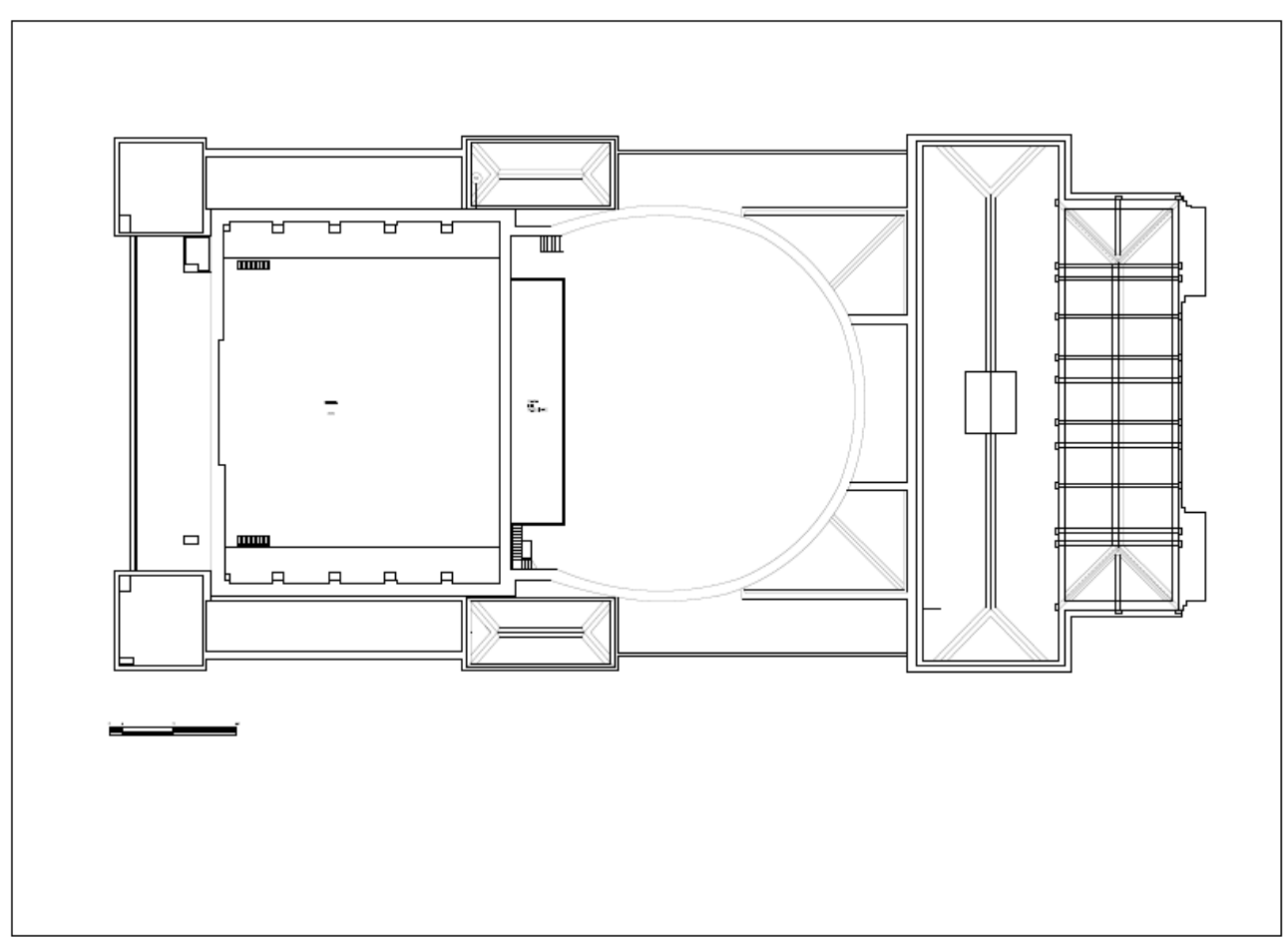

Anexo 5.10: Planta do nono andar.

Fonte: Acervo da Fundação Theatro Municipal de São Paulo 


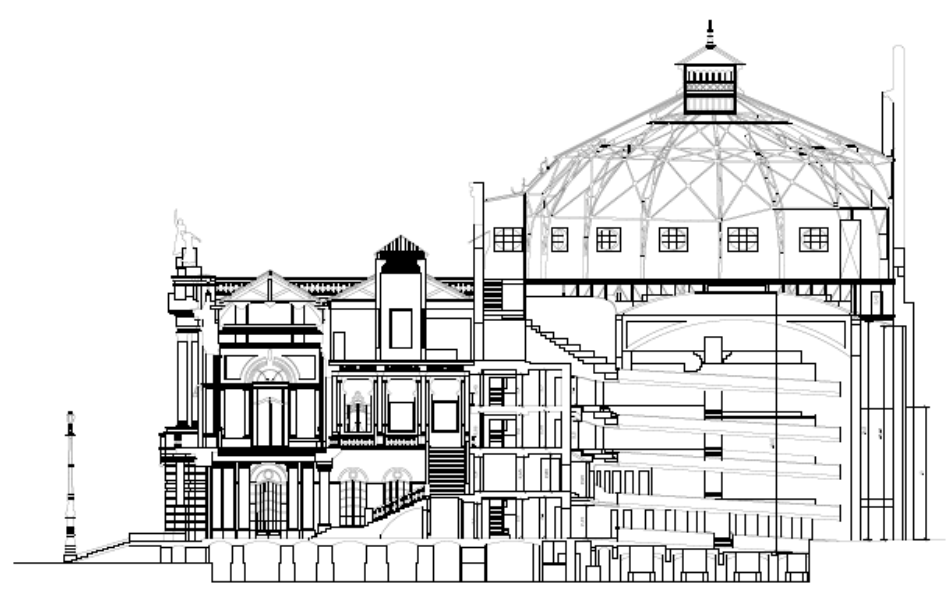

Anexo 5.11: Corte longitudinal.

Fonte: Acervo da Fundação Theatro Municipal de São Paulo

Anexo 5.12: Cortes transversais.

Fonte: Acervo da Fundação Theatro Municipal de São Paulo 